\author{
UNIVERSIDADE DE SÃO PAULO \\ ESCOLA DE ENGENHARIA DE SÃO CARLOS
}

MARCOS JOSÉ DE OLIVEIRA

Incertezas associadas à temperatura do ar no contexto das mudanças climáticas:

determinação das causas e efeitos de heterogeneidades e discussão das implicações práticas

São Carlos, SP 

Incertezas associadas à temperatura do ar no contexto das mudanças climáticas: determinação das causas e efeitos de heterogeneidades e discussão das implicações práticas

Dissertação apresentada à Escola de Engenharia de São Carlos, da Universidade de São Paulo, como parte dos requisitos para obtenção de Título Mestre em Ciências - Programa de Ciências da Engenharia Ambiental.

Área de Concentração: Climatologia Aplicada Orientador: Prof. Dr. Francisco A. S. Vecchia São Carlos, SP 
AUTORIZO A REPRODUÇÃO E DIVULGAÇÃO TOTAL OU PARCIAL DESTE TRABALHO, POR QUALQUER MEIO CONVENCIONAL OU ELETRÔNICO, PARA FINS DE ESTUDO E PESQUISA, DESDE QUE CITADA A FONTE.

Ficha catalográfica preparada pela Seção de Tratamento da Informação do Serviço de Biblioteca - EESC/USP

Oliveira, Marcos José de

Incertezas associadas à temperatura do ar no contexto das mudanças climáticas : determinação das causas e efeitos de heterogeneidades e discussão das implicações práticas / Marcos José de Oliveira ; orientador Francisco A. S. Vecchia. -- São Carlos, 2010.

Dissertação (Mestrado-Programa de Pós-Graduação em Ciências da Engenharia Ambiental) -- Escola de Engenharia de São Carlos da Universidade de São Paulo, 2010.

1. Aquecimento global. 2. Mudanças climáticas. 3. Temperatura do ar. 4. Climatologia. I. Título. 
FOLHA DE JULGAMENTO

Candidato(a): Engenheiro MARCOS JOSÉ DE OLIVEIRA.

Dissertação defendida e julgada em 08.10.2010 perante a Comissão Julgadora:

Flanimo/Lenliad Ppordo

Prof. Assdciado FRANCISCO ARTHUR DA SILVA VECCHIA - (Orientador) (Escola de Engenharia de São Carlos/USP)

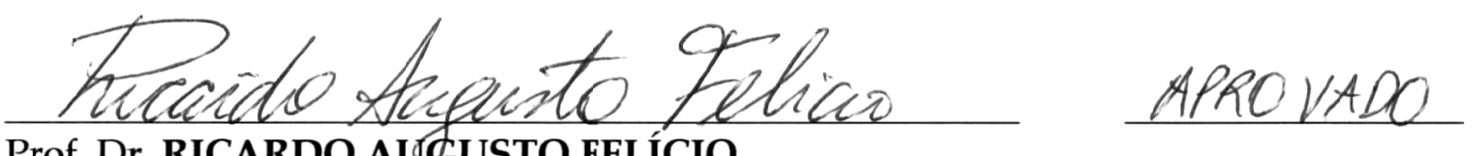

Prof. Dr. RICARDO AUGUSTO FELÍCIO

(Faculdade de Filosofia, Letras e Ciências Humanas/USP)
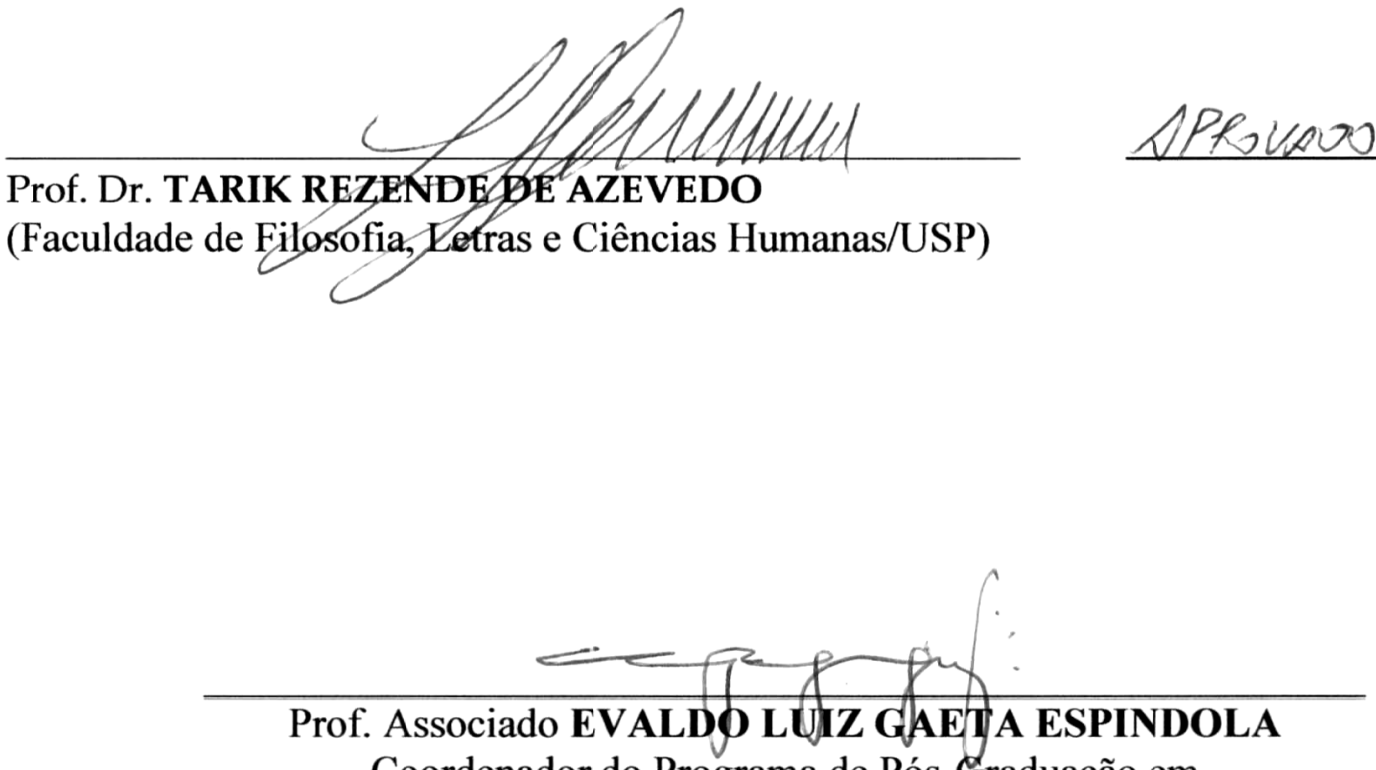

Coordenador do Programa de Pós-Graduação em

Ciências da Engenharia Ambiental

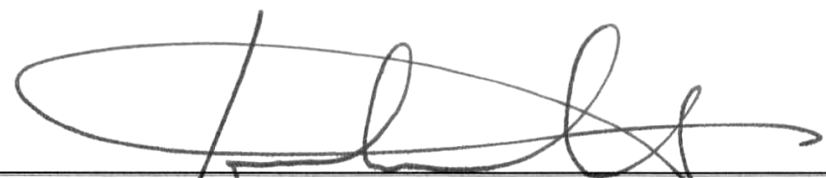

Prof. Titular GERALDO ROBERTO MARTINS DA COSTA Presidente da Comissão da Pós-Graduação da EESC 

Todas as verdades são fáceis de compreender uma vez que são descobertas; o ponto é descobri-las.

Galileo Galilei $(1564-1642)$

A Ciência se compõe de erros que, por sua vez, são os passos até a verdade.

Júlio Verne $(1828-1905)$

De erro em erro, vai-se descobrindo toda a verdade.

Sigmund Freud

$(1856-1939)$ 



\section{AGRADECIMENTOS}

Agradeço:

A Deus, pela vida e oportunidade de evoluir e contribuir.

Às pessoas e instituições que deram apoio e condições à realização deste trabalho. Imensamente agradeço:

Ao Prof. Dr. Francisco Vecchia, pela orientação fundamental, que começou em 2003 quando tive a oportunidade de realizar iniciação científica, a qual me motivou a aprofundar no tema durante o mestrado. Fica minha imensa gratidão, além do seu papel de pesquisador como fonte brilhante de conhecimentos e experiências de vida, pela amizade única e sincera que construímos durante esses anos de convivência.

Aos colegas de laboratório, Grace, Ludimila, Ricardo e em especial pela ajuda essencial, na condução dos experimentos e discussões, de Anthony, Marquinhos, Rodrigo Chinaglia, Andrés, Caio e Mariana Duó.

Ao Betão e demais técnicos que realizaram as medições de temperatura do ar, desde 1973, na estação climatológica do CRHEA, sem as quais não teriam sido possíveis as análises aqui conduzidas.

Aos Professores Roberto Massimo Leonardi e Vincenzo Malvestuto, do Istituto di Scienze dell'Atmosfera e del Clima (CNR), Roma, Itália, pela conversão e digitalização dos termogramas.

Aos Professores Wiclef e Nivaldo, que contribuíram com sugestões valiosas na qualificação.

Aos amigos e colaboradores nas discussões na Internet sobre o clima e aquecimento global, em especial à participação e liderança do Prof. Ricardo Felício. 
À EESC, pela minha formação na graduação em Engenharia Ambiental e continuação no mestrado do PPG-SEA.

A todos os docentes da graduação e pós-graduação que se dedicaram aos cursos e contribuíram com o meu crescimento intelectual e científico.

Ao Nelson, Claudete, Paulo, José Luiz e demais funcionários do PPG-SEA, que sempre me auxiliaram no decorrer da pesquisa.

A Rose, recepcionista do SHS, pela atenção a disposição em ajudar.

À USP São Carlos e todos os seus funcionários, que contribuíram, coletivamente, com a infraestrutura e apoio necessário, principalmente em relação aos serviços oferecidos nas bibliotecas.

Ao INMET e funcionários que se prontificaram quando solicitados.

Ao CNPq, pela bolsa de mestrado concedida.

A todos os amigos e pessoas que contribuíram de alguma forma para a realização deste trabalho.

E, carinhosamente agradeço:

Aos meus pais, Marcos e Nicélia, pelos princípios e valores transmitidos e pelo carinho sempre dedicado na minha vida.

Aos meus irmãos, Nelson e Antônio, pelos anos de convivência e experiências de vida compartilhadas.

A minha noiva e futura esposa Tatiana, pelo incentivo, apoio e companheirismo. 


\section{RESUMO}

OLIVEIRA, M. J. Incertezas associadas à temperatura do ar no contexto das mudanças climáticas: determinação das causas e efeitos de heterogeneidades e discussão das implicações práticas. 2010. 419p. Dissertação (Mestrado-Programa de Pós-Graduação em Ciências da Engenharia Ambiental) - Escola de Engenharia de São Carlos, Universidade de São Paulo, São Carlos, 2010.

O registro da temperatura terrestre é um indicador fundamental nas análises de mudanças do clima global. A presente investigação tratou da verificação e quantificação dos efeitos de heterogeneidades (erros) em séries da temperatura do ar obtidas em estação climatológica localizada em Itirapina, SP, Brasil. As principais causas de heterogeneidades estudadas foram: mudanças dos horários de observação e cálculos da temperatura média diária; mudanças dos tipos de instrumentos utilizados (convencionais e automáticos) e mudanças nos abrigos meteorológicos. A metodologia aplicada consistiu em comparar, em diferentes escalas temporais, várias séries de temperatura do ar em relação a uma série de referência, assumida como mais confiável. As diferenças obtidas, em termos de desvios, resultaram em valores nas seguintes ordens de grandeza, de acordo com cada escala: $10,0^{\circ} \mathrm{C}$ na escala das medições horárias; $5,0^{\circ} \mathrm{C}$ na escala das médias diárias; $2,0^{\circ} \mathrm{C}$, na escala mensal; $1,0^{\circ} \mathrm{C}$ na escala anual; e $1,5^{\circ} \mathrm{C}$ na escala de normal climatológica (30 anos) de exibição dos valores médios da temperatura do ar. Conclui-se que em escalas reduzidas (horárias e diárias) existem erros de alta magnitude de variação, porém de baixa frequência de ocorrência. Com o aumento da escala, a magnitude dos desvios diminui. As causas de heterogeneidades, de acordo com os desvios observados, ficam classificadas, na ordem de menor para a maior intensidade de influência: mudanças dos abrigos; mudanças dos cálculos das médias diárias; e mudanças dos instrumentos. No contexto da discussão do aquecimento global, na ordem de $0,6^{\circ} \mathrm{C}$ no último século, a ocorrência de erros e incertezas de mesma ou maior magnitude pode comprometer o uso da temperatura do ar como uma evidência confiável de mudanças do clima, uma vez que mudanças não-climáticas interferem significativamente nas medições. $\mathrm{O}$ uso da evidência é discutido no contexto da interação entre a Ciência, Política, Mídia e Economia. Foi identificado que, neste âmbito externo ao meio científico, as incertezas são diminuídas e ignoradas, tanto devido ao processo de simplificação da informação para sua difusão, quanto devido a interesses que norteiam a manipulação intencional e tendenciosa do tema. Devido à disputa de diferentes interesses, foi feita uma breve discussão de alguns aspectos controversos, permeando a atuação de cientistas céticos à crença da contribuição humana significativa nas mudanças climáticas.

Palavras-chave: Aquecimento global, mudanças climáticas, temperatura do ar, climatologia. 



\begin{abstract}
OLIVEIRA, M. J. Uncertainties associated with the air temperature in the context of climate change: determination of the causes and effects of heterogeneities and discussion of the practical implications. 2010. 419p. Master Thesis. Escola de Engenharia de São Carlos, Universidade de São Paulo, São Carlos, 2010.
\end{abstract}

The instrumental temperature record is a key indicator in the analysis of global climate change. This research dealt with the verification and quantification of the effects of heterogeneities (errors) in air temperature series obtained from a climatological station located in Itirapina, SP, Brazil. The main causes of heterogeneity studied were: changes on the times of observation and on the daily mean air temperature calculation; changes on the types of instruments (conventional and automatic); and changes in thermometer screens. The methodology consisted of comparing, at different time scales, several series of air temperature series in relation to a reference series, assumed to be more reliable. The differences obtained, in terms of deviations, resulted in the following orders of magnitude, according to each scale: $10.0^{\circ} \mathrm{C}$ in the range of hourly measurements, $5.0^{\circ} \mathrm{C}$ in the range of daily mean, $2.0^{\circ} \mathrm{C}$ in monthly scale, $1.0^{\circ} \mathrm{C}$ in the annual scale and $1.5^{\circ} \mathrm{C}$ in the climatological normal scale (30 years). It follows that at small scales (hourly and daily) exist errors of high magnitude of change, but low frequency of occurrence. With increasing scale, the magnitude of the deviations decreases. The causes of heterogeneity, according to the observed deviations, are ranked in order of lowest to highest extent of influence: changes on screens, changes on daily mean air temperature calculation, and changes of the instruments. In the context of the discussion of global warming, on the order of $0.6^{\circ} \mathrm{C}$ over the last century, the occurrence of errors and uncertainties in same or greater magnitude can compromise the use of air temperature as a reliable evidence of climate changes, since non-climatic changes significantly interfere the measurements. The use of evidence is discussed in the context of the interaction between Science, Politics, Media and Economics. It was identified that, outside the scientific environment context, the uncertainties are reduced and neglected, both due to the simplification process for the information dissemination, as due to concerns that guide the intentional and biased manipulation on the subject. Due to the competition of different interests, there was held a brief discussion of some controversial aspects, permeating the work of skeptical scientists on the belief of the significant human contribution to the climate change.

Keywords: Global warming, climate change, air temperature, climatology. 



\section{LISTA DE FIGURAS*}

Figura 1 - Esquema representativo das escalas empregadas nos estudos climáticos .. 16

Figura 2 - Termógrafo. (A) Mecanismo de funcionamento de um termógrafo; (B) Foto de um termógrafo moderno ............................................. 27

Figura 3 - Principais características de um termômetro de mercúrio......................28

Figura 4 - Sistema automático de aquisição de dados Campbell Scientific Inc.......... 30

Figura 5 - Detalhes da caixa ambientalmente selada e os componentes do sistema automático de aquisição de dados............................................... 30

Figura 6 - Sensor de Temperatura e Umidade Relativa do ar modelo HMP45C...... 31

Figura 7 - Modelo de um termômetro de resistência de platina.............................. 32

Figura 8 - Sensor HMP45C e abrigo de radiação 41003..................................... 32

Figura 9 - Representação esquemática do princípio de funcionamento de um termopar........................................................................... 33

Figura 10 - Gráfico do comportamento da temperatura sob influências da cobertura vegetal exibindo o padrão cíclico da variação diária da temperatura externa do ar tomado em dois bairros da cidade de São Carlos, bosque correspondendo a uma região melhor vegetada e a praça correspondendo ao espaço árido do centro da cidade. 36

Figura 11 - Gráfico do dia 25 de janeiro de 2004 com o comportamento da temperatura externa do ar sob influências da incidência da radiação solar direta, tomada em abrigo meteorológico sem isolamento e sem aspiração do ar, que ocasionou a aparência de "orelhas", às 7h30 e às 16h30 distorcendo a senóide habitual................................................... 37

Figura 12 - Estimativas do aumento do nível médio do mar de 1910 a 1990 ........... 44

\footnotetext{
* Alguns títulos nesta lista foram reduzidos por motivo de simplificação e facilitação da leitura.
} 
Figura 13 - Variações da temperatura da superfície terrestre ao longo nos últimos 140 anos e ao longo do último milênio.

Figura 14 - Mudanças de temperatura e nível do mar desde 1850. .48

Figura 15 - Balanço global anual médio de energia da Terra.

Figura 16 - Distribuição proporcional setorial das emissões de GEEs em 2004 em termos de equivalência em dióxido de carbono .50

Figura 17 - Concentrações atmosféricas de (A) dióxido de carbono, (B) metano e (C) óxido nitroso ao longo dos últimos 10.000 anos e desde 1750 .

Figura 18 - Média global do forçamento radiativo em 2005.

Figura 19 - Variações paleoclimáticas do nível médio relativo do mar (A) Variações eustáticas do nível do mar durante o último ciclo glacial-interglacial. (B) Recorte das variações ao longo dos últimos 32 mil anos .56

Figura 20 - Variação do nível do mar ao longo dos últimos 550 milhões de anos atrás .57

Figura 21 - Variações da temperatura terrestres em diferentes escalas temporais .....58

Figura 22 - Variações estimadas do nível eustático do mar e da temperatura global durante o Fanerozóico, ilustrando os modos quentes e frios.

Figura 23 - Variações desde 1978 da: (A) radiação solar total e (B) do número de manchas solares

Figura 24 - Variação da quantidade de manchas solares desde 1610

Figura 25 - Reconstruções das atividades solares passadas: (A) Variação da quantidade de manchas solares nos últimos 11.000 anos; (B) Concentração de radiocarbono atmosférico nos últimos 1.100 anos

Figura 26 - Variações orbitais terrestres: (A) excentricidade orbital; (B) inclinação do eixo terrestre; (C) precessão dos equinócios .67 
Figura 27 - Parâmetros orbitais e Ciclos de Milankovitch no passado e futuro 69

Figura 28 - Ciclos de Milankovitch registrados nos testemunhos de gelo..... 70

Figura 29 - Impacto de erupções vulcânicas na temperatura, no período de 1700-2000 73

Figura 30 - Raios cósmicos e Eras glaciais na Terra 81

Figura 31 - Representação esquemática do espectro de variância para o sistema climático, com escalas de tempo variando entre horas e bilhões de anos. 83

Figura 32 - Temperaturas simuladas no último milênio com e sem forçamentos antropogênicos e também com forçamentos solares fracos e fortes 85

Figura 33 - Cenários de emissões globais de GEEs (A) e efeitos na temperatura média global (B) para o período de 2000 a 2100 86

Figura 34 - Série temporal do nível global médio do mar no passado e projetado para o futuro, com desvio em relação à média de 1980-1999 87

Figura 35 - Algumas séries paleoclimáticas representativas dos tipos de variações climáticas. 91

Figura 36 - Comparação entre mudanças continentais e globais observadas na temperatura superficial entre 1900 e 2000 96

Figura 37 - Distribuição espacial mundial das mudanças da temperatura superficial no período de 1970-2004 97

Figura 38 - Evolução e declínio na quantidade de estações climatológicas da rede Global Historical Climatology Network ( $G H C N)$..... 100

Figura 39 - Distribuição global de estações terrestres integrantes da rede Global Historical Climatology Network (GHCN) 101

Figura 40 - Rede de estações do projeto “Berkeley Earth Surface Temperature” ... 102

Figura 41 - Temperatura global obtida por satélites desde 1979. 104 
Figura 42 - Reconstrução das anomalias de temperatura no Hemisfério Norte nos últimos 2.000 anos, exibindo o Período Medieval Quente (950-1300) e a Pequena Era do Gelo $(1400-1750)$................................................ 107

Figura 43 - Perspectiva histórica do aquecimento global............................... 109

Figura 44 - Fluxograma de abordagem das questões climáticas. ..........................114

Figura 45 - Normais climatológicas da temperatura média nos períodos de 1931-1960 (curvas em azul) e 1961-1990 (curvas em vermelho) nas cidades de (A) São Paulo; (B) Curitiba; (C) Florianópolis; (D) Santos; e (E) Franca... 132

Figura 46 - Síntese das normais climatológicas das temperaturas média, máxima e mínima nos períodos de 1931-1960 (curvas em azul) e 1961-1990 (curvas em vermelho) nas cidades de São Paulo e Franca 134

Figura 47 - Dados e localização da estação meteorológica de Franca/SP no sítio eletrônico do INMET 142

Figura 48 - Possível localização da estação meteorológica do INMET na cidade de Franca/SP 143

Figura 49 - Área urbanizada, segundo períodos de expansão, da Região Metropolitana de São Paulo com recortes ampliados da localização da estação meteorológica do INMET em São Paulo 146

Figura 50 - Síntese das normais climatológicas das temperaturas média, máxima e mínima nos períodos de 1939-1960 (curvas em azul) e 1961-1990 (curvas em vermelho) da cidade de São Carlos/SP

Figura 51 - Locais em que a estação meteorológica do INMET pode ter realizado medições na cidade de São Carlos 151

Figura 52 - Distribuição visual das falhas diárias na série de temperaturas obtidas por termômetros de máximas e mínimas, no período de 1973-2008. 170

Figura 53 - Spaghetti plot das temperaturas mensais ao longo de um ano, com cada curva representando um ano do período 1973-2008 176 
Figura 54 - Diferentes versões das temperaturas no formato de climatogramas anuais,

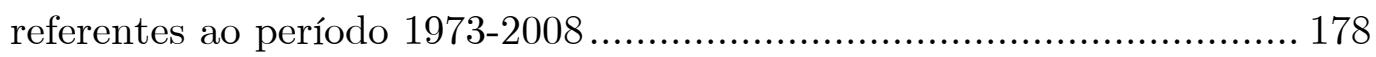

Figura 55 - Valores anuais das temperaturas absolutas (A) máximas e (B) mínimas, e respectivas tendências para o período de 1973-2008. .......................... 182

Figura 56 - Desvios e tendências das temperaturas (A) médias, (B) máximas e (C)

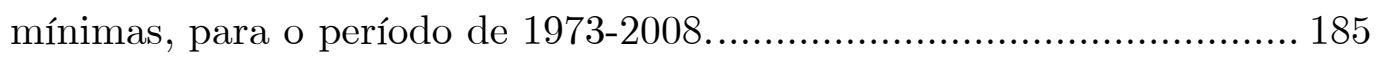

Figura 57 - Temperaturas mensais (A) médias, (B) máximas e (C) mínimas, com respectivas tendências para o período de $1973-2008$.......................... 187

Figura 58 - Composição unificada das temperaturas mensais médias, máximas e

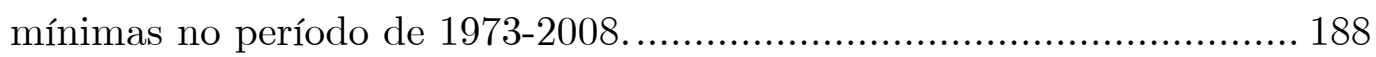

Figura 59 - Temperaturas diárias (A) médias, (B) máximas e (C) mínimas, com respectivas tendências para o período de 1973-2008. .......................... 190

Figura 60 - Composição unificada das temperaturas diárias médias, máximas e

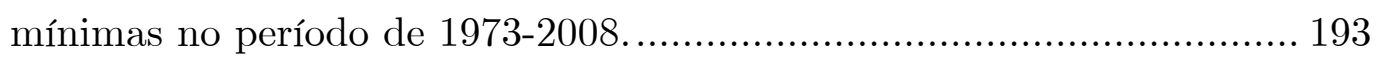

Figura 61 - Amplitudes de variação da temperatura e tendência de suas variações, obtidas pela diferença dos valores diários da temperatura máxima pelos valores da temperatura mínima................................................ 194

Figura 62 - Distribuição visual das falhas diárias na série de temperaturas obtidas pela estação automática, no período de 1999-2006. 195

Figura 63 - Distribuição visual das falhas diárias na série de temperaturas com leituras as 9, 15 e 21h, no período de 1999-2008. 196

Figura 64 - Histogramas dos desvios de temperatura das séries $T_{M-m}, T_{9-21-M-m}$ e $T_{\text {automática }}$ no período 2001-2005.

Figura 65 - Gráficos de dispersão demonstrando a correlação entre as séries $T_{M-m}, T_{9-}$

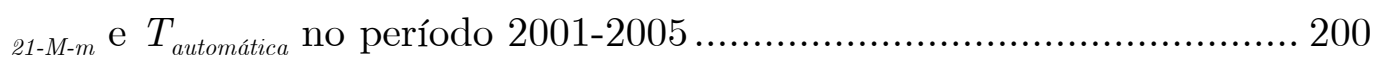

Figura 66 - Desvios diários e tendências das temperaturas das séries $T_{M-m}, T_{9-21-M-m} \mathrm{e}$ $T_{\text {automática }}$ no período 2001-2005. 
Figura 67 - Temperaturas mensais das séries $T_{M-m}, T_{9-21-M-m}$ e $T_{\text {automática }}$ no período 2001-2005. 202

Figura 68 - Desvios mensais e tendências das temperaturas das séries $T_{M-m}, T_{9-21-M-m}$ e $T_{\text {automática }}$ no período 2001-2005.

Figura 69 - Comparação, no perfil da representação de uma normal, das séries $T_{M-m}$, $T_{\text {9-21-M-m }}$ e $T_{\text {automática }}$ no período 2001-2005, em relação à normal calculada para o período $1973-2008$. 204

Figura 70 - Gráficos de dispersão demonstrando a correlação entre as séries $T_{A_{-} M-m}$, $T_{A_{-} 9-15-21}, T_{A_{-} \gamma_{-14-21}}$ e $T_{A_{-} \text {9-21-M-m }}$ em relação à $T_{\text {automática }}$ no período 20012005. 207

Figura 71 - Histogramas dos desvios de temperatura das séries $T_{A_{-} M-m}, T_{A_{-} 9-15-21}$, , $T_{A_{-} \text {7-14-21 }}$ e $T_{A_{-} \text {9-21-M-m }}$ em relação à $T_{\text {automática }}$ no período 2001-2005. .208

Figura 72 - Desvios diários e tendências das temperaturas das séries $T_{A_{-} M-m}, T_{A_{-} 9-15-21}$, , $T_{A_{-} \gamma-14-21}$ e $T_{A_{-} \text {9-21-M-m }}$ em relação à $T_{\text {automática }}$ no período 2001-2005.......209

Figura 73 - Temperaturas mensais das séries $T_{A_{-} M-m}, T_{A_{-} 9-15-21}, T_{A_{-} \gamma-14-21}, T_{A_{-} 9-21-M-m} \mathrm{e}$ $T_{\text {automática }}$ no período 2001-2005.

Figura 74 - Desvios mensais e tendências das temperaturas das séries $T_{A_{-} M-m}, T_{A_{-} 9-15-}$ ${ }_{21},, T_{A_{-} \gamma-14-21}$ e $T_{A_{-} 9-21-M-m}$ em relação à $T_{\text {automática }}$ no período $2001-2005 \ldots . .211$

Figura 75 - Comparação, no perfil da representação de uma normal, das séries $T_{A_{-} M-}$ ${ }_{m}, T_{A_{-} 9-15-21}, T_{A_{-} \gamma_{-14-21}}, T_{A_{-} \text {9-21-M-m }}$ e $T_{\text {automatica }}$ no período 2001-2005

Figura 76 - Estações convencional e automática: (A) Termógrafo R. Fuess; (B) Câmara de Stevenson; (C) Estação climatológica automática, com indicação do sensor de umidade e temperatura do ar modelo HMP45C, acondicionado no abrigo modelo 41008. .225

Figura 77 - Distribuição visual das falhas diárias na série de temperaturas obtidas pelo termógrafo, no período de 2001-2002. .227 
Figura 78 - Termogramas (A) original e (B) convertido para o período de 16 a 23 de abril de 2001.

Figura 79 - Trecho do arquivo de dados - gerado pelo software Plot2Data - após a conversão do termograma e extração dos valores de temperatura.

Figura 80 - Correlação das temperaturas provenientes das estações convencional $\left(T_{\text {conv }}\right)$ e automática $\left(T_{\text {aut }}\right)$

Figura 81 - Histograma de distribuição relativa dos desvios de temperatura da série $T_{\text {convencional }}$ em relação à $T_{\text {automática }}$ no período 2001-2002

Figura 82 - Perfis de temperatura e respectivos desvios de temperatura das séries $T_{\text {convencional }}$ e $T_{\text {automática }} \operatorname{nos} \operatorname{anos}(\mathbf{A}) 2001$ e (B) 2002 232

Figura 83 - (A) Perfis de temperatura e (B) desvios de temperatura das séries $T_{\text {convencional }}$ e $T_{\text {automática }}$ no período de 19 a 28 de dezembro de 2001. 232

Figura 84 - Desvios em diferentes escalas e tendências das temperaturas da série $T_{\text {convencional }}$ em relação à $T_{\text {automática }}$ no período $2001-2002$ 233

Figura 85 - Diferentes tipos de abrigos de baixo custo cujos desempenhos foram avaliados por Tarara e Hoheisel (2007) 241

Figura 86 - Avaliação, realizadas por Tarara e Hoheisel (2007), do desempenho dos abrigos experimentais (Figura 85), em termos dos desvios de temperatura dos abrigos em relação à temperatura tomada como referência (sensor comercial HMP45C) 242

Figura 87 - Representação esquemática, com vista em planta, da disposição dos 4 abrigos experimentais da primeira estação experimental 246

Figura 88 - Representação gráfica do conjunto de termopares com o 4 diferentes abrigos de PVC de 4 polegadas 247

Figura 89 - Comportamento da temperatura ao longo do dia 13 de maio de 2006 para os 4 diferentes abrigos em estudo na primeira estação experimental. .... 251 
Figura 90 - Diferenças de temperatura ao longo do dia 13 de maio de 2006 para os 4 diferentes abrigos em estudo na primeira estação experimental.

Figura 91 - Histogramas: distribuição das diferenças relativas ao abrigo \#3. .253

Figura 92 - Correlações dos valores das medições de temperatura entre os abrigos da primeira estação experimental. .254

Figura 93 - Distribuição das diferenças dos valores de temperatura ao longo do dia. .255

Figura 94 - Mês de maio de 2006, sob escala de abordagem de episódios climáticos. 256

Figura 95 - Imagens em infravermelho captadas pelo satélite GOES para as fases da massa de ar frio com entrada no dia 16 de maio de 2006. .258

Figura 96 - Correlações da diferenças de temperatura versus radiação solar global. 260

Figura 97 - Distribuição em representação do tipo boxplot das diferenças de temperatura versus radiação solar, em condições de velocidade do vento externo abaixo de $1 \mathrm{~m} / \mathrm{s}$. 260

Figura 98 - Correlações das diferenças de temperatura versus velocidade média do ar externo .262

Figura 99 - Distribuição em representação do tipo boxplot das diferenças de temperatura versus velocidade do vento exterior, em condições de radiação solar acima de $150 \mathrm{w} / \mathrm{m}^{2}$ 263

Figura 100 - Representação bidimensional da correlação das diferenças de temperatura, em termos de isotermas, em relação aos efeitos combinados da velocidade média do ar e da radiação solar global .264

Figura 101 - Representação tridimensional das diferenças de temperatura em relação aos efeitos combinados da velocidade média do ar e da radiação solar global .265 
Figura 102 - Temperatura dos abrigos ao longo da noite da passagem do dia 13 para o dia 14 de setembro de 2006. 266

Figura 103 - Diferenças de temperatura dos abrigos ao longo da noite da passagem do dia 13 para o dia 14 de setembro de 2006.

Figura 104 - Imagens em infravermelho captadas às 12h pelo satélite GOES nos dias 12,15 e 16 de setembro 269

Figura 105 - Temperatura dos abrigos ao longo do dia 12 de setembro de 2006, com registros realizados a cada 5 minutos. 270

Figura 106 - Temperatura dos abrigos ao longo do dia 12 de setembro de 2006, com registros realizados a cada 30 minutos. 270

Figura 107 - Diferenças de temperatura dos abrigos ao longo do dia 12 de setembro de 2006, abrigo \#3 como referência, com registros a cada 5 minutos.... 272

Figura 108 - Diferenças de temperatura dos abrigos ao longo do dia 12 de setembro de 2006, abrigo \#3 como referência, com registros a cada 30 minutos. . 272

Figura 109 - Análise dos dias 26, 27 e 28 de maio de 2006 com o uso do sensor HMP45C acoplado ao abrigo 41003. 274

Figura 110 - Variações das temperaturas após a imersão em gelo fundente durante a calibração dos termopares da segunda estação experimental, com 9 abrigos. 278

Figura 111 - Diagrama tabular, anual e mensal, apresentando as falhas de dados diários na série de temperatura do ar registrada na segunda estação experimental, com 9 abrigos. 279

Figura 112 - Gráficos de correlação entre as séries $T_{\text {azul }}, T_{\text {vermelho }}, T_{\text {verde }}, T_{\text {branco }}, T_{\text {preto }}$, $T_{\text {foil }}, T_{\text {anteparo }}, T_{\text {sem_proteção }}$ e $T_{\text {metálico }}$ em relação à $T_{\text {automática }}$ no ano de 2009.281

Figura 113 - Histogramas dos desvios de temperatura das séries $T_{a z u l}, T_{\text {vermelho }}, T_{\text {verde }}$, $T_{\text {branco }}, T_{\text {preto }}, T_{\text {foill }}, T_{\text {anteparo }}, T_{\text {sem_proteção }}$ e $T_{\text {metálico }}$ em relação à $T_{\text {automática }}$ no ano de 2009. 282 
Figura 114 - Desvios horários e tendências das temperaturas das séries $T_{\text {azul }}, T_{\text {vermelho }}$, $T_{\text {verde }}, T_{\text {branco }}, T_{\text {preto }}, T_{\text {foil }}, T_{\text {anteparo }}, T_{\text {sem_protecão }}$ e $T_{\text {metálico }}$ em relação à $T_{\text {automática }}$ no ano de 2009 .

Figura 115 - Desvios diários e tendências das temperaturas das séries $T_{\text {azul }}, T_{\text {vermelho }}$, $T_{\text {verde, }}, T_{\text {branco }}, T_{\text {preto }}, T_{\text {foil }}, T_{\text {anteparo }}, T_{\text {sem_protecão }}$ e $T_{\text {metálico }}$ em relação à $T_{\text {automática }}$ no ano de 2009 . .286

Figura 116 - Desvios mensais e tendências das temperaturas das séries $T_{\text {azul }}, T_{\text {vermelho }}$, $T_{\text {verde }}, T_{\text {branco }}, T_{\text {preto }}, T_{\text {foil }}, T_{\text {anteparo }}, T_{\text {sem_protecãa }}$ e $T_{\text {metálico }}$ em relação à $T_{\text {automática }}$ no ano de 2009 . 288

Figura 117 - Climatiris da temperatura do ar ao longo do ano de 2009. .294

Figura 118 - Climatiris dos desvios de temperatura $\left(T_{\text {foil }}-T_{\text {aut. }}\right)$ ao longo do ano de 2009 294

Figura 119 - Isolinhas com recorte de dois episódios climáticos representando as temperaturas (A) $T_{\text {automática }}$, (B) $T_{\text {foil }}$ e (C) desvios de temperatura $\left(T_{\text {foil }}-\right.$ $\left.T_{\text {automática }}\right)$ no período de 15 de fevereiro a 13 de março de 2009 . .296

Figura 120 - Representação tridimensional das isolinhas apresentadas na Figura 119. 297

Figura 121 - Curvas idealizadas representando o comportamento das temperaturas $T_{\text {foil }}$ e $T_{\text {automática }}$ e os respectivos desvios $\left(T_{\text {foil }}-T_{\text {aut. }}\right)$, referente ao corte indicado pela linha vertical tracejada indicada na Figura 119. 298

Figura 122 - Gastos com mudanças climáticas (vermelho) em relação aos (A) gastos mundiais (escala normal) e (B) valores cotidianos (escala logarítmica). 339

Figura 123 - Desvios máximos e mínimos de todas as séries sob diferentes escalas de abordagem. .350 



\section{LISTA DE TABELAS}

Tabela 1 - Cenários do aumento do nível médio do mar para o ano 2100

Tabela 2 - Normais das temperaturas médias das cidades de São Paulo, Curitiba, Florianópolis, Santos e Franca, para os períodos de 1931-1960 e 19611990.

Tabela 3 - Normais das temperaturas médias, máximas e mínimas das cidades de São Paulo e Franca, para os períodos de 1931-1960 e 1961-1990. 133

Tabela 4 - Temperaturas máximas absolutas da cidade de São Paulo nos períodos de 1931-1960 e 1961-1990.

Tabela 5 - Normais das temperaturas médias, máximas e mínimas da cidade de São Carlos, para os períodos de 1939-1960 e 1961-1990. 148

Tabela 6 - Temperaturas médias, mensais e anuais, calculadas com base nos dados da estação convencional, no período de 1973-2008. 173

Tabela 7 - Temperaturas máximas médias, mensais e anuais, calculadas com base nos dados da estação convencional, no período de 1973-2008.

Tabela 8 - Temperaturas mínimas médias, mensais e anuais, calculadas com base nos dados da estação convencional, no período de 1973-2008. 175

Tabela 9 - Temperaturas máximas absolutas, mensais e anuais, para o período de 1973-2008. 180

Tabela 10 - Temperaturas mínimas absolutas, mensais e anuais, para o período de 1973-2008. 181

Tabela 11 - Tendências de temperatura $\left({ }^{\circ} \mathrm{C}\right)$ relativas às diferentes escalas temporais de abordagem 191

Tabela 12 - Temperatura média (2001-2005) das séries $T_{M-m}, T_{9-21-M-m}$ e $T_{\text {automatica }} \ldots 197$

Tabela 13 - Análise estatística das séries $T_{M-m}, T_{9-21-M-m}$ e $T_{\text {automática }}$ no período 20012005 . 
Tabela 14 - Valores médios de temperatura $\left({ }^{\circ} \mathrm{C}\right)$ das séries $T_{M-m}, T_{9-21-M-m}$ e $T_{\text {automática }}$ no período 2001-2005, relativos às diferentes escalas temporais de abordagem. .205

Tabela 15 - Temperatura média $(2001-2005)$ das séries $T_{\text {automática }}, T_{A_{-} M-m}, T_{A_{-} 9-15-21}$, ,

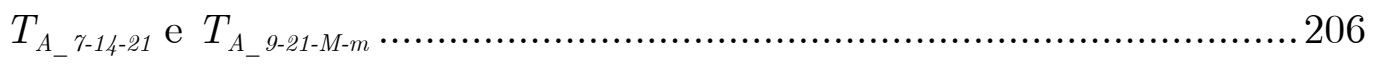

Tabela 16 - Análise estatística das séries $T_{\text {automática }}, T_{A_{-} M-m}, T_{A_{-} 9-15-21}, T_{A_{-} \gamma_{-14-21}}$ e $T_{A_{-} 9-}$ 21-M-m no período 2001-2005. 207

Tabela 17 - Valores médios de temperatura $\left({ }^{\circ} \mathrm{C}\right)$ das séries $T_{A_{-} M-m}, T_{A_{-} 9-15-21}, T_{A_{-} \gamma_{-14}}$ 21, $T_{A_{-} \text {9-21-M-m }}$ e $T_{\text {automatica }}$ no período 2001-2005, relativos às diferentes escalas temporais de abordagem.

Tabela 18 - Índices estatísticos para análise da concordância de $T_{\text {convencional }}$ e $T_{\text {automática }}$ .229

Tabela 19 - Análise estatística da série $T_{\text {convencional }}$ em relação à $T_{\text {automática }}$ no período 2001-2002. .234

Tabela 20 - Constituição dos 4 abrigos experimentais da primeira estação 247

Tabela 21 - Valores de temperatura $\left({ }^{\circ} \mathrm{C}\right)$ nos 4 diferentes abrigos da primeira estação experimental, sob diferentes intervalos de registros 271

Tabela 22 - Constituição dos nove abrigos experimentais 276

Tabela 23 - Análise estatística das séries $T_{\text {azul }}, T_{\text {vermelho }}, T_{\text {verde }}, T_{\text {branco }}, T_{\text {preto }}, T_{\text {foil }}$, $T_{\text {anteparo }}, T_{\text {sem_proteção }}$ e $T_{\text {metálico }}$ em relação à $T_{\text {automática }}$ no ano de $2009 \ldots \ldots . . .280$

Tabela 24 - Valores médios dos desvios de temperatura $\left({ }^{\circ} \mathrm{C}\right)$ nos diferentes abrigos, sob diferentes escalas 289

Tabela 25 - Síntese estatística dos desvios, por tipo de heterogeneidade, em diferentes escalas, de todas as séries estudadas.

Tabela 26 - Síntese de todas as séries estudadas no trabalho, com colorações proporcionais à relatividade dos valores em cada coluna. 349 
Tabela 27 - Ponderação dos efeitos por tipo de heterogeneidade, com base nas médias dos valores máximos, mínimos e médios............................................. 351 



\section{SUMÁRIO}

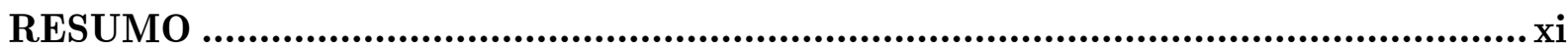

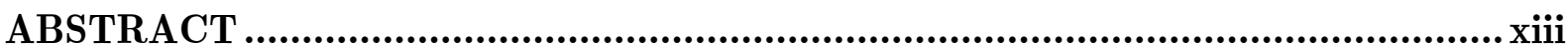

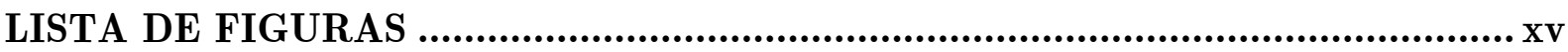

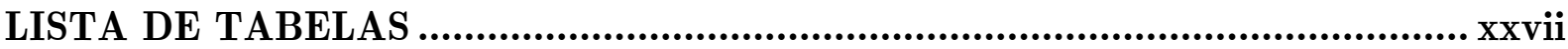

1. INTRODUÇÃ̃

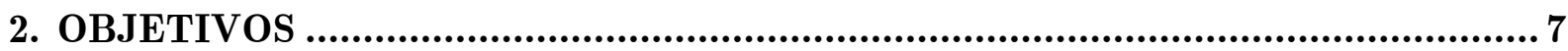

3. CAPÍTULO 1 - Base Conceitual ............................................................9

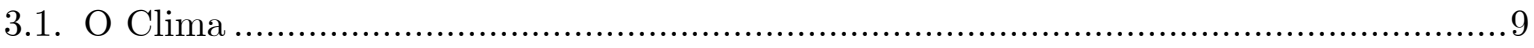

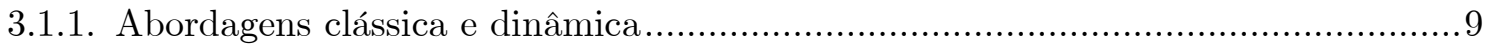

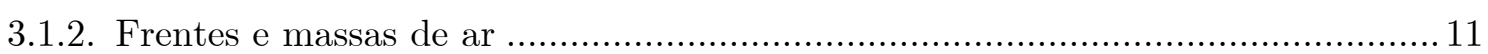

3.1.3. Ritmo climático e episódios representativos ........................................................ 11

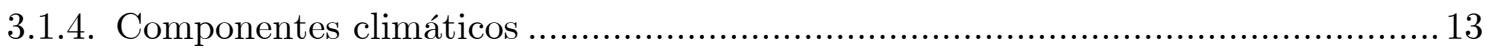

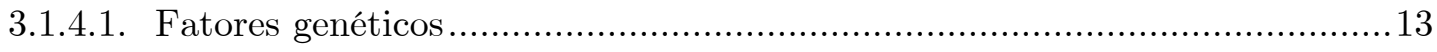

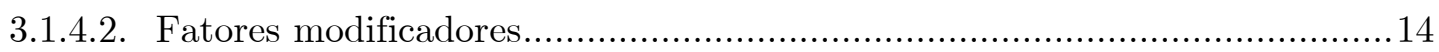

3.1.4.3. Fatores resultantes (elementos climáticos) ............................................ 14

3.1.5. Escalas de abordagem têmporo-espacial ....................................................... 15

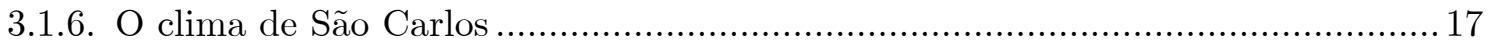

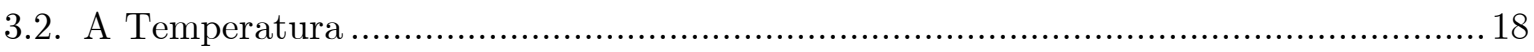

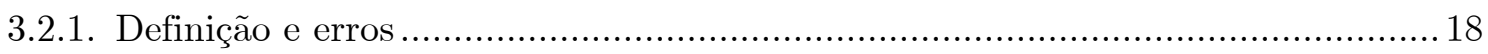

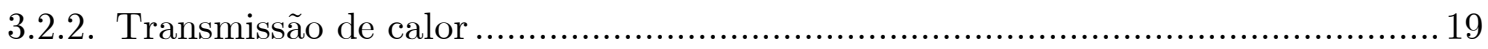

3.2.3. Determinação da temperatura terrestre........................................................ 22

3.2.3.1. Reconstruções da temperatura no passado ..............................................22

3.2.3.2. Estimativas futuras da temperatura do ar .............................................2 23

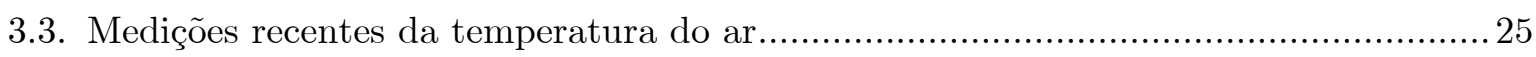

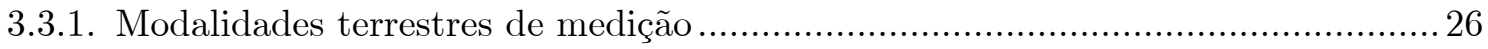

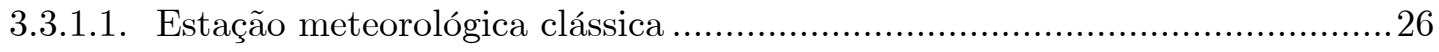

3.3.1.2. Estação meteorológica automática .........................................................29

3.3.2. Interferências nas medições terrestres........................................................ 34

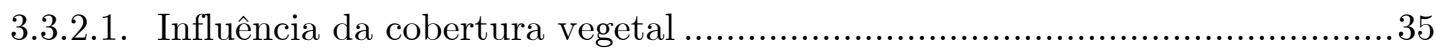

3.3.2.2. Influência da incidência de radiação solar direta........................................ 36

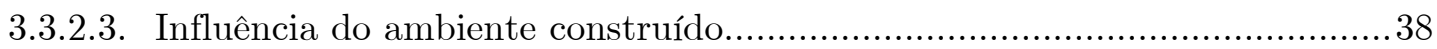




\section{CAPÍTULO 2 - Variabilidade e Mudanças Climáticas Globais..............................41}

4.1. Mudanças climáticas recentes: o aquecimento global antropogênico..........................42

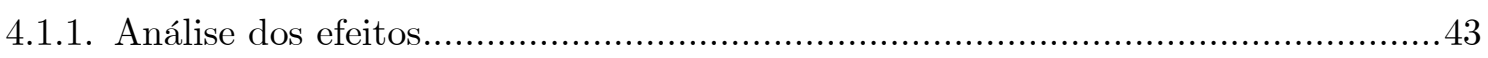

4.1.1.1. Aumento do nível médio do mar ..........................................................43

4.1.1.2. Aumento da temperatura média na superfície terrestre ...........................45

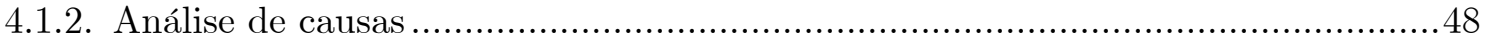

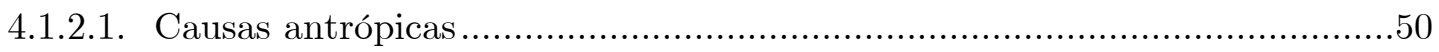

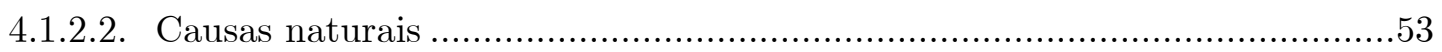

4.1.3. Atribuição de causas das mudanças climáticas recentes .....................................53

4.2. Mudanças climáticas passadas (paleoclimáticas): variabilidades naturais...................55

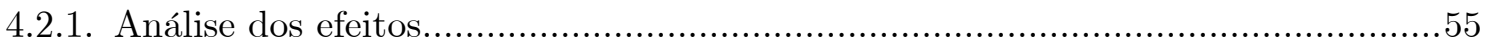

4.2.1.1. Variações do nível médio do mar...........................................................55

4.2.1.2. Variações da temperatura média na superfície terrestre.............................57

4.2.1.3. Síntese em escala geológica......................................................................58

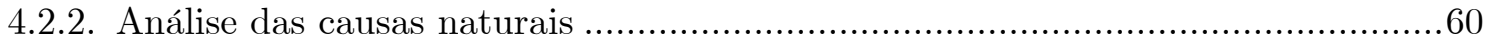

4.2.2.1. Variações das emissões solares.................................................................61

4.2.2.2. Variações orbitais terrestres .................................................................66

4.2.2.3. Variações da atmosfera e superfície terrestre.............................................71

4.2.2.4. Outras causas naturais de mudanças climáticas ........................................75

4.2.3. Atribuição de causas das mudanças climáticas no passado .................................82

4.2.3.1. Síntese em escala geológica ............................................................ 82

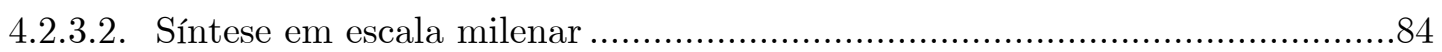

4.3. Mudanças climáticas futuras: projeções e cenários ................................................... 85

4.4. Considerações e Discussões: aprofundamento, ponderação e controvérsias ..................88

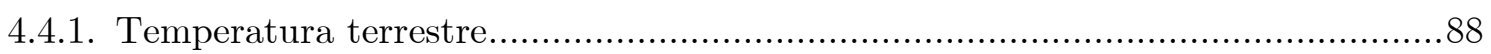

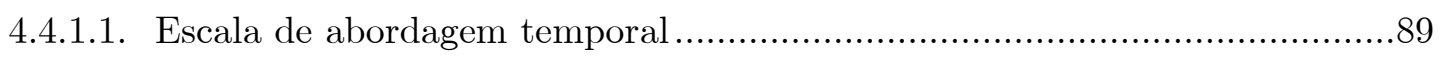

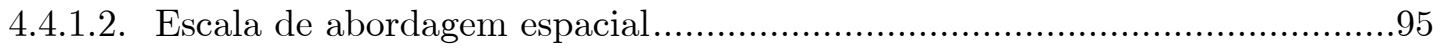

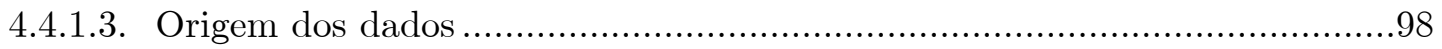

4.4.1.4. Ordem de grandeza utilizada na escala de temperatura ...........................107

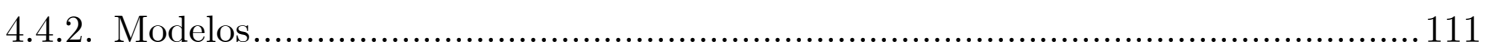

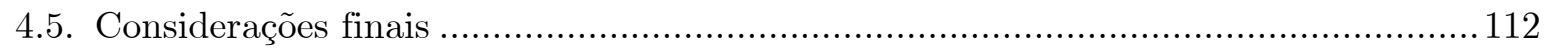

5. CAPÍTULO 3 - Caracterização e Tendências Climáticas Locais ........................ 117

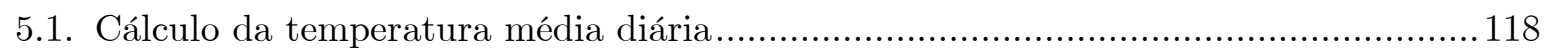

5.2. Cálculo da temperatura média mensal e anual: Normais climatológicas ....................123 
5.3. Controle de qualidade e homogeneização: identificação e remoção de

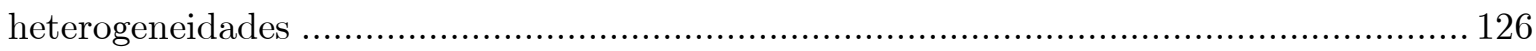

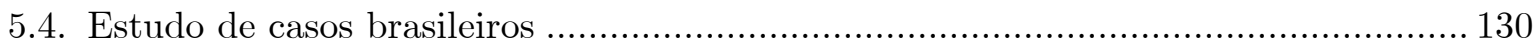

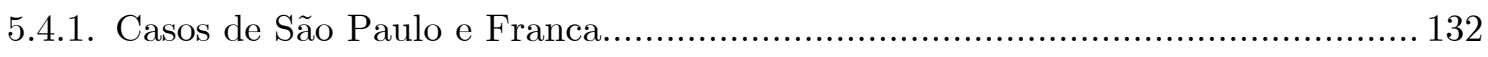

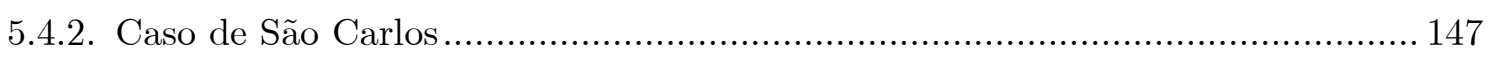

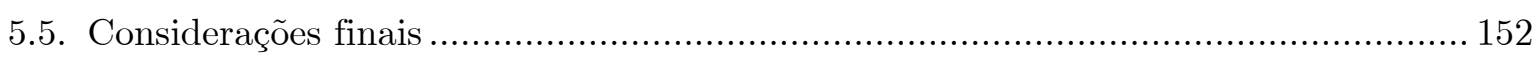

6. CAPÍtulo 4 - Mudanças dos Horários de Observações e dos Cálculos de

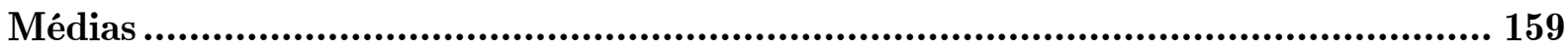

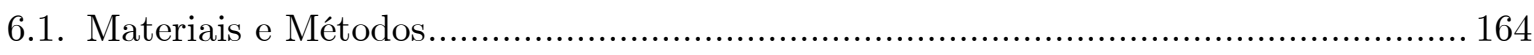

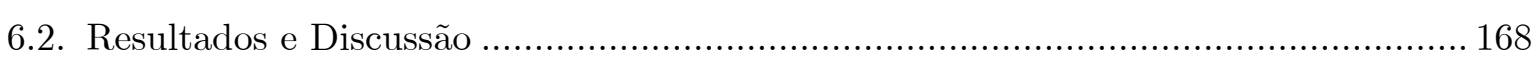

6.2.1. Caracterização e tendências: confecção das normais............................................ 168

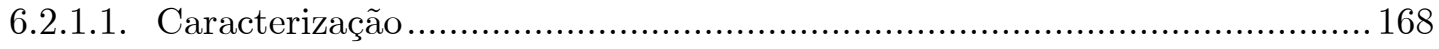

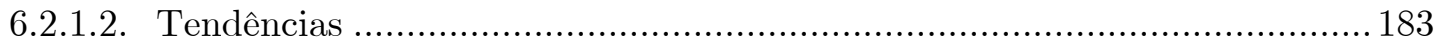

6.2.2. Comparações de diferentes fórmulas: implicações a curto, médio e longo prazo 194

6.2.2.1. Comparações com dados obtidos em instrumentos convencionais............. 196

6.2.2.2. Comparações com dados obtidos em instrumento automático ...................205

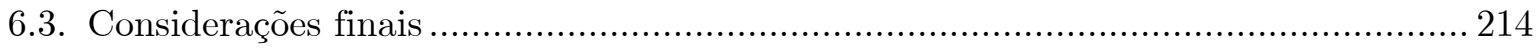

7. CAPÍTULO 5 - Mudanças dos Instrumentos ............................................. 219

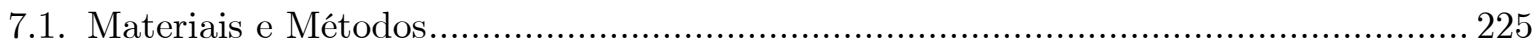

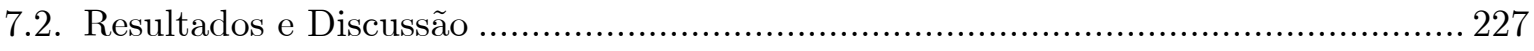

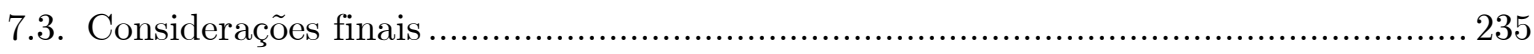

8. CAPÍTUlO 6 - Mudanças dos Abrigos ................................................. 237

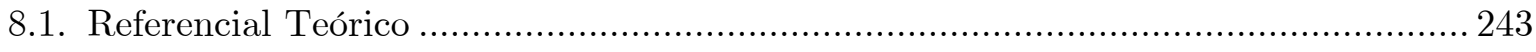

8.2. PARTE A - Causas e efeitos de curto prazo: as influências dos ventos e das trocas de calor por radiação nas medições da temperatura do ar ................................................ 244

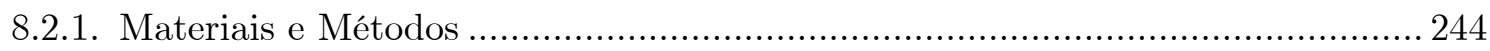

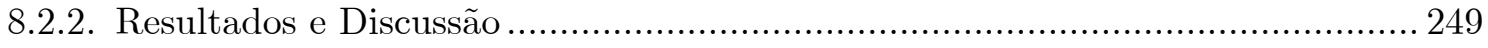

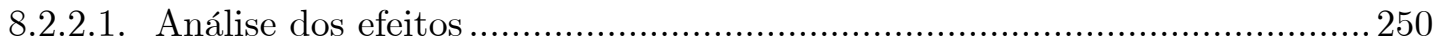

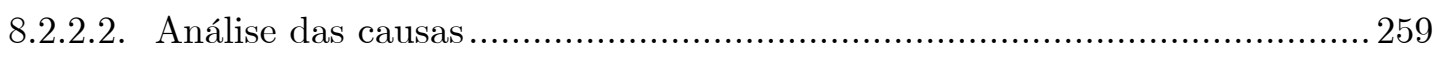

8.3. PARTE B - Efeitos de médio e longo prazo: repercussões das influências nas escalas

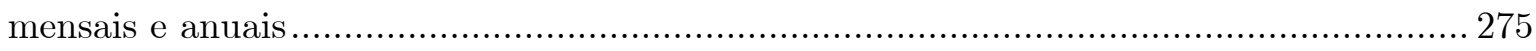

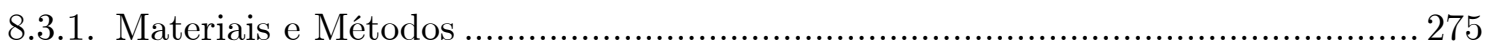

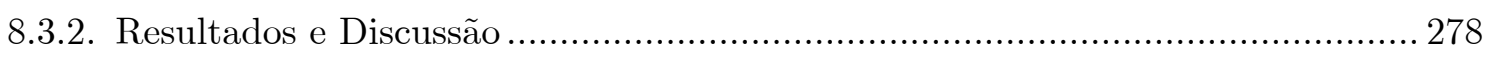

8.3.2.1. Análise rítmica anual dos desvios de temperatura do ar ......................... 291 
9. CAPÍTULO 7 - Implicações e repercussões no contexto da interação entre Ciência, Mídia, Política e Economia ...................................................................... 301

9.1. Breve histórico das Mudanças Climáticas ............................................................ 302

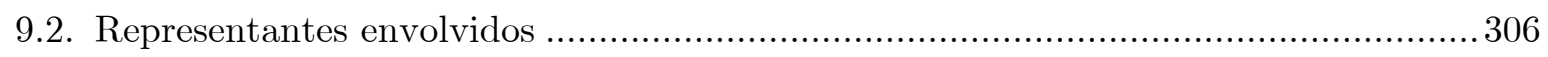

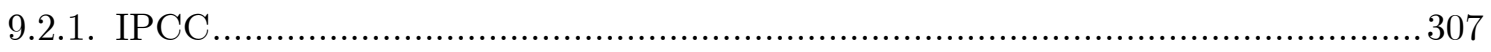

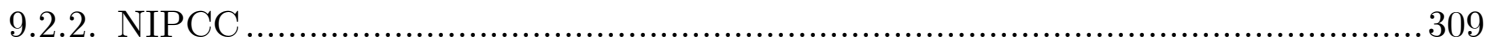

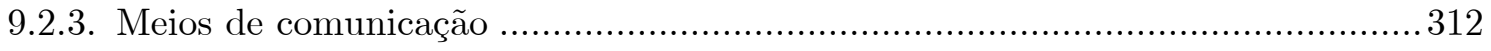

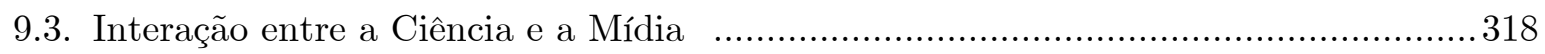

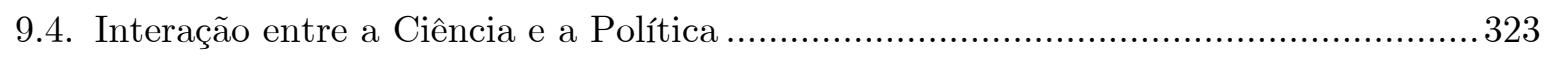

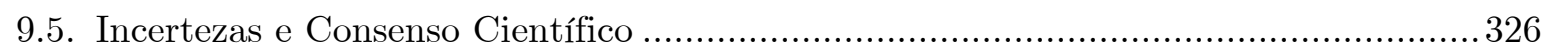

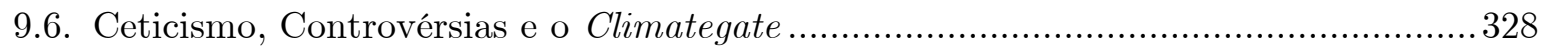

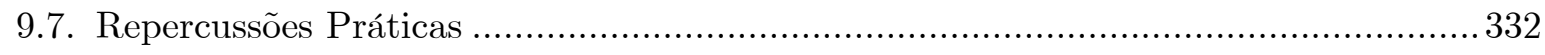

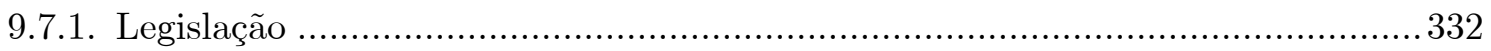

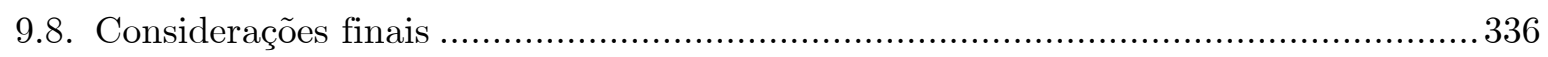

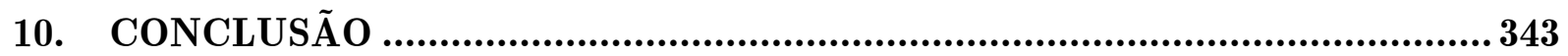

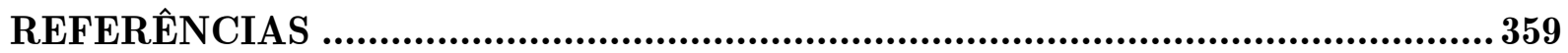

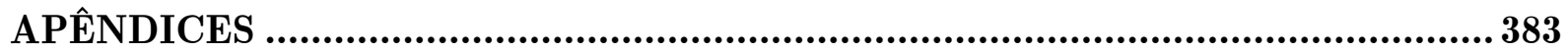




\section{INTRODUÇÃO}

A humanidade tem sido fascinada e afetada pelo clima desde os primórdios. A vida dos povos agrícolas primitivos estava ligada ao ciclo das estações chuvosas e secas, assim o homem pré-histórico precisava observar o tempo para saber quais eram as melhores épocas para colheita e semeadura. Não somente atreladas à agricultura, as condições climáticas estão vinculadas a diversas atividades humanas na atualidade: produção de energia, construção civil, transporte, lazer, entre outras atividades cotidianas.

Da mesma forma que o clima afeta o homem, igualmente o homem pode afetar o clima, em diferentes escalas espaciais e temporais. O aumento da temperatura média na superfície terrestre no último século, popularmente conhecido como "aquecimento global" - fenômeno dito como maior evidência na questão das mudanças antropogênicas no clima - pode estar relacionado ao aumento do efeito estufa decorrente do aumento de emissões de gases do efeito estufa, especialmente devido ao dióxido de carbono oriundo da queima de combustíveis fósseis.

Ao homem tem sido atribuída a responsabilidade de ser o principal indutor das mudanças climáticas recentes. Entretanto, as causas de mudanças climáticas não são exclusividade da humanidade; são variadas e estão sujeitas a diversos fatores naturais: variações da radiação solar; variações dos parâmetros orbitais terrestres; variações da composição atmosférica e superfície terrestre causadas por atividades vulcânicas e colisão de meteoritos e cometas; variações dos raios cósmicos; tectonismo etc. Muitas destas causas naturais, que tem ocorrido há milhões de anos, possuem uma magnitude de influência extraordinária, capazes de deflagrar eras glaciais, cuja amplitude de variação da temperatura média global pode atingir cerca de $10^{\circ} \mathrm{C}$ entre um período glacial frio, ocorrido há 20 mil anos atrás, e um período interglacial quente, momento presente. Em contraste, as mudanças observadas na temperatura desde 1900 representam um aumento de cerca de $0,6^{\circ} \mathrm{C}$ no valor global.

Apesar de a temperatura do ar na superfície terrestre (troposfera) ser uma variável resultante de diversos processos - logo a temperatura não representa uma boa variável para o estudo do clima e suas mudanças, já que ela mascara os processos anteriores a ela - ela tem sido utilizada como variável básica no estudo e na análise 
do clima, devido a sua atual e relevante possível atribuição dos impactos de responsabilidade da ação antrópica nas mudanças climáticas globais. Portanto, para monitorar a mudança climática de forma adequada e determinar em que medida as influências antrópicas estão contribuindo para as mudanças climáticas observadas, é fundamental dispor de dados de temperatura de alta qualidade. Em particular, é importante ter os dados de temperatura cujas alterações reflitam mudanças reais no clima e não mudanças das circunstâncias em que as temperaturas foram tomadas.

Existem inúmeros fatores não-climáticos (heterogeneidades) que podem influenciar na medição de temperatura na superfície terrestre. Algumas dos mais significativos incluem mudanças na localização do local de observação, as alterações do ambiente local em torno de um local de observação (seja por causa da urbanização ou por quaisquer outras razões) e as mudanças nas práticas utilizadas para a tomada de observações. Todas estas heterogeneidades têm o potencial, se não forem corrigidas, de influenciar nos registros de temperatura em locais individuais cuja magnitude dos erros é similar ou maior do que a tendência de aquecimento observado no último século na escala global. Ou seja, podem ocorrer erros na ordem de até $10^{\circ} \mathrm{C}$ - na escala horária de uma medição de temperatura do ar - devido à influência de heterogeneidades indesejadas; enquanto que, em contraste, o aquecimento observado no último século foi de $0,6^{\circ} \mathrm{C}$.

Uma vez realizada a medição de temperatura, esta requer armazenamento, transmissão e envio a um sistema de registros digitais. Em todas essas etapas, erros ou modificações, potencialmente incorretas e não registradas, podem ser incorporados à série de dados. Qualquer erro na aquisição de registros da temperatura implica na redução da confiança nas previsões não só das condições climáticas existentes, assim como das previsões das mudanças do clima, ou na determinação de possíveis mudanças climáticas em distintas escalas de abordagem tempo e espaço.

Logo, é crucial a identificação e a remoção destes erros, sendo necessária a correta distinção das mudanças climáticas reais das virtuais, estas causadas por mudanças de técnicas de observação, mudanças dos instrumentos e abrigos térmicos para os sensores de temperatura, mudanças nos cálculos das temperaturas médias diárias, mudanças da posição da estação e mudanças nas características dos arredores do local das medições.

Sendo a temperatura terrestre a principal evidência utilizada no contexto da discussão das atribuições das mudanças climáticas recentes, de causas naturais ou antropogênicas, e considerando as incertezas e erros associados no processo de 
medição desta grandeza física, este trabalho visou verificar e quantificar a influência das heterogeneidades em séries de temperatura, sob o enfoque de diferentes escalas temporais: horárias, diárias, mensais, anuais e normais (média de 30 anos).

Justifica-se o propósito da realização do trabalho, neste contexto de atualidade e relevância da pesquisa no panorama mundial, não somente pelo estudo de caráter científico da quantificação das incertezas nas medições incorporadas devido a heterogeneidades; mas, igualmente ressalta-se a importância no sentido de se avaliar a responsabilidade do uso de dados gerados pela Ciência como evidências de um processo de tomada de decisão política, a qual afeta a vida de toda uma sociedade por meio de regulamentações previstas em leis. Ou seja, evidências científicas possuem implicações práticas para a população em geral, e, dependendo do objetivo que se pretende satisfazer, as incertezas podem ser desprezadas, ignoradas e intencionalmente manipuladas em favorecimento de determinados interesses. Uma discussão é realizada neste sentido, avaliando as interações entre a Ciência, os meios de comunicação, a Política e a Economia no contexto das mudanças climáticas.

\section{Organização do trabalho}

Para facilitar a compreensão do tema vasto e complexo, o trabalho está organizado na forma de capítulos.

No "CAPÍTULO 1 - Base Conceitual" (pg. 9) são abordados conceitos fundamentais sobre: a Climatologia, com a definição de clima, suas abordagens clássica e dinâmica, os elementos e escalas climáticas; e sobre a temperatura, o que ela representa, como ela é determinada (medida ou estimada) e quais os tipos de erros e influências estão associados às medições.

Para contextualização, o "CAPÍTULO 2 - Variabilidade e Mudanças Climáticas Globais" (pg. 41) apresenta conceitos relacionados às questões dos efeitos e das causas, naturais e antropogênicas, das mudanças climáticas. Com uma abordagem nas escalas do presente, passado e futuro, procurou-se identificar os principais fenômenos envolvidos e ilustrar suas magnitudes relativas de influência no clima terrestre.

Uma vez entendido o clima e suas mudanças em escala global, o "CAPÍTULO 3 - Caracterização e Tendências Climáticas Locais" (pg. 117) enfoca no estudo de séries locais de temperatura, estas que, reunidas, representam a base dos valores globais. Neste capítulo, foi oferecida uma primeira abordagem de séries de 
temperatura do ar, em algumas cidades brasileiras, na escala de normais climatológicas (médias de 30 anos de dados). Antes de chegar à escala das normais, inicialmente descreveu-se como que são determinadas as temperaturas médias diárias, mensais e anuais.

Considerando os diferentes métodos de cálculos de médias da temperatura diária levantados no Capítulo 3, no "CAPÍTULO 4 - Mudanças dos Horários de Observações e dos Cálculos de Médias" (pg. 159) é apresentado um estudo descritivo e comparativo das principais fórmulas utilizadas no cálculo da temperatura do ar. Preliminarmente à comparação, elaborou-se a normal climatológica para uma série local, a qual representou o referencial de comparação. Na sequência, foram comparadas algumas fórmulas, verificando tendências e erros relativos à referência adotada em cada caso.

No "CAPÍTULO 5 - Mudanças dos Instrumentos" (pg. 219) foram analisadas as diferenças provocadas pela substituição de instrumentos analógicos por digitais. Para isto, foram comparados os dados contínuos de temperatura do ar de duas séries obtidas em um mesmo período, sendo uma série proveniente de uma estação convencional com termógrafo, e outra série oriunda de uma estação automática 21X, Campbell Scientific.

Além dos diferentes tipos de sensores de temperatura, os abrigos que os protegem foram avaliados, quanto ao seu desempenho, no "CAPÍTULO 6 Mudanças dos Abrigos" (pg. 237). Foram determinadas as influências do fluxo dos ventos e das trocas por radiação nas medições automáticas da temperatura do ar a curto e médio prazo, por meio de abrigos experimentais de baixo custo, compatíveis com abrigos comerciais, os quais possuíam termopares conectados a um sistema aquisição e de armazenamento de dados modelo CR10X Campbell Scientific.

Por fim, o último capítulo, possui uma vertente diferente da até então adotada nos capítulos anteriores. Esquivando um pouco do estudo aprofundado das medições das temperaturas, o "CAPÍTULO 7 - Implicações e repercussões no contexto da interação entre Ciência, Mídia, Política e Economia" (pg. 301) abordou aspectos do uso da informação científica em um contexto mais amplo, abrangendo a participação e conduta de outros setores, além da Ciência, envolvidos com a temática climática: a Mídia, a Política e a Economia. A discussão das implicações práticas permeou as evidências e incertezas sob o enfoque destas áreas. Na medida do possível, procurou-se identificar os interesses envolvidos. Inevitavelmente, a disputa de diferentes interesses 
gera controvérsias, aspecto que foi levantado em diferentes momentos ao longo de todo trabalho, mas que neste capítulo final foi descrito com mais detalhes. 



\section{OBJETIVOS}

O objetivo principal do estudo foi verificar a ocorrência de heterogeneidades em séries da temperatura do ar, obtidas em estações terrestres, e determinar a magnitude dos efeitos, nas escalas de curto, médio e longo prazo, quando comparados a uma referência. Em um contexto de discussão das mudanças climáticas, um segundo objetivo, decorrente dos resultados das análises das séries, teve o propósito de ponderar a confiabilidade do uso, no processo de tomada de decisão, da temperatura do ar, cujos valores podem estar incorporando valores não-climáticos, e, portanto, as incertezas embutidas poderiam invalidar a utilização destas evidências como indicadoras fiéis de mudanças reais no clima.

De acordo com o tipo de heterogeneidade analisado, uma série, em princípio mais confiável, foi adotada como referência e a ela foram comparadas as demais séries. Em termos do desvio, ou seja, da diferença dos valores em análise com os de referência, pretendeu-se determinar quais as ordens de grandeza verificadas nas escalas horária, diária, mensal, anual e normal (média de 30 anos).

Dentre as principais causas de heterogeneidades, procurou-se avaliar: mudanças de técnicas de observação (mudanças de horários de observação e nos cálculos da temperatura média diária); mudanças dos tipos de instrumentos utilizados, especialmente quando considerada a tendência de substituição de estações convencionais pelas automáticas; mudanças nos abrigos meteorológicos; mudanças da localização da estação; e mudanças dos entornos locais em que se situava a estação na ocasião das medições.

Uma vez quantificada as incertezas inerentes a cada fator analisado, procurouse estabelecer uma discussão da implicação do uso das evidências no contexto social mais amplo, considerando os aspectos políticos, midiáticos e econômicos, na tentativa de compreender qual a postura adotada por cada área frente às mudanças climáticas. Assim, procurou-se identificar os possíveis entrelaçamentos dos interesses setoriais com os do meio científico. 



\section{CAPÍTULO 1 - Base Conceitual}

A compreensão de três conceitos básicos será fundamental nas análises ao longo de todo o trabalho: o que é o clima, o que é a temperatura e como ela é determinada (medida ou estimada).

\subsection{O Clima}

Algumas considerações são necessárias para a compreensão dos fenômenos climáticos. A primeira dela é a própria definição e diferenciação entre tempo e clima. Ambas são combinações realizadas por certos valores de elementos climáticos, tais como temperatura do ar, umidade, pressão, regime de ventos, pluviosidade, entre outros. Tais combinações são chamadas de estado da atmosfera. O tempo se caracteriza por um estado passageiro e efêmero da atmosfera; enquanto que o clima é caracterizado por um conjunto de tendências duradouras, oriundas de combinações permanentes analisadas e estudadas ao longo de um período, definido por normais, de no mínimo 30 anos (VECCHIA, 1990).

Portanto, o clima pode ser entendido como um conjunto de elementos estudados por meio de registros meteorológicos ao longo de muitos anos, enquanto que o conceito de tempo pode ser visto como a experiência atual, momentânea, ou seja, que expressa as condições atmosféricas observadas em um determinado instante na atmosfera (CUNHA; VECCHIA, 2007).

\subsubsection{Abordagens clássica e dinâmica}

A Climatologia - área do conhecimento na qual se estudam as características da atmosfera em contato com a superfície terrestre e a divisão espacial dessas características - apresentou uma evolução nos conceitos de clima, em que se verificam duas diferentes abordagens: a clássica e a dinâmica. 


\section{- Climatologia Clássica}

As definições clássicas do clima, propostas por $\operatorname{Hann}^{1}$ (1882, apud SORRE, 2006) e Köppen² (1948, apud PITTON, 1985) compreendiam o clima como o estado médio da atmosfera sobre um lugar, fundamentadas em parâmetros estáticos, cujo objetivo era calcular as médias, abrangendo longas séries de observações e, por meio da avaliação de cada uma destas e de sua comparação, se chegar à caracterização do clima.

Porém, de acordo com Conti (1997), as dificuldades encontradas nessa abordagem quando do trato da realidade e o elevado grau de abstração do método. A Climatologia Clássica não vai além da descrição, quase nada contribuindo para a explicação ou gênese dos fenômenos climáticos.

\section{- Climatologia Dinâmica}

No início da segunda metade do séc. XX, rompendo com a concepção estática do clima, Sorre (1951) foi o responsável pela introdução de uma definição do clima como a "síntese do tempo" ou "ambiente atmosférico constituído pela série de estados da atmosfera acima de um dado local, em sua sucessão habitual" (Tipos de Tempo).

A grande vantagem desse conceito de clima, segundo Tarifa e Armani (2001), é o dinamismo que se atribuiu ao clima, dado pela sucessão habitual. Enquanto que para Hann (1882) o que definia o clima de um lugar era o estado médio da atmosfera, o movimento e o encadeamento de tipos de tempo vinculam-se mais com a vida e com as práticas sociais e econômicas.

Em uma nova abordagem, a Climatologia Dinâmica consiste no estudo do clima por meio de eventos climáticos, perspectiva distinta da proposta clássica, que estuda o clima utilizando-se de medições de longos períodos e desvinculada das condições dos fenômenos da atmosfera (SPECIAN, 2003).

No Brasil, essa visão da climatologia foi introduzida por Monteiro (1969, 1971 e 1973), que define o clima como sendo a "sucessão habitual dos tipos de

\footnotetext{
${ }^{1}$ HANN, J. Handbuch der Klimatologie, Wien. 1882.

${ }^{2}$ KÖPPEN, W. Climatología. Sección de Obras Geografía, México: Editorial Fondo de Cultura Económica 1948. $478 \mathrm{pp}$.
} 
tempo". Nimer ${ }^{3}$ (1979, apud SPECIAN, 2003) destaca a importância dos estudos de massas de ar como fundamento da climatologia moderna. O estudo do deslocamento, frequência e intensidade das massas de ar, constituem a base da climatologia dinâmica.

A análise dinâmica do clima volta-se ao estudo do ritmo climático de uma determinada localidade. Segundo Monteiro (1971), o ritmo climático só poderia ser compreendido por meio da representação concomitante dos elementos fundamentais do clima, em unidade de tempo cronológico, pelo menos diários, compatíveis com a representação da circulação atmosférica regional, geradora dos estados atmosféricos que se sucedem e constituem o fundamento do ritmo.

Para Monteiro (1969), o ritmo é a essência da análise dinâmica, sendo que a sequência, sucessão de tipos de tempo, ou seja, encadeamento dos estados atmosféricos sobre determinado local, é que conduz ao ritmo. Dessa forma, a análise dinâmica reveste-se de um estudo dos tipos de tempo, sobre um determinado lugar, considerando os valores reais registrados e usando a análise do ritmo climático para interpretar o fenômeno atmosférico.

\subsubsection{Frentes e massas de ar}

Entre os conceitos meteorológicos mais difundidos, destacam-se os termos massas de ar e frentes. Massa de ar é definida como uma grande porção de ar, de grande área, que apresenta certa homogeneidade horizontal, em que as propriedades físicas são quase uniformes no mesmo nível, principalmente em relação à temperatura e umidade (ANUNCIAÇÃO, 1984). Por frente, entendese que é a linha de contato dentre duas massas de ar, de qualidades diferentes, formando uma instabilidade térmica e barométrica, sendo, portanto, uma zona de instabilidade (DEFFUNE, 1993).

\subsubsection{Ritmo climático e episódios representativos}

De acordo com a penetração de massas de ar frio sobre uma dada região, podem ser identificados processos cíclicos ou séries, mas não necessariamente

\footnotetext{
3 NIMER, E. Climatologia do Brasil. Série recursos naturais e Meio Ambiente, N. 4. Rio de Janeiro: FIBGE - Superintendência de Recursos Naturais e Meio Ambiente (SUPREN). 1979.
} 
com períodos regulares entre as fases dos eventos. As massas polares (por exemplo, a massa Polar Atlântica - mPA) adentram no sudeste brasileiro ao longo do ano todo, variando-se a intensidade e o rigor das mesmas. Esta sucessão de entradas de massas polares sobre o sudeste brasileiro permite ainda identificar o seu padrão cíclico, denominado por Monteiro (1967), de sucessão encadeada de tipos de tempo. O encadeamento de tipos de tempo remete ao estudo dinâmico do clima, situação em que os mecanismos da circulação da atmosfera são imprescindíveis para a sua compreensão. Decorre dessa abordagem a constituição de episódios de clima, sequência de dias em que ocorre a atuação de uma massa de ar polar, dividida em quatro fases distintas:

1. Prenúncio da penetração de uma massa polar sobre a região definida;

2. Avanço da frente fria sobre a região (momento da entrada da frente e efetiva atuação da massa polar);

3. Dominio da massa polar; e

4. Transição ou Tropicalização da massa polar.

De acordo com Monteiro (1967), os estados atmosféricos podem ser subdivididos em duas categorias básicas: a etapa pré-frontal e a pós-frontal:

- Pré-frontal: expressa os períodos que antecedem a penetração da frente fria e é subdividida nas fases de prenúncio e avanço. Caracteriza-se pela elevação dos valores de temperatura do ar e pela redução dos valores da umidade do ar; e na fase de avanço, pela queda da pressão atmosférica e pela ruptura do regime de ventos predominantes - ocorrência de ventos com velocidades muito acima dos valores habituais (rajadas).

- Pós-frontal: expressa os períodos que sucedem a penetração da frente fria e divide-se nas fases de domínio e transição. É caracterizado pela redução dos valores de temperatura do ar e pela elevação da umidade do ar, dependendo das propriedades da massa de ar dominante. Pode estar acompanhada de períodos chuvosos e com ventos predominantes nesse período, oriundos de direções distintas dos da fase anterior, apresentando comportamento também diferenciado de suas velocidades. Percebe-se também um aumento da pressão atmosférica. 
Os episódios podem ser recortados de acordo com a necessidade de cada estudo, sem perder a precisão e a representatividade dos dados meteorológicos, que, obedecendo à gênese do clima, permite análise mais apurada e conclusões mais próximas da realidade concreta.

\subsubsection{Componentes climáticos}

O estudo do clima e o conhecimento de sua gênese implicam necessariamente no entendimento dos fatores relacionados à circulação atmosférica e marítima global e os elementos fisiográficos que atuam como modificadores do clima em diversas regiões (SILVA, 2001).

\subsubsection{Fatores genéticos}

Os fenômenos meteorológicos têm origem na radiação solar e nas circulações atmosférica e marítima, fatores dinâmicos que condicionam inicialmente o clima. Detalhadamente, tem-se:

- Radiação solar: fator predominante e mais importante do clima, pois promove processos de trocas térmicas globais em função do aquecimento da superfície terrestre. A absorção de energia é maior na faixa equatorial (superávit energético), decrescendo com o aumento das latitudes até os pólos (déficit de energia). O processo de transferência da energia absorvida na faixa equatorial em direção aos pólos ocorre por meio da circulação geral da atmosfera e das correntes marítimas (STRAHLER ${ }^{4}$, 1971, apud CARLETTO, 2005).

- Circulação geral da atmosfera: este fator decorre da ação combinada de dois fatores principais: 1. Força térmica - a exemplo da lei dos cossenos, da lei das massas e o fotoperíodo, que tende a igualar o aquecimento diferencial das diversas zonas, estabelecendo uma circulação meridiana (direção norte-sul); e 2. Força dinâmica - provocada pela rotação da terra e que introduz uma profunda modificação no fluxo de ar (força de

\footnotetext{
${ }^{4}$ STRAHLER, A. N. The earth sciences. 2d. Ed. New York: Harper \& Row. 1971.
} 
Coriolis), que tende a definir uma circulação zonal (sentido leste-oeste) (VECCHIA, 2001).

- Correntes marítimas: transferem o calor das regiões quentes para as regiões frias, por meio de suas correntes quentes. O mesmo processo, inversamente, arrefece as regiões menos quentes, com a ação das correntes frias. As correntes atuam de duas maneiras principais sobre o espaço geográfico: aumentando os valores de pressão de vapor d'água (umidade do ar); e modificando o regime de ventos predominantes (VECCHIA, 2001).

\subsubsection{Fatores modificadores}

Uma vez determinadas as condições iniciais do clima, fatores estáticos (geográficos, topológicos, biológicos e culturais) atuam sobre elas e criam variações localizadas. Quase sempre, essas variações assumem magnitudes extraordinárias, sendo necessária a distinção em escalas climáticas (macro, meso, local e microclima). Vecchia (1990) resume os principais fatores modificadores na seguinte ordem decrescente de magnitude:

- Geográficos: latitude; altitude/elevação acima do nível do mar; e relação entre massas de terra e água.

- Topográficos: elevação; orientação do sol; e estrutura do solo.

- Biológicos: fauna (incluindo os microorganismos) e flora.

- Culturais: alterações do solo pelo ambiente construído (asfalto, edificações); poluição atmosférica (quantidades de poeira, fuligem e gases do efeito estufa diferentes das fontes naturais); modificação da dinâmica hidrológica (redução da capacidade de retenção de água devido ao aumento do escoamento superficial e redução da infiltração impermeabilização).

\subsubsection{Fatores resultantes (elementos climáticos)}

A designação elementos do clima é preferível em relação a elementos meteorológicos, uma vez que a primeira é mais ampla e inclui não só as 
condições dos fenômenos meteorológicos (fatores genéticos), mas, igualmente, as influências desempenhadas pelas condições exercidas pelas condições do local (fatores modificadores). Segundo Vecchia (1990, 2001), os elementos do clima são:

- Temperatura do ar;

- Umidade do ar;

- Pressão atmosférica;

- Ventos predominantes (sentido e velocidade);

- Nebulosidade; $e$

- Precipitações atmosféricas (chuva, neve, granizo).

\subsubsection{Escalas de abordagem têmporo-espacial}

A escolha adequada da escala de abordagem, no tempo e espaço, é componente importante na análise dos elementos do clima, tendo em vista a adequação da representatividade e a resolução dos dados climáticos com os quais se trabalha.

Nesse contexto, Cuadrat e Pita (1997) ressaltam que na análise de clima é comum diferenciar quatro escalas, onde cada uma delas tem características próprias e permite níveis diferentes de generalizações. São elas:

- Macroclimática: ou clima zonal, que representa o campo das grandes áreas geográficas, de milhares de $\mathrm{km}^{2}$ de superfície, controlado pela circulação geral da atmosfera. A permanência temporal de um estado climático, nesta escala, pode durar de uma semana a alguns meses.

- Mesoclimática: ou clima regional, que constitui uma faixa do clima zonal de dimensões lineares variando entre 200 a $2000 \mathrm{~km}$, com tempo de atuação de 1 a 30 dias. A compreensão dos climas de escala regional apóia-se na busca do ritmo da variação anual, sazonal e mensal dos elementos do clima e estes, por sua vez, estão ligados aos centros de ação intermediários, que ocorrem entre a circulação geral e secundária, e podem ser representados pelas massas de ar e frentes.

- Local: corresponde a unidades menores do clima regional, apresentando significativas variações em seu interior devido à ação de determinadas feições fisiográficas ou antrópicas, com extensão no sentido horizontal 
entre 100 e $1.000 \mathrm{~m}$, e no sentido vertical, em torno de $100 \mathrm{~m}$. Apresenta escala temporal análoga à escala do nível regional.

- Microclimática: representa os climas de lugares pequenos e bem delimitados, onde a natureza dos elementos climáticos está muito mais condicionada por fatores do entorno imediato do que por fatores regionais. Permite o registro de pequenas mudanças ambientais em condições muito específicas (na maioria dos casos a menos de 2,0 m de altura), e em períodos de tempo curto, porque a proximidade com o solo faz com que as variações das condições atmosféricas sejam muito rápidas.

A Figura 1, a seguir, representa as escalas do clima propostas por Cuadrat e Pita (1997).

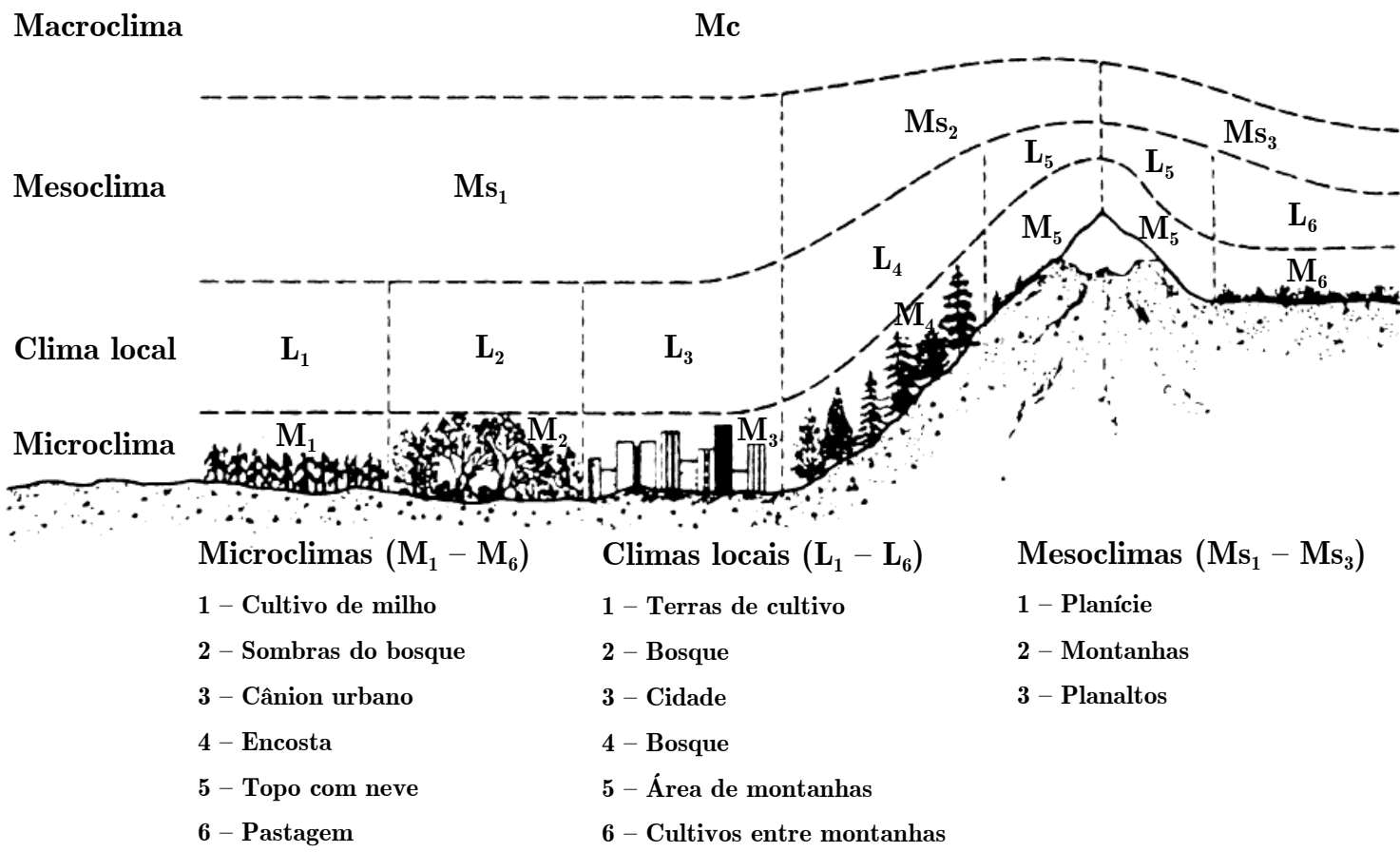

Figura 1 - Esquema representativo das escalas empregadas nos estudos climáticos. Fonte: Cuadrat e Pita (1997).

Quanto à escala temporal, Cuadrat e Pita (1997) indicam que três escalas temporais de análise são usadas com mais frequência: paleoclimática, secular e instantânea. A escala paleoclimática intenciona reconstruir as condições atmosféricas do passado, com investigações apoiadas em evidências do tipo 
geológico. As escalas secular e instantânea se apóiam em fontes diretas procedentes de estações de observação meteorológica existentes em superfície e por meio de sensores remotos instalados em satélites.

\subsubsection{O clima de São Carlos}

São Carlos, município situado no estado de São Paulo, tem como coordenadas geográficas $22^{\circ} 01^{\prime} 23$ " de latitude sul, $47^{\circ} 53^{\prime}$ 60" de longitude oeste, e possui altitude média de $855 \mathrm{~m}$. Sua localização em planalto, e dividindo as bacias do Rio Pardo e Tietê, impõe características climáticas específicas, que são acentuadas pela sua situação topográfica, estando sujeita a intensa ocorrência de ventos e insolação.

\section{- Visão clássica}

De acordo com a visão clássica da climatologia, que toma por parâmetro as normais climatológicas, o clima de São Carlos é do tipo Cwa de acordo com a classificação de Köppen, sendo $C$ - grupo mesotérmico; $w$ - inverno seco e frio; $a$ - verão quente e úmido, em que a temperatura média do ar no mês mais quente é maior do que $22^{\circ} \mathrm{C}$. (PITTON, 1985)

\section{- Visão dinâmica}

Carletto (2005) define que, de um modo geral, na fase de prenúncio e avanço, pode-se caracterizar o comportamento do clima de São Carlos por meio de seus elementos climáticos, que sofrem significativas variações. Por exemplo, nessas fases, conforme tendência habitual, o regime de ventos apresenta ventos de nordeste (NE) como a frequência de ocorrência de maior expressão. Na entrada da frente, surgem ventos episódicos de sudoeste (SW) e de noroeste (NW), quase sempre apresentados com elevadas velocidades do ar e na forma de rajadas.

Na fase de dominio é possível observar uma profunda alteração na direção dos ventos, que assume nessa fase o sentido sudeste-noroeste. Surgem assim, os ventos de sudeste (SE), de escala zonal, que atuam na região devido a sua 
localização geográfica, principalmente, em função da altitude e da localização na parte mais alta e desprotegida das cuestas basálticas existentes. São ventos frios e úmidos, com velocidades em torno de 3,0 m/s (CARLETTO, 2005).

De forma geral, a fase pré-frontal apresenta as seguintes características (CARLETTO, 2005):

- Tempo quente e seco: tendência geral dessa relação entre temperatura e a umidade do ar. A temperatura do ar tende a se elevar e, ao contrário, os valores da umidade relativa tendem a diminuir.

- Pressão atmosférica: sofre uma diminuição dos valores.

Já as características da fase pós-frontal são:

- Tempo frio e úmido: tendência mais habitual depende do vigor da frente fria, que carrega diferentes proporções de umidade, uma vez que as massas polares são formadas nas proximidades dos círculo polar antártico sobre os oceanos (anticiclones migratórios ou móveis) e penetram em direção às latitudes menores, devido a um jogo de ciclones transientes que forçam o escoamento do frio até a América do Sul.

- Pressão atmosférica: sofre uma descontinuidade no seu ritmo, rompendo a maré barométrica habitual e, posteriormente, assume valores mais elevados na fase de domínio da massa polar.

\subsection{A Temperatura}

Antes de qualquer estudo aprofundado da utilização da temperatura no âmbito da interpretação climática, se torna imprescindível a sua definição, as formas de medição, os erros e as influências associadas a sua medição.

\subsubsection{Definição e erros}

A temperatura é definida por Emiliani (1987) como sendo o nível da energia cinética interna de um sistema ou de um corpo. A energia interna, por sua vez, é resultante da movimentação de seus constituintes atômicos e moleculares. Ao conceito de temperatura está associado intrinsecamente o conceito de calor. Isaacs (1985) acrescenta que a temperatura é uma 
propriedade física de um corpo ou de região do espaço que determina se haverá transferência de calor para, ou, de sua vizinhança. Se não há transferência de calor entre os corpos ou regiões, eles estão em equilíbrio termodinâmico e, logo, na mesma temperatura; se há transferência, o calor será transferido da região de maior temperatura para a de menor temperatura (GRAY; ISAACS, 1975).

Se há alguma premissa básica para medições de qualquer propriedade é essa: não existe nenhuma medida que não esteja associada a um erro, uma vez que nem o valor exato da propriedade medida nem o valor exato do erro associado à medida podem ser determinados (BENEDICT, 1984).

O erro pode ser causado por instrumentos que não estejam bem calibrados e/ou tenham más condições de uso, assim como nas usuais variações de parâmetros que afetam as medições (ASTM, 1987). Os resultados da maioria dos experimentos são baseados em medições. A confiabilidade das medidas não depende apenas das variações de parâmetros controlados, dependem também, de modo geral, de variações de fatores que não são controlados e que muitas vezes são desconhecidos. Alguns desses fatores que podem afetar as medições são: operador, equipamento, e condições do ambiente. Erros causados pelo operador e pelo equipamento podem ser minimizados por meio de leituras de diferentes observadores além de utilizar diferentes equipamentos de medição (BENEDICT, 1984).

Não obstante, medições da temperatura do ar estão submetidas a erros de diferentes proveniências, conforme será abordado nos capítulos posteriores.

\subsubsection{Transmissão de calor}

Segundo Kreith (1973), a energia térmica é transmitida sempre que existir um gradiente de temperatura no interior de um sistema ou, quando dois sistemas com diferentes temperaturas são colocados em contato. O processo pelo qual a energia é transportada é chamado de transmissão de calor. O fluxo de calor é um processo pelo qual a energia interna de um sistema é alterada em um regime não permanente, sendo o fenômeno governado por uma combinação de leis da física. Os três modos de transmissão de calor são: condução, convecção e irradiação. 


\section{- Condução}

A condução é um processo pelo qual o calor flui de uma região de maior temperatura para outra de temperatura menor nos sólidos opacos, em comunicação molecular direta, sem apreciável deslocamento relativo das moléculas. Ela também ocorre nos fluidos, mas nesse caso é normalmente combinada com a convecção e em alguns casos com a radiação (KREITH, 1973).

Em um corpo sólido, os átomos se situam em posições de equilíbrio determinadas pelo retículo cristalino, ao redor das quais eles podem oscilar. Suas vibrações são tanto mais intensas quanto maior a temperatura dos corpos. Aumentando-se a temperatura, e consequentemente, a amplitude das vibrações por aquecimento, essa vibração se propagará e a energia será transmitida das partes mais quentes para as mais frias. Após tempo suficiente para o equilíbrio ser atingido, o corpo possuirá uma temperatura uniforme (SALMONI, 1966).

A transmissão por simples condução se dá também nos líquidos e nos gases, porém é muito difícil evitar que seja acompanhada por convecção, uma vez que o aquecimento ou esfriamento de fluidos provoca via de regra a formação de correntes convectivas, devido ao gradiente de densidade.

Condutividade térmica é uma propriedade física dos materiais que descreve a habilidade de conduzir calor. Coeficiente de condutividade térmica (k) é uma característica da natureza do material. Corresponde à quantidade de energia transmitida através de um corpo homogêneo, por unidade de espessura, unidade de área e unidade de tempo.

\section{- Convecção}

É a transferência de calor entre corpos com temperaturas diferentes que devem estar em contato molecular, de forma que o começo do processo se realize por condução e depois, devido à alteração de temperatura sofrida pelo fluido, tem a sua densidade modificada, originando-se um movimento convectivo ascendente ou descendente, dependendo do modo como for a troca de calor. Ocorre, portanto, simultaneamente um fluxo não só de calor, mas também de matéria (fluido). 
Para Kreith (1973), a convecção é um processo de transporte de energia pela ação combinada da condução de calor, do armazenamento de energia e do movimento de mistura. A convecção é mais importante como mecanismo de transferência de energia entre uma superfície sólida e um líquido ou gás.

A transmissão de calor por convecção é classificada de acordo com o modo de motivação do transporte, podendo ser classificada em convecção natural e convecção forçada.

Quando o movimento de mistura tem lugar meramente como resultado das diferenças de densidades causadas pelos gradientes de temperatura, verificase a convecção natural ou livre. Quando o movimento de mistura é induzido por algum agente externo, tal como bomba ou ventilador, o processo é chamado de convecção forçada. A velocidade do ar, junto com as diferenças de temperatura, é o fator fundamental na determinação da quantidade de calor transmitido.

\section{- Irradiação}

Todos os corpos possuem energia térmica e a transforma em energia radiante por meio da emissão de ondas eletromagnéticas. As duas principais características da onda eletromagnética são o seu comprimento de onda $(\lambda)$ e a sua frequência $(v)$. A energia radiante é classificada de acordo com o comprimento de onda. Quanto menor o comprimento de onda, maior é a energia associada a esta onda.

Para Kreith (1973), radiação é um termo aplicado a todas as formas de fenômenos de ondas eletromagnéticas, mas para a transmissão de calor, só interessam as formas que resultam da diferença de temperatura. Como as ondas eletromagnéticas se propagam no vácuo, a transferência de calor de um corpo a outro ocorre mesmo se não existir meio material entre os dois, ao contrário da condução e da convecção.

A energia incidente em um corpo receptor pode ser transmitida, absorvida, e refletida em quantidades que dependem das propriedades físicas do corpo. A energia absorvida se transforma em calor, enquanto que a irradiação refletida e transmitida não sofre modificações, mantendo o mesmo comprimento de onda.

Segundo Kreith (1973), quatro principais formas de transmissão de calor por irradiação podem influenciar o comportamento dos sensores de temperatura: 
1. Radiação direta do Sol: de pequeno comprimento de onda (onda curta);

2. Radiação difusa: de pequeno comprimento de onda proveniente do céu;

3. Radiação refletida: de pequeno comprimento de onda (albedo); e

4. Radiação reemitida: de onda longa que é produzida no processo de absorção das superfícies, aquecendo o solo ou superfícies, materiais, objetos, etc.

\subsubsection{Determinação da temperatura terrestre}

A temperatura na Terra pode ser referente à temperatura próxima à superfície (esta comumente denominada de temperatura do ar na superfície terrestre) tanto sob os continentes quanto sob os oceanos; pode se referir à temperatura nos fundos de oceanos ou no fundo de poços profundos (boreholes) na superfície terrestre; ou ainda pode denotar a temperatura da troposfera (camadas superiores).

A temperatura terrestre pode ser determinada ou estimada de acordo com a escala temporal de abordagem adotada. Basicamente, está classificada em três grandes categorias:

- Passado: reconstruções por meio do resgate de informações em documentação histórica ou pela determinação indireta utilizando testemunhos e datação radiométrica;

- Presente (passado recente): medições diretas com base em estações nos continentes ou nos oceanos, satélites e radiossondas;

- Futuro: estimativas, previsões e projeções com base em modelos matemáticos e possíveis cenários.

\subsubsection{Reconstruções da temperatura no passado}

Qualquer tentativa de estabelecer e identificar mudanças climáticas no passado deve utilizar informações históricas. Uma primeira modalidade é o estudo de registros em documentos históricos, que possui a desvantagem de serem subjetivas, uma vez os relatos históricos são geralmente qualitativos e seletivos, ao enfatizarem informações de condições incomuns que provocaram, na 
percepção das pessoas na época, algum impacto significativo. Logo, estes registros transmitem poucas informações das condições normais, porém mais das condições anormais. Além disso, os relatos não permitem identificar se estas condições excepcionais foram resultado de oscilações da variabilidade natural do clima ou de alguma mudança climática expressiva.

Somente por técnicas indiretas ou por testemunhos (proxy), baseados essencialmente em informações biológicas ou geológicas, que é possível inferir condições climáticas que predominaram antes dos alguns milhares de anos da história humana. Esta segunda modalidade provavelmente fornece os indicadores de clima mais confiáveis, seguros e temporalmente abrangentes. Os principais métodos de reconstrução estão baseados nas análises: de seres vivos que apresentam estratificação anual, como anéis de árvores e corais; de evidências geomorfológicas superficiais, como mudanças do nível dos mares, formação e movimentação de solos, assinaturas de geleiras; de estratigrafia convencional que não utiliza isótopos, como deposição de sedimentos físicos e biológicos (pólen, esporos, fósseis, conchas) em lagos e oceanos; e métodos baseados nas variações da composição de isótopos. (SALTZMAN, 2002)

É cada vez mais utilizada nos estudos climáticos a determinação indireta das condições climáticas, especialmente a temperatura, com o uso de isótopos átomos, de um mesmo elemento químico, que possuem a mesma quantidade de prótons, mas quantidade diferente de nêutrons. Isótopos estáveis e radioativos são utilizados tanto no monitoramento de fluxos em processos quanto na datação radiométrica de eventos - esta baseada no decaimento dos isótopos radioativos. Os principais isótopos usados na pesquisa do clima são: hidrogênio $\left({ }^{1} \mathrm{H},{ }^{2} \mathrm{H}\right.$ - deutério, ${ }^{3} \mathrm{H}$ - trítio), oxigênio $\left({ }^{16} \mathrm{O},{ }^{17} \mathrm{O},{ }^{18} \mathrm{O}\right)$, carbono $\left({ }^{12} \mathrm{C},{ }^{13} \mathrm{C},{ }^{14} \mathrm{C}-\right.$ radiocarbono) e radônio $\left({ }^{222} \mathrm{Rn}\right)$ (MCGUFFIE; HENDERSON-SELLERS, 2005).

\subsubsection{Estimativas futuras da temperatura do ar}

As temperaturas futuras são estimadas por meio de modelos matemáticos climáticos. Um modelo climático é uma representação do sistema atmosférico terrestre baseada em cálculos computacionais de equações de Navier-Stokes em uma esfera rotativa, com termos termodinâmicos para diferentes fontes de energia. Os modelos climáticos resolvem equações matemáticas que descrevem o balanço de energia do planeta, com o objetivo de compreender e reproduzir os 
processos de controle do clima. Os modelos diferem amplamente em sua complexidade, alguns consideram apenas o balanço de energia que entra e sai da Terra, enquanto outros tentam descrever todo o sistema climático, incluindo as complexas interações entre as diferentes componentes do planeta (como o oceano e a atmosfera) (PHILANDER, 2008).

O uso de modelos climáticos não é uma exclusividade de estimativas de temperatura no futuro, pois elas também são utilizadas em reconstruções passadas do clima. Todavia, a questão das mudanças climáticas induzidas pelo homem mudou o foco da modelagem do clima. Agora, muitos modelos são projetados para verificar o efeito da mudança emissões humanas sobre o clima e previsão do clima futuro. As previsões ou projeções climáticas são feitas com modelos climáticos globais, que tem como base Modelos de Circulação Global (MCGs, ou do inglês Global Circulation Model - GCM).

Nos MCGs o planeta é dividido em uma grade tridimensional em forma de blocos retangulares. $\mathrm{Na}$ atmosfera, os modelos climáticos globais normalmente têm uma resolução horizontal 200 a 300 km; e uma resolução vertical de algumas centenas de metros a $1 \mathrm{~km}$. A resolução vertical dos modelos é geralmente mais fina na superfície (onde ela é necessária para resolver importantes processos de pequena escala) e torna-se grosseira em grandes altitudes. Na superfície, os níveis do modelo normalmente acompanham o terreno (níveis paralelos à topografia da superfície), mas em níveis mais altos do modelo o efeito da topografia da superfície é menor, e os níveis se tornam mais espessos. Os componentes nos oceano do MCG geralmente têm uma resolução maior que o componente terrestre, pois as estruturas de pequena escala como redemoinhos são importantes para o transporte de calor no oceano. A resolução do oceano varia tipicamente de 125 a $250 \mathrm{~m}$ na horizontal e 200 a $400 \mathrm{~m}$ na vertical (PHILANDER, 2008).

Com a divisão gradeada do planeta, cálculos são feitos para as trocas verticais e horizontais de energia e matéria (umidade) entre os blocos. Incertezas nas parametrizações utilizadas nos modelos climáticos contribuem para a incerteza nas previsões climáticas. Para investigar a sensibilidade do modelo a estas incertezas, é executado um conjunto de várias simulações. Para verificar a validade de um novo modelo, tenta-se reproduzir os eventos que já ocorreram no passado. Se os modelos descrevem o passado com sucesso, então eles podem ser 
usados para prever o futuro com algum grau de confiança. O sucesso de um modelo depende em parte da capacidade dos cientistas para explicar as interações entre terra, atmosfera, oceanos e os seres vivos. No entanto, alguns fatores não são bem compreendidos. Nuvens, por exemplo, têm dois efeitos concorrentes sobre o clima: elas refletem a luz solar de volta para o espaço e elas bloqueiam o calor emitido pela superfície. Se temperaturas mais altas aumentam a quantidade de nuvens, os efeitos são pouco claros e por isso não são fáceis de modelar. Além desses fatores ainda pouco compreendidos, os modelos devem ter em conta os mecanismos de feedback, tanto os positivos quanto os negativos. Nos feedbacks positivos, existem situações em que uma pequena alteração em algum aspecto no sistema amplia o efeito original e, portanto, causa um efeito muito maior. (DESONIE, 2008).

Os modelos de previsão climática tentam elaborar cenários do clima de muitos anos no futuro. Eles não têm o objetivo de prever determinados acontecimentos de pequena escala (em comparação com a previsão do tempo, que tenta prever, por exemplo, a ocorrência de uma tempestade em um determinado dia). Em vez disso, a elaboração de cenários do clima tem uma abordagem estatística na qual as propriedades gerais do clima podem ser previsíveis; normalmente a média ou a variância das variáveis climáticas são previsíveis (como a temperatura média em determinado mês ou ano). Os modelos climáticos consideram uma série de variáveis climáticas diferentes, algumas das quais podem ser modelados com um grau relativamente elevado de confiança (tais como a temperatura), enquanto outros permanecem muito mais incertos (como a precipitação). Nos modelos climáticos são considerados os tipos diferentes de variabilidade no sistema da Terra, como as mudanças naturais e as induzidas pelo homem (PHILANDER, 2008).

\subsection{Medições recentes da temperatura do ar}

Os valores da temperatura do ar podem ser mensurados, de um modo geral, por três diferentes métodos de medição: observações de superfície, observações de satélite e observações por radiossondas. As medições realizadas por satélite não representam a temperatura do ar na superfície terrestre, mas sim as ondas emitidas pelas superfícies radiantes. Ou seja, com as radiâncias medidas em várias bandas de comprimento de onda, são feitas correlações que 
permitem realizar inferências indiretas de temperatura. Já as radiossondas de fato medem a temperatura do ar, porém é traçado um perfil vertical de acordo com a ascensão do balão na atmosfera.

As medições de superfície, por sua vez, são divididas em dois tipos: em superfície terrestre, tendo os sensores de temperatura dispostos em abrigos; e em superfície marinha, em que são realizadas medições em navios ou por meio de bóias, fixas ou móveis.

Embora a tecnologia de construção de termômetros precisos e de confiança para medições ambientais, in situ, exista há mais de 150 anos, e nos últimos 30 anos, com o avanço da microeletrônica, existam sensores elétricos de grande precisão, ainda estão presentes muitos problemas no processo de medição de dados por meio destes instrumentos.

Apesar dos problemas, o registro do clima por meio de instrumentos em superfície pode proporcionar uma boa noção da distribuição espacial e previsões da temperatura em muitas áreas do mundo. Porém, considerando-se a magnitude dos erros de medição, a não homogeneidade nos registros das variáveis climáticas na superfície terrestre pode estar produzindo uma série de erros no diagnóstico do clima atual e, portanto, no diagnóstico do clima futuro (LIN, 1999).

\subsubsection{Modalidades terrestres de medição}

As modalidades de medição utilizadas nos registros de valores da temperatura do ar devem ser tomadas, em primeiro lugar, de acordo com as Normas Técnicas da Organização Mundial de Meteorologia (OMM) e, também, as que são adotadas em estações meteorológicas, clássicas e automáticas, para a medição dessa variável climática. Os abrigos utilizados para proteção dos sensores contra a radiação solar direta e outras fontes que possam interferir nas medições são, respectivamente, a câmara de Stevenson e abrigos plásticos de modelos variados.

\subsubsection{Estação meteorológica clássica}

Em uma estação meteorológica clássica ou convencional, os principais 
instrumentos medidores de temperatura utilizados são: termógrafo, termômetro de mercúrio, termômetros de máximas e mínimas e psicrômetro.

\section{- Termógrafo}

O termógrafo é um instrumento que registra a temperatura do ar por meio de uma agulha com tinta que marca um papel envolto em um cilindro. Os termógrafos são baseados na expansão sofrida por metais distintos sob alterações de temperatura. A maioria consiste em lâminas bimetálicas (bronze, latão, etc.) que possuem distintos coeficientes de dilatação. Também são utilizadas outras ligas que possuem alto coeficiente de dilatação. Quando a temperatura varia, uma das lâminas se dilata mais que a outra, resultando na movimentação de todo o mecanismo sob a lâmina mais curta.

Tais movimentos se amplificam por meio de um sistema de alavancas que possui na outra extremidade uma agulha, que indica o valor da temperatura. Geralmente esse tipo de instrumento é utilizado para obtenção de registros contínuos do comportamento da temperatura do ar, uma vez que um tambor cilíndrico coberto por um papel específico (termograma) graduado e ajustado a um relógio permite este registro (AYLLÓN, 1996). O mecanismo de funcionamento pode ser observado na Figura 2-A.

A

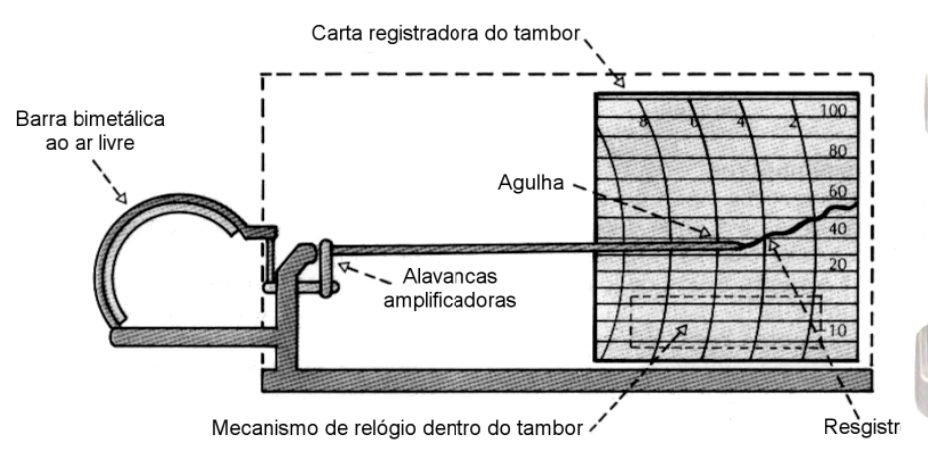

B

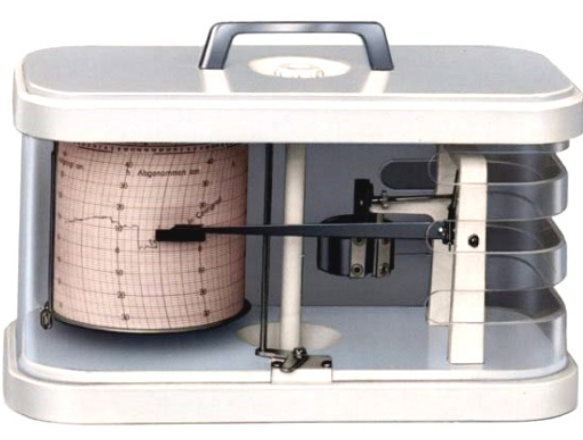

Figura 2 - Termógrafo. (A) Mecanismo de funcionamento de um termógrafo; (B) Foto de um termógrafo moderno. Fonte: Ayllón (1996).

Termógrafos modernos são construídos com materiais resistentes à corrosão, normalmente são utilizados alumínio, além de peças cromadas (Figura 
2-B). A acurácia de tais instrumentos é da ordem de $\pm 0,5^{\circ} \mathrm{C}$, possuindo graduações de $1^{\circ} \mathrm{C}$.

\section{- Termômetro de mercúrio}

O termômetro de mercúrio (Figura 3) é um instrumento muito simples que permite medições relativamente acuradas, podendo ser realizadas sob um extenso intervalo de temperatura. (QUINN, 1983). O funcionamento deste tipo de termômetro é baseado na expansão do líquido de acordo com a variação da temperatura, ou seja, o líquido atua como um transdutor em converter energia térmica em uma forma mecânica. Assim que o líquido no bulbo se aquece, ele se expande e é forçado a subir o capilar da haste (NICHOLAS; WHITE, 1994). A temperatura do bulbo é indicada pela posição do topo da coluna de mercúrio de acordo com a respectiva escala marcada. A escala é necessária para permitir ao usuário a leitura da temperatura indicada pela coluna. Para um termômetro bem construído, a variação da coluna é proporcional à mudança do volume e da temperatura (NICHOLAS; WHITE, 1994).

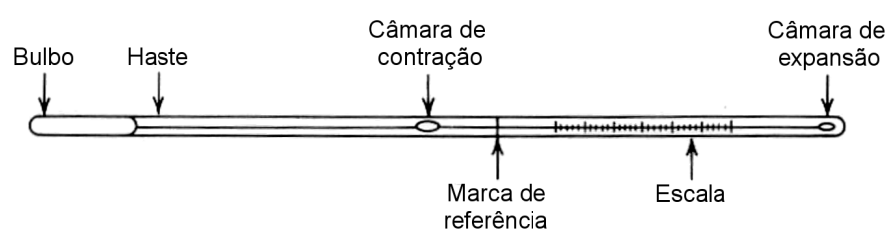

Figura 3 - Principais características de um termômetro de mercúrio. Fonte: Benedict (1984).

\section{- Termômetro de máximas e mínimas}

O termômetro de máxima, do tipo líquido em vidro, tem como elemento sensível o mercúrio. Possui como característica uma constrição no capilar, que impede o retorno do bulbo, indicando a maior temperatura ocorrida. Já no termômetro de mínima, tendo o álcool como elemento sensível, existe no interior do tubo um indicador no formato de Haltere $(\mathrm{H})$ cuja extremidade oposta ao bulbo indica a menor temperatura do ar ocorrida (AYLLÓN, 1996). 


\section{- Psicrômetro}

O psicrômetro é um instrumento para determinação da temperatura e a umidade relativa do ar atmosférico, constituído de dois termômetros de mercúrio, bulbo úmido e bulbo seco, sendo que o de bulbo úmido é envolto em gaze e deve ser mantido constantemente molhado. Quanto mais seco estiver o ar, maior será a quantidade de água evaporada, apresentando como consequência a redução da temperatura do termômetro de bulbo úmido. A diferença da temperatura entre os termômetros indica indiretamente a umidade relativa do ar com o uso de uma tabela psicrométrica.

\subsubsection{Estação meteorológica automática}

Em uma estação meteorológica automática, constituem como instrumentos responsáveis pela medição da temperatura do ar: o sistema de aquisição e armazenamento de dados e o sensor elétrico de temperatura, que pode ser um sensor comercial ou termopares.

\section{- Sistema de aquisição automático de dados modelo CR10X}

O sistema (Figura 4) mantém conectados, além dos sensores meteorológicos, sensores termopares tipo $\mathrm{T}$, que estão conectados ao multiplexador AM416 que transfere os dados registrados ao sistema de aquisição e armazenamento de dados CR10X (datalogger) por meio de cabos telefônicos.

Os sensores meteorológicos comumente utilizados são: anemômetro WIND SENTRY 03001; anemoscópio WIND SENTRY 03001; painel solar MSX10; sensor pressão atmosférica CS105 (PTA 427); sensor de umidade relativa CS 500, sensor de temperatura do ar CS 500; sensor tipo piranômetro LI 200X; pluviômetro TR-525M. O sistema completo contém: uma caixa termicamente isolada do meio exterior (foto (A) da Figura 5), contendo sílica gel em seu interior para evitar condensações, com suporte para fixação do sistema de aquisição e armazenamento dos registros do monitoramento, o CR10X vide fotos (A) e (B) da Figura 5. Além disso, permite ainda acoplar um multiplexador de canais, tipo AM416, que amplia a capacidade de aquisição de dados, passando 
de 8 canais analógicos para 40 canais. Um de conjunto bateria de $12 \mathrm{~V}$, reguladores de voltagem, filtros contra ruídos de origem elétrica, proteção contra queda de raios, etc., também fazem parte do sistema de monitoramento. Embora os novos equipamentos eletrônicos possuam melhor resolução temporal de coleta de dados e relativa maior precisão dos valores mensurados, em comparação com os instrumentos analógicos, deve-se ressaltar que tais sensores e circuitos eletrônicos possuem outras fontes intrínsecas de erros, como os erros de propagação elétrica.

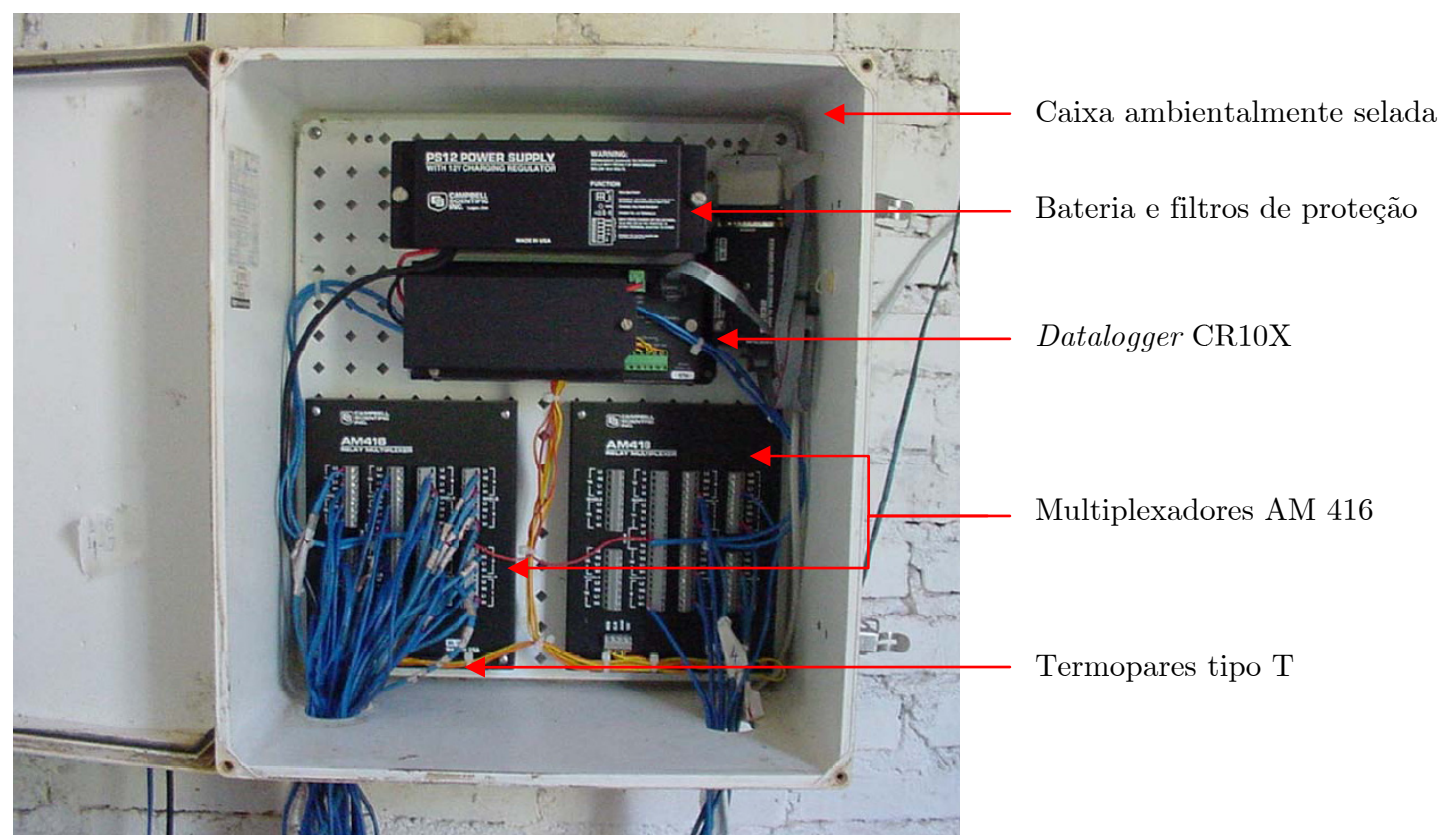

Figura 4 - Sistema automático de aquisição de dados Campbell Scientific Inc.
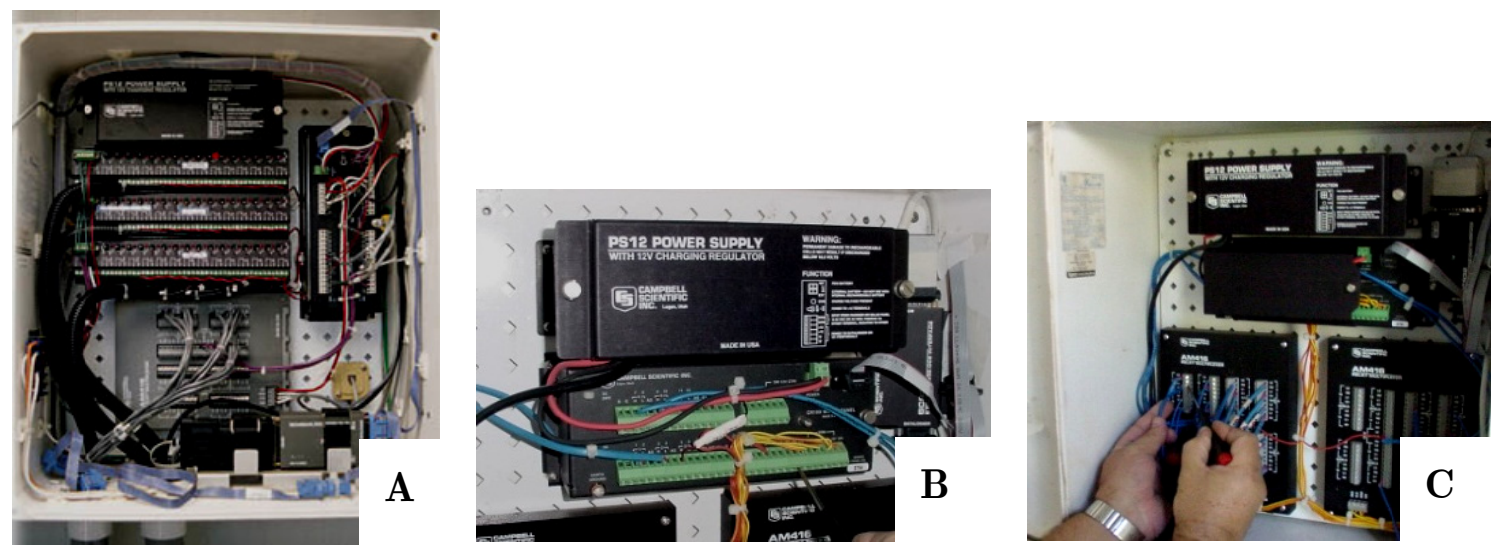

Figura 5 - Detalhes da caixa ambientalmente selada e os componentes do sistema automático de aquisição de dados. (A): Caixa ambientalmente selada que abriga a bateria $12 \mathrm{~V}$ (abastecida por painel solar), com o datalogger CR10X, composto ainda pelo multiplexador de 32 canais AM416. (B) e (C): Detalhes do conjunto CR10X, bateria de $12 \mathrm{~V}$ e multiplexador AM 416 de 32 canais. 


\section{- Sensor de temperatura e umidade relativa do ar}

O sensor do tipo HMP45C-Vaisala (Figura 6), acoplado a uma estação automática, é um robusto e acurado sensor de temperatura e de umidade relativa do ar desenvolvido para aplicações de medições automáticas e de longo prazo. Porém, para resultados confiáveis, o instrumento deve ser anualmente (re)calibrado. As medidas de temperatura utilizam o mecanismo PRT Platinum Resistance Thermometer (CAMPBELL SCIENTIFIC INC, 2004).

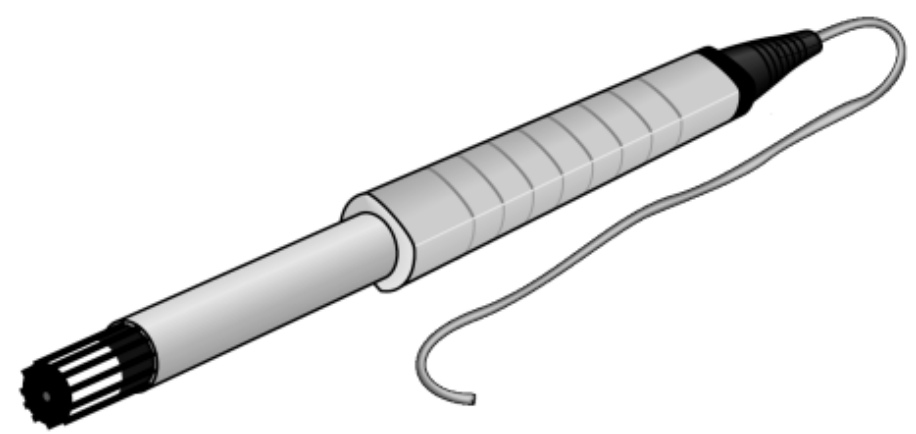

Figura 6 - Sensor de Temperatura e Umidade Relativa do ar modelo HMP45C. Fonte: Campbell Scientific Inc. (2004).

Os PRTs são sensores de temperatura de grande qualidade e precisão. A resistência elétrica de platina é registrada por um dispositivo de saída conectada ao sensor. A resistência do sensor, medida em ohms, é convertida para valores de temperatura por meio de um programa aplicativo (software) no dispositivo de leitura da saída, utilizando coeficientes únicos de caracterização do sensor, que são armazenados na memória do dispositivo de saída (ICL CALIBRATION LABORATORIES INC, 2010). O princípio de funcionamento dos termômetros de resistência é baseado no fato de que a resistência de qualquer material oferece à passagem de uma corrente elétrica é dependente da sua temperatura. A utilização da platina como o material resistor é devida à alta ductibilidade (capacidade de produção de fios finos), pela característica de ser relativamente imune à corrosão e por estar disponível em um estado altamente puro e reprodutível (BAKER; RYDER; BAKER, 1961).

Os termômetros de resistência são constituídos: 1.) pelo sensor, 2.) por um circuito elétrico cuja resistência varia de acordo com a temperatura, 3.) por uma estrutura na qual se sustenta o sensor, 4.) por uma capa protetora, e 
finalmente, 5.) por fios através dos quais o sensor é conectado ao instrumento de medida, que é utilizado para indicar os efeitos das variações no sensor resistor. Uma representação gráfica de um $P R T$ pode ser observada na Figura 7.

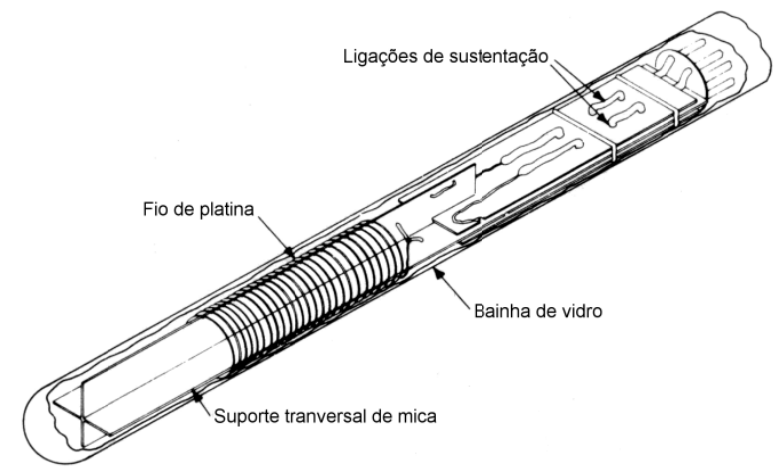

Figura 7 - Modelo de um termômetro de resistência de platina. Fonte: Quinn (1983).

- Abrigos de proteção para os sensores de temperatura de umidade do ar

O abrigo de proteção contra radiação solar direta e também contra as precipitações modelo 41003 R.M. Young é acoplado ao sensor de temperatura e umidade relativa (Figura 8). O funcionamento ocorre sem ventilação artificial e nele são instalados os sensores de umidade e de temperatura do ar. O fabricante (CAMPBELL SCIENTIFIC INC., 2003) afirma que este abrigo assegura a reflexão de parte da radiação solar global e reduz o acúmulo de calor (inércia térmica), porém admite que ele proporciona interferências nas medições da temperatura do ar.

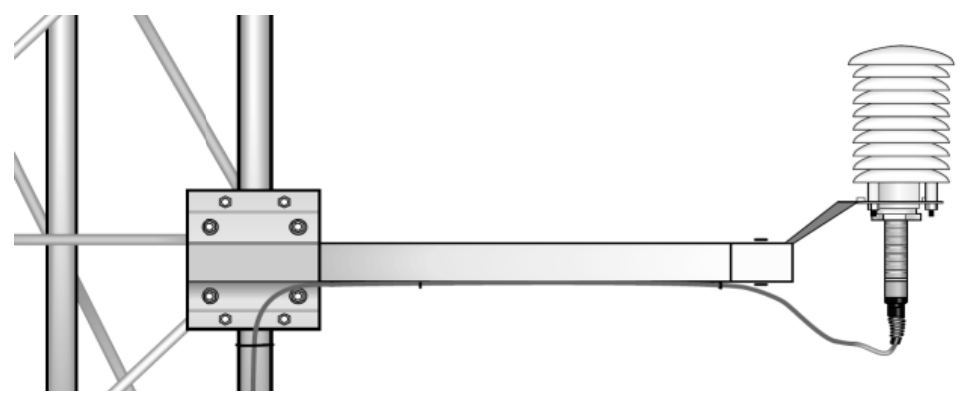

Figura 8 - Sensor HMP45C e abrigo de radiação 41003. Fonte: Campbell Scientific Inc. (2003). 


\section{- Termopares tipo $\mathbf{T}$}

Os termopares são instrumentos muito utilizados tanto para medidas de temperaturas elevadas (até $1600^{\circ} \mathrm{C}$ ) quanto para temperaturas reduzidas (até $1^{\circ} \mathrm{C}$ ), como também de pequenas diferenças de temperatura (ANTUNES, 1966). Tal instrumento fornece a medida da diferença da temperatura entre junções quente e fria por meio da medida da diferença de potencial elétrico entre dois termo-elementos, compostos por fios de diferentes metais, soldados em uma das extremidades em uma junção de temperatura mais baixa (QUINN, 1983). Em outras palavras, se dois metais distintos são soldados em uma das extremidades (A), vide Figura 9, e esta é mantida a uma temperatura $\left(T_{A}\right)$, diferente da temperatura da extremidade não soldada $\left(T_{B}\right)$, pode-se medir entre os dois metais uma diferença de potencial elétrico. A esse fenômeno dá-se o nome de efeito termoelétrico.

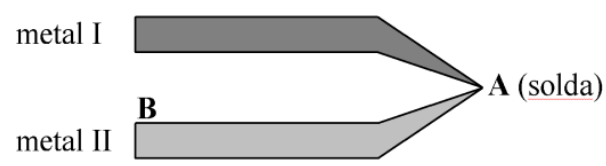

Figura 9 - Representação esquemática do princípio de funcionamento de um termopar. Fonte: Antunes (1966).

O bipolo constituído por dois metais, consideradas as duas extremidades não soldadas como terminais acessíveis, mantidas a certa temperatura $\left(T_{B}\right)$ e estando a junção outra temperatura $\left(T_{A}\right)$, constitui um gerador. A força eletromotriz desse gerador depende, de modo geral, das temperaturas das extremidades $\left(T_{A}\right.$ e $\left.T_{B}\right)$ e se denomina f.e.m. (força eletromotriz) termoelétrica (ANTUNES, 1966). O conjunto que compõe um termopar consiste basicamente em um ou mais dos componentes: sensor composto por dois diferentes fios metálicos, sustentados ou separados por um isolante elétrico e soldados um ao outro em uma das extremidades; tubo de proteção com o intuito de evitar efeitos deletérios no sensor na presença de atmosferas e ambientes hostis.

Os termopares do Tipo T são resistentes à corrosão em atmosferas úmidas e são apropriados para o uso em medições de temperatura do ar, uma vez que sua faixa de aplicação está situada entre -270 a $400^{\circ} \mathrm{C}$ e ainda pelo fato de se oxidarem em atmosferas oxidantes somente em ambientes acima de $370^{\circ} \mathrm{C}$. A constituição deste tipo de termopar é de cobre e constantan [liga metálica de 
cobre e níquel $(\mathrm{Cu}+43 \% \mathrm{Ni})]$ (ASTM, 1987). A acurácia dos termopares é tal que as temperaturas podem ser medidas com erro de $\pm 0,1$ ou $0,2^{\circ} \mathrm{C}$ com alguns tipos de termopares, desde que estejam precisamente calibrados e em ótimas condições de uso e aplicação (KINZIE, 1973).

\subsubsection{Interferências nas medições terrestres}

A ordem de grandeza dos valores do aumento da temperatura média global está em torno dos décimos de graus centígrados. Entretanto, os erros de medição são de maior magnitude que as diferenças dos registros da temperatura média global. (LIN, 1999).

Vários fatores têm influenciado nas medições de temperatura do ar, principalmente, sobre o continente terrestre. O uso dos solos, principal fator, mudou devido à urbanização e, assim, muitos dos termômetros responderam às mudanças das propriedades térmicas de suas vizinhanças, indicando mudanças na temperatura que são reais, mas que não estão relacionadas às causas em larga escala da mudança climática global (COMMITTEE ON SURFACE TEMPERATURE RECONSTRUCTIONS FOR THE LAST 2,000 YEARS, 2006).

Além deste, outros fatores não climáticos têm gerado dados não representativos da atual variação climática que vem ocorrendo, tais como: mudanças nos instrumentos, práticas de observação, locais das estações, fórmulas para cálculo de médias. Todos estes desvios podem gerar erros que levam a interpretações errôneas do clima, a não ser que sejam ajustados ou evitados estes fatores. (PANEL ON RECONCILING TEMPERATURE OBSERVATIONS, 2000)

Da discussão dos fatores anteriormente citados é importante detalhar os erros de medições da temperatura provenientes tanto do sensor quanto e, principalmente, do sistema de aquisição de dados associado, particularmente da ineficiência dos abrigos de proteção contra os efeitos radiação. (SUN; BAKER, 2004)

Portanto, medições adequadas da temperatura do ar, representativa para da área em que são realizadas as medições na estação, requerem minimização dos efeitos locais relacionados à situação da estação, como por exemplo, a 
presença de árvores e prédios, além de minimização dos efeitos ambientais que influenciam as medições da temperatura na posição em que se encontra o sensor.

\subsubsection{Influência da cobertura vegetal}

Em estudo sobre o efeito da vegetação na atenuação do calor, ShashuaBar e Hoffman (2000) mostram indicações de que as principais variáveis que afetam os registros da temperatura do ar são as áreas sombreadas por árvores, que atenuam o aquecimento do solo pela radiação solar direta, incluindo o efeito secundário da temperatura do ar junto a essas áreas circundantes.

Da mesma forma, o efeito da umidificação do ar se mostra proporcional ao de resfriamento. O estudo realizado por Dimoudi e Nikolopoulou (2003), com base em simulações do comportamento microclimático, em diferentes texturas urbanas, concluíram que o aumento das dimensões de áreas verdes implica na diminuição da temperatura do ar nas imediações. Há indicações de que ocorre decréscimo de $1^{\circ} \mathrm{C}$, na temperatura do ar, para cada 100 metros quadrados de vegetação adicionada.

Estudos $^{5}$ realizados trataram de comparar valores da temperatura e da umidade do ar em diversos pontos da cidade de São Carlos. Os resultados obtidos demonstram que os valores de temperatura tendem a ser menores em áreas arborizadas do que em áreas áridas, assim como acontece para os valores da amplitude térmica. Foram verificadas diferenças de 2 a $3^{\circ} \mathrm{C}$, nas horas mais quentes do dia, entre os locais de estudos selecionados. Tais resultados são similares aos obtidos em outras investigações ${ }^{6}$. Outros resultados também relativos aos valores da temperatura externa do ar corroboram com outros obtidos em estudos anteriores ${ }^{7}$, indicando que a vegetação arbórea provoca a atenuação da amplitude térmica em comparação com áreas não vegetadas, conforme pode ser observado na Figura 10.

\footnotetext{
${ }^{5}$ MODNA (2004).

${ }^{6}$ BARBOSA; BARBINATO; VECCHIA, 2004; LINACRE; GEERTS, 1997; TAHA, 1997.

7 MODNA; VECCHIA, 2003; SHASHUA-BAR; HOFFMANN, 2000.
} 


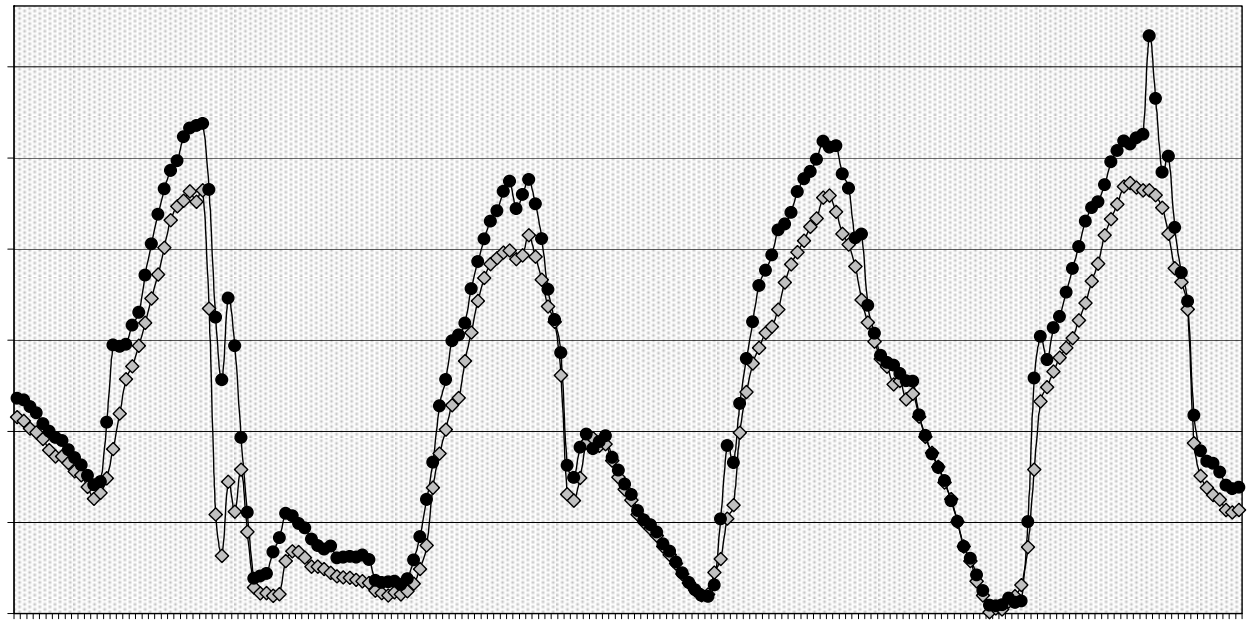

Figura 10 - Gráfico do comportamento da temperatura sob influências da cobertura vegetal exibindo o padrão cíclico da variação diária da temperatura externa do ar tomado em dois bairros da cidade de São Carlos, bosque correspondendo a uma região melhor vegetada e a praça correspondendo ao espaço árido do centro da cidade. Fonte: Modna e Vecchia (2003).

Outra indicação que se obteve ao longo da investigação foi quanto à diminuição dos valores de temperatura promovida pelas áreas verdes. As constatações feitas a partir dos resultados deste trabalho - de que a diferença de temperatura entre um local arborizado e outro árido é pequena em termos absolutos - são semelhantes às constatações de outros pesquisadores (MODNA; VECCHIA, 2003). Há que se considerar também, em estudo posterior, as diferenças existentes entre as árvores que compõem as áreas verdes, como discutem Marincic e Ochoa (2003) e Barry e Chorley (1980). Fatores estruturais e morfológicos como a geometria das copas, o número de indivíduos, o tipo de folhas e das adaptações ao meio influenciam o clima característico das áreas verdes.

\subsubsection{Influência da incidência de radiação solar direta}

As medições de temperatura do ar realizadas por Modna e Vecchia (2003), em duas regiões de São Carlos, em janeiro de 2002, registraram a ocorrência de uma senóide com duas inexplicáveis "orelhas de Batman" às 7 
horas e 30 minutos e outra às 16 horas e 30 minutos, conforme a Figura 11. Nesse primeiro momento nada parecia justificar esses dois registros que distorciam o comportamento em formato senoidal habitual das temperaturas do ar. Mais tarde, descobriu-se que esses desvios ocorreram pela incidência direta da radiação solar sobre os abrigos de proteção, pois nessa época do ano, janeiro, a trajetória aparente do Sol se desloca sobre o quadrante Sul, quando o abrigo ficou exposto aos raios solares. Isso ocorreu por que os sensores não ficaram totalmente abrigados (à sombra) no pátio da escola e, nesses dois horários específicos, a exposição à radiação elevou os valores da temperatura do ar.

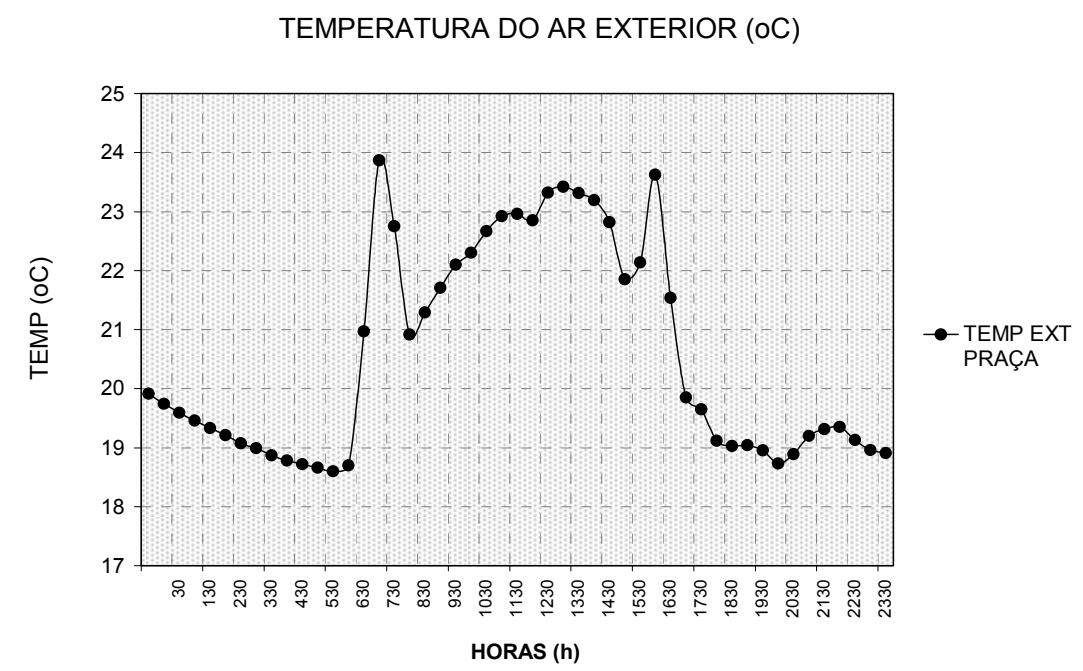

Figura 11 - Gráfico do dia 25 de janeiro de 2004 com o comportamento da temperatura externa do ar sob influências da incidência da radiação solar direta, tomada em abrigo meteorológico sem isolamento e sem aspiração do ar, que ocasionou a aparência de "orelhas", às 7h30 e às 16h30 distorcendo a senóide habitual. Fonte: Modna e Vecchia (2003).

Portanto, concluiu-se que ocorria uma alteração na leitura de aproximadamente três graus Celsius quando o abrigo estava exposto à radiação solar. Para corrigir a ação da radiação foi aplicado um isolamento por barreira de radiação (foil) sobre o abrigo e instalado uma ventoinha de computador para aspiração do ar no abrigo meteorológico. Após a instalação desses dispositivos os registros da temperatura externa do ar não apresentaram distorções, voltando a possuir a aparência habitual de senóides. 


\subsubsection{Influência do ambiente construído}

No tema ilhas de calor apontado por Gonçalvez et al. (2004), em Lisboa, medições nos anos 70 indicaram um gradiente térmico de 1 a 2 graus Celsius, com base nos valores das temperaturas mínimas médias mensais do período entre 1958 e 1967. Posteriormente, entre 1968 e 1981, identificou-se um alongamento da ilha de calor e provável gradiente de intensificação para 2 a 3 graus Celsius. Segundo Alcoforado (1988), a ilha de calor possui uma intensidade que não excede os 5 graus Celsius e que é mais frequente durante o período noturno e durante a estação de verão, sem que, no entanto, tenha sempre a mesma intensidade e configuração.

Gonçalvez et al. (2004) ainda afirma que a atenuação e a mobilidade da ilha de calor se deve à influencia do oceano (30 km de distância) além dos parâmetros climáticos que, segundo ele, mais determinam o estabelecimento de ilhas de calor em Lisboa, que são: o regime de ventos predominantes, a nebulosidade (que impede a penetração da radiação solar direta) e a ocorrência de nevoeiro (mesma perturbação que a anterior). As diferenças encontradas para os valores médios da temperatura externa do ar registradas nas estações urbanas de Lisboa comparativamente à estação de referência não foram significativas nas estações de Telheiras e da Praça de Espanha. Para as estações próximas ao rio Tejo e outras, essas diferenças foram superiores, cerca de 1,3 e 0,8 graus Celsius, respectivamente.

\subsubsection{Influências dos ventos e da radiação solar nos abrigos térmicos}

A radiação do sol e a radiação refletida pelas nuvens, pelo solo e por outros objetos circunvizinhos atravessam o ar sem proporcionar alterações apreciáveis na sua temperatura, mas um termômetro exposto ao ar livre pode absorver radiação considerável. Como consequência, a temperatura indicada pode ser diferente da temperatura real do ar, sendo a diferença dependente da intensidade da radiação e a taxa de radiação absorvida transformada para dissipação de calor (WMO, 2008).

Consequentemente, a fim de assegurar-se que o termômetro está indicando a verdadeira temperatura do ar, é necessário protegê-lo contra 
radiação com o uso de um abrigo, que ao mesmo tempo tem a função de suporte. Este abrigo, ainda, evita interferências da precipitação, permite a circulação livre de ar em torno do termômetro, e previne danos acidentais (WMO, 2008).

Medições adequadas da temperatura do ar, representativa para a área que a estação representa, requerem minimização dos efeitos locais relacionados à situação da estação, como por exemplo, a presença de árvores e prédios, além de minimização dos efeitos ambientais que influenciam a medida da temperatura na posição em que se encontra o sensor (VAN DER MEULEN, 2008).

Deste modo, as condições ambientais afetam os abrigos de modos diferentes, cada um gerando um microclima próprio e, muitas vezes, provocando alterações indevidas nas medições realizadas pelos sensores abrigados.

Van der Meulen (1998) lista várias circunstâncias ambientais que podem influenciar nos sensores e consequentemente nas medições da temperatura do ar. Dentre elas as mais relevantes são:

- Radiação direta do Sol no sensor - radiação de onda curta;

- Radiação indireta do Sol no sensor (após reflexão na superfície terrestre, água, no abrigo do sensor);

- Radiação infravermelha direta e indireta pelo abrigo e por outras fontes externas no sensor - radiação de onda longa;

- Ventilação natural ou artificial insuficientes do ar interno ao abrigo, causando efeitos microclimáticos típicos. 



\section{CAPÍTULO 2 - Variabilidade e Mudanças Climáticas Globais}

O termo mudanças climáticas é normalmente utilizado para descrever alguma alteração sistemática ou alguma variação estatisticamente significante tanto nos valores médios dos elementos climáticos (como precipitação, temperatura, ventos ou pressão) quanto na sua variabilidade, sustentado ao longo de um período temporal finito, compreendendo escalas da ordem de décadas até milhões de anos atrás (PHILANDER, 2008). Pode ser referido, deste modo, como mudanças de longo termo nos padrões climáticos, associadas especialmente ao aumento da temperatura superficial terrestre, que remete ao difundido termo aquecimento global - aumento, natural ou induzido pelo homem, da temperatura média global da atmosfera próxima à superfície terrestre. No caso deste segundo termo, insere-se no contexto uma escala espacial de distribuição das alterações dos padrões climáticos, podendo determinadas circunstâncias serem consideradas como mudanças locais ou regionais, ou, quando no caso de assumido o valor médio global de determinado elemento obtido em diferentes regiões, serem consideradas como mudanças globais.

A Convenção-Quadro das Nações Unidas sobre a Mudança do Clima (CQNUMC) define as mudanças climáticas associadas intrinsecamente às contribuições antrópicas nas alterações dos elementos do complexo sistema climático, considerando as alterações naturais do clima - que sempre têm ocorrido, antes mesmo à própria existência humana - como variabilidades climáticas:

Mudanças climáticas significam uma mudança do clima que é
atribuída, direta ou indiretamente, à atividade humana que altera a
composição da atmosfera global e que, em adição à variabilidade
natural do clima, é observada sobre longos períodos de tempo
comparáveis. (UNITED NATIONS, 1992a, pg. 3).

Já o "Painel Intergovernamental sobre Mudanças Climáticas" (do inglês Intergovernmental Panel on Climate Change) reconhecido amplamente pela sua 
sigla IPCC, define diferentemente as mudanças climáticas, que podem ser devido tanto por processos naturais quanto por fatores antropogênicos:

\footnotetext{
Mudanças climáticas no uso do IPCC referem-se à mudança no estado do clima que pode ser identificada (por exemplo, utilizando testes estatísticos) por mudanças na média e/ou na variabilidade de suas propriedades, e que persistem por um período prolongado, tipicamente por décadas ou mais tempo. Refere-se a qualquer mudança no clima ao longo do tempo, seja devido à variabilidade natural ou como resultado da atividade humana. (IPCC, 2007a).
}

A definição de mudanças climáticas adotada e utilizada ao longo do trabalho seguirá a linha exposta pelo IPCC. Pelo exposto acima, é essencial compreender e discernir, portanto, as causas naturais e antrópicas das mudanças climáticas, assim como verificar os efeitos observados para atribuição apropriada destes fatores. As séries temporais - que consistem em sequências únicas de dados obtidos (ou estimados) representativos para um determinado período de tempo - representam a base de toda análise do clima. As séries descrevem tendências, sejam elas de aumento, redução ou manutenção dos valores antecedentes. Portanto, a exibição de gráficos, sempre que possível, ilustrará as variações dos diferentes aspectos apresentados ao longo do texto.

As mudanças climáticas podem ser divididas em três categorias temporais de análise: presente (passado recente), passado e futuro, as quais serão detalhadamente descritas na sequência.

\subsection{Mudanças climáticas recentes: o aquecimento global antropogênico}

No estudo das mudanças climáticas no presente, ou melhor, no passado recente, elas são normalmente associadas ao período histórico de medições da temperatura do ar, ou seja, referente aos últimos 150 anos. A abordagem de causa e efeito é adotada como mais compreensível nas interpretações dos fenômenos envolvidos. 


\subsubsection{Análise dos efeitos}

Uma primeira análise dos efeitos observáveis revela que as principais evidências utilizadas como indicadores das mudanças climáticas recentes são: aumento da temperatura média terrestre global e do nível médio dos mares, derretimento de geleiras e calotas polares, mudanças na precipitação e em eventos climáticos extremos, como secas, chuvas intensas, tempestades, furacões, ondas de calor, entre outros. Enfoque será dado no comportamento do nível médio dos mares e dos valores da temperatura média, pois representam os efeitos mais utilizados, além do fato de apresentarem relativa confiança nos registros históricos e reconstruções passadas.

\subsubsection{Aumento do nível médio do mar}

Em relação ao nível do mar, verificou-se em marégrafos que o nível médio global dos mares aumentou entre 0,1 e 0,2 metros durante o séc. XX. A causa é atribuída à expansão térmica da água devido ao aquecimento, e também ao derretimento de geleiras e calotas de gelo que se encontram em continentes (IPCC, 2007b), vide mostrado na Figura 12. Nota-se no gráfico (A) que existem contribuições negativas devido à expansão das calotas polares da região Antártica. 


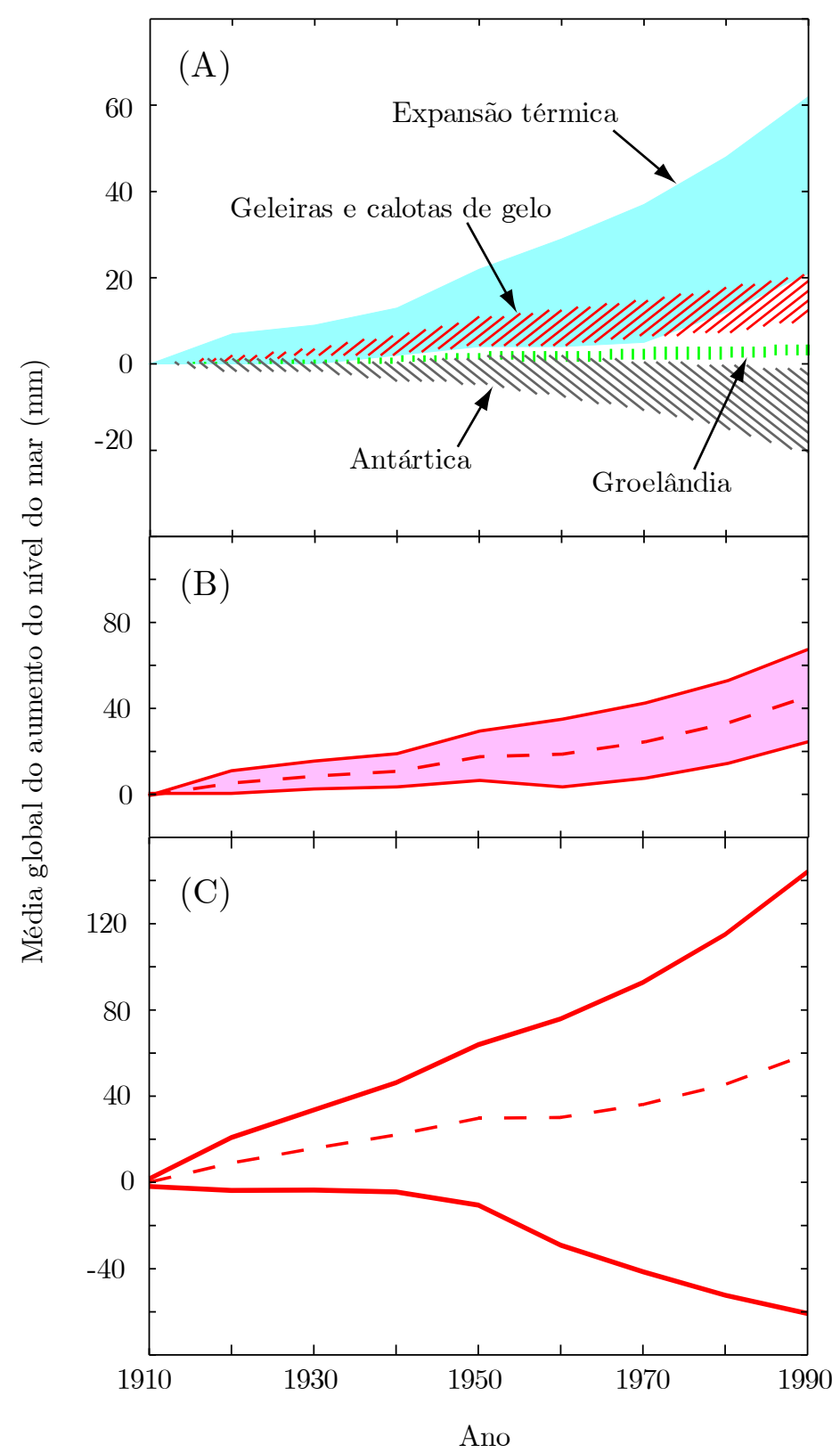

Figura 12 - Estimativas do aumento do nível médio do mar de 1910 a 1990. (A) Contribuições da expansão térmica, de geleiras e calotas de gelo, Antártica e Groelândia que resultam das mudanças climáticas do séc. XX; (B) Faixa média com limites superior e inferior da resposta do aumento do nível do mar às mudanças climáticas (soma dos termos em (A) mais a contribuição de mudanças no permafrost). Estas curvas representam a estimativa do impacto antropogênico; (C) Idem gráfico anterior, com acréscimo de contribuições dos efeitos da deposição de sedimentos, ajustes de longo termo dos mantos de gelo às mudanças climáticos do passado, e termos de armazenamento terrestre. Fonte: IPCC (2001b), pg. 666. 


\subsubsection{Aumento da temperatura média na superfície terrestre}

Um primeiro gráfico do comportamento da temperatura média na superfície terrestre é exibido na Figura 13, onde é possível notar as variações de temperatura nos últimos 140 anos, gráfico (A), e ao longo do último milênio, gráfico (B). Este segundo - publicado originalmente por Mann, Bradley e Hughes (1998) e Mann e Bradley (1999) - ficou conhecido como o "Taco de Hóquei" (do inglês hockey stick), devido ao seu formato, e foi e amplamente utilizado em 2001 no Terceiro Relatório de Avaliação do IPCC. Por este gráfico infere-se que a temperatura média superficial global tem aumentado desde 1861. Ao longo do século XX, o aumento foi de $0,6 \pm 0,2^{\circ} \mathrm{C}$. Globalmente, é provável (com probabilidade de ocorrência entre $66 \%$ a 90\%) que a década de 90 foi a década mais quente e 1998 foi o ano mais quente no período de registros instrumentais, desde 1861. O IPCC (2007b, pg. 2) afirma que novas análises das reconstruções da temperatura dos últimos 1.000 anos no Hemisfério Norte indicam que o aumento da temperatura no séc. XX seja o maior de todos os séculos durante o último milênio.

As linhas verticais pretas que representam os intervalos de confiança de 95\% na Figura 13-A são devido às falhas de dados, erros aleatórios e incertezas instrumentais, incertezas em correções nas distorções e tendências nos dados da temperatura da superfície oceânica e ajustes devidos aos efeitos da urbanização nos dados da temperatura obtidos na superfície continental. A região cinza da Figura 13-B, também indicando os intervalos de confiança de 95\%, vai aumentando de tamanho conforme mais remotos os anos, sendo que estas incertezas possuem amplitudes maiores em relação às do registro instrumental devido ao uso de dados de testemunhos relativamente escassos.

Apesar de todo cuidado estatístico e tratamento das incertezas inerentes a qualquer processo de medição, seja ela direta ou indireta, o "Taco de Hóquei" levantou controvérsias sobre a validade e veracidade na correspondência com a realidade (conforme discutido em detalhes no item "Reconstruções", pg. 106). Diante de uma possível tentativa de fraude ou tendência de adoção parcial dos fatos, o Quarto Relatório de Avaliação do IPCC (AR4), publicado em 2007, não passou a utilizar mais o referido gráfico. 
O Relatório Síntese (IPCC, 2007a) e a Síntese para Políticos (IPCC, 2007b) do "Grupo de Trabalho 1 (Working Group 1 - WG1) - As bases científicas" exibem as variações globais da temperatura e do nível do mar desde 1850 apenas, conforme exibido na Figura 14, omitindo as variações no último milênio. Análises de períodos maiores que centenas de anos são exibidas somente no sexto capítulo intitulado "Paleoclima" do Relatório de Avaliação do WG1 (IPCC, 2007c).

A utilização do gráfico "Taco de Hóquei" favorece a atribuição dos efeitos do aquecimento global às atividades antropogênicas de gases que contribuem com o aumento do efeito estufa, sendo suposta principal causa das mudanças climáticas recentes. 


\section{Variações da temperatura terrestre para:}

(A) os últimos 140 anos

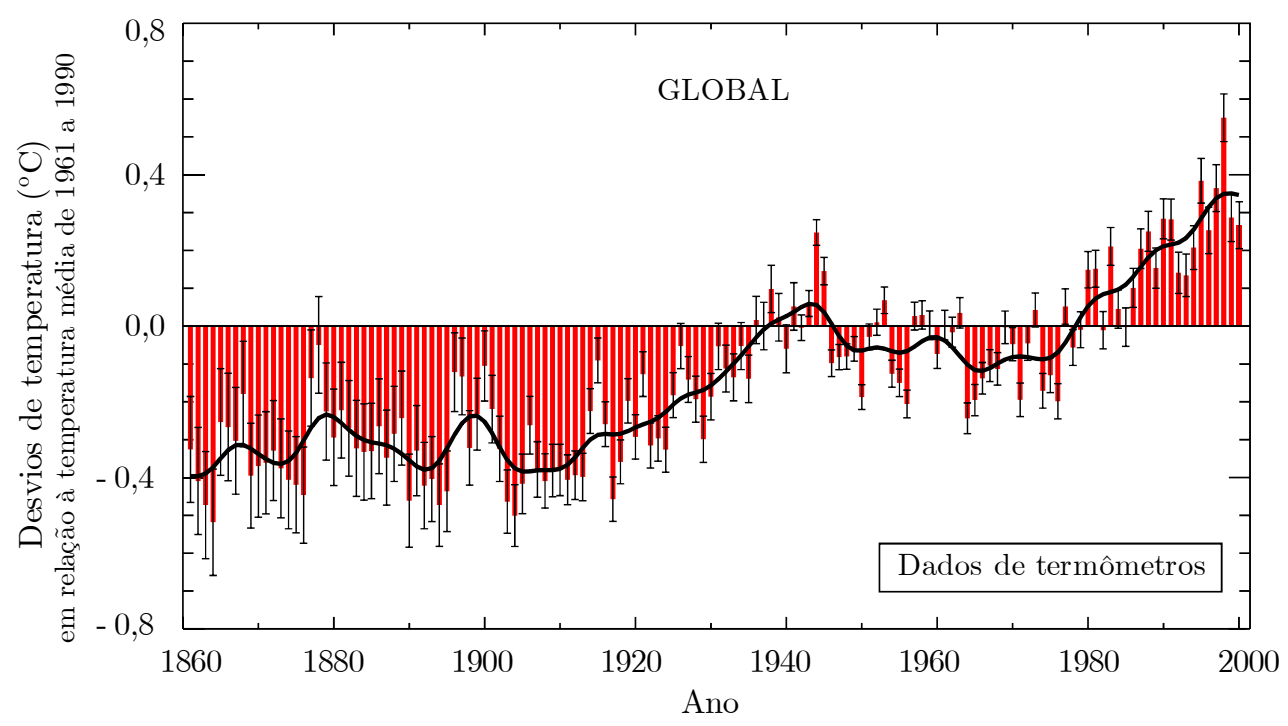

(B) os últimos 1.000 anos

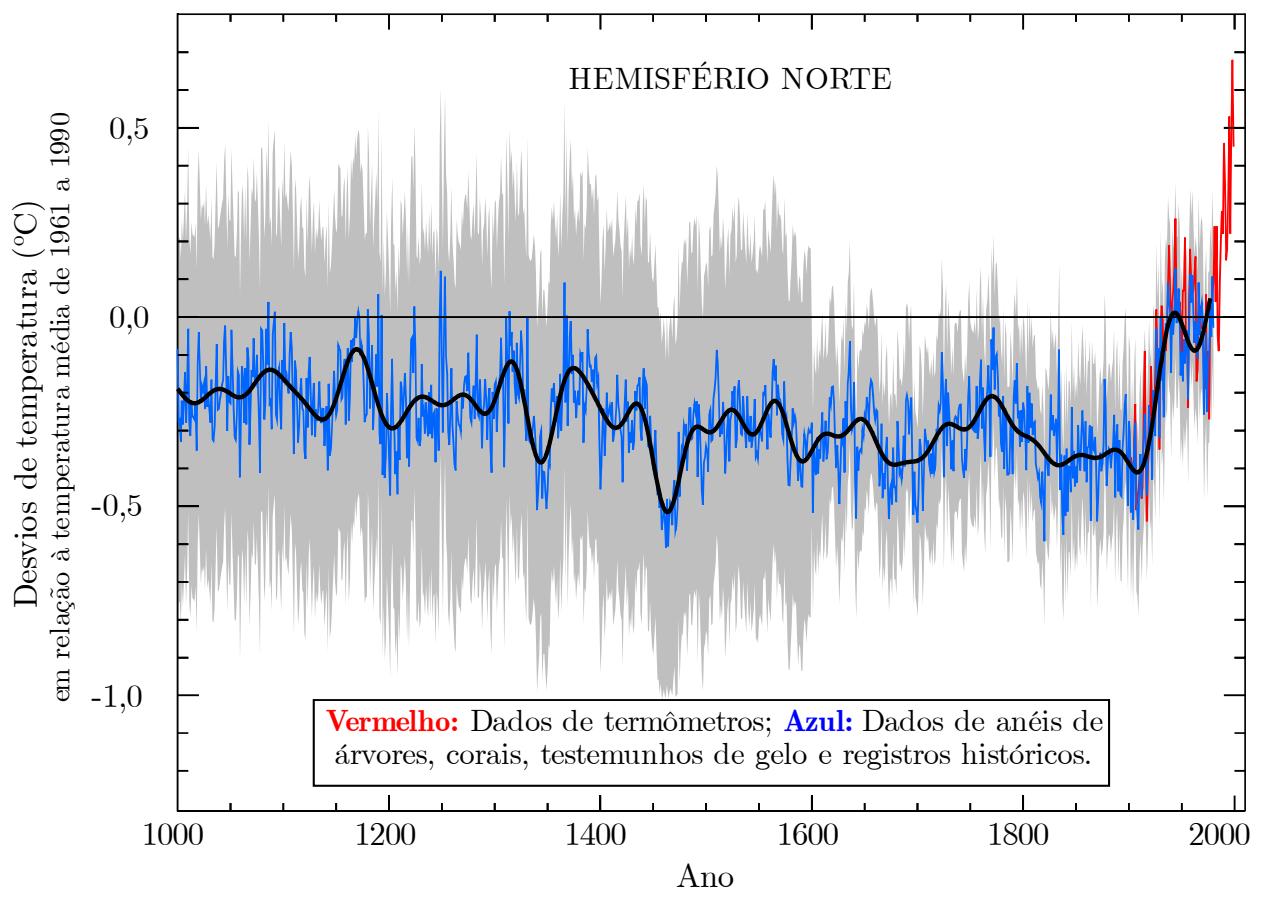

Figura 13 - Variações da temperatura da superfície terrestre ao longo nos últimos 140 anos e ao longo do último milênio. (A) A temperatura na superfície terrestre é apresentada anualmente por barras verticais vermelhas e a curva preta representa uma curva filtrada que suprime flutuações abaixo de escalas decadais. As barras verticais pretas representam o intervalo de $95 \%$ de confiança dos dados. (B) Variações anuais (curva azul) e médias de 50 anos (curva preta) da temperatura no Hemisfério Norte para os últimos 1.000 anos. O intervalo de $95 \%$ de confiança é representado pela região cinza. Fonte: IPCC (2001a), pg. 3. 
Mudanças na temperatura e no nível do mar

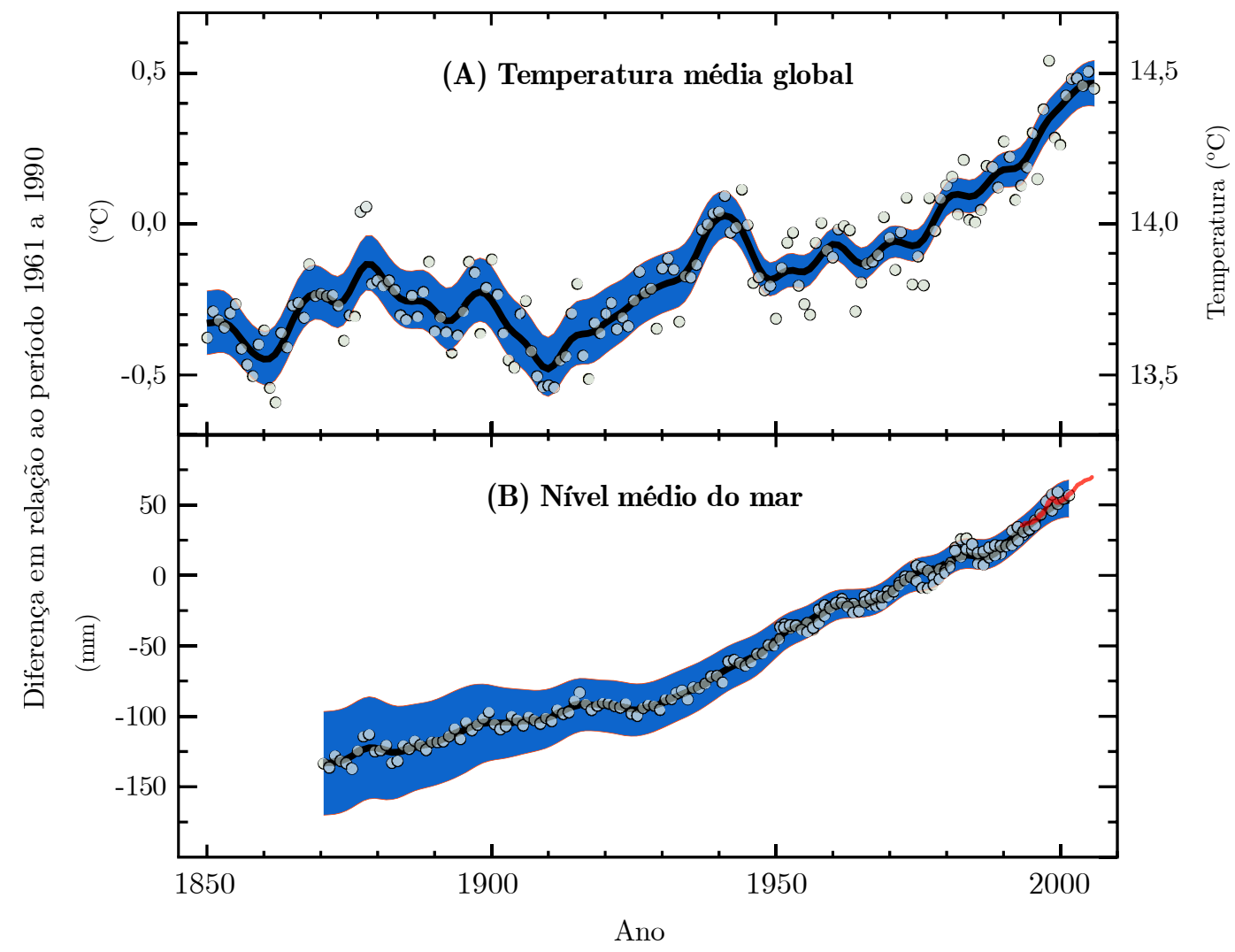

Figura 14 - Mudanças de temperatura e nível do mar desde 1850: (A) temperatura média na superfície terrestre; (B) nível médio do mar medido por marégrafos (azul) e satélites (vermelho). As curvas pretas representam a os valores médios decadais, enquanto os círculos mostram os valores anuais. As áreas azuis representam os intervalos de confiança para as séries. Fonte: IPCC (2007a), pg. 31.

\subsubsection{Análise de causas}

As mudanças climáticas podem ser atribuídas direta ou indiretamente às atividades humanas que impactam e alteram a composição da atmosfera. Também podem ser resultantes de forças naturais externas, como variáveis orbitais da Terra, emissão solar, e outros processos naturais internos do sistema climático terrestre.

As influências relativas de fatores antropogênicos e fatores naturais no clima podem ser comparados de um modo amplo, usando o conceito de "forçamento radiativo", que se refere simplesmente a um processo que perturba o balanço de radiação (Figura 15) entre a radiação recebida do Sol e da radiação 
de saída da Terra. O forçamento radiativo é medido na unidade $\mathrm{W} \cdot \mathrm{m}^{-2}$. Um forçamento radiativo positivo resulta principalmente no aquecimento relativo da superfície da Terra, podendo ser devido ao aumento de gases do efeito estufa; e um forçamento radiativo negativo, que podem surgir de um aumento de alguns tipos de aerossóis, tende a provocar o resfriamento da superfície da Terra. (PHILANDER, 2008).

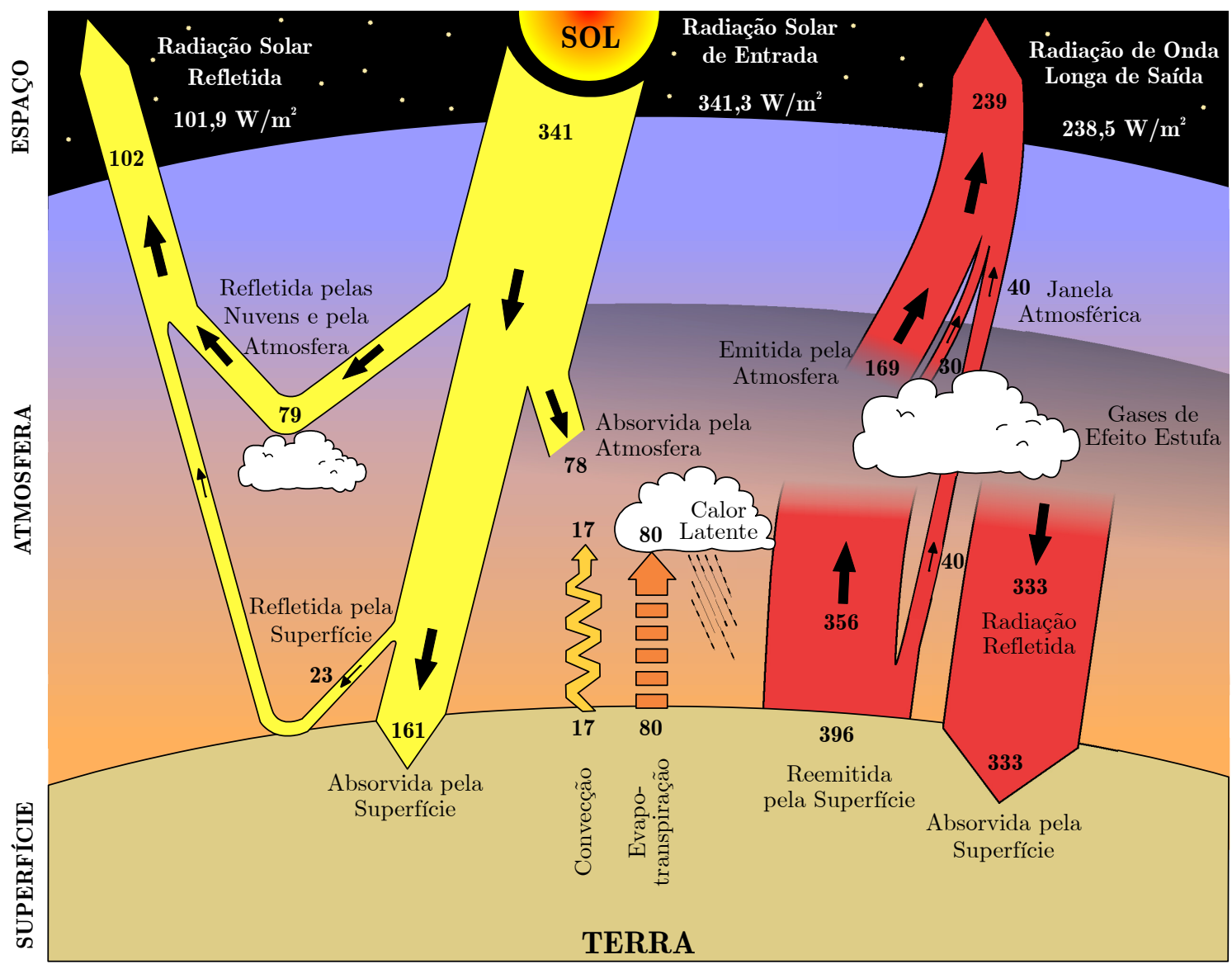

Figura 15 - Balanço global anual médio de energia da Terra. As setas indicam o fluxo esquemático proporcionalmente a sua importância. Fonte: Trenberth, Fasullo e Kiehl (1999).

Mudanças nas concentrações atmosféricas dos gases do efeito estufa (GEEs) e aerossóis, mudanças na cobertura dos solos e na radiação solar alteram o balanço de energia do sistema climático, representando os fatores determinantes das mudanças climáticos. Eles afetam a absorção, reflexão, dispersão e emissão da radiação na atmosfera e na superfície terrestre. A resultante positiva ou negativa no balanço de energia é expressa pelo forçamento 
radiativo, que é utilizado para comparar as influências do aquecimento ou resfriamento nas mudanças climáticas. (IPCC, 2007a, pg. 37)

\subsubsection{Causas antrópicas}

Atividades humanas resultam em emissões de quatro principais GEEs: gás carbônico $\left(\mathrm{CO}_{2}\right)$, metano $\left(\mathrm{CH}_{4}\right)$, óxido nitroso $\left(\mathrm{N}_{2} \mathrm{O}\right)$, e halocarbonetos [grupo de gases que contém fluor, cloro e bromo, como os clorofluorcarbonetos (CFCs)]. O forçamento radiativo do sistema climático é determinado pelos GEEs de vida longa, sendo estes gerados principalmente nas atividades de geração e abastecimento de energia, transporte e indústria, residências, comércio, agricultura e silvicultura (desmatamento). (IPCC, 2007a, pg. 36). A contribuição destes setores na emissão total de GEEs antropogênicos no ano de 2004 é apresentada no diagrama proporcional da Figura 16.

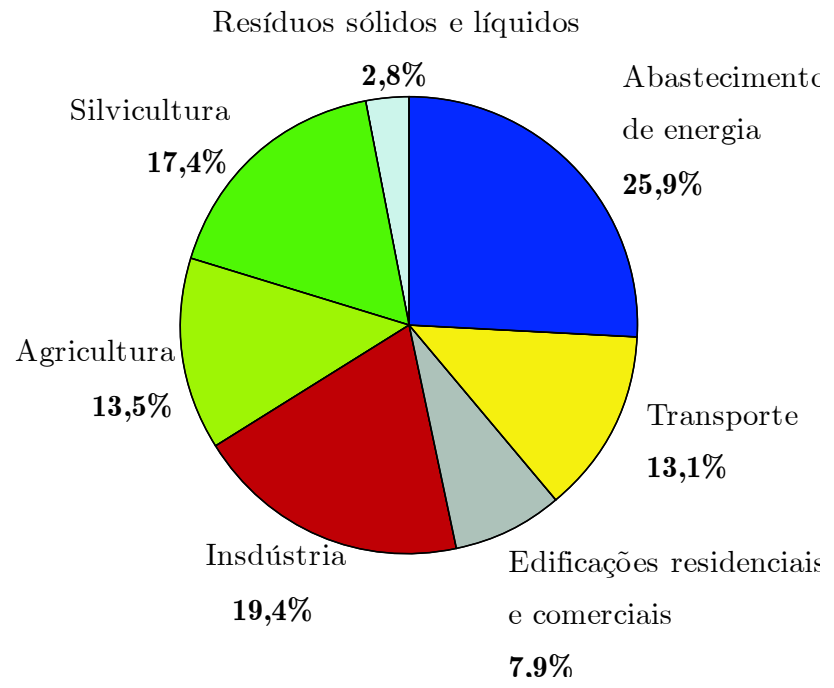

Figura 16 - Distribuição proporcional setorial das emissões de GEEs em 2004 em termos de equivalência em dióxido de carbono. Fonte: IPCC (2007a), pg. 36.

As concentrações globais de $\mathrm{CO}_{2}, \mathrm{CH}_{4}$ e $\mathrm{N}_{2} \mathrm{O}$ têm aumentado significativamente como resultado das atividades humanas desde 1750 e atualmente excedem em muito os valores pré-industriais determinados por testemunhos de gelo abrangendo milhares de anos. O aumento da concentração de gás carbônico, o mais importante GEE antropogênico, é devido primariamente à queima de combustíveis fósseis, com mudanças no uso dos solos proporcionando uma contribuição menor, porém significativa. É bastante 
provável que o aumento na concentração do metano é por causa das atividades agrícolas e do uso de combustível fóssil. E o aumento na concentração do $\mathrm{N}_{2} \mathrm{O}$ é devido à agricultura. (IPCC, 2007a, pg. 37). A Figura 17 exibe as variações das concentrações destes três gases na atmosfera nos últimos 10.000 anos e desde o ano de 1750 (quadros internos).

Conforme pode ser observado na Figura 17, os GEEs diferem-se no potencial de aquecimento (forçamento radiativo) do sistema climático devido aos seus distintos tempos de vida na atmosfera e propriedades radiativas. Estas influências no aquecimento podem ser expressas por meio de uma referência comum, baseada no forçamento radiativo do gás carbônico. Logo, o potencial de aquecimento global do $\mathrm{CO}_{2}$ possui valor 1 , enquanto o $\mathrm{CH}_{4}$ e o $\mathrm{N}_{2} \mathrm{O}$ possuem potencial de 25 e 298 vezes maior, respectivamente, para um período de 100 anos. (IPCC, 2007c, pg. 212) 
Variações nos GEE obtidas por testemunhos de gelo e por observações recentes
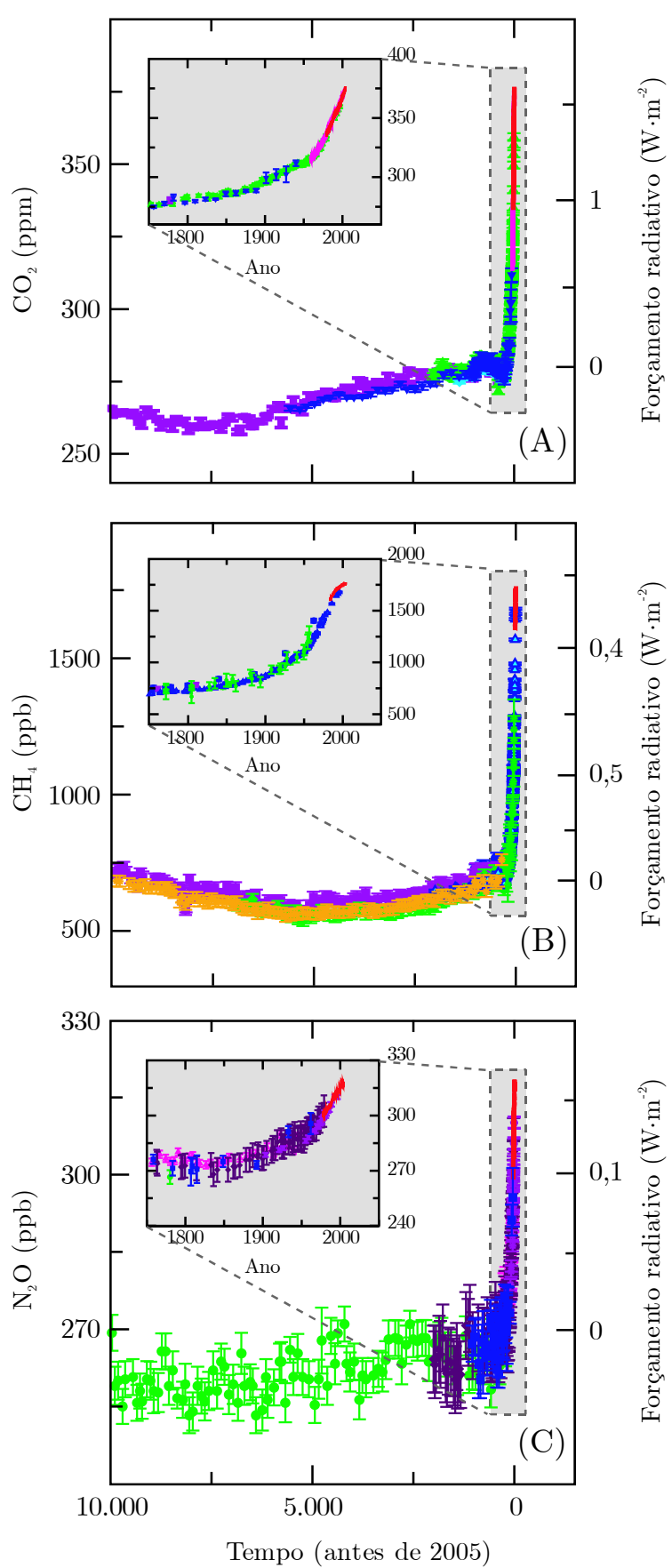

Figura 17 - Concentrações atmosféricas de (A) dióxido de carbono, (B) metano e (C) óxido nitroso ao longo dos últimos 10.000 anos e desde 1750 (painéis internos). Os valores mostrados foram obtidos de diferentes sondagens no gelo (cada cor representa um estudo) e amostras observadas são apresentadas pelas linhas vermelhas. Os forçamentos radiativos correspondentes são mostrados nos eixos laterais direitos. Fonte: IPCC (2007b), pg. 3. 


\subsubsection{Causas naturais}

Segundo o IPCC (2007b), o aquecimento observado desde 1950 sustenta as seguintes conclusões: é extremamente improvável (com probabilidade de ocorrência menor que 5\%) que as mudanças climáticas globais possam ser explicadas sem os forçamentos radiativos antrópicos; é muito provável (com probabilidade de ocorrência maior que 90\%) que estes efeitos não são devidos às causas naturais somente. Durante esse período, a soma dos forçamentos das atividades solares e vulcânicas teria provavelmente (com probabilidade de ocorrência maior que $66 \%$ ) produzida um resfriamento, e não um aquecimento.

\subsubsection{Atribuição de causas das mudanças climáticas recentes}

Levando-se em conta que os gases que apresentam baixa concentração na atmosfera possuem alto potencial de aquecimento, a Figura 18 sintetiza, em termos de forçamento radiativo, a contribuição dos GEEs e de outros agentes e mecanismos importantes que influenciam no balanço da radiação terrestre. 


\section{Componentes de forçamento radiativo}

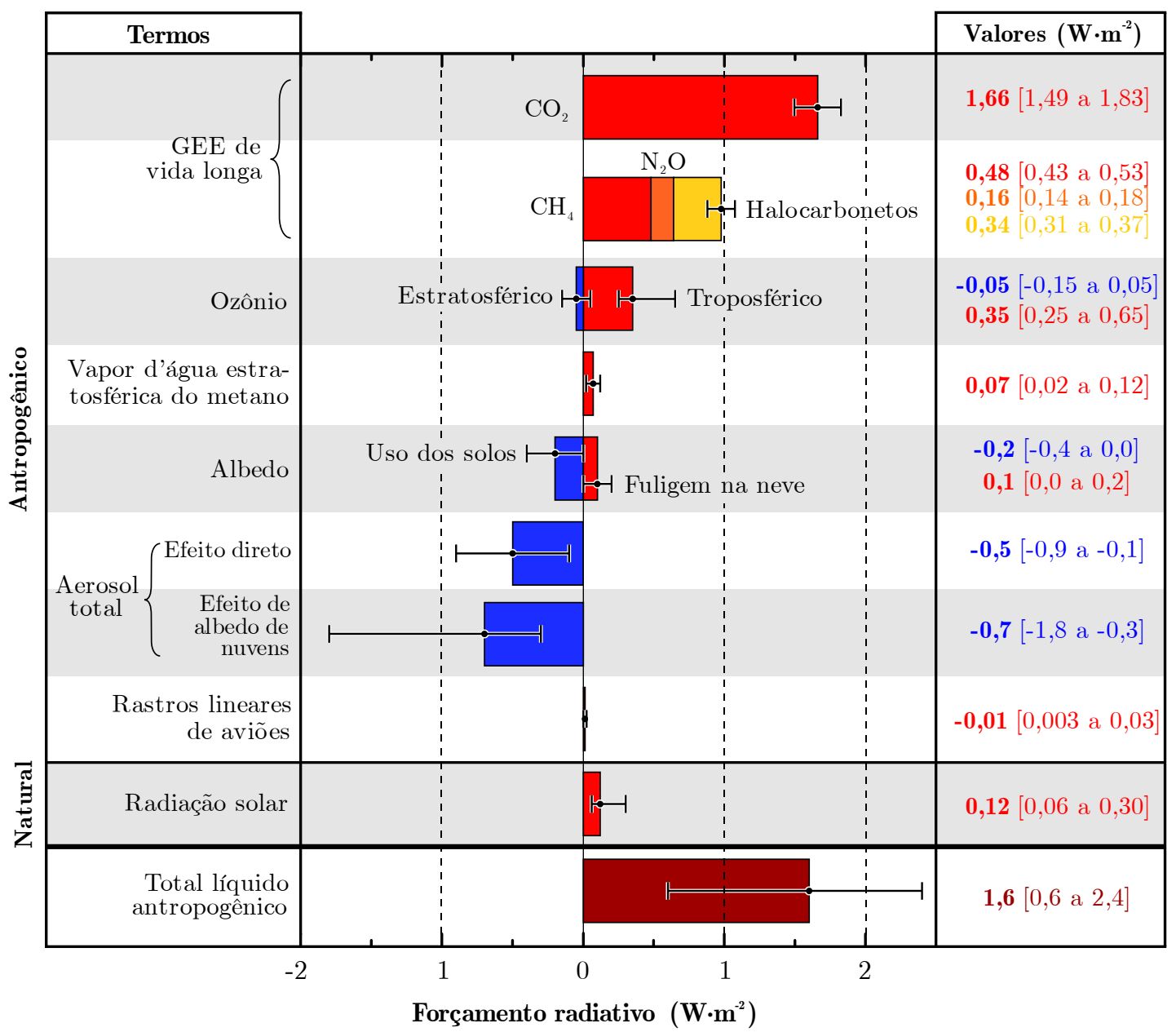

Figura 18 - Média global do forçamento radiativo em 2005. Fonte: IPCC (2007a), pg. 39.

Baseado nesta relação da influência causada pelos diferentes fatores antropogênicos e naturais e no saldo positivo do forçamento radiativo, o AR4 afirma que a maior parte do aumento observado na temperatura média global desde meados do séc. XX é muito provavelmente (com probabilidade de ocorrência maior que 90\%) devido ao aumento observado nas concentrações de GEEs antropogênicos. Esta declaração representou um avanço em relação ao relatório anterior, que atribuía o aquecimento dos últimos 50 anos provavelmente (com probabilidade de ocorrência maior que 66\%) devido às atividades antrópicas emissoras de GEEs (IPCC, 2007a, pg. 39). 


\subsection{Mudanças climáticas passadas (paleoclimáticas): variabilidades naturais}

$\mathrm{Na}$ intenção de compreender o clima passado e os efeitos observados na temperatura média global e no nível médio dos mares, assim como as respectivas causas destas variações, a Paleoclimatologia representa o ramo do conhecimento que estuda o clima em escalas geológicas, da ordem de décadas a milhões de anos atrás. Os elementos climáticos são indiretamente estimados, com o uso de testemunhos de gelo, anéis de árvores (Dendroclimatologia), sedimentos, fósseis, corais (Esclerocronologia) e rochas (conforme citado no item "3.2.3.1. Reconstruções da temperatura no passado", pg. 22), e, assim, as condições climáticas na Terra no passado são reconstruídas, ou seja, determinadas de modo indireto.

A compreensão das condições climáticas na Terra no passado permite discernir quais são os mecanismos determinantes e condutores de mudanças climáticas globais, dando subsídios para implementações nos modelos numéricos, e assim, favorecendo na elaboração de previsões satisfatórias e mais próximas da realidade do clima no futuro.

\subsubsection{Análise dos efeitos}

Apresentadas as causas recentes de mudanças climáticas, na sequência elencam-se os efeitos principalmente com relação às variações do nível do mar e da temperatura na superfície terrestre.

\subsubsection{Variações do nível médio do mar}

O nível médio do mar tem flutuado por todo tempo geológico, periodicamente invadindo ou recuando através das planícies costeiras. A reconstrução no nível do mar no pretérito indica que na escala temporal de milhares de anos houve grandes variações, com amplitude de variação na ordem de centenas de metros. Pouco antes do final da última era glacial, há aproximadamente 25 mil anos atrás, o nível médio dos mares estava a cerca de 120 metros abaixo do nível atual, conforme pode ser observado na Figura 19. 
As flutuações no nível global do mar resultantes de alterações no volume de água no oceano ou o volume das bacias oceânicas constituem no processo denominado de eustasia. A variação global do nível do mar em relação ao nível da terra firme é consequência principalmente das expansões e retrações das calotas polares. Durante uma era glacial, quando o clima da Terra esfria, uma maior proporção de água é armazenada em massas na forma de geleiras, calotas polares, neve etc., resultando em uma diminuição relativa do nível do mar global. Nos períodos inter-glaciais, mais quentes, as calotas se reduzem com o degelo glacial e ocorre a recarga das bacias oceânicas no final da era glacial, aumentando o nível do mar.

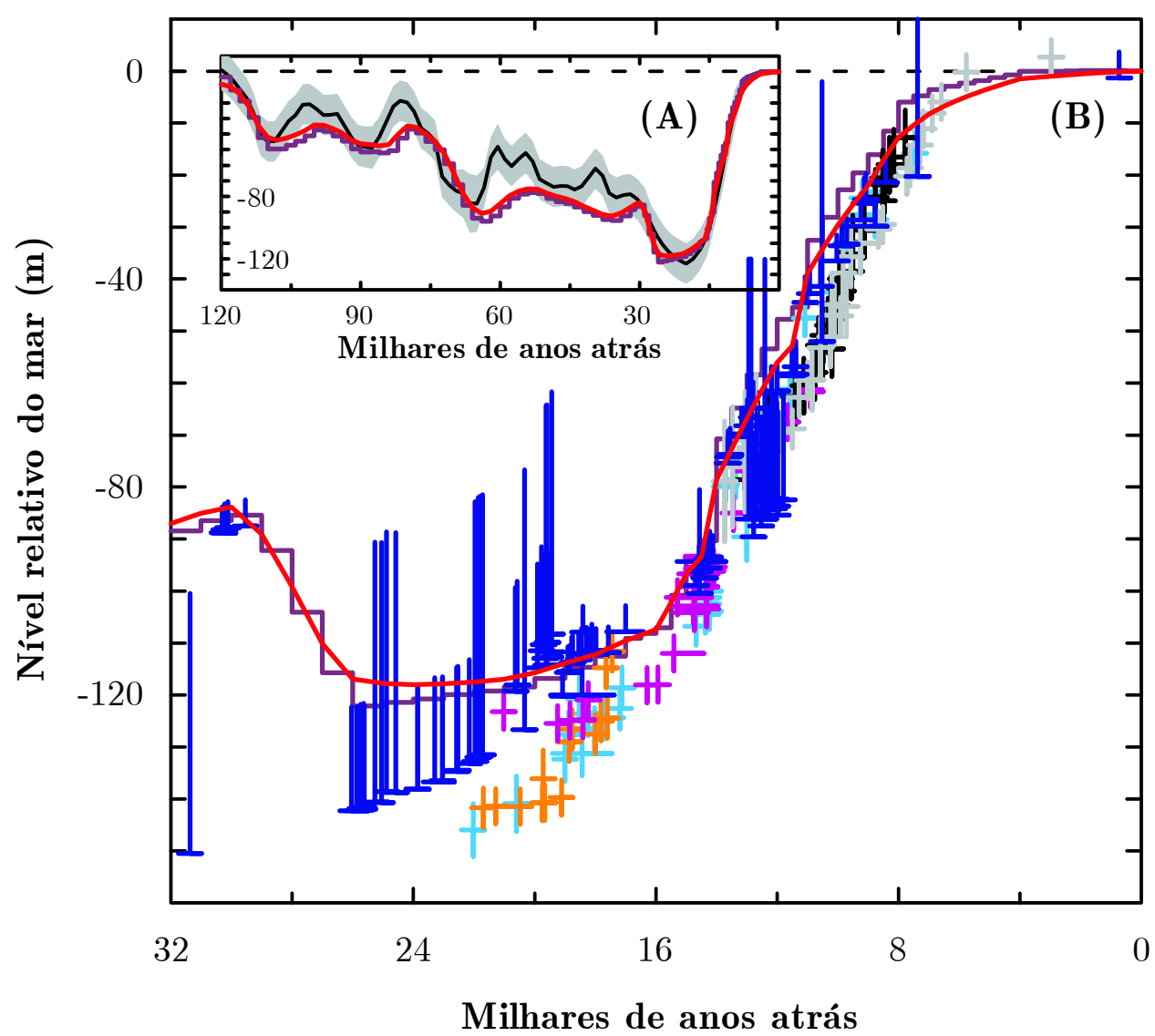

Figura 19 - Variações paleoclimáticas do nível médio relativo do mar (A) Variações eustáticas do nível do mar durante o último ciclo glacial-interglacial. (B) Recorte das variações ao longo dos últimos 32 mil anos. Fonte: IPCC (2007c), pg. 458.

Sob a abordagem na escala de tempo de milhões de anos, mudanças globais implicaram no passado em amplitudes de variação na ordem de centenas de metros, tendo alcançado extraordinariamente até cerca de 300 a 600 metros 
acima do nível atual, de acordo com os autores Hallam (1984) e Vail, Mitchum e Thompson (1977), respectivamente (Figura 20). Porém, de acordo com Miller et al. (2005), a curva de Hallam (1984) deve ser interpretada apenas qualitativamente, por ela não estar calibrada, enquanto que a curva de Vail et al. (1977) é mais realista e condizente com trabalhos mais atuais. Ou seja, o valor da variação máxima do nível do mar estaria na ordem de 200 metros acima do nível atual.

Estas grandes variações estão relacionadas principalmente às mudanças induzidas pela movimentação de placas tectônicas, favorecendo a ocorrência de processos mais lentos de isostasia - alterações da profundidade da estruturas geológicas oceânicas e continentais quem leva à alteração relativa do nível do mar sem que o volume das águas seja alterado. (LAMBECK; CHAPPELL, 2001).

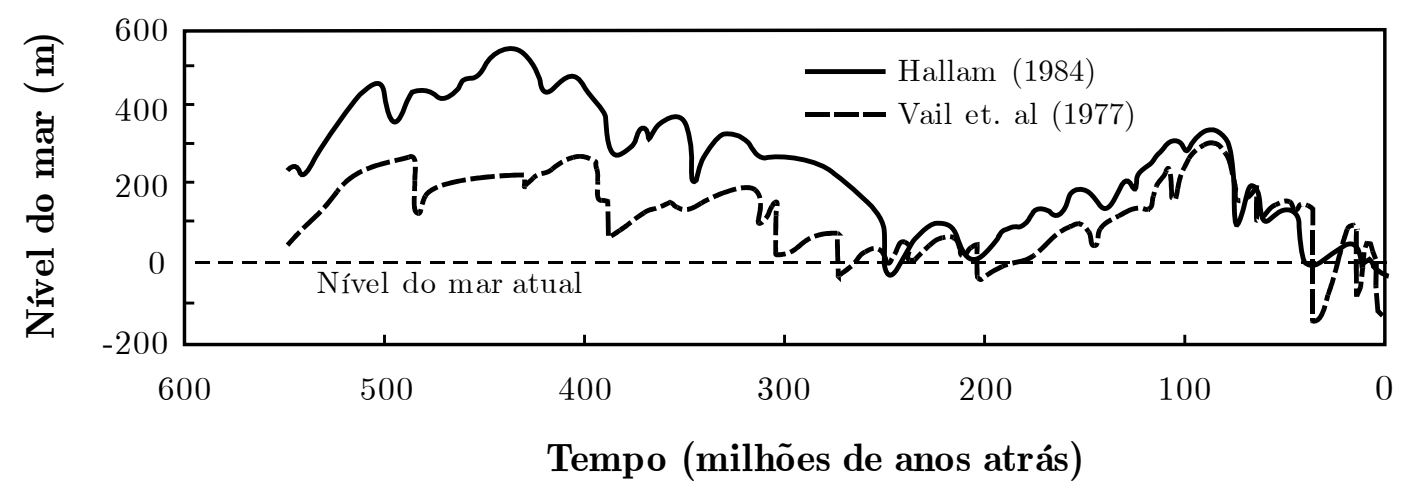

Figura 20 - Variação do nível do mar ao longo dos últimos 550 milhões de anos atrás. A alta frequência de mudanças reflete uma combinação de sinais globais e locais, porém as grandes oscilações são essencialmente globais, estas associadas com a separação dos continentes e a formação de novos sistemas de dorsais oceânicas. Fonte: adaptado de Holland (2005).

\subsubsection{Variações da temperatura média na superfície terrestre}

Analogamente às reconstruções do nível médio do mar, os valores de temperatura foram reconstruídos em diferentes escalas de tempo, de modo que é possível notar grandes amplitudes de variação no comportamento deste elemento climático. Uma primeira ilustração é apresentada na Figura 21, revelando as variações da temperatura terrestre em diferentes escalas: milhões, milhares, centenas e dezenas de anos. 


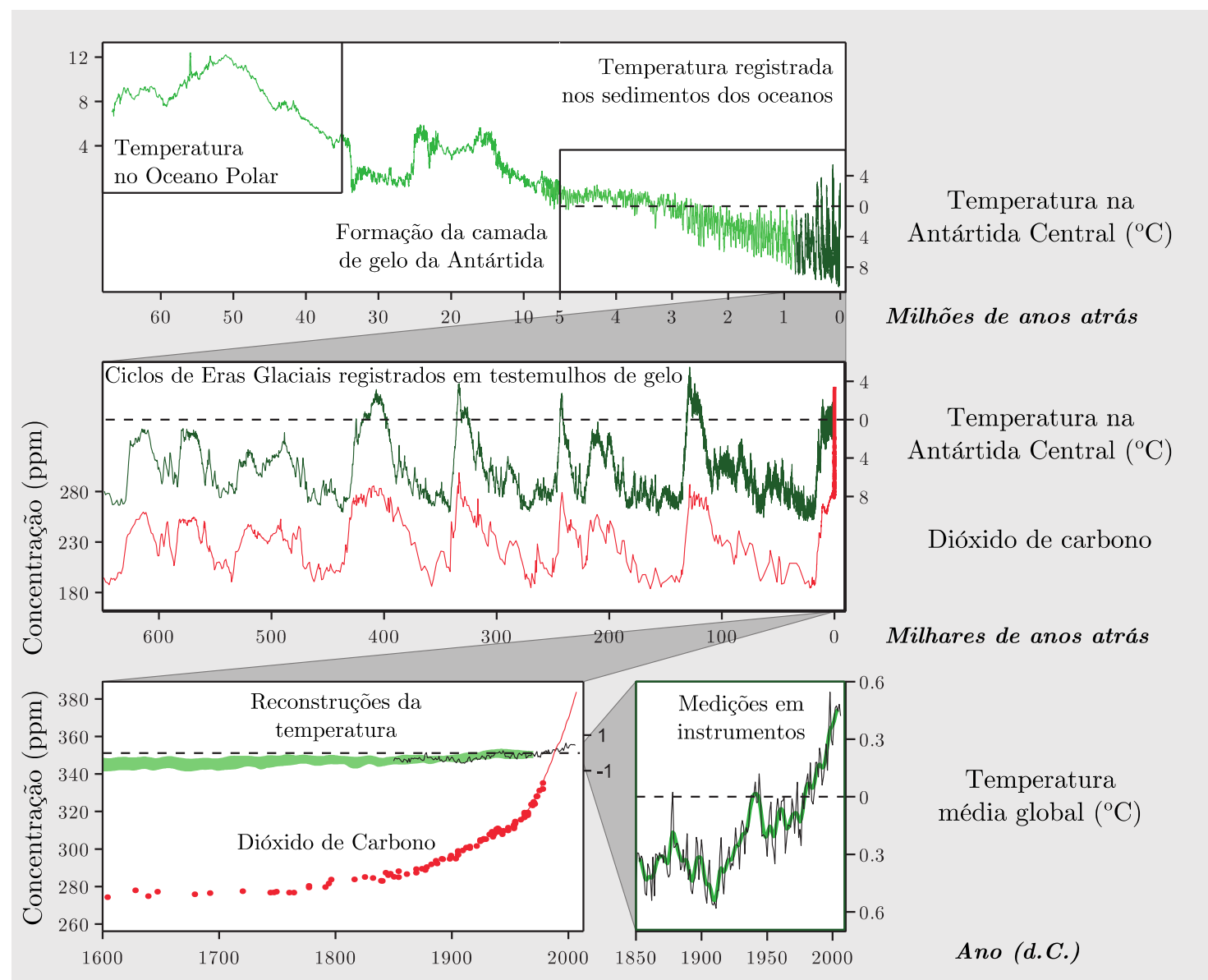

Figura 21 - Variações da temperatura terrestres em diferentes escalas temporais.

Gráfico superior: resfriamento global nos últimos 60 milhões de anos. Gráfico intermediário: eras glaciais periódicas nos últimos 600 mil anos. Gráficos inferiores: aumento da temperatura e do dióxido de carbono ao longo dos últimos quatro séculos. As informações no painel superior vêm de poços perfurados no fundo dos oceanos, onde os sedimentos contêm restos de organismos primitivos que viveram perto da superfície do oceano. As informações no painel do meio são da Antártida, onde a neve acumulada de centenas de milênios criou geleiras profundas. Fonte: Philander (2008).

\subsubsection{Síntese em escala geológica}

Longe de ser estático, o clima na Terra nos últimos 600 milhões de anos variou consideravelmente: passou de fases extremamente frias e glaciações a períodos áridos de aquecimento global. Sumarizando tais variações, Frakes, Francis e Syktus (1992) identificaram períodos de tempo com padrões de similaridades nas condições climáticas, e propuseram os Modos Climáticos do 
Fanerozóico, dividindo os períodos da história climática entre Modo Quente e Modo Frio. O Modo Frio é atribuído a épocas de resfriamento global em que predominava a ocorrência de grandes extensões de gelo; enquanto que o Modo Quente é atribuído a épocas em que o clima se apresentava quente, indicado pela abundância de dados geoquímicos de distribuições de fauna e pela presença de pouco ou nenhum gelo polar.

Informações paleoclimáticas da temperatura média terrestre e do nível médio do mar revelam que a história do clima ao longo dos 600 milhões de anos não apresentou uma tendência simples de resfriamento e aquecimento, mas sim foi caracterizado pela alternância de períodos quentes e frios, conforme pode ser constatado na Figura 22. Os Modos Quentes duraram entre 50 a 100 milhões de anos; e os Modos Frios cerca de 40 a 80 milhões de anos. Análises de fatores que afetam o clima sugerem que processos tectônicos, particularmente aqueles relacionados às atividades vulcânicas, governam o início das fases quentes e frias do clima terrestre (FRAKES; FRANCIS; SYKTUS, 1992). 


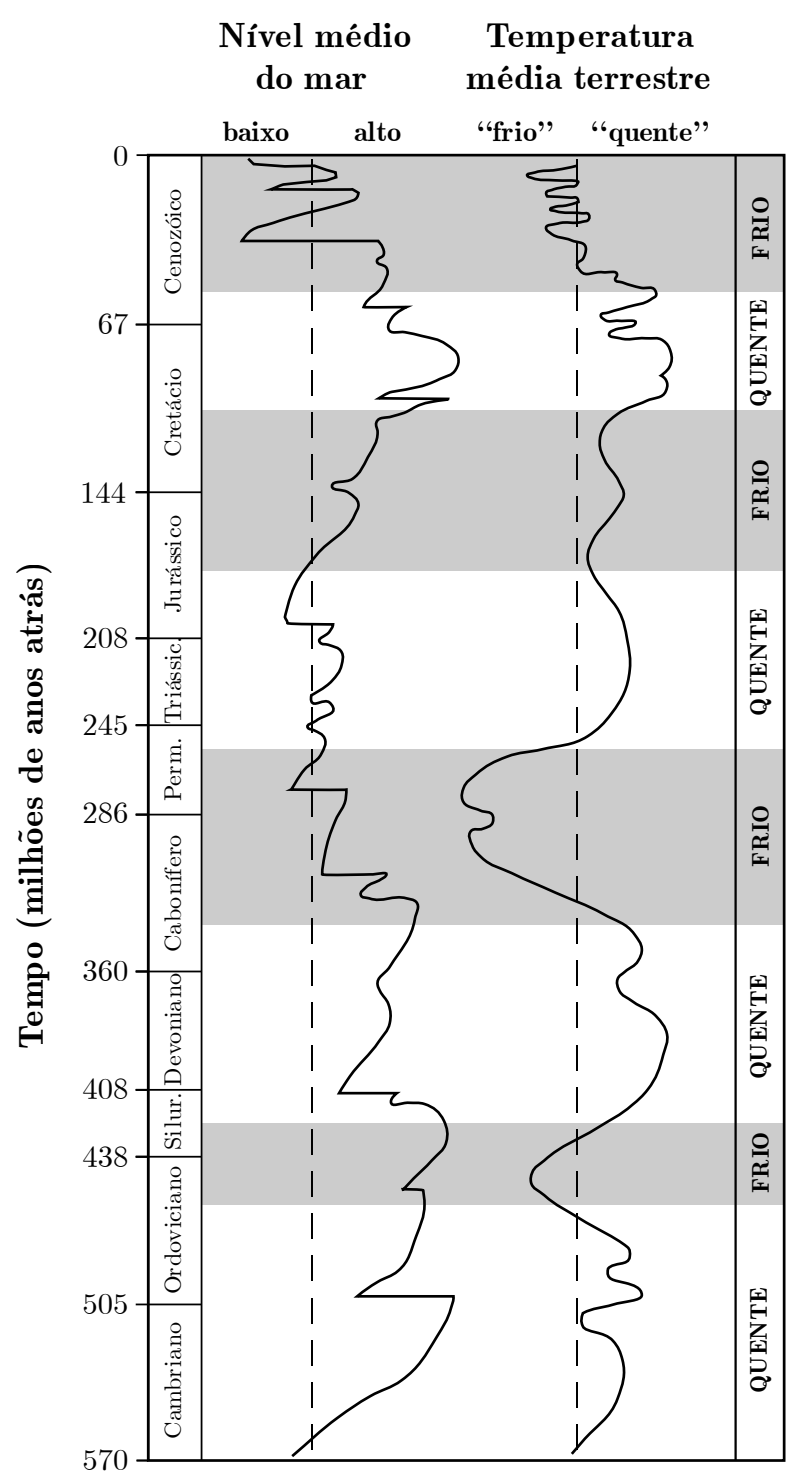

Figura 22 - Variações estimadas do nível eustático do mar e da temperatura global durante o Fanerozóico, ilustrando os modos quentes e frios. Fonte: Frakes, Francis e Syktus (1992).

\subsubsection{Análise das causas naturais}

Conforme apresentado na Figura 18 (pg. 54), a radiação solar representa o principal fator natural de influência nos forçamentos radiativos e, consequentemente, consiste em uma contribuição significativa nas mudanças climáticas. O balanço de radiação terrestre varia de acordo com a quantidade de radiação que entra e que sai no planeta Terra, dependendo basicamente de três fatores que variam ao longo do tempo. Em ordem sequencial do caminho que a 
radiação solar percorre, desde o corpo emissor (Sol) até corpo receptor (Terra), os fatores que afetam o balanço de radiação terrestre são:

1. Emissão da radiação: fator primário determinado pelas variações solares, como os ciclos solares de Schwabe e outros.

2. Recepção da radiação: fator secundário determinado pelas variações da posição terrestre em relação ao Sol, conforme observado nos ciclos de Milankovitch.

3. Reflexão, absorção e re-emissão da radiação: fator terciário determinado pelas alterações na atmosfera e na superfície terrestre.

As causas naturais das mudanças climáticas atuam nestes três grandes fatores. As causas humanas, não atuando nas duas primeiras categorias astronômicas, poderiam interferir somente no fator terrestre de terceira ordem, alterando as concentrações de gases e partículas na atmosfera e o uso e ocupação dos solos.

As causas de mudanças climáticas são classificadas em duas grandes categorias. Causas externas são referentes aos agentes modificadores exteriores ao sistema climático que influenciam nos três fatores acima descritos. Causas internas compreendem os agentes que influenciam no fator terciário, com mudanças nas características da atmosfera e superfície terrestres (MCGUFFIE; HENDERSON-SELLERS, 2005).

\subsubsection{Variações das emissões solares}

As variações solares referem-se às mudanças na quantidade de radiação total emitida pelo Sol e na sua na distribuição espectral. A Terra recebe no topo de sua atmosfera um fluxo de energia eletromagnética de aproximadamente 1365 $\mathrm{W} \cdot \mathrm{m}^{-2}$ do Sol. Anteriormente à disponibilidade de satélites de alta precisão, a radiação solar emitida era considerada constante por muitos cientistas. Tal fato é refletido no termo "constante solar". Devido às interferências atmosféricas, todas tentativas de detectar, em solo, as variações na constante solar fracassaram. Foi então que, com o uso de satélites fora da atmosfera, o monitoramento da radiação solar permitiu identificar pequenas variações (BEER; MENDER; STELLMACHER, 2000). 
A radiação solar medida pelos satélites durante as décadas recentes indicam que as variações se apresentam de forma periódica, fenômeno conhecido

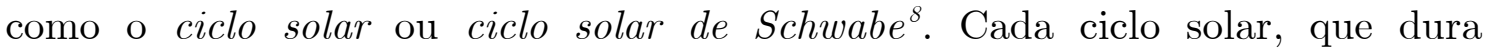
aproximadamente 11 anos, é caracterizado por uma oscilação no surgimento e desaparecimento de manchas solares, onde os períodos de atividades solares elevadas são conhecidos por máxima solar, e os períodos de atividades reduzidas são denominados de mínimo solar. Esta oscilação causou nos dois últimos ciclos uma variação de $0,1 \%$ (cerca de $1,3 \mathrm{~W} \cdot \mathrm{m}^{-2}$ ) na amplitude da radiação solar emitida. A Figura 23 exibe os ciclos 21,22 e $23^{9}$.

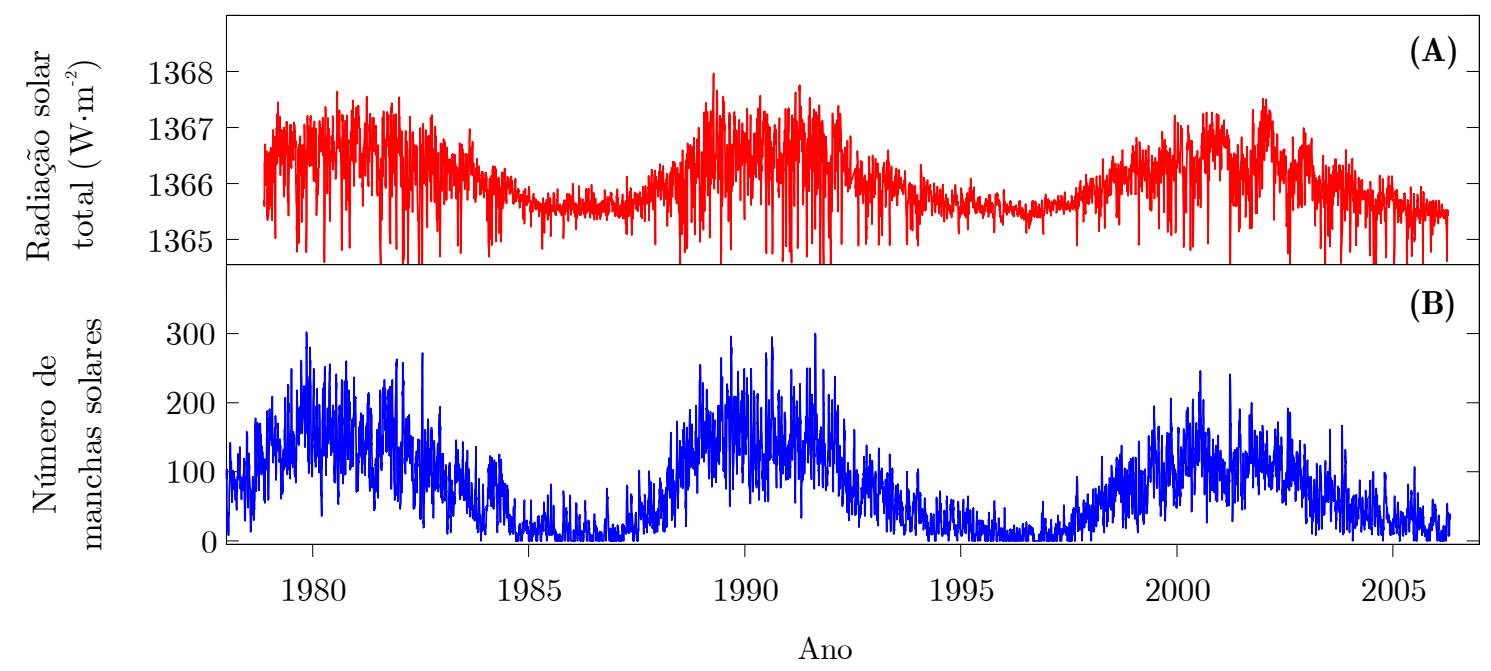

Figura 23 - Variações desde 1978 da: (A) radiação solar total e (B) do número de manchas solares. Fonte: Schöll et al. (2007).

Uma vez que não existem dados de observações diretas para estudar a variabilidade da radiação solar em escalas de tempo maiores do que décadas, estimativas são realizadas com base em correlações comparativas a medições em testemunhos, da mesma forma que é feito nas reconstruções da temperatura média global. Conforme apresentado na Figura 23-A, os valores da radiação solar foram disponibilizadas apenas durante os últimos três ciclos e se baseiam em uma composição de diversos satélites de observação. No entanto, uma alta correlação entre as medições de radiação e outros testemunhos de atividade

\footnotetext{
8 Homenagem a Samuel Heinrich Schwabe (1789 - 1875), astrônomo alemão, conhecido pela descoberta da periodicidade das manchas solares em 1843.

${ }^{9}$ O ciclo número 1 é tradicionalmente designado para o período de 1755 a 1766.
} 
solar permite estimar razoavelmente a atividade solar no passado. O mais importante método entre esses testemunhos é o registro das observações a olho nu do número de manchas solares (Figura 23-B), que tem sido registrada desde aproximadamente 1610, vide apresentado na Figura 24.

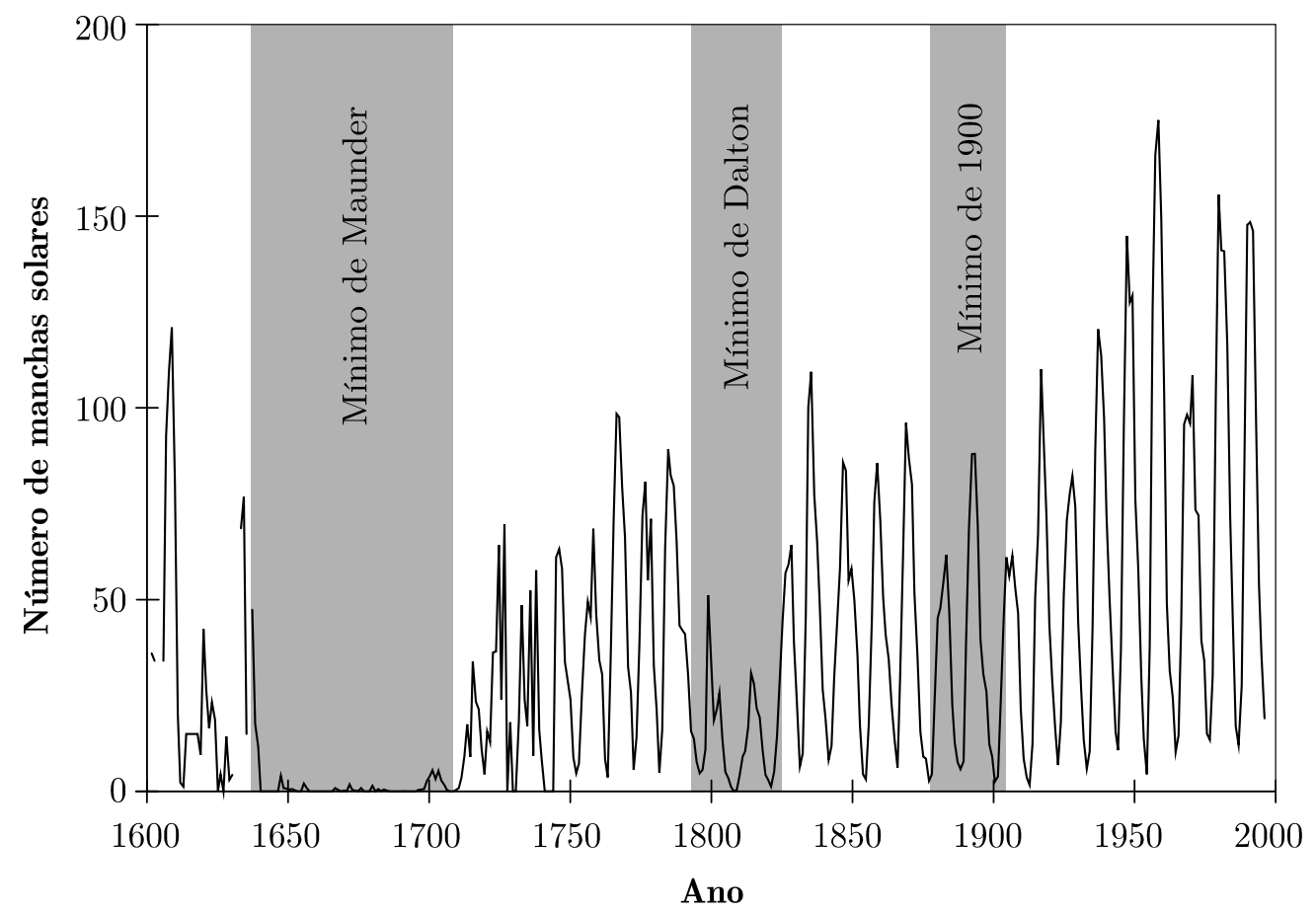

Figura 24 - Variação da quantidade de manchas solares desde 1610. Fonte: Beer, Mender e Stellmacher (2000).

Reconstruções dendroclimatológicas da atividade solar, com base em datações radiométricas em anéis de árvores, foram realizadas para períodos maiores que as quatro décadas de observações diretas do número de manchas solares. A Figura 25-A exibe reconstruções do número de manchas solares nos últimos 11.000 anos, enquanto que um recorte do período desde o ano 900 d.C., mostrado na Figura 25-B, exibe os valores da variação da concentração do radiocarbono $\left({ }^{14} \mathrm{C}\right)$.

O radiocarbono é produzido por interações nucleares induzidas por raios cósmicos que entram na atmosfera. A intensidade dos raios cósmicos depende da atividade solar através da mudança do campo magnético interplanetário. Uma vez que o ${ }^{14} \mathrm{C}$ atmosférico é assimilado pelas árvores, a variação atmosférica do ${ }^{14} \mathrm{C}$ reflete mudanças na atividade solar, e, portanto, pode ser reconstruída por meio de analises de anéis de árvores (MASUDA et al., 2009). A concentração do 
${ }^{14} \mathrm{C}$ na atmosfera é baixa durante os máximos solares e elevada durante os mínimos solares. O eixo vertical da Figura 25-B está invertido para que o mínimo da concentração de ${ }^{14} \mathrm{C}$ corresponda ao máximo do número de manchas solares.

Observando a reconstrução nos últimos 1.000 anos, os períodos de alta produção de ${ }^{14} \mathrm{C}$ correspondem a períodos de baixa atividade solar, nomeados de Minimos de Maunder, Spörer, Wolf e Oort. Musada et al. (2009) apontam que o Mínimo de Maunder está possivelmente associado à Pequena Era do Gelo, implicando em uma correlação entre atividades solares e o clima terrestre global.

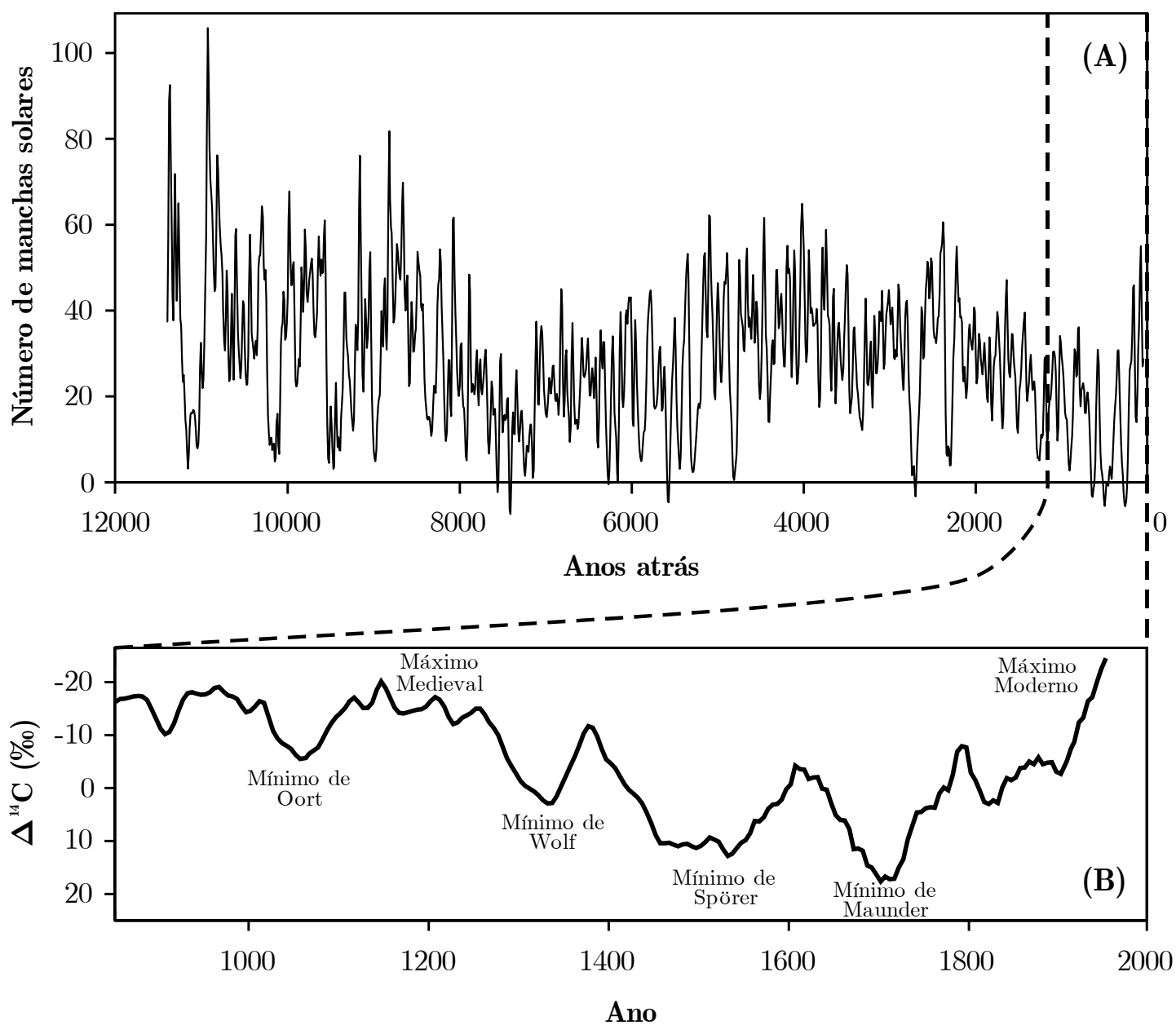

Figura 25 - Reconstruções das atividades solares passadas: (A) Variação da quantidade de manchas solares nos últimos 11.000 anos; (B) Concentração de radiocarbono atmosférico nos últimos 1.100 anos. Fonte: elaborada com base em Solanki et al. (2004), gráfico (A); e Reimer et al. (2004), gráfico (B). 
As reconstruções do ${ }^{14} \mathrm{C}$, e por inferência as atividades solares, indicam que, além do ciclo de Schwabe, o Sol possui outros ciclos, de acordo com Beer, Mender e Stellmacher (2000): ciclo de Hale ${ }^{10}$, revelando que o ciclo solar é um ciclo magnético onde a polarização magnética das manchas solares inverte a cada 22 anos; ciclo de Gleissberg, de 88 anos; ciclo de Suess, de 208 anos; e ciclos consideravelmente maiores, da ordem de 2.000 anos ou mais.

Desta breve introdução das variações cíclicas das atividades solares, verifica-se que esta área do conhecimento está sendo intensamente pesquisada pela comunidade científica internacional. Uma breve busca em um banco de dados eletrônico" pelos termos "sun climate", no campo do título de artigos em periódicos internacionais indexados, revela numerosos trabalhos publicados. Da mesma forma, uma quantidade considerável de livros recentes aborda o mesmo tema.

Ou seja, com um volume imenso de informações geradas nestas pesquisas, é possível inferir que existem evidências suficientes para supor uma influência significativa dos efeitos do Sol no clima na Terra, uma vez que os diferentes ciclos solares representaram um forçamento radiativo expressivo nas mudanças climáticas nos últimos milênios. Inclusive, trabalho recente de Scafetta (2010) alega que $60 \%$ do aquecimento global observado desde 1970 é devido a causas naturais decorrentes dos ciclos solares de Schwabe e Hale, além do ciclo lunar de 9,1 anos e da influência dos períodos orbitais de Júpiter e Saturno.

A influência da radiação solar no clima é, de fato, bastante significativa, responsável pelos ciclos glaciais e inter-glaciais, conforme será apresentado no próximo item.

A propósito, Scafetta (2010) explica que os planetas, em particular Júpiter e Saturno, com seus movimentos em torno do Sol dão origem a grandes oscilações gravitacionais e magnéticas que fazem vibrar o sistema solar. Estas vibrações têm as mesmas frequências das órbitas planetárias. As vibrações do sistema solar podem ser direta ou indiretamente sentidas pelo sistema climático e podem fazer com que oscilem com as mesmas frequências. Mecanismos físicos mais específicos envolvidos no processo incluem forças de maré gravitacional,

\footnotetext{
10 Homenagem a George Ellery Hale (1868 - 1938), astrônomo norte-americano, que junto com colaboradores elucidou as bases físicas do ciclo solar em 1908.

${ }^{11}$ Scopus. Disponível em: <http://www.scopus.com/>. Acesso em 15 dez. 2009.
} 
fenômenos de transferência de rotação orbital e perturbações magnéticas. Os grandes planetas jovianos, Júpiter e Saturno, possuem amplos campos magnéticos que interagem com o plasma solar e com o campo magnético de interação. Estas forças gravitacionais e magnéticas agem como forças externas do dínamo solar, do vento solar e do sistema Terra-Lua e pode modular tanto a dinâmica solar e, direta ou indiretamente, através do Sol, o clima da Terra. Por exemplo, o ciclo solar de 11 anos está bem sincronizado com o alinhamento de Vênus, Terra e Júpiter. O ciclo das manchas solares também apresenta uma bimodalidade com períodos que oscilam entre 10 e 12 anos, que está entre os períodos sinódicos opostos de Júpiter e Saturno e o período de Júpiter, respectivamente. Estes resultados indicam que Júpiter, Saturno, Urano e Netuno modulam a dinâmica solar. Estes evidências indicam que o clima pode ser parcialmente impulsionado por forças mecânicas, tais como torques gravitacionais e magnéticos, e não apenas as forças radiativas como suposto pelo IPCC.

\subsubsection{Variações orbitais terrestres}

A variação da radiação incidente na atmosfera terrestre ocorre não somente devido às variações das atividades solares, mas também devido às variações orbitais da Terra. Estas variações implicam em influências de longo prazo no clima de ordem superior às causadas pelas variações das emissões solares.

O matemático sérvio Milutin Milankovitch (1879-1958) passou 30 anos pesquisando mudanças em características orbitais da Terra e sua influência sobre a quantidade de radiação solar recebida na superfície da Terra. Três características da órbita terrestre mudam lentamente ao longo de dezenas de milhares de anos, vide ilustrado na Figura 26:

- Excentricidade orbital;

- Inclinação axial ${ }^{12} ; \mathrm{e}$

\footnotetext{
12 A propósito, a o termo clima surgiu da palavra grega klima, que se refere à suposta inclinação da Terra, aproximando à atual concepção de latitude. A origem histórica da palavra klima remete aos estudos realizados pelas civilizações sumérias datadas no ano de 400 a.C. (CRITCHFIELD, 1966).
} 
- Precessão dos equinócios (ou orientação do eixo de rotação).

Estas características apresentam diferentes ciclos de mudança que afetam a quantidade de insolação. As causas das variações orbitais terrestres estão relacionadas à influência dos movimentos dos corpos do sistema solar. Ou seja, os parâmetros orbitais de Terra oscilam de acordo com a variação dos campos gravitacionais e magnéticos gerados pelo Sol, pela Lua e pelos outros planetas, especialmente Júpiter e Saturno. (SCAFETTA, 2010).

(A)

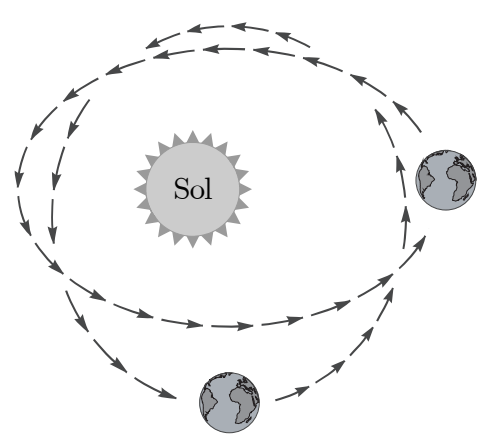

(B)

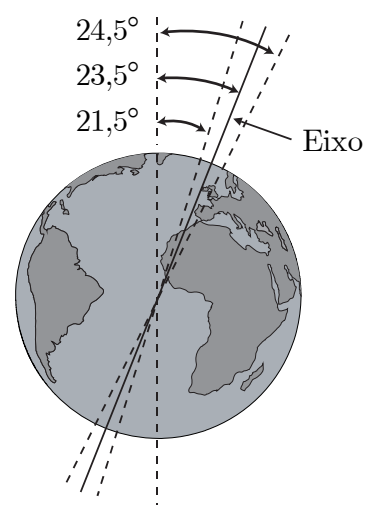

(C)

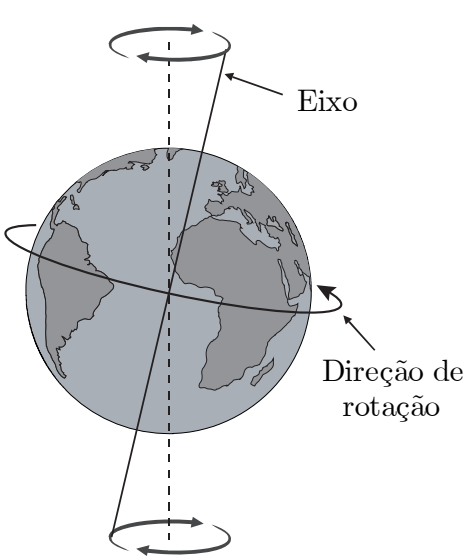

Figura 26 - Variações orbitais terrestres: (A) excentricidade orbital; (B) inclinação do eixo terrestre; (C) precessão dos equinócios. Fonte: adaptado de Harper (2007).

A Terra gira sobre um eixo que forma atualmente ${ }^{13}$ um ângulo de $23,5^{\circ}$ em relação ao plano de rotação. Este não é um ângulo constante, variando de $21,5^{\circ}$ a $24,5^{\circ}$ durante um período de 41.000 anos (Figura 26-B). Quando o ângulo é menor, ocorrem diferenças menores de temperatura entre o verão e o inverno do que quando o ângulo é maior. Com um ângulo maior, os invernos são mais frios e os verões mais quentes, devido aos diferentes tempos de exposição à insolação atmosférica (HARPER, 2007).

A excentricidade orbital muda conforme ciclos de 100.000 anos, sendo mais circular (como agora) para mais elíptica e, em seguida, volta a ser circular (Figura 26-A). Quando é mais circular, então a distância Terra ao Sol varia

\footnotetext{
${ }^{13}$ A inclinação está em fase de redução do seu anglo no ciclo, e atingirá o valor mínimo em torno do ano 10.000 .
} 
pouco entre as estações, e quando a órbita é elíptica, há uma diferença significativa entre a distância ao Sol no verão e no inverno. O efeito da excentricidade no clima da Terra depende também da última característica orbital: a precessão dos equinócios (HARPER, 2007).

A Terra oscila sobre seu eixo em um movimento análogo ao de um pião, fenômeno conhecido precessão dos equinócios. Durante um período de 26.000 anos, o eixo de rotação oscila e forma um círculo (Figura 26-C). Esta oscilação determina a estação do ano durante a qual a Terra estará mais próxima do Sol (HARPER, 2007).

O efeito destas três características orbitais fica claro quando os extremos todos combinam. Se a órbita é a mais excêntrica possível, a oscilação coloca a Terra muito longe do Sol durante o inverno e se o ângulo do eixo é o máximo de $24,5^{\circ}$, então os invernos serão muito frios e verões serão muito quentes. Estas variações orbitais mudam, além do total da quantidade de luz solar que atinge a superfície da Terra, também a distribuição da radiação no globo. A compreensão das variações orbitais induziu Milankovitch a relacionar a influência destas com os efeitos no clima terrestre de longo prazo, tornando-se uma teoria plausível para a ocorrência das glaciações.

Milankovitch estudou dados astronômicos desde 600.000 anos até 1800 e calculou a quantidade de insolação em diferentes latitudes para cada ano. Em seguida, ele previu que estas mudanças cíclicas induziriam as eras glaciais, quando o montante de radiação solar fosse a menor durante os meses de verão, reduzindo assim o derretimento da neve nas altas latitudes. Assim, a neve que caiu durante o inverno não derreteria durante o verão, e ano após ano, ao longo de milhares de anos, o gelo acumulado formaria geleiras que avançariam em direção ao equador e, por fim, produziriam uma idade do gelo (HARPER, 2007).

Os cálculos foram aperfeiçoados e comparados com resultados paleoclimáticos recentes, e foi identificado um ciclo de ocorrência intercalada de eras glaciais e interglaciais, fenômenos periódicos denominados de ciclos de Milankovitch, conforme ilustrado na Figura 27. 


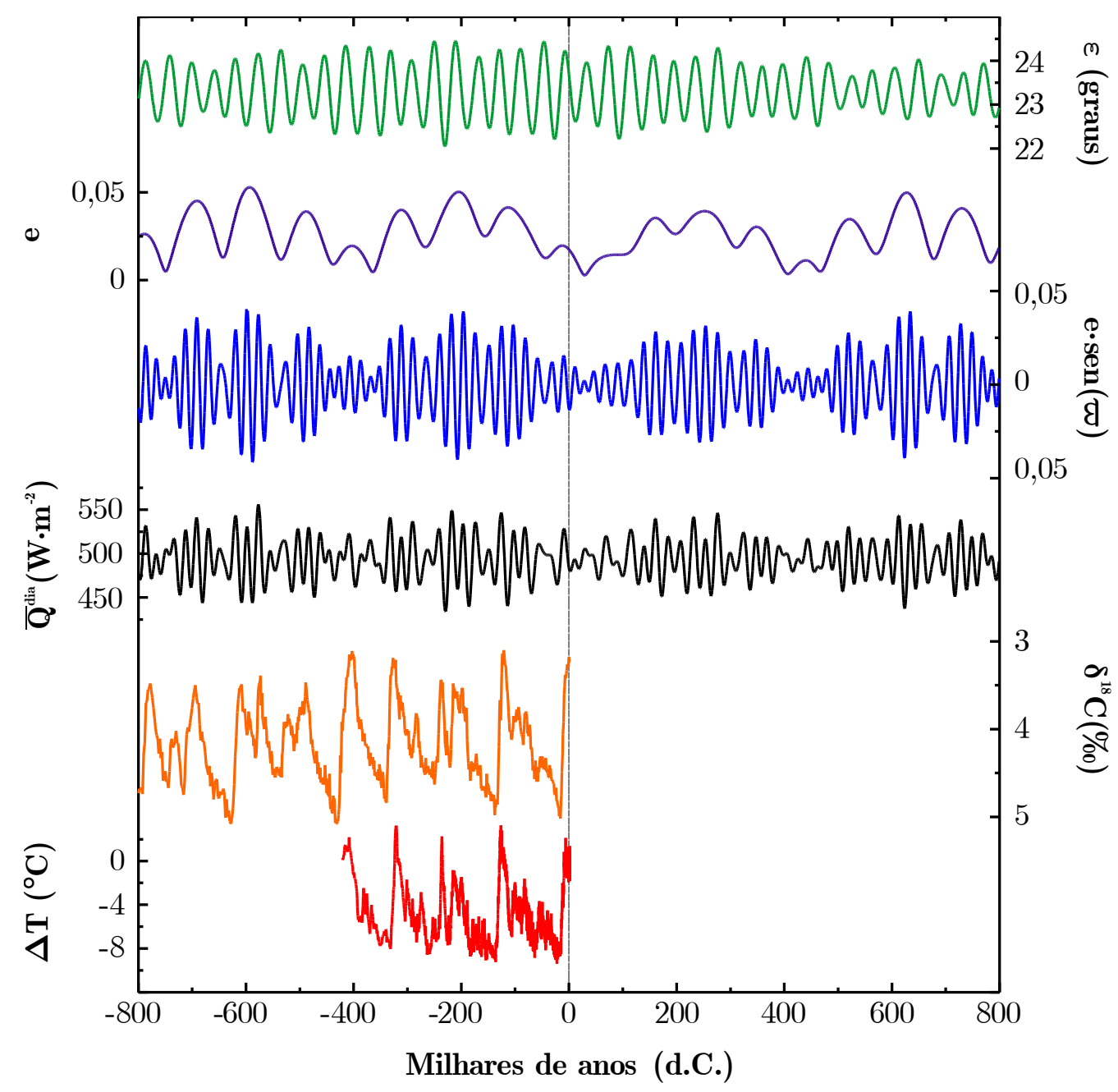

Figura 27 - Parâmetros orbitais e Ciclos de Milankovitch no passado e futuro. Curva verde: $\varepsilon$ é a obliquidade (inclinação axial). Curva roxa: e é a excentricidade. Curva azul: $\bar{\omega}$ é a longitude do periélio e esen $(\pi)$ é o índice de precessão, que, juntamente com obliquidade, controla o ciclo sazonal da insolação. Curva preta: $Q^{-d i a}$ é a radiação média de insolação no topo da atmosfera, no dia do solstício de verão na latitude $65^{\circ}$ norte. Foraminíferos bentônicos e testemunhos de gelo em Vostok mostram duas reconstruções diferentes para o nível do mar (curva laranja) e a variação da temperatura global no passado (curva vermelha); curvas a partir de sedimentos oceânicos e de gelo da Antártida, respectivamente. A linha vertical cinza corresponde ao ano 2000 d.C. Fonte: Fiedler (2009).

Análises de perfurações no gelo na Estação Vostok, Antártida, produziram um registro de condições ambientais do passado que remonta a 420 mil anos e que abrangem quatro períodos glaciais anteriores (Figura 28). É claramente visível que um padrão de repetição relativa existe correlação entre o $\mathrm{CO}_{2}$ e a temperatura por quatro ciclos glacial-interglacial. Florides e 
Christodoulides (2009) explicam que o aumento de concentração de $\mathrm{CO}_{2}$ ocorre com atraso de 400 a 1000 anos após a mudança de temperatura, portanto, indicando que a relação entre temperatura e $\mathrm{CO}_{2}$ parece ser exatamente o contrário do que se presume ser do modelo convencional de estudos do clima. Um gatilho inicial de mudança na temperatura (como pequenas mudanças na órbita da Terra, por exemplo) resulta em uma liberação de $\mathrm{CO}_{2}$ dos reservatórios naturais, como o oceano, para a atmosfera com uma defasagem de alguns séculos.

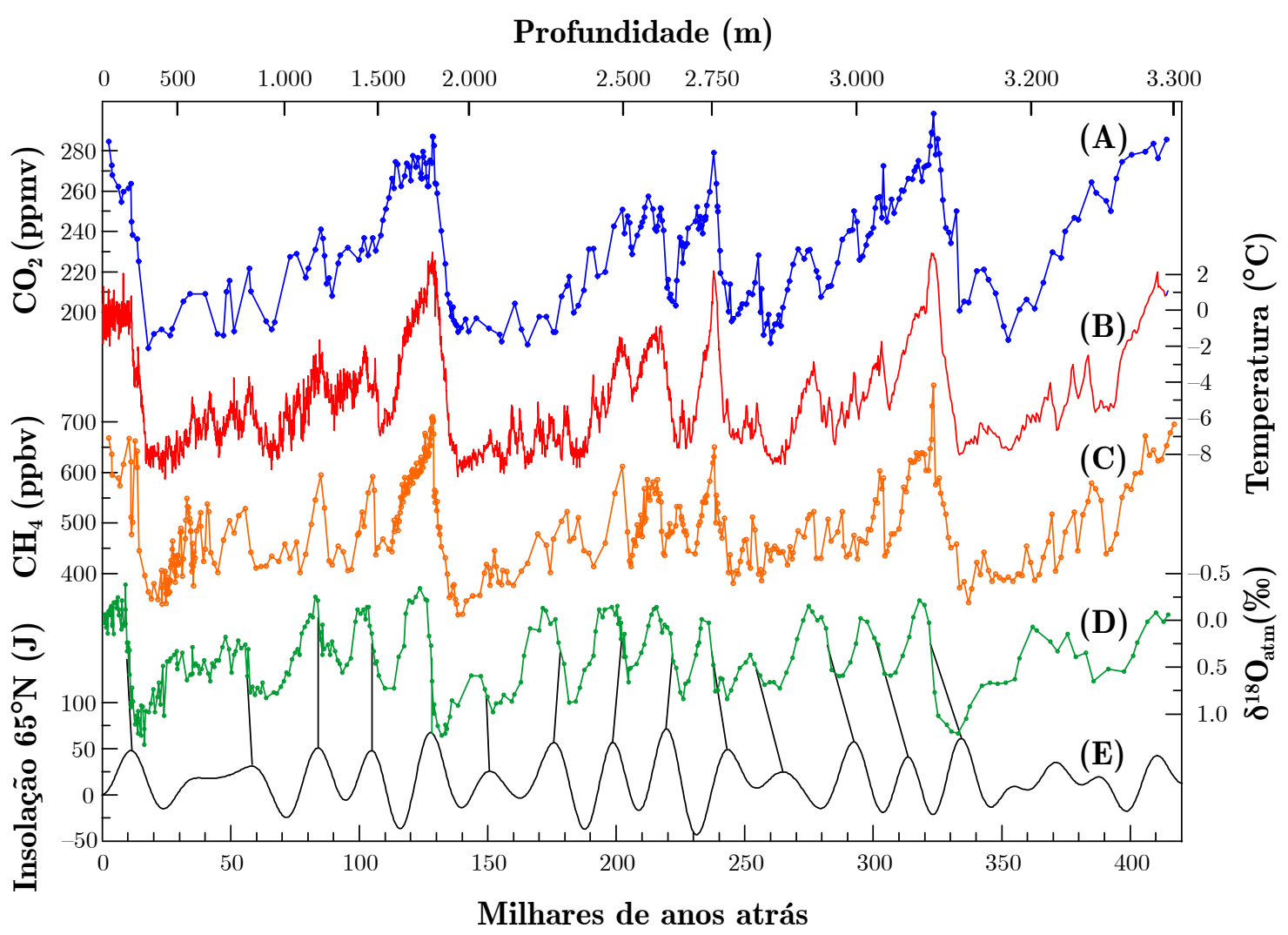

Figura 28 - Ciclos de Milankovitch registrados nos testemunhos de gelo. Séries de Vostok (curvas coloridas) e insolação (curva preta). Série com relação ao tempo (escala com indicação de profundidades correspondentes no eixo superior): (A) de $\mathrm{CO}_{2} ;(\mathbf{B})$ da temperatura isotópica da atmosfera; (C) de $\mathrm{CH}_{4}$; (D) de $\delta^{18} \mathrm{O}_{\text {atm }}$; e (E) insolação, em meados de junho, na latitude $65^{\circ} \mathrm{N}\left(\mathrm{em} \mathrm{W} / \mathrm{m}^{2}\right)$. Fonte: Petit et al. (1999).

Sabe-se que a solubilidade do $\mathrm{CO}_{2}$ nos oceanos varia inversamente proporcional à temperatura. Ou seja, há evidências de que o aumento (redução) de temperatura do ar cause o aumento (redução) das concentrações de $\mathrm{CO}_{2}$ e não o contrário. $\mathrm{O} \mathrm{CO}_{2}$ acompanha a temperatura: isto é, a solubilidade do $\mathrm{CO}_{2}$ 
nos oceanos varia inversamente a sua temperatura. Ou seja, a concentração de $\mathrm{CO}_{2}$ na atmosfera é diretamente proporcional à temperatura: no equilíbrio químico do gás carbônico, quanto maior a temperatura terrestre, menos gás será solubilizado nos oceanos na forma de ácido carbônico $\left(\mathrm{H}_{2} \mathrm{CO}_{3}\right)$, e, portanto, maior é a concentração deste gás na atmosfera (FLORIDES; CHRISTODOULIDES, 2009).

\subsubsection{Variações da atmosfera e superfície terrestre}

Além das variações solares e orbitais terrestre, as variações na composição da atmosfera e do uso e ocupação dos solos representam o terceiro fator de alteração do balanço de radiação terrestre, cuja consequência implica em mudanças climáticas em diferentes escalas têmporo-espaciais. As causas dessas variações podem ser devido às ações humanas ou devido a eventos naturais, principalmente por:

- Atividades vulcânicas; e

- Colisão de meteoritos e cometas.

A principal causa humana de modificação da atmosfera, emissões de GEEs, foi discutida no item "4.1.2.1 Causas antrópicas" (de mudanças climáticas recentes), pg. 50. Além dessa causa, a influência de aerossóis troposféricos pode estar associada à poluição industrial e à queima de combustíveis fósseis e biomassa vegetal.

Partículas sólidas de sulfato resultam da oxidação de dióxido de enxofre $\left(\mathrm{SO}_{2}\right)$ emitido quando combustíveis fósseis são queimados. Processos industriais, a queima de biomassa vegetal natural ou induzida pelo homem e a erosão dos solos também contribuem na formação de gotículas e materiais particulados, ambos denominados aerossóis, para a troposfera. Estes aerossóis representam dois efeitos ao sistema climático. O efeito direto da maioria dos aerossóis é refletir a radiação solar para o espaço e, consequentemente, conferir um esfriamento na área afetada, enquanto que alguns particulados, como a fuligem, são escuros e possuem o efeito contrário, causando um efeito de aquecimento local. A magnitude de resfriamento ou aquecimento depende da natureza dos 
aerossóis e da sua distribuição na atmosfera (MCGUFFIE; HENDERSONSELLERS, 2005).

O efeito indireto dos aerossóis é mais difícil de avaliar que os efeitos diretos, mas não por isso são menos importantes. Os aerossóis agem como núcleos de condensação adicionais, favorecendo a formação de gotículas que formam as nuvens. Com o aumento de nuvens, ocorre o aumento da refletividade delas, e, consequentemente, menos radiação solar entra no sistema, resfriando o planeta (vide forçamento negativo apresentado na Figura 18, pg. 54). O efeito de mudanças nas nuvens pode ter repercussões complexas, uma vez que as nuvens também afetam a quantidade de radiação re-emitida pela superfície terrestre (MCGUFFIE; HENDERSON-SELLERS, 2005).

As atividades vulcânicas projetam grandes quantidades de partículas e gases na atmosfera, influenciando no mecanismo dos aerossóis descrito acima e, portanto, também no clima. A principal contribuição dos vulcões é decorrente de partículas estratosféricas de ácido sulfúrico $\left(\mathrm{H}_{2} \mathrm{SO}_{4}\right)$, que rapidamente se condensam e formam aerossóis de sulfato.

Erupções vulcânicas podem produzir anomalias significativas na temperatura, da ordem de décimos de graus centígrados. Grandes erupções vulcânicas - como os recentes casos do Monte Tambora (1815), Krakatoa (1883), El Chichón (1982) e Monte Pinatubo (1991), Figura 29 - não são tão frequentes, porém causam efeitos climáticos significativos. Exemplos: as últimas cinco maiores erupções vulcânicas dos últimos 100 anos podem ter provocado a queda de 0,1 a $0,4{ }^{\circ} \mathrm{C}$ da temperatura média global; a erupção do Monte Pinatubo resultou no resfriamento de $0,5^{\circ} \mathrm{C}$; em consequência da erupção do Monte Tambora, maior erupção vulcânica recente, não houve verão no Hemisfério Norte e o resfriamento foi tão intenso que o ano de 1816 ficou conhecido como o "Ano Sem Verão". Claramente, verifica-se um efeito notável dessas atividades no clima terrestre global. O vulcanismo entre 1250-1500 e 1550-1700, em conjunção com os efeitos climáticos do Mínimo de Spörer e de Maunder, tem sido cogitado como a possível causa da Pequena Idade do Gelo. (MCGREGOR; NIEUWOLT, 1998; MCGUFFIE; HENDERSON-SELLERS, 2005). 


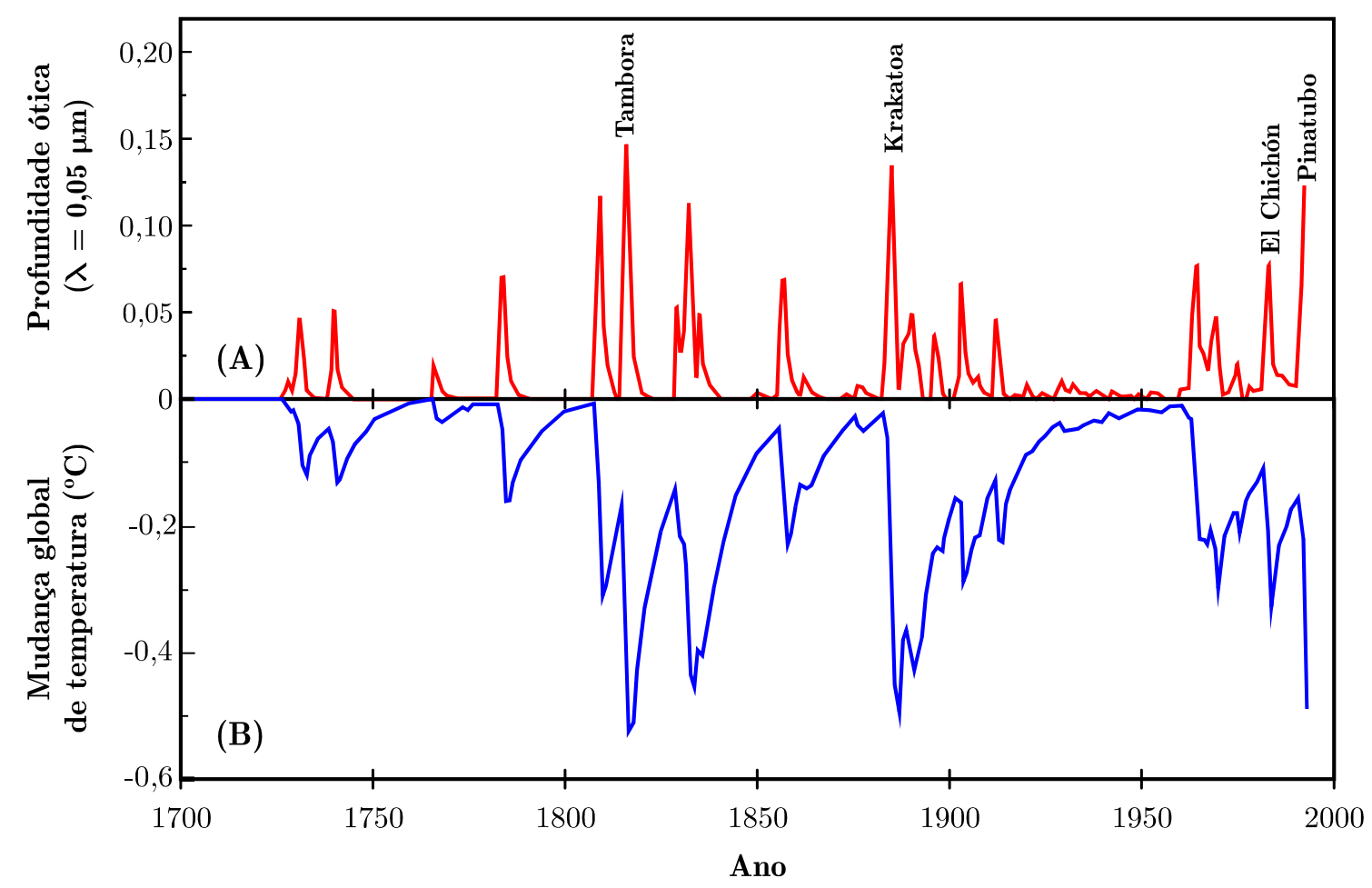

Figura 29 - Impacto de erupções vulcânicas na temperatura, no período de 1700-2000.

(A) Erupções e variações correspondentes da profundidade ótica (medida da quantidade de radiação solar que é bloqueada através de uma coluna da atmosfera. Quanto maior o valor, menor a passagem de radiação); (B) Variações da temperatura média global (desconsiderando forçamentos solares positivos, que compensam o efeito negativo do vulcanismo). Fonte: adaptado de Bertrand, Van Ypersele e Berger (1999).

Com menor frequência de ocorrência, erupções vulcânicas de elevada magnitude no passado causaram impactos drásticos e duradouros no clima terrestre. O caso do supervulcão Toba, localizado ao norte da Ilha de Sumatra na Indonésia, ilustra a grandeza deste fenômeno natural e o impacto climático decorrente. O evento de Toba, ocorrido há 73.000 anos atrás, representou a maior erupção vulcânica dos últimos 2 milhões de anos. Um volume de 2500 a $3000 \mathrm{~km}^{3}$ de magma foi projetado - comparado ao volume de 100 a $200 \mathrm{~km}^{3}$ da erupção de 1815 de Tambora - e 1\% da superfície terrestre ficou coberta com 10 cm de cinzas vulcânicas. O sulfato vulcânico produzido nesta mega-erupção causou a queda de $10{ }^{\circ} \mathrm{C}$ no verão em altas latitudes, além de um inverno vulcânico de 6 anos, seguido por um período de resfriamento que durou 1800 anos (RAMPINO; SELF, 1993; MASON; PYLER; OPPENHEIMER, 2004; WILLIAMS et al., 2009). 
Por fim, uma causa externa de mudanças climáticas que influencia no fator da atmosfera é devida à colisão de asteróides ou cometas na superfície terrestre. As maiores catástrofes naturais da Terra são causadas por estes eventos de baixa frequência, mas de alto poder causador de mudanças severas. Os impactos dessas colisões têm sido propostas como uma possível causa de grandes mudanças climáticas. Muitos dos distúrbios que os impactos de asteróides causam, como o aumento da concentração dos aerossóis troposféricos e estratosféricos, são similares aos distúrbios internos do sistema climático, tanto artificial (atividades antrópicas) quanto natural (vulcanismos) (MCGUFFIE; HENDERSON-SELLERS, 2005). A cratera de Chicxulub, soterrada ao sul da Península de Yucatán no México, representa uma antiga cratera (de 180 a 200 $\mathrm{km}$ de diâmetro) do impacto de um grande asteróide ou cometa (com aproximadamente $10 \mathrm{~km}$ de diâmetro) que colidiu há 65 milhões de anos atrás, causando o evento mais devastador na história da vida na Terra. Mais da metade das espécies no planeta foram extintas, inclusive pondo fim à era dos dinossauros. A energia do seu impacto foi de 1 bilhão de vezes maior do que o da bomba lançada em Hiroshima. Além dos efeitos colaterais imediatos ao impacto deste corpo celeste na superfície terrestre - incêndios globais, terremotos, tsunamis de mais de 100 metros que poderiam provocar inundações em regiões $20 \mathrm{~km}$ adentro dos continentes - efeitos ambientais catastróficos foram causados, com o sistema climático drasticamente alterado devido à escuridão prolongada causada pela poeira e cinzas liberadas no impacto e ao inverno de impacto causado pelos aerossóis de sulfato. Um cenário de escurecimento completo, em que a poeira levantada pelo impacto impede a luz solar de chegar à superfície, pode ter durado vários meses após o impacto. A intensidade de luz pode ter sido tão baixa que a fotossíntese cessou em grande parte da Terra e a visão pode ter sido impossível. O resfriamento global pode ter durado de anos a décadas, com a redução de $10^{\circ} \mathrm{C}$ na temperatura da superfície terrestre (TOON; TURCO; COVEY, 1997; SCHULTE et al., 2010; AGÊNCIA FAPESP, 2010).

A propósito, além do inverno vulcânico e do inverno de impacto, a possibilidade de ocorrência de uma guerra nuclear mundial durante a Guerra Fria (retratado no filme "O Dia Seguinte" de 1983, do original em inglês "The Day After") favoreceu o surgimento do termo inverno nuclear, proposto por 
Turco et al. (1983). As explosões das bombas nucleares produziriam efeitos semelhantes de resfriamento global, por causa das fuligens e aerossóis lançados na atmosfera. Para várias simulações feitas por Turco et al. (1983), os efeitos da poeira e a fumaça geradas nas explosões poderiam reduzir os níveis médios de intensidade de luz a uma pequena percentagem durante semanas, além de provocar quedas a curto prazo da temperatura, na ordem de -15 a $-25^{\circ} \mathrm{C}$. Enquanto isso, os modelos climáticos modernos confirmam que as previsões da década de 80 dos efeitos do inverno nuclear foram, no mínimo, subestimadas (TOON; ROBOCK; TURCO, 2008). Um fato distinto destes conflitos nucleares é a presença de mecanismos e efeitos específicos das causas naturais de mudanças da composição da atmosfera, tal como a radioatividade, que não está presente nas atividades vulcânicas nem quando os cometas ou asteróides atingem a Terra. A vulnerabilidade humana frente à ameaça de uma guerra nuclear seria muito maior em relação aos efeitos indiretos - incluindo danos nas atividades agrícolas, transporte, energia, medicina, política e de infra-estrutura social - especialmente devido aos efeitos adversos na produtividade e disponibilidade de alimentos, do que em relação os efeitos diretos da guerra nuclear em si. A compreensão sobre as consequências climáticas e os efeitos indiretos do colapso da sociedade, que seria tão grave que o inverno nuclear resultante produziria fome para milhões de pessoas, pode ter sido um fator importante no fim da corrida armamentista entre os Estados Unidos e a União Soviética (URSS). Os presidentes das nações envolvidas, Ronald Reagan (EUA) e Mikhail Gorbachev (URSS), reconheceram o dano ambiental potencial relativo ao uso de armas nucleares e assinaram tratados para redução da quantidade de ogivas nucleares, que teve seu pico em 1986 e está um declínio que continua até hoje. Entretanto, apesar da redução significativa nos arsenais nucleares americanos e russos, cada país ainda mantém armas suficientes para produzir um inverno nuclear (ROBOCK et al., 2007; TOON; ROBOCK; TURCO, 2008).

\subsubsection{Outras causas naturais de mudanças climáticas}

Além das três principais causas naturais de mudanças climáticas variações solares, variações orbitais e variações na composição da atmosfera causadas por atividades vulcânicas e impactos de asteróides ou cometas - 
existem outras causas naturais que afetam o clima em diferentes escalas têmporo-espaciais. Podem ser destacadas dentre as diversas causas:

- El Niño - Oscilação Sul (ENOS);

- Circulação Termohalina;

- Magnetismo terrestre e Inversões magnéticas;

- Raios Cósmicos; e

- Tectonismo.

O El Niño - Oscilação Sul (ENOS) é um fenômeno que ocorre no Oceano Pacífico, cuja influência sobre o clima pode ser verificada globalmente. O ENOS é caracterizado pelo aquecimento periódico, em média a cada 5 anos, das águas superficiais no Oceano Pacífico tropical oriental. Sua fase de resfriamento é denominada de La Ninã. Estudo de Mclean, Freitas e Carter (2009) relata que o ENOS pode ser um dos principais condutores de anomalias de temperatura, não só nos trópicos, mas representando também uma influência dominante e consistente na escala global. Os autores afirmam que o forçamento do clima associado ao ENOS contribui majoritariamente para a variabilidade e tendências recentes e, talvez, contribua inclusive na temperatura global, fato que não está sendo considerado nos modelos climáticos globais atuais. Molion (2006) aponta que as temperaturas médias globais, obtidas por meio de satélites desde 1979, aumentaram quando da ocorrência de eventos El Niño e diminuíram quando da ocorrência dos La Niñas. O autor afirma que o sistema Terra-atmosfera pode sofrer, naturalmente, uma variação de temperatura de cerca de $1,5^{\circ} \mathrm{C}$ entre fases fria e quente do ENOS.

A circulação termohalina é um componente-chave do sistema climático. Conduzido pelos diferentes gradientes de densidade criados pelo calor da superfície e pelos fluxos de água doce, este mecanismo de correntes oceânicas transporta grandes quantidades de calor e sal do equador aos pólos. Uma mudança na força da circulação termohalina pode levar a grandes mudanças climáticas regionais e globais. Um colapso no transporte de calor pode provocar um deslocamento para o sul da Zona de Convergência Intertropical, além de desencadear um evento de El Niño (LAURIAN et al., 2010). De acordo com Wood, Vellinga e Thorpe (2003), a interrupção da circulação pode ser grave, 
implicando no resfriamento do Hemisfério Norte, sendo que em algumas regiões a magnitude poderia ser maior do que as mudanças esperadas pelo aquecimento global nos próximos 50 anos. Estudo de Bryden, Longworth e Cunningham (2005) relata que a circulação diminuiu substancialmente na metade do século passado, em cerca de $30 \%$. Tal fato poderia implicar na redução de $4^{\circ} \mathrm{C}$ da temperatura média na Europa, provocando uma pequena era do gelo. A interrupção fictícia da Corrente do Golfo inspirou o filme "O Dia Depois de Amanhã" (do original em inglês "The Day After Tomorrow") em 2004. Mas segundo Schiermeier (2005), as mudanças drásticas do clima retratado no filme, em que Nova York é engolida por uma idade do gelo instantaneamente, são mera fantasia. Não está claro se existe uma relação do aquecimento global com a tendência de enfraquecimento da circulação termohalina. Possíveis distúrbios tais como redemoinhos do oceano e flutuações naturais na força do sistema de circulação - devem ser considerados. Apesar das possíveis repercussões climáticas significativas, a chance de ocorrência de um colapso iminente do sistema de circulação é pequena. Schiermeier (2006) aponta que os resultados de Bryden, Longworth e Cunningham (2005) surpreenderam os cientistas da área. Os resultados de Bryden et al. (2005) poderiam ser causados por variação natural ou "ruídos", ou seja, coincidência. Mesmo se os resultados estivessem corretos, o enfraquecimento da circulação termohalina não teria os efeitos drásticos que foram previstos no resfriamento na Europa. Por fim, Schiermeier (2006, pg. 259) cita a seguinte frase de Wallace S. Broecker, um dos primeiros cientistas a notar efeito do transporte global do clima: "A noção de que um colapso da circulação termohalina pode desencadear uma pequena era do gelo é um mito". Trabalho recente de Willis (2010) indica que a circulação termohalina não tem mais sofrido desaceleração significativa nos últimos 15 anos; ao contrário, é sugerido que a circulação pode mesmo ter acelerado cerca de $20 \%$ no passado recente. O autor, segundo NASA (2010), propõe que as mudanças verificadas são, provavelmente, parte de um ciclo natural, coincidindo com um padrão natural decadal de aquecimento e resfriamento do Atlântico.

O magnetismo terrestre e sua influência no clima é um tema de pesquisas recentes. A correlação entre geomagnetismo e o clima pode estar associado a variações do campo magnético, que está ligada com correntes externas na ionosfera e magnetosfera induzida pelos ventos solares e pela radiação eletromagnética. Portanto, a evolução da tendência magnética possui alta 
correlação com a evolução da radiação solar. As variações entre a temperatura média e variações no campo geomagnético são tentadoras. Todavia, esta correlação aparente não é por si só suficiente para demonstrar uma conexão de causa e efeito (COURTILLOT et al., 2007). Os deslocamentos dos pólos magnéticos nos últimos 105 anos demonstraram forte correlação com variações na temperatura, sugerindo uma conexão potencial entre esses dois fenômenos. O movimento dos pólos magnéticos afeta o formato do campo geomagnético e, consequentemente, altera os padrões de proteção da Terra contra raios cósmicos galácticos e solares. Assim, os deslocamentos afetam a distribuição e dispersão de raios cósmicos em áreas mais sensíveis da atmosfera. (KERTON, 2009). Inversões magnéticas, em uma escala de tempo geológico, podem estar associadas às glaciações. Porém, não é sugerido que todas as inversões magnéticas estejam relacionadas a mudanças no clima. Forças astronômicas podem ser supostamente os precursores das inversões. (WORM, 1997). Estas forças astronômicas poderiam estar relacionadas com o impacto de asteróides na Terra. Eventos de impacto e inversões magnéticas dependem de um súbito resfriamento no clima causado pelo impacto. O resfriamento global provocaria o aumento do volume do gelo nas calotas polares, que seria responsável pela redução do momento de inércia terrestre e, assim, causaria o aumento da velocidade rotacional, que, por sua vez, induziria ao cisalhamento do núcleo terrestre. Este mecanismo induzido pela glaciação eventualmente deflagraria o rompimento da geração do campo magnético. Mas tais mecanismos ainda não estão bem compreendidos e aceitos como uma hipótese totalmente válida. (SCHNEIDER; KENT; MELLO, 1992).

A influência de raios cósmicos no clima terrestre tem sido verificada por vertente de estudos que relacionam a Climatologia com a Astronomia. A Cosmoclimatologia, termo cunhado por Svensmark (2007), sugere que a intensidade incidente de raios cósmicos na atmosfera terrestre correlaciona-se estreitamente com variações de cobertura global de nuvens. As nuvens refletem a entrada e saída de radiação, e, portanto, elas desempenham um papel importante no balanço de radiação da Terra. Em escalas de tempo muito mais longo, parece existir também uma correlação entre as variações na fonte de raios cósmicos causadas pela passagem de sistemas solares através dos braços espirais da Via Láctea, e as variações no clima da Terra no último 1 bilhão de anos. A 
Figura 30 ilustra esta possível correlação, que permite inferir que os Modos Quentes e Frios do clima na Terra podem estar associados à influência dos raios cósmicos. Scafetta (2010) assinala que as oscilações do campo magnético do sistema solar induzido pelo movimento dos planetas (em especial de Júpiter e Saturno) podem influenciar o plasma solar e o vento solar. O vento solar modula a ionosfera terrestre, que influencia o circuito elétrico atmosférico global. O último afeta a formação de nuvens e, portanto, o clima global. Os efeitos observados em diferentes escalas e os mecanismos físico-químicos envolvidos na relação da formação de nuvens com os raios cósmicos podem ser consultados na revisão detalhada realizada por Kirkby (2007).

Por fim, movimentações tectônicas, que ocorrem em escalas de tempo de milhões de anos, podem causar mudanças nos padrões da circulação atmosférica e da circulação oceânica. As correntes oceânicas dependem da geometria dos oceanos e este é controlado pela tectônica de placas. Assim, em escalas de tempo geológico, o movimento das placas e continentes tem um efeito profundo sobre a distribuição de massas de terra, serras e da conectividade dos oceanos. Como consequência, as placas tectônicas representam uma influência fundamental no clima global. O movimento das placas tectônicas resulta na formação e separação de continentes e em escalas geológicas provoca a formação ocasional de um supercontinente contendo todos ou quase todos os continentes. Estas configurações constituem ciclos de supercontinentes, cujo ciclo completo ocorre a cada 300 a 500 milhões de anos. No último 1 bilhão de anos, foram identificadas a formação e dissolução de três grandes supercontinentes: Rodínia (1000-750 milhões anos atrás), Gondwana (650-550 m.a.) e Pangeia (450-250 m.a.), com um possível supercontinente de curta duração, Pannotia (600-540 m.a.). (CONDIE, 1998). A separação dos continentes componentes da dissolução da Pangeia constituem a configuração atual. Ao longo da história da Terra o constante movimento dos continentes e da formação episódica de supercontinentes tem influenciado tanto o clima global e os climas dos continentes individualmente. A presença de continentes e sua topografia afetam climas de diversas maneiras: as temperaturas nas altitudes elevadas são mais baixas do que nas altitudes baixas; cadeias de montanhas, ao desviar os ventos, forçam o ar a subir em regiões mais frias da atmosfera, provocando chuvas apenas de um lado das montanhas (chuvas orográficas); os centros das grandes massas continentais geralmente têm elevações relativamente altas e, 
consequentemente, são regiões secas e frescas - condição conhecida como "continentalidade" (ROGERS; SANTOSH, 2004). A divisão dos continentes geralmente induz a formação de novos oceanos ao longo de orogenias (formação de montanhas) mais velhas, levando a um processo cíclico de fechamento e reabertura dos oceanos ao longo de praticamente as mesmas zonas, além de consequente formação e dissolução de supercontinentes. A abertura e fechamento de bacias oceânicas constituem os Ciclos de Wilson (RYAN; DEWEY, 1997). 


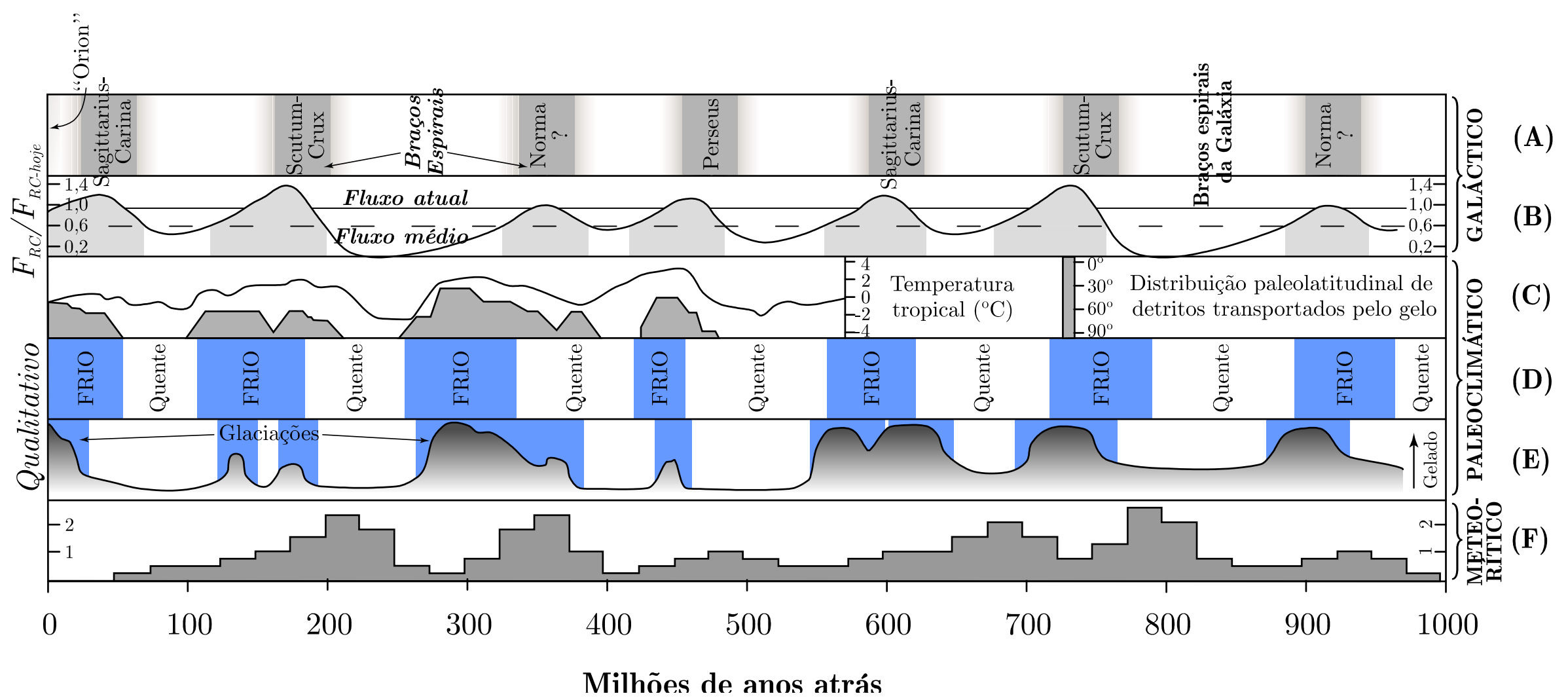

Figura 30 - Raios cósmicos e Eras glaciais na Terra. (A) descreve as passagens pelos braços espirais da Galáxia; (B) representa o Fluxo de Raios Cósmicos $\left(F_{R C}\right)$ atingindo o sistema solar; Em (C), a curva denota a temperatura na superfície oceânica tropical relativamente aos dias atuais, e as áreas preenchidas expressam a distribuição paleolatitudinal de detritos transportados pelo gelo; (D) e (E) descrevem qualitativamente as épocas pelas quais a Terra experienciou Eras do Gelo; (F) Histograma de épocas de exposição a meteoros de Fe/Ni - a época de exposição a meteoros são previstos para se agrupar em torno de épocas com um fluxo menor de raios cósmicos. Fonte: adaptado de Shaviv (2003). 


\subsubsection{Atribuição de causas das mudanças climáticas no passado}

Conforme apresentado, as causas naturais são variadas: causas internas e externas são complexas, interligadas, sujeitas e vários mecanismos de retroalimentação e a eventos aleatórios de grande impacto. Apresentar todos estes fatores interferentes no clima de uma forma conjunta e sintetizada representa um desafio, pois cada um possui influência em escalas de espaciais e temporais distintas. Apesar da dificuldade, esta representação é possível, mostrada a seguir.

\subsubsection{Síntese em escala geológica}

Uma abordagem para caracterizar ou descrever a variabilidade do clima é o espectro de variância, que exibe uma propriedade estatística de variância, em função do período ou a frequência da variação. O espectro de variância tem sido frequentemente utilizado para ilustrar a importância relativa das variações climáticas em escalas diferentes. "Picos" em tal tipo de representação apontam para frequências particulares ou escalas de tempo em que a variabilidade está concentrada. Na Figura 31 a seguir está ilustrada uma versão esquemática de um espectro de variância para o sistema climático, com escalas de tempo variando entre horas e bilhões de anos.

O espectro de variância exibe a magnitude relativa ou absoluta de variância em uma série temporal em um determinado período de tempo ou frequência, em função do período ou frequência, fornecendo um "domínio da frequência" que sintetiza a variabilidade climática. A aplicação deste espectro para ilustrar o calendário da variabilidade climática naturalmente induz à compreensão das características periódicas ou oscilatórias em uma série temporal. Assim, a visualização destes aspectos normalmente evidencia alguns mecanismos cíclicos regulares, sejam eles externos (Sol, Lua, planetas) ou internos ("Modos Climáticos" oscilatórios) (BARTLEIN, 2006). 
Frequência (ciclos/ano)

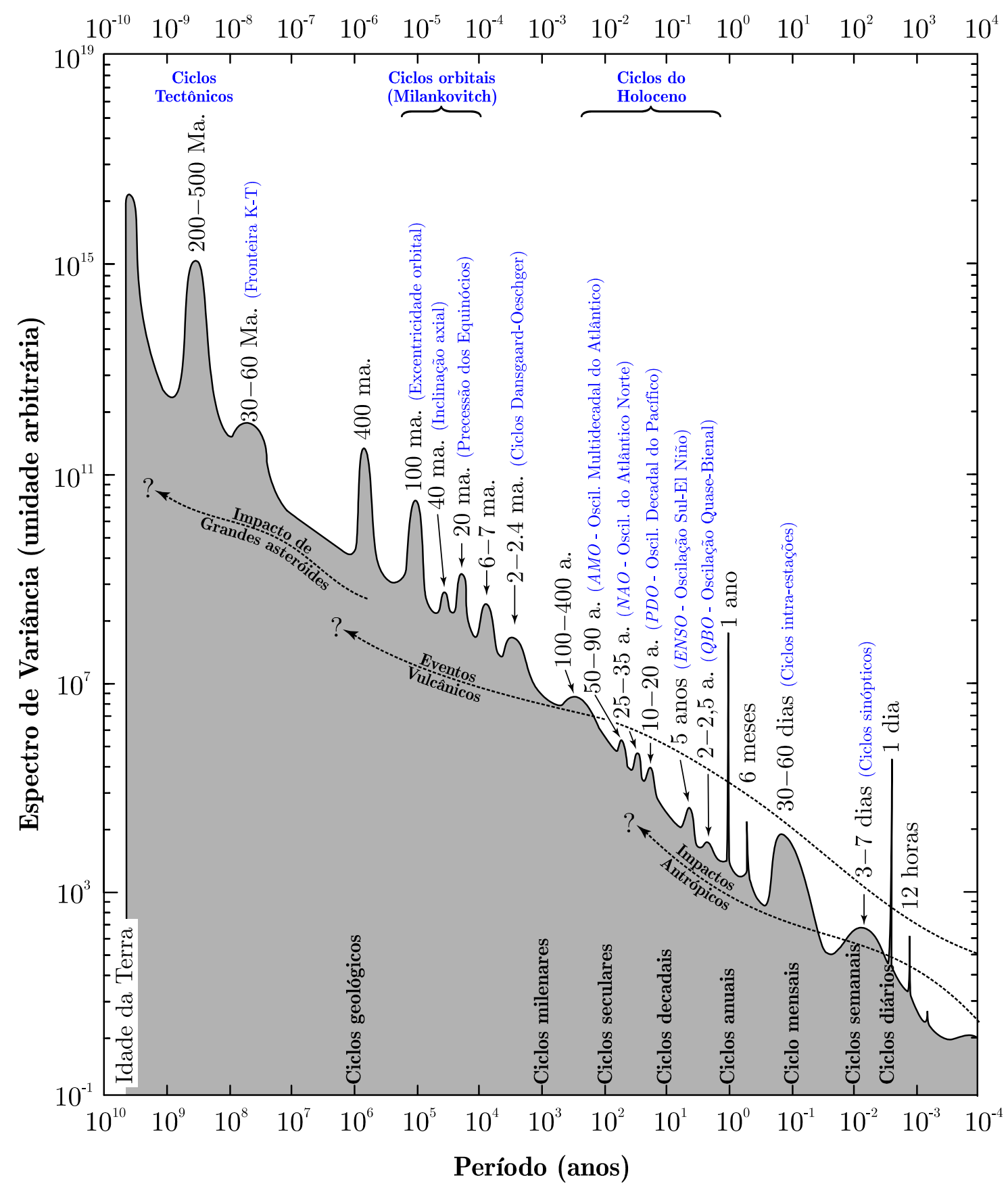

Figura 31 - Representação esquemática do espectro de variância para o sistema climático, com escalas de tempo variando entre horas e bilhões de anos. Fonte: Elaborada a partir de compilação com base em Mitchell (1976), Ghil (2002) e Bartlein (2007).

A variabilidade climática ocorre sobre todas as escalas de tempo, com uma variabilidade muito maior com o aumento da escala, porém com concentrações de variância em algumas escalas de preferência. 
As variações climáticas ocorrem dentro de uma hierarquia de controles e respostas, que começa no mais alto nível com os controles externos de clima, prosseguem através dos níveis em escala global, hemisférico, continental e regional, e terminam no nível mais baixo com as alterações das variáveis climáticas individuais em locais específicos. Respostas em qualquer nível da hierarquia se tornam o controle das variações dos componentes em níveis inferiores (BARTLEIN, 2006).

Mudanças graduais nos controles de grande escala podem, às vezes, produzir mudanças bruscas locais, quando a circulação atmosférica é reorganizada. Por outro lado, mudanças abruptas na circulação de grande escala podem produzir aquecimento em algumas regiões, resfriamento ou nenhuma alteração em outros locais, como pode ser visto nos padrões espaciais de anomalias de variações anuais do clima. Por conseguinte, embora possa ser difícil ou mesmo impossível atribuir uma variação do clima em um dado local a uma configuração específica de controles de nível superior, as variações de curto prazo em níveis mais baixos são fortemente condicionadas pelo estado particular do sistema nos níveis mais elevados. Portanto, qualquer discussão sobre os prazos de variabilidade climática deve reconhecer a dimensão espacial ou extensão do sistema que está sendo discutido (BARTLEIN, 2006).

\subsubsection{Síntese em escala milenar}

Uma vez caracterizadas as principais causas, naturais e antrópicas, das mudanças climáticas, é conveniente sintetizar de que forma estas atuaram conjuntamente no clima nos últimos mil anos. Em termos de forçamentos radiativos, a Figura 32 retirada do AR4 (IPCC, 2007c, pg. 479), exibe as influências no comportamento da temperatura provocadas pelas variações nas atividades vulcânicas, variações solares e variações das concentrações de GEEs e aerossóis troposféricos. 


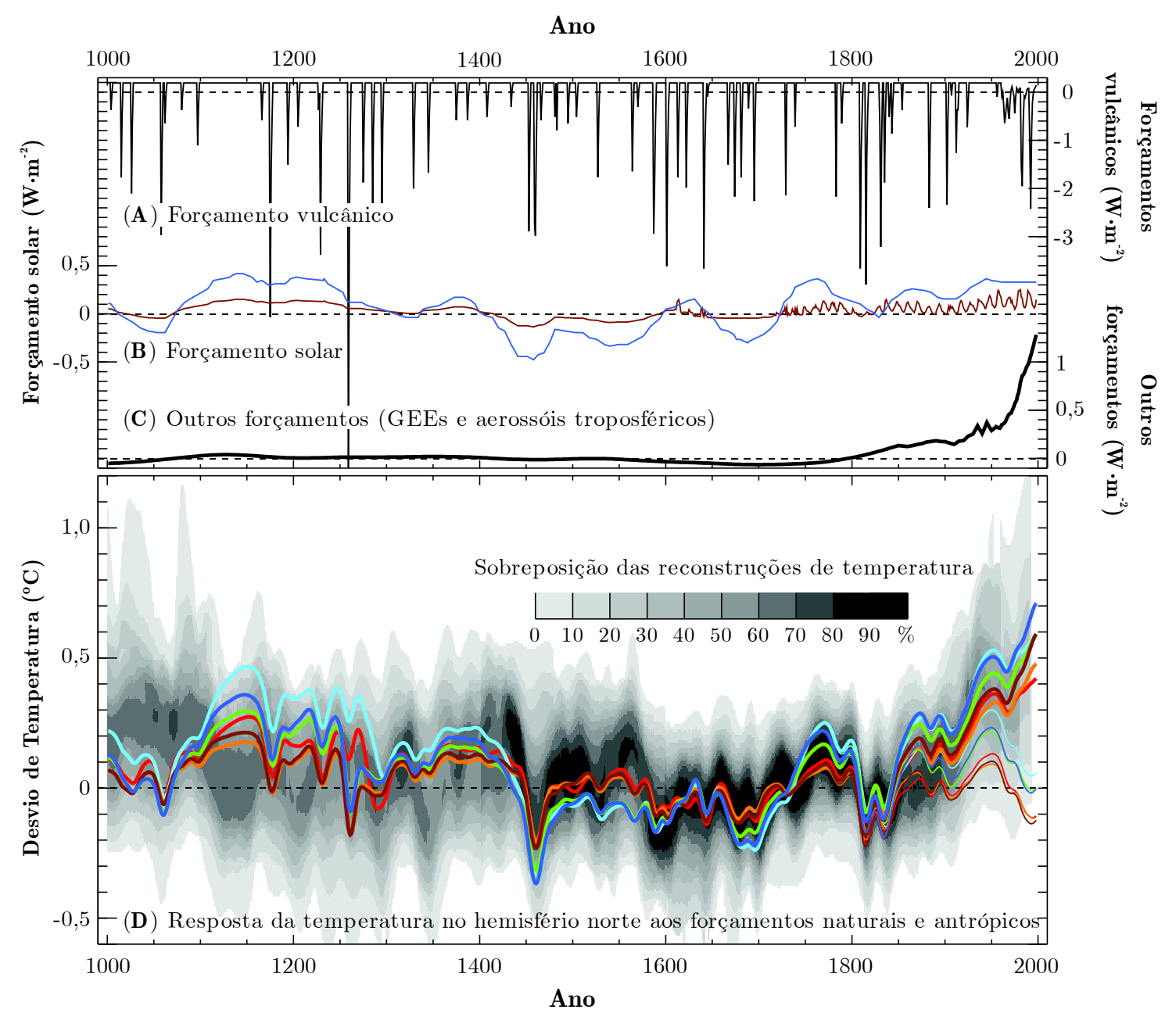

Figura 32 - Temperaturas simuladas no último milênio com e sem forçamentos antropogênicos e também com forçamentos solares fracos e fortes. Forçamentos radiativos globais médios $\left(\mathrm{W} / \mathrm{m}^{2}\right)$ utilizados como condutores do clima nos modelos climáticos: (A) atividade vulcânica; (B) variações fortes (azul) e fracas (marrom) da radiação solar; e (C) todos os outros forçamentos, incluindo gases do efeito estufa e aerossóis troposféricos de sulfato. (D) Desvios da temperatura média anual no hemisfério norte, simulada por três modelos, sobreposta a reconstruções (tons de cinza). As curvas grossas representam simulações que utilizaram tanto os forçamentos naturais quanto os antropogênicos; As curvas finas utilizaram apenas os forçamentos naturais. Todos os forçamentos e temperaturas estão expressos em termos de anomalias com referência à média do período de 1500 a 1899. Fonte: IPCC (2007c), pg. 479.

\subsection{Mudanças climáticas futuras: projeções e cenários}

Baseado na hipótese de os GEEs serem a forçamento radiativo determinante no clima terrestre, e supondo que os forçamentos naturais não sofrerão nenhuma variação significativa no futuro de curto prazo, o AR4 (IPCC, 
2007a) apresenta diferentes projeções de emissões antropogênicas de GEEs até o ano de 2100 (Figura 34-A) e, com base em modelagens, elabora cenários dos respectivos possíveis efeitos na temperatura média global (Figura 33-B).
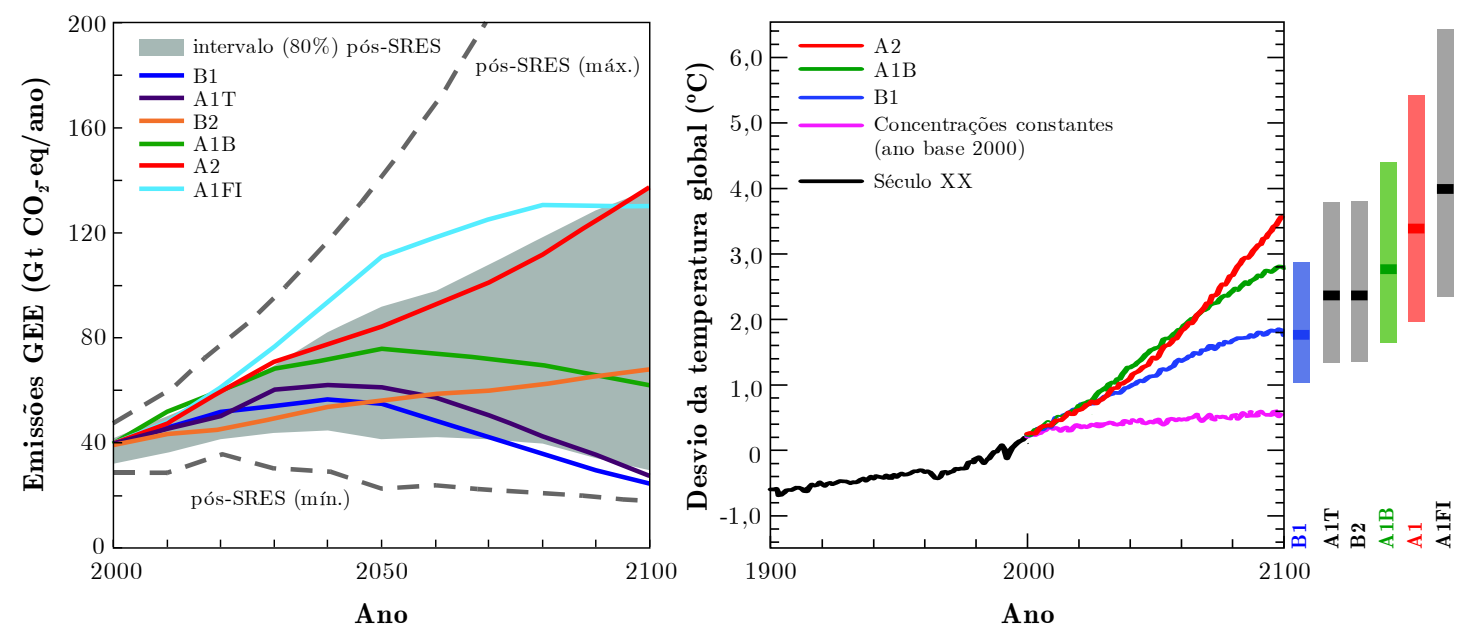

Figura 33 - Cenários de emissões globais de GEEs (A) e efeitos na temperatura média global (B) para o período de 2000 a 2100. (A) As linhas coloridas representam os diferentes cenários; a área cinza representa o intervalo de confiança de $80 \%$; e as linhas tracejadas representam os limites do intervalo de confiança. (B) Projeções dos desvios da temperatura média global (relativa à temperatura média no período de 1980 a 1999) para os diferentes cenários de emissões de GEEs, mostrados como continuação das simulações do século XX. As barras à direta representam os intervalos de confiança no período de 2090-2099. As linhas no meio de cada barra representam a melhor estimativa dos valores para cada cenário. Os cenários representam diferentes alternativas de caminhos de desenvolvimento: desde um mundo com rápido crescimento econômico e mudanças tecnológicas com uso intensivo de combustíveis fósseis (A1FI), com uso de energias alternativas (A1T) e com uso equilibrado entre as fontes (A1B); até cenários que consideram um mundo mais convergente com mudanças rápidas na estrutura econômica (B1), com menos crescimento econômico e mais preocupado com questões ambientais (B2); e um cenário mundial com grande crescimento populacional, baixo desenvolvimento econômico e com pouca mudança tecnológica (A2). Fonte: IPCC (2007a), pg. 44 e 46.

Cenários para o aumento do nível médio do mar também foram realizadas e publicadas no AR4 (Tabela 1), levando-se em consideração as diferentes projeções de emissões de GEEs. É válido destacar que para o cenário A1FI, cenário que implica em maior aumento no nível dos mares, do intervalo de aumento de 0,26 a 0,59m cerca de 0,17 a 0,41m é devido à expansão térmica 
da água nos oceanos. A Figura 34 ilustra as projeções do aumento do nível do médio mar até 2100 para o cenário A1B.

Tabela 1 - Cenários do aumento do nível médio do mar para o ano 2100.

\begin{tabular}{|c|c|c|c|c|}
\hline & \multirow{2}{*}{ Caso } & \multicolumn{2}{|c|}{$\begin{array}{c}\text { Mudança na temperatura em } \\
2090-2099^{2}\left({ }^{\circ} \mathrm{C}\right)\end{array}$} & \multirow{2}{*}{ 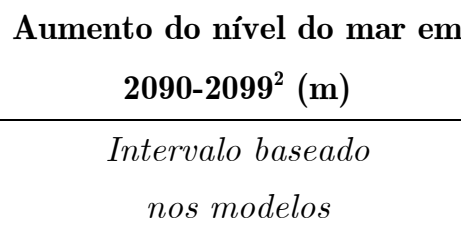 } \\
\hline & & Melhor & Intervalo de & \\
\hline & $\begin{array}{c}\text { Concentrações } \\
\text { constantes }^{1}\end{array}$ & 0,6 & $0,3-0,9$ & Não disponível \\
\hline \multirow{6}{*}{ 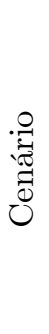 } & B1 & 1,8 & $1,1-2,9$ & $0,18-0,38$ \\
\hline & $\mathrm{A} 1 \mathrm{~T}$ & 2,4 & $1,4-3,8$ & $0,20-0,45$ \\
\hline & $\mathrm{B} 2$ & 2,4 & $1,4-3,8$ & $0,20-0,43$ \\
\hline & $\mathrm{A} 1 \mathrm{~B}$ & 2,8 & $1,7-4,4$ & $0,21-0,48$ \\
\hline & $\mathrm{A} 2$ & 3,4 & $2,0-5,4$ & $0,23-0,51$ \\
\hline & A1FI & 4,0 & $2,4-6,4$ & $0,26-0,59$ \\
\hline
\end{tabular}

${ }^{1}$ Ano base: 2000. ${ }^{2}$ Com referência a 1980-1999. Fonte: IPCC (2007a), pg. 45.

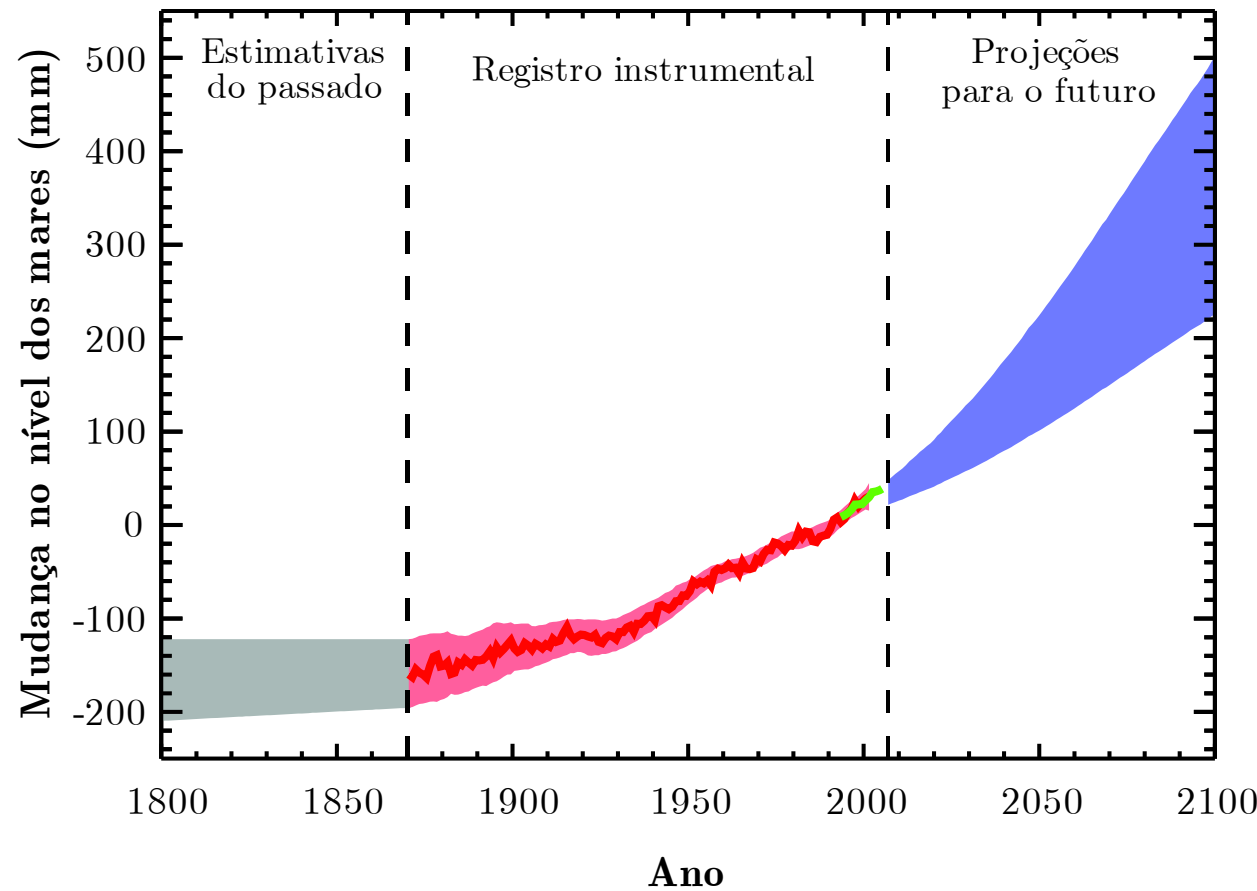

Figura 34 - Série temporal do nível global médio do mar no passado e projetado para o futuro, com desvio em relação à média de 1980-1999. A área cinza representa a incerteza das mudanças estimadas no passado. A área vermelha denota o intervalo de variação da curva suavizada, obtida das observações em marégrafos. A linha verde representa as mudanças observadas por satélites de altimetria. A área azul representa o intervalo da projeção com base no cenário A1B. Fonte: IPCC (2007c), pg. 409. 


\subsection{Considerações e Discussões: aprofundamento, ponderação e controvérsias}

Conforme constatado nos itens anteriores, o clima da Terra tem variado consideravelmente ao longo das eras, forçado por diferentes fenômenos em escalas de tempo distintas. Segundo Molion (2008), no final da década de 1970 surgiu a hipótese de que a temperatura média global da superfície estaria aumentando devido à influência humana. Essa hipótese está fundamentada em três argumentos:

1. A série de temperatura média global do ar na superfície "observada" nos últimos 150 anos;

2. O aumento observado na concentração de gás carbônico; e

3. Os resultados obtidos com modelos numéricos de simulação de clima.

O enfoque das considerações será dado às séries de temperatura observadas no passado, seguida por uma breve discussão das estimativas previstas pelos modelos que assumem a hipótese de que o efeito dos GEEs é determinante no balanço de radiação terrestre.

\subsubsection{Temperatura terrestre}

As alterações interanuais do comportamento atmosférico não denotam, necessariamente, variação do clima. Para caracterizar de fato uma tendência indicadora de alteração, é necessária a produção de uma sequência considerável de anos. Portanto, o clima possui alta variabilidade espacial e temporal, pois é resultante de um sistema complexo e dinâmico que envolve a interação de trocas de energia e massa entre a atmosfera, hidrosfera (incluindo a neve e o gelo) e a litosfera (superfícies sólidas vegetadas ou não). A evolução do comportamento atmosférico nunca é igual de um ano para outro e mesmo de uma década para outra, podendo-se verificar flutuações a curto, médio e longo prazo. (CONTI, 2000).

$\mathrm{Na}$ análise da temperatura na superfície terrestre, quatro aspectos são fundamentais na elaboração de gráficos e respectivas interpretações, de acordo com o objetivo que se deseja alcançar com a divulgação da informação: escala de 
abordagem temporal, escala de abordagem espacial, origem dos dados (método de determinação ou estimativa dos valores) e magnitude ou ordem de grandeza utilizada na escala de temperatura.

\subsubsection{Escala de abordagem temporal}

A abordagem temporal pode ser dada em escalas na ordem de bilhões, milhões, milhares, centenas, dezenas e unidades de anos. Para ilustrar as características das alterações climáticas através de uma série de prazos, é útil examinar algumas séries representativas de tempo. Na escala do último 1 bilhão de anos, a Figura 30 (pg. 81), apresenta a variação da temperatura para esta escala. Na Figura 35 são apresentados alguns gráficos de reconstruções da temperatura para as escalas menores subsequentes.

Com base nas variações de temperatura, é possível notar que o clima não é constante nem permanente, pelo contrário, possui uma alta variabilidade. Existem períodos de aquecimento, de resfriamento, alguns seguindo padrões ou ciclos, outros apresentando um comportamento mais complexo e irregular. Algumas destas escalas de variabilidade temporal refletem a natureza dos fatores externos do sistema climático ou os fatores internos dos componentes do próprio sistema climático.

A Figura 35-A fornece uma descrição geral do resfriamento global durante o Cenozóico (era com início há 65 milhões de anos atrás que se estende até hoje), que culminou nas variações dos períodos glaciais/interglaciais no Quaternário (período com início há 2,5 milhões de anos atrás que se estende até hoje). Além da tendência geral, são evidentes as medidas individuais para condições mais frias nesta escala adotada.

Na Figura 35-B são exibidas as variações periódicas associadas a elementos orbitais da Terra nos últimos 5 milhões de anos, bem como as mudanças na importância relativa das variações em escalas de tempo diferentes. A Figura 35C é um recorte do último 1 milhão de anos, exibindo uma visualização melhor dos ciclos glaciais/interglaciais.

A Figura 35-D mostra a grande amplitude de variações na escala de tempo milenar, conhecida como os ciclos Dansgaard-Oeschger que ocorrem durante a maior parte do registro, além de exibir o Dryas Recente (evento de breve 
período frio que ocorreu entre 12.800 a 11.600 anos atrás) e outras variabilidades com amplitude menor neste registro durante o Holoceno (época com início há aproximadamente 12.000 anos atrás que se estende até hoje).

A Figura 35-E apresenta declínio de longo prazo na força das monções da Ásia Oriental, juntamente com variações decadais-a-seculares ao longo do Holoceno. A Figura 35-F ilustra a reconstrução de anomalias de temperatura do Hemisfério Norte ao longo dos últimos dois milênios, juntamente com o registro de observação do século passado. Como outras reconstruções similares, este gráfico mostra variações na escala interanual-a-secular, e o aumento de temperatura nas últimas décadas. Neste gráfico, apesar do rigor necessário que o autor deve ter tido para a composição de um mesmo gráfico com duas fontes distintas de dados, deve-se atentar que esta prática não permite uma homogeneização totalmente fiel da série de dados, ainda mais ao mesclar dados de reconstruções indiretas da temperatura com medições diretas da temperatura do ar.

Estas séries não ilustram toda a gama de variações experimentadas pelo sistema do clima ao longo do Quaternário. De acordo com Bartlein (2006), seria necessária uma rede de séries temporais que se estendem os prazos e os diferentes níveis na hierarquia, e essa rede não existe. A variedade de características climáticas em séries temporais está vinculada aos locais de onde foram retiradas as amostras para a reconstrução das respectivas temperaturas das condições locais no passado. Cada reconstrução é representativa para uma dada região, e, portanto, a escala espacial é um aspecto que determina a variabilidade climática cuja distribuição não é uniforme no globo terrestre. 

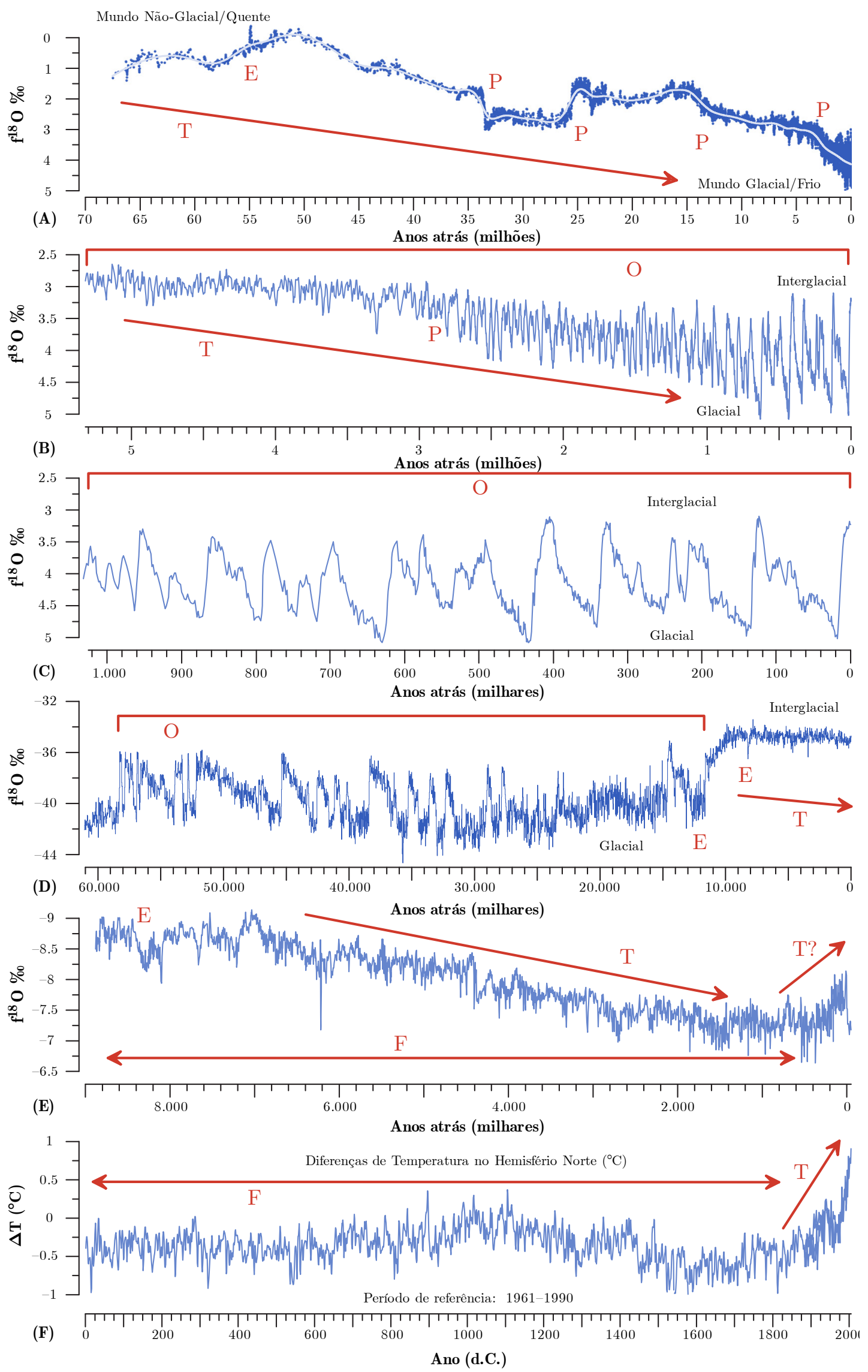

Figura 35 - Algumas séries paleoclimáticas representativas dos tipos de variações climáticas: (A) registro global composto de isótopos de oxigênio para o (continua) 
(continuação da legenda da Figura 35) Cenozóico; (B) e (C) registro composto global de isótopos de oxigênio; (D) as variações de isótopos de oxigênio a partir da série GISP, na Groelândia, a partir de testemunhos de gelo; (E) registros de isótopos de oxigênio de espeleotemas da Caverna Dongge, sul da China; e (F) reconstrução de anomalias de temperatura do Hemisfério Norte ao longo dos últimos dois milênios, juntamente com o registro de observação do século passado. As escalas dos isótopos diferem porque os testemunhos são de locais distintos. Tipos de variações climáticas: $\mathbf{T}$ $=$ tendência $; \mathbf{P}=$ passo; $\mathbf{O}=$ oscilação; $\mathbf{F}=$ flutuação; e $\mathbf{E}=$ evento. Fonte: Bartlein (2006).

Diferente da abordagem das causas de variabilidade climática fornecida pelo espectro de variância (Figura 31, pg. 83), a abordagem apresentada na figura anterior representa uma alternativa de descrição da natureza dos efeitos da variabilidade do clima, pois descreve os tipos de feições típicas ou variações características que se repetem em muitas séries climáticas nas diferentes escalas de tempo.

Existe um número relativamente reduzido de tipos diferentes de variações climáticas que as séries temporais exibem. Diante destes padrões, Bartlein (2006) elaborou uma taxonomia de características típicas de séries temporais climáticas. Um primeiro aspecto nesta taxonomia diz respeito aos níveis na hierarquia do sistema climático que contêm os controles da variação, e aqueles que estão envolvidos na resposta. Os controles e respostas podem ser classificados em: externo, global, hemisférico, continental, regional e local. A taxonomia também indica sobre a previsibilidade e a reversibilidade dos tipos de variações individuais. Variações climáticas podem ser: previsíveis, se o tempo e a amplitude das variações podem ser especificados; esperados, se o tempo ou a amplitude podem ser especificados, mas não ambos; ou imprevisiveis, se nem o tempo nem a amplitude da variação podem ser especificados. Quanto à reversibilidade, as variações podem ser: reversíveis, se o clima volta ao estado geral anterior, após a ocorrência da variação; ou irreversiveis, se o clima não retornar. Por fim, a classificação define também a amplitude relativa da variação temporal entre as categorias de alta, média, e baixa importância nos componentes das variações que apresentam comportamento regular, irregular ou de tendência. 
Levando em conta os critérios citados anteriormente, são definidos os tipos de variações climáticas (BARTLEIN, 2006):

- Tendências (T): As tendências são aumentos ou reduções progressivas nos níveis de uma variável climática particular, presente em várias escalas de tempo nas séries paleoclimáticas, mas particularmente evidentes em certas escalas. Na série de longo prazo apresentada na Figura 35-A, o resfriamento durante o Cenozóico é evidente, sendo esta tendência provavelmente impulsionada pelo controle externo do sistema climático, com todos os níveis inferiores da hierarquia respondendo. A Figura 35-B mostra também uma tendência generalizada, com um recorte do resfriamento mais acentuado na última parte da mudança climática da Série A. Em uma escala de tempo mais curta (Figura 35-D), a transição geral entre o último máximo glacial (cerca de 21 mil anos atrás) e do presente pode ser visto como uma tendência (previsível e reversível). Durante o Holoceno (Figura 35-E), muitos locais de latitudes médias no hemisfério experimentaram uma tendência de resfriamento no verão. Finalmente, durante o último século (Figura 35-F), a temperatura média global, bem como que em estações individuais, aumentou em geral.

- Passos (P): Os passos (ou etapas) são transições abruptas (relativamente às escalas temporais em das variações em consideração) de um nível para outro, e aparecem em escalas de tempo diferentes. Exemplos notáveis de passos nas séries representativas incluem as variações imprevisíveis e irreversíveis na temperatura global durante a tendência média de resfriamento no Cenozóico (Figura 35-A). Da mesma forma, as alterações abruptas ocorreram no início e no final da reversão do clima do Dryas Recente, e na extremidade dos ciclos Dansgaard-Oeschger entre 60 e 20 mil anos atrás (Figura 35-C). Estas etapas são esperadas, porém imprevisíveis, além de possuírem uma pequena variação irregular sobreposta na transição de um nível para outro.

- Oscilações (0): As oscilações, uma das características mais proeminentes de séries temporais paleoclimáticas, são variações periódicas ou quaseperiódicas sobre um nível estacionário ou que está mudando lentamente. As oscilações dominam as variações glaciais-interglaciais na temperatura 
global, sendo estas governadas por controles externos gerados pelas variações periódicas dos elementos orbitais da Terra [gráficos (B) e (C) da Figura 35]. Consequentemente, estas variações são altamente previsíveis e regulares. Variações quase-periódicas (ou seja, variações que são menos regulares do que as estritamente periódicas) aparecem nas escalas de tempo "sub-orbitais", como nos ciclos Dansgaard-Oeschger (Figura 35-D). Variações climáticas interanuais, como o El Niño Oscilação Sul (ENOS), também têm sido descritas como quase-periódicas.

- Flutuações (F): Flutuações são variações aperiódicas do clima presentes em todas as escalas de tempo, mas tendem a ser mais evidentes em escalas temporais mais curtas. Variações na temperatura do Hemisfério Norte são dominadas por flutuações interanuais, com variações decadais e seculares de menor importância, com exceção do século passado [gráficos (E) e (F) da Figura 35]. Flutuações são esperadas, porém não são previsíveis especificamente as características nas séries temporais individuais. Distinguem-se dos passos por serem inerentemente reversíveis.

- Eventos (E): Os eventos são de natureza semelhante aos passos, mas são variações que retornam rapidamente para um estado anterior (em relação à escala de tempo das variações em análise) e, portanto, são sempre reversíveis e distintos dos passos. Exemplos de eventos são o Máximo Térmico do Paleoceno, que ocorreu há 55 milhões anos atrás (Figura 35A) e o Dryas Recente, evento de inversão climática que ocorreu há 12.000 anos atrás (Figura 35-C). Ao invés de uma das muitas flutuações no registro, o que constitui um evento é subjetivo, mas, geralmente, os eventos são grandes e isolados, em relação às flutuações contíguas.

Em dado momento ou lugar, o clima predominante é o produto da sobreposição de todas estas características à medida que elas ocorrem em todas as distintas escalas de tempo. As condições climáticas dependem: da amplitude da variação climática associada e a sua duração; da quantidade de características sobrepostas; da tendência de uma variação particular ser previsível ou reversível; e também da existência de limites intrínsecos. (BARTLEIN, 2006). 


\subsubsection{Escala de abordagem espacial}

Um conjunto de séries de temperatura está atrelado à região na qual foram realizadas medições in situ da temperatura ou de onde foram coletadas amostras de testemunhos indiretos das variações de temperatura. Tais séries representam um registro das condições climáticas que ocorreram no passado e são representativas para cada respectiva região, sendo possível - em alguns casos, dependendo da escala temporal adotada - serem extrapoladas pra regiões maiores, até mesmo ao nível global. Constitui-se, desta maneira, uma temperatura média global baseada em uma série ou um conjunto de séries de diferentes origens, que são compilados, basicamente, com o uso de médias.

Essex, Mckitrick e Andersen (2007) afirmam que não existe uma temperatura global da Terra com significado físico no contexto do aquecimento global. Embora seja sempre possível construir estatísticas para um dado conjunto de dados de temperatura local, uma gama infinita de tais estatísticas é matematicamente admissível se os princípios físicos não fornecem nenhuma base explícita para escolher entre elas. Segundo o autor, a média dos dados da temperatura em amostras colhidas em um campo de não-equilíbrio não é uma temperatura. Além disso, os autores são taxativos em dizer que a Terra não possui apenas uma temperatura.

De fato, existe uma variabilidade espacial da temperatura na Terra nas diferentes regiões, variando dentro de um intervalo de temperatura entre os extremos de $-80 \mathrm{a}+40^{\circ} \mathrm{C}$. Não se aprofundando no mérito de discutir se existe fundamento físico ou não a utilização de uma temperatura média global, não deve ser ignorado o fato da intensa utilização destas séries que representam as condições médias do clima, em especial a temperatura nas circunstâncias da discussão do aquecimento global.

A Figura 36 ilustra nove séries históricas de diferenças de temperatura no século passado. De um modo geral, verifica-se uma tendência de aumento das temperaturas nas diferentes regiões apresentadas, sendo que as séries de regiões que se encontram no Hemisfério Norte apresentam uma variação de temperatura maior do que as regiões do Hemisfério Sul. Porém, um olhar atento comparando o comportamento da temperatura indica um aumento no período analisado de: quase $1,0^{\circ} \mathrm{C}$ na América do Norte; cerca de $0,5^{\circ} \mathrm{C}$ na América do Sul; e $0,7^{\circ} \mathrm{C}$ globalmente. Portanto, a extrapolação de uma série local ou regional para uma 
escala global, pode reproduzir diferentes "situações globais". Tomando como exemplo estes três casos destacados, seria possível dizer que a Terra aqueceu $1,0^{\circ} \mathrm{C}$ com base na série da América do Norte, superestimado em relação ao valor "global"; ou então seria possível dizer houve um aquecimento de $0,5^{\circ} \mathrm{C}$, com base na série da América do Sul, subestimado em relação ao valor "global".

É comum observar a exibição dos maiores valores e piores cenários na mídia em geral ${ }^{14}$, ou seja, normalmente são exibidas séries correspondentes ao Hemisfério Norte $^{15}$, Europa, América do Norte ou do Pólo Norte. A simplificação e generalização ocultam a variabilidade espacial inerente ao clima. Este tipo de atitude pode induzir no público em geral uma interpretação distorcida da realidade climática.
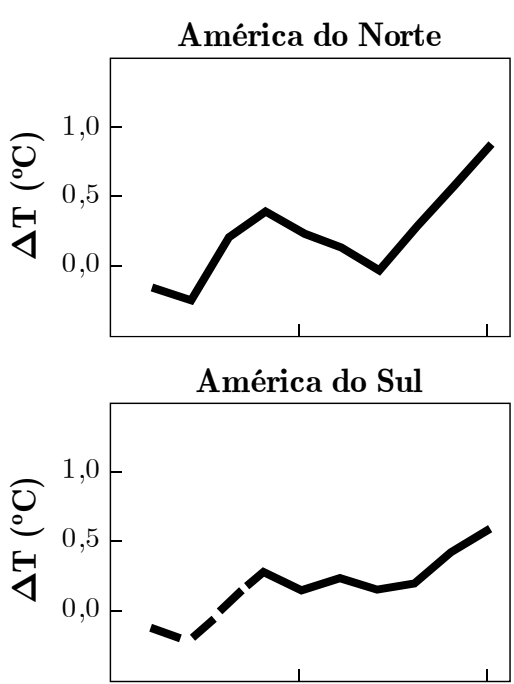

GLOBAL

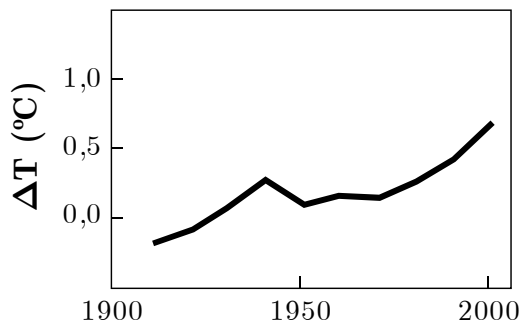

Europa

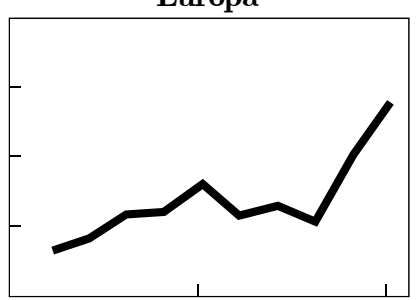

África

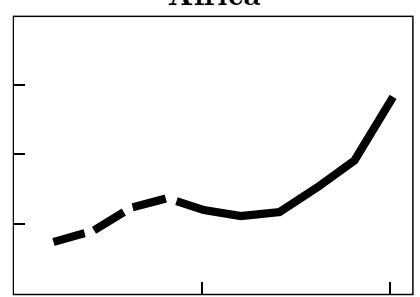

GLOBAL - Continentes

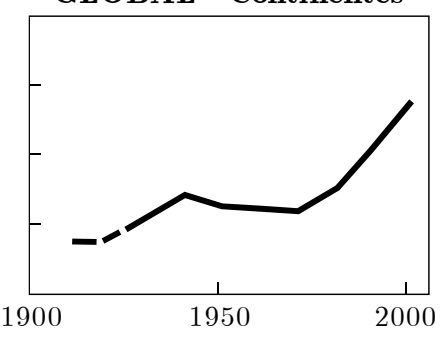

Ano

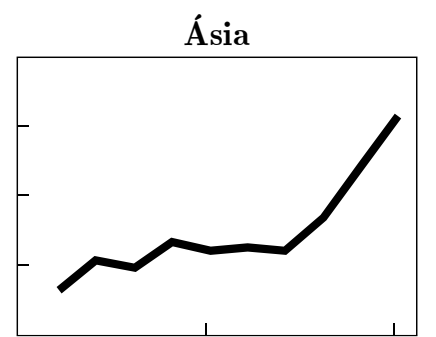

Austrália

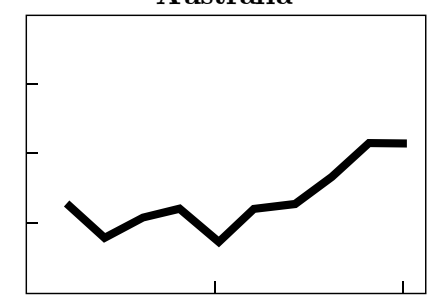

GLOBAL - Oceanos

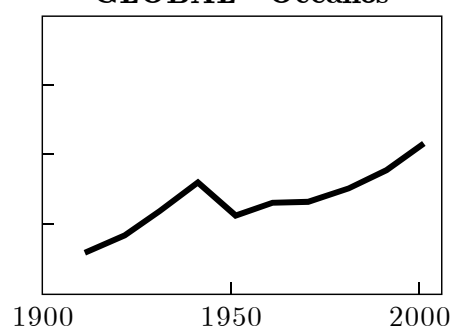

1900

Figura 36 - Comparação entre mudanças continentais e globais observadas na temperatura superficial entre 1900 e 2000. Fonte: adaptado de IPCC (2007a), pg. 40.

\footnotetext{
14 Ver a discussão sobre o alarmismo climático nos itens "9.2.3. Meios de comunicação", pg. 308 e "9.3. Interação entre a Ciência e a Mídia", pg. 313.

${ }^{15}$ Vide o "Taco de Hóquei", Figura 13, pg. 43 e a Figura 32, pg. 81 - ambas do IPCC.
} 
O fato da diferença existente entre o Hemisfério Norte e o Sul é atribuído à relação entre a área continental e área oceânica. A água, por possuir um alto calor específico, aquece menos em relação ao solo. Logo, no Hemisfério Norte, onde a proporção continental é maior, o aquecimento é preponderante; enquanto que no Hemisfério Sul, o aquecimento é amortecido e atenuado em virtude da inércia térmica predominantemente oceânica.

Embora todas as séries da figura anterior apresentem uma tendência de aumento da temperatura, nem todas as regiões do mundo estão aquecendo. Com base em registros, a Figura 37 ilustra a distribuição espacial da diferença de temperatura entre 1970 e 2004 na superfície terrestre. Como é possível notar, o Hemisfério Norte apresenta um aumento significativo na temperatura, em contraste com o Hemisfério Sul que sofre bem menos aquecimento, ocorrendo até mesmo resfriamento em regiões da Antártida. Assim, o "aquecimento global" não é um fenômeno global de elevação da temperatura em todas as regiões. Tomada com base em uma série que utiliza dados obtidos globalmente, a temperatura média terrestre representa um valor médio que não corresponde à variabilidade da distribuição espacial; não representa as especificidades locais e regionais, ocultando até mesmo regiões que estão resfriando.

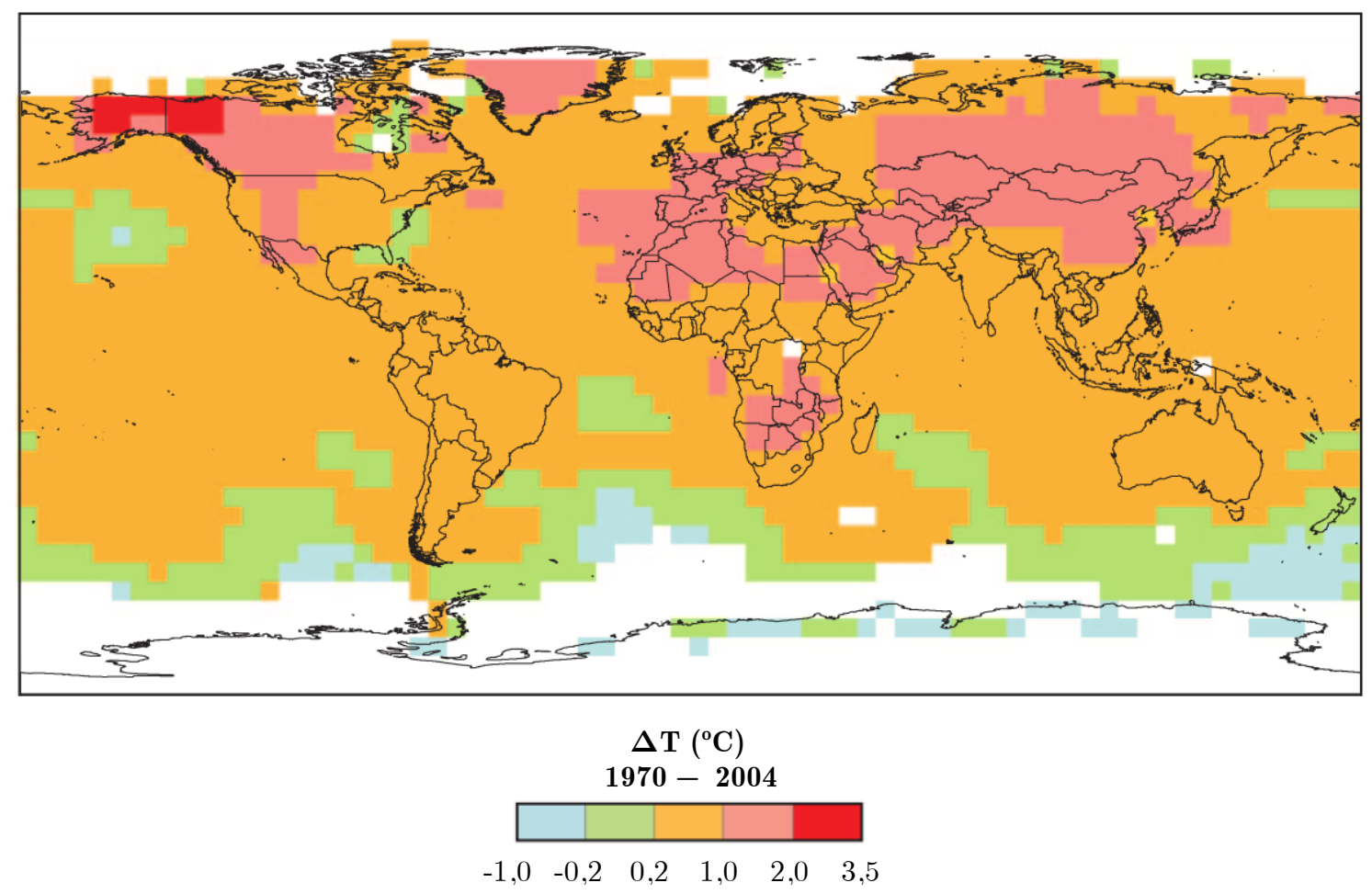

Figura 37 - Distribuição espacial mundial das mudanças da temperatura superficial no período de 1970-2004. Fonte: adaptado de IPCC (2007a), pg. 32. 


\subsubsection{Origem dos dados}

Também relacionada ao local físico (continentes ou oceanos), a origem dos dados está relacionada ao método utilizado para determinação ou estimativa dos valores de temperatura. Conforme descrito em "3.3. Medições recentes da temperatura do ar" (pg. 25), existem diferentes modalidades de medição da temperatura na superfície terrestre: medições in situ da temperatura do ar com a utilização instrumentos analógicos ou digitais, distribuídos tanto nos oceanos quanto nos continentes; medições da temperatura de superfície por meio de medições remotas, com o uso de satélites; e medições com distribuição vertical da temperatura do ar, com o uso de sondas.

\section{- Registros históricos de estações na superfície}

Grande parte das séries históricas é baseada em registros de medições instrumentais in situ. Os gráficos geralmente difundidos são provenientes desta modalidade, possuindo séries consistentes de até 150 anos de dados. Atualmente, o registro de temperatura local mais longo é de uma série de dados da Inglaterra Central (Central England Temperature - CET), que com início dos dados em 1659. O registro instrumental global de maior duração começa em 1850. Nestas séries, boa parte dos registros apresenta uma tendência de aumento da temperatura no último século. De acordo com a origem física de coleta dos dados, as principais séries instrumentais utilizadas pelo IPCC (IPCC, 2007c, cap. 3) são:

1. Temperatura da superfície do solo:

a. CRUTem3: série da University of East Anglia Climate Research Unit $(C R U)$

b. NCDC: National Climatic Data Center, série da National Oceanic and Atmospheric Administration (NOAA)

c. GISS: Goddard Institute for Space Studies, série da National Aeronautics and Space Administration's (NASA) 
Obs: Ambos NCDC e GISS utilizam os dados coletados pela rede GHCN (Global Historical Climatology Network)

2. Temperatura da superfície do mar:

a. HadSST2: série da Hadley Centre

b. HadMAT: Hadley Centre Marine Air Temperature

c. COBE-SST: Centennial in-situ Observation-Based Estimates of SSTs, série da Japan Meteorological Agency

3. Temperatura combinada da superfície do solo e do mar

a. HADCRUT3: série da Hadley Centre e Climate Research Unit (CRU)

b. GISTEMP: GISS Surface Temperature Analysis

Devido à influência das mudanças no uso do solo, especialmente pela urbanização e formação de ilhas de calor urbana ${ }^{16}$, e à deterioração das redes de observação, nestas séries podem estar incorporados erros de difícil identificação nas medições, prejudicando nas análises de atribuição de causas de mudanças climáticas recentes.

Para tentar mitigar o efeito da urbanização nas séries de temperaturas, ajustes são realizados, porém os algoritmos de correção não são necessariamente apropriados ou representam a realidade, já que esse procedimento é subjetivo e, portanto, questionável (MOLION, 2008). Molion sintetiza que existem problemas de representatividade, tanto espacial como temporal, das séries de temperaturas observadas na superfície da Terra, o que torna extremamente difícil seu tratamento e globalização. Segundo o autor, as estações climatológicas de superfície, portanto, são inadequadas para determinar a temperatura média global da atmosfera terrestre.

Já em relação deterioração das redes de observação, um dos maiores problemas com os dados globais é o desaparecimento das estações de monitoramento da temperatura das redes depois de 1990. Em meados de 1970, mais de 6.000 estações estavam na base de dados da Global Historical Climatology Network ( $G H C N)$ (rede de estações em terra que serve de base para

\footnotetext{
16 Vide item "3.3.2.3. Influência do ambiente construído", pg. 34, citando a influencia da mudança uso do solo, especialmente pela urbanização.
} 
principais séries globais de temperatura utilizadas), mas apenas 1.500 ou menos, são usados hoje, quantidade equivalente ao número de estações utilizadas no ano 1.900 (ver Figura 38). Além da perda de estações não ter sido uniforme em todo o mundo (Figura 39), D'Aleo e Watts (2010) alertam para o fato de que a remoção de estações de maior altitude, maior latitude e as estações rurais pode ter induzido a erros graves, induzindo a um aquecimento irreal. O motivo alegado para esta queda acentuada na quantidade das estações seria o atraso em compilar e disponibilizar os dados em tempo real, prática presente em somente 1.500 estações, enquanto que as demais observações ainda são tomadas e registradas à mão, cuja organização e digitalização de milhares de registros em todo o mundo são complexas e onerosas. Entretanto, muitas das estações podem, de fato, terem sido desativadas após o colapso da União Soviética no final da década de 80, declínio súbito bastante evidente no gráfico da Figura 38.

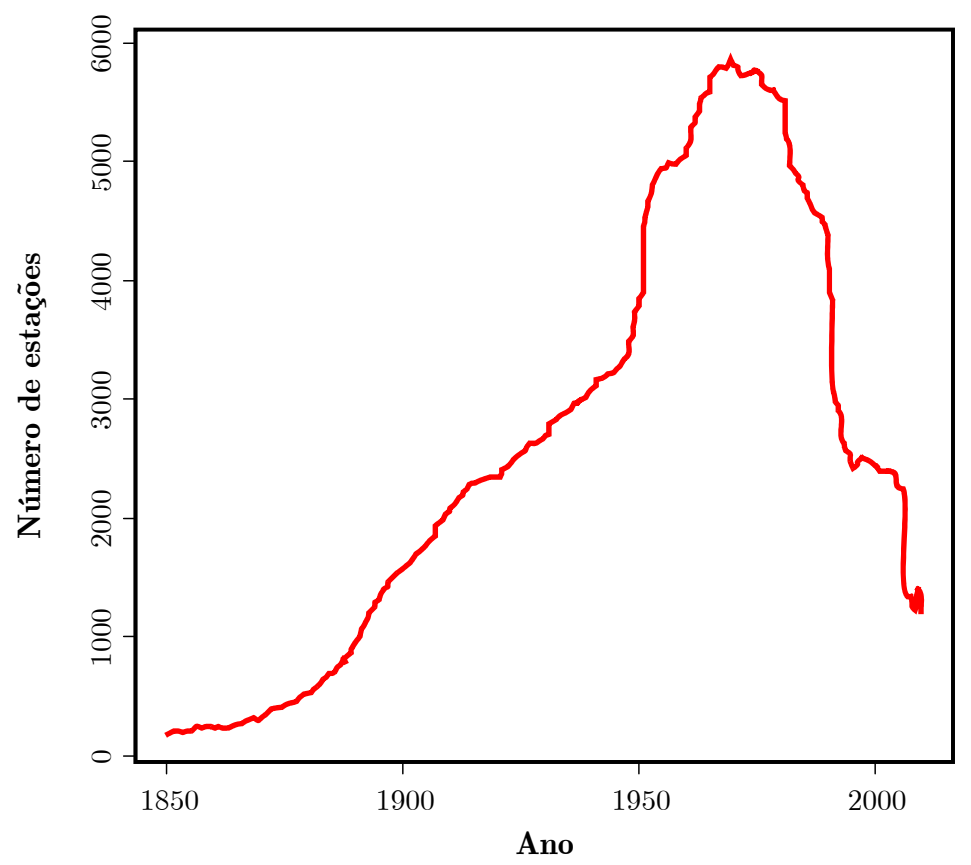

Figura 38 - Evolução e declínio na quantidade de estações climatológicas da rede Global Historical Climatology Network (GHCN). Fonte: Peterson e Vose (1997), com dados atualizados a partir de NCDC (2010). 


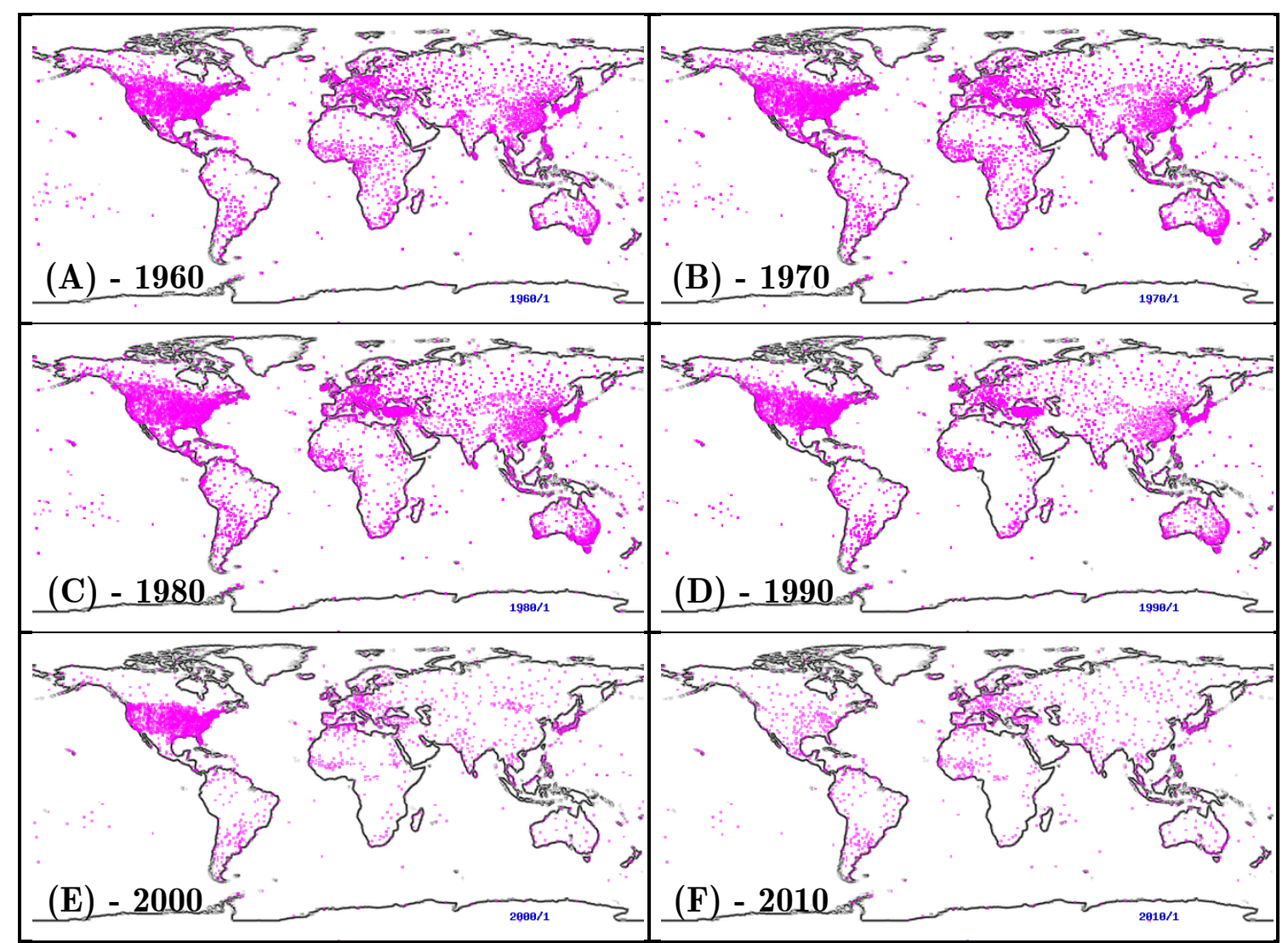

Figura 39 - Distribuição global de estações terrestres integrantes da rede Global Historical Climatology Network (GHCN). Distribuição em diferentes décadas: (A) 1960; (B) 1970; (C) 1980; (D) 1990; (E) 2000; e (F) 2010. Fonte: Unur (2010), com base em NCDC (2010).

O projeto "Berkeley Earth Surface Temperature" ${ }^{17}$ pretende calcular uma série da temperatura média global a partir de 39.000 estações terrestres e oceânicas, que são 5 vezes mais estações que a $G H C N$. Além de disponibilizar todos os dados, métodos, cálculos, resultados e incertezas associadas, esta nova rede irá aumentar substancialmente a densidade de estações em algumas regiões do mundo, como Ásia, América do Sul, Antártica e Indonésia (Figura 40-A). A expectativa positiva deste projeto é que a base de dados não possui o mesmo declínio de disponibilidade de dados que a GHCN, conforme pode ser observado na Figura 40-B. Os resultados do projeto Berkeley podem representar uma esperança quanto ao declínio da rede $G H C N$.

17 Disponível em: <http://www.berkeleyearth.org/>. Acesso em: 10 set. 2010. 


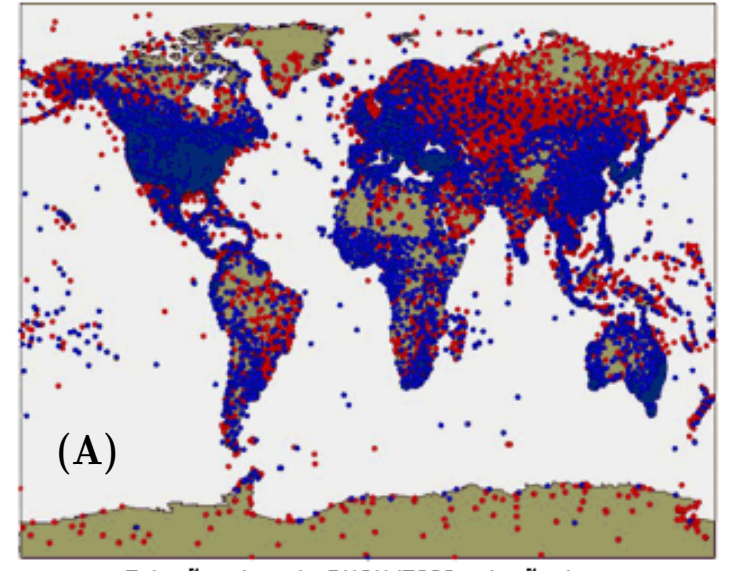

- Estações da rede GHCN (7280 estações)

- Estações adicionais da Berkeley $(32,110$ estações)

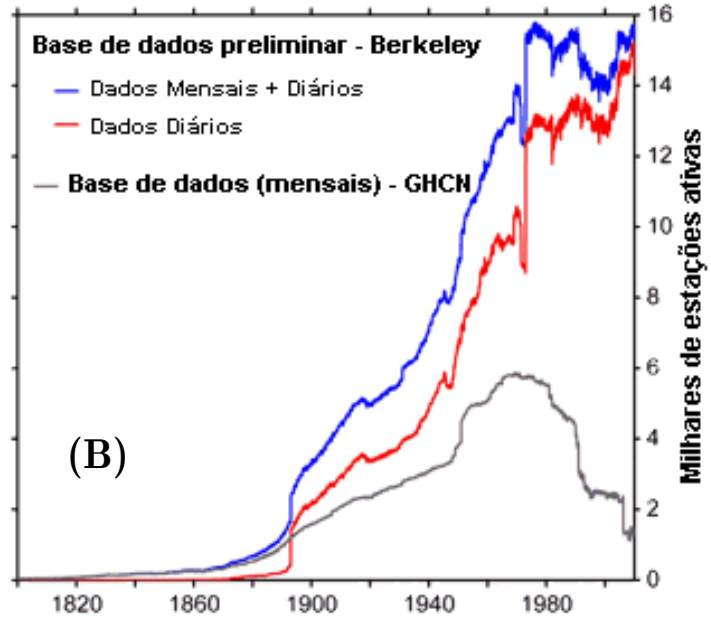

Figura 40 - Rede de estações do projeto "Berkeley Earth Surface Temperature". (A) Comparação da localização das estações da rede GHCN (em azul, exibido na frente) com a localização das estações da rede Berkeley (em vermelho, exibido por trás). Há também muitos registros adicionais nos EUA e na Europa, mas estes estão encobertos pela alta densidade de estações nestas regiões. (B) Quantidade de estações ativas da rede Berkeley (azul e vermelho) em relação à rede GHCN (preto). Fonte: adaptado de Berkeley Earth Surface Temperature (2010).

No Brasil o declínio das redes de observações também é algo preocupante, conforme alertou Zavatini (2000) na década passada: o número de estações meteorológicas de superfície era bastante superior ao de hoje. Existe a preocupação constante com o sucateamento da rede meteorológica brasileira, cada vez mais obsoleta, onde estações são fechadas a cada dia, os dados estão sendo perdidos, o despreparo ainda é frequente nos poucos observadores meteorológicos que ainda restam, a distribuição da rede de estações meteorológicas é desigual e pouco uniforme, apresentando certas áreas com sobreposições e outras áreas com imensos vazios de cobertura de coleta de informação. A sobreposição das redes meteorológicas ocorre uma vez que não existe uma rede única integrada, pois cada Ministério possui sua própria rede, como é o caso da Marinha, da Aeronáutica e da Agricultura, Pecuária e Abastecimento, sendo que a deste último é tida como "oficial" - rede mantida pelo Instituto Nacional de Meteorologia (INMET). Existem ainda inúmeras outras redes, tais como: a da Embrapa, as pertencentes aos institutos agronômicos estaduais (IAC, IAPAR), a do DNAEE, DNOS, além de outras. A representatividade das séries globais, portanto, pode estar comprometida pelo 
fato de a base de dados locais estar sofrendo redução da quantidade das estações (ZAVATINI, 2000)

Além do aspecto da quantidade, a qualidade dos dados destas estações é um fato preocupante. Por exemplo, estudo de Watts (2009) diagnosticou a qualidade da rede de estações dos EUA - na grande maioria são do tipo MMSTs, que medem apenas os valores das temperaturas máximas e mínimas diárias -, que é a maior e mais densa rede de estações em todo o globo. Mais de $70 \%$ das 1200 estações da rede dos EUA foram estudadas, verificando a ocorrência de fatores que podem influenciar nas medições: presença de estacionamentos ao lado das estações, influência da ventilação de aparelhos de ar-condicionado, entre outras fontes de calor. As estações foram classificadas de acordo com fontes potenciais de calor: classe 1, estação dentro do padrão, sem fontes interferentes; classe 2, estação com fontes de calor além de 30 metros; classe 3 , estação com fontes além de 10 metros, implicando em erros potenciais de $1^{\circ} \mathrm{C}$; classe 4 , estação com fontes a menos de 10 metros, implicando em erros de $2^{\circ} \mathrm{C}$; e classe 5 , estação com fontes de calor muito próximas ao sensor (superfícies de concreto, edificações, vias asfaltadas, estacionamentos), implicando em erros na ordem de $5^{\circ} \mathrm{C}$. Com base nesta classificação, Watts (2009) chegou à seguinte conclusão: apenas 3\% das estações estão classificadas na classe $1 ; 8 \%$ foi classificada como classe $2 ; 20 \%$ como classe $3 ; 58 \%$ como classe 4; e $11 \%$ como classe 5 . Ou seja, $89 \%$ das estações estão susceptíveis a erros potenciais acima de $1^{\circ} \mathrm{C}$, produzindo dados com viés de aquecimento provocado por alguma fonte de calor próxima aos sensores que fazem as medições. Tal estudo demonstrou que mesmo a maior rede de estações do mundo está sujeita a erros e incertezas dos dados, reduzindo a confiança no uso destes como indicadores de mudanças reais do clima.

\section{- Registros históricos por sensoriamento remoto}

Em princípio, satélites são mais apropriados para medir a temperatura global, pois fazem médias sobre grandes áreas, incluindo oceanos, enquanto as estações climatológicas de superfície registram variações na escala do seu ambiente microclimático, representando as condições atmosféricas em um raio de cerca de $150 \mathrm{~m}$ (MOLION, 2008). Além disso, as estações são sujeitas a problemas de falta de padronização de métodos, mudança de instrumentação, e 
influência de mudanças no uso do solo, como a urbanização. A partir de 1978, o monitoramento da temperatura por satélites proporcionou uma alternativa para as estações terrestres ao compilar registros da temperatura global da baixa troposfera. As duas principais séries de temperatura da baixa troposfera obtidas por sensoriamento remoto são:

\section{RSS: Remote Sensing Systems}

2. MSU/UAH: Microwave Sounding Units, série da University of Alabama in Huntsville.

A Figura 41, a seguir, apresenta o gráfico dos desvios de temperatura (em relação ao período 1961-90) de 1979 a 2009 para as duas séries de satélite. Nesta escala temporal de 30 anos, aparentemente não parece existir uma tendência de aquecimento. Notadamente desde 1998, os desvios de temperatura têm sofrido uma redução nos valores, fato que tem sido utilizado como argumento contrário ao aquecimento global causado pelos gases do efeito estufa. As emissões destes gases têm crescido exponencialmente (vide Figura 17, p. 52), no entanto os valores de temperatura não estão, aparentemente, acompanhando este aumento de maneira diretamente proporcional.

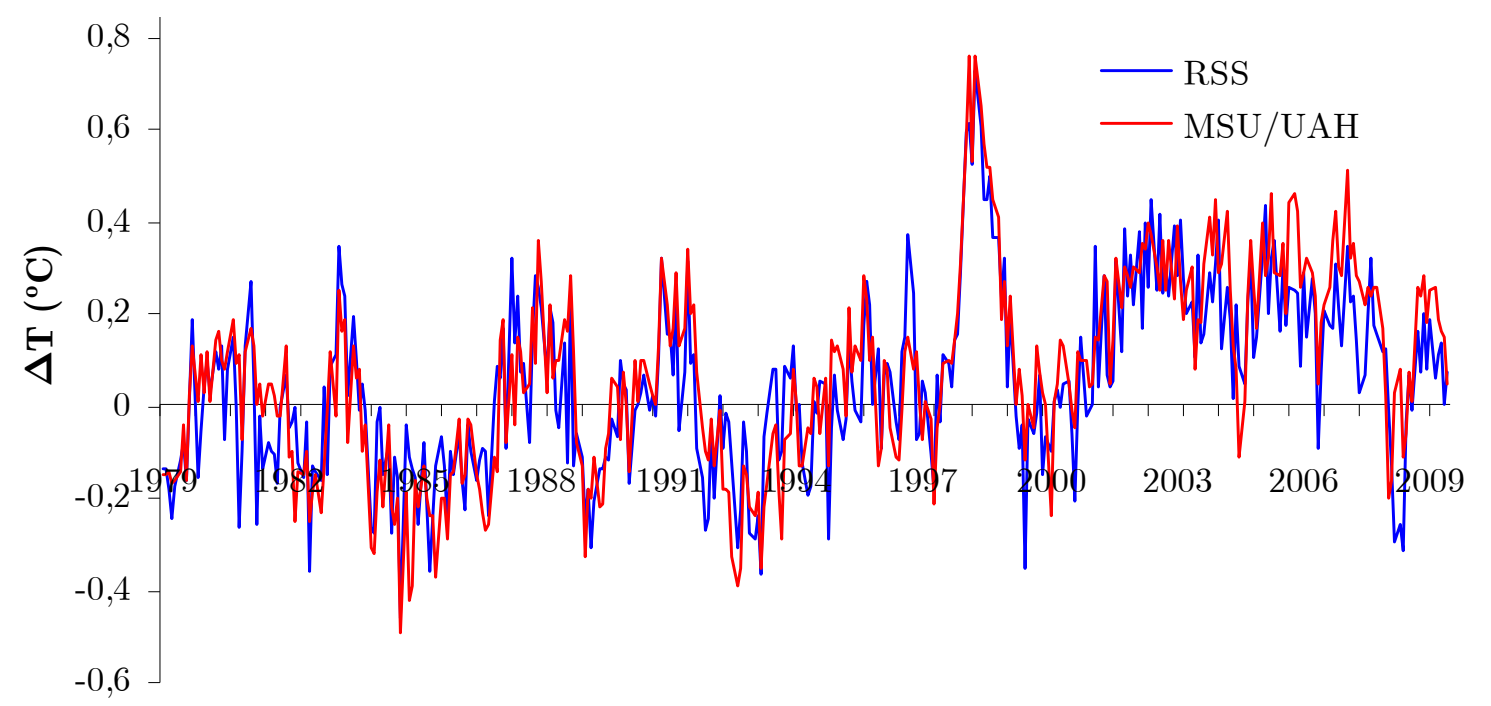

\footnotetext{
Ano

Figura 41 - Temperatura global obtida por satélites desde 1979. (Vermelho) Dados da série MSU/UAH, de janeiro de 1979 a junho de 2009; (Azul) Dados da série RSS, de janeiro de 1979 a junho de 2009. O pico evidente em 1998 foi devido a ocorrência de um intenso El Niño. Fonte: Elaborado com base em Loehle (2009).
} 
Em comparação com os dados obtidos em satélites, os resultados dos registros de estações em terra são cada vez mais divergentes, de uma forma consistente com a evidência de uma tendência de aquecimento no registro da temperatura de superfície. Segundo Molion (2006), a tendência da temperatura média global da troposfera nos últimos 25 anos foi de apenas $+0,08^{\circ} \mathrm{C}$ de acordo com os dados do MSU, valor que está aquém da acurácia do próprio sensor do satélite. Já a tendência estimada das estações de superfície foi significativamente maior, igual a $+0,32^{\circ} \mathrm{C}$.

\section{- Registros históricos por radiossondas}

A temperatura do ar nas camadas superiores não é determinada somente por satélites. Os conjuntos de dados mais longos de temperatura na troposfera e na baixa estratosfera são derivados de instrumentos transportados por balões no ar (radiossondas). As radiossondas começaram a registrar globalmente os perfis de temperaturas a partir de 1958, porém a distribuição atual de pontos de lançamento ainda é reduzida. Além da baixa cobertura geográfica, ela também é pouco uniforme. A cobertura do Hemisfério Sul permanece escassa; os oceanos e as partes dos continentes tropicais permanecem pouco representados. (PARKER et al., 2000)

Segundo Parker et al. (2000), comparações de superfície, radiossondagem e dados de satélite têm mostrado uma diminuição aparente no gradiente de resfriamento da troposfera global e tropical da baixa troposfera, durante os últimos 20 anos. Razões para uma mudança real incluem enfraquecimento de inversões de superfície de alta latitude devido ao fortalecimento da circulação atmosférica, e/ou por causa do forçamento térmico da perda do ozônio estratosférico. Senão, estas mudanças na taxa de lapso podem ser resultantes de erros em qualquer um dos conjuntos de dados, ou a partir dos erros de amostragem da esparsa rede de radiossondas. Uma das séries de radiossondas mais utilizada é a HadAT2 (Hadley Centre Atmospheric Temperature Data Set versão 2). 


\section{- Reconstruções}

Diversas inferências e afirmações podem ser feitas dependendo da origem dos dados utilizados. Ultimamente, com o alarmismo do aquecimento global antropogênico, são comuns notícias de que as últimas décadas e os últimos 10 anos foram os mais quentes do século e da história registrada. Isto faz sentido se forem tomadas as medições instrumentais, mas não as medições realizadas por satélites. Algumas notícias veiculam que o aquecimento atual é um fenômeno sem precedentes no último milênio. Tal consideração é baseada no "Taco de Hóquei" (Figura 13, pg. 47) que, neste caso, ocorrem controvérsias quanto à origem dos dados utilizados nesta reconstrução.

Onça (2008) relata com detalhes o histórico e os motivos das controvérsias deste gráfico bastante difundido. A autora indica que os dados empregados pelos autores do Taco de Hóquei continham uma série de erros, truncagens e extrapolações injustificadas, dados obsoletos, cálculos de componentes principais incorretos, localizações geográficas incorretas e outros defeitos. Segundo a autora, o formato do gráfico é devido a uma rotina na programação que dava um peso maior a séries de dados de testemunhos de anéis de árvores mais variáveis em comparação com séries mais homogêneas. Por exemplo, uma série de dados recebeu um peso de 390 vezes maior que o da série de menor peso. Estas manipulações estatísticas invalidam as alegações de que o século XX, as décadas recentes e os últimos anos foram os mais quentes do milênio.

O Taco de Hóquei simplesmente ignorou o Período Medieval Quente e Pequena Era do Gelo. Loehle (2007), posteriormente revisto em Loehle e Mcculloch (2008), elaborou uma reconstrução com base na média de 18 testemunhos - que não são de anéis árvores - de 12 locais em todo o Hemisfério Norte (Figura 42). Isso demonstra claramente a variabilidade natural do clima, sendo que estes testemunhos coincidem com eventos conhecidos na história humana. 


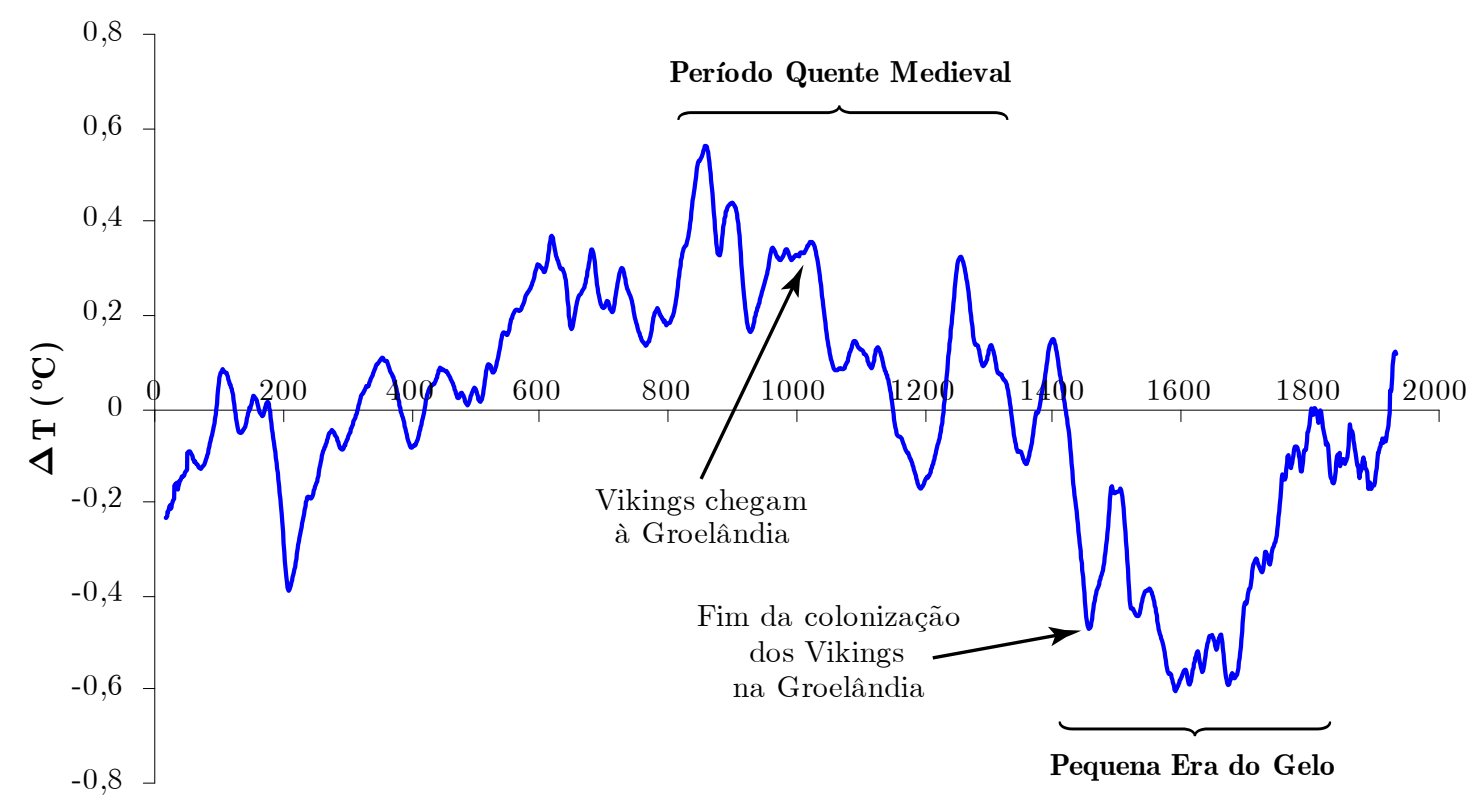

Ano

Figura 42 - Reconstrução das anomalias de temperatura no Hemisfério Norte nos últimos 2.000 anos, exibindo o Período Medieval Quente (950-1300) e a Pequena Era do Gelo (1400-1750). Os Vikings colonizaram a Groelândia de 985 a 1450. Fonte: gráfico de Loehle e Mcculloch (2008); informações dos períodos e colonização Viking retiradas de Gornitz (2009).

No estudo de Loehle e Mcculloch (2008) é descrito porque os anéis de árvore não podem ser confiados como um testemunho para as variações de temperatura no passado. Os dados de anéis da árvore possuem o que é chamado de problema de divergência: no final do século XX os dados dos anéis de árvore sugerem um resfriamento, quando na verdade tem havido aquecimento. Isso sugere dúvidas sérias nas estimativas da variação da temperatura global no passado quando reconstruções são utilizadas com base em anéis de árvore, como é o caso do Taco de Hóquei.

\subsubsection{Ordem de grandeza utilizada na escala de temperatura}

As escalas temporal e espacial, além da origem dos dados, determinam a ordem de grandeza adotada na escala de temperatura dos gráficos que exibem suas variações. As variações exibidas nos gráficos com escalas temporais de curto prazo - com séries anuais, decadais, seculares e do último milênio - são da ordem de $\pm 1^{\circ} \mathrm{C}$, ou muitas vezes até menor. Esta magnitude não reflete a 
variabilidade natural, que é de ordem de grandeza bastante superior. Assim, as variações recentes, com tendência de aquecimento, podem fazer parte de um ciclo natural das oscilações habituais do clima.

Para contextualização das recentes variações de temperatura com o passado, convém realizar uma perspectiva histórica do aumento dos últimos 150 anos em relação às mudanças de temperatura no passado em diferentes escalas. $\mathrm{Na}$ Figura 43 a seguir são apresentados alguns gráficos de temperatura com diferentes escalas temporais: dos gráficos $(\mathbf{A})$ a $(\mathbf{F})$ as curvas azuis representam as variações da temperatura na Groelândia (ALLEY, 2004); no gráfico (G), a curva azul representa os desvios de temperatura na Antártida (PETIT et al., 2001). As reconstruções dos dados de temperatura foram obtidas por análise de isótopos em testemunhos de gelo, sendo tomadas, nesta análise, como representativas das condições médias globais nas escalas exibidas. A curva em vermelho representa, aproximadamente, o aumento de $0,6^{\circ} \mathrm{C}$ no último século determinado pelos registros instrumentais, ajustados de acordo com a escala do gráfico da temperatura reconstruída.

É possível notar na Figura 43-A que os registros instrumentais são relativamente superiores às variações observadas no período analisado nesta escala temporal desde o ano 1.400, evidenciando um formato do gráfico compatível com o do Taco de Hóquei. Já na Figura 43-B, observa-se o Período Quente Medieval, e a magnitude das medições instrumentais é diminuída de acordo com a nova escala de temperatura adotada. Conforme o recorte da escala temporal vai aumentando, percebe-se que as variações de temperatura observadas pelos instrumentos vão adquirindo uma magnitude menor em relação à série exibida. Nos gráficos (C), (D) e (E) da Figura 43, os registros instrumentais parecem estar revelando apenas oscilações normais que o clima apresentou no decorrer do tempo passado. A partir dos gráficos (E), (F) e (G), essa variação se torna quase imperceptível e insignificante frente às enormes variações de temperatura, especialmente ao analisar sob a perspectiva da escala de temperatura na amplitude de aproximadamente $10^{\circ} \mathrm{C}$ entre os períodos glaciais e interglaciais. 

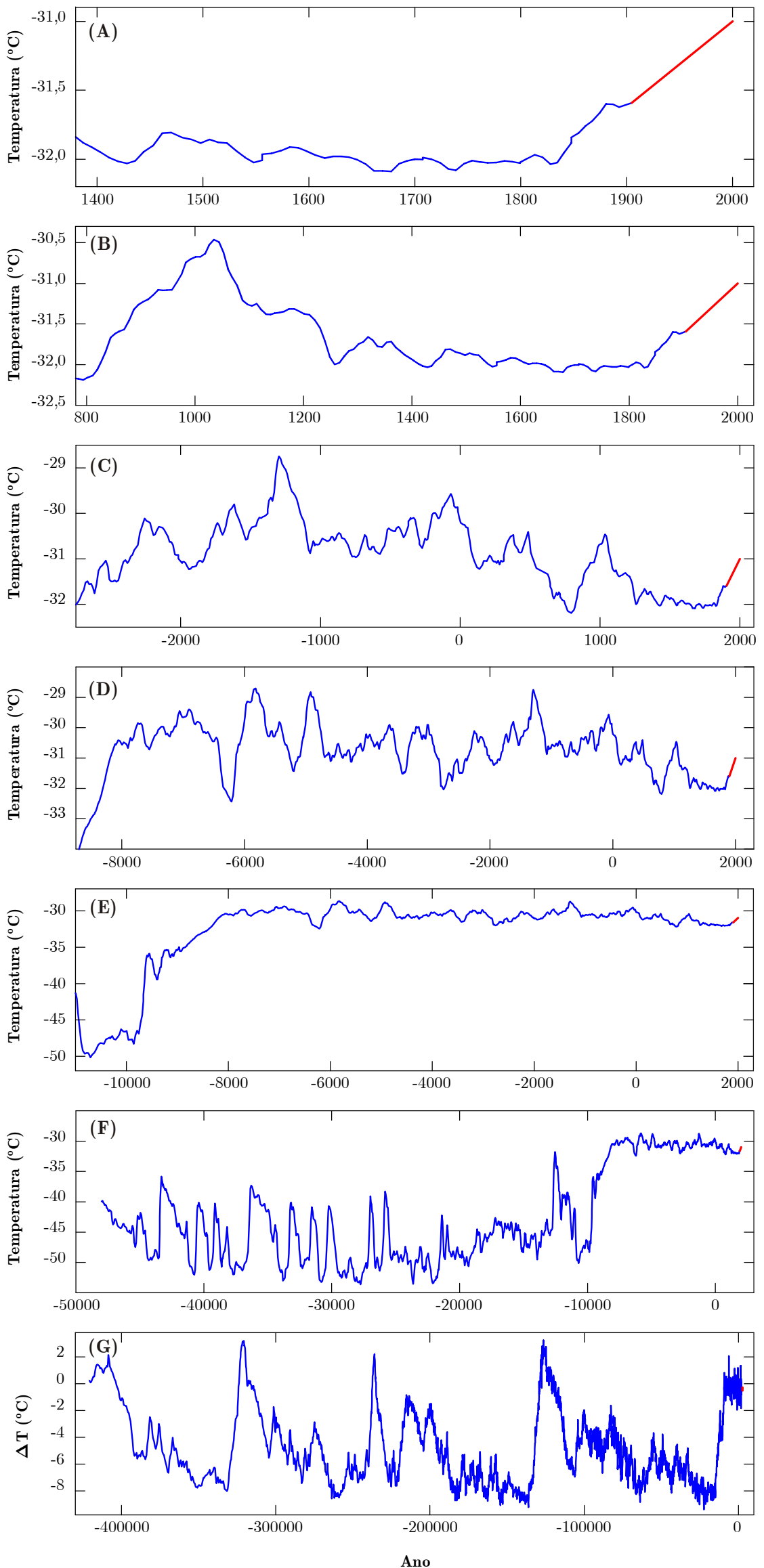

Figura 43 - Perspectiva histórica do aquecimento global. Reconstruções (continua) 
(continuação da legenda da Figura 43) da temperatura na Groelândia (azul) e aquecimento global dos últimos 150 anos (vermelho). Comparação nas escalas dos: (A) 600 anos; (B) 1.200 anos; (C) 5.000 anos; (D) 9.000 anos; (E) 11.000 anos; (F) 60.000 anos; e (G) 450.000 anos. Fonte: Petit et al. (2001) e Alley (2004).

Neste exemplo fica ilustrada a relatividade da magnitude das mudanças nos valores atuais de temperatura em comparação com mudanças que já ocorreram nas diferentes épocas pretéritas. A ordem de grandeza utilizada na escala de temperatura está intimamente vinculada à escala temporal adotada e à escala espacial representativa das variações descritas. De acordo com o interesse de quem veicula a informação, diferentes escalas e recortes temporais são adotados. Gráficos com escala temporal reduzida - que exaltam um aquecimento "sem precedentes" no período analisado - são difundidos na intenção de induzir o público a acreditar que o clima sempre foi constante na tendência, mas sofrendo pequenas oscilações. $\mathrm{O}$ crescimento repentino e acentuado seria atribuído ao aumento das emissões de GEEs.

As controvérsias que existem não são coincidências, e dessa breve exposição de gráficos e conceitos relacionados fica a impressão de a Ciência não é neutra, sendo que os diversos setores interessados (economia, política e mídia) expõem as informações de forma parcial e tendenciosa de acordo com seus interesses ${ }^{18}$.

Embora as variações climáticas em um local específico sejam fundamentalmente reguladas por controles em escala global (vide discutido nas hierarquias das causas de mudanças climáticas no item "4.2.3.1. Síntese em escala geológica", pg. 82), um registro paleoclimático específico não é representativo do estado geral do sistema global (BARTLEIN, 2006). Devido a isto que é constante a elaboração e publicação de inúmeras reconstruções no meio científico. Muitas delas são reconstruções locais, e algumas outras representam uma composição global destas, na tentativa de se estabelecer uma reconstrução que sintetize as condições climáticas globais "médias", se é que são válidas e representativas.

18 O "CAPÍTULO 7 - Implicações e repercussões no contexto da interação entre Ciência, Mídia, Política e Economia" (pg. 299) aprofunda nesta discussão. 


\subsubsection{Modelos}

Estudadas em detalhe diversas séries passadas de temperatura, discute-se brevemente alguns aspectos relacionadas às projeções futuras da temperatura, valores determinados por modelos matemáticos (cuja descrição foi abordada em "3.2.3.2. Estimativas futuras da temperatura do ar", pg. 23).

O desenvolvimento de modelos é crítico para se adquirir habilidade futura de entender melhor ou mesmo prever o clima. Molion (2008) afirma que os modelos atuais são representação ainda simples e grosseiros da complexa interação entre os processos físicos diretos (forçamentos) e de retroalimentação (feedbacks) que controlam o clima do globo. No sentido das previsões realizadas pelos modelos e das observações direta dos fenômenos climáticos, os modelos ainda carecem de validação de seus resultados. Os Modelos Climáticos Globais (MCGs) comumente têm dificuldade em reproduzir as características principais do clima atual, tais como a temperatura média global, a diferença de temperatura entre equador e pólo, entre outras limitações.

A quantidade dos diferentes tipos de nuvens, que produzem diferentes efeitos no balanço de radiação terrestre, está sujeita a aproximações e parametrizações. A parametrização é, em geral, feita com algoritmos físicoestatísticos que dependem da intuição física do modelador e, portanto, são questionáveis se os MCGs representam fielmente a realidade física (Molion, 2008).

Portanto, apesar dos avanços em termos de velocidade no processamento de cálculos e aumento da resolução espacial, ainda persistem problemas de modelagem dos processos físicos e as possíveis fontes de erros dos MCGs atuais. Molion (2008) afirma que as "previsões" ou projeções feitas pelos modelos para os próximos 100 anos podem estar superestimadas e que, portanto, a hipótese do aquecimento pelo efeito estufa intensificado, aceita pela maioria, segundo se afirma, pode não ter fundamento sólido, já que os resultados de modelos são um de seus três argumentos básicos utilizados em defesa da hipótese do aquecimento global antropogênico.

Analisando sob ótica diferente, o uso dos modelos não seria necessariamente o problema de fato. A sensibilidade do clima frente às concentrações de GEEs pode estar sendo superestimada. Todavia, o cerne da questão é que várias projeções e cenários são traçados (Figura 33, pg. 86), mas 
apenas os piores cenários, com maiores valores de temperatura, por exemplo, são os que têm maior repercussão e publicidade nos meios de comunicação. Por exemplo, existem projeções de aumento da temperatura em até $1,0^{\circ} \mathrm{C}$, entretanto, os valores que são citados e divulgados com maior ênfase são os cenários mais pessimistas, com valores em torno de $5^{\circ} \mathrm{C}$. Existe, portanto, uma tendência negativa e pessimista na divulgação das informações científicas.

Por fim, um último aspecto na modelagem climática é o fato de os modelos terem que admitir que os forçamentos naturais sejam constantes no futuro, ou seja, é assumido que fatores naturais não sofrerão variações bruscas. Estimar como serão as variações das emissões solares, por exemplo, pode ser algo bastante especulativo e subjetivo. Além disso, é imprevisível a ocorrência de certos eventos que exercem influência expressiva no clima, como atividades vulcânicas e o impacto de meteoros e cometas na Terra.

\subsection{Considerações finais}

$\mathrm{Na}$ tentativa de sumarizar tantas informações até então levantadas, elaborou-se um fluxograma (Figura 44) indicando algumas questões mais relevantes na temática climática. Seguindo a hierarquia:

1. Existem mudanças climáticas?

Mudanças climáticas sempre existiram na história da Terra. No contexto atual, remete à idéia do aquecimento global, que é apenas um tipo de mudança do clima. Assumir que não existem mudanças climáticas poderia ser o motivo alegado para não ser fazer nada para impedir que elas ocorram. Antes de tentar controlar as mudanças no clima, é necessário entender qual o seu tipo e o que causa as alterações.

2. Qual o tipo de mudança?

Vai depender de qual o recorte temporal e espacial adotado como referência. Em diferentes escalas temporais, remontando desde bilhões, milhões, milhares e centenas de anos atrás, a Terra passou por diferentes 
fases de resfriamento e aquecimento. Na atualidade (últimos 150 anos), o tipo de mudanças está relacionado a um aquecimento global - o que não significa que está ocorrendo aquecimento em todo o planeta, mas que está havendo o incremento da temperatura média na superfície terrestre. $\mathrm{Ou}$ seja, apesar do incremento do valor médio que represente a escala espacial em termos globais, existem regiões que não estão sofrendo aumento da temperatura na escala espacial local.

3. Quais as causas de mudanças climáticas?

As causas podem ser tanto naturais quanto humanas. Dentre as causas naturais, tem-se: variações das emissões solares; variações dos parâmetros orbitais terrestres; variações da atmosfera e superfície terrestre causadas por atividades vulcânicas e colisão de meteoritos e cometas; variações no El Niño - Oscilação Sul (ENOS); variações na circulação termohalina; variações dos raios cósmicos; tectonismo. Dentre as causas antrópicas, tem-se: aumento das emissões de gases do efeito estufa, alteração do uso dos solos, emissões de aerossóis.

4. O que fazer frente às mudanças climáticas?

Pode-se agir no sentido de mitigação (tentar evitar e controlar as causas) e adaptação (ajustar-se aos efeitos já estabelecidos), conceitos bastante difundidos atualmente; ou pode-se simplesmente não agir, se for assumido que o homem não tem controle sob o clima. 


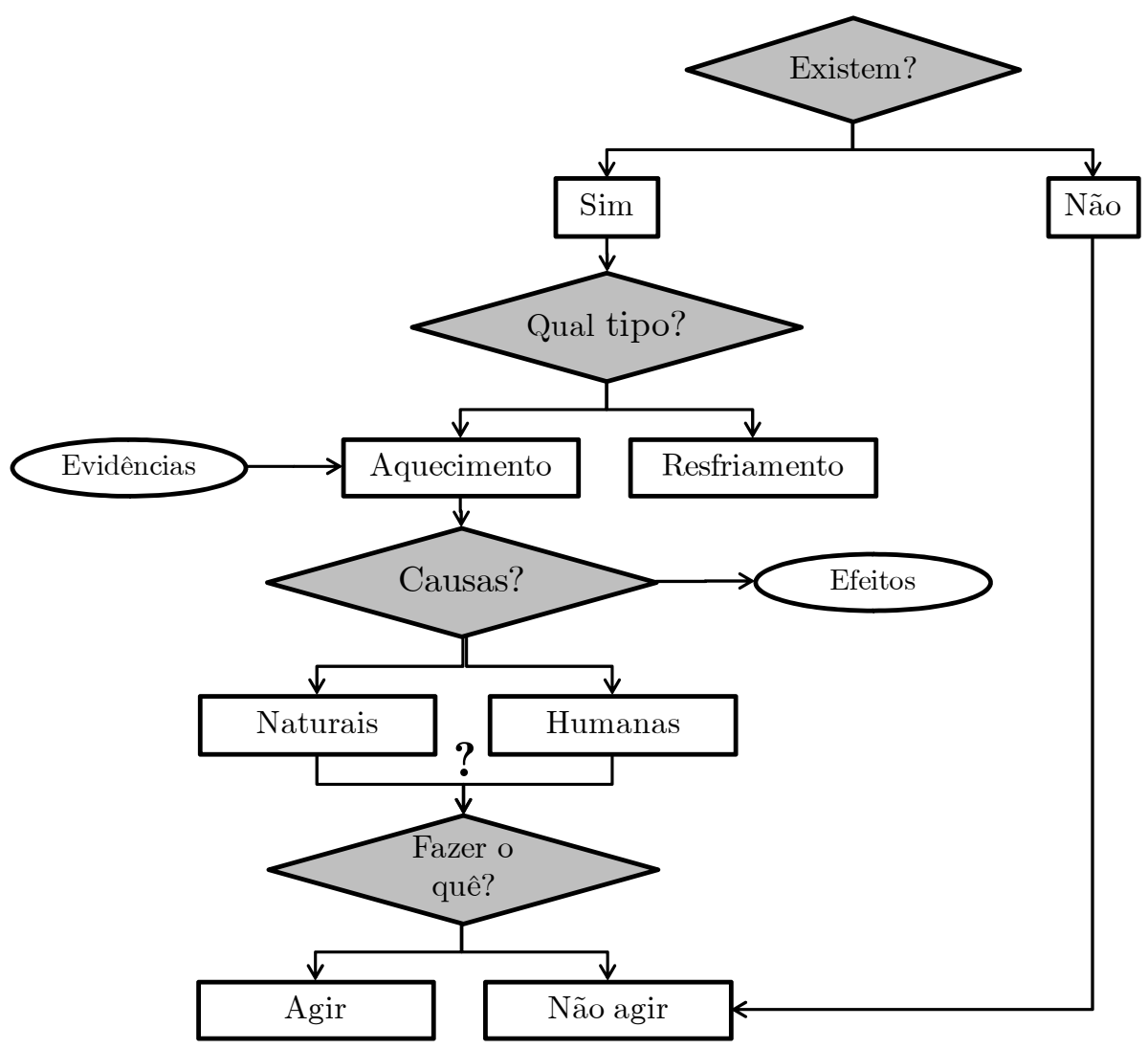

Figura 44 - Fluxograma de abordagem das questões climáticas.

Mas antes de agir ou não, a decisão depende da determinação correta de causas das mudanças climáticas. Identificar e estabelecer o grau influência dos diferentes forçamentos radiativos representa o ponto crucial na atribuição das causas das mudanças climáticas e do hipotético recente aquecimento global.

O IPCC tem se posicionado favorável à contribuição predominantemente humana no aquecimento global. Apesar de um consenso científico alegado, ainda permanecem vários pontos polêmicos.

Mesmo não sabendo exatamente qual(is) a(s) causa(s) determinante(s), seriam significativos e sem precedentes os efeitos decorrentes das mudanças climáticas atuais? Fala-se muito do aumento do nível dos mares, como se fosse ocorrer um grande dilúvio. De fato existe uma tendência de aumento, que pode chegar até $60 \mathrm{~cm}$ em 2100 no pior dos cenários, porém este aumento é pouco significativo se comparado sob uma perspectiva de milhares de anos, em que o nível do mar era de cerca de 120 m abaixo do nível atual.

Além do exagero exacerbado dos efeitos futuros, as evidências passadas não são apresentadas de forma imparcial e esclarecedora. As informações apresentadas pelo IPCC, a princípio, denotam que a verdade é dita, porém, só 
meia-verdade. Enfatizam apenas as variações recentes, omitindo ou dando pouca importância às variações passadas, de magnitude muito maior. Ignoram ou subestimam as causas naturais, que representam uma importância capaz de ter mudado tanto o clima no passado. O papel do Sol no recente aquecimento da Terra, por exemplo, permanece controverso, embora haja uma boa quantidade de evidências que sustentem a tese de que as variações da energia solar são um fator muito significativo na mudança do clima, tanto atualmente quanto no passado.

Parece existir uma tentativa do IPCC de mostrar que o clima não variou muito no passado, e que, de repente, ele começou a mudar. Esta tentativa ficou clara no uso do polêmico gráfico que ficou conhecido como Taco de Hóquei. Além da distorção intencional da informação, a quantidade de informação é outro aspecto a ser considerado. Por exemplo, os Relatórios dos Grupos de Trabalho do IPCC são documentos extensos, de cerca de 1.000 páginas cada. Eles apresentam várias informações importantes, inclusive as incertezas inerentes à pesquisa científica. Mas devido ao tamanho, estes documentos são pouco lidos, ao contrário de seus respectivos resumos que são acessíveis ao público em geral e à mídia. Tais resumos, entretanto, contêm apenas os pontos fundamentais, onde são omitidas todas as incertezas e perspectivas históricas que comparam com as mudanças no passado. Desta forma, fica favorecida a simplificação inadequada do tema, expressando um direcionamento que não corresponde à realidade e complexidade climática.

Enfim, a forma com que foi escrito este primeiro capítulo visou dar ênfase maior na descrição dos componentes naturais interferentes no clima. Normalmente, as causas naturais são brevemente citadas, e em seguida um volume imenso de informação é dedicado à influência humana no clima. Pelo apresentado aqui, espera-se que uma análise ponderada seja a mais sensata na discussão das atribuições de mudanças climáticas.

Paralelamente à determinação das causas, devem ser estudadas a fundo as evidências utilizadas como indicativas de mudanças climáticas. A temperatura do ar, principal indicador utilizado no contexto da discussão sobre o aquecimento global, está sujeita a diferentes causas de erros (heterogeneidades), decorrentes de mudanças de instrumentos, de métodos de observação, de cálculo de médias, de mudanças de lugar das estações e de modificações microclimáticas no entorno da estação. Ou seja, a composição de 
temperatura média global, que está baseada em séries locais, pode estar incorporando heterogeneidades não-climáticas que expressam valores não correspondentes a uma mudança real do clima. O conteúdo geral deste trabalho se insere justamente na pesquisa e análise das evidências com base nas séries de temperatura obtidas em estações terrestres. Nos capítulos seguintes serão estudadas algumas destas causas de heterogeneidades, demonstrando que muitas incertezas estão associadas às medições, trazendo à tona dúvidas sobre a temperatura do ar, medida em estações, ser uma evidência suficientemente confiável nos estudos de mudanças no clima. 


\section{CAPÍTULO 3 - Caracterização e Tendências Climáticas Locais}

Galileu Galilei inventou o termômetro em 1584. Quase que coincidente a esta época, foram verificadas as primeiras citações referentes a dados climáticos da temperatura do ar (Oliveira, 1969). No entanto, instrumentos que mediam confiavelmente a temperatura do ar foram desenvolvidas no final do século XVII. Conhecido pela fabricação de instrumentos meteorológicos de precisão, Gabriel Daniel Fahrenheit inventou o termômetro de mercúrio em 1714. Logo, organizações e indivíduos começaram a estabelecer redes de instrumentos meteorológicos para ajudar a quantificar e registrar o tempo. Havia muitas razões para isso, que vão desde aplicações na agricultura à previsão do tempo (PETERSON; VOSE, 1997).

Desde o início do estudo climatológico, houve a aceitação de que a média de 24 observações horárias da temperatura feitas durante um dia era a verdadeira média diária. As médias diárias eram, por sua vez, usadas para calcular as temperaturas mensais e anuais pelos climatologistas. Entretanto, a falta de observações horárias excluía a maioria das estações climáticas. Por este motivo, numerosos métodos de substituição de aproximação da verdadeira média diária foram utilizados.

Desde então, a obtenção de dados que representem a média das variações da temperatura do ar durante as vinte e quatro horas do dia tem sido um aspecto fundamental. Devido ao uso de instrumentos analógicos até a invenção dos instrumentos digitais - somente na segunda metade do século XX - a obtenção da temperatura exigia a presença de um observador para sua leitura, criando uma dependência humana sujeita a diferentes situações indesejáveis: o operador poderia esquecer-se de medir; realizar leituras erradas; anotar incorretamente os valores observados; realizar leituras nem sempre nos mesmos horários; etc. Neste sentido, era essencial a realização do menor número possível de leituras horárias, porém representativas dos valores médios diários da temperatura do ar. 


\subsection{Cálculo da temperatura média diária}

Um dos primeiros a se preocupar com temperaturas médias obtidas a partir de um número reduzido de leituras foi Debauve (1875) ${ }^{19}$ apud Oliveira (1969), que comparou a média diária das vinte e quatro horas obtida por leituras horárias em relação às médias resultantes de oito e quatro leituras diárias. Foi determinado que a média das leituras a cada três horas (8 leituras) se confundia, sensivelmente, com aquela calculada a partir de 24 leituras, e que mesmo a média de apenas 4 leituras pouco se diferia desta última. Afirmou ainda que na falta de quatro leituras diárias podia-se recorrer a apenas à leitura nos termômetros de máxima e mínima, tomando-se a média de suas leituras como a temperatura média diária.

Oliveira (1969) cita as contribuições de Loomis $(1888)^{20}$ e Trabert $(1926)^{21}$ : o primeiro autor obteve médias diárias bastante representativas a partir de apenas três leituras (às 7, 14 e 21 horas), critério até hoje adotado na íntegra ou parcialmente alterado; e o segundo autor confirmou, para a região de suas observações, a excelência do horário proposto por Loomis $(1888)^{20}$, constatando que leituras feitas às 7, 13 e 21 horas ou às 6, 13 e 22 horas permitiam, também, a obtenção de médias diárias bem representativas.

Além das contribuições de Trabert (1926), há numerosas sugestões em torno da ideia de Loomis (1888). Abreu (1961) e Oliveira (1969), na época de suas pesquisas, relatam que a Comissão Internacional de Meteorologia recomendava a leitura nos seguintes horários:

- Para estações com três observações diárias:
a) $7 \mathrm{~h}, 14 \mathrm{~h}, 21 \mathrm{~h}$;
b) $6 \mathrm{~h}, 14 \mathrm{~h}, 22 \mathrm{~h}$;
c) $7 \mathrm{~h}, 14 \mathrm{~h}, 22 \mathrm{~h}$;
d) $7 \mathrm{~h}, 13 \mathrm{~h}, 21 \mathrm{~h}$;

\footnotetext{
19 DEBAUVE, A. Manuel de l'ingeniur des ponts et chaussees. Paris, Dunod, 1875. 169p.

20 LOOMIS, E. Treatise on meteorology. New York, Harper \& Brothers, 1888. 305p.

${ }^{21}$ TRABERT, W. Meteorologia. Barcelona, Labor, 1926. 146p.
} 
e) $8 \mathrm{~h}, 14 \mathrm{~h}, 20 \mathrm{~h}$.

- Para estações com duas observações diárias:

a) $8 \mathrm{~h}, 20 \mathrm{~h}$;

b) $9 \mathrm{~h}, 21 \mathrm{~h}$;

c) $10 \mathrm{~h}, 22 \mathrm{~h}$.

Estas seriam apenas sugestões gerais, pois em função das condições locais, diversas fórmulas regionais passaram a ser particularizadas. Abreu (1961) e Oliveira (1969) citam algumas fórmulas utilizadas em diferentes países e regiões:

$$
\begin{aligned}
& \text { Groelândia } \quad T=\frac{1}{9}\left(2 T_{8}+2 T_{14}+5 T_{21}\right) \\
& \text { Europa Ocidental } \quad T=\frac{1}{4}\left(T_{7}+T_{14}+2 T_{21}\right) \\
& \text { Austrália } \\
& T=\frac{1}{2}\left(T_{9}+T_{15}\right) \\
& T=T_{9} \\
& \text { Índia e Paquistão } \\
& T=\frac{1}{2}\left(T_{8}+T_{17}\right) \\
& T=T_{8} \\
& T=\frac{1}{4}\left(T_{7}+T_{13}+2 T_{18}\right) \\
& \text { Inglaterra } \\
& T=\frac{1}{2}\left(T_{9}+T_{21}\right) \\
& T=\frac{1}{4}\left(T_{7}+T_{13}+T_{19}+T_{1}\right) \\
& \text { Estados Unidos } \\
& T=\frac{1}{2}\left(T_{8}+T_{20}\right) \\
& \text { Regiões tropicais } \quad T=\frac{1}{3}\left(T_{7}+0,9 T_{14}+1,1 T_{21}\right) \\
& \text { Regiões subtropicais } \quad T=\frac{1}{7}\left(2 T_{7}+2 T_{14}+3 T_{21}\right)
\end{aligned}
$$

onde $T=$ temperatura média diária; $T_{i}=$ temperatura anotada na hora local da leitura, representada pelo índice numérico $i$. 
Brooks (1921) identificou que a média direta calculada por $\left(T_{7}+T_{13 \text { ou } 14}+T_{21}\right) / 3$ era muito maior que a temperatura real correspondente. Ele concluiu que a melhor combinação seria o uso de uma média ponderada do tipo $\left(T_{7}+T_{13 \text { ou } 14}+2 T_{21}\right) / 4$.

O uso de temperaturas mínimas $\left(T_{m}\right)$ e ou máximas $\left(T_{M}\right)$ foi também introduzido em muitos países. Segue alguns exemplos de fórmulas desse tipo, segundo Oliveira (1969):

Egito e Sudão

$$
T=\frac{1}{4}\left(T_{8}+T_{14}+T_{20}+T_{m}\right)
$$

$$
\begin{aligned}
& T=\frac{1}{2}\left(T_{M}+T_{m}\right) \\
& T=\frac{1}{4}\left[T_{7}+T_{13}+T_{19}+\frac{1}{2}\left(T_{19}+T_{m}\right)\right]
\end{aligned}
$$

Tunísia

Oliveira (1969) aponta que em algumas localidades são utilizadas fórmulas específicas para cada estação do ano, por exemplo, o caso das fórmulas utilizadas em Hamburgo:

De maio a agosto

$$
\begin{array}{ll}
\text { De maio a agosto } & T=\frac{1}{4}\left(T_{8}+T_{20}+T_{M}+T_{m}\right) \\
\text { De setembro a abril } & T=\frac{1}{12}\left(5 T_{8}+2 T_{14}+5 T_{20}\right)
\end{array}
$$

Um tipo ainda mais complexo de fórmula é utilizado na Suécia, onde o algoritmo aplicado é (TREWIN, 2004):

\section{Suécia}

$$
T=A \cdot T_{6}+B \cdot T_{12}+C \cdot T_{18}+D \cdot T_{M}+E \cdot T_{m}
$$

em que $A, B, C, D$ e $E$ são parâmetros que variam em funções do mês e longitude da estação.

No Brasil, na década de 60 e 70, Abreu (1961) e Oliveira (1969) relatam que as fórmulas geralmente usadas eram:

$$
\begin{aligned}
& \text { Instituto Agronômico } \\
& \text { de Campinas (IAC) }
\end{aligned} \quad T=\frac{1}{4}\left(T_{7}+T_{14}+2 T_{21}\right)
$$


Serviço de Meteorologia

$\begin{array}{ll}\text { do Ministério da } & T=\frac{1}{5}\left(T_{9}+2 T_{21}+T_{M}+T_{m}\right) \\ \begin{array}{l}\text { Agricultura (SM - MA) } \\ \text { Ministério da } \\ \text { Aeronática }\end{array} & T=\frac{1}{5}\left(T_{9}+T_{15}+T_{21}+T_{M}+T_{m}\right)\end{array}$

O uso de diferentes fórmulas, para o cálculo da temperatura média diária verdadeira com o uso de poucas leituras, é um fato que sempre despertou interesse na Meteorologia. Matematicamente há uma infinidade de opções legítimas para se calcular a temperatura média diária. Na verdade, mais de cem diferentes fórmulas de cálculos de temperaturas médias diárias têm sido utilizados em meteorologia e estudos climáticos, conforme aponta (PETERSON; VOSE, 1997). Logo, a ideia de temperatura média é uma abstração humana, dada a enorme variedade de fórmulas para sua obtenção.

A Organização Meteorológica Mundial (WMO, 1983) define a temperatura média diária como a "média da temperatura observada 24 vezes em intervalos de tempo equidistantes ao longo de um intervalo contínuo de 24 horas, ou uma combinação de temperaturas observadas em quantidade de vezes menos numerosas, organizada de modo a diferir o menos possível da média acima definida". Esta definição é traduzida matematicamente pela expressão:

$$
T=\frac{1}{24} \sum_{i=1}^{24} T_{i}=\frac{1}{24}\left(T_{1}+T_{2}+T_{3}+\ldots+T_{24}\right)
$$

em que $i$ é a hora do dia (variando de 1 a 24) e $T_{i}$ é o valor da temperatura na hora $i$.

Na prática, a média das 24 observações horárias oferece a temperatura média diária com grande exatidão, e pode ser considerada como sendo a temperatura diária verdadeira. Trewin (2004) define a temperatura média diária verdadeira como a integral da temperatura durante 24 horas, dividida pela unidade de tempo utilizado. Expresso em termos matemáticos, segundo Dall'amico e Hornsteiner (2006), à altura padronizada de $2 \mathrm{~m}$ acima do nível do solo, a temperatura média diária verdadeira $\left(T_{V}\right)$ é dada pela seguinte equação: 


$$
T_{V}=\frac{1}{24 \mathrm{~h}} \int_{24 \mathrm{~h}} T \mathrm{~d} t
$$

onde $T$ é a temperatura e $24 \mathrm{~h}$ indica o tempo total de um dia. Esta é melhor aproximação estatística de uma média, que é baseada na integração das observações contínuas durante um período de tempo, no caso, um dia. Quanto maior a frequência das observações, mais precisa será a média.

O padrão ideal para a temperatura média diária poderia ser obtido pela altura média do traço dado por um termógrafo, corrigido para todas as fontes de erros instrumentais. Entretanto, não é possível definir com precisão a curva da temperatura por meio de observações em intervalos finitos de tempo. A utilização de sistemas automáticos de medição permite que sejam efetuadas medições em intervalos muito pequenos (por exemplo, um segundo), que muito se aproxima da curva exata da variação da temperatura, mas esses sistemas são relativamente recentes (e não está em uso universal). Logo, a aproximação do valor da temperatura média diária ainda é embasada em observações em horários específicos ou nos valores máximos e mínimos diários (TREWIN, 2004). Ou seja, considerações de ordem práticas geralmente impedem o cálculo da melhor aproximação: a maioria das estações de observação não mede um elemento de forma contínua. Para efeitos comparativos, a metodologia de processamento padrão é desejável para todas as estações em todo o mundo, com o número maximizado de estações. (WMO, 2009).

Considerando que todas as estações climatológicas ordinárias devem, no mínimo, observar as temperaturas máximas e mínimas diariamente, a Organização Mundial de Meteorologia (OMM) (WMO, 2009) estabelece que a metodologia recomendada para o cálculo da temperatura média diária é tomar a média das temperaturas máximas e mínimas. Apesar de sua simplicidade, este método apresenta alguns inconvenientes. Abreu (1961) adverte que os termômetros de máximas e mínimas estão mais sujeitos a erros sistêmicos do que os termômetros comuns e que a diferença entre a média das máximas e mínimas e a média verdadeira não é constante, o que torna difícil o cálculo da correção. Mesmo que esse método não seja a melhor aproximação estatística, a sua utilização consistente satisfaz os efeitos comparativos das normais. Porém isto não impede que sejam realizados outros tipos de cálculos; ao contrário, a 
OMM sugere aos órgãos responsáveis nacionais que também as médias sejam calculadas diariamente utilizando outros métodos, desde que estes cálculos possam melhorar a compreensão do clima do país.

\subsection{Cálculo da temperatura média mensal e anual: Normais climatológicas}

Os conjuntos de dados espacializados do clima mais utilizados são distribuições estimadas da precipitação total e das temperaturas diária máxima, mínima e média, em etapas mensais de tempo, a partir da média de dados de um período nominal de 30 anos. A demanda por esses conjuntos de dados tem sido requisitada, em parte, devido à fusão dos sistemas de informação geográfica com uma variedade de modelos e ferramentas de apoio à decisão, tais como aqueles usados na agricultura, engenharia, hidrologia, ecologia e conservação dos recursos naturais.

A temperatura do ar possui aplicação direta principalmente na agricultura, devido à necessidade de irrigação. As condições climáticas radiação solar, velocidade dos ventos e particularmente a temperatura do ar determinam a umidade do ar e evapotranspiração das plantações. Estimativas da quantidade de água a ser utilizada na irrigação são realizadas com base em médias mensais de temperatura, estas determinadas pela integração dos dados diários da temperatura do ar. Correlacionada à temperatura do ar, outro aspecto diz respeito à temperatura do solo, que é um elemento do clima determinante da velocidade de germinação das sementes. Dependendo de sua variação, podem ocorrer inibição ou prejuízos no processo de desenvolvimento do sistema radicular das culturas.

Em estudos de médio prazo do clima, na escala temporal na ordem de décadas de anos, os dados climáticos são muitas vezes mais úteis quando são comparados com os valores padrões ou normais. Os valores diários da temperatura do ar representam a base dos valores mensais, que por sua vez determinam os valores anuais. A média de uma série padronizada de 30 anos destes últimos consiste em uma normal climatológica.

De acordo com a OMM (WMO, 1989), os regulamentos técnicos definem as normais como "médias computadas para um período relativamente longo e uniforme, compreendendo pelo menos três períodos consecutivos de dez anos" e normais climatológicas padronizadas [ou normais-padrão] como "médias de 
dados climatológicos calculadas para períodos consecutivos de 30 anos da seguinte forma: 01 de janeiro de 1901 a 31 de Dezembro de 1930, 01 de janeiro de 1931 a 31 de Dezembro de 1960, etc.". No caso das estações mais recentes em que a normal climatológica padrão não está disponível (ou porque a estação não está em funcionamento por um período de 30 anos por algum outro motivo), as normais provisórias podem ser calculadas. Normais provisórias são médias de curto prazo com base em observações que se prolonguem por um período de pelo menos dez anos.

As normais climatológicas têm servido a dois propósitos principais. Em primeiro lugar, elas constituem uma referência contra o qual as condições (especialmente as condições atuais ou recentes) podem ser apreciadas e, segundo, elas são amplamente utilizadas (explícita ou implicitamente) para fins preditivos, como um indicador das condições susceptíveis de ocorrer em uma dada região. (WMO, 2007)

O termo normal apareceu pela primeira vez na literatura meteorológica em 1840, e em 1872 o Comitê Meteorológico Internacional decidiu que a compilação de valores médios - para fins comparativos, com o intuito de garantir a comparabilidade entre os dados coletados em várias estações - seria relativa a períodos uniformes de 30 anos, com o período inicial estabelecido em 1901-1930 e períodos subsequentes obedecendo a intervalos consecutivos de trinta anos: 1931-1960, 1961-1990, 1991-2021 e assim por diante. No Brasil, entretanto, somente a partir de 1910 as observações meteorológicas começaram a ser realizadas sistematicamente. Logo, o primeiro período padrão calculado foi o de 1931-1960 (BRASIL, 1992; WMO, 2007).

As normais, obtidas por cálculos de médias, seguem critérios estabelecidos pela OMM, que sucedeu à Comissão Meteorológica Internacional. Em 1989 foi publicado um documento, WCPD N. 10 (WMO, 1989), com o objetivo de estabelecer procedimentos gerais a serem utilizados para o cálculo de normais mensais e anuais padronizadas (séries de 30 anos) ou provisórias (séries com menos de 30 anos e mais de 10 anos) e sugerir outros descritores climáticos. No Brasil, as séries provisórias foram adotadas apenas para períodos superiores a 15 anos. (BRASIL, 1992; WMO, 1989).

Para as medições de temperatura e utilização nos procedimentos dos cálculos das normais, a norma WCPD N. 10 (WMO, 1989) recomenda a adoção 
da unidade de temperatura na escala de graus Celsius e valores com precisão na casa decimal $\left(0,1^{\circ} \mathrm{C}\right)$. O cálculo das temperaturas mensais máximas $\left(\bar{T}_{M}\right)$, mínimas $\left(\bar{T}_{m}\right)$, e médias $(\bar{T})$ deve ser realizado a partir dos valores diários, por meio das seguintes fórmulas:

$$
\begin{aligned}
& \bar{T}_{M}=\frac{\sum T_{M}}{N} \\
& \bar{T}_{m}=\frac{\sum T_{n}}{N} \\
& \bar{T}=\frac{\sum\left[\left(T_{M}+T_{m}\right) / 2\right]}{N}
\end{aligned}
$$

Note que, devido a erros de arredondamento, a temperatura média mensal $(\bar{T})$ não deve ser calculada pela média das médias mensais das temperaturas máxima $\left(\bar{T}_{M}\right)$ e mínima $\left(\bar{T}_{m}\right)$, mas sim pela soma e pela média de valores diários $\left(T_{M}\right.$ e $\left.T_{N}\right)$. A variável $N$ é o número de dias em que as médias mensais são calculadas, podendo variar de 23 a 31 dias. O número de dias menor que a quantidade de dias de um mês é devido a uma regra referida como " $3 / 5$ ", ou seja, se os valores de mais de 3 dias consecutivos ou mais de 5 valores no total do mês estão faltando, a média mensal não deve ser computada e o ano deve ser considerado como incompleto. Este critério é um pouco mais restrito que a recomendação das duas edições do Guia de Práticas Climatológicas (WMO, 1983, 2009), que recomenda que o uso da regra "5/10", ou seja, o valor mensal não deveria ser calculado se estivessem faltando 5 ou mais valores diários consecutivos ou 10 valores diários não consecutivos ao longo do mês (WMO, 2007).

O cálculo dos valores de temperatura procede com o cálculo da média mensal no seu período das normais. As médias das normais-padrão (30 anos) são calculadas a partir dos valores mês-ano (Jan-1961, Jan-1962... Jan-1990). Se para um dado mês (por exemplo, janeiro), 3 ou mais valores mês-ano consecutivos estão ausentes (por ex., janeiro de 1970, 1971, 1972), ou se 5 valores no total do mês dado estiverem faltando, então o valor médio da normal-padrão de 30 anos não deve ser calculado. Assim, segundo a WCPD N. 10 (WMO, 1989), a normal da temperatura $\left(T_{N}\right)$ para cada mês é calculada por: 


$$
T_{N}=\frac{\sum \bar{T}}{M}
$$

onde $M$, variando de 25 e 30 , é o número de meses que tem os valores de mêsano disponíveis.

Por fim, o valor anual das normais de 30 anos de temperatura é obtido pela média aritmética dos 12 valores das normais mensais. Neste caso, todos os meses devem possuir os valores normais, ou seja, não é permitida a falta de qualquer mês no cálculo da normal anual.

Após uma análise empírica detalhada, WMO (2007) sugere que as falhas nos dados, desde que envolva elementos não-aditivos (chuva, por exemplo) e não ocorram de forma sistemática, adiciona apenas uma pequena quantidade de incerteza na estimativa da normal climatológica. Além disso, se ocorrer um grande número de valores faltantes de forma consecutiva, somente uma pequena quantidade de incerteza será adicionada. Como tal, WMO (2007) afirma que parece haver pouca justificativa para os critérios mais rigorosos para a falta de dados utilizados na OMM (WMO, 1989) (em relação ao que foi utilizado no Guia de 1983), tendo em vista que um número maior de estações adicionais poderiam ser utilizadas para o cálculo das normais se os critérios fossem mais flexíveis para a disponibilidade de dados. Da mesma forma, também parece haver pouca justificação para ter um critério de "anos consecutivos" para o número máximo de anos que faltam. Logo, foi recomendada a criação de normais operacionais (WMO, 2007), que não teriam o rigor em relação aos critérios de anos consecutivos, além de serem possíveis de se calcular com dados de um período de 10 anos, sob determinadas circunstâncias.

\subsection{Controle de qualidade e homogeneização: identificação e remoção de heterogeneidades}

Pelo exposto anteriormente, percebe-se que o cálculo das normais não envolve meramente realizações de médias, mas também consiste na avaliação de homogeneidade, ou seja, o controle de qualidade é uma etapa essencial nas análises que envolvem séries climáticas. Além desse critério apresentado para a ocorrência de falhas e dados faltantes, a WCPD N. 10 (WMO, 1989) descreve a necessidade de verificação de tendências, desvios, valores alterados e outros 
problemas que possam evidenciar a heterogeneidade dos dados. Estes procedimentos visam à identificação de variações e descontinuidades nãoclimáticas.

O controle de qualidade envolve primeiramente a avaliação das estimativas para lacunas ou valores inexistentes de temperatura nos registros. Tais estimativas são geradas usando a técnica de interpolação, que por meio de iterações encontram um valor otimizado com base em série vizinhas. A segunda etapa consiste na identificação e remoção de valores não representativos das condições climáticas reais, provocadas por fatores não-climáticos.

A identificação e remoção de heterogeneidades não é uma tarefa simples, pois em uma série elas podem surgir devido a um número grande de razões. Vários tipos de erros, aleatórios ou sistemáticos, afetam os dados. Todos eles provocam um desvio ou diferença da temperatura registrada em relação à temperatura verdadeira do ar . Quanto menores os desvios, mais "precisos" são os dados.

Uma contribuição aleatória, geralmente pequena, decorre do erro da calibração do instrumento ou imprecisão da leitura, que pode ser, por exemplo, o erro de aproximação na ordem de $0,1^{\circ} \mathrm{C}$, referida como erro de precisão; ou o erro de calibração do instrumento descalibrado, que no caso do termômetro deve ser trocado se exceder $0,2^{\circ} \mathrm{C}$ em relação a uma referência certificada. Outra contribuição aleatória, mas de maior magnitude, é provocada no registro manual incorreto e/ou sua digitalização errada do valor anotado em papel, erro este, da ordem de mais de $10^{\circ} \mathrm{C}$. Estes erros de distração ocorrem nas ocasiões em que o valor é manualmente anotado errado ou quando na hora de digitar para o computador um valor registrado em papel, digita-se equivocamente a vírgula na casa errada; por exemplo, às vezes aparecem valores máximos abaixo dos valores mínimos, como $3,1^{\circ} \mathrm{C}$ ao invés de $31,0^{\circ} \mathrm{C}$. Ambos os erros aleatórios são influenciados pelo tipo do instrumento e das práticas de observação e registro dos dados. Antigamente, quando as observações e os registros dependiam de um observador humano, os valores estavam mais sujeitos a estes erros aleatórios, de causa humana - fato minimizado a partir da informatização e automatização das leituras e registros de dados do clima (PARKER; HORTON, 2005).

Diferenças sistemáticas entre a temperatura registrada e os valores verdadeiros são descritos como erros tendenciais. Os erros com as implicações mais graves para o monitoramento climático são tendências que mudam com o 
tempo. Estas tendências podem ser, por exemplo: quedas ou elevações bruscas (ou saltos) causados por alterações da instrumentação ou realojamento dos instrumentos; desvios decorrentes da calibração instrumental instável; saltos ou desvios resultantes de alterações no ambiente próximo dos instrumentos, como o crescimento ou a poda de uma árvore, ou a construção ou demolição de um edifício perto do recinto instrumental. (PARKER; HORTON, 2005).

O processo de remoção de mudanças sistemáticas de erros tendenciais em uma série climática é chamado de homogeneização, e as descontinuidades sistemáticas artificiais em uma série são frequentemente referidas como heterogeneidades. Um conjunto de dados pode ser considerado homogêneo quando alterações nos dados refletem uma mudança nas condições meteorológicas, ao invés de uma mudança nas condições em que as observações foram feitas. (WMO, 2007; MENNE; WILLIAMS JR.; VOSE, 2009).

A fim de criar uma série homogênea, uma prática comum em conjuntos de dados que são utilizados para a análise das alterações climáticas a longo prazo é fazer ajustes de alguns dos dados, visando à remoção dos erros tendenciais incorporados pelas mudanças citadas anteriormente. A falta de homogeneidade pode ser identificada através de exame visual ou através de métodos estatísticos. As duas etapas de correção de dados heterogêneas são:

1. Identificar a existência de uma falta de homogeneidade e do momento em que ela ocorreu;

2. Determinar os ajustes adequados para fazer com os dados heterogêneos para produzir uma série de tempo homogêneo.

Dentre as causas de heterogeneidades sistemáticas, WMO (2007) e Menne, Williams Jr. e Vose (2009) destacam as principais:

- Mudanças nos procedimentos utilizados para fazer as observações (como alterações no horário de observação) ou processar dados (diferentes cálculos de médias);

- Mudanças na instrumentação utilizada para fazer uma observação;

- Mudanças da localização da estação; e

- Mudanças no ambiente local ao redor de um local de observação. 
O erro do horário de observação seria de pouca preocupação no que diz respeito às tendências de temperatura, desde que o tempo de observação em uma estação de dado não tenha sido alterada durante a sua história operacional. Entretanto, conforme relatam Menne, Williams Jr. e Vose (2009), nos Estados Unidos tem havido uma conversão generalizada dos horários de medição do período da tarde para o período da manhã. Antes da década de 1940, por exemplo, a maioria dos observadores fazia a leitura dos instrumentos no final da tarde, em conformidade com as instruções normativas da época. Como consequência, o registro das temperaturas nos EUA contém um leve viés positivo (quente) durante a primeira metade do século. A mudança dos horários de observação ocorreu para satisfazer requisitos operacionais hidrológicos. O resultado foi uma redução, em larga escala, das temperaturas médias que foi simplesmente causada pela conversão do calendário de leitura diária dos observadores. Em outras palavras, nos Estados Unidos durante os últimos 50 anos, a conversão gradual do horário de observação para o período da manhã artificialmente reduziu a verdadeira tendência temperatura no registro climático. Tais influências causaram diferenças de temperatura na ordem de cerca de $0,2^{\circ} \mathrm{C}$.

Além das mudanças no horário de observação, a maioria das estações meteorológicas de superfície também experimenta mudanças de sua localização ou da instrumentação, por várias vezes, ao longo de suas histórias. Tais modificações geralmente implicam em alterações na exposição do sensor e/ou em erros de medição. Logo, podem ocorrer heterogeneidades na série de temperatura que não estão relacionados às variações climáticas reais. Infelizmente, as histórias das estações normalmente são incompletas. Como resultado, a descontinuidade pode ocorrer sem nenhuma menção no registro dos dados associados.

A maioria das mudanças documentadas na rede de estações climatológicas dos EUA está associada a realocações das estações. A identificação destas descontinuidades é realizada por meio de algoritmos de comparação pareada de registros da temperatura. Ou seja, os dados de uma estação são comparados com os de outras estações próximas, e qualquer discrepância evidente é acusada pelo algoritmo. Os resultados do algoritmo de Menne e Williams Jr. (2008), por exemplo, são usados para avaliar a evidência de heterogeneidades nos dados mensais de temperatura nos EUA. Em relação às 
mudanças de instrumentos, a troca de termômetros convencionais de mercúrio pelos termômetros de máxima e mínima levaram a uma queda média das temperaturas máximas de cerca de $0,5^{\circ} \mathrm{C}$ e um aumento médio das temperaturas mínimas de $0,4^{\circ} \mathrm{C}$ em estações que não foram transferidas de local (MENNE; WILLIAMS JR.; VOSE, 2009).

E por fim, ocorrem erros associados à urbanização e a localização em desconformidade com os padrões estabelecidos. Acredita-se que o efeito de ilha de calor urbana seja importante somente para as temperaturas mínimas. A este respeito, a documentação por fotografias tem sido bastante valiosa e utilizada para documentar o momento e as causas de mudanças dos entornos das estações.

Todos os fatores interferentes nos registros climáticos - sejam eles provenientes de estimativas de falhas de dados ou de erros associados às mudanças de instrumentos, procedimentos e às condições locais da estação dificultam as tentativas de quantificar as verdadeiras atribuições de variabilidade e mudanças climáticas. Tendo estes fatores em mente, estudos têm sido desenvolvidos e aprimorados para redução destas falhas e incertezas associadas. Caracterizar e compreender as variações em diferentes locais é um primeiro passo neste sentido. O item a seguir apresenta o estudo de normais climatológicas de algumas cidades brasileiras, onde são caracterizadas as tendências destes locais; e são identificadas possíveis descontinuidades e suas causas.

\subsection{Estudo de casos brasileiros}

Duas publicações do Ministério da Agricultura exibem as normais climatológicas no Brasil: a primeira, referente ao período 1931-1960, foi publicada em 1969 (BRASIL, 1969); a segunda, referente ao período 1961-1990, foi publicada em 1992 (BRASIL, 1992).

Na publicação de 1969, constam vinte cidades (para os estados de SP, PR e MG) com normais climatológicas. Destas cidades, apenas oito possuem normais climatológicas publicadas em 1992 para o segundo período. Convém analisar e descrever algumas destas normais, na tentativa de identificar algum padrão ou tendência nos valores das temperaturas média, máxima e mínima. 
Como critérios de seleção das cidades e para uma análise mais aprofundada foram escolhidas: as capitais dos três estados, São Paulo/SP, Curitiba/PR e Florianópolis/SC; uma cidade do litoral e outra do interior do Estado de São Paulo, Santos e Franca, respectivamente.

Para os dois períodos padrões, a Tabela 2 apresenta as normais de temperaturas médias mensais e a média anual dos valores mensais. A Figura 45 exibe graficamente os valores correspondentes. Pelos valores apresentados na Tabela 2 e comparando os períodos das duas normais, constata-se que houve um aumento de $0,8^{\circ} \mathrm{C}$ na temperatura média anual na cidade de São Paulo; com a temperatura se mantendo a mesma, não houve alteração em Curitiba; em Florianópolis teve um resfriamento desprezível de $0,1^{\circ} \mathrm{C}$; Santos sofreu um resfriamento de $0,6^{\circ} \mathrm{C}$; e Franca apresentou um resfriamento significativo de $2,1^{\circ} \mathrm{C}$. A comparação dos valores mensais entre as normais dos dois períodos fica mais bem evidenciada visualmente nos gráficos da Figura $\mathbf{4 5}$.

Tabela 2 - Normais das temperaturas médias das cidades de São Paulo, Curitiba, Florianópolis, Santos e Franca, para os períodos de 1931-1960 e 1961-1990.

\begin{tabular}{ccccccccccccccc}
\hline \hline Cidade & Período & JAN & FEV & MAR & ABR & MAI & JUN & JUL & AGO & SET & OUT & NOV & DEZ & ANO \\
\hline \multirow{2}{*}{ São Paulo } & $1931-1960$ & 21,6 & 21,7 & 20,8 & 18,7 & 16,9 & 15,6 & 14,6 & 16,2 & 17,3 & 18,6 & 19,2 & 20,2 & 18,5 \\
\cline { 2 - 13 } & $1961-1990$ & 22,1 & 22,4 & 21,7 & 19,7 & 17,6 & 16,5 & 15,8 & 17,1 & 17,8 & 19,0 & 20,3 & 21,1 & 19,3 \\
\hline \multirow{2}{*}{ Curitiba } & $1931-1960$ & 20,1 & 20,1 & 19,2 & 16,8 & 14,5 & 13,2 & 12,5 & 14,0 & 14,8 & 16,2 & 17,4 & 18,9 & 16,5 \\
\cline { 2 - 12 } & $1961-1990$ & 19,6 & 19,9 & 19,0 & 16,7 & 14,6 & 12,2 & 12,8 & 14,0 & 15,0 & 16,5 & 18,2 & 19,3 & 16,5 \\
\hline \multirow{2}{*}{ Florianópolis } & $1931-1960$ & 24,4 & 24,3 & 23,8 & 21,3 & 19,3 & 17,6 & 16,5 & 16,8 & 17,8 & 19,3 & 20,8 & 22,8 & 20,4 \\
\cline { 2 - 12 } & $1961-1990$ & 24,3 & 24,7 & 23,7 & 21,4 & 18,5 & 16,7 & 16,3 & 16,9 & 17,5 & 19,6 & 21,5 & 22,5 & 20,3 \\
\hline \multirow{2}{*}{ Santos } & $1931-1960$ & 25,2 & 25,3 & 24,8 & 22,8 & 20,8 & 19,3 & 18,5 & 19,0 & 19,7 & 20,9 & 22,2 & 23,9 & 21,9 \\
& $1961-1990$ & 23,8 & 24,1 & 25,1 & 22,5 & 19,8 & 18,2 & 16,9 & 18,2 & 19,3 & 21,3 & 23,0 & 23,6 & 21,3 \\
\hline \multirow{2}{*}{ Franca } & $1931-1960$ & 21,6 & 21,4 & 21,2 & 20,0 & 18,5 & 17,3 & 17,3 & 19,2 & 20,5 & 21,0 & 21,1 & 21,0 & 20,0 \\
\cline { 2 - 12 } & $1961-1990$ & 19,0 & 18,3 & 18,5 & 17,5 & 16,6 & 15,4 & 15,3 & 17,8 & 18,9 & 19,7 & 18,8 & 18,7 & 17,9 \\
\hline
\end{tabular}

Fonte: Brasil $(1969,1992)$. 

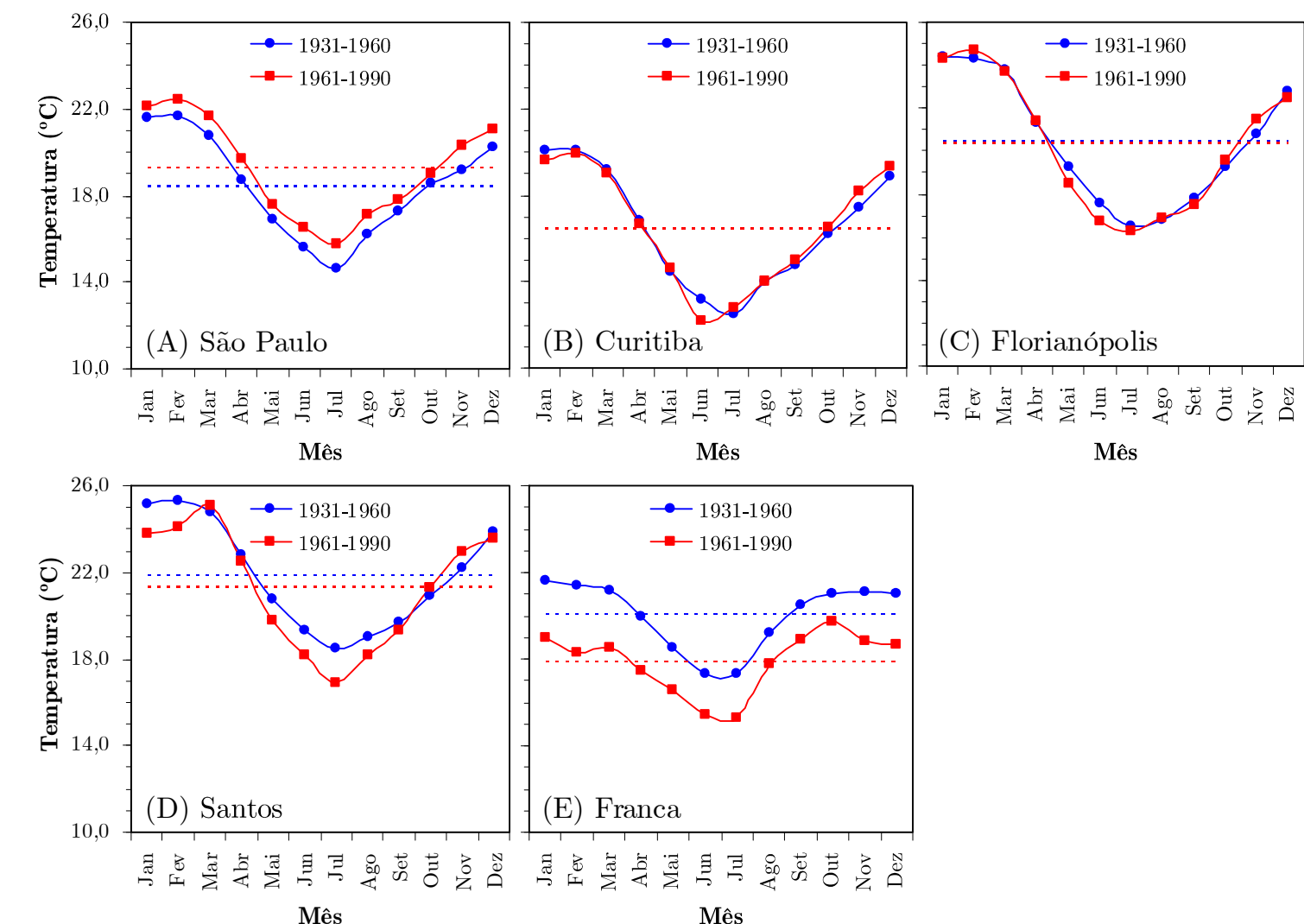

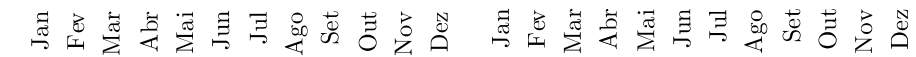

Figura 45 - Normais climatológicas da temperatura média nos períodos de 1931-1960 (curvas em azul) e 1961-1990 (curvas em vermelho) nas cidades de (A) São Paulo; (B) Curitiba; (C) Florianópolis; (D) Santos; e (E) Franca. As linhas horizontais tracejadas representam os valores anuais médios. Obs.: Escala vertical idêntica em todos os gráficos. Fonte: elaborada com dados de Brasil $(1969,1992)$.

Nota-se que não há homogeneidade no comportamento da temperatura para estas cidades analisadas, ou seja, uma sofre aquecimento, outras não apresentam alteração significativa e outra deparou com um resfriamento bastante expressivo na escala em estudo. Cabe analisar em detalhes as normais de São Paulo e Franca, que exibiram os dois extremos de variações.

\subsubsection{Casos de São Paulo e Franca}

No caso da cidade de São Paulo, uma primeira análise das normais de temperatura máxima revela que o valor médio anual do segundo período (19611990) apresentou-se inferior, com $24,7^{\circ} \mathrm{C}$, em relação ao período anterior (19311960), com $24,9^{\circ} \mathrm{C}$ - diferença de apenas $0,2^{\circ} \mathrm{C}$ (vide dados apresentados na Tabela 2). Porém, como seria possível São Paulo estar aquecendo, com normal 
da temperatura média apresentando um aumento de $0,8^{\circ} \mathrm{C}$, se as temperaturas máximas não estão aumentando à mesma proporção? Tal acontecimento só seria possível se as temperaturas mínimas estivessem subindo, o que de fato é verificado ao comparar os valores do primeiro período $\left(14,3^{\circ} \mathrm{C}\right)$ com os do segundo período $\left(15,5^{\circ} \mathrm{C}\right)$, denotando uma diferença de $1,2^{\circ} \mathrm{C}$. Ou seja, quando se verifica um aquecimento nas normais de temperaturas médias não quer dizer, necessariamente, que os dias estão ficando mais quentes, embora seja esta a primeira impressão que fique. A questão, nesse caso, é que as noites - período em ocorrem os valores de temperatura mínima - que estão ficando "mais quentes", ou melhor, "menos frias". Na escala adotada de 30 anos das normais, este aquecimento nas temperaturas médias, portanto, não representaria grandes efeitos nas atividades humanas cotidianas urbanas ao longo do dia. E conforme visto na Figura 46-A-SP, as temperaturas no segundo período se apresentam, no período do verão, abaixo das temperaturas do período anterior. Nesta escala, pode-se inferir que os meses não estão ficando mais quentes no verão. Ao contrário, todos os meses estão ficando menos frios ao longo de todo o ano Figura 46-B-SP. O gráfico (C-SP) ilustra uma compilação das temperaturas máxima, média e mínima, ressaltando que a amplitude de variação da temperatura foi reduzida, ou seja, não houve alteração perceptível nos valores máximos, mas sim um aumento dos valores mínimos que, consequentemente, conduziram o valor médio para cima.

Tabela 3 - Normais das temperaturas médias, máximas e mínimas das cidades de São Paulo e Franca, para os períodos de 1931-1960 e 1961-1990.

\begin{tabular}{|c|c|c|c|c|c|c|c|c|c|c|c|c|c|c|c|}
\hline Cidade & Período & Temp. & JAN & FEV & MAR & ABR & MAI & JUN & JUL & AGO & SET & OUT & NOV & DEZ & ANO \\
\hline \multirow{6}{*}{ 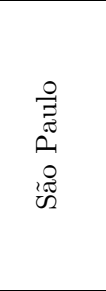 } & \multirow{3}{*}{$1931-1960$} & $T$ & 21,6 & 21,7 & 20,8 & 18,7 & 16,9 & 15,6 & 14,6 & 16,2 & 17,3 & 18,6 & 19,2 & 20,2 & 18,5 \\
\hline & & $T_{M}$ & 27,3 & 28,0 & 27,2 & 25,1 & 23,0 & 21,8 & 21,8 & 23,3 & 23,9 & 24,8 & 25,9 & 26,3 & 24,9 \\
\hline & & $T_{m}$ & 17,6 & 17,9 & 17,2 & 14,8 & 12,9 & 11,0 & 10,1 & 11,3 & 12,7 & 14,4 & 15,0 & 16,2 & 14,3 \\
\hline & \multirow{3}{*}{ 1961-1990 } & $T$ & 22,1 & 22,4 & 21,7 & 19,7 & 17,6 & 16,5 & 15,8 & 17,1 & 17,8 & 19,0 & 20,3 & 21,1 & 19,3 \\
\hline & & $T_{M}$ & 27,7 & 27,6 & 26,6 & 24,6 & 22,9 & 21,8 & 21,2 & 23,4 & 24,5 & 24,8 & 25,2 & 25,9 & 24,7 \\
\hline & & $T_{m}$ & 18,7 & 18,8 & 18,2 & 16,3 & 13,8 & 12,4 & 11,7 & 12,8 & 13,9 & 15,3 & 16,6 & 17,7 & 15,5 \\
\hline \multirow{6}{*}{ 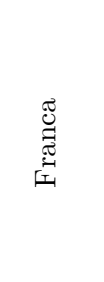 } & \multirow{3}{*}{$1931-1960$} & $T$ & 21,6 & 21,4 & 21,2 & 20,0 & 18,5 & 17,3 & 17,3 & 19,2 & 20,5 & 21,0 & 21,1 & 21,0 & 20,0 \\
\hline & & $T_{M}$ & 27,0 & 27,2 & 27,2 & 26,2 & 25,1 & 24,3 & 24,6 & 26,8 & 27,8 & 27,8 & 27,2 & 26,5 & 26,5 \\
\hline & & $T_{m}$ & 17,2 & 17,2 & 16,8 & 15,1 & 13,1 & 11,7 & 11,4 & 12,6 & 14,3 & 15,7 & 16,2 & 16,7 & 14,8 \\
\hline & \multirow{3}{*}{$1961-1990$} & $T$ & 19,0 & 18,3 & 18,5 & 17,5 & 16,6 & 15,4 & 15,3 & 17,8 & 18,9 & 19,7 & 18,8 & 18,7 & 17,9 \\
\hline & & $T_{M}$ & 23,3 & 22,8 & 22,9 & 22,2 & 21,6 & 20,8 & 20,7 & 23,9 & 25,0 & 25,1 & 23,8 & 23,2 & 22,9 \\
\hline & & $T_{m}$ & 15,4 & 15,4 & 15,4 & 15,4 & 15,4 & 15,4 & 15,4 & 15,4 & 15,4 & 15,4 & 15,4 & 15,4 & 15,4 \\
\hline
\end{tabular}

$T, T_{M}$ e $T_{m}=$ Temperaturas média, máxima e mínima, respectivamente.

Fonte: Brasil $(1969,1992)$. 

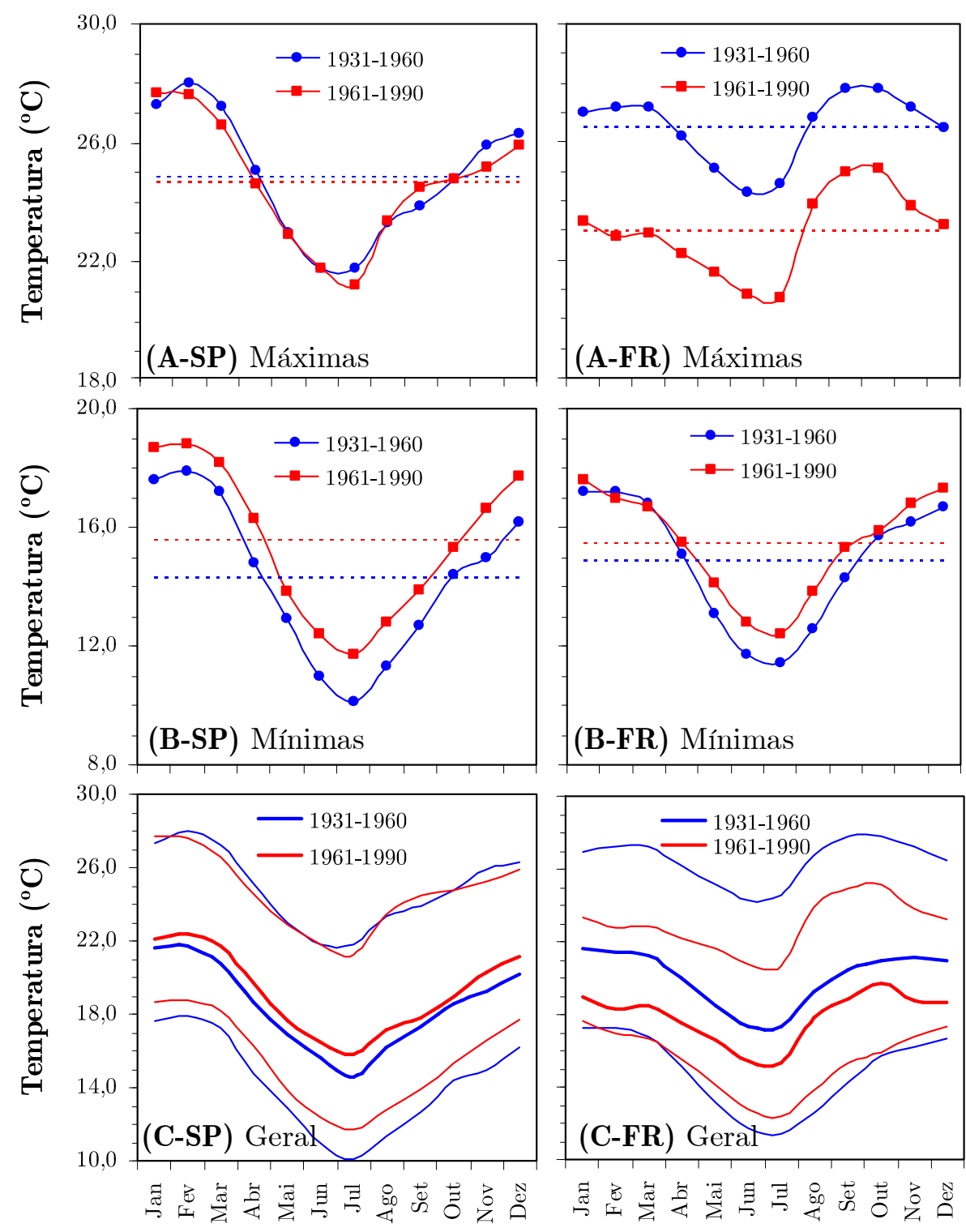

Mês
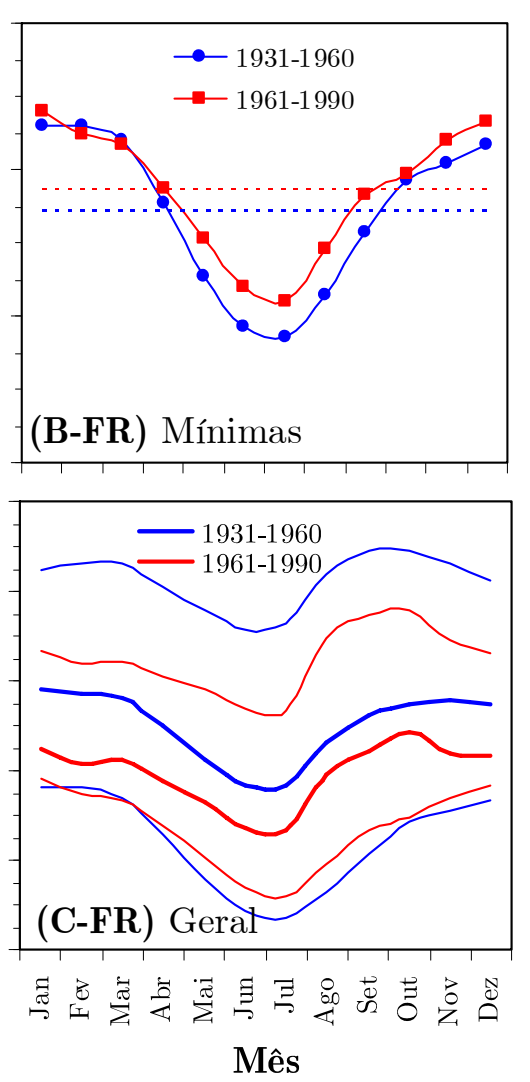

Figura 46 - Síntese das normais climatológicas das temperaturas média, máxima e mínima nos períodos de 1931-1960 (curvas em azul) e 1961-1990 (curvas em vermelho) nas cidades de São Paulo e Franca. Nos gráficos em (C), as curvas mais grossas representam os valores médios e as curvas mais finas denotam os valores máximos (linhas superiores) e mínimos (linhas inferiores). Fonte: elaborada com dados de Brasil $(1969,1992)$.

Por um lado, tomando como base apenas as normais da temperatura média, poderia ser alegado que o aumento verificado é reflexo do aquecimento global, contudo, nem os dias nem os meses estão mais quentes no período do verão, vide análise das temperaturas máximas. Por outro lado, pode ser 
argumentado que as pessoas têm sentido mais calor ultimamente. Primeiro que em relação à sensação de desconforto dos habitantes na cidade, outros fatores físicos estão envolvidos, como a redução de áreas arborizadas, em contraste com o aumento de superfícies que aquecem com maior intensidade durante o dia (asfalto, concreto, telhas, solo exposto, etc.). Além das trocas térmicas por condução e convecção, os ganhos de energia por uma pessoa são intensificados no ambiente urbano devido às superfícies irradiantes, que se encontram em temperaturas mais elevadas. Esta contribuição favorece com o desconforto térmico dos indivíduos presentes ao ar livre, mas não quer dizer que a temperatura do ar está maior ou que os dias estão mais quentes, mas as pessoas estão realmente sentindo mais calor, devido ao ganho incremental de energia proveniente das superfícies quentes irradiantes. Segundo que seja considerado ainda o fato de cada vez mais as pessoas passam um tempo expressivo dentro de veículos, estes que estão sujeitos ao aquecimento solar direto. Quando presos em congestionamentos, os veículos ficam um tempo maior de exposição ao Sol, aumentando o aquecimento interno do carro e também, consequentemente, o desconforto se seus ocupantes. Relacionado à temperatura, outro aspecto essencial a ser considerado no conforto das pessoas é a umidade relativa do ar. Enfim, devido a esses e outros fatores físicos e, principalmente, ao fator da subjetividade humana, o ideal seria não utilizar este critério como indicativo de aquecimento na escala das normais. Se, de um modo geral, está ocorrendo uma percepção de aquecimento por parte dos habitantes das grandes cidades, boa parte desta sensação de aquecimento pode ser devido à ocorrência das ilhas de calor urbana ${ }^{22}$. Se estiver ocorrendo uma quantidade de dias mais quentes ao longo do ano, na escala das normais climatológicas essas ocorrências seriam, a princípio, pouco perceptíveis.

\footnotetext{
22 A ilha de calor urbana corresponde a uma área na qual a temperatura da superfície é mais elevada que as áreas circunvizinhas. O efeito da ilha de calor sobre as cidades ocorre devido: à redução da evaporação (decorrente da presença de poucas áreas verdes, aumento da impermeabilidade dos solos e aumento do escoamento superficial); ao aumento da rugosidade e às propriedades térmicas dos edifícios e dos materiais pavimentados; e à produção de energia antropogênica de emissões de calor pelas indústrias, trânsito e habitações. Na cidade de São Paulo, em termos de temperatura da superfície radiante, obtida por sensoriamento remoto com o uso de satélites, chega a ocorrer uma diferença de até $10{ }^{\circ} \mathrm{C}$ entre o centro da cidade e a área rural. (LOMBARDO, 1985).
} 
Logo, são necessários estudos de verificação de anomalias e tendências, crescentes ou não, de ocorrência de dias mais quentes ao longo do ano, qual a magnitude desses aumentos, e por fim, quais as repercussões destas variações nos valores expressos pelas normais climatológicas. Uma primeira análise é feita ao comparar as temperaturas máximas absolutas nos dois períodos, cujos valores são apresentados na Tabela 4. Nela é possível verificar que, em São Paulo, o maior valor de temperatura máxima absoluta no período de 1931-1960 foi de $35,2^{\circ} \mathrm{C}$, enquanto no período de $1961-1990$ foi de $35,5^{\circ} \mathrm{C}$, representando assim uma diferença pouco significativa de $0,3^{\circ} \mathrm{C}$. Na Tabela 4, estão destacados com sombreamento cinza os valores do período que se apresentam acima dos valores do outro período. Pelo realce, nota-se que existe um equilíbrio entre os períodos que apresentam os meses com as temperaturas máximas maiores: ora o primeiro período apresentou meses (7 no total, não consecutivos) com temperaturas máximas maiores, ora o segundo no período ocorreram meses (5 no total, não consecutivos) com valores de temperaturas máximas superiores. Fica nítida uma variabilidade que é inerente aos complexos sistemas climáticos, que neste caso apresenta oscilações, mas nenhum sinal de tendência de um período apresentar em relação ao outro, em todos os meses, maiores valores de temperatura máxima absoluta.

Tabela 4 - Temperaturas máximas absolutas da cidade de São Paulo nos períodos de 1931-1960 e 1961-1990.

\begin{tabular}{cccccccccccccc}
\hline \hline Periodo & JAN & FEV & MAR & ABR & MAI & JUN & JUL & AGO & SET & OUT & NOV & DEZ & ANO \\
\hline $1931-1960$ & 34,6 & 35,2 & 32,8 & 31,8 & 31,2 & 27,8 & 29,2 & 33,1 & 34,3 & 35,0 & 34,2 & 34,2 & 35,2 \\
\hline $1961-1990$ & 33,2 & 34,7 & 33.5 & 31,4 & 29,7 & 28,6 & 29,3 & 33,0 & 35,2 & 34,5 & 35,3 & 33,5 & 35,5 \\
\hline
\end{tabular}

Fonte: Brasil $(1969,1992)$.

Retomando as análises das normais para o caso de Franca, a situação se torna um pouco mais intrigante. $\mathrm{Na}$ estação localizada nesta cidade foi registrada uma queda de $2,1^{\circ} \mathrm{C}$ na normal da temperatura média. Analogamente ao caso de São Paulo, cabe descrever o comportamento das normais das temperaturas máximas e mínimas. De um modo geral, este resfriamento pode ter ocorrido de duas formas: ou as temperaturas máximas (ou mínimas) sofreram consideravelmente uma redução nos valores e os dias (ou as noites) se tornaram mais frios (frias). É possível que um destes extremos tenham se 
mantido praticamente constante, enquanto que o outro tenha variado (conforme o caso de São Paulo); também é possível que os dois tenham variado e assim alterando os valores da temperatura média; por fim existe, em outros casos não analisados aqui, a chance de os dois variarem proporcionalmente de modo que não seja percebida alteração alguma nos valores da temperatura média. Enfim, várias combinações podem ocorrer.

Observando as normais de temperatura mínima na Tabela 3 (pg. 133), verifica-se na média anual que para o período de 1931-1960 o valor de $14,8^{\circ} \mathrm{C}$ e $15,4^{\circ} \mathrm{C}$ para o período posterior $\left(0,6^{\circ} \mathrm{C}\right.$ de diferença). Ou seja, as noites (onde ocorrem as temperaturas mínimas) se tornaram mais quentes. Para que a temperatura média tenha caído tanto, só uma inferência pode ser deduzida: a diminuição dos valores das temperaturas máximas deve ter sido ainda maior. O que, de fato, aconteceu. O valor anual da normal do primeiro período foi de $26,5^{\circ} \mathrm{C}$; já no segundo, foi de $22,9^{\circ} \mathrm{C}$, significando uma diferença de $3,6^{\circ} \mathrm{C}$. Esta mudança induz a uma inquietação de difícil compreensão dos fatores que teriam levado a essa brusca discrepância. Fica em evidência, ao reparar a Figura 46-AFR, que os dias se tornaram bem menos quentes (ou mais frios). Relativamente, na Figura 46-B-FR, as noites ficaram mais quentes (ou menos frias). A Figura 46-C-FR exibe a compilação de todas as temperaturas (máxima, média e mínima), denotando a redução da temperatura média compelida pela queda dos valores de temperatura máxima.

Além da probabilidade destas mudanças serem devido à variabilidade natural do clima, outros possíveis fatores relacionados às práticas de observação podem ter influenciado nestes valores. Iniciando que a primeira dificuldade nos registros das variáveis climáticas é a própria realização da medição, anotação, armazenamento e tratamento dos dados. Ou seja, a disponibilidade de dados é essencial, embora seja comum verificar a ausência de dados em boa parte da superfície terrestre. Por exemplo, tomando o Estado de São Paulo - o mais desenvolvido economicamente e, de um modo geral, tendo à disposição uma infraestrutura de excelência nacional nas diferentes áreas - com mais de 600 municípios hoje, apenas 6 apresentaram normais climatológicas na primeira publicação de 1969 e somente 9 municípios na publicação de 1972. Ou seja, menos de 1\% dos municípios do Estado de São Paulo tiveram dados suficientes, de pelo menos ao longo de 30 anos, que permitiram a composição das normais. 
Mesmo com a coleta periódica de dados climáticos, qualquer local que realiza medições está sujeito à ocorrência de falhas em suas séries. A primeira publicação das normais apresenta tabelas com os períodos das estações com dados completos, falhos e ausentes. Na segunda publicação, não existe este tipo de informação.

Apresentado o primeiro problema de disponibilidade de dados, e uma vez sanado este fator, o segundo aspecto refere-se ao registro dos procedimentos adotados na coleta dos dados, tais como:

1. Quais os métodos e cálculos de médias foram adotados.

2. Quais os instrumentos utilizados; e

3. Qual a localização da estação e dos instrumentos;

Ao longo do tempo, conforme apresentado no item "5.1. Cálculo da temperatura média diária", pg. 118, diferentes fórmulas têm sido utilizadas para se determinar a temperatura média diária. O segundo fator diz respeito às mudanças dos instrumentos conforme as tecnologias de medições vão se aprimorando. Uma das grandes mudanças verificadas foi a transição do uso de instrumentos convencionais de medição de temperatura (termômetros e termógrafos, com base em princípios físicos de dilatação de materiais) para o uso dos instrumentos automáticos (com base em princípios elétricos e digitais). Associadas a esta mudança, também estão relacionadas mudanças nos abrigos meteorológicos utilizados na proteção dos sensores de temperatura, que sofreram alterações nas dimensões e nos materiais utilizados em sua fabricação. E no caso da localização das estações, é comum que elas sejam movidas de local devido alguma necessidade circunstancial, e assim, com a alteração de sua localização e também das propriedades microclimáticas específicas, uma descontinuidade pode ser inserida na série histórica. Logo, a realocação, substituição ou calibração de um instrumento pode levar a uma mudança brusca, ou descontinuidade, não relacionada a qualquer mudança real no clima.

São muito raros os registros das condições e metodologias adotadas nas medições climatológicas em geral. Dos três principais fatores envolvidos, esperase que na confecção das normais tenham sido tomados, pelos responsáveis, os 
cuidados para evitar uma influência e erros indesejáveis, que pudessem comprometer a representatividade e homogeneidade dos dados.

Em relação aos cálculos adotados, esta etapa não é de grande dificuldade prática. Está relacionado aos horários e à quantidade de medições realizadas ao longo do dia. Pelo observado nas publicações das normais, os valores diários foram obtidos por duas diferentes médias ponderadas dos valores máximos, mínimos e valores obtidos em diferentes horários, conforme as fórmulas apresentadas a seguir:

Normais 1931-1960

até 1937

$$
T=\frac{1}{4}\left(T_{7}+T_{14}+T_{21}\right)
$$

a partir de $1938 \quad T=\frac{1}{5}\left(T_{9}+2 T_{21}+T_{M}+T_{m}\right)$

Normais 1961-1990

$$
T=\frac{1}{5}\left(T_{9}+2 T_{21}+T_{M}+T_{m}\right)
$$

Os índices indicam as horas das observações no horário local. As vezes os índices são exibidos no formato TMG (Tempo Médio de Greenwich), em que 12, 18 e 24 horas TMG correspondem, no fuso horário de Brasília, a 9, 15 e 21 horas do horário local. Segundo Dall'amico e Hornsteiner (2006), a primeira fórmula é conhecida como método de Kaemtz, que historicamente tem sido utilizado amplamente na Europa central. Ela também é conhecida como o método da hora-de-Mannheim, método estabelecido pela Sociedade de Meteorologia baseada em Mannheim, Alemanha, onde uma rede meteorológica pioneira foi estabelecida no século 18 .

Portanto, as normais de temperatura média diária apresentam no primeiro período um marco de mudanças em 1937-1938, com alterações nos horários de realização das leituras e respectivas fórmulas de cálculo das médias diárias, que podem representam alguma alteração e descontinuidade nas séries. De qualquer forma, acredita-se que este fator, a princípio, não teria sido responsável pela discrepância dos valores observados no caso da cidade de Franca. Não tendo disponíveis os dados primários, não é possível fazer a verificação desta influência nestas séries em estudo. Porém, mais adiante neste trabalho (CAPÍTULO 4 - Mudanças dos Horários de Observações e dos Cálculos de Médias, pg. 159), será apresentada uma análise de algumas séries históricas de temperaturas obtidas na Estação Climatológica do Centro de 
Recursos Hídricos e Ecologia Aplicada, da Escola de Engenharia de São Carlos, Universidade de São Paulo (CRHEA/EESC/USP).

Já em relação aos instrumentos utilizados, com base nos valores disponíveis e horários acima destacados nas fórmulas adotadas, infere-se que as estações possuíam no mínimo termômetros de máxima e de mínima, além de outro convencional; ou então possuíam apenas um termógrafo, capaz de registrar todos os valores diários continuamente. Neste caso seriam apenas especulações quaisquer afirmações a respeito de quais instrumentos foram utilizados para a medição da temperatura do ar. Fica desta maneira, assumida a hipótese de que os instrumentos sempre foram os mesmos em todo o período, e que eles estavam sempre calibrados e em boas condições de uso. Supõe-se também as leituras dos instrumentos e registros realizados adequadamente pelo observador responsável, com erros negligenciáveis ao longo de toda série. Neste trabalho, também são avaliados os efeitos nas séries de temperatura decorrentes das mudanças dos instrumentos (CAPÍTULO 5 - Mudanças dos Instrumentos, pg. 219) e dos abrigos (CAPÍTULO 6 - Mudanças dos Abrigos, pg. 237).

E por fim, em relação à localização, é possível que o local da estação tenha sido alterado uma vez ou mais durante o período de coleta de dados. Este é um fato comum, mas raramente documentado. Felizmente, este tipo de informação está apresentado nas duas publicações das normais. Para o caso de Franca, a estação está localizada nas coordenadas geográficas Lat. $22^{\circ} 33^{\prime} \mathrm{S}$, Long. $47^{\circ} 26^{\prime} \mathrm{W}$ nas normais do primeiro período, e Lat. $20^{\circ} 33^{\prime} \mathrm{S}$, Long. $47^{\circ} 26^{\prime}$ W. Verifica-se uma incoerência nos valores da latitude, com uma diferença de $2^{\circ}$. Após verificação, o segundo valor é o correto (o valor escrito errado, provavelmente por erro de digitação, está localizado em Limeira). Neste caso, supondo que a segunda publicação não teria simplesmente copiado o valor da primeira publicação, assume-se que a estação não sofreu mudança de posição, em termos de deslocamento no plano horizontal das coordenadas, ao longo dos períodos em questão. No entanto, deve-se atentar para os valores das coordenadas, que não possuem nenhum valor na casa dos segundos. Tendo a incerteza na casa dos minutos, e considerando que cada segundo pode representar até $30 \mathrm{~m}$ de distância na projeção com sistemas de coordenadas geográfica, um minuto (ou $60 \mathrm{~s}$ ) pode representar até $1.800 \mathrm{~m}$ de distância. Ou seja, a estação pode ter sido deslocada fisicamente no plano horizontal em até 
quase $2 \mathrm{~km}$, e isso não teria mudado o valor de sua posição nas coordenadas geográficas com precisão na casa dos minutos.

Já em relação à posição vertical, ou seja, a altitude em que se encontrava a estação, percebe-se que na primeira publicação ela se encontrava a $1.035 \mathrm{~m}$; já na segunda publicação, 1.026,2 m, implicando em uma diferença de quase $10 \mathrm{~m}$. Mesmo com essa alteração, não é possível estabelecer com um grau de certeza satisfatório o que teria, de fato, acontecido: ou a estação mudou de altitude e/ou lugar; ou não houve alteração real da localização física dela, mas a partir de novas medições, com o uso de técnicas e equipamentos mais precisos e modernos, o valor da altitude foi atualizado com base em uma nova medição ou determinação.

Portanto, embora exista um valor da localização da estação de Franca e sua altitude, não é possível determinar se houve ou não alguma mudança do local em que foram coletados os dados, ao longo de todo o período, e depois utilizados na composição das normais em questão. Pior ainda seria se não houvesse divergência entre os valores, isto é, se eles fossem idênticos em tudo - e até mesmo com os valores das coordenadas apresentando precisão na ordem dos segundos - e tivesse ocorrido uma mudança real da localização da estação, mas sem a anotação e menção deste fato nos registros. Isto seria um erro grave por parte dos responsáveis pela operação e manutenção da estação e daqueles que manipularam os dados nela coletados e registrados. Esta falha seria propagada aos usuários dos dados publicados, que também teriam, porém em grau bem mais reduzido, uma certa responsabilidade em não conferir a origem e qualidade dos dados primários. Para estes usuários, serve de justificativa plausível a dificuldade em se estabelecer ou recuperar informações sobre as condições exatas da estação há mais de décadas atrás.

Com as vantagens do uso de tecnologias atuais, proporcionadas, de um modo geral, pelo avanço nas áreas de microinformática e eletrônica, é simples consultar mapas e imagens aéreas disponíveis em formato digital na Internet. Tais mapas e fotografias, obtidas por sensoriamento remoto realizado por satélites, permitem a visualização de praticamente todas as regiões na superfície terrestre, com uma imagem de boa resolução espacial e relativa qualidade no georreferenciamento. Embora não recomendável em estudos científicos, esta ferramenta foi utilizada de forma improvisada, garantindo uma análise expedita e provisória, porém indicativa e com resultado aceitável perante a necessidade. 
Feitas as ressalvas e aproveitando esta facilidade, bastou conferir a posição indicada nas normais nos mapas disponíveis. Durante a busca da posição, encontrou-se no sítio eletrônico ${ }^{23}$ do Instituto Nacional de Meteorologia (INMET) uma relação das estações convencionais que compõem a rede nacional de medições. Ao selecionar o município de Franca, alguns outros detalhes interessantes foram exibidos (vide Figura 47). A altitude apresentada é a mesma da normal de 1960-1991, com 1026,2 m; a posição geográfica difere um pouco das normais, tendo os valores de Lat. 20³4'48' S e Long. 47²2'12" W (valores convertidos; no gráfico os valores estão em graus somente). Ainda, nota-se que a estação está em operação desde 1911.

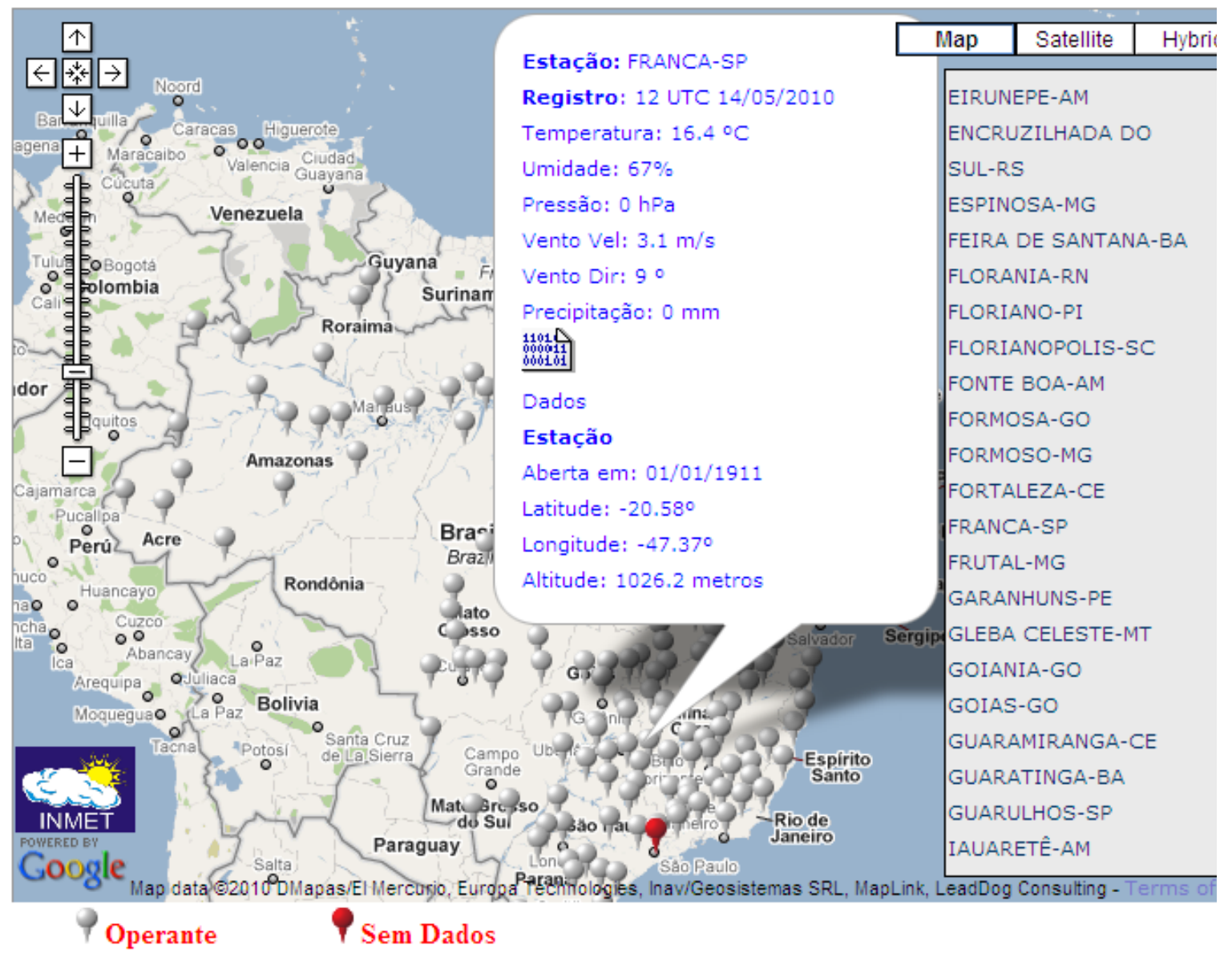

Figura 47 - Dados e localização da estação meteorológica de Franca/SP no sítio eletrônico do INMET. Fonte: INMET (2010).

${ }^{23}$ Endereço eletrônico: <http://www.inmet.gov.br/>. Acesso em 14 ago. 2010. 
Ampliando o mapa e mudando o tipo exibição, foi possível determinar o local em que, teoricamente, a estação se encontra. Observa-se a seguir na Figura 48 que a estação se encontra em um bairro aparentemente residencial, com padrão de ocupação por edificações térreas. Este fato trás à tona a questão já levantada anteriormente: pode ser que a estação nunca tenha sido deslocado ou removida de seu lugar inicial, porém as mudanças no uso e ocupação na região circundante ao local do instrumento alteram as propriedades das superfícies irradiantes além do microclima em termos dos regimes de ventos. Assim, o balanço de radiação e as trocas térmicas modificados no local de realização das leituras podem alterar os valores que serão lidos nos instrumentos sensores de temperatura.

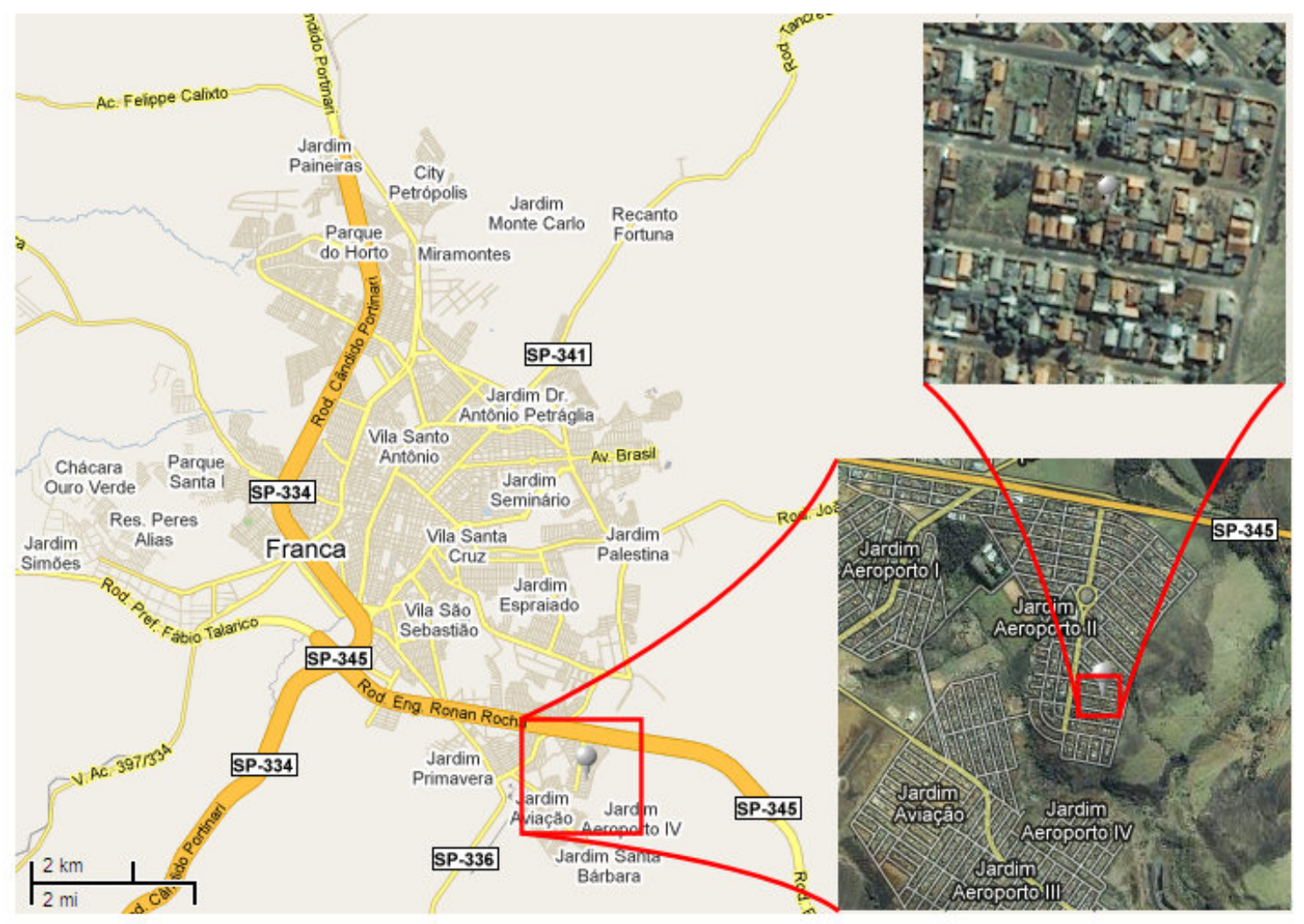

Figura 48 - Possível localização da estação meteorológica do INMET na cidade de Franca/SP. Fonte: composição de imagens a partir de Google (2010).

Deve-se considerar, portanto, como fator determinante de provável indução de uma descontinuidade, o momento em que o local de medição deixou de ser uma área rural para se tornar uma área urbana. Verificar a evolução da 
expansão urbana, neste caso, permitiria verificar nas séries alguma heterogeneidade e correlação perceptível. A expansão urbana em Franca está bem documentada no trabalho de Chiquito (2006), no qual é apontado que o bairro Jardim Aeroporto - possível local em que se encontra a estação - teve seu loteamento aprovado no final da década de 70 , e o as obras de infraestrutura foram iniciadas na década de 80 .

Retomando o motivo desta investigação minuciosa que conduziu às análises anteriores, permanece a dúvida das causas na queda relativamente brusca nos valores das temperaturas máximas e médias das normais comparadas. Mesmo que em uma cidade pequena, a formação de ilhas de calor induziria, com menor magnitude, ao aumento da temperatura do ar. Tornar-seia contraditória a redução da temperatura se fosse tentar correlacionar com a expansão urbana e a mudança das características do solo no local das medições. Os possíveis motivos, porém de determinação incerta, seriam os já citados: ou este fenômeno foi uma ocorrência de origem natural, ligado à variabilidade inerente do clima; ou foi devido a alguma descontinuidade decorrente das mudanças dos métodos de cálculos, dos instrumentos utilizados, ou das condições microclimáticas alteradas pela alteração do uso e ocupação dos solos. Além de realizar um levantamento histórico detalhado, somente uma visita ao local de medição e o acesso às séries originais poderiam dirimir estas dúvidas.

A propósito, em relação ao uso do solo e da influência da formação de ilhas de calor urbana, torna-se oportuna a análise deste fator no caso da cidade de São Paulo, sujeita a ocorrência de ilhas de calor de alta magnitude devido à alta densidade de edificações e ruas em sua malha urbana.

Consultando novamente o sítio eletrônico do INMET com a relação das estações convencionais, são constatadas duas estações em São Paulo: estação do IAG (Instituto Astronômico, Geofísico e de Ciências Atmosféricas da USP), em funcionamento desde 1933; e a estação do Mirante de Santana, observatório inaugurado na Praça Vaz Guaçu em 1929, com início de medições meteorológicas em 1945. Distinguir de qual delas foram utilizados os dados só é possível ao comparar a localização e/ou altitude de cada uma. Feita esta análise, verificou-se que a altitude da estação do Mirante de Santana coincide exatamente com o valor $(792,06 \mathrm{~m})$ apresentado nas duas normais. Localizada na Zona Norte, próximo ao Aeroporto Campo de Marte, esta é principal estação 
do INMET na cidade. As coordenadas geográficas indicadas nos normais apresentam os mesmo valores de Lat. $23^{\circ} 30^{\prime} \mathrm{S}$ e Long. $46^{\circ} 37^{\prime} \mathrm{W}$, concordando exatamente com os valores apresentados nas informações da estação no sítio eletrônico do INMET. Entretanto, ao ampliar a visualização do mapa, foi notado que a localização indicada no mapa não estava apontando à localização real da estação no Mirante, representando um deslocamento de aproximadamente $0,5 \mathrm{~km}$. Logo, duas explicações são possíveis: ou o valor da coordenada geográfica está incorreto (ou insuficientemente com pouca precisão, pois não apresenta os segundos da coordenadas), ou o mapa não está corretamente georreferenciado. Supõe-se que o segundo caso seja a razão do erro, uma vez que é razoável esperar que estes tipos de visualizações não possuem uma precisão compatível com o rigor científico necessário, pois o públicos alvos são distintos. Esse erro remete ao caso de Franca. Se fosse considerado que o deslocamento ocorrido em São Paulo fosse o mesmo em Franca, logo poderia ser assumido que a estação estaria localizada, na verdade, em um fragmento de área florestal (canto superior esquerdo da primeira ampliação da Figura 47). Porém, mais uma vez, essa consideração se torna apenas uma suposição sem muito embasamento, sendo ideal a conferência in situ da real localização e situação da estação. No caso da estação de São Paulo, sua localização foi determinada com sucesso devido ela estar em um Mirante, ponto de referência facilmente identificado.

Não tendo havido mudança de local da estação no Mirante de Santana, o caso de São Paulo ilustra que as mudanças que ocorreram nas proximidades do local onde são realizadas as medições de temperatura podem ser um fator determinante de influência nos valores registrados. Mudanças do uso e ocupação do solo são evidenciadas pela urbanização e avanço da malha urbana, além do aumento da densidade das edificações e das vias asfaltadas. A evolução da expansão da área urbanizada da Região Metropolitana de São Paulo é apresentada na Figura 49. Nela pode-se notar que a estação está localizada em uma região que teve sua expansão, ao Sul, no período de 1882 a 1929. No entorno, a urbanização se procedeu no período de 1929 a 1949. E mais especificamente nas proximidades e na localidade da estação, a ocupação foi dada entre 1950 e 1960. Deste modo, poderia ser estabelecida a hipótese de que o período das normais de 1961-1990 não teria sido influenciado pela ocupação já estabelecida anteriormente. Porém, é fato que o padrão de ocupação vai se 
alterando com o tempo, ocorrendo em grandes metrópoles a substituição gradual de edificações residenciais térreas por edificações prediais. Logo, a concentração de uma massa densa de novos materiais (asfalto, concreto) com desempenhos térmicos diferenciados da situação pretérita, poderia ser um fator contribuinte e, talvez, determinante na incorporação de uma tendência de aquecimento na série histórica de temperatura do ar nesta estação.

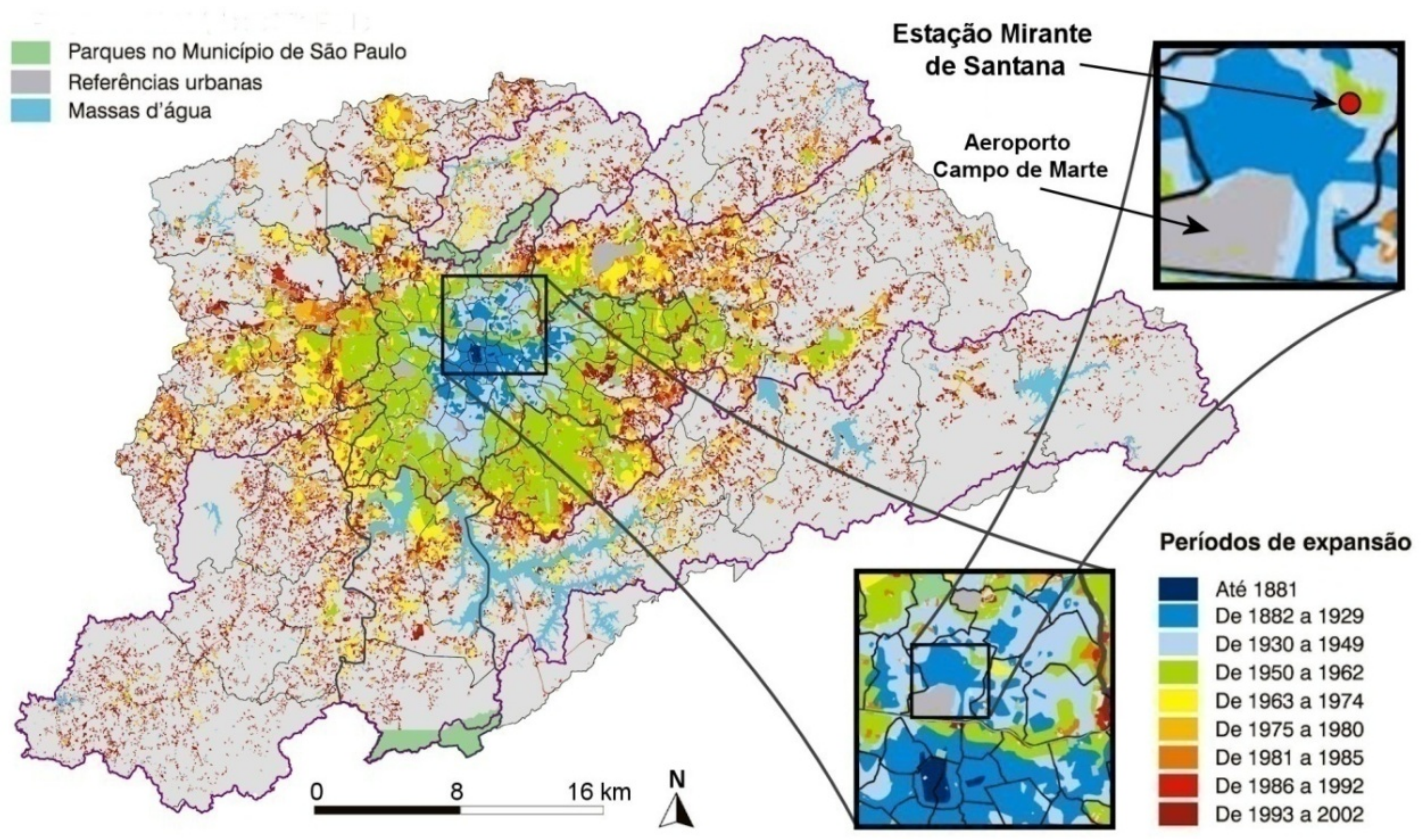

Figura 49 - Área urbanizada, segundo períodos de expansão, da Região Metropolitana de São Paulo com recortes ampliados da localização da estação meteorológica do INMET em São Paulo. Fonte: modificado de EMPLASA (2003).

Deve ficar claro, acima de tudo, que este aquecimento presente nos valores de temperatura não é, necessariamente, devido a um aquecimento em escala global, mas pode ser devido ao aquecimento do microclima local decorrente das alterações no uso e ocupação do solo e dos efeitos da ilha de calor urbana. Portanto, a extrapolação a partir de uma série local para uma escala global deve ser feita com bastante prudência e cautela. São duas escalas espaciais diferentes em questão, e que nem sempre uma é representativa e fiel à outra. Conforme já apresentado (na Figura 37, pg. 97), as diferentes regiões apresentam padrões diversos no comportamento da temperatura, inclusive ocorrendo até resfriamento em determinados locais. A distinção de aquecimento provocado pela urbanização ou pelas variações climáticas globais seria possível 
em uma situação de comparação de duas estações relativamente perto uma da outra. Inicialmente as duas estariam situadas na área rural e, ao passar o tempo, com crescimento da cidade, uma delas teria sido englobada pela urbanização. Logo, tendo disponíveis duas séries, uma estritamente rural e outra sob efeitos das mudanças de ocupação urbana, seria simples a determinação da diferença observada na série da estação sob interferência urbana. Fica, no entanto, a dificuldade de encontrar no Brasil a disponibilidade de duas estações próximas, na mesma cidade, com uma série suficiente de dados, e, ainda, na situação de uma ter sido englobada pela cidade e a outra não.

Finalizando esta primeira análise das mudanças climáticas e tendências locais, tendo o período médio de 30 anos das normais como a escala temporal adotada, salienta-se que cada local possui situações específicas. Além dos casos detalhadamente caracterizados da cidade de Franca e de São Paulo, é fundamental analisar as demais cidades disponíveis, caso a caso. Cada região possui suas peculiaridades locais, onde diversas situações poderiam interferir na medição da temperatura do ar e incorporar tendências não-climáticas às séries. Em suma, os três fatores principais seriam: mudanças nas práticas de observação, com uso de diferentes métodos e fórmulas nos cálculos das temperaturas médias diárias, incluindo os respectivos e distintos horários de leitura adotados; mudanças dos instrumentos sensores de temperatura e seu respectivo abrigo; e mudanças no local da medição, seja devido a alguma alteração da localização da estação e/ou modificação do uso e ocupação dos solos no entorno da estação.

\subsubsection{Caso de São Carlos}

A cidade de São Carlos não foi contemplada na publicação das normais do período referente a 1931-1960. Desta maneira, o estudo das séries de temperatura coletadas em São Carlos é baseado em duas publicações: as normais climatológicas do período de 1961-1990 (BRASIL, 1992) e o "Estudo Crítico sobre o Clima da Região de São Carlos", de Tolentino (1967), com o período de dados apreciado de 1939-1960, cujo autor afirma ser uma quantidade de anos de observações "dignas de toda confiança" em relação ao estabelecimento de normais climatológicas - neste caso, trata-se de uma normal provisória. 
Antes de proceder às análises, é importante advertir que o trabalho de Tolentino (1967) utilizou uma fórmula diferente de cálculo das temperaturas médias diárias, que na época era "recomendação dos tratadistas":

$$
T=\frac{1}{4}\left(t_{9}+t_{15}+2 t_{21}\right)
$$

A utilização de um método diferente das normais climatológicas brasileiras pode induzir a tendências não-climáticas (heterogeneidades) nos valores de temperatura. Feita a ressalva, cabe comparar e verificar as diferenças entre os valores médios de cada trabalho. Esta análise é apresentada pela Tabela 5 e respectiva representação gráfica destes valores na Figura 50. Observando as curvas das temperaturas médias, máximas e mínimas, nota-se uma discrepância bastante evidente. Na média anual: a temperatura média no período 1939-1960 é $1,6^{\circ} \mathrm{C}$ maior que a do período posterior; a temperatura máxima média de 19391960 é 5,8 $8^{\circ} \mathrm{C}$ maior que a de 1961-1990; e a temperatura mínima média de 19391960 é 4,9 ${ }^{\circ} \mathrm{C}$ menor em relação ao período 1961-1990. Ou seja, a amplitude de variação da temperatura é imensamente maior no primeiro período, que na média anual é de $20,8^{\circ} \mathrm{C}$, sendo que no segundo período a amplitude é a metade desse valor $\left(10,1^{\circ} \mathrm{C}\right)$.

Tabela 5 - Normais das temperaturas médias, máximas e mínimas da cidade de São Carlos, para os períodos de 1939-1960 e 1961-1990.

\begin{tabular}{ccccccccccccccc}
\hline \hline Periodo & Temp. & JAN & FEV & MAR & ABR & MAI & JUN & JUL & AGO & SET & OUT & NOV & DEZ & ANO \\
\hline \multirow{3}{*}{ 1939-1960 } & $T$ & 23,1 & 23,0 & 22,7 & 21,3 & 19,4 & 18,1 & 18,4 & 20,6 & 21,6 & 22,4 & 22,3 & 22,7 & 21,3 \\
\cline { 2 - 13 } & $T_{M}$ & 32,2 & 31,7 & 31,2 & 29,9 & 28,3 & 27,1 & 28,0 & 30,8 & 32,4 & 33,4 & 32,4 & 32,5 & 30,8 \\
\cline { 2 - 13 } & $T_{m}$ & 13,8 & 14,3 & 13,7 & 10,0 & 7,7 & 6,2 & 6,1 & 7,2 & 7,7 & 9,5 & 11,3 & 12,9 & 10,0 \\
\cline { 2 - 13 } & $T$ & 21,6 & 21,9 & 21,7 & 20,2 & 18,1 & 16,7 & 16,0 & 17,8 & 19,6 & 19,7 & 21,1 & 21,4 & 19,7 \\
\cline { 2 - 12 } 1961-1990 & $T_{M}$ & 26,8 & 27,2 & 27,0 & 25,7 & 23,6 & 22,7 & 22,1 & 24,2 & 25,0 & 24,7 & 25,7 & 25,2 & 25,0 \\
& $T_{m}$ & 17,5 & 17,7 & 17,2 & 15,5 & 13,2 & 12,0 & 11,4 & 12,5 & 14,2 & 14,7 & 16,0 & 17,2 & 14,9 \\
\hline
\end{tabular}

$T, T_{M}$ e $T_{m}=$ Temperaturas média, máxima e mínima, respectivamente.

Fonte: Tolentino (1967) e Brasil (1992). 


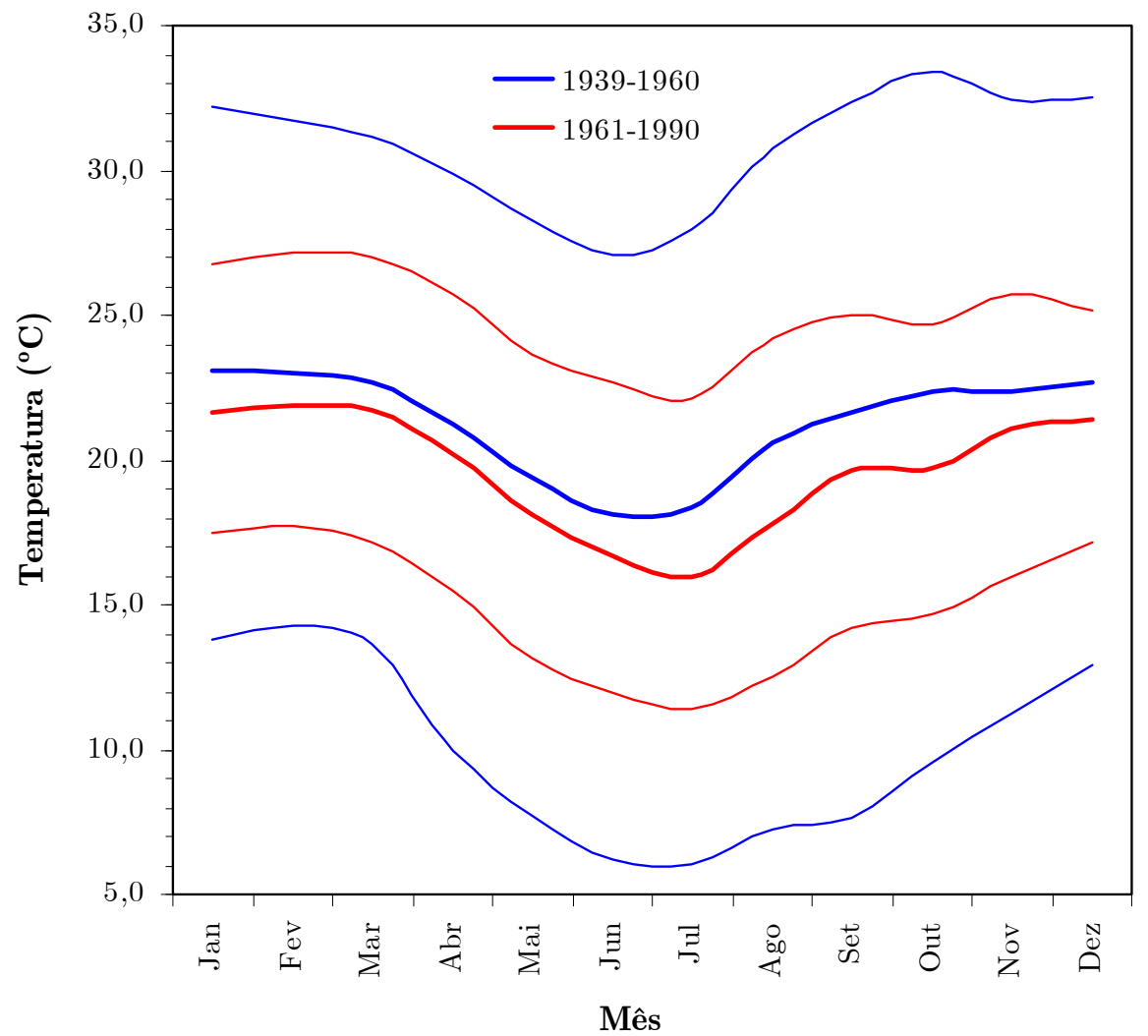

Figura 50 - Síntese das normais climatológicas das temperaturas média, máxima e mínima nos períodos de 1939-1960 (curvas em azul) e 1961-1990 (curvas em vermelho) da cidade de São Carlos/SP. As curvas mais grossas representam os valores médios e as curvas mais finas denotam os valores máximos (linhas superiores) e mínimos (linhas inferiores). Fonte: elaborada com dados de Tolentino (1967) e Brasil (1992).

As diferenças encontradas entre as temperaturas dos dois períodos não poderiam ser explicadas somente e exclusivamente pelas distintas fórmulas utilizadas. Conforme já elencados anteriormente, outros fatores podem induzir a diferenças nas séries, tais como mudanças dos instrumentos utilizados e mudanças na localização da estação. No caso dos instrumentos, existe a informação em Tolentino (1967) de que o termômetro utilizado era da marca Fuess, contudo não foi indicado qual o líquido de expansão; provavelmente tenha sido um termômetro de mercúrio. Já nas normais climatológicas oficiais publicadas em 1992, a informação do instrumento não está disponível. De qualquer forma, as mudanças dos instrumentos também não seriam suficientes para explicar as enormes diferenças encontradas.

A explicação das disparidades reside na mudança da localização da estação. Analisando este aspecto, constatou-se que as séries são provenientes de lugares diferentes da cidade. Com base nos registros históricos, a estação de 
prefixo "83726" teve 3 localizações em São Carlos $^{24}$. De acordo com Tolentino (1967), a primeira localização desta estação, com funcionamento desde 1901, era na Rua Marechal Deodoro, na altura Rua Campos Salles (ponto 1 da Figura 51, altitude não especificada). O segundo local da estação, sem especificação da data de início da coleta de dados, situava-se no norte da cidade, ao lado do Cemitério Nossa Senhora do Carmo (ponto 2 da Figura 51, altitude não especificada), local que possuía um arquivo de dados razoavelmente bons a partir de 1939, utilizados por Tolentino (1967). E sobre o terceiro local, existem três possibilidades: a localização dada pelas normais climatológicas de 1992 (ponto provavelmente com valor errado, pois está fora do Município de São Carlos Lat. $22^{\circ} 0$ '36" S, Long. $47^{\circ} 31^{\prime} 48^{\prime \prime} \mathrm{W}$, altitude de $856 \mathrm{~m}$ ) e as localizações das estações convencional e automática disponíveis no sítio eletrônico do INMET

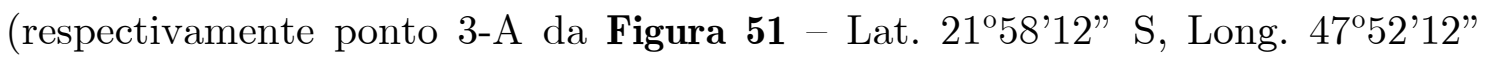
W, 856 m de altitude; e ponto 3-B da Figura 51 - Lat. 2158'48" S, Long. 47 53'1" W, $863 \mathrm{~m}$ de altitude). Na hipótese de estarem errados os valores das coordenadas geográficas da estação convencional, mostrou-se a localização da estação automática, supondo que as duas estações estejam funcionando no mesmo lugar.

Distantes em no máximo $10 \mathrm{~km}$ de cada um, todos os locais da estação estão situados na mesma cidade. Mesmo assim, as séries são representativas para o microclima local das medições, e por esta razão, apresentaram valores tão distintos uns dos outros durante o ano todo. Outro fator que influencia nas condições microclimáticas é a mudança do uso do solo, causada especialmente pela expansão urbana da cidade. Há décadas atrás o ponto 2 da Figura 51 já pode ter estado em uma área com condições tipicamente rurais, com predominância de vegetação. O local deste mesmo ponto sofreu modificações que implicaram, hoje, em um ambiente com características urbanas, com a presença de asfalto e concreto.

\footnotetext{
24 A cada mudança do local da estação, deveria-se ter a série encerrada para dar início a uma nova série, com prefixo ou designação diferente da precedente. Em nenhuma publicação consultada foi declarada explicitamente qualquer informação sobre as alterações dos locais da estação, fato que deveria estar especificado no metadado das séries históricas. Sem a análise e comparação aqui realizada da localização específica de cada série, poderia ocorrer uma falha por desatenção caso fosse assumido que os dados das três séries haviam sido coletados em um mesmo local.
} 


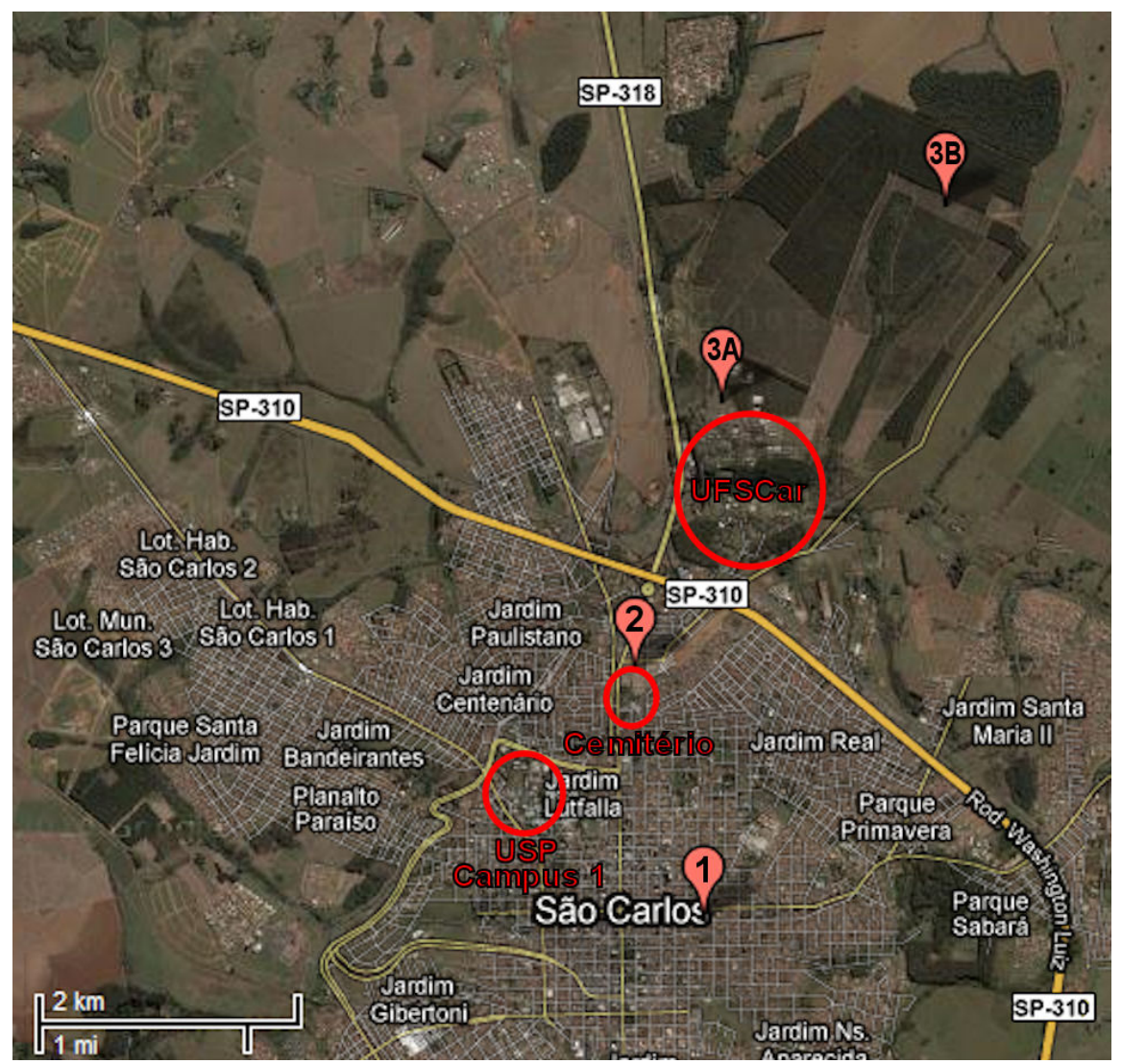

Figura 51 - Locais em que a estação meteorológica do INMET pode ter realizado medições na cidade de São Carlos. Ponto 1: dados coletados desde 1901; Ponto 2: série de dados confiáveis a partir de 1937; Pontos 3-A e 3-B: prováveis pontos da localização atual da estação. Fonte: elaborada com imagem de Google (2010).

Enfim, o caso das séries de temperatura obtidas em diferentes locais, relativamente próximos, na cidade de São Carlos ilustra a magnitude da influência que heterogeneidades exercem nos valores registrados. Uma vez havendo qualquer tipo de mudança, seja dos instrumentos, do local das medições, do cálculo das médias ou das condições do entorno, fica extremamente complicado identificar e remover as heterogeneidades. A série cujos valores assimilaram tais influências indesejáveis não é confiável e suficientemente adequada nas análises de alterações e mudanças climáticas. Não que a existência de heterogeneidades significa que todas as diferenças entre os períodos comparados sejam devidos somente às mudanças de técnicas e métodos de observação. O clima continua mantendo seu comportamento mutável de acordo com sua variabilidade natural. Porém, o discernimento de quanto cada parcela da mudança é devido a fatores climáticos ou não-climáticos se torna uma tarefa difícil e desafiadora. Mesmo com possíveis correções, sujeitas a inúmeros fatores 
de subjetividade, as séries sempre terão incorporados erros e incertezas. Portanto, a disponibilidade de séries com a qualidade necessária é crucial nos estudos das mudanças climáticas. Antes mesmo de discutir atribuições humanas e naturais nas variações da temperatura do ar, deve-se priorizar a atenção ao método de obtenção desta variável climática, para que as séries sejam fielmente representativas das condições do clima, sem a influência de fatores nãoclimáticos.

Levando-se em consideração a ocorrência de heterogeneidades, não é possível determinar e concluir, pelas séries analisadas, se o clima de São Carlos está esquentando ou esfriando. Tomando o valor da temperatura média e supondo que as heterogeneidades não estão presentes, poderia-se dizer que o clima ficou $1,6^{\circ} \mathrm{C}$ mais frio no período de 1961-1990 em relação ao período anterior (1939-1960). Mas esta inferência não deve ser assumida em hipótese alguma, uma vez que a mudança do local da estação proporcionou mudanças no microclima das medições, e, portanto, estas séries não devem ser consideradas compatíveis e homogêneas.

\subsection{Considerações finais}

As series históricas representam a base dos estudos das variações climáticas no passado. Sua representatividade depende primeiramente da disponibilidade do registro, que muitas vezes estão sujeitos a falhas nos dados. Uma vez superada a dificuldade da deficiência de observação, outros fatores introduzem incertezas e erros naqueles valores de observações realizadas: alterações no horário de observação; mudanças de lugar da estação; alterações do instrumento; e as alterações das condições circundantes ao local do instrumento.

Em relação à temperatura, cada região apresenta um comportamento: aquecimento, resfriamento, ou um estado relativamente constante. Portanto, a escala temporal e espacial - conforme visto em "4.4.1.1. Escala de abordagem temporal", pg. 89, e "4.4.1.2 Escala de abordagem espacial", pg. 95, respectivamente - é um critério importante na caracterização do clima local e global. A elaboração de normais e composição de séries históricas globais depende exclusivamente de quais séries locais estão sendo utilizadas no cômputo 
da média final. As séries locais compõem as séries regionais, que por sua vez compõem séries nacionais, e assim por diante até a composição de uma série global.

Neste contexto que se insere as análises das séries das cidades de São Paulo, Franca e São Carlos. A investigação das mudanças observadas nas normais da temperatura média do ar de dois períodos padronizados de São Paulo e Franca indicou aquecimento e resfriamento, respectivamente, nas duas cidades analisadas. São Carlos sofreu resfriamento, porém não é possível determinar se houve de fato uma alteração climática e qual a sua magnitude, já que as diferenças discrepantes nitidamente decorreram da alteração da localização da estação.

No caso de São Paulo, a tendência de aquecimento não significa, necessariamente, que os períodos diurnos estão ficando mais quentes. Na verdade, em São Paulo os valores das temperaturas mínimas médias aumentaram, ou seja, as noites que estão ficando menos frias (ou mais quentes). Já em Franca, onde foi observada uma queda severa nos valores da temperatura média, verificou-se que a temperatura máxima média que sofreu uma redução. Tal alteração pode ser devida a mudanças reais do clima local, ou, ainda, a mudanças artificiais causadas por heterogeneidades não-climáticas, oriundas de fatores como, suspeita-se, a mudança da localização da estação.

Portanto, os resultados permitem concluir que os valores médios dependem intrinsecamente dos valores máximos e mínimos. Nenhum deles representa, isoladamente, um indicativo plenamente fiel e representativo de tendências de mudanças climáticas. As temperaturas médias devem ser analisadas em conjunto com as temperaturas máximas e mínimas, de modo a proporcionar análises mais apropriadas e abrangentes de alterações climáticas. $\mathrm{O}$ caso de São Paulo incita à reflexão: o aquecimento global médio, dado em termos de temperatura média, seria decorrente do aumento das temperaturas máximas ou mínimas, ou ambas?

Das análises das três cidades conclui-se também que cada local possui suas peculiaridades. Logo, são fundamentais estudos complementares que analisem as tendências locais do clima em outras cidades e regiões, uma vez que séries globais são compostas a partir de séries locais. Fica a indagação: Como poderia um valor médio global representar as especificidades locais, em que 
algumas localidades apresentam tendências de aquecimento e outras deparam com resfriamento?

A escolha correta, imparcial e livre de interesses escusos das séries locais é crucial na elaboração de séries globais. Logo, é comum a apresentação de séries globais em que o aquecimento é evidentemente súbito, dando a impressão de que em todas as regiões do globo estão enfrentando aquecimento. A escolha minuciosa e tendenciosa é uma prática cada vez mais frequente no contexto científico, de forma que a manipulação de dados tem visado à manutenção da defesa de um posicionamento frente às atribuições das alterações climáticas e, especialmente, do grau de contribuição humana nesse processo natural em constante mudança. Da mesma forma, é possível que outros pesquisadores, com opiniões opostas e divergentes das convencionalmente divulgadas de aquecimento, possam excluir intencionalmente as séries que apresentam aumento nos valores de temperatura e selecionar somente aquelas que exibem queda nos valores.

O mais sensato seria imaginar uma situação ideal em que todas as séries são igualmente ponderadas, de maneira que fossem incluídas tantas as séries com tendência de aquecimento, quanto as com tendência de resfriamento, além daquelas que se mantém relativamente constantes. Porém, é fato que a composição de uma média mundial é uma abstração que simplesmente suprime toda a variabilidade espacial que cada região diferente apresenta intrínseca e especificamente.

Sob a perspectiva da utilização de valores médios, tradicionalmente as normais climatológicas são centradas no valor médio de um elemento do clima ao longo de um período de tempo. WMO (2007) cita autores que argumentam que a média aritmética de um elemento é uma descrição inadequada do clima, e que muitas aplicações necessitam de informações sobre outros aspectos da distribuição de frequência dos elementos, ou outras características do comportamento estatístico do elemento, tais como a frequência de longos períodos quando o seu valor está acima do limiar.

Neste sentido, levanta-se a questão de quais os parâmetros ou distribuições poderiam ser usados para fornecer informações adicionais sobre a distribuição da frequência de um elemento, desde que eles pudessem ser considerados representativos do elemento. Existem algumas tentativas para 
determinar quais as distribuições idealizadas são mais apropriados para os elementos climáticos. Entre as distribuições mais comuns utilizados para este fim existem as distribuições de Gauss (distribuição normal) e as distribuições gama. A abordagem mais comum tem sido a de calcular os parâmetros associados com a distribuição de frequência empiricamente-derivada. Parâmetros comuns utilizados para esse fim incluem o número de dias em que um elemento está acima ou abaixo de determinado nível (por exemplo, o número de dias com temperaturas superiores a $30^{\circ} \mathrm{C}$ ), os valores dos quantis diferentes de um elemento (por exemplo, o $10^{\circ}$ ou $90^{\circ}$ percentil), e os valores extremos de alta e baixa de um elemento durante um período determinado.

Segundo WMO (2007), vários autores têm observado que a média aritmética de uma variável climática é apenas uma descrição parcial de seu comportamento, e uma descrição completa do clima exige a especificação integral da distribuição de frequência. Surge o desafio, portanto, de como maximizar a quantidade de informação que pode ser fornecida, com um número finito de parâmetros numéricos, sobre as propriedades estatísticas de uma variável.

Outro ponto levantado de extrema importância é a representatividade dos dados. Documento da OMM (WMO, 2000) discute esse tema juntamente com a relação das falhas de dados e incertezas associadas às observações do clima. É enfatizada a necessidade de qualidade e homogeneidade de séries, além da disponibilidade de séries longas o suficiente para análises adequadas da variabilidade do clima e dos fatores antrópicos que podem interferir nos registros climáticos. Ainda, alerta que os sistemas de observação e de dados atuais - que a propósito tem sofrido um declínio na sua cobertura de coleta de dados, sejam elas observações em superfície terrestre, marinha ou por radiossondas - são inadequados para uma descrição completa do clima. Praticamente todos os sistemas de monitoramento requerem aprimoramentos na qualidade e continuidade dos dados. Para o caso dos sistemas de radiossondas, por exemplo, são verificadas falhas sérias de dados nos oceanos e no Hemisfério Sul, tornando a avaliação e detecção de mudanças climáticas particularmente difíceis na troposfera e na baixa estratosfera.

Em sua conclusão, em WMO (2000) é reconhecido que "a rede atual de dados não foi projetada adequadamente, ou em sua totalidade, para medir, detectar ou atribuir mudanças climáticas". Consequentemente, esforços enormes 
são necessários para ajustar dados que estão sujeitos a inúmeros fatores influentes e indutores de erros que estão sendo incorporados às séries climáticas. Lacunas de dados em escalas variáveis de tempo e distribuição espacial nos registros históricos causam incertezas significativas que estão começando a serem quantificadas, mas que, no momento, prejudicam no monitoramento de algumas mudanças climáticas regionais. O declínio nas redes de observação é outro fator que contribui no impacto danoso em séries de dados climáticos essenciais (vide apresentado no item "Registros históricos de estações na superfície", pg. 98). Métodos de análises podem melhorar ou estimar as detecções de mudanças no clima e ajudar a quantificar incertezas, porém elas não devem ser substitutas de dados homogêneos, com densidade de distribuição e qualidade adequadas.

Uma vez que maioria das redes instrumental foi criada para monitorar o clima local e não o clima a longo prazo, existem problemas práticos na utilização desses dados para estudar as mudanças climáticas. Por exemplo, os registros frequentemente não estão digitalizados e/ou não estão facilmente disponíveis fora do país em que foram medidos. Uma distribuição desigual de estações de rede introduz erros que têm efeitos significativos sobre as tendências estimadas da temperatura, particularmente na escala regional. Registros instrumentais também frequentemente contêm erros de dados resultantes da coleta e registro de dados. Esses erros reduzem a confiança nas análises. Além disso, os registros instrumentais estão sujeitos a heterogeneidades causadas por diversos fatores, tais como mudanças do local da estação e a introdução de novos termômetros, introduzindo variações não-climáticas nos registros históricos. Em suma, cada uma destes fatores contribui para uma influência embutida no registro histórico que dificulta a deteç̧ão de mudanças climáticas em qualquer escala. (PETERSON; VOSE, 1997).

Sumarizando, deve-se aprimorar as atuais redes de monitoramento responsáveis pela coleta de dados, além de realizar cuidadosas técnicas de controle de qualidade dos dados já existentes. Assim, a representatividade dos dados registrados será cada vez mais fiel às condições climáticas reais quando as falhas de dados e incertezas incorporadas forem gradualmente sanadas nas observações do clima. O efeito dos fatores não-climáticos exige atenção constante, uma vez que eles influenciam nas medições e incorporam sequelas 
adversas nas séries de dados. Todas as séries devem ser submetidas a controles de qualidade capazes de identificar e remover heterogeneidades indesejáveis, a fim de não comprometer os registros históricos nem invalidar projeções futuras do clima. 



\section{CAPÍTULO 4 - Mudanças dos Horários de Observações e dos Cálculos de Médias}

As temperaturas médias mensais e anuais, historicamente, tem sido o indicador mais comum usado para a avaliação das alterações climáticas, tanto no contexto das mudanças historicamente observadas quanto das mudanças futuras projetadas. Desta maneira, as temperaturas médias representam o parâmetro mais comumente utilizado no monitoramento contínuo da temperatura, especialmente na escala global e hemisférica.

Conforme já apresentado no capítulo anterior, diferentes fórmulas têm sido utilizadas ao longo do tempo, havendo alta diversidade nos procedimentos observacionais em vários países. De acordo com Peterson e Vose (1997), mais de cem diferentes fórmulas de cálculos de temperaturas médias diárias têm sido utilizados. Cada lugar possui horários de leituras distintos e as respectivas fórmulas acabam muitas vezes diferindo bastante uma das outras.

Existem muitos métodos para calcular a temperatura média diária. Estes incluem métodos que usam valores máximos e mínimos diários, 24 observações horárias, observações realizadas em intervalos iguais (por exemplo, a cada 3 horas, totalizando 8 registros diários), observações sinóticas e observações em determinadas horas especificas do dia. (WMO, 2009).

Em uma análise da utilização das diferentes categorias de métodos, Trewin (2004) apresenta a comparação da distribuição de utilização de $85 \%$ dos países do mundo: cerca de $43 \%$ dos países analisados utilizam temperaturas médias com base em temperaturas máximas e mínimas (ex: EUA, o Canadá e a Austrália); $41 \%$ dos países usam médias das observações em horários fixos, que são tomadas a intervalos regulares (ex: China e Países da Ex-União Soviética); e 16\% empregam médias (muitas vezes ponderadas) de temperaturas medidas em horários fixos irregularmente espaçados (principalmente na Europa e América do Sul, inclusive o Brasil).

Foco deste estudo, as fórmulas fundamentadas em um número reduzido de leituras são baseadas em: 
- Duas leituras diárias: com base nas temperaturas máximas e mínimas, conforme recomendado pela OMM nos cálculos das normais (WMO, 1989);

- Três leituras com horários fixos: por exemplo às 7, 14 e 21 horas do horário local, conforme foi utilizado no cálculo das normais no Brasil até 1937 (BRASIL, 1969); ou

- Quatro leituras combinadas: com base na leitura dos valores máximos e mínimos, acrescidos de dois valores em horários fixos, como as 9 e 21 horas locais, adotado no cálculo das normais brasileiras a partir de 1938 .

As médias das leituras combinadas podem ser, ainda, com base em média aritmética simples (divisão da soma dos valores pela quantidade de valores) ou média ponderada, em que a leitura de um horário pode receber a atribuição de um peso maior em relação às demais leituras. De fato, os métodos para estimar a temperatura média diária variam de país para país, dependendo de fatores como a frequência das observações disponíveis, o tempo de observações e, mais recentemente, à disponibilidade de estações automáticas.

O uso de diferentes métodos de cálculos da temperatura média diária é um dos principais fatores indutores de heterogeneidades nas séries. Zaiki, Kimura e Mikami (2002) apontaram que as mudanças no horário de observação no método de cálculo das temperaturas médias mensais são importantes fontes de erros, estando entre as principais causas de heterogeneidades nos dados de temperatura. A quantificação das incertezas nos registros climáticos é um prérequisito para a interpretação das tendências e valores extremos. Considerando, portanto, a variedade significativa de fórmulas, estudos têm sido realizados na tentativa de quantificar quais as diferenças existentes entre valores obtidos pelas várias fórmulas utilizadas, e assim, determinam-se as incertezas incorporadas nas séries.

Os primeiros estudos (BROOKS, 1921; BAKER, 1975; SCHAAL; DALE, 1977) identificaram e quantificaram as diferenças da temperatura média diária de acordo com o horário de observação. Edwards (1982) alertava, na década de 80, que os métodos geralmente usados para medir temperaturas médias diárias estão sujeitos a diversos erros e, portanto, não seriam suficientemente precisos para determinar tendências climáticas - fato reconhecido desde 1890. Desde 
então, estudos têm sido constantemente realizados, comparando os efeitos das mudanças dos novos cálculos que são adotados nos diferentes países.

Collison e Tabony (1984) ${ }^{25}$ apud Trewin (2004), em uma comparação de temperaturas diárias médias calculadas a partir de temperaturas máximas e mínimas com as obtidas através da média de observações horárias (24 registros em um dia), encontrou, em um estudo de quinze estações britânicas, que as diferenças eram em geral inferior a $0,3^{\circ} \mathrm{C}$, com as médias provenientes das leituras horárias geralmente maiores do que aquelas calculadas pelas máximas e mínimas no inverno, e menores no verão.

Weber (1993) comparou as temperaturas médias diárias calculadas a partir de temperaturas máximas e mínimas em 8 estações na Suíça, com os calculados usando a seguinte fórmula: $T=\left(T_{7}+T_{13}+2 T_{21}\right) / 4$. O autor descobriu que, dependendo da estação, as médias calculadas pelas máximas e mínimas foi de $0,06^{\circ} \mathrm{C}$ a $0,83^{\circ} \mathrm{C}$ maiores do que os calculados por meio de observações com horários fixos. Ele também encontrou que havia diferenças espaciais menores entre as estações nas tendências observadas da temperatura média quando a temperatura média era calculada usando máximos diários e mínimos. Logo, ele concluiu que isto sugere que as temperaturas máximas e mínimas diárias foram menos sensíveis a pequenas variações locais, ao contrário das médias obtidas pelas observações com horários fixos.

Trewin (2004) analisou os efeitos da mudança, em 1994, dos cálculos da média na Austrália. O algoritmo utilizado para o cálculo das temperaturas médias foi alterado a partir de um método com base nas temperaturas máximas e mínimas para um baseado em observações a cada três horas (8 valores diários). Uma comparação entre os dois métodos foi realizada com dados de 35 estações, juntamente com outros métodos baseados em observações com horários fixos que estão em uso em outros países. A temperatura média calculada utilizando o método de pós-1994 foi $0,14^{\circ} \mathrm{C}$ menor do que a calculada pelo método pré-1994, enquanto os métodos com base em horários fixos produziram médias entre $0,17^{\circ} \mathrm{C}$ e $0,43^{\circ} \mathrm{C}$ menores do que os derivados de temperaturas máximas e mínimas.

\footnotetext{
${ }^{25}$ COLLISON, P.; TABONY, R.C. (1984). The estimation of mean temperatures from daily maxima and minima. Met. Mag., London, v. 113, p. 329-37, 1984.
} 
Mais recentemente, Dall'amico e Hornsteiner (2006) apresentam um método simples para estimar a temperatura média diária com base nos extremos de temperatura (temperaturas máximas e mínimas), na hora do pôr-do-sol e na temperatura mínima da noite seguinte. O método se mostrou viável e representativo nas regiões alpinas alemãs em que foi testado, e, além disso, o fato de necessitar apenas de dados diários das temperaturas extremas é uma grande vantagem, pois ele pode ser aplicado a grandes conjuntos de dados históricos das observações de estações climatológicas convencionais.

No Brasil, dois estudos foram conduzidos a respeito do uso de diferentes fórmulas da temperatura diária. O primeiro deles, "Contribuição ao estudo da determinação da temperatura média diária", tese defendida em 1961 na ESALQ/USP por Clovis Pompílio de Abreu (ABREU, 1961), comparou as temperaturas obtidas por cinco fórmulas com temperatura verdadeira (obtida por 24 leituras horárias), utilizando dados obtidos na cidade de São Paulo no período de 1953-1956:

$$
\begin{aligned}
& T_{(1)}=\left(T_{7}+T_{14}+2 T_{21}\right) / 4 \\
& T_{(2)}=\left(T_{9}+T_{15}+2 T_{21}\right) / 4 \\
& T_{(3)}=\left(T_{9}+T_{15}+T_{21}+T_{m}\right) / 4 \\
& T_{(4)}=\left(T_{9}+2 T_{21}+T_{M}+T_{m}\right) / 5 \\
& T_{(5)}=\left(T_{M}+T_{m}\right) / 2
\end{aligned}
$$

Comparadas as médias, Abreu (1961) determinou os seguintes desvios médios $\left({ }^{\circ} \mathrm{C}\right): T_{(1)}=-0,04 ; T_{(2)}=0,48 ; T_{(3)}=-0,17 ; T_{(4)}=-0,05 ;$ e $T_{(5)}=1,02$. Pelas análises de variância, a média que mais se aproximou da temperatura verdadeira foi a $T_{(4)}$, enquanto que a $T_{(5)}$ apresentou maior diferença. Em relação à média verdadeira, as médias obtidas das fórmulas $T_{(2)}$ e $T_{(5)}$ sempre superestimaram os valores; $T_{(3)}$ sempre subestimou os valores; e $T_{(1)}$ e $T_{(4)}$ mais subestimaram do que superestimaram a referida média.

O segundo trabalho notável foi uma tese intitulada "Umidade relativa e temperatura do ar: fórmulas usuais e fórmulas novas com horários para leituras simultâneas", defendida em 1969 na ESALQ/USP por Antonio Sanchez de Oliveira (OLIVEIRA, 1969). Utilizando dados de temperatura de janeiro de 1957 a julho 1968 da cidade de São Paulo, o autor comparou fórmulas usuais [as 
mesmas utilizadas por Abreu (1961), com a inclusão da fórmula: $T=T_{9}$, ou seja, a temperatura média diária seria o valor da medição realizada as 9h] e novas possíveis fórmulas, obtidas por combinações de duas, três e quatro leituras diárias, realizadas entre as 6 às 22h. Por meio de programação computacional, 6392 combinações possíveis foram determinadas. Uma análise preliminar eliminou 136 fórmulas obtidas por duas leituras diárias, em razão dos desvios encontrados. Das fórmulas restantes, com três e quatro leituras diárias, foram selecionadas as seguintes fórmulas:

$$
\begin{aligned}
& T=\left(T_{6}+T_{12}+T_{21}\right) / 3 \\
& T=\left(T_{11}+T_{21}+T_{22}\right) / 3 \\
& T=\left(T_{8}+T_{16}+T_{22}\right) / 3 \\
& T=\left(T_{8}+T_{14}+T_{21}+T_{22}\right) / 4 \\
& T=\left(T_{6}+T_{12}+T_{18}+T_{22}\right) / 4 \\
& T=\left(T_{6}+T_{9}+T_{15}+T_{22}\right) / 4 \\
& T=\left(T_{7}+T_{13}+T_{19}+T_{21}\right) / 4 \\
& T=\left(T_{6}+T_{9}+T_{15}+T_{21}\right) / 4 \\
& T=\left(T_{6}+T_{9}+T_{16}+T_{19}\right) / 4 \\
& T=\left(T_{6}+T_{7}+T_{14}+T_{18}\right) / 4
\end{aligned}
$$

Das fórmulas usuais, Oliveira (1969) afirma que podem ser utilizadas, indistintamente, as fórmulas $T_{(1)}, T_{(3)}$ e $T_{(4)}$ para determinação da média mensal para qualquer mês do ano. As demais fórmulas não podem ser utilizadas, pois apresentam valores diferentes da temperatura verdadeira em todos ou quase todos os meses do ano. Em relação às novas fórmulas, as que representaram melhor a temperatura verdadeira foram a $T=\left(T_{11}+T_{21}+T_{22}\right) / 3$ e $T=\left(T_{6}+T_{12}+T_{18}+T_{22}\right) / 4$.

Nos estudos descritos acima, as diferenças observadas entre o uso de diferentes métodos de cálculos são substanciais na conjuntura da evolução das temperaturas ao longo do século passado, reforçando a importância de documentar e levar em conta as heterogeneidades nos registros antes de se fazer avaliações das tendências de temperatura e possíveis alterações climáticas. 
No contexto da grande variedade de fórmulas, o presente capítulo tem como objetivo identificar e quantificar as diferenças diárias, mensais e anuais do uso de diferentes métodos de cálculo da temperatura média, além da possível repercussão na escala das normais. Como primeira etapa, é realizada a caracterização do clima, em termos de temperatura, a partir da elaboração de normais para a região em estudo. Logo após, verificam-se as tendências observadas durante o período analisado. Feito isso, são avaliados e comparados os valores obtidos por diferentes fórmulas e também são verificadas possíveis alterações nas respectivas tendências para cada método utilizado. Além do diagnóstico comparativo, procurou-se caracterizar as ocorrências de valores de diferença consideravelmente acima do desvio médio, identificando possíveis fatores que influenciam nos processos de medições e incorporam efeitos adversos nas séries de dados.

Sob duas escalas temporais de abordagens foram analisados os métodos de determinação da média diária. Uma delas é a magnitude, em escala de curto prazo, do erro induzido por cada fórmula utilizada no cálculo das médias diárias. A segunda, na escala de médio e longo prazo, avaliou-se a magnitude dos erros nas médias mensais e anuais resultantes dos erros diários.

\subsection{Materiais e Métodos}

Foram utilizados os dados diários da temperatura coletados e registrados na Estação Climatológica do Centro de Recursos Hídricos e Ecologia Aplicada (CRHEA), Escola de Engenharia de São Carlos (EESC), Universidade de São Paulo (USP), localizada no município de Itirapina, São Paulo, Brasil (Latitude: $22^{\circ} 10^{\prime}$ S, Longitude: $47^{\circ} 50^{\prime} \mathrm{O}$, Altitude: $753 \mathrm{~m}$ ), a $25 \mathrm{~km}$ do município de São Carlos.

Três séries de temperatura foram examinadas: (1) a série de dados de temperatura mais extensa - com dados provenientes da estação convencional, equipada com termômetros de máximas e mínimas acondicionados em uma câmara de Stevenson - teve início da coleta das temperaturas máximas e mínimas no ano de 1973, estendendo até os dias atuais; (2) a segunda série, com coleta desde 1999, é representada pelas leituras da temperatura às 9,15 e $21 \mathrm{~h}$ do horário local, obtidas pela leitura dos termogramas registrados em um 
termógrafo bi-metálico da marca R. Fuess, modelo 17, n. G3851, acondicionados na câmara de Stevenson; e (3) a terceira série de temperatura foi também inaugurada em 1999, início do período de coleta de dados por uma estação automática da Campbell Scientific, com sistema de aquisição e armazenamento de dados modelo 21X, com o sensor de temperatura e umidade relativa modelo HMP35 acoplado ao abrigo não aspirado modelo 41003 da fabricante R.M. Young. Os dados de temperatura obtidos pela estação automática foram registrados em intervalos regulares de 30 minutos, totalizando 48 registros diários.

Os dados foram organizados em planilha eletrônica no programa aplicativo Microsoft Office Excel(C), onde foram realizados os cálculos e confeccionados os respectivos gráficos. Um processo semi-automatizado foi implementado na planilha, visando economia de tempo com o ganho de agilidade e praticidade, além de redução de erros humanos acidentais e indesejáveis. Algoritmos relativamente simples foram criados para a análise das séries em questão, podendo facilmente ser adaptados a outras séries. Algumas etapas envolveram ajustes e verificações visuais, entretanto, a planilha, de um modo geral, foi elaborada visando minimizar erros humanos de digitação e distração. A planilha é semi-automatizada, pois, os algoritmos são automatizados em acusar alguma inconsistência, de acordo com os critérios especificados, cabendo ao usuário decidir o que fazer com os alertas ou avisos visuais apontados. Portanto, a alteração ou correção de algum valor suspeito, é um processo manual que exige a intervenção e discernimento humano.

Conforme se organizavam os dados em uma planilha padronizada semiautomatizada, uma primeira etapa do controle de qualidade realizado foi verificar a ocorrência de dados faltantes no registro de cada série. Identificação dos dias com falhas de dados foi essencial e determinante na escolha dos meses a serem descartados nos cálculos posteriores das médias mensais e anuais. Vide recomendação da OMM (WMO, 2007), a regra "5/10" foi aplicada, ou seja, não foram calculados os valores mensais em que estavam faltando 5 ou mais valores diários consecutivos ou 10 valores diários não consecutivos ao longo do mês.

Não foi realizado preenchimento das falhas identificadas, embora este procedimento tenha sido aplicado e detalhado em estudo anterior de Krusche, Saraiva e Reboita (2002). Na elaboração das normais climatológicas provisórias do Rio Grande do Sul para o período de 1991 a 2000, Krusche, Saraiva e 
Reboita (2002) realizaram o preenchimento de falhas da temperatura do ar empregando o método de média da série. Este método consistiu na identificação do dia com falha seguido pelo cálculo da média aritmética dos dados desta variável na mesma data dos demais anos da série. Por exemplo, a série de temperatura possui um dado faltante no dia 20 de agosto de 1992. Para preencher esta falha, calcula-se a média aritmética utilizando o dado do dia 20 de agosto de todos os anos da série.

A justificativa de rejeitar o uso deste tipo de método no presente estudo reside no fato de que esta reconstrução de falhas de dados está baseada apenas em uma técnica estatística, em que não é levada em consideração nenhuma característica das condições climáticas reais dos dias ausentes de dados. Nenhum dia é igual ao outro nos diferentes anos, ou seja, o mesmo dia do calendário não possui ano após o outro, necessariamente, as mesmas características, semelhantes ou próximas, muito menos idênticas. Não existe esta correspondência direta de dias e condições do clima, portanto este artifício matemático utilizado pelos autores não seria, a princípio, adequado. Da mesma forma que existem anos com invernos mais rigorosos, ou verões mais intensos; anos mais chuvosos ou mais secos; os dias possuem uma variabilidade habitual que seguem estas variações inter-anuais. Além disso, acrescenta-se o efeito da dinâmica das massas de ar, que não seguem o mesmo padrão todos os anos, e desta maneira não é rígida a frequência da passagem e domínio de massas de ar frias sob determinada região. Por exemplo, em um determinado ano, o dia com falha pode ter estado sob efeito de uma massa fria, enquanto que nos anos anteriores os mesmos dias do calendário poderiam estar sob domínio de uma massa de ar quente.

Logo, o valor médio calculado por esta técnica não possui um significado físico real para os dias com falhas, não sendo recomendado este procedimento. Trata-se apenas de uma aproximação que possibilita o cálculo das médias mensais e anuais. De fato não existem grandes diferenças nos valores mensais e anuais com este tipo de preenchimento de dados, pois nestas escalas o peso de cada dia é pouco expressivo dentro de uma extensa série de dados em um mês ou um ano. Porém, deve ficar claro que os valores diários preenchidos não representam, na escala diária, o valor que ocorreu veridicamente no passado e não foi registrado. Este tipo de abordagem ilustra nitidamente a análise o clima 
sob a perspectiva da visão clássica do clima, ou seja, com o uso de médias que abstraem a variabilidade inter-anual e a dinâmica das massas de ar, fenômenos melhor estudados pela Climatologia Dinâmica. Assim sendo, é discutível a adequação do método utilizado por Krusche, Saraiva e Reboita (2002), sendo fundamental a realização de estudos específicos que elucidem com maior embasamento as críticas aqui inicialmente apreciadas, de modo a determinar métodos mais apropriados ao preenchimento de falhas.

Em relação à ocorrência de descontinuidades, os dados não passaram por nenhum processo de homogeneização, ou seja, não se verificou a ocorrência de erros sistemáticos (ou heterogeneidades) na série, supondo que não houve mudanças significativas dos procedimentos nas observações e registros, nem da instrumentação. Quanto à localização da estação não houve nenhuma alteração; ainda é a mesma desde a sua inauguração. $O$ ambiente local é predominantemente coberto por grama nas proximidades da estação ou por capim mais alto nas redondezas mais distantes (vide APÊEDICE G, pg. 397), o que provavelmente seja assim desde o começo das medições. Com exceção de um edifício térreo (escritório da estação, ao fundo da foto no APÊEDICE F, pg. 395) a mais de 30 metros do local da leitura, não há mais nenhum outro prédio, nem árvore ou obstáculo que possa influenciar nas medições, conforme recomenda o "Guia de Instrumentos Meteorológicos e Métodos de Observação" da OMM (WMO, 2008).

Apenas a verificação visual de erros aleatórios e grosseiros foi realizada. Foram identificados valores discrepantes decorrentes principalmente de problemas nos instrumentos de medição, falhas dos observadores e dos erros de digitação na hora de armazenar os dados. A identificação destes erros aleatórios é consideravelmente simples, pois os números registrados assumem valores fisicamente impossíveis, como, por exemplo, temperatura do ar de $60^{\circ} \mathrm{C}$, valores máximos abaixo de valores mínimos, valores mínimos acima dos valores máximos, etc.

Realizado o controle de qualidade, procedeu-se para os cálculos das médias diárias, mensais, anuais e normais. As normais foram calculadas com base na série das temperaturas máximas e mínimas, maior série disponível. Nas demais escalas, foram utilizadas e comparadas as outras séries de dados de temperatura. As seguintes fórmulas foram utilizadas no cálculo das médias diárias: 
OMM (WMO, 2009)

$$
T_{M-m}=\frac{1}{2}\left(T_{M}+T_{m}\right)
$$

Tolentino (1967)

$$
T_{9-15-21}=\frac{1}{4}\left(T_{9}+T_{15}+2 T_{21}\right)
$$

Normais Brasileiras

até 1937 (BRASIL, 1967)

Normais Brasileiras a partir

de 1938 (BRASIL, 1967)

Temperatura verdadeira

$$
\begin{array}{ll}
T_{7-14-21}=\frac{1}{4}\left(T_{7}+T_{14}+2 T_{21}\right) & \text { Eq. (7) } \\
T_{9-21-M-m}=\frac{1}{5}\left(T_{9}+2 T_{21}+T_{M}+T_{m}\right) & \text { Eq. (8) } \\
T_{\text {automática }}=\frac{1}{48}\left(T_{00: 30}+T_{01: 00}+\ldots+T_{24: 00}\right) & \text { Eq. (9) }
\end{array}
$$

\subsection{Resultados e Discussão}

Antes de determinar quais as diferenças diárias, mensais e anuais do uso de diferentes métodos de cálculo da temperatura média é necessário ter disponível um referencial de comparação. Portanto, seguem inicialmente os resultados da elaboração de normais de temperaturas médias, máximas e mínimas para a região da estação em estudo.

\subsubsection{Caracterização e tendências: confecção das normais}

As normais calculadas representam o valor médio do período analisado. Diferentes formas de apresentação gráfica são apresentadas com o intuito de facilitar a visualização e significado relativo dos valores uns com os outros, o que é praticamente inviável ao analisar a tabela dos dados. As tendências são baseadas em diferenças ou desvios anuais em relação à média do período total, permitindo verificar variações inter-anuais. A tendência de temperatura do período total pode indicar o aquecimento, resfriamento ou manutenção de uma comportamento médio sem variações, ou seja, constante.

\subsubsection{Caracterização}

Utilizando a maior série de temperatura, com dados das temperaturas máximas e mínimas, a identificação das falhas presentes resultou na elaboração de uma tabela, representada pela Figura 52 a seguir. Os valores médios diários 
apresentados nesta Figura foram calculados com base na Eq. (5). A coloração apresentada nesta figura indica que: em vermelha estão representados os dias com falhas na temperatura média diária (decorrentes de falhas nos dados da temperatura máxima e/ou mínima); a cor amarela significa os meses que tiveram completamente todos os dias com valores inexistentes ou mais de 5 dias consecutivos ou 10 dias no total do mês com falhas (regra "5/10"); e os meses em azul são aqueles que apresentam falhas, porém dentro do limite estabelecido pela regra "5/10", ou seja, menos de 5 dias consecutivos com falhas e, no total do mês, menos de 10 dias não consecutivos com falhas. Em cinza estão representados os dias nulos dos meses que possuem 28 (fevereiro) 29 (fevereiro em ano bissexto) e 30 dias (abril, junho, setembro e novembro). 


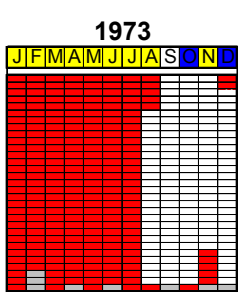

1979

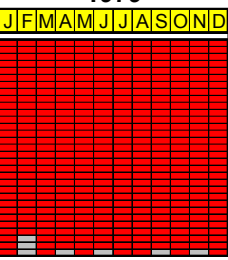

1985

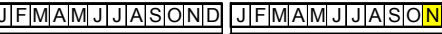

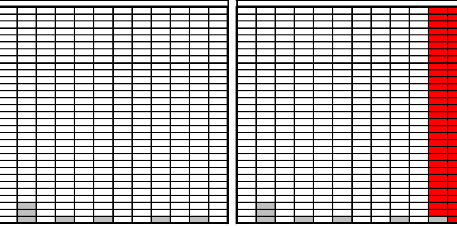

1991

1992

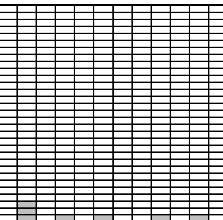

1997

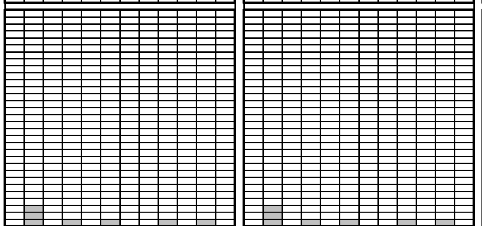

2003

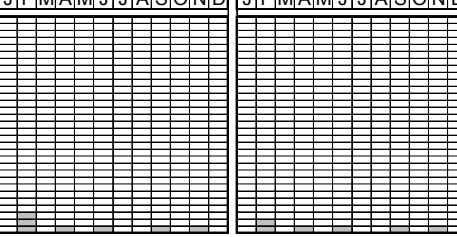

Falhas de dados diários
$1992 \quad 1993$

1987

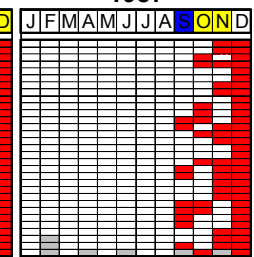

1981

1981

\begin{abstract}
1982
\end{abstract}
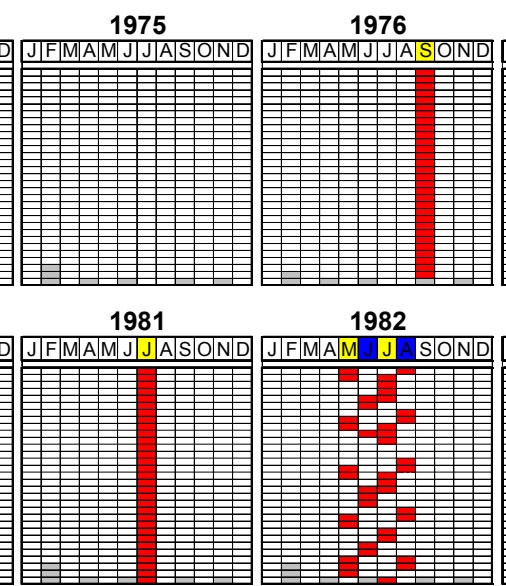

1988
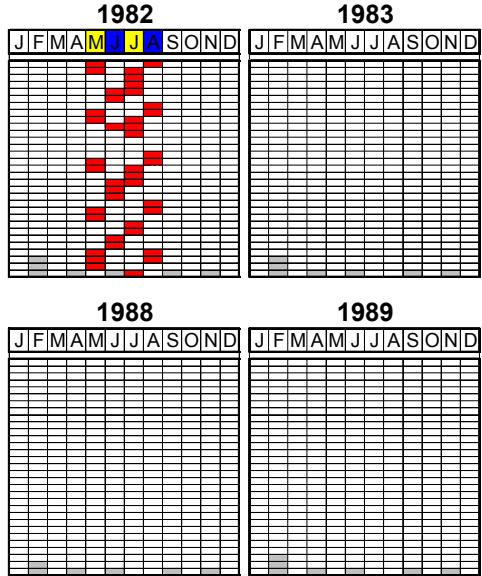

1994
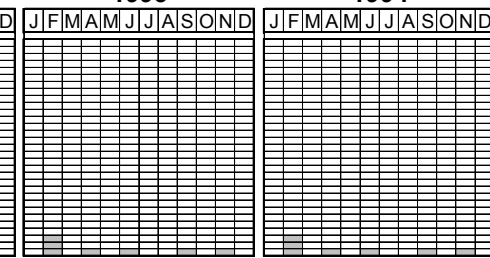

2000

1999

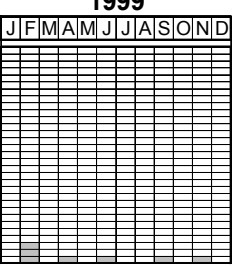

2005

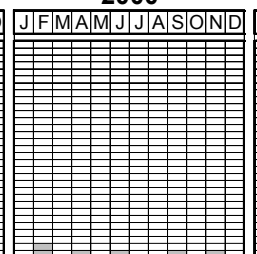

2006

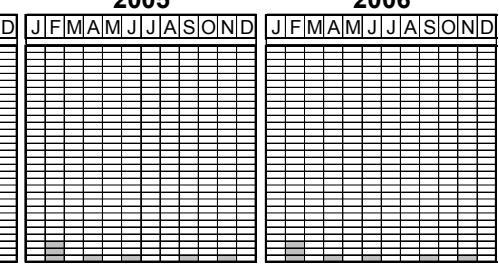

Meses com falhas; valores

desconsiderados nos cálculos
1977

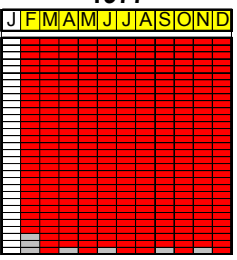

1983

1989

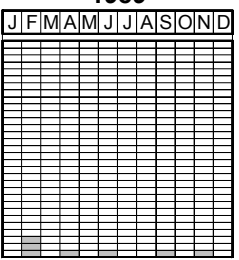

1995

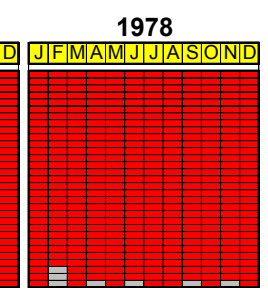

1984

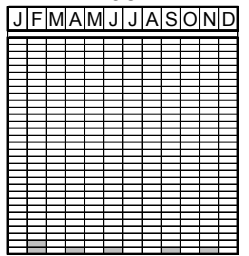

1990

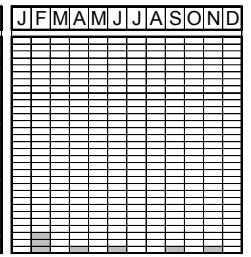

1996

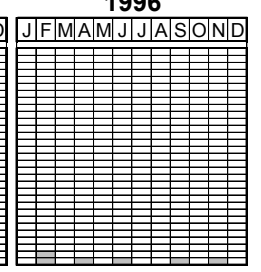

2002

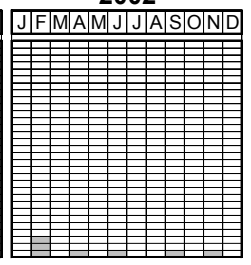

2008

2007 .

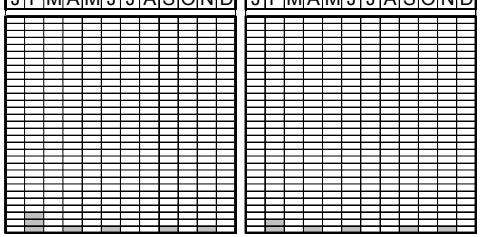

Meses com falhas; valores

considerados nos cálculos

Figura 52 - Distribuição visual das falhas diárias na série de temperaturas obtidas por termômetros de máximas e mínimas, no período de 1973-2008.

Pela Figura 52 nota-se que os anos iniciais são os que apresentam maior quantidade de falhas. Há anos completos com falhas (1977, 1978 e 1979), ano com falha em sua metade (1973), e anos com um ou até 3 meses com falhas 
(1976, 1981, 1982, 1986 e 1987). A partir de 1988 a série se apresenta isenta de falhas.

Considerando estas falhas e a regra "5/10" recomendadas pela OMM (WMO, 2007), a Tabela 6, Tabela 7 e Tabela 8, na sequência, exibem o resultado final das normais de temperatura média, máxima e mínima, respectivamente. Nestas tabelas, as células amarelas representam os meses inteiramente com dados diários faltando; as células azuis são meses parcialmente com dias falhos, porém o suficiente e dentro de regra " $5 / 10 "$; e as células laranja são os meses (ou médias anuais) que foram desconsiderados nas médias anuais (ou média de 30 anos). Os valores desconsiderados foram exibidos entre colchetes apenas como ilustração, não tendo sido utilizados estes valores nos cálculos das médias.

As médias mensais de cada ano foram calculadas conforme as Eq. (1), Eq. (2) e Eq. (3), pg. 125, mostrada no "CAPÍTULO 3 - Caracterização e Tendências Climáticas Locais". Na parte inferior das tabelas (última linha) são apresentadas as médias que representam as normais para cada mês - calculadas pela Eq. (4), pg. 126 - e a respectiva quantidade de meses que foram contemplados no cálculo das médias. Note que o mês de julho é único que não possui 30 meses no cálculo da normal, sendo que os demais possuem de 30 a 32 meses. Na última coluna da tabela, ao lado direito, as médias para cada ano foram calculadas pela média aritmética dos valores mensais. $\mathrm{O}$ valor no canto direito inferior é a média anual de todos os anos, sendo o mesmo valor tanto quando calculado verticalmente quanto calculado horizontalmente. Nos anos que apresentam meses com falhas, as médias anuais também foram determinadas com os dados disponíveis, no entanto os valores mostrados em laranja e entre colchetes não são representativos da temperatura média real destes anos, sendo mostrados apenas ilustrativamente.

Para ter uma noção do peso que representa um mês na média anual, considere-se o exemplo do ano de 1982. A temperatura média anual, desconsiderando os meses de maio e julho, o valor anual é de $21,0^{\circ} \mathrm{C}$. Considerando estes meses, o valor se torna $20,5^{\circ} \mathrm{C}$, diferença pouco significativa de $0,5^{\circ} \mathrm{C}$. Sob a perspectiva do valor médio para cada mês, tomando todos os valores disponíveis no período 1973-2008, incluindo o mês de maio o valor médio neste período muda de 18,41 para $18,37^{\circ} \mathrm{C}$; e no caso do mês de julho, a variação é de 16,95 para $16,98^{\circ} \mathrm{C}$. É importante ressaltar o valor centesimal faz 
parte do erro instrumental e não é significativo; logo, em ambos os casos, a diferença é desprezível. Os números foram apresentados com duas casas após a vírgula apenas para mostrar que a diferença é realmente muito pequena. Como a precisão está na primeira casa após a vírgula, arrendodando os números, eles na verdade possuem os mesmos valores. Infere-se, por consequência, com base nestes casos, que a ausência de valores mensais representa diferenças pouco expressivas nas médias anuais (médias obtidas nas linhas, horizontalmente), e praticamente nenhuma diferença nas médias de cada respectivo mês no período total (médias obtidas nas colunas, verticalmente).

Análise análoga pode ser feita para verificação da utilização da regra "5/10" ao invés da regra mais restritiva, "3/5". No caso de adotar a regra mais rigorosa, todos os meses em azul seriam excluídos e não poderiam estar no cômputo das médias anuais e normais. Analisando o mesmo ano de 1982, os meses de junho e agosto seriam descartados por essa nova regra, alterando a média atual (mas não representativa) de 21,0 para $21,6^{\circ} \mathrm{C}$. Nas médias mensais para o período total, os valores antigos e novos são respectivamente: 17,03 e $16,99^{\circ} \mathrm{C}$ para junho, e 18,66 e $18,64^{\circ} \mathrm{C}$ para agosto. Da mesma forma, meses faltantes só causam diferenças maiores para as médias anuais, e diferenças bastante reduzidas nas médias das normais. Este tipo de mudança gera erros da mesma ordem de magnitude para os casos da temperatura máxima e mínima. Em todos os casos, os efeitos da inclusão ou exclusão de valores mensais, de acordo com o critério adotado, vão depender de qual mês está sendo considerado ou não. Meses mais frios, com valores abaixo da média anual, tendem a reduzir (ou aumentar) o valor anual quando inclusos (ou excluídos). Ao contrário, meses mais quentes implicam no aumento (ou redução) do valor anual quando inclusos (ou excluídos). Esta análise superficial permite prosseguir com a utilização do critério "5/10" sem provocar diferenças significativas nem grandes prejuízos nos valores. Todavia, este procedimento, não sendo o ideal, deve ser analisado com cuidado no caso de uso de outras séries de temperatura. 
Tabela 6 - Temperaturas médias, mensais e anuais, calculadas com base nos dados da estação convencional, no período de 1973-2008.

\begin{tabular}{|c|c|c|c|c|c|c|c|c|c|c|c|c|c|}
\hline & JAN & FEV & MAR & ABR & MAI & JUN & JUL & AGO & SET & OUT & NOV & DEZ & ANO \\
\hline 1973 & & & & & & & & {$[19,7]$} & 20,8 & 21.5 & {$[21,5]$} & 23.4 & {$[21,9]$} \\
\hline 1974 & 23,8 & 25,0 & 23,3 & 21,4 & 18,6 & 17,4 & 18,0 & 18,5 & 20,5 & 20,1 & 20,9 & 21,1 & 20,7 \\
\hline 1975 & 21,9 & 22,6 & 23,2 & 18,9 & 17,0 & 16,4 & 15,1 & 20,0 & 20,6 & 20,8 & 20,9 & 22,5 & 20,0 \\
\hline 1976 & 23,1 & 21,4 & 21,4 & 19,8 & 17,2 & 15,5 & 14,7 & 17,5 & & 20,3 & 22,2 & 22,4 & {$[19,6]$} \\
\hline 1977 & 23,3 & & & & & & & & & & & & \\
\hline \multicolumn{14}{|l|}{1978} \\
\hline \multicolumn{14}{|l|}{1979} \\
\hline 1980 & 22,6 & 23,3 & 23,9 & 21,4 & 19,5 & 16,3 & 18,9 & 19,8 & 18,9 & 21,8 & 22,4 & 23,4 & 21,0 \\
\hline 1981 & 23,2 & 24,1 & 23,3 & 20,9 & 19,6 & 16,3 & & 18,9 & 21,3 & 20,2 & 23,0 & 22,1 & {$[21,2]$} \\
\hline 1982 & 21,9 & 23,6 & 22,3 & 19,6 & {$[17,3]$} & 18,4 & {$[17,8]$} & 19,2 & 20,4 & 20,8 & 22,5 & 21,6 & {$[21,0]$} \\
\hline 1983 & 22,4 & 22,9 & 21,8 & 22,1 & 20,7 & 17,8 & 18,9 & 18,3 & 18,5 & 20,3 & 21,2 & 22,1 & 20,6 \\
\hline 1984 & 24,0 & 25,0 & 23,7 & 21,1 & 21,0 & 18,6 & 19,0 & 18,1 & 19,1 & 22,4 & 23,0 & 22,1 & 21,4 \\
\hline 1985 & 22,1 & 23,7 & 22,9 & 21,9 & 18,5 & 15,6 & 15,5 & 19,3 & 20,6 & 22,9 & 23,3 & 23,6 & 20,8 \\
\hline 1986 & 24,1 & 23,4 & 22,7 & 21,9 & 20,0 & 16,6 & 16,3 & 18,6 & 19,5 & 20,9 & & & {$[20,4]$} \\
\hline 1987 & 23,5 & 22,6 & 22,1 & 22,1 & 18,1 & 16,4 & 19,1 & 17,9 & 19 & {$[22,6]$} & {$[24,2]$} & & {$[20,2]$} \\
\hline 1988 & 23,6 & 23,6 & 23,1 & 22,3 & 19,7 & 16,2 & 15,0 & 18,7 & 22,2 & 21,2 & 22,0 & 23,3 & 20,9 \\
\hline 1989 & 23,0 & 23,4 & 23,2 & 21,9 & 17,9 & 16,7 & 15,6 & 18,4 & 18,9 & 20,0 & 21,8 & 22,8 & 20,3 \\
\hline 1990 & 24,4 & 24,1 & 23,7 & 22,5 & 17,7 & 16,5 & 16,1 & 17,8 & 18,5 & 22,6 & 24,6 & 24,0 & 21,0 \\
\hline 1991 & 23,1 & 23,6 & 22,3 & 21,0 & 18,3 & 17,4 & 16,6 & 19,1 & 20,7 & 22,0 & 23,5 & 23,3 & 20,9 \\
\hline 1992 & 23,4 & 22,7 & 22,3 & 20,6 & 19,5 & 18,4 & 17,6 & 18,7 & 18,3 & 22,1 & 22,4 & 22,8 & 20,7 \\
\hline 1993 & 23,6 & 22,8 & 23,9 & 21,3 & 18,4 & $\begin{array}{ll}16,8 \\
\end{array}$ & $\begin{array}{ll}17,4 \\
\end{array}$ & 17,3 & 19,9 & 22,2 & 23,5 & 22,9 & 20,8 \\
\hline 1994 & 23,1 & 25,0 & 22,3 & 21,4 & 20,0 & 16,8 & 17,1 & 18,4 & 21,3 & 23,3 & 22,5 & 23,2 & 21,2 \\
\hline 1995 & 24,5 & 22,5 & 22,4 & 21,6 & 18,4 & 17,0 & 18,6 & 20,0 & 20,1 & 20,1 & 21,4 & 21,9 & 20,7 \\
\hline 1996 & 23,1 & 23,5 & 22,7 & 20,6 & 17,3 & 15,8 & 15,7 & 19,2 & 20,0 & 22,3 & 22,2 & 23,8 & 20,5 \\
\hline 1997 & 23,6 & 23,8 & 22,2 & 20,3 & 17,9 & 16,7 & 17,4 & 17,5 & 21,0 & 21,9 & 23,0 & 23,3 & 20,7 \\
\hline 1998 & 24,0 & 23,4 & 23,4 & 20,4 & 16,8 & 15,3 & 16,4 & 18,9 & 20,1 & 19,8 & 21,3 & 22,5 & 20,2 \\
\hline 1999 & 23,6 & 22,0 & 21,1 & 18,7 & 15,4 & 15,3 & 16,9 & 17,0 & 19,3 & 20,2 & 20,5 & 22,4 & 19,4 \\
\hline 2000 & 22,4 & 21,9 & 21,3 & 21,4 & 18,7 & 18,6 & 16,5 & 18,9 & 21,0 & 24,4 & 23,3 & 23,9 & 21,0 \\
\hline 2001 & 24,6 & 23,2 & 24,0 & 22,8 & 18,1 & 16,7 & 17,1 & 18,3 & 19,4 & 20,5 & 22,3 & 21,9 & 20,7 \\
\hline 2002 & 23,2 & 21,9 & 23,5 & 22,3 & 19,8 & 19,0 & 17,0 & 20,1 & 18,8 & 24,5 & 23,8 & 24,7 & 21,5 \\
\hline 2003 & 24,2 & 24,5 & 23,4 & 21,9 & 18,0 & 19,2 & 18,1 & 17,5 & 20,2 & 21,6 & 21,4 & 23,0 & 21,1 \\
\hline 2004 & 22,0 & 21,8 & 21,7 & 21,2 & 17,5 & 17,3 & 16,6 & 17,7 & 22,1 & 19,9 & 21,2 & 22,1 & 20,1 \\
\hline 2005 & 22,3 & 22,0 & 22,5 & 21,8 & 18,4 & 17,2 & 16,0 & 18,9 & 19,2 & 22,6 & 21,2 & 21,6 & 20,3 \\
\hline 2006 & 23,2 & 22,7 & 24,1 & 21,1 & 16,5 & 16,5 & 17,1 & 20,1 & 20,5 & 22,7 & 23,0 & 24,1 & 21,0 \\
\hline 2007 & 23,5 & 24,6 & 24,6 & 22,8 & 18,6 & 18,3 & 16,7 & 19,6 & 22,5 & 23,2 & 22,2 & 23,8 & 21,7 \\
\hline 2008 & 22,8 & 23,7 & 22,9 & 21,9 & 17,7 & 18,1 & 17,3 & 19,0 & 18,7 & 22,2 & 21,9 & 22,1 & 20,7 \\
\hline Meses & 32 & 31 & 31 & 31 & 30 & 31 & 29 & 31 & 31 & 31 & 30 & 30 & \\
\hline MÉDIA & 23,2 & 23,3 & 22,9 & 21,3 & 18,4 & 17,0 & 16,9 & 18,7 & 20,1 & 21,6 & 22,3 & 22,8 & 20,7 \\
\hline & Falhas & etas & & & has & $\begin{array}{l}\text { is co } \\
\text { dos }\end{array}$ & pres & & 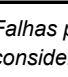 & 50 & lores & & \\
\hline
\end{tabular}

[ ] Valores exibidos como ilustração; não foram utilizados nos cálculos das médias anuais 
Tabela 7 - Temperaturas máximas médias, mensais e anuais, calculadas com base nos dados da estação convencional, no período de 1973-2008.

\begin{tabular}{|c|c|c|c|c|c|c|c|c|c|c|c|c|c|}
\hline & JAN & FEV & MAR & ABR & MAI & JUN & JUL & AGO & SET & OUT & NOV & DEZ & ANO \\
\hline 1973 & & & & & & & & {$[27,3]$} & 27,2 & 28.0 & {$[27,0]$} & 27.7 & {$[27,6]$} \\
\hline 1974 & 28,3 & 30,8 & 27,7 & 27,0 & 25,6 & 23,1 & 25,9 & 26,6 & 28,5 & 26,2 & 27,9 & 25,3 & 26,9 \\
\hline 1975 & 27,3 & 27,3 & 29,0 & 26,3 & 24,2 & 24,4 & 23,4 & 28,3 & 27,7 & 27,2 & 26,4 & 28,2 & 26,7 \\
\hline 1976 & 28,6 & 26,7 & 27,9 & 26,7 & 23,7 & 24,4 & 22,9 & 25,1 & & 26,7 & 28,1 & 27,1 & {$[26,2]$} \\
\hline 1977 & 28,1 & & & & & & & & & & & & \\
\hline \multicolumn{14}{|l|}{1978} \\
\hline \multicolumn{14}{|l|}{1979} \\
\hline 1980 & 27,6 & 28,3 & 30,0 & 27,0 & 26,3 & 23,2 & 26,0 & 26,9 & 25,7 & 28,7 & 28,6 & 28,4 & \\
\hline 1981 & 27,8 & 30,1 & 28,9 & 27,1 & 26,5 & 22,6 & & 26,6 & 29,4 & 26,0 & 28,6 & 27,1 & {$[27,3]$} \\
\hline 1982 & 27,1 & 29,3 & 26,8 & 25,2 & {$[23,6]$} & 24 & {$[24,4]$} & 25,7 & 28,2 & 26,8 & 28,9 & 26,8 & {$[26,9]$} \\
\hline 1983 & 27,3 & 29,1 & 27,8 & 27,7 & 26,4 & 23,1 & 25,4 & 26,5 & 23,7 & 26,9 & 27,8 & 27,2 & 26,6 \\
\hline 1984 & 30,3 & 31,7 & 30,0 & 26,8 & 28,3 & 26,8 & 27,0 & 25,1 & 26,4 & 29,9 & 29,5 & 27,4 & 28,3 \\
\hline 1985 & 27,2 & 29,6 & 28,1 & 27,4 & 25,7 & 23,7 & 23,6 & 27,8 & 28,0 & 31,5 & 30,0 & 30,2 & 27,7 \\
\hline 1986 & 29,8 & 28,3 & 27,8 & 28,1 & 26,2 & 24,3 & 23,7 & 25,5 & 26,9 & 28,3 & & & {$[26,9]$} \\
\hline 1987 & 28,7 & 27,9 & 28,3 & 28,2 & 23,9 & 23,1 & 26,3 & 25,9 & 26. & {$[29,8]$} & {$[31,9]$} & & {$[26,5]$} \\
\hline 1988 & 28,9 & 28,4 & 29,0 & 27,8 & 25,5 & 24,1 & 23,0 & 27,5 & 30,6 & 27,6 & 28,5 & 28,9 & 27,5 \\
\hline 1989 & 27,5 & 28,2 & 28,7 & 28,0 & 25,0 & 23,5 & 23,5 & 26,1 & 25,1 & 27,7 & 28,0 & 28,8 & 26,7 \\
\hline 1990 & 30,7 & 31,0 & 30,1 & 29,4 & 24,9 & 24,8 & 23,7 & 25,4 & 26,4 & 29,9 & 31,4 & 30,3 & 28,2 \\
\hline 1991 & 28,1 & 29,0 & 26,6 & 27,2 & 25,7 & 24,5 & 24,1 & 27,3 & 28,3 & 28,4 & 30,1 & 29,1 & 27,4 \\
\hline 1992 & 29,1 & 28,7 & 28,1 & 27,1 & 25,6 & 25,7 & 23,7 & 25,6 & 22,5 & 27,8 & 27,8 & 29,1 & 26,7 \\
\hline 1993 & 28,6 & 27,6 & 29,9 & 27,1 & 25,0 & 23,8 & 25,5 & 25,3 & 26,2 & 29,4 & 30,9 & 28,4 & 27,3 \\
\hline 1994 & 28,7 & 31,5 & 28,2 & 28,0 & 26,7 & 24,3 & 25,9 & 27,6 & 30,5 & 31,1 & 29,5 & 29,9 & 28,5 \\
\hline 1995 & 30,2 & 28,2 & 29,4 & 28,1 & 25,2 & 25,2 & 26,3 & 29,7 & 28,4 & 27,6 & 29,0 & 28,6 & 28,0 \\
\hline 1996 & 29,5 & 30,4 & 29,3 & 28,2 & 24,9 & 24,2 & 23,8 & 27,5 & 26,2 & 28,6 & 27,7 & 28,9 & 27,4 \\
\hline 1997 & 28,2 & 29,6 & 28,3 & 27,1 & 24,3 & 22,8 & 25,3 & 27,3 & 29,4 & 29,1 & 29,6 & 30,0 & 27,6 \\
\hline 1998 & 30,6 & 29,4 & 30,0 & 27,7 & 24,0 & 23,3 & 25,3 & 27,0 & 27,3 & 26,7 & 29,1 & 28,9 & 27,4 \\
\hline 1999 & 28,0 & 26,7 & 26,6 & 25,0 & 22,0 & 21,8 & 23,3 & 25,2 & 26,5 & 26,5 & 27,1 & 27,8 & 25,6 \\
\hline 2000 & 27,6 & 26,3 & 26,1 & 28,2 & 25,3 & 25,8 & 23,8 & 25,6 & 26,6 & 31,1 & 28,8 & 28,9 & 27,0 \\
\hline 2001 & 30,1 & 30,1 & 30,1 & 28,9 & 24,5 & 24,5 & 26,0 & 27,6 & 27,4 & 28,3 & 29,6 & 28,5 & 28,0 \\
\hline 2002 & 28,9 & 28,2 & 31,3 & 31,0 & 26,0 & 27,1 & 25,3 & 28,6 & 26,8 & 33,4 & 29,9 & 30,4 & 28,9 \\
\hline 2003 & 28,7 & 31,6 & 29,1 & 28,4 & 25,1 & 27,3 & 25,9 & 25,8 & 28,8 & 29,6 & 28,4 & 29,9 & 28,2 \\
\hline 2004 & 28,4 & 28,6 & 29,0 & 28,3 & 23,4 & 23,9 & 23,1 & 27,4 & 31,8 & 27,0 & 28,4 & 29,1 & 27,4 \\
\hline 2005 & 28,0 & 29,9 & 29,2 & 29,4 & 26,5 & 25,5 & 24,3 & 28,5 & 26,5 & 30,2 & 28,6 & 28,5 & 27,9 \\
\hline 2006 & 30,3 & 29,4 & 29,8 & 27,6 & 24,3 & 25,3 & 26,3 & 28,5 & 27,7 & 29,0 & 29,3 & 29,4 & 28,1 \\
\hline 2007 & 28,1 & 30,6 & 31,5 & 29,0 & 24,9 & 26,3 & 24,2 & 27,9 & 31,0 & 31,9 & 28,3 & 30,0 & 28,6 \\
\hline 2008 & 28,3 & 29,6 & 28,7 & 28,1 & 24,8 & 24,9 & 26,5 & 28,3 & 25,6 & 28,2 & 27,8 & 27,6 & 27,4 \\
\hline Meses & 32 & 31 & 31 & 31 & 30 & 31 & 29 & 31 & 31 & 31 & 30 & 30 & \multirow{2}{*}{27,4} \\
\hline MÉDIA & 28,6 & 29,1 & 28,8 & 27,7 & 25,2 & 24,4 & 24,8 & 26,9 & 27,4 & 28,6 & 28,8 & 28,6 & \\
\hline \multicolumn{5}{|c|}{ Falhas completas } & \multicolumn{3}{|c|}{$\begin{array}{l}\text { Falhas parciais com valores } \\
\text { desconsiderados }\end{array}$} & & . & ais $c c$ & ores & & \\
\hline
\end{tabular}

Para facilitar a visualização das diferenças relativas deste aglomerado de números apresentados, é interessante observar a representação gráfica dos valores presentes nas tabelas. Um primeiro tipo de gráfico é exibido na Figura 53. Este tipo de representação é denominado de spaghetti plot, em alusão ao aspecto visual de uma macarronada. Notam-se as diferentes curvas de cada ano para as temperaturas média (Figura 53-A), máxima (Figura 53-B) e mínima (Figura 53-C). 
Tabela 8 - Temperaturas mínimas médias, mensais e anuais, calculadas com base nos dados da estação convencional, no período de 1973-2008.

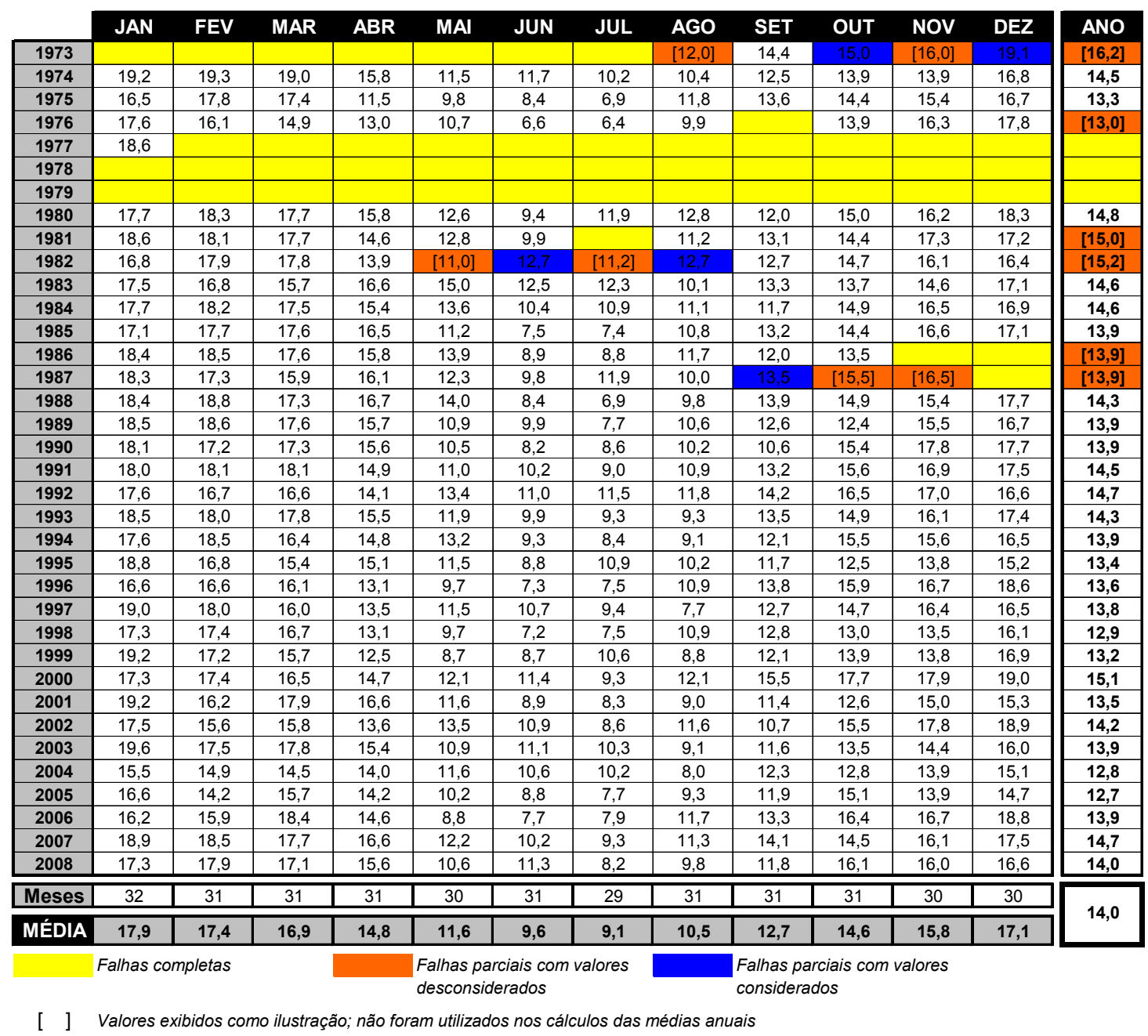

Não é muito convencional este tipo de representação devido à sua feição aparentemente bagunçada e confusa. Mas justamente por este motivo que pode ser nitidamente verificado que a média normal tomada no período total (representada pela curva em preto na figuras) é uma abstração que oculta as variações de temperatura habituais e naturais de cada ano. Existem anos tipicamente mais frios (1976 e 1999, destacados respectivamente em verde claro e escuro nos gráficos) e existem anos notadamente mais quentes (2002 e 2007, rosa e vermelho, respec.). Este tipo de gráfico poderia ser adotado como uma forma mais adequada de mostrar as variações de temperatura, diferentemente daquele que é convencionalmente mostrado em climatogramas, em que somente é mostrada a curva média do período total. 

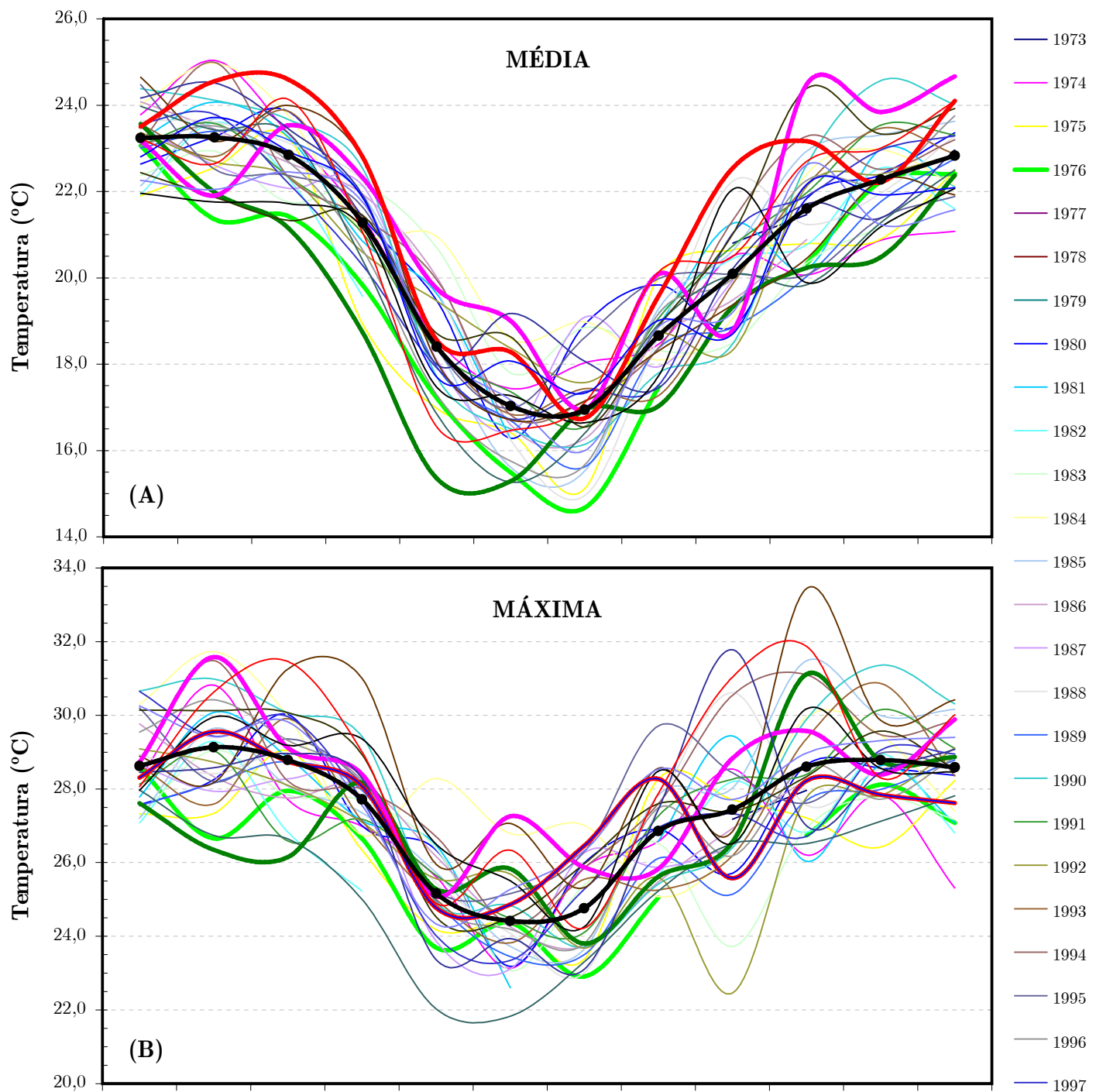

1985

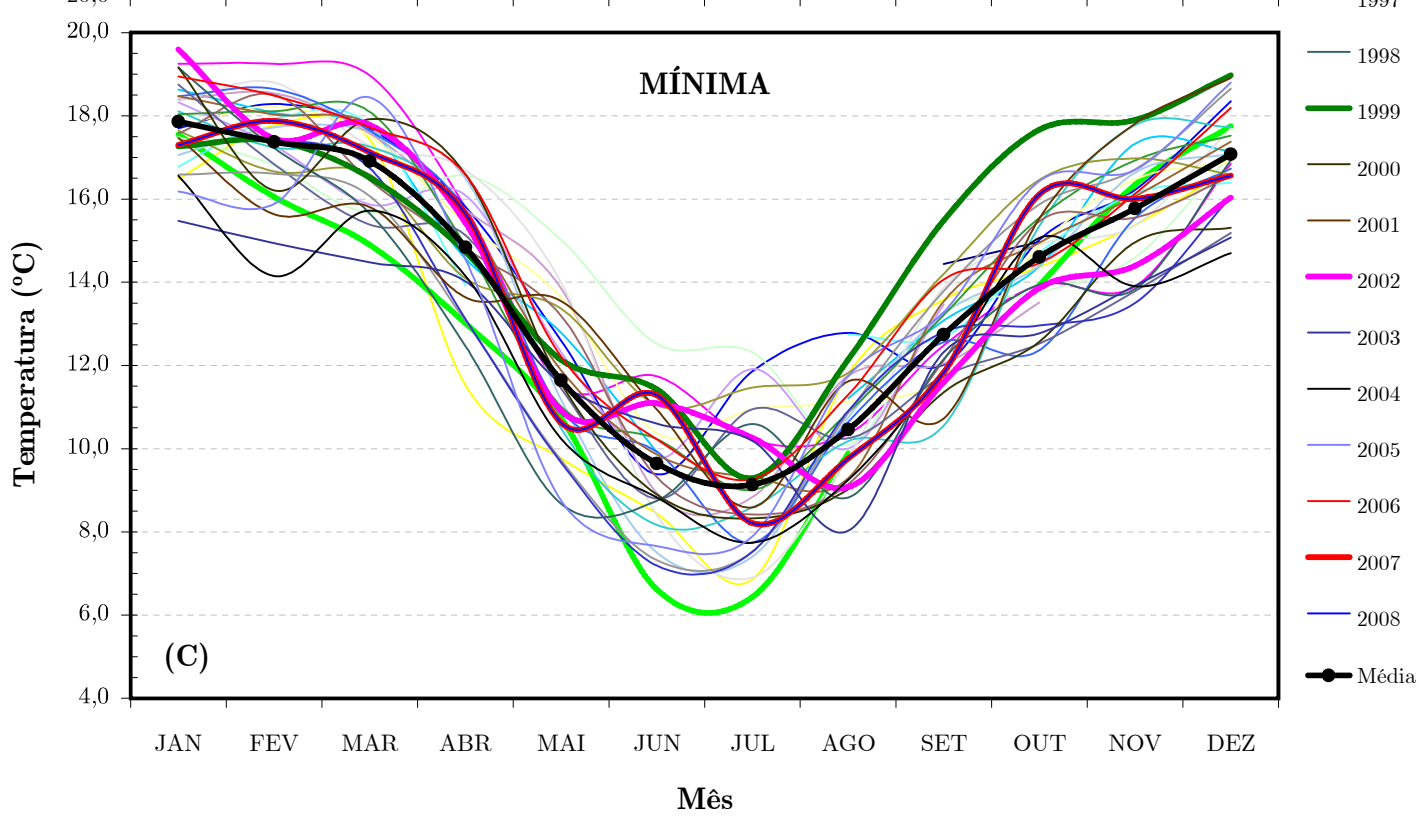

Figura 53 - Spaghetti plot das temperaturas mensais ao longo de um ano, com cada curva representando um ano do período 1973-2008. Temperaturas (A) médias, (B) máximas e (C) mínimas. 
O tipo de gráfico simplificado que mostra a variação da temperatura em climatogramas - representações dos parâmetros básicos climáticos (temperatura média mensal e precipitação) em um determinado local - são exibidos na Figura 54-A. Na mesma Figura, são apresentadas outros tipos de representações, cada uma com uma informação adicional em relação à figura anterior: o gráfico (B) apresenta as curvas das temperaturas máxima (vermelho) e mínima (azul); o gráfico (C) exibe os valores máximos absolutos (cruz vermelha) e mínimos absolutos (cruz azul) de todo o período, para cada mês; e o gráfico (D) mostra uma área que abrange $80 \%$ dos valores médios mensais para cada temperatura, ou seja, a área hachurada é limitada pela curva superior que representa o $90^{\circ}$ percentil dos valores, e o limite inferior da área é dado pela curva que representa o $10^{\circ}$ percentil. Os valores dos percentis podem ser facilmente alterados e ajustados de acordo com a necessidade e interesse.

O último tipo de representação (Figura 54-D) é visualmente mais "limpo" em relação aos gráficos do tipo spaghetti plot, e, além disso, exibem todas as informações das três temperaturas no mesmo gráfico, com seus intervalos de variações mensais médias e também os valores absolutos, máximos e mínimos. A amplitude de variação de cada temperatura não é aparentemente igual aos da figura anterior (Figura 53) porque para as três curvas serem exibidas no mesmo gráfico, a escala da temperatura teve que ser expandida. Seria interessante fazer este mesmo tipo de representação utilizando-se de valores diários. Porém, para não se prolongar demasiadamente, esta atividade fica para outra ocasião. 

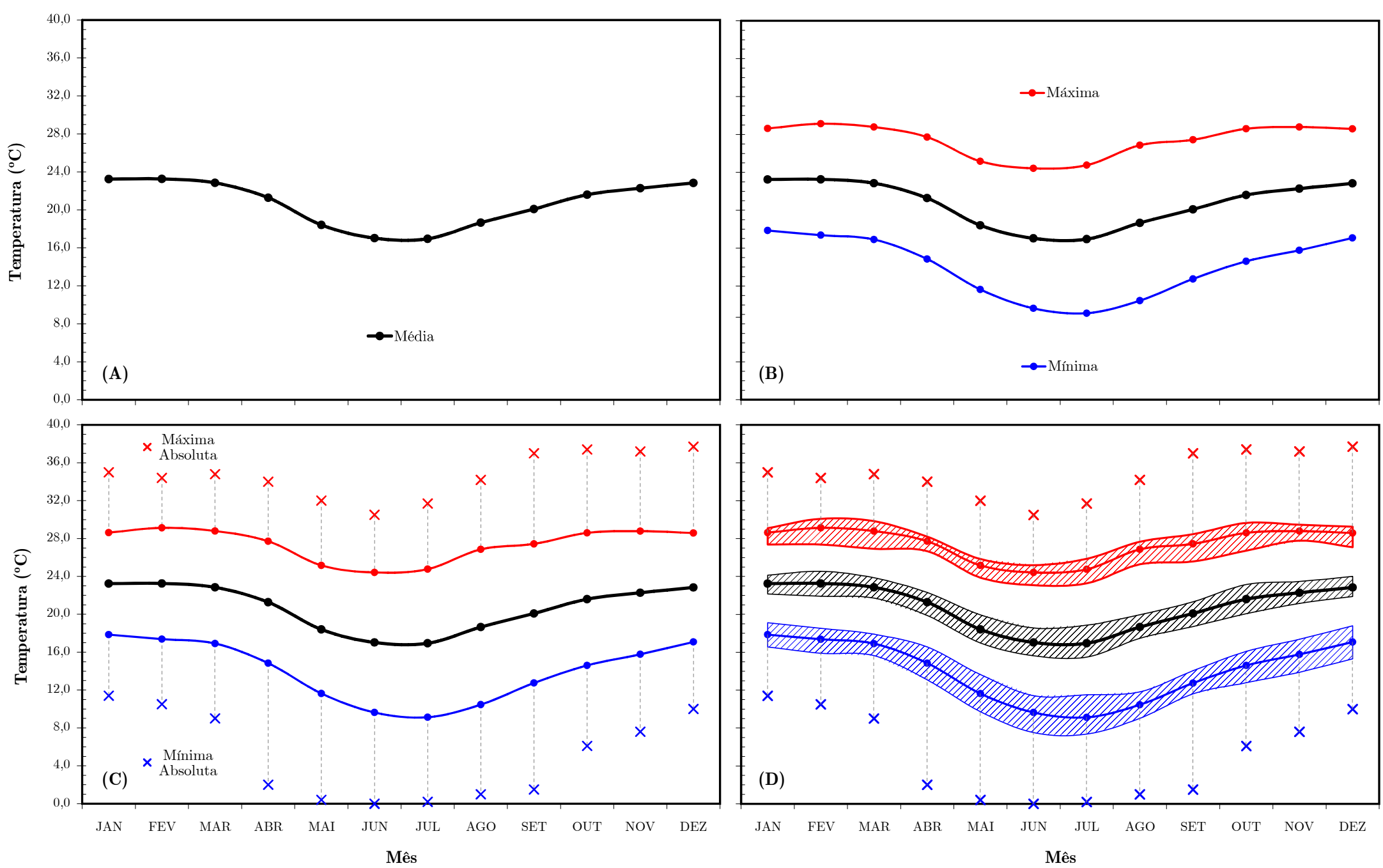

Figura 54 - Diferentes versões das temperaturas no formato de climatogramas anuais, referentes ao período 1973-2008. (A) Formato convencional; (B) Apenas de máximas e mínimas médias; (C) Apenas de máximas e mínimas absolutas. (D) Apenas de intervalo de confiança. 
Aproveitando a exibição gráfica das temperaturas máximas e mínimas absolutas na Figura 54, convém apresentar as tabelas com os valores correspondentes. A Tabela 9 apresenta os valores máximos absolutos e Tabela 10 apresenta os valores mínimos absolutos. Em cada tabela, as últimas colunas apresentam os valores máximos ou mínimos e os dias/meses em que ocorreram em cada ano; as últimas linhas mostram os maiores e menores valores para cada mês no período 1973-2008, além do ano em que ocorreram esses valores. No canto inferior direito está o valor máximo ou mínimo absoluto de todos os dias do período total.

A determinação dos dias de máximas e mínimas absolutas nestas tabelas foi realizada por um algoritmo simples. No caso, ele indicava os dias em cada mês que tivesse o maior ou menor valor de temperatura. Às vezes ocorria de no mesmo mês ter dois ou mais dias com o mesmo valor de temperatura máxima ou mínima. Com a inspeção visual destes meses que possuíam mais de um dia com o mesmo valor, verificava-se, por exemplo, qual dos dias com mesma temperatura máxima apresentou a maior média de temperatura (ou o maior valor de temperatura mínima). Assim, adotava-se o dia com maior temperatura média ou mínima como sendo o dia em que ocorreu a temperatura máxima absoluta do mês. O mesmo critério foi aplicado na distinção dos dias com mesmos valores de temperatura mínima, considerando neste caso que o dia mais frio seria aquele que tivesse apresentado o menor valor de temperatura média ou máxima.

Deve-se ficar atento aos valores representados em azul e laranja, que são aqueles cujos meses apresentam falhas parciais de dias, e que foram excluídos ou considerados nos cálculos das médias das normais. Portanto, os valores máximos e mínimos mostrados não são, necessariamente, os valores que ocorreram de verdade no respectivo mês ou ano. Eles são apenas os valores máximos ou mínimos registrados. Os dias faltantes podem ter sido tanto mais quentes ou mais frios na realidade, mas como não foram registrados, não é possível determinar se os valores registrados representam exatamente os máximos e mínimos absolutos verdadeiros. 
Tabela 9 - Temperaturas máximas absolutas, mensais e anuais, para o período de 1973-2008. JAN MAR ABR MAI JUN JUL AGO SET OUT NOV

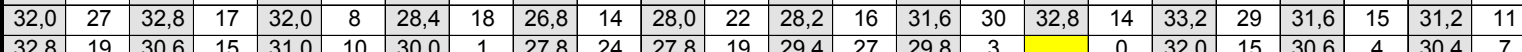
\begin{tabular}{|l|l|l|l|l|l|l|l|l|l|l|l|l|l|l|l|l|l|l|l|l|l|l|l|}
32,8 & 19 & 30,6 & 15 & 31,0 & 10 & 30,0 & 1 & 27,8 & 24 & 27,8 & 19 & 29,4 & 27 & 29,8 & 3 & & 0 & 32,0 & 15 & 30,6 & 4 & 30,4 & 7 \\
\hline 31,6 & 11 & & & & & & & & & & &
\end{tabular}

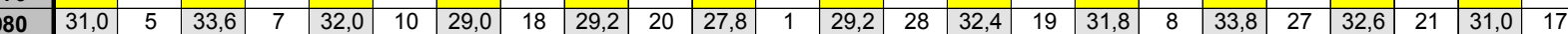
\begin{tabular}{lllllllllllllllllllllllllllllll}
31,2 & 30 & 31,6 & 14 & 34,8 & 1 & 30,4 & 8 & 29,4 & 3 & 26,4 & 15 & & 0 & 32,0 & 27 & 34,0 & 20 & 30,6 & 15 & 31,4 & 24 & 30,6 & 21 \\
\hline
\end{tabular} \begin{tabular}{|l|l|l|l|l|l|l|l|l|l|l|l|l|l|l|l|l|l|l|l|l|l|l|l|l|l|l}
31,0 & 14 & 32,6 & 15 & 30,4 & 21 & 29,8 & 4 & {$[28,0]$} & 17 & 27,4 & 14 & {$[27,2]$} & 29 & 30,4 & 25 & 32,0 & 12 & 31,2 & 27 & 32,8 & 5 & 31,2 & 1 \\
\hline
\end{tabular}

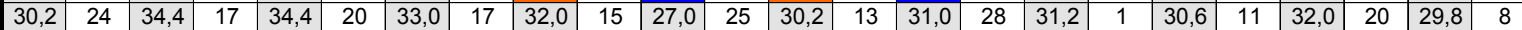

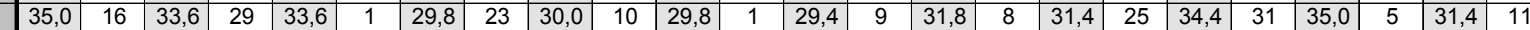

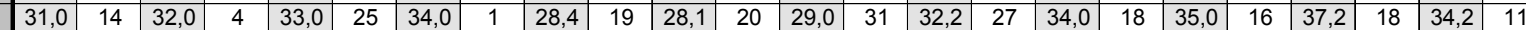
\begin{tabular}{|l|l|l|l|l|l|l|l|l|l|l|l|l|l|l|l|l|l|l|l}
32,0 & 23 & 32,2 & 2 & 31,2 & 16 & 31,4 & 7 & 30,0 & 17 & 27,0 & 15 & 29,0 & 21 & 30,0 & 5 & 33,0 & 18 & 33,0 & 8 \\
\hline
\end{tabular} \begin{tabular}{|l|l|l|l|l|l|l|l|l|l|l|l|l|l|l|l|l|l|l|l|l|l|l|l|l}
34,0 & 15 & 32,0 & 24 & 32,0 & 28 & 31,8 & 9 & 28,6 & 7 & 28,4 & 14 & 29,6 & 16 & 33,2 & 30 & 34,0 & 16 & {$[34,8]$} & 15 & {$[34,4]$} & 16 \\
\hline
\end{tabular} \begin{tabular}{|l|l|l|l|l|l|l|l|l|l|l|l|l|l|l|l|l|l|l|l|l|l|l|l|}
31,4 & 1 & 31,1 & 1 & 32,0 & 7 & 33,0 & 7 & 29,4 & 17 & 28,2 & 29 & 27,0 & 7 & 33,2 & 29 & 37,0 & 25 & 33,0 & 4 & 36,4 & 3 & 33,0 & 8 \\
\hline 32,0 & 31 & 32 & 1 & 32,0 & 12 & 31,4 & 6 & 30,2 & 1 & 27,8 & 6 & 28 & 1 & 31,8 & 8 & 32,3 & 23 & 33,2 & 25 & 33,0 & 8 & 35,6 & 26 \\
\hline
\end{tabular}

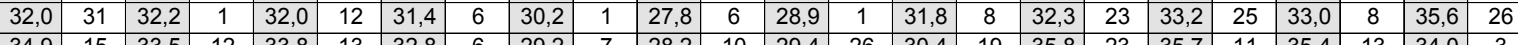

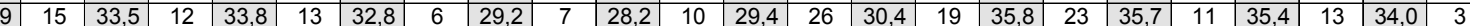

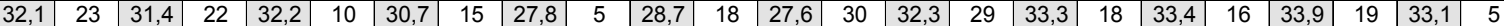

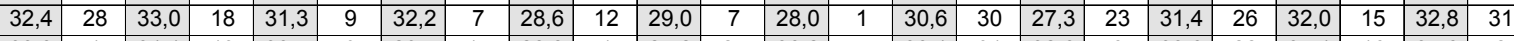

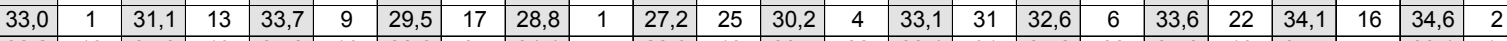

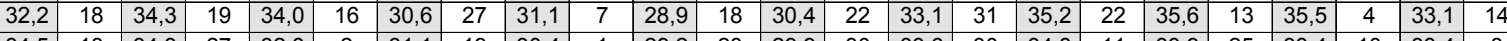

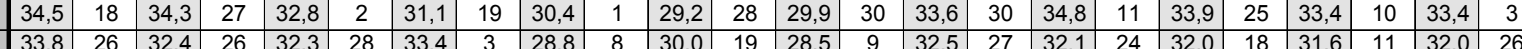
\begin{tabular}{|l|l|l|l|lllllllllllllllllllllllll}
32,1 & 7 & 32,5 & 22 & 31,3 & 13 & 29,6 & 14 & 29,7 & 2 & 27,2 & 22 & 27,8 & 16 & 31,8 & 27 & 35,1 & 9 & 35,6 & 15 & 35,4 & 10 & 34,2 & 24 \\
\hline
\end{tabular}

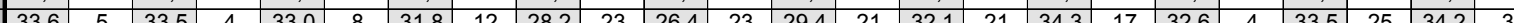

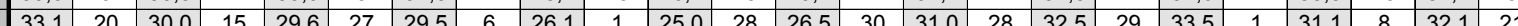
\begin{tabular}{|l|l|l|l|l|l|l|l|l|l|l|l|l|l|l|l|l|l|l|l|l|l|l|l}
31,0 & 9 & 29,6 & 26 & 29,2 & 31 & 32,0 & 9 & 30,0 & 3 & 29,0 & 25 & 28,5 & 9 & 32,8 & 26 & 32,2 & 24 & 35,0 & 22 & 31,6 & 2 & 325 & 12 \\
\hline
\end{tabular} \begin{tabular}{|l|l|l|l|l|l|l|l|l|l|l|l|l|l|l|l|l|l|l|l|l|l|l|l|l|}
33,5 & 18 & 33,1 & 24 & 32,5 & 23 & 320 & 11 & 30,5 & 3 & 28,6 & 25 & 30,2 & 20 & 31.4 & 31 & 33,7 & 10 & 33,8 & 30 & 33,6 & 9 & 32,4 & 19 \\
\hline
\end{tabular}

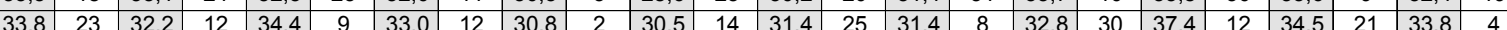

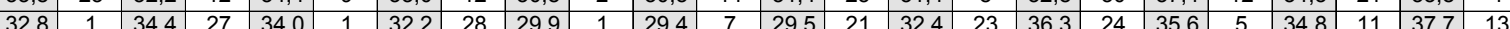

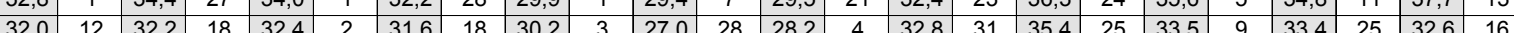

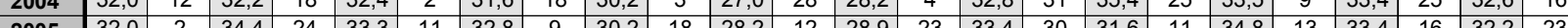

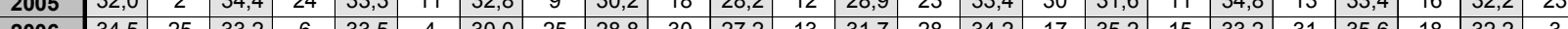
\begin{tabular}{lllllllllllllllllllllllll}
2006 & 34,5 & 25 & 33,2 & 6 & 33,5 & 4 & 30,0 & 25 & 28,8 & 30 & 27,2 & 3 & 31,7 & 28 & 34,2 & 17 & 35,2 & 15 & 33,2 & 31 & 35,6 & 18 & 32,2 & 3 \\
\hline 2007 & 32, & 11 & 33,3 & 1 & 34,0 & 28 & 33,0 & 2 & 30,2 & 16 & 29,8 & 8 & 29,6 & 22 & 31,8 & 26 & 36, & 29 & 37,0 & 29 & 334 & 1 & 34,9 & 3 \\
\hline
\end{tabular}

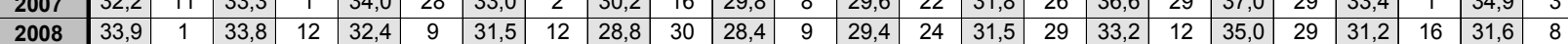

\begin{tabular}{|c|c|c|c|c|c|c|c|c|c|c|c|c|}
\hline MÁX. & 35,0 & 34,4 & 34,8 & 34,0 & 32,0 & 30,5 & 31,7 & 34,2 & 37,0 & 37,4 & 37,2 & 37,7 \\
\hline
\end{tabular}

MAX.

Falhas completas

\begin{tabular}{|c|c|}
\hline & 34,8 \\
\hline
\end{tabular}

\begin{tabular}{|l|l|}
\hline & 1985 \\
\hline
\end{tabular}

\begin{tabular}{r|r}
\hline & 1983 \\
\hline
\end{tabular}
Falhas parciais diárias acima do critério
" $5 / 10$ "
ANO

MÁX. $\quad$ Dia/mês \begin{tabular}{|c|c|}
\hline$[34,5]$ & $17 /$ set \\
\hline 33,4 & $20 /$ nov \\
\hline 33,2 & $29 /$ ut \\
\hline
\end{tabular}

\begin{tabular}{ll}
33,2 & $29 /$ out \\
\hline
\end{tabular} $[32,8] \quad 19 / j a n$

\begin{tabular}{|l|l|}
\hline 33,8 & $27 /$ out \\
\hline
\end{tabular} \begin{tabular}{|l|l|}
\hline$[34,8]$ & $1 / \mathrm{mar}$ \\
\hline
\end{tabular} \begin{tabular}{|c|c|}
\hline 32,8$]$ & $5 /$ nov \\
\cline { 2 - 2 } & $17 / \mathrm{fev}$ \\
\hline
\end{tabular} \begin{tabular}{|l|l|}
\hline 34,4 & $17 / \mathrm{fev}$ \\
\hline 35,0 & $16 / \mathrm{jan}$ \\
\hline
\end{tabular} 37,2 18/nov $[33,0] \quad 18 /$ set $\begin{array}{ll}{[34,8]} & 15 / \text { out } \\ & \end{array}$ \begin{tabular}{|l|l|}
\hline 37,0 & $25 /$ set \\
\hline 35,6 & $26 /$ dez \\
\hline
\end{tabular} \begin{tabular}{l|l|}
35,6 & $26 / \mathrm{dez}$ \\
\hline 35,8 & $23 / \mathrm{set}$ \\
\hline
\end{tabular} \begin{tabular}{l|l|}
35,8 & $23 /$ set \\
\hline 33,9 & $19 / n o v$ \\
\hline
\end{tabular} \begin{tabular}{|l|l|}
33,9 & $19 / \mathrm{nov}$ \\
\hline 33,0 & $18 / \mathrm{fev}$ \\
\hline 34,6 & $2 / \mathrm{ez}$
\end{tabular} $34,6 \quad 2 / \mathrm{dez}$ \begin{tabular}{l|l}
334,6 & $2 / \mathrm{dez}$ \\
\hline 35,6 & $13 /$ out \\
\hline
\end{tabular} \begin{tabular}{|l|l|}
\hline 35,6 & $13 /$ out \\
\hline 34,8 & $11 / \mathrm{set}$ \\
\hline
\end{tabular} \begin{tabular}{|l|l|}
\hline 34,8 & $11 /$ set \\
\hline 33,8 & $26 / j a n$ \\
\hline
\end{tabular} \begin{tabular}{|l|l|}
33,8 & $26 /$ jan \\
\hline 35,6 & $15 /$ out \\
\hline 34,3 & $17 /$ set
\end{tabular} \begin{tabular}{l|l|}
35,6 & $15 /$ out \\
\hline 34,3 & $17 /$ st \\
\hline
\end{tabular} \begin{tabular}{|c|c|}
\hline 34,3 & $17 /$ set \\
\hline 335 & $1 /$ out \\
\hline
\end{tabular} \begin{tabular}{l|l|}
35,0 & $22 /$ out \\
\hline
\end{tabular} \begin{tabular}{|l|l|}
33,8 & $10 / \mathrm{set}$ \\
\hline
\end{tabular} \begin{tabular}{|l|l|}
37,4 & $12 /$ out \\
\hline
\end{tabular} \begin{tabular}{l|l}
\hline 37,7 & $13 / \mathrm{dez}$ \\
\hline
\end{tabular} \begin{tabular}{|l|l|}
35,4 & $25 /$ set \\
\hline 34,8 & $13 /$ out \\
\hline
\end{tabular} \begin{tabular}{|c|c|}
34,8 & $13 /$ out \\
\hline 35,6 & $18 /$ nov \\
\hline 37,0 & $29 /$ out \\
\hline
\end{tabular} 29/out 37,7 13/dez \begin{tabular}{|l|l|}
37,7 & 2003 \\
\hline
\end{tabular} Falhas parciais diárias abaixo do critério
"5/10"

[ ] Os valores exibidos são os valores registrados, não correspondem, necessariamente, aos valores máximos que ocorreram de fato. 
Tabela 10 - Temperaturas mínimas absolutas, mensais e anuais, para o período de 1973-2008. JAN FEV MAR MAI JUN AGO SET OUT NOV

DEZ

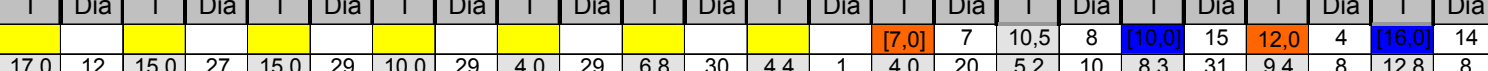

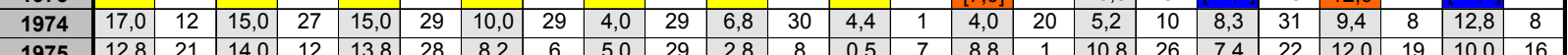

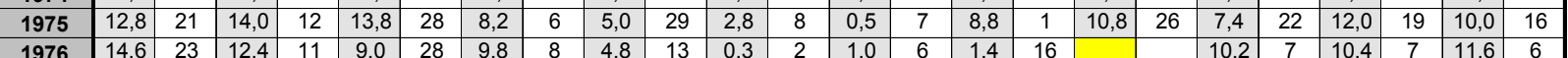

1976

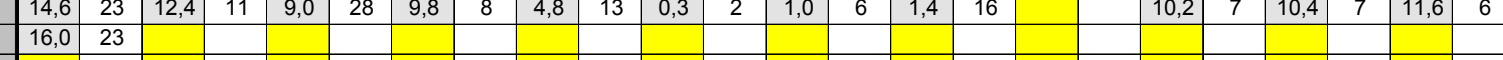
1978

1979

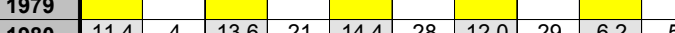

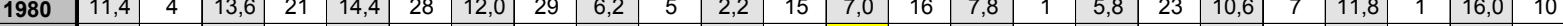

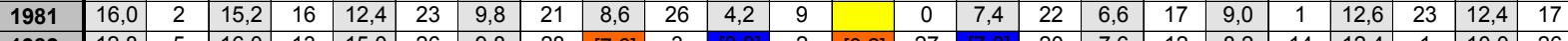

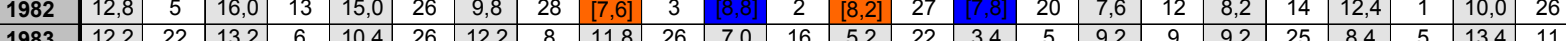

\begin{tabular}{|l|l|l|l|l|l|l|l|l|l|l|l|l|l|l|l|l|l|l|l|l|l|l|l|l|l|l|}
1983 & 12,2 & 22 & 13,2 & 6 & 10,4 & 26 & 12,2 & 8 & 11,8 & 26 & 7,0 & 16 & 5,2 & 22 & 3,4 & 5 & 9,2 & 9 & 9,2 & 25 & 8,4 & 5 & 13,4 & 11 \\
\hline 1984 & 14,0 & 1 & 14,0 & 11 & 14,2 & 24 & 11,0 & 2 & 6,8 & 31 & 5,2 & 11 & 5,2 & 23 & 1,2 & 27 & 5,8 & 11 & 8,2 & 1 & 12,2 & 15 & 12,4 & 23 \\
\hline
\end{tabular}

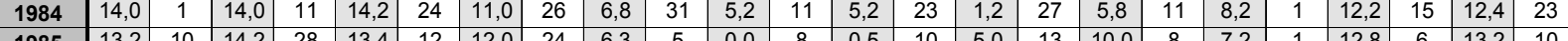

\begin{tabular}{l|l|l|l|l|l|l|l|l|l|l|l|l|l|l|l|l|l|l|l|l|l|l|l|l|l|l|l|l|l|l|l|l|l|l|l}
1985 & 13,2 & 10 & 14,2 & 28 & 13,4 & 12 & 12,0 & 24 & 6,3 & 5 & 0,0 & 8 & 0,5 & 10 & 5,0 & 13 & 10,0 & 8 & 7,2 & 1 & 12,8 & 6 & 13,2 & 10 \\
\hline
\end{tabular}

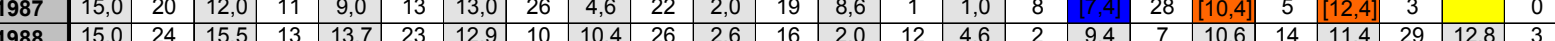

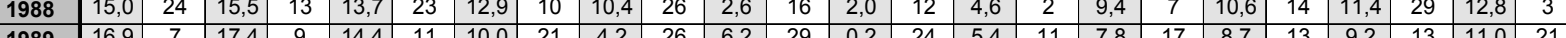

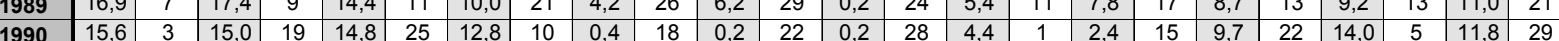

\begin{tabular}{|l|l|l|l|l|l|l|l|l|l|l|l|l|l|l|l|l|l|l|l|l|l|l|l|l|l|l}
1991 & 15,2 & 5 & 12,4 & 24 & 14,6 & 16 & 10,4 & 26 & 6,7 & 31 & 5,8 & 11 & 2,2 & 23 & 5,1 & 16 & 6,2 & 1 & 9,6 & 10 & 12,6 & 5 & 13,2 & 3 \\
\hline
\end{tabular}

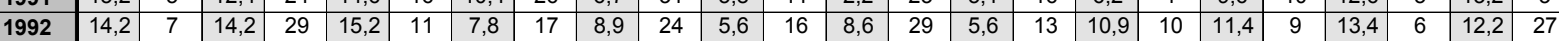

\begin{tabular}{|l|l|l|l|l|l|l|l|l|l|l|l|l|l|l|l|l|l|l|l|l|l|l|l|l|l|l|l|l|l|l}
1993 & 17,0 & 19 & 15,0 & 24 & 15,9 & 12 & 12,0 & 27 & 7,7 & 20 & 3,1 & 19 & 3,0 & 31 & 3,7 & 11 & 8,2 & 12 & 6,1 & 7 & 10,6 & 3 & 12,4 & 29 \\
\hline
\end{tabular}

\begin{tabular}{|l|l|l|l|l|l|l|l|l|l|l|l|l|l|l|l|l|l|l|l|l|l|l|l|l|}
1994 & 13,4 & 10 & 16,2 & 8 & 2,5 & 26 & 8,2 & 7 & 7,5 & 16 & 1,2 & 27 & 1,2 & 10 & 4,0 & 5 & 8,4 & 10 & 10,8 & 7 & 11,0 & 20 & 11,4 & 27 \\
\hline
\end{tabular}

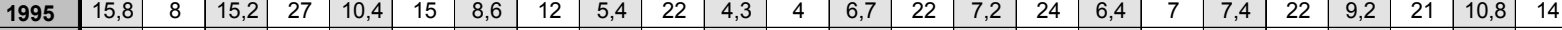

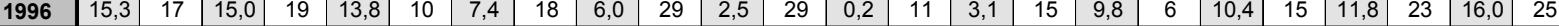

\begin{tabular}{|l|l|l|l|l|l|l|l|l|l|l|l|l|l|l|l|l|l|l|l|l|l|l|l|l|l|l|}
1997 & 16,1 & 3 & 15,7 & 3 & 12,5 & 27 & 8,5 & 28 & 7,2 & 31 & 1,8 & 8 & 4,5 & 26 & 2,4 & 10 & 5,4 & 7 & 8,5 & 3 & 13,1 & 28 & 13,7 & 10 \\
\hline
\end{tabular}

\begin{tabular}{|l|l|l|l|l|l|l|l|l|l|l|l|l|l|l|l|l|l|l|l|l|l|l|l|l|l|l}
1998 & 14,7 & 9 & 14,8 & 16 & 11,5 & 26 & 4,2 & 30 & 5,0 & 1 & 2,4 & 7 & 3,0 & 16 & 5,8 & 2 & 7,5 & 23 & 6,6 & 4 & 10,0 & 11 & 11,7 & 18 \\
\hline
\end{tabular}

\begin{tabular}{|l|l|l|l|l|l|l|l|l|l|l|l|l|l|l|l|l|l|l|l|l|l|l|l|l|l|}
1999 & 16,8 & 27 & 14,0 & 23 & 13,0 & 20 & 2,0 & 18 & 2,0 & 21 & 4,0 & 23 & 5,5 & 13 & 3,0 & 17 & 7,2 & 25 & 9,0 & 11 & 0,0 & 1 & 13,0 & 17 \\
\hline 2000 & 12,5 & 29 & 12,8 & 9 & 12,4 & 9 & 9,0 & 21 & 4,0 & 30 & 35 & 22 & 0,2 & 18 & 7,1 & 5 & 10,6 & 5 & 10,8 & 1 & 14,5 & 16 & 15,0 & 2 \\
\hline
\end{tabular}

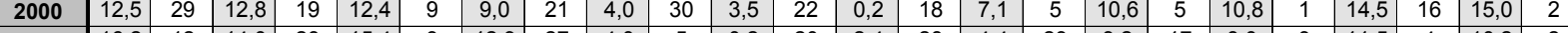

\begin{tabular}{ll|l|l|l|l|l|l|l|l|l|l|l|l|l|l|l|l|l|l|l|l|l|l|l|l|}
2001 & 16,2 & 12 & 14,0 & 28 & 15,4 & 3 & 12,9 & 27 & 4,0 & 5 & 0,2 & 20 & 2,4 & 28 & 4,4 & 23 & 3,2 & 17 & 8,0 & 3 & 11,5 & 4 & 10,2 & 2 \\
\hline
\end{tabular}

\begin{tabular}{|l|l|l|l|l|l|l|l|l|l|l|l|l|l|l|l|l|l|l|l|l|l|l|l|l|l|}
2002 & 12,6 & 16 & 12,4 & 14 & 13,4 & 30 & 10,5 & 26 & 7,7 & 24 & 5,7 & 20 & 0,8 & 7 & 9,1 & 12 & 1,5 & 2 & 10,2 & 2 & 11,2 & 7 & 15,5 & 26 \\
\hline
\end{tabular}

\begin{tabular}{|l|l|l|l|l|l|l|l|l|l|l|l|l|l|l|l|l|l|l|l|l|l|l|l|l|}
2003 & 17,0 & 7 & 14,3 & 18 & 15,0 & 28 & 11,0 & 12 & 4,0 & 7 & 6,4 & 21 & 5,7 & 2 & 2,4 & 17 & 5,8 & 11 & 6,6 & 15 & 9,0 & 4 & 12,8 & 9 \\
\hline
\end{tabular}

\begin{tabular}{ll|l|l|l|l|l|l|l|l|l|l|l|l|l|l|l|l|l|l|l|l|l|l|l|l|}
2004 & 11,4 & 18 & 11,9 & 26 & 11,4 & 21 & 6,0 & 29 & 4,4 & 26 & 3,6 & 12 & 3,5 & 26 & 1,0 & 13 & 8,0 & 15 & 6,8 & 6 & 7,6 & 12 & 11,3 & 12 \\
\hline
\end{tabular}

\begin{tabular}{|l|l|l|l|l|l|l|l|l|l|l|l|l|l|l|l|l|l|l|l|l|l|l|l|l|}
2005 & 13,4 & 26 & 10,5 & 8 & 11,9 & 4 & 9,8 & 30 & 6,0 & 5 & 5,4 & 25 & 2,9 & 9 & 3,0 & 9 & 4,6 & 2 & 12,4 & 31 & 10,5 & 1 & 10,6 & 3 \\
\hline
\end{tabular}

\begin{tabular}{|l|l|l|l|l|l|l|l|l|l|l|l|l|l|l|l|l|l|l|l|l|l|l|l|l|l|l|l|}
2006 & 13,0 & 12 & 13,4 & 1 & 15,1 & 12 & 9,6 & 20 & 4,0 & 22 & 4,1 & 28 & 2,8 & 5 & 4,0 & 23 & 3,0 & 5 & 9,8 & 21 & 9,4 & 10 & 15,2 & 1 \\
\hline 2007 & 1 & 19 & 140 & 12 & 120 & 21 & 14, & 28 & 45 & 24 & 2, & 4 & 3,8 & 25 & 7,8 & 17 & 10,5 & 30 & 9,2 & 1 & 11,2 & 29 & 12, & 2 \\
\hline
\end{tabular}

\begin{tabular}{l|cc|c|c|c|c|c|c|c|c|c|c|c|c|c|c|c|c|c|c|c|c|c|c|}
$\mathbf{2 0 0 7}$ & 16,9 & 19 & 14,0 & 12 & 12,0 & 21 & 14,2 & 28 & 4,5 & 24 & 2,6 & 4 & 3,8 & 25 & 7,8 & 17 & 10,5 & 30 & 9,2 & 1 & 11,2 & 29 & 12,9 & 2 \\
\hline $\mathbf{2 0 0 8}$ & 11,8 & 30 & 15,8 & 2 & 14,0 & 31 & 10,0 & 23 & 5,0 & 7 & 4,3 & 17 & 4,4 & 16 & 4,7 & 28 & 5,0 & 23 & 9,8 & 3 & 11,2 & 20 & 12,5 & 4 \\
\hline
\end{tabular}

\begin{tabular}{|c|c|c|c|c|c|c|c|c|c|c|c|c|}
\hline MíN. & 11,4 & 10,5 & 9,0 & 2,0 & 0,4 & 0,0 & 0,2 & 1,0 & 1,5 & 6,1 & 7,6 & 10,0 \\
\hline
\end{tabular}

Ano

\begin{tabular}{l|c|c|c|c|}
\hline 1980 & 2005 & 1087 & \\
\hline
\end{tabular}

Falhas completas

Falhas parciais diárias acima do critério
" $5 / 10 "$

\begin{tabular}{|l|c|c|c|c|}
\hline 2002 & 1993 & 2004 & 1982 \\
\hline
\end{tabular}

Falhas par

\footnotetext{
[ ] Os valores exibidos são os valores registrados, não correspondem, necessariamente, aos valores minimos que ocorreram de fato.
} 
Novamente, com o intuito de permitir uma compreensão mais imediata dos valores apresentados, a visualização gráfica das temperaturas máximas e mínimas é proporcionada, respectivamente, pelos gráficos (A) e (B) da Figura 55.

Pelo gráfico (A) da Figura 55, é possível notar que existe uma tendência de aumento da temperatura máxima absoluta, tanto quando se utiliza os dados dos meses incompletos e com falhas (regressão linear, reta tracejada preta) quanto quando são utilizados somente os anos com meses completos (reta contínua vermelha). O aumento médio da temperatura máxima absoluta nos 35 anos analisados (1973-2008) foi de $1,8^{\circ} \mathrm{C}$ ao utilizar os anos com meses completos e sem falhas, e de $2,1^{\circ} \mathrm{C}$ com base nos dados que incluem os anos com meses incompletos.
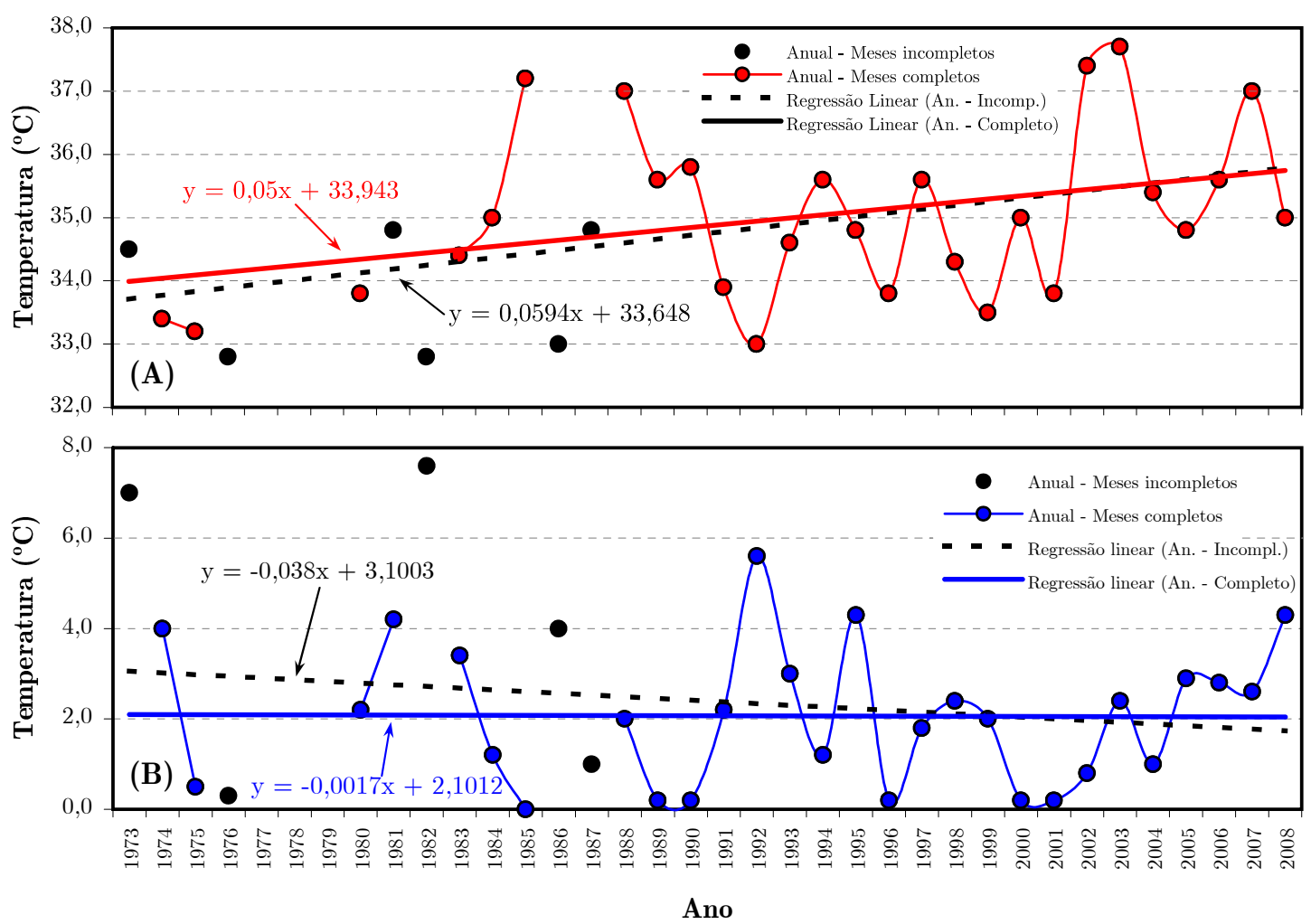

Figura 55 - Valores anuais das temperaturas absolutas (A) máximas e (B) mínimas, e respectivas tendências para o período de 1973-2008.

Em relação ao comportamento das temperaturas mínimas absolutas, pelo gráfico (B) da Figura 55, é possível notar que existe uma tendência de quase manutenção de uma constante quando são utilizados os dados dos meses completos (reta de regressão linear contínua azul), porém, quando se utiliza os 
anos com meses incompletos e com falhas diárias (reta tracejada preta) a tendência é de resfriamento. A redução média da temperatura mínima absoluta no período $1973-2008$ foi de $0,1^{\circ} \mathrm{C}$ ao utilizar os anos com meses completos e sem falhas, e de $1,3^{\circ} \mathrm{C}$ com base nos dados que incluem os anos com meses incompletos. A diferença é devido ao fato de que os anos de 1973 e 1982 apresentarem valores registrados de mínimos absolutos consideravelmente altos, decorrente das falhas que nos dois anos nos meses mais frios da estação de inverno. $\mathrm{Ou}$ seja, os registros não permitem alegar que estes anos fizeram menos frio.

Este primeiro tipo de abordagem já induz às investigações dos valores e seus significados individuais em relação aos demais e ao conjunto todo da série. Uma vez com os dados disponibilizados e passados por um controle de qualidade, com as médias calculadas dos valores diários, mensais, anuais e normais, é consequência natural averiguar quais as tendências observadas nestas diferentes escalas.

\subsubsection{Tendências}

As tendências são determinadas por meio da reta de regressão linear que melhor se ajusta aos dados em uma série temporal. Uma forma de representar os dados pode ser utilizando os dados no formato natural em que eles se apresentam, vide as temperaturas máximas e mínimas absolutas, ou então podem ser exibidos em termos de desvios em relação ao valor médio do período. Neste segundo caso, a média aritmética dos valores disponíveis de temperatura é calculada, e para cada ano realiza-se a diferença entre o valor anual e o valor médio. Se o valor dessa diferença for positivo, quer dizer que o ano é mais quente que o valor médio; e se for negativo, significa que o ano é mais frio que a média do período total. Sobre estes desvios pode ser determinada a reta de regressão linear, indicando qual a tendência média observada no período total.

Uma primeira composição utilizando desvios e tendência é apresentada na Figura 56. Com base nos valores normais anuais das temperaturas média, máxima e mínima, são exibidos os respectivos gráficos (A), (B) e (C) nesta figura. Em vermelho estão representados os anos que apresentam valores acima do valor médio do período, e em verde, estão os anos com valores inferiores. Em 
azul está representada uma curva de média móvel a cada 2 anos, e em preto a reta de regressão linear exprime a tendência.

Para o caso da temperatura média (Figura 56-A), a tendência é de aquecimento, que foi da ordem de $0,13^{\circ} \mathrm{C}$ em 35 anos (valor obtido pela multiplicação do coeficiente angular da reta de regressão pela quantidade de anos do período total, ou seja, 0,0085 × 35). Mas ao mesmo tempo, é possível notar que existe uma variabilidade natural com alternância de anos bem mais frios que a média (1976 e 1999) e anos mais quentes (1984, 2002 e 2007).

Analisando as normais anuais da temperatura máxima média (gráfico (Figura 56-B), verifica-se um aumento mais significativo: a tendência foi de $1,00^{\circ} \mathrm{C}$. No entanto, embora os dias possam estar ficando mais quentes, as noites parecem estar ficando mais frias. É o que o gráfico (C) da Figura 56 indica para as normais anuais das temperaturas mínimas médias: a tendência é de resfriamento de $0,74^{\circ} \mathrm{C}$ nos 35 anos analisados. Considerando estes três gráficos conjuntamente - supondo que nenhuma heterogeneidade não-climática seja o motivo das alterações dos valores, e sim fatores climáticos que determinaram estas mudanças - infere-se que na região representativa à coleta dos dados apresentou, nos 35 anos, um aumento da amplitude de variação da temperatura, ou seja, as temperaturas máximas estão maiores e as mínimas menores, resultando, na média, em um aquecimento local. Os dias estão ficando mais quentes, e as noites mais frias. Na média, a magnitude do aquecimento durante o dia (horário em que ocorrem as temperaturas máximas) é maior que a magnitude de redução dos valores mínimos, implicando assim na tendência de aumento do valor médio.

O mesmo tipo de análise pode ser feito utilizando-se dos valores mensais invés dos anuais. Os gráficos da Figura $\mathbf{5 7}$ apresentam os valores "brutos" da temperatura (não estão na forma de desvios), e neles as tendências estão indicadas em retas de regressão linear. Em comparação com as retas apresentadas na Figura 56, com os desvios anuais, a inclinação visual das retas dos gráficos da Figura $\mathbf{5 7}$ com valores mensais é consideravelmente menor. No caso da temperatura média (Figura 57-A), é quase imperceptível, a olho nu, verificar alguma inclinação ou indicação de tendência de aumento nos valores da temperatura. 

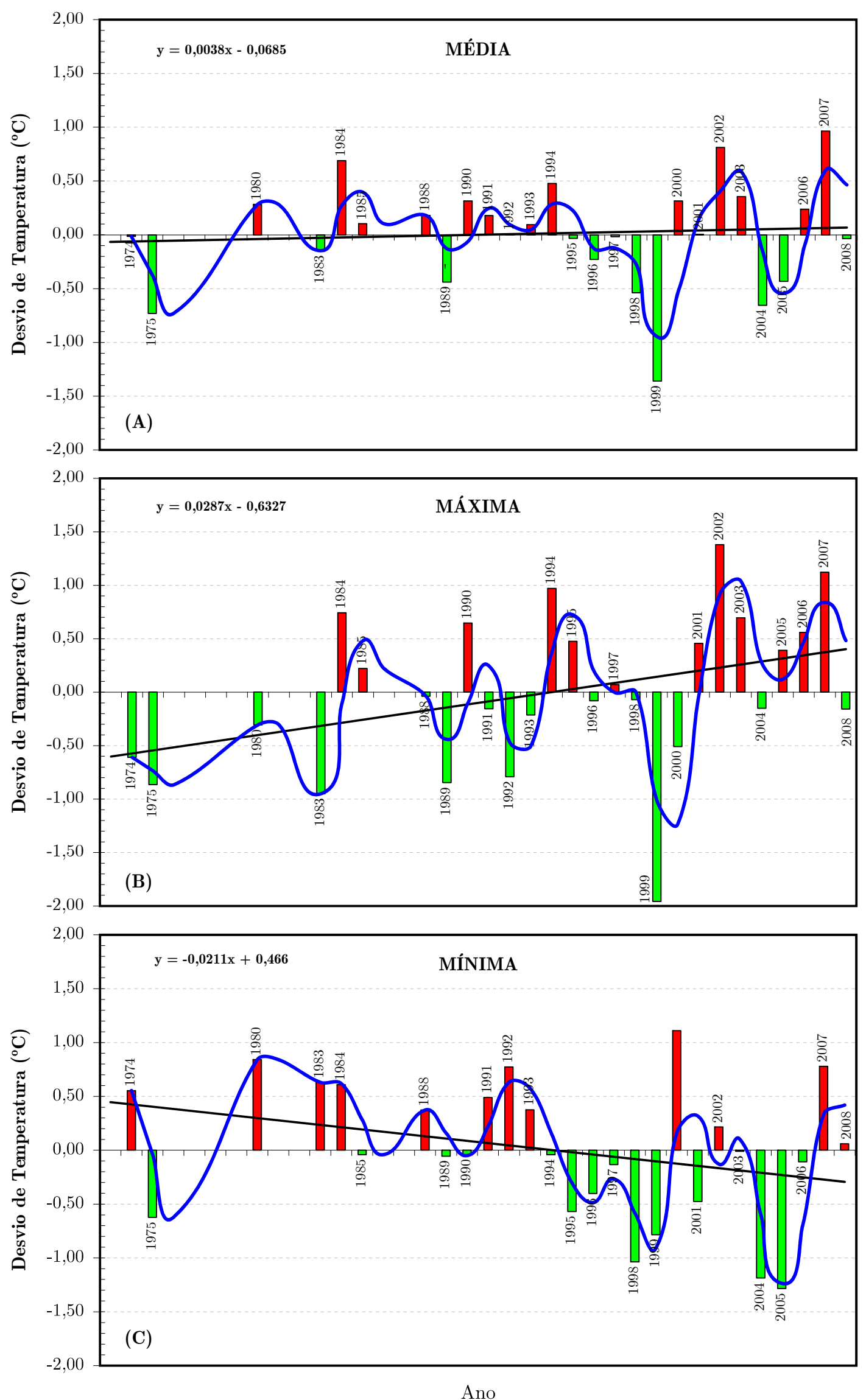

Figura 56 - Desvios e tendências das temperaturas (A) médias, (B) máximas e (C) mínimas, para o período de 1973-2008. 
A diferença entre as duas representações gráficas ocorre porque as escalas verticais das figuras são diferentes. Quando se exibem desvios, qualquer variação pequena, da ordem de $0,1^{\circ} \mathrm{C}$, já é perceptível no gráfico que possui uma escala de $4^{\circ} \mathrm{C}$ de amplitude. Já no gráfico em que estão plotados os valores brutos, a amplitude de variação de temperatura é mais que 3 vezes maior, na ordem de $12^{\circ} \mathrm{C}$ ou mais. Esta alteração na escala apenas dá uma impressão diferente do mesmo fenômeno, onde o uso de desvios, com escala reduzida, proporciona um efeito visual amplificador de diferenças.

Entretanto, ao verificar os coeficientes angulares das retas de regressão lineares correspondentes nos gráficos da Figura 56 e Figura 57, nota-se que os valores se distinguem um pouco. Caso não houvesse nenhuma falha em toda série de temperatura, os valores deveriam ser idênticos. Mas como existem muitos dias, meses completos e até anos com dados faltantes, os coeficientes angulares se diferem. Isto ocorre pois o cálculo das normais com médias possui um efeito simplificador da realidade e da variabilidade do clima. Além disso, alguns anos não foram considerados nos cálculos dos desvios, uma vez que não foram calculadas as normais anuais dos anos com um ou mais meses incompletos. Logo, a utilização dos valores mensais seria uma abordagem mais próxima e condizente com as variações reais. Com o uso de valores mensais, a reta de regressão é calculada com base em todos os valores mensais disponíveis e utilizáveis, ao invés de um único valor anual determinado nas normais.

Verificando a magnitude das tendências obtidas pelas retas de regressão linear dos gráficos da Figura 57, constata-se que: a temperatura média teve um aumento de $0,17^{\circ} \mathrm{C}$; a temperatura máxima sofreu aumento de $1,17^{\circ} \mathrm{C}$; e a temperatura mínima foi de $0,91^{\circ} \mathrm{C}$. Uma composição com as variações mensais das temperaturas médias, máximas e mínimas é mostrada na Figura 58. No mesmo gráfico, fica mais fácil observar as variações relativamente umas as outras, além de perceber a tênue tendência de aumento da amplitude das temperaturas. 

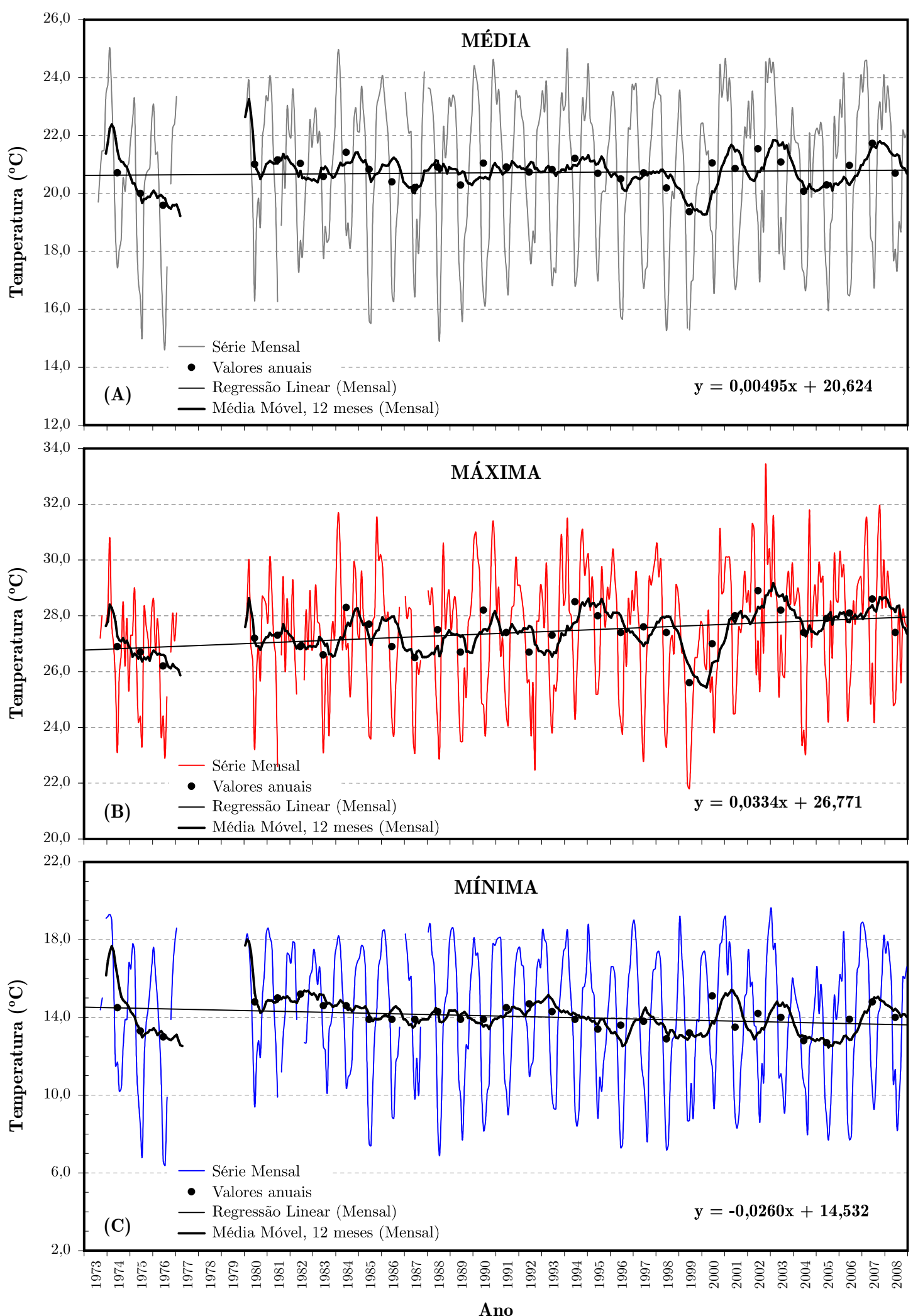

Figura 57 - Temperaturas mensais (A) médias, (B) máximas e (C) mínimas, com respectivas tendências para o período de 1973-2008. 


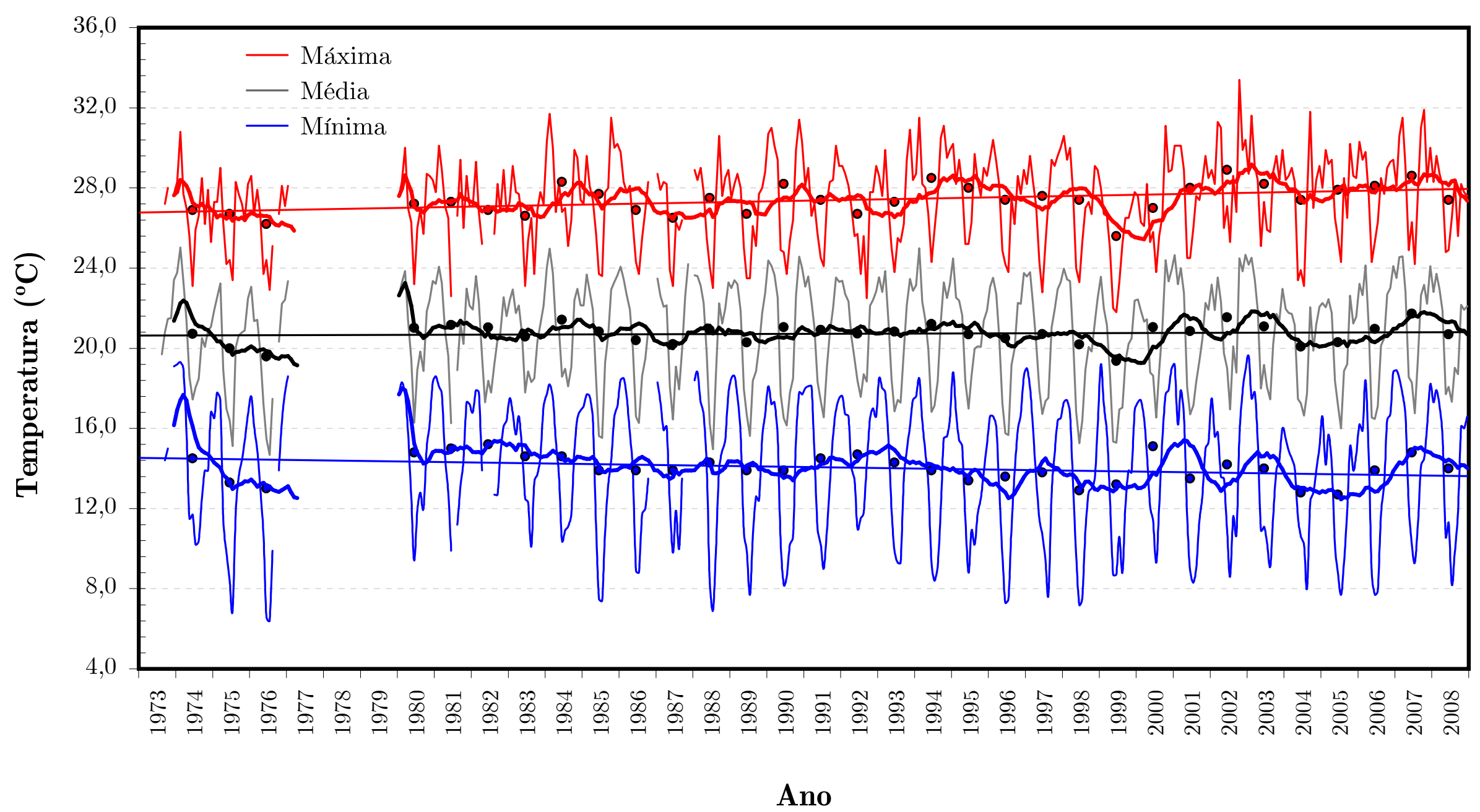

Figura 58 - Composição unificada das temperaturas mensais médias, máximas e mínimas no período de 1973-2008. 
Apresentadas as variações em escalas anuais e mensais, por fim é interessante analisar a comparação com base nos valores diários da temperatura do ar. Tal comparação é apresentada na Figura 59. Novamente, observa-se que as retas de tendência não apresentam a mesma inclinação das figuras precedentes. A primeira razão da diferença visual é, analogamente, a diferença da escalas de temperaturas adotadas. O segundo motivo que explica a diferença dos coeficientes angulares é a utilização de todos os valores diários de temperatura presentes na série, sendo esta abordagem é mais próxima ainda da realidade. Uma vez que os cálculos das normais envolvem critérios de exclusão de meses que apresentem uma determinada quantidade de lacunas de dados diários, a análise de todos os dados diários disponíveis, a princípio, condiz de maneira mais próxima às condições reais.

$\mathrm{Na}$ Figura 59, os valores obtidos pelas retas de regressão linear são: aumento de $0,16^{\circ} \mathrm{C}$ da temperatura média; aumento de $1,18^{\circ} \mathrm{C}$ da temperatura máxima; e redução de $0,87^{\circ} \mathrm{C}$ da temperatura mínima. A Tabela 11 resume os valores das tendências obtidas quando são utilizados dados em diferentes escalas (anual, mensal e diária). Em relação às tendências obtidas com dados mensais e diários, as tendências com base nos valores anuais - que são as mais utilizadas nos estudos do clima - apresentam valores de temperatura média e mínima menores, e valor intermediário da temperatura mínima. Apesar da difundida utilização de tendências com base e valores anuais, a tendência fundamentada nos valores diários são mais realistas, pois utilizam todos os valores disponíveis da série. A ocorrência de falhas diárias e a aplicação dos critérios de exclusão de meses e anos com dados faltantes impedem a utilização de vários muitos valores diários. 

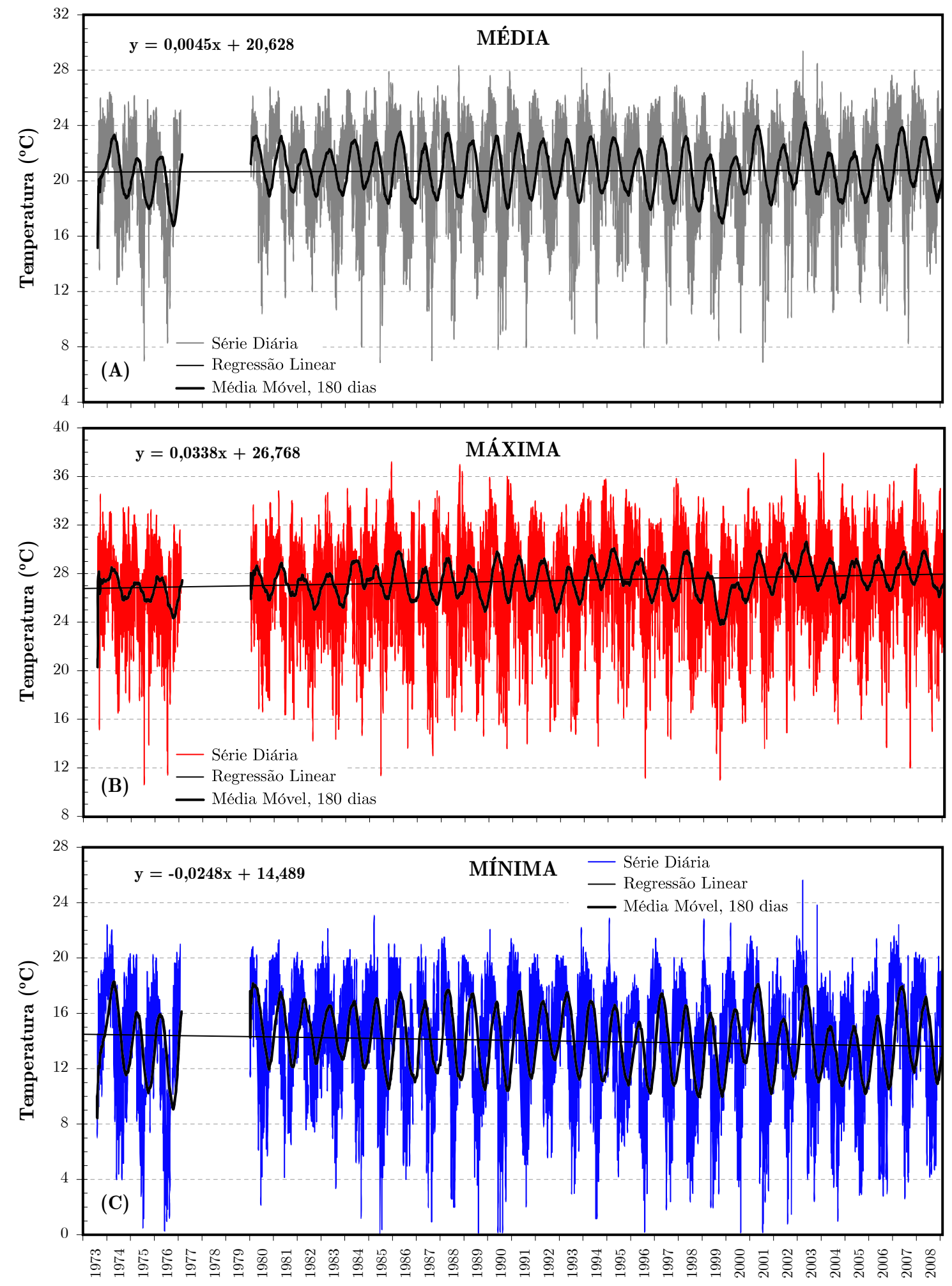

Ano

Figura 59 - Temperaturas diárias (A) médias, (B) máximas e (C) mínimas, com respectivas tendências para o período de 1973-2008.

Para ser ter uma ideia melhor do motivo das diferenças nos valores das tendências obtidas pelos dados anuais, mensais e diários, basta fazer um 
levantamento da quantidade de dados diários utilizados em cada escala. Na escala diária, obviamente, todos os valores diários compuseram o cálculo da tendência; na escala mensal, 123 dias foram descartados nos meses com muitas falhas; e na escala anual - em que foram desconsiderados os anos 1973, 1976, 1977, 1981, 1982, 1986 e 1987 - não foram levados em consideração 1507 dias, pois os anos citados não tiveram a média anual calculada devido à falta de um ou mais meses. Nos casos dos anos de 1973 e 1977, para se evitar uma representatividade não ideal, é compreensível e razoável que não sejam utilizados os escassos dados de cada ano, que são, respectivamente, menos da metade de um ano (141 dias) e um mês (31 dias). Porém, nos demais anos, apenas um mês ou dois não possuem dados diários, desconsiderando os demais valores diários disponíveis, que variam de 298 a 336 dias do total com valores presentes.

De qualquer forma, todas as tendências indicam, em diferentes intensidades, que está ocorrendo aquecimento dos dias e resfriamento das noites, com uma tendência de aumento da temperatura média diária.

Tabela 11 - Tendências de temperatura $\left({ }^{\circ} \mathrm{C}\right)$ relativas

às diferentes escalas temporais de abordagem

\begin{tabular}{lccc}
\hline \hline \multirow{2}{*}{ Temperatura } & \multicolumn{3}{c}{ Dados } \\
\cline { 2 - 4 } & Anuais & Mensais & Diários \\
\hline Média & 0,13 & 0,17 & 0,16 \\
Máxima & 1,00 & 0,91 & 1,18 \\
Mínima & $-0,74$ & $-1,17$ & $-0,87$ \\
\hline
\end{tabular}

Uma composição que permite a visualização, em uma escala única, das variações diárias das temperaturas médias, máximas e mínimas é oferecida na Figura 60. Analisando visualmente, de fato não existe, aparentemente, nenhuma heterogeneidade evidente, ou seja, nenhuma mudança brusca nos valores, como um salto ou queda abrupta, dando maior credibilidade à consideração feita no controle de qualidade. Outro aspecto interessante diz respeito à alta frequência de variações apresentadas. Conforme se faz a redução das escalas temporais anuais, mensais até a escala diária, é possível perceber a magnitude das variações e, assim, ponderar e contextualizar a relevância relativa dos valores exibidos. Embora erros sejam frequentes, variando desde alguns décimos (ordem 
de grandeza de $10^{-1}$ ) até algumas poucas unidades de graus centígrados (ordem de grandeza de $10^{\circ}$ ), a Figura 60 evidencia que a amplitude de variação da temperatura é significativamente superior, apresentando valores com amplitude de variação na ordem de, na média, $13,0^{\circ} \mathrm{C}$ (ordem de grandeza de $10^{1}$ ).

A amplitude de variação representada na Figura 61 é obtida pela diferença dos valores diários da temperatura máxima pelos valores da temperatura mínima. Os valores máximos e mínimos das amplitudes são respectivamente 28,0 e $0,2^{\circ} \mathrm{C}$. Claro que estes valores não devem ser reais; não é possível que algum dia tenha tido uma diferença de apenas $0,2^{\circ} \mathrm{C}$ entre a temperatura máxima e a mínima. Tais extremos são devidos a algum erro na leitura dos instrumentos ou digitação incorreta dos valores em planilha eletrônica. Para se ter valores mais compatíveis com a realidade, considere-se apenas o intervalo de $95 \%$ de confiança, que compreende o intervalo de 6,8 a $21,9^{\circ} \mathrm{C}$ da variação da amplitude de temperatura diária. A tendência de aumento da amplitude da temperatura também está resumida pela reta de regressão linear, que permite inferir, pelo coeficiente angular, que no período de 1973-2008, a amplitude aumentou em $2,0^{\circ} \mathrm{C}$ (de 12,3 para $14,3^{\circ} \mathrm{C}$ ). 


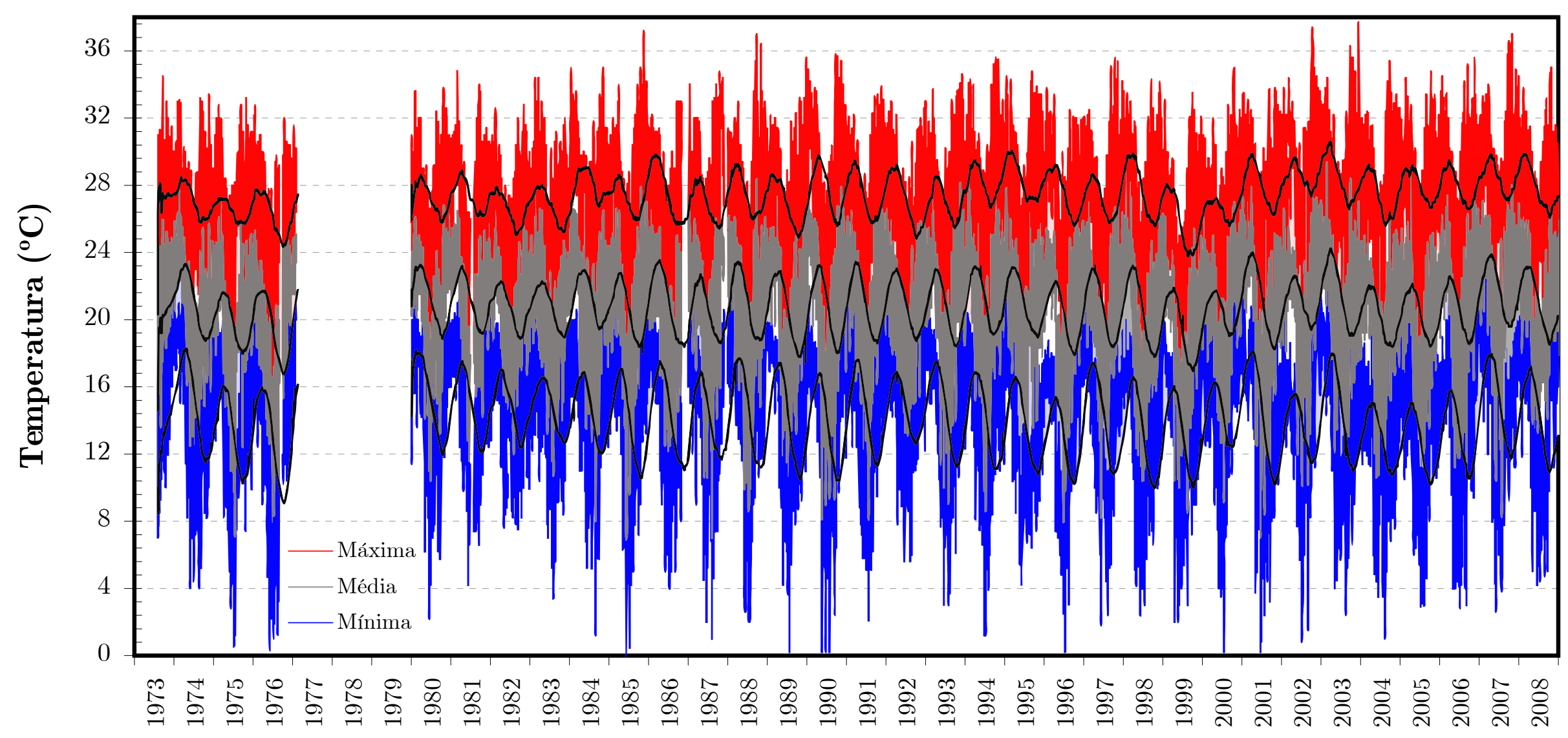

Ano

Figura 60 - Composição unificada das temperaturas diárias médias, máximas e mínimas no período de 1973-2008. 


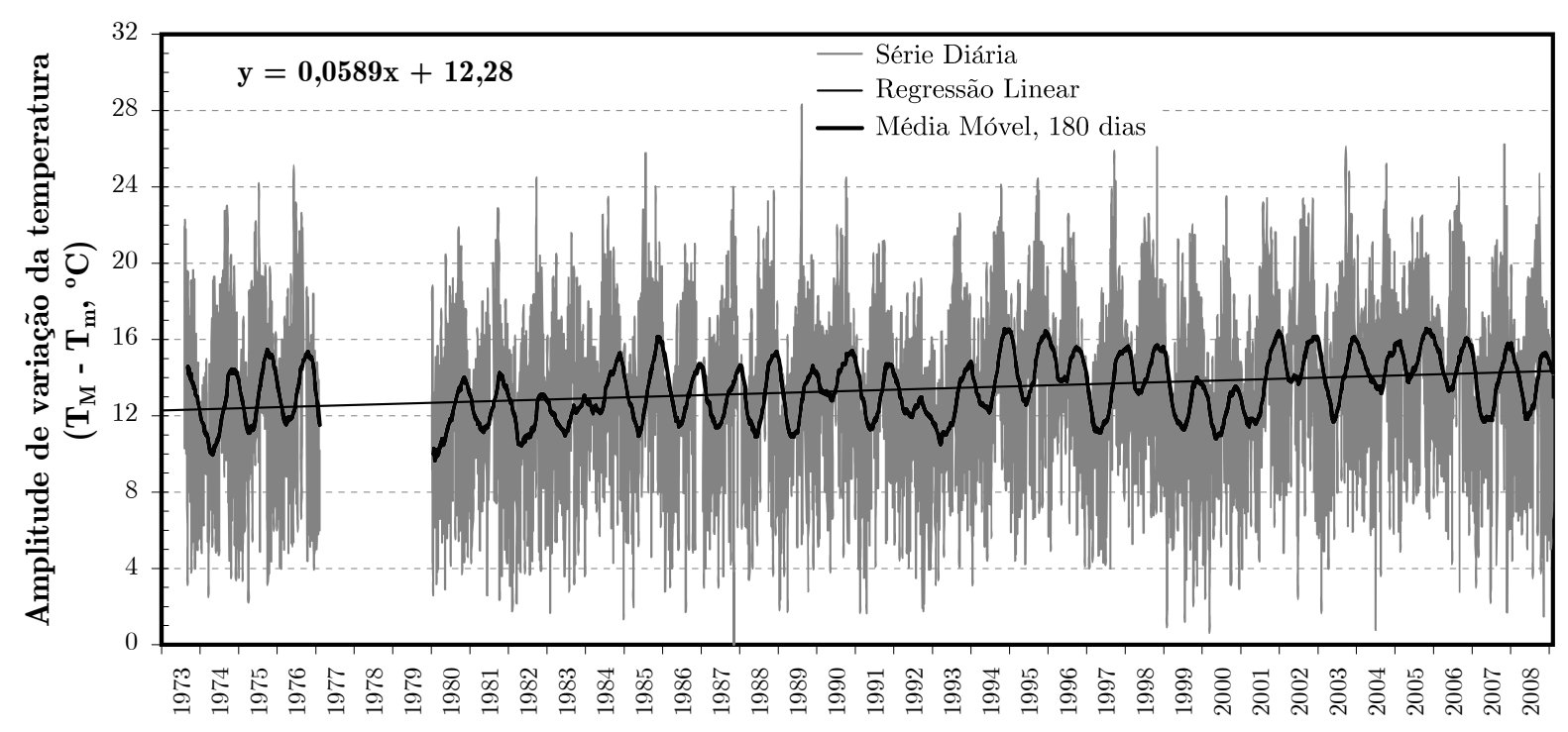

Ano

Figura 61 - Amplitudes de variação da temperatura e tendência de suas variações, obtidas pela diferença dos valores diários da temperatura máxima pelos valores da temperatura mínima.

\subsubsection{Comparações de diferentes fórmulas: implicações a curto, médio e longo prazo}

Elaborada a caracterização geral por meio das normais, e determinadas as tendências utilizando-se da maior série de temperatura (com base nas temperaturas máximas e mínimas), agora se prossegue com a avaliação e a comparação dos valores obtidos por diferentes fórmulas. São verificadas de que forma os erros advindos destas mudanças podem culminar em alterações nas respectivas tendências de acordo com cada método de cálculo utilizado.

Duas etapas principais foram realizadas:

1. A primeira foi comparar os valores obtidos por instrumentos convencionais entre eles (termômetros de máximas e mínimas e termógrafo) e respectivas médias, calculadas pelas diferentes fórmulas [Eq. (5) e Eq. (8), pg. 168]; e também comparar estes valores com os obtidos por instrumentos automáticos, supondo que a média obtida por valores registrados em intervalos regulares de meia hora representa a temperatura média diária verdadeira do ar [Eq. (9)].

2. A segunda etapa foi determinar, com base somente nas leituras da estação automática, quais as fórmulas comumente utilizadas proporcionam médias 
diárias [Eq. (5), Eq. (6), Eq. (7) e Eq. (8)] mais próximas da temperatura verdadeira [Eq. (9)].

Como já mencionado, a menor série de temperatura é aquela obtida a partir da estação automática, tem dados disponíveis a partir de 1999. Entretanto, apesar de ser uma estação que coleta e registra automaticamente vários elementos do clima, o registro dos dados apresenta falhas significativas na série de temperatura (Figura 62). Tais lacunas podem induzir ao pensamento de que as estações automáticas podem ser tão ruins quanto às estações automáticas. Os motivos de tantas falhas são incertos, podendo ser atribuídos, talvez, a problemas de manutenção, operação e/ou coleta de dados. Do período de 1999 a 2006, pode-se notar na Figura 62, que apenas os anos de 2001 a 2005 possuem poucos dias com dados ausentes. Portanto, foram descartados os anos de 1999, 2000 e 2006 da série automática.

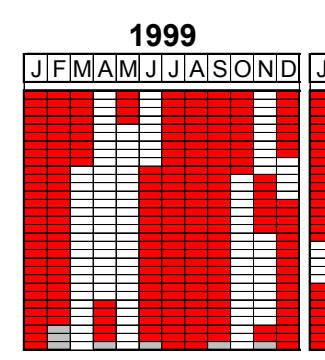

2003

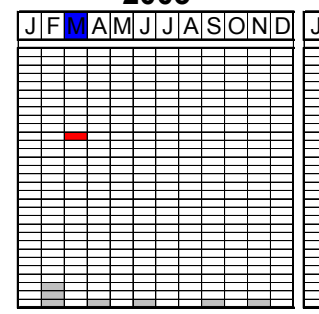

Falhas de dados diários
2000

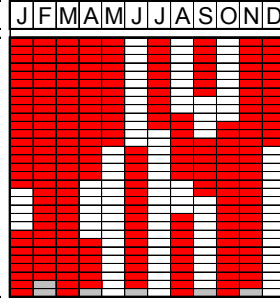

2004

JTFMA|M JJJAISTO

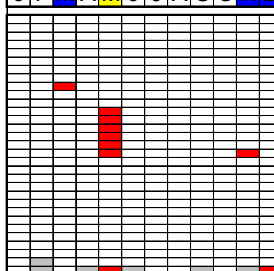

2001

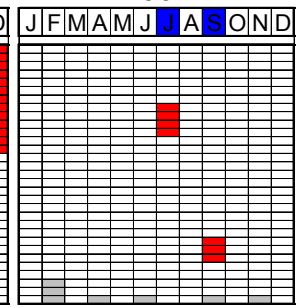

2005

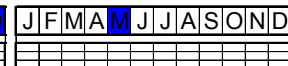

2002

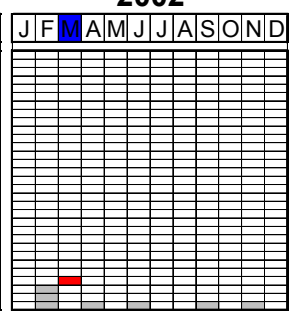

2006

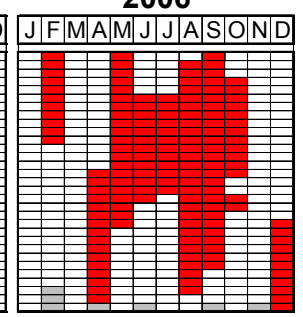

Meses com falhas acima do critério "5/10".

Meses com falhas abaixo do critério "5/10".

Figura 62 - Distribuição visual das falhas diárias na série de temperaturas obtidas pela estação automática, no período de 1999-2006.

Aproveitando, o diagnóstico das falhas presentes na série de temperatura com leituras às 9, 15 e 21h é apresentado na Figura 63 a seguir. Apenas os meses de junho a setembro de 2005 apresentam lacunas nos valores de temperatura nesta série. 


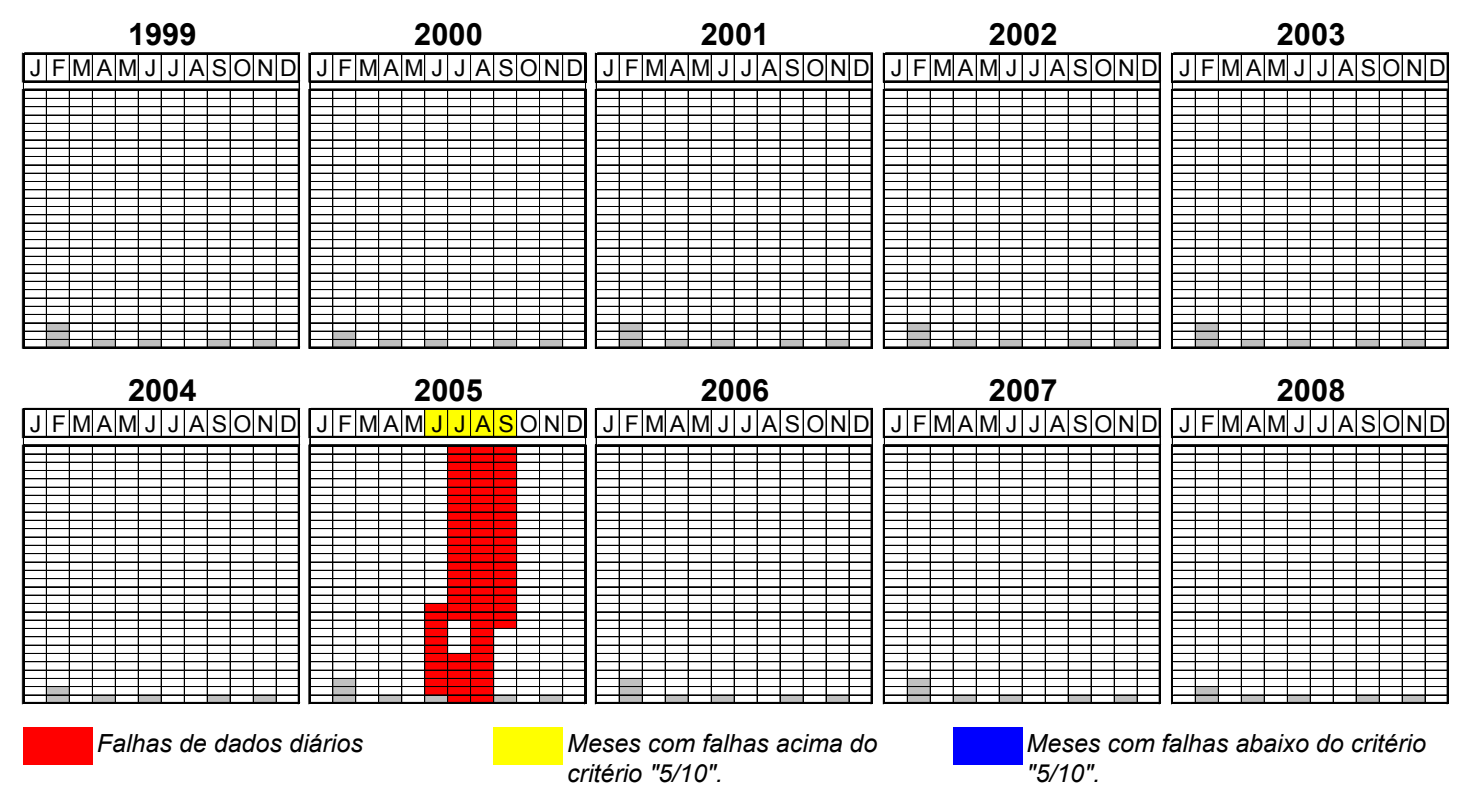

Figura 63 - Distribuição visual das falhas diárias na série de temperaturas com leituras as 9 , 15 e 21h, no período de 1999-2008.

Levando-se em consideração as peculiaridades e disponibilidade de cada uma das séries mais recentes, o período de análise fica restrito à menor delas, ou seja, à série de dados obtida pela estação automática, cujos anos aproveitáveis compreendem o período de 2001 a 2005.

\subsubsection{Comparações com dados obtidos em instrumentos convencionais}

Com base nos valores diários, a Tabela 12 exibe o resultado da temperatura média dos 5 anos analisados. Se fosse considerada somente a temperatura média neste período, obtida para cada método de cálculo da temperatura média diária, poderia ser inferido que não ocorrem erros significativos, uma vez que as diferenças são de: $0,16^{\circ} \mathrm{C}$ ao comparar o valor médio (de 5 anos) das temperaturas verdadeiras (obtidas pela estação automática) com o valor médio (de 5 anos) das médias diárias calculadas pelos valores máximos e mínimos $\left(T_{M-m}\right)$; e $0,36^{\circ} \mathrm{C}$ quando se compara o valor médio da temperatura verdadeira com o valor médio das médias diárias calculadas com base nos valores obtidos as 9 e $21 \mathrm{~h}$ do dia e valores máximos e mínimos $\left(T_{9-21-M-m}\right)$. 
Tabela 12 - Temperatura média (2001-2005)

\begin{tabular}{cc} 
das séries $T_{M-m}, T_{9-21-M-m}$ e $T_{\text {automática }}$ \\
\hline \hline Série & Valor $\left({ }^{\circ} \mathbf{C}\right)$ \\
\hline$T_{\text {automática }}$ & 20,88 \\
$T_{M-m}$ & 20,72 \\
$T_{9-21-M-m}$ & 20,52 \\
\hline
\end{tabular}

Entretanto, nesta parte do estudo é adotada uma abordagem inversa àquela realizada na confecção das tendências anteriores: o ponto de partida inicial das análises será realizado com base nos valores diários, seguindo pelos valores mensais e finalizando com valores anuais, acompanhando a propagação dos $\operatorname{desvios}^{26}$ e a sua influência relativa em cada escala.

O primeiro resultado de uma análise estatística simples, porém já indicativa das características dos valores calculados pelas médias das fórmulas utilizadas [Eq. (5), Eq. (8) e Eq. (9), pg. 168], no período de 2001 a 2005, é apresentado na Tabela 13. Os valores apresentados estão na forma de desvios de temperatura, ou seja, é feita a diferença entre valores de duas séries e sobre os quais alguns parâmetros estatísticos são calculados. Sobre o uso de desvios daqui em diante, cabe uma explicação. Os desvios serão utilizados por meio da diferença de pares de temperatura de duas origens distintas, sendo que o conjunto dessas diferenças irá compor as análises de correlação. Por exemplo, considere uma suposta temperatura média diária da estação automática no valor de $30^{\circ} \mathrm{C}$, que no caso é a temperatura verdadeira, e logo este é o valor de referência. Quando se realiza a diferença do valor de uma segunda fonte com a temperatura de referência, o resultado desta comparação fornece um valor que pode ser positivo, negativo ou zero. Se for zero, que dizer que as temperaturas são idênticas, e, logo, $30^{\circ}$ também é o valor da segunda temperatura comparada e a correlação neste caso é perfeita. Quanto maior for o desvio, menor a correlação dos valores comparados. O desvio, ou o resultado da diferença, é positivo quando a segunda temperatura é maior que os $30^{\circ} \mathrm{C}$ da temperatura verdadeira. Um desvio de $2,0^{\circ} \mathrm{C}$ positivo significa que o valor da segunda temperatura é de $32^{\circ} \mathrm{C}$. Inversamente,

\footnotetext{
${ }^{26}$ A propagação dos desvios de temperatura, no contexto de todo o trabalho, não possui o mesmo conceito de propagação de erros, obtida por cálculos matemáticos envolvidos em operações de soma, subtração, divisão e multiplicação dos valores dos erros associados às medições. Ou seja, não foram feitos cálculos de propagação dos erros. Foi feita apenas a análise das diferenças dos valores de temperatura (assumidas como desvios) em diferentes escalas temporais. A propagação consistiu na verificação da amplificação ou redução da magnitude dos desvios conforme a escala temporal fosse aumentando, partindo da escala horária para a diária, mensal, anual, etc.
} 
no caso do desvio negativo, significa que a segunda temperatura é menor que a temperatura de referência da estação automática. Portanto, um desvio de $-2,0^{\circ} \mathrm{C}$ indica que a segunda temperatura possui o valor de $28^{\circ} \mathrm{C}$.

A primeira comparação é realizada com as séries de instrumentos convencionais, ou seja, são correlacionadas as médias de temperatura baseadas nas máximas e mínimas $\left(T_{M-m}\right)$ com as médias obtidas com os valores das leituras as 9 e 21 com inclusão também das máximas e mínimas $\left(T_{9-21-M-m}\right)$. A segunda e terceira comparações possuem como referência os valores médios provenientes das leituras registradas, de meia em meia hora, na estação automática, sendo estas médias diárias consideradas representativas fiéis à temperatura verdadeira.

Pela Tabela 13 nota-se que valores com magnitude significativa, na ordem de grandeza de $10^{1}$. Este fato pode surpreender, porém, não é motivo de preocupação. Ao contrário, incita-se identificar os motivos e circunstâncias que ocasionaram tais valores extremos. Pelas informações dadas pelo desvio padrão e pelo intervalo de confiança de 95\% (ou seja, intervalo que compreende 95\% dos valores totais da série), fica a impressão de que os valores aparentemente absurdos são pouco frequentes.

\begin{tabular}{lccc} 
Tabela 13 - Análise estatística das séries $T_{M-m}, T_{9-21-M-m}$ e $T_{\text {automática }}$ no período 2001-2005. \\
\hline \hline \multirow{2}{*}{ Índice } & \multicolumn{3}{c}{ Desvio de temperatura $\left({ }^{\circ} \mathbf{C}\right)$} \\
\cline { 2 - 4 } & \multicolumn{1}{c}{$T_{M-m}-T_{9-21-M-m}$} & $T_{M-m}-T_{\text {automática }}$ & $T_{9-21-M-m}-T_{\text {automática }}$ \\
\cline { 2 - 4 } Máximo & 8,4 & 11,7 & 6,5 \\
Mínimo & $-13,3$ & $-8,4$ & -5 \\
Desvio padrão & 1,1 & 1,0 & 1,3 \\
Média dos desvios & 0,4 & $-0,5$ & $-0,1$ \\
Intervalo de confiança - $95 \%$ & $-1,7-2,4$ & $-2,5-1,3$ & $-2,6-2,4$ \\
\hline
\end{tabular}

Para confirmar a suspeita, nada melhor do que representar os dados em um diagrama de distribuição relativa de frequências (histograma) e um gráfico de dispersão, que expõe de forma clara a correlação dos dados. Os histogramas dos dados diários, respectivos às diferenças da Tabela 13, são exibidos na Figura 64; e os gráficos de dispersão são mostrados na Figura 65. Nos histogramas, os dados estão concentrados, quase em sua totalidade, nos intervalos de $-3 \mathrm{a}+3^{\circ} \mathrm{C}$ dos desvios. $\mathrm{O}$ que vale realçar neste tipo de representação que quanto mais concentradas estão as colunas perto do zero e quanto maiores elas forem nesta região, maior é a correlação dos dados, ou seja, mais parecidos e próximos são os valores comparados. 
Examinando o gráfico (A) da Figura 64, percebe-se que na distribuição normal existe um deslocamento para a direita em relação à linha que divide simetricamente o diagrama na metade, esta que não coincide com o valor zero (em vermelho). Isto denota que as temperaturas médias diárias com origem nas medições das máximas e mínimas $\left(T_{M-m}\right)$ são geralmente maiores que as daquelas médias calculadas com o acréscimo das leituras as 9 e $21 \mathrm{~h}\left(T_{\text {9-21-M-m }}\right)$.

A finalidade que mais interessa, no entanto, é diferenciar qual dos métodos de cálculos com base em dados obtidos em instrumentos convencionais produzem valores de temperatura mais próximos da temperatura verdadeira $\left(T_{\text {automática }}\right)$, esta resultante dos dados obtidos na estação automática. Observando os gráficos (B) e (C) da Figura 64, verifica-se que os dados obtidos pela fórmula com leituras as 9 e $21 \mathrm{~h}$ apresenta maior concentração próximo ao desvio zero e, logo a correlação é maior em relação às médias obtidas somente pelas temperaturas máximas e mínimas. Ainda, nota-se que o meio do diagrama está deslocado um pouco para esquerda nos dois gráficos.
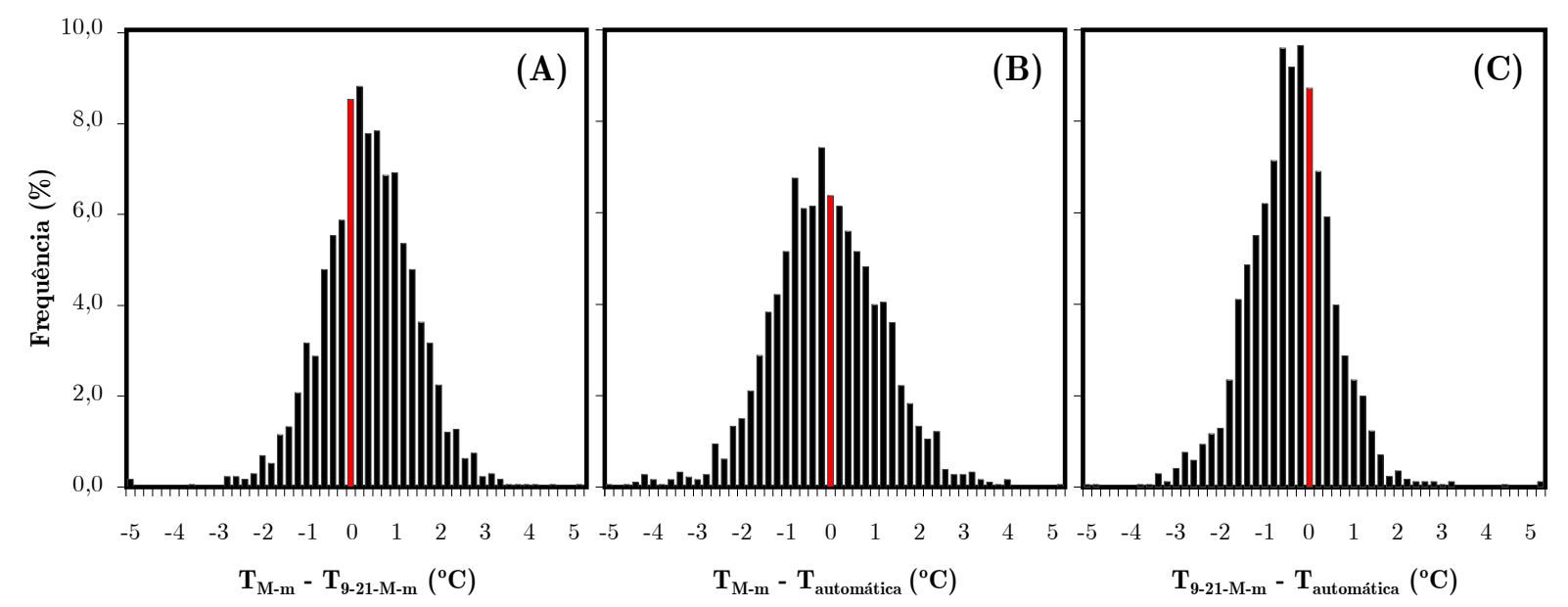

Figura 64 - Histogramas dos desvios de temperatura das séries $T_{M-m}, T_{9-21-M-m}$ e $T_{\text {automática }}$ no período 2001-2005.

A correlação dos dados fica mais bem evidenciada nos gráficos de dispersão da Figura 6. Nesta representação é fácil de notar, também, os valores divergentes extremos. Comparando as temperaturas médias obtidas pelas máximas e mínimas $\left[T_{M-m}\right.$, gráfico (B)] com as obtidas com leituras adicionais as 9 e $21 \mathrm{~h}$ [ $T_{\text {9-21-M-m }}$, gráfico (C)], de fato confirma-se que as segundas possuem maior correlação com as temperaturas verdadeiras. Mesmo apresentando pontos distantes da reta de regressão, o coeficiente de correlação da $T_{9-21-M-m}$ é maior $\left(\mathrm{R}^{2}=0,905\right)$ do que a da $T_{M-m}\left(\mathrm{R}^{2}=\right.$ $0,8576)$. 

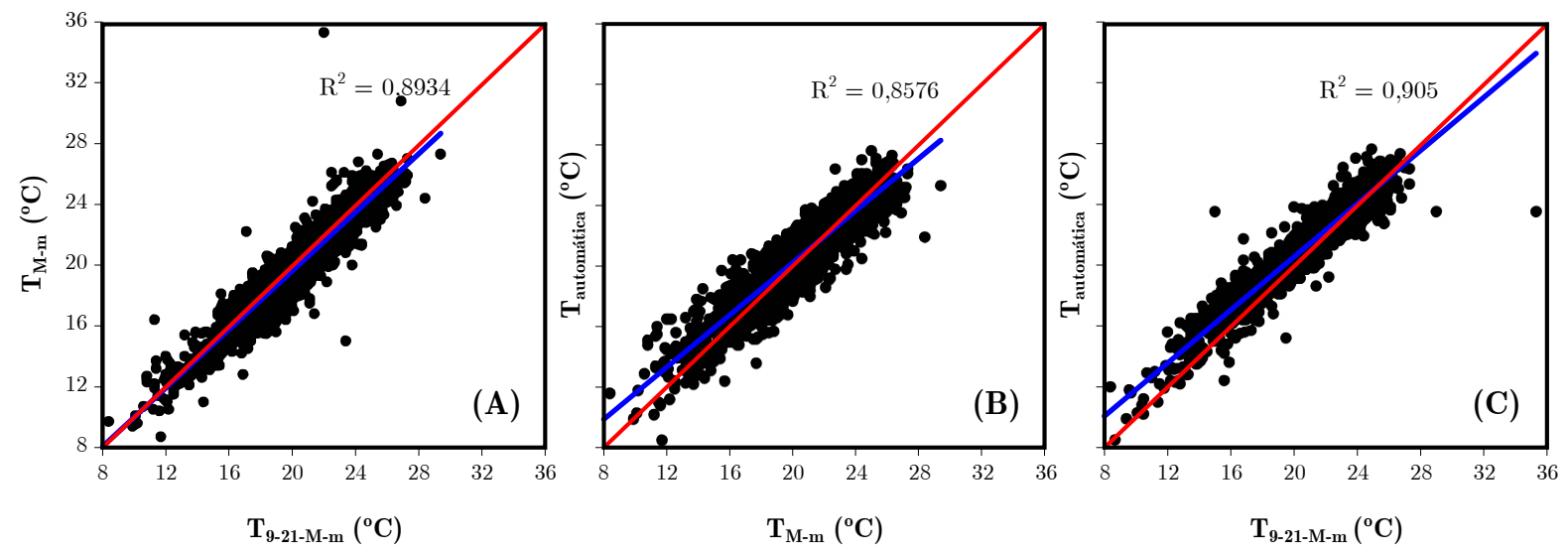

Figura 65 - Gráficos de dispersão demonstrando a correlação entre as séries $T_{M-m}, T_{9-21-M-m} \mathrm{e}$ $T_{\text {automática }}$ no período 2001-2005. Obs.: Escala vertical idêntica para todos os gráficos.

Apesar da $T_{\text {9-21-M-m }}$ possuir maior correlação com a temperatura verdadeira, ela apresenta pontos bastante fora da reta, fato que não ocorreu com a $T_{M-m}$. Se fossem analisados os valores médios da temperatura no período de 2001 a 2005 apresentados na Tabela 13, poderia ser inferido que a $T_{M-m}$ é mais próximo e preciso que a $T_{9-21-M-m}$. Mas, na verdade, os pontos extremos que ocorrem na série da $T_{9-21-M-m}$ que causaram um desvio maior da temperatura média no período dos 5 anos. As temperaturas máximas e mínimas passaram por um controle de qualidade que identificou e removeu erros aleatórios de digitação, como, por exemplo, a ocorrência de valores máximos menores que valores mínimos. Tal procedimento não foi realizado, propositalmente, para as leituras realizadas as 9 e 21h. A intenção de não realizar este controle de qualidade é verificar qual a magnitude de influência destes valores diários errôneos nas escalas superiores (mensais e anuais).

Para facilitar realizar tal remoção destes erros aleatórios, as diferenças são plotadas em gráficos, expostos na Figura 66. São relativamente poucos pontos que apresentam erros acima de $4^{\circ} \mathrm{C}$. Pelo gráfico (C), procede-se à identificação dos maiores erros. Por exemplo, o maior deles, com diferença de $11,7^{\circ} \mathrm{C}$ é decorrente do valor de $56,0^{\circ} \mathrm{C}$ na leitura das $21 \mathrm{~h}$ do dia $16 / 01 / 2004$, claramente inconsistente. No caso, a temperatura do dia anterior, no mesmo horário, era de $22^{\circ} \mathrm{C}$, e no dia anterior foi de $28^{\circ} \mathrm{C}$. Portanto, neste caso a correção foi feita com a alteração do valor para $26^{\circ} \mathrm{C}$ (supondo um erro de digitação do número "5" invés do "2"). Este erro teria induzido a um erro no mês de janeiro de $0,39^{\circ} \mathrm{C}$, aumentando o valor correto de 22,07 para $22,46^{\circ} \mathrm{C}$. Outro caso, agora para a maior diferença negativa que ocorreu no dia 
$12 / 04 / 2005$. Neste dia, o valor registrado para as $21 \mathrm{~h}$ foi de $2,2^{\circ} \mathrm{C}$, sendo que a temperatura mínima no dia foi de $15,0^{\circ} \mathrm{C}$. No mesmo horário do dia anterior e posterior, as temperaturas foram de 21,5 e $23,0^{\circ} \mathrm{C}$, respectivamente. Logo, o valor foi corrigido para $22,0^{\circ} \mathrm{C}$ (supondo um erro de digitação da vírgula na casa errada). Este erro causaria uma redução de $0,03^{\circ} \mathrm{C}$, alterando o valor correto de 21,27 para $22,21^{\circ} \mathrm{C}$. Além destes, outras diferenças incoerentes, acima de $4^{\circ} \mathrm{C}$, foram corrigidas ou foram descartados os valores na ausência de um critério válido que permitisse uma correção razoável.

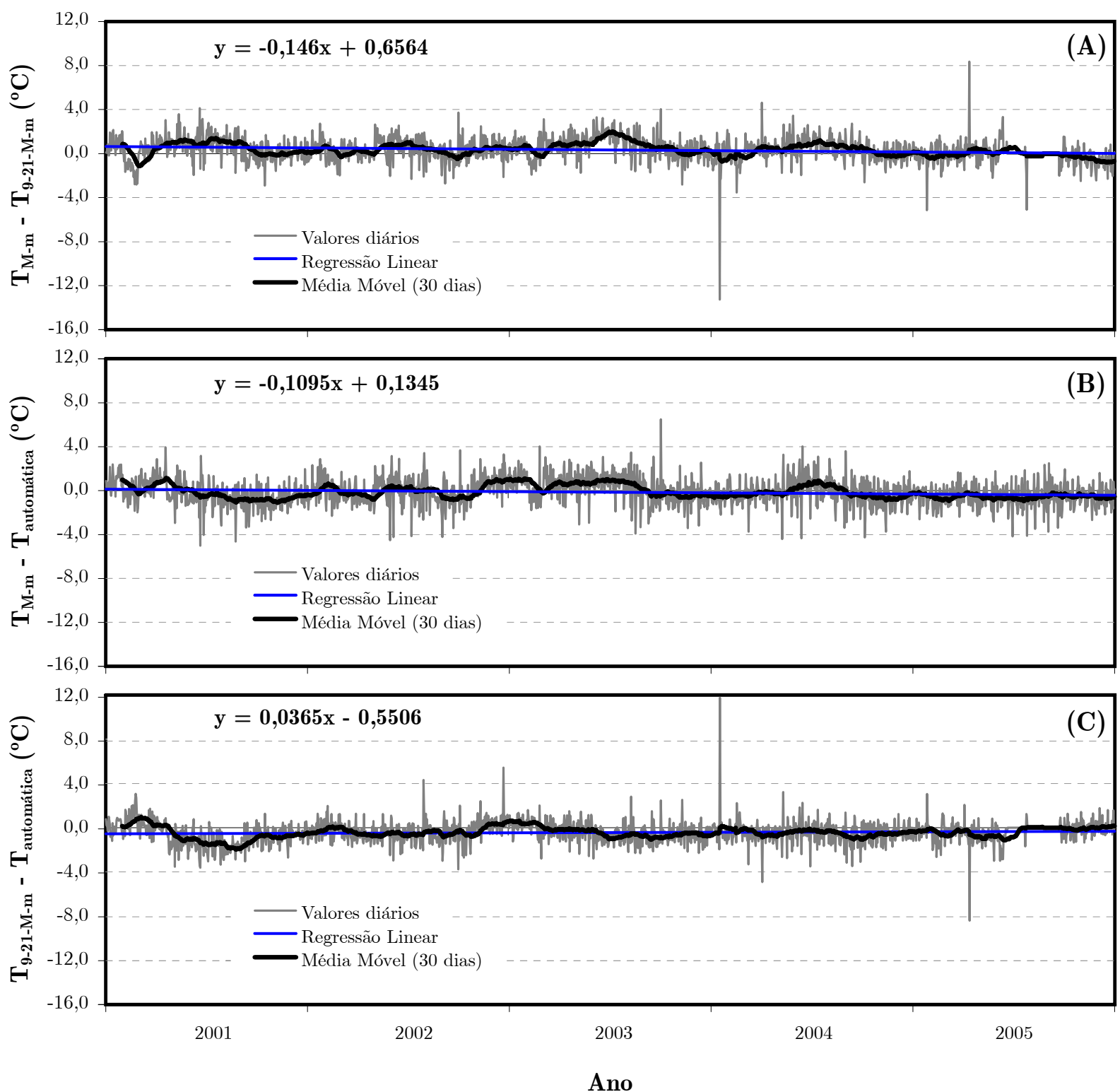

Figura 66 - Desvios diários e tendências das temperaturas das séries $T_{M-m}, T_{9-21-M-m}$ e $T_{\text {automática }}$ no período 2001-2005. 
Após a remoção de erros mais evidentes, foi conferido se houve alguma mudança significativa nos índices estatísticos. $\mathrm{O}$ valor da média de 5 anos da $T_{\text {9-21-M-m }}$ mudou de 20,52 para $20,48^{\circ} \mathrm{C}$, ou seja, diferença desprezível. Nem mesmo a ocorrência de erros de alta magnitude - mas de baixa frequência - altera de modo expressivo as médias de longo prazo. Portanto, apesar da $T_{9-21-M-m}$ possuir maior correlação com a

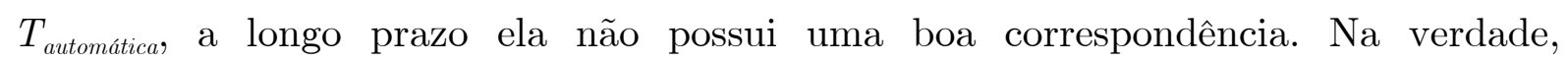
observando atentamente os gráficos (B) e (C) da Figura 66, os valores diários da $T_{\text {9-21- }}$ ${ }_{M-m}$ se apresentam com amplitudes de variações menores que $T_{M-m}$; porém a reta de regressão linear da $T_{9-21-M-m}$ está deslocada para baixo do desvio zero, ao contrário da $T_{M-m}$ que possui a reta quase que coincidente ao paralelo do desvio zero. Conclui-se que: a $T_{M-m}$ é mais sensível a variações do clima, por possuir menor quantidade de leituras, mas ao longo prazo os valores são fielmente representativos da temperatura verdadeira; e a $T_{9-21-M-m}$ possui um efeito de amortecimento das variações por possuir mais leituras, entretanto para esta série de dados, quando avaliado na escala de longo prazo, a tendência baseada nela se mostrou abaixo do valor verdadeiro.

Sob a perspectiva da escala mensal, uma análise gráfica é apresentada na Figura 67. Nela é possível, para período de 2001 a 2005, notar que existe uma predominância dos valores obtidos na estação automática serem maiores que os obtidos convencionalmente. Em determinados momentos, como na passagem de 2002 a 2003, os valores de $T_{\text {automática }}$ são superados pelos de $T_{M-m}$ e $T_{9-21-M-m}$.

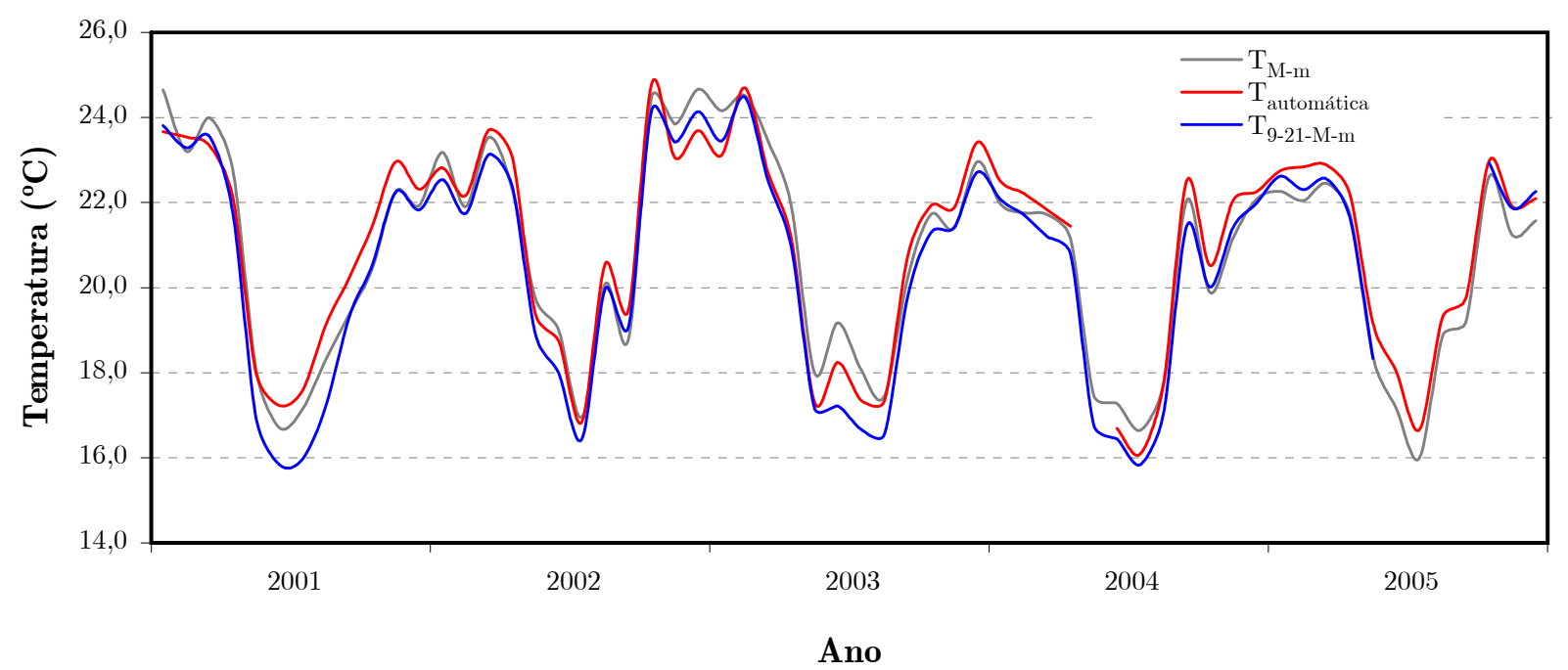

Figura 67 - Temperaturas mensais das séries $T_{M-m}, T_{9-21-M-m}$ e $T_{\text {automatica }}$ no período 2001-2005. 
Ou seja, essas diferenças não são lineares, fato que é comprovado pelos gráficos de desvios de temperatura da Figura 68. Para o caso da $T_{M-m}$ (Figura 68-A), ela apresenta valores maiores no começo de 2001, no final de 2002 e mais da metade do ano de 2003, e em dois meses do ano de 2004. Já a $T_{9-21-M-m}$ (Figura 68-B) apresenta um desvio positivo pouco expressivo apenas no final de 2002 e começo de 2003. Na tendência geral, a $T_{M-m}$ parece apresentar valores menores ou mais "frios", enquanto que $T_{9-21-M-m}$ tende a se aproximar dos valores da temperatura verdadeira.

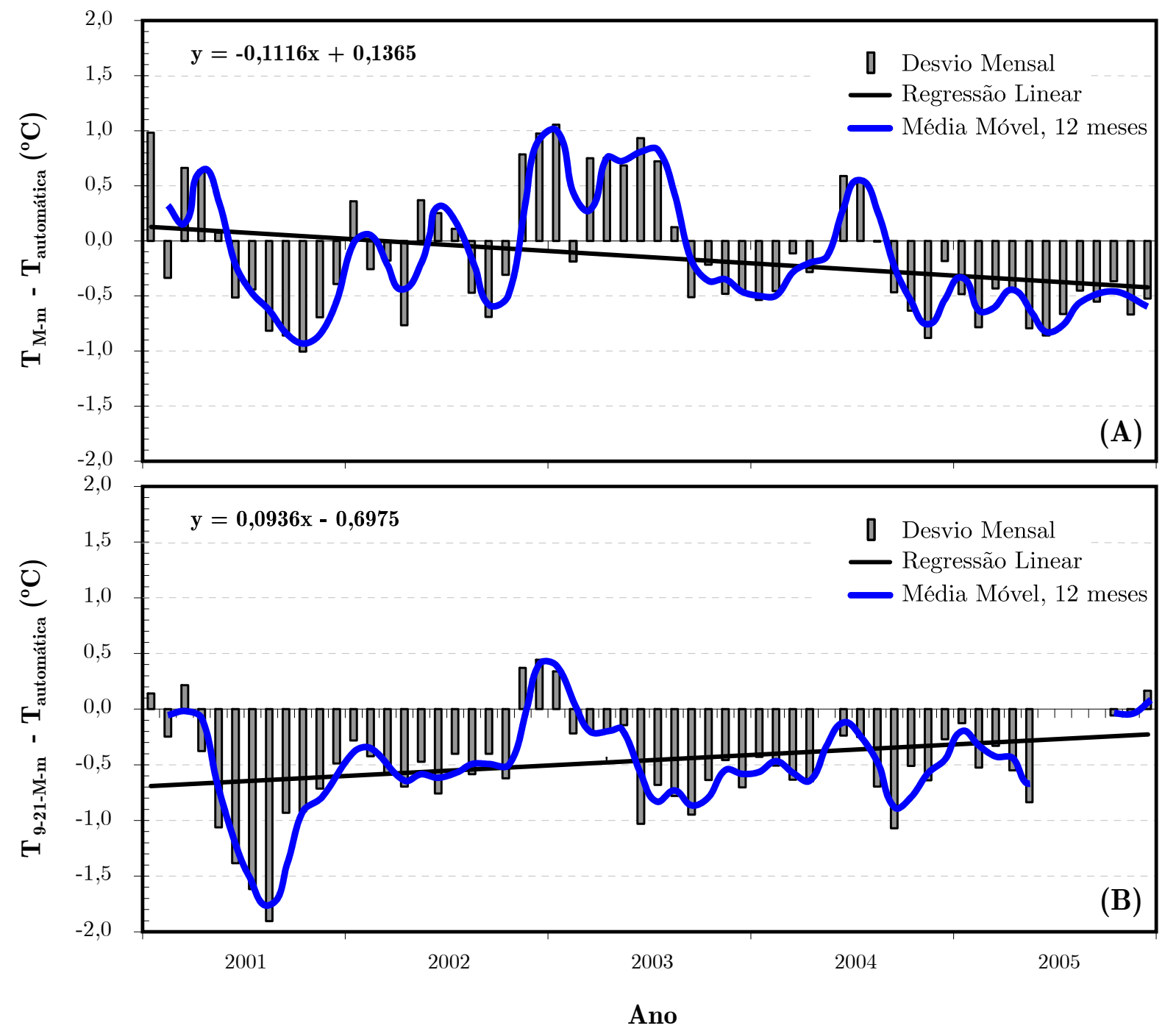

Figura 68 - Desvios mensais e tendências das temperaturas das séries $T_{M-m}, T_{9-21-M-m}$ e $T_{\text {automática }}$ no período 2001-2005.

Apesar das tendências gerais observadas nos valores mensais, existe uma variação não-linear considerável em que as oscilações são mais acentuadas no comportamento da $T_{M-m}$ do que da $T_{9-21-M-m}$. Portanto, nesta escala não existe uma boa 
concordância entre os meses, apesar de, em 5 anos, as médias das temperaturas serem relativamente próximas: $20,93^{\circ} \mathrm{C}\left(T_{\text {automática }}\right) 20,68^{\circ} \mathrm{C}\left(T_{M-m}\right)$ e $20,53^{\circ} \mathrm{C}\left(T_{9-21-M-m}\right)$.

Finalizando a análise com a ótica da escala anual, e na limitação dos 5 anos disponíveis, elaborou-se um gráfico de variação mensal média de 5 anos, nos moldes do perfil da representação de uma normal. O resultado é mostrado na Figura 69. Nota-se que a média de 5 anos da $T_{\text {automática }}$ está acima de todas, seguida pela $T_{M-m}$, pela normal (que foi calculada pelos 35 anos de dados da $T_{M-m}$ e apresentada na Figura 54, pg. 178) e pela $T_{9-21-M-m}$. As médias anuais da temperatura de todos os meses são: $20,91^{\circ} \mathrm{C}\left(T_{\text {automática }}\right) 20,74^{\circ} \mathrm{C}\left(T_{M-m}\right)$ e $20,37^{\circ} \mathrm{C}\left(T_{9-21-M-m}\right)$. A Tabela 14 a seguir sintetiza os valores médios dos 5 anos, obtidos quando utilizadas as escalas diárias, mensais e anuais. As diferenças entre os valores de cada escala são em boa parte menores que 0,05, ou seja, ao fazer o arredondamento para a cada dos decimais, apenas um valor terá diferença de $0,1^{\circ} \mathrm{C}$. Independente de qual escala for adotada, conclui-se que, para o período e as séries estudadas, as temperaturas obtidas pelos métodos convencionais são, em média, $0,20\left(T_{M-m}\right)$ e $0,45^{\circ} \mathrm{C}\left(T_{9-21-M-m}\right)$ menores que a temperatura verdadeira $\left(T_{\text {automática }}\right)$.

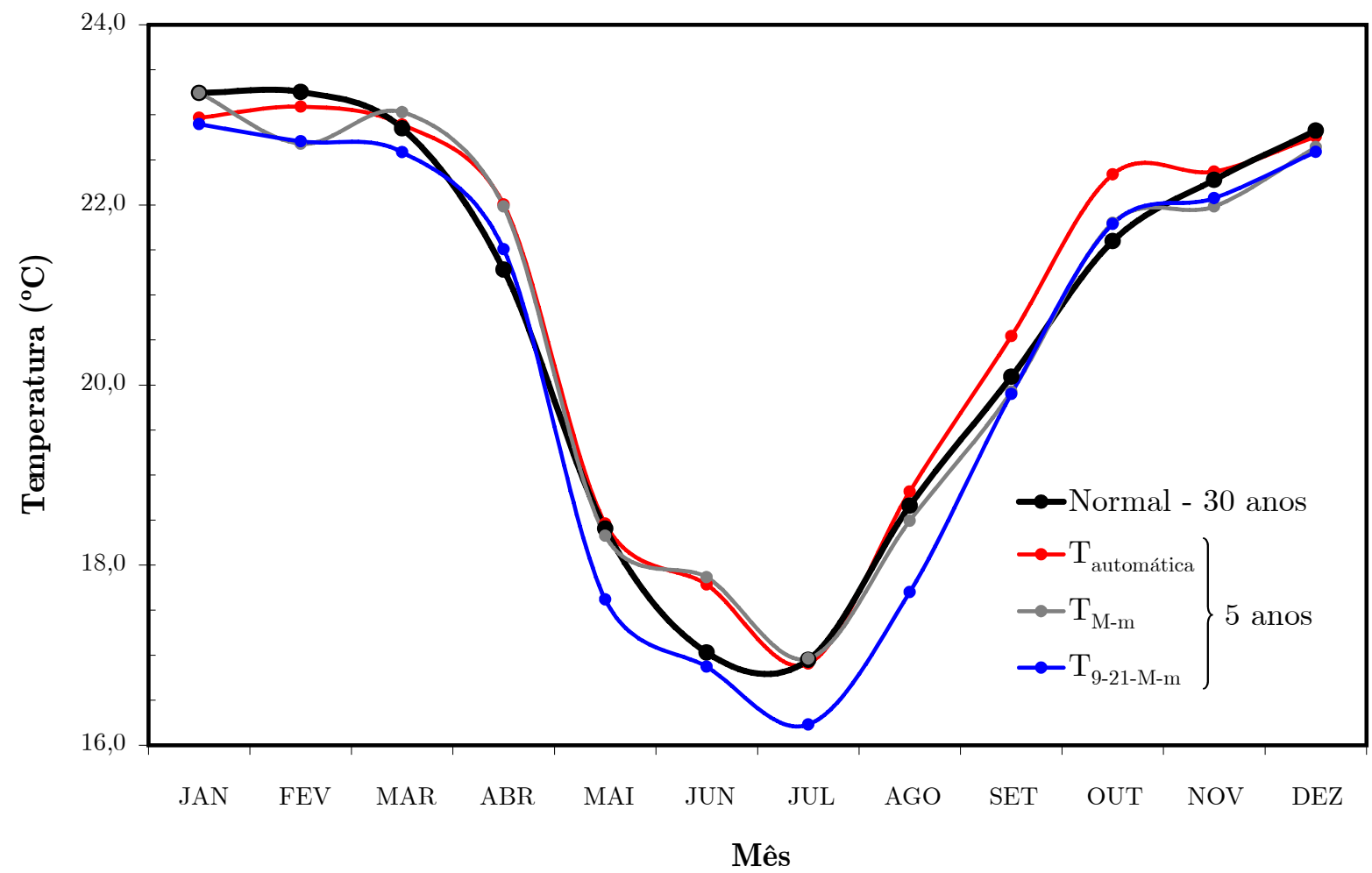

Figura 69 - Comparação, no perfil da representação de uma normal, das séries $T_{M-m}, T_{9-}$ 21-M-m e $T_{\text {automática }}$ no período 2001-2005, em relação à normal calculada para o período 19732008. 
Tabela 14 - Valores médios de temperatura $\left({ }^{\circ} \mathrm{C}\right)$ das séries $T_{M-m}, T_{9-21-M-m}$ e $T_{\text {automática }}$ no período 20012005, relativos às diferentes escalas temporais de abordagem.

\begin{tabular}{lccc}
\hline \hline \multirow{2}{*}{ Temperatura } & \multicolumn{3}{c}{ Dados } \\
\cline { 2 - 4 } & Anuais & Mensais & Diários \\
\hline$T_{\text {automática }}$ & 20,91 & 20,93 & 20,88 \\
$T_{M-m}$ & 20,74 & 20,68 & 20,72 \\
$T_{9-21-M-m}$ & 20,37 & 20,53 & 20,48 \\
\hline
\end{tabular}

Conclui-se, portanto, que na escalas de longo prazo (anuais e normais) o método recomendado pela OMM (WMO, 2009), cuja temperatura média [Eq. (5), pg. 168] é obtida pela média aritmética dos valores máximos e mínimos diários $\left(T_{M-m}\right)$, apresenta maior correlação e concordância com a temperatura verdadeira. Apesar de ser um método simples, que utiliza apenas dois registros diários, esta média se mostrou um método adequado, diferindo cerca de $0,2^{\circ} \mathrm{C}$ da temperatura verdadeira. Por outro lado, em outras escalas (mensais e diárias), tanto o método recomendado da OMM quanto o empregado nas estações convencionais brasileiras do INMET a partir de 1938 [T $T_{9-21-M-m}$, Eq. (8), pg. 168], apresentam desvios não-lineares da temperatura verdadeira $\left[T_{\text {automatica }}\right.$, Eq. (9), pg. 168]. A escala temporal de análise é um aspecto primordial na intercomparação de fórmulas e dados de diferentes instrumentos. Além disso, os resultados aqui são representativos para a região e os instrumentos nela utilizados. Extrapolações a respeito da classificação do método mais adequado, a partir dos resultados obtidos aqui, devem ser realizadas com ressalvas.

\subsubsection{Comparações com dados obtidos em instrumento automático}

Comparados os valores obtidos por instrumentos convencionais entre eles e em relação aos valores obtidos por instrumentos automáticos, resta agora determinar, com base nas leituras da estação automática, se as fórmulas utilizadas nos cálculos das temperaturas médias diárias com leituras reduzidas se aproximam da temperatura verdadeira. Além das fórmulas já comparadas no item anterior [Eq. (5), Eq. (8) e Eq. (9), pg. 168], também foram comparadas as fórmulas utilizada por Tolentino (1967) no estudo do clima de São Carlos [Eq. (6)] e a fórmula utilizada pelas Normais Brasileiras (BRASIL, 1967) até o ano de 1937 [Eq. (7)]. 
Neste item são comparados os valores determinados pelas fórmulas mais comuns que são utilizadas nas estações convencionais, porém os dados utilizados nos cálculos serão aqueles que foram coletados pela estação automática no período disponível de 2001 a 2005. Utilizando a mesma fonte de dados e os mesmos instrumentos automáticos, a comparação se torna mais consistente e evita-se as diferenças existentes entre os instrumentos convencionais e automáticos, cuja comparação foi realizada no item anterior.

Analogamente às análises feitas até o momento, a primeira abordagem desta comparação é elaborada a partir dos dados diários. Pela Tabela 15, nota-se que da temperatura verdadeira $\left(T_{\text {automática }}\right)$ média de 5 anos difere: $0,8^{\circ} \mathrm{C}$ a temperatura obtida pelos valores máximos e mínimos $\left(T_{A_{-} M-m}\right) ; 0,63^{\circ} \mathrm{C}$ a temperatura obtida às $9,15 \mathrm{e}$ $21 \mathrm{~h}\left(T_{A_{-} \text {-9-15-21 }}\right) ; 0,18$ a temperatura obtida às 7,14 e $21 \mathrm{~h}\left(T_{A_{-} \gamma_{-14-21}}\right) ;$ e 0,33 a temperatura obtida às $9,21 \mathrm{~h}$ e os valores máximos e mínimos diários $\left(T_{A_{-} \text {9-21-M-m }}\right)$.

\begin{tabular}{cc} 
Tabela $\mathbf{1 5}-$ Temperatura & média $(2001-2005)$ \\
das séries $T_{\text {automática }}, T_{A_{-} M-m}, T_{A_{-} 9-15-21}, T_{A_{-} \gamma_{-14-21}}$ \\
e $T_{A_{-}-9-21-M-m}$ & Valor $\left({ }^{\circ} \mathbf{C}\right)$ \\
\hline \hline Série & 20,90 \\
\hline$T_{\text {automática }}$ & 21,70 \\
$T_{A_{-} M-m}$ & 21,53 \\
$T_{A_{-} \text {9-15-21 }}$ & 20,72 \\
$T_{A_{-} \gamma-14-21}$ & 20,57 \\
$T_{A_{-}-9-21-M-m}$ &
\end{tabular}

Nesta escala de 5 anos, se fosse utilizado somente a média deste período como critério de escolha, poderia-se considerar o cálculo da $T_{A_{-} \gamma_{-14-21}}$ como a melhor forma de calcular a temperatura diária do ar. Porém, uma análise mais criteriosa é necessária. A Tabela 16 exibe alguns índices estatísticos que apresentam detalhes importantes. Por exemplo, o menor desvio padrão foi apresentado pela fórmula $T_{A_{-} g-}$ 21-M-m, que também apresenta a maior correlação dos dados $\left(\mathrm{R}^{2}=0,9447\right)$, vide apresentado nos gráficos de dispersão da Figura 70. Nas distribuições de desvios apresentados na Figura 71, o gráfico (D) $\left(T_{A_{-} 9-21-M-m}\right)$ é que possui maior concentração de desvios nulos, embora o meio da distribuição esteja deslocado um pouco para o lado negativo dos desvios, enquanto que $T_{A_{-} \gamma_{-1}-21}$ [gráfico $\left.(\mathbf{C})\right]$ possui uma distribuição de desvios bastante equilibrada, ou seja, simetricamente dividida pelo desvio zero. 
Tanto $T_{A_{-} M-m}$ quanto $T_{A_{-} 9-15-21}$ apresentam desvios majoritariamente positivos, conforme denotam os gráficos (A) e (B) da Figura 70 e Figura 71, respectivamente.

Tabela 16 - Análise estatística das séries $T_{\text {automática, }}, T_{A_{-} M-m}, T_{A_{-} 9-15-21}, T_{A_{-} 7-14-21}$ e $T_{A_{-} \text {9-21-M-m }}$ no período 2001-2005

\begin{tabular}{lcccc}
\hline \multirow{2}{*}{ Índice } & \multicolumn{4}{c}{ Desvio de temperatura $\left({ }^{\circ} \mathbf{C}\right)$} \\
\cline { 2 - 5 } & $T_{A_{-} M-m}-$ & $T_{A_{-} \text {9-15-21 }}-$ & $T_{A_{-} \text {7-14-21 }}-$ & $T_{A_{-} \text {9-21-M-m }}-$ \\
Máximo & $T_{\text {automática }}$ & $T_{\text {automática }}$ & $T_{\text {automática }}$ & $T_{\text {automática }}$ \\
\cline { 2 - 5 } & 3,26 & 3,73 & 2,34 & 1,44 \\
Mínimo & $-2,16$ & $-2,41$ & $-4,10$ & $-3,70$ \\
Desvio padrão & 0,60 & 0,65 & 0,64 & 0,49 \\
Média dos desvios & 0,80 & 0,62 & $-0,18$ & $-0,33$ \\
Intervalo de confiança - 95\% & $-0,33-2,03$ & $-0,71-1,88$ & $-1,55-1,14$ & $-1,33-0,58$ \\
\hline
\end{tabular}
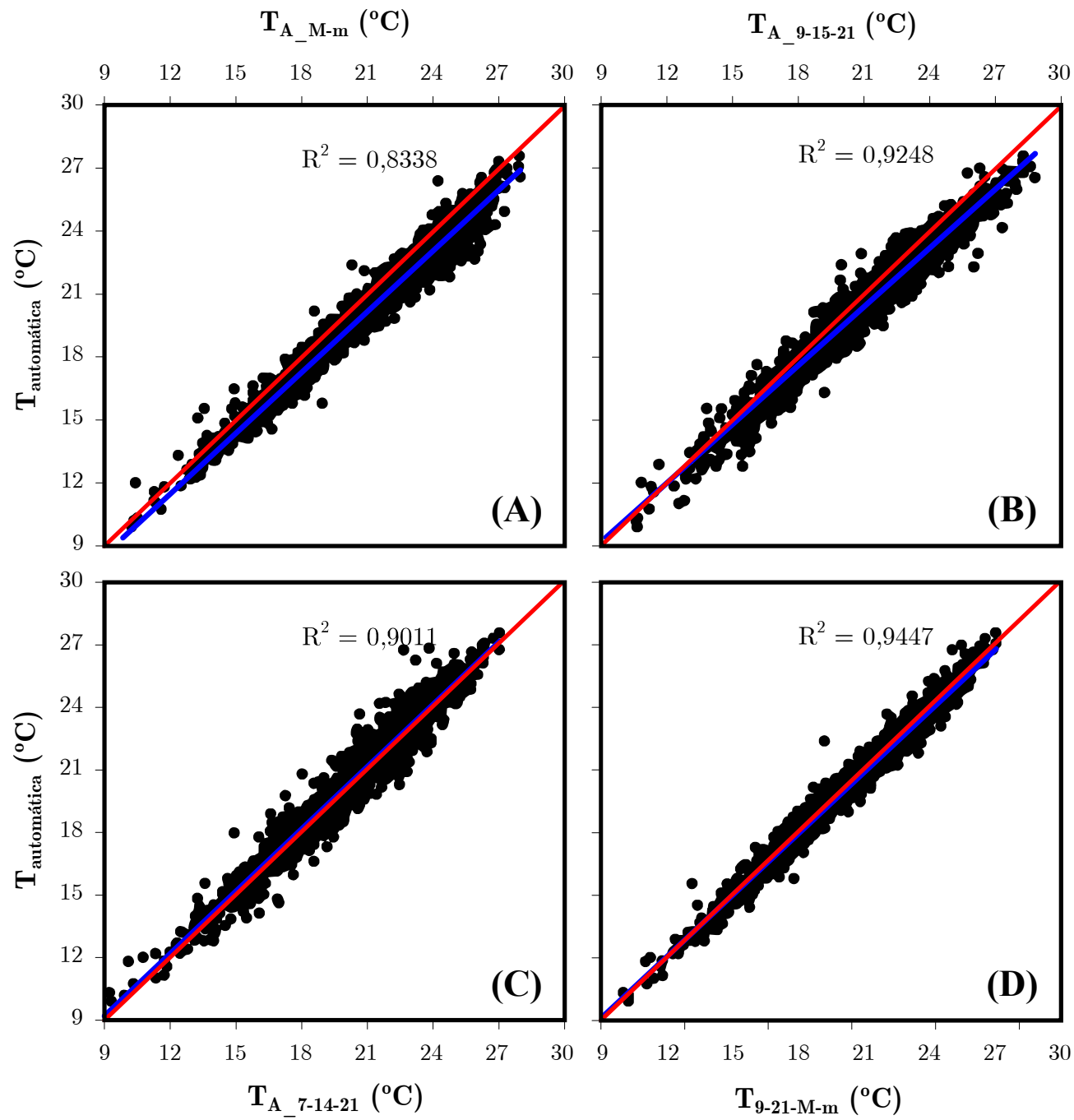

Figura 70 - Gráficos de dispersão demonstrando a correlação entre as séries $T_{A_{-} M-m}$, $T_{A_{-} 9-15-21}, T_{A_{-} 7_{-14-21}}$ e $T_{A_{-} 9-21-M-m}$ em relação à $T_{\text {automática }}$ no período 2001-2005. 


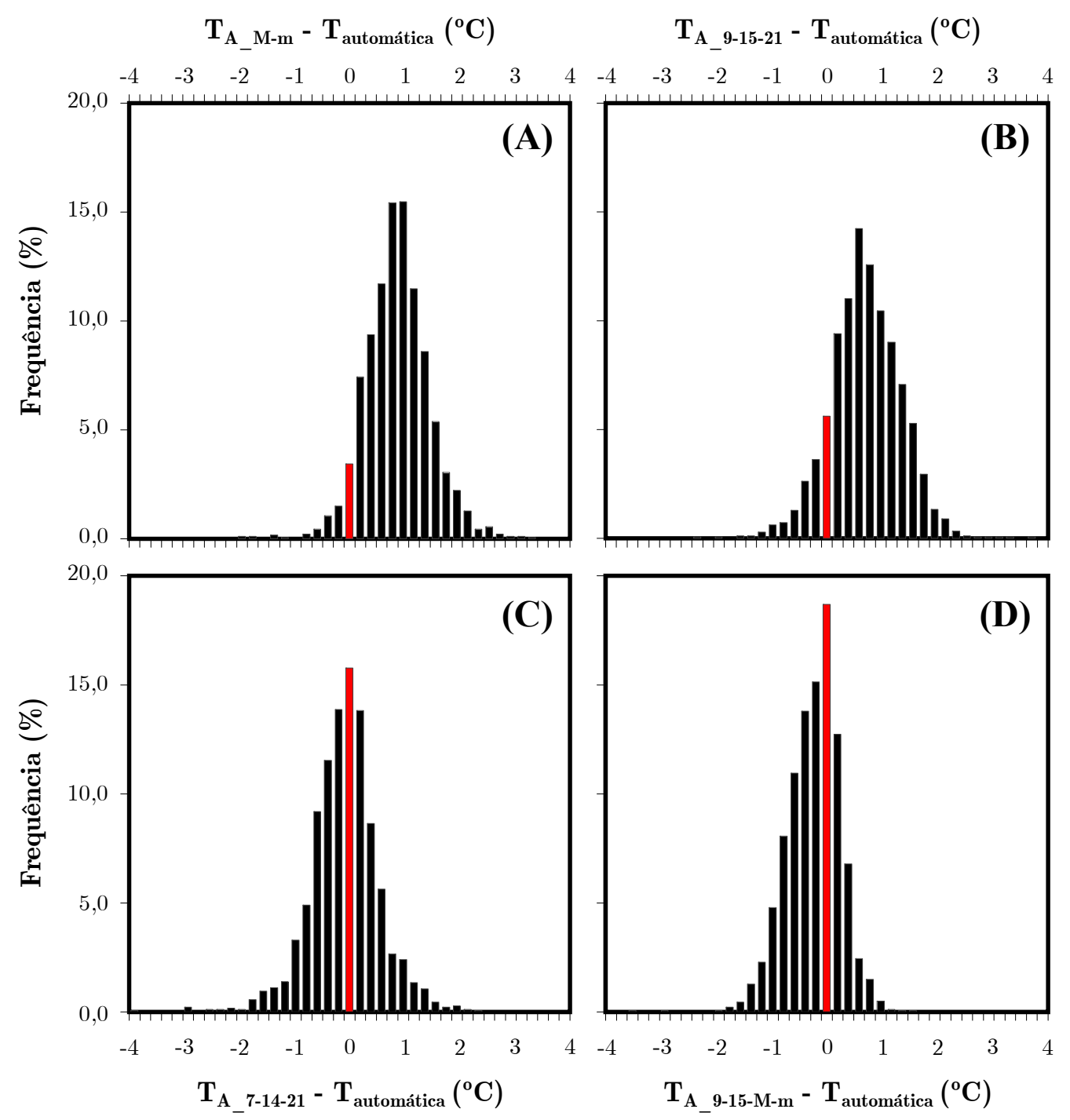

Figura 71 - Histogramas dos desvios de temperatura das séries $T_{A_{-} M-m}, T_{A_{-} 9-15-21}, T_{A_{-} \gamma_{-}}$ 14-21 e $T_{A_{-} \text {9-21-M-m }}$ em relação à $T_{\text {automática }}$ no período 2001-2005.

A distribuição diária dos desvios ao longo dos 5 anos (2001-2005) é mostrada na Figura 72. São confirmados os desvios positivos predominantes de $T_{A_{-} M-m}$ quanto $T_{A_{-} \text {9-15-21 }}\left[\right.$ gráficos (A) e (B)]. Os valores de desvios de $T_{A_{-} \text {- } 14-21}$ [gráfico (C)] se mantêm relativamente oscilantes próximos de zero, porém ocorre uma mudança no padrão dos desvios nos anos de 2003 e 2004. O caso de $T_{A_{-} \text {9-21-M-m }}$ [gráfico (D)] é mais curioso, em que os desvios apresentam um padrão cíclico anual: durante o verão esta fórmula resulta em desvios nulos, ou seja, os valores obtidos são bastante próximos da temperatura verdadeira $\left(T_{\text {automática }}\right)$; enquanto que no inverno o desvio se torna negativo, ou seja, os valores obtidos por este tipo de cálculo chegam a ser cerca de $0,3^{\circ} \mathrm{C}$ menores que $T_{\text {automatica. }}$ 


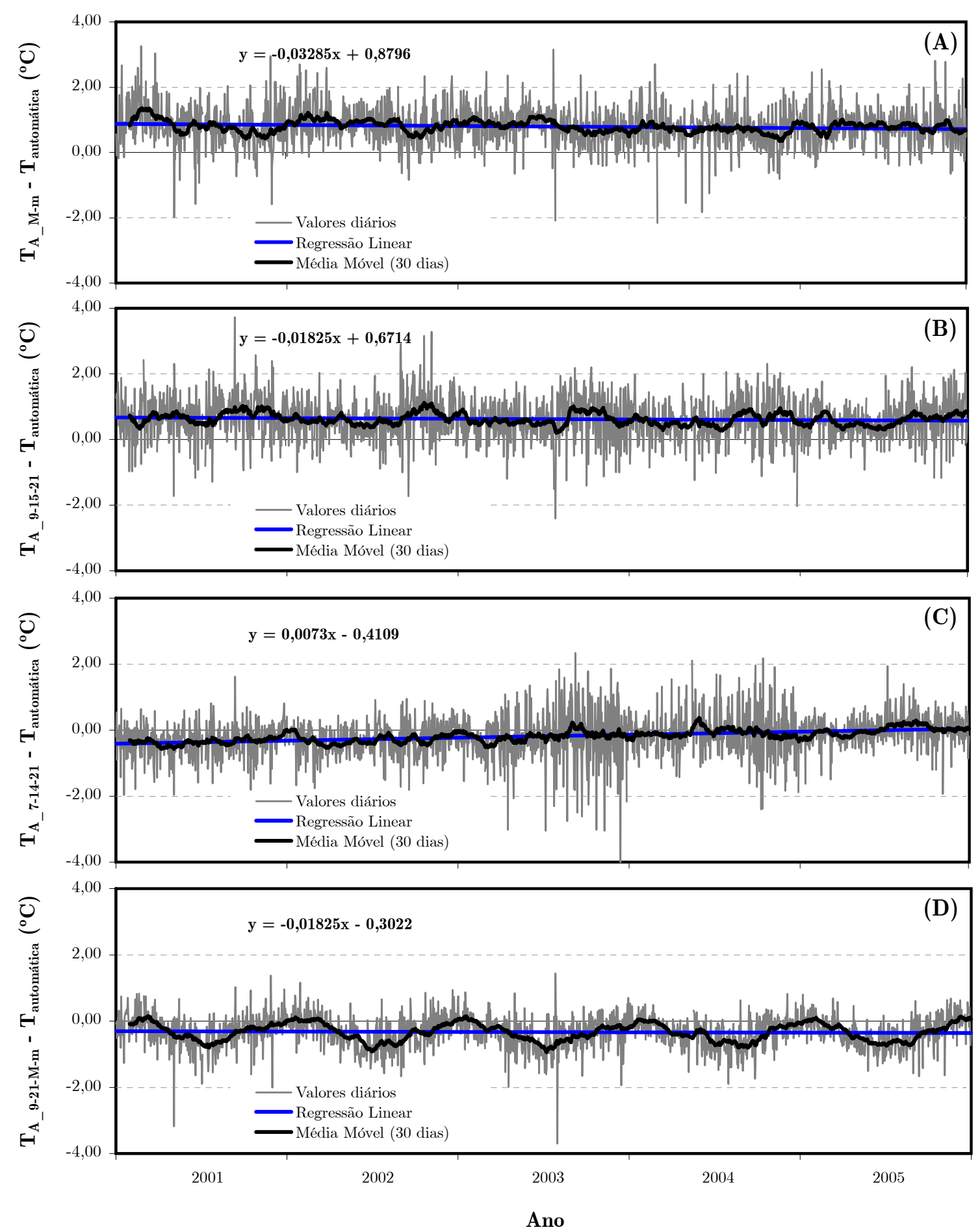

Figura 72 - Desvios diários e tendências das temperaturas das séries $T_{A_{-} M-m}, T_{A_{-} 9-15-21}$, , $T_{A_{-} \gamma_{-14-21}}$ e $T_{A_{-} 9-21-M-m}$ em relação à $T_{\text {automática }}$ no período 2001-2005.

Sob a perspectiva das médias mensais (Figura 73), no período de inverno fica evidenciado que $T_{A_{-} 9-21-M-m}$ (curva azul) realmente é menor que a temperatura verdade (curva vermelha). As temperaturas oriundas de $T_{A_{-} M-m}$ e $T_{A_{-} 9-15-21}$ (curvas preta e verde) são maiores que a temperatura verdadeira especialmente durante os períodos 
quentes de verão. Por fim, a curva de $T_{A_{-} \gamma_{-14-21}}$, em amarelo, quase se confunde com a temperatura verdadeira. Na mesma escala mensal, a Figura $\mathbf{7 4}$ mostra os desvios de temperatura para cada fórmula. Neste modo de exibição, ficam ressaltadas as análises já descritas anteriormente. Na escala mensal, as médias das temperaturas no período de 5 anos são: $20,95^{\circ} \mathrm{C}\left(T_{\text {automática }}\right), 21,75^{\circ} \mathrm{C}\left(T_{A_{-} M-m}\right), 21,57^{\circ} \mathrm{C}\left(T_{A_{-} 9-15-21}\right), 20,76^{\circ} \mathrm{C}\left(T_{A_{-} \gamma-}\right.$ $\left.{ }_{14-21}\right)$ e $20,62^{\circ} \mathrm{C}\left(T_{A_{-} 9-21-M-m}\right)$.

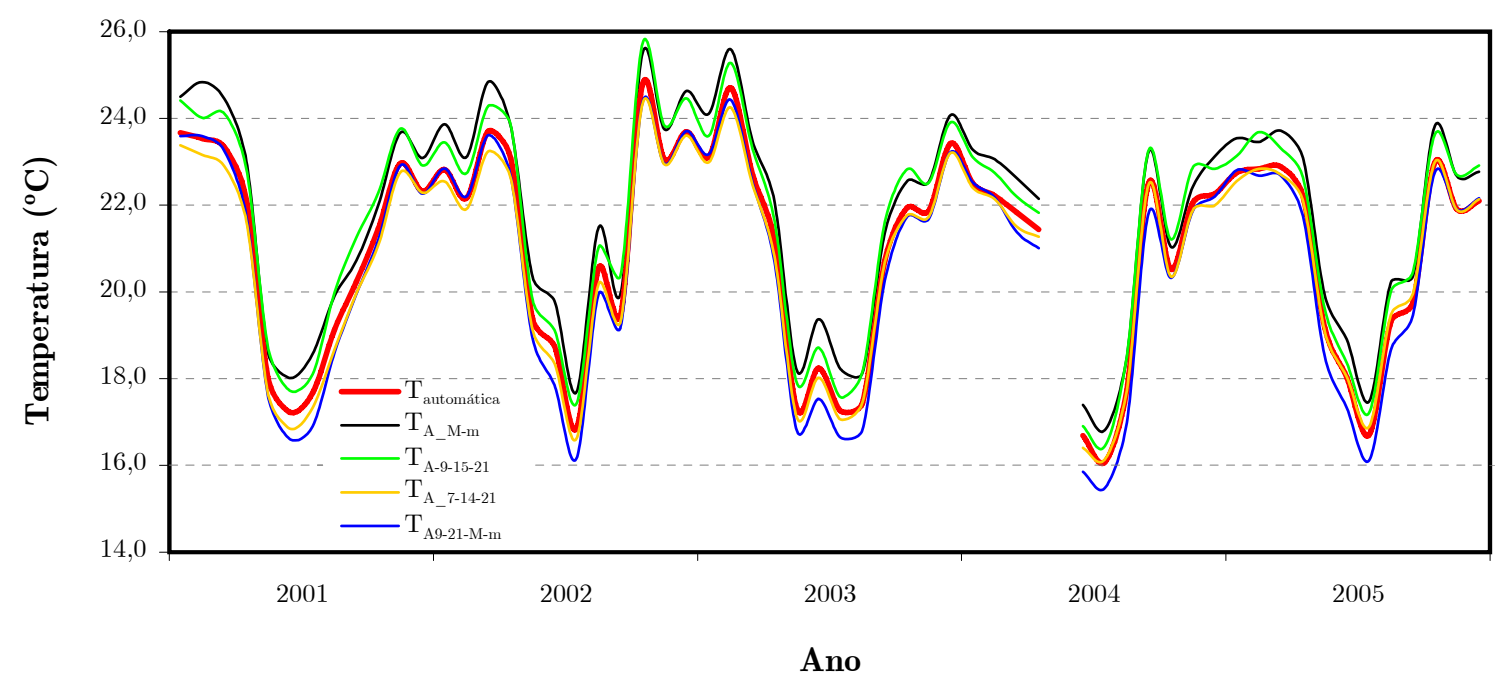

Figura 73 - Temperaturas mensais das séries $T_{A_{-} M-m}, T_{A_{-} 9-15-21}, T_{A_{-} \gamma_{-14-21},} T_{A_{-} \text {9-21-M-m }}$ e $T_{\text {automática }}$ no período 2001-2005. 


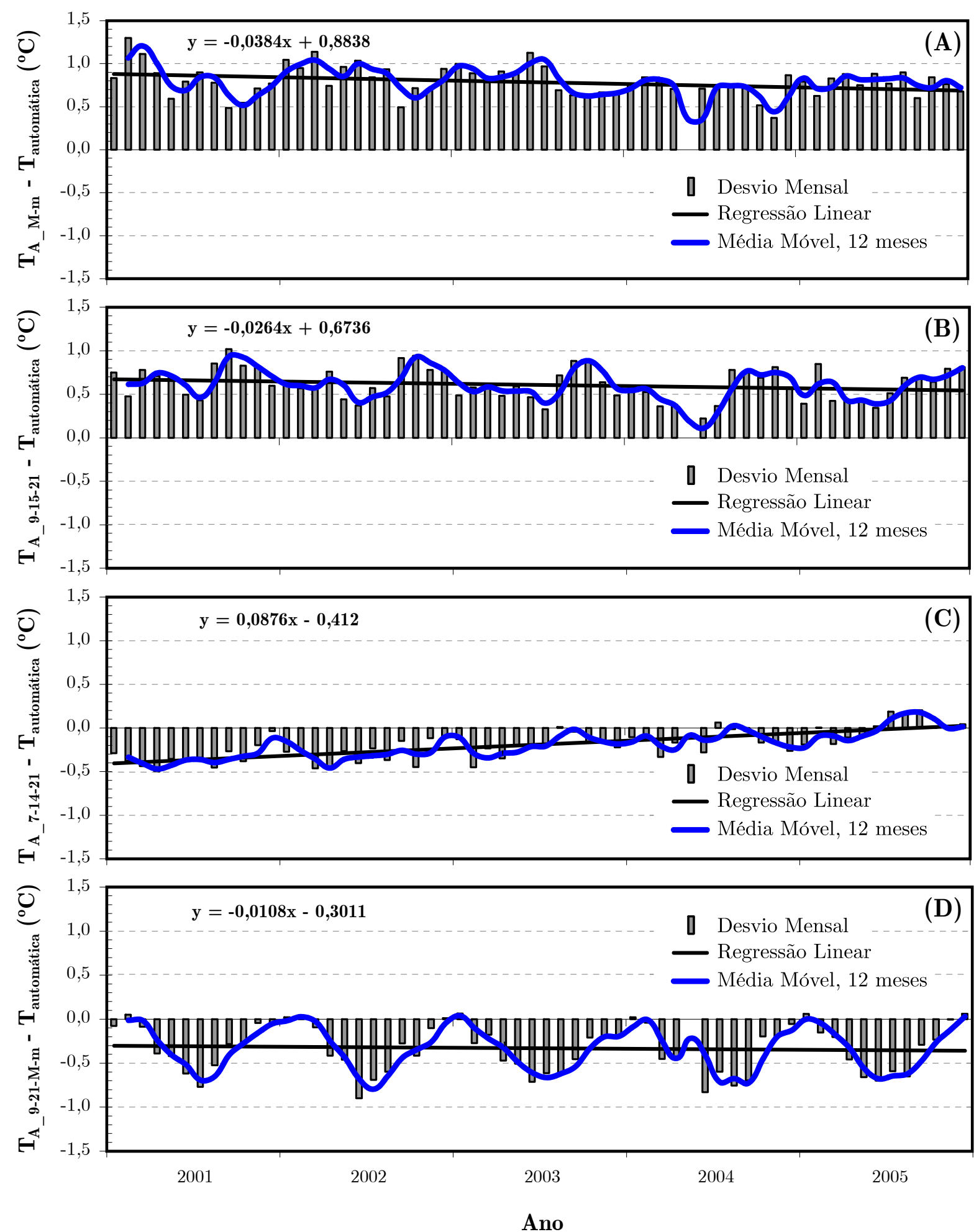

Figura 74 - Desvios mensais e tendências das temperaturas das séries $T_{A_{-} M-m}, T_{A_{-} 9-15-21}$, , $T_{A_{-} \gamma_{-14-21}}$ e $T_{A_{-} 9-21-M-m}$ em relação à $T_{\text {automática }}$ no período 2001-2005.

Por fim, a última apreciação é realizada na escala anual de 5 anos, no formato análogo das normais climatológicas. A Figura 75 ilustra a distribuição mensal dos valores médios das diversas fórmulas de temperatura média do ar, utilizando o 
período total (2001-2005) de dados coletados pela estação automática. Novamente, os comportamentos das temperaturas obtidas, já descritos nas escalas diárias e mensais, mantêm-se nesta escala anual. Neste último, as médias das temperaturas no período de 5 anos são: $20,91^{\circ} \mathrm{C}\left(T_{\text {automática }}\right), 21,71^{\circ} \mathrm{C}\left(T_{A_{-} M-m}\right), 21,53^{\circ} \mathrm{C}\left(T_{A_{-} 9-15-21}\right), 20,72^{\circ} \mathrm{C}\left(T_{A_{-}} \gamma_{-}\right.$ 14-21 $)$ e $20,57^{\circ} \mathrm{C}\left(T_{A_{-} 9-21-M-m}\right)$.

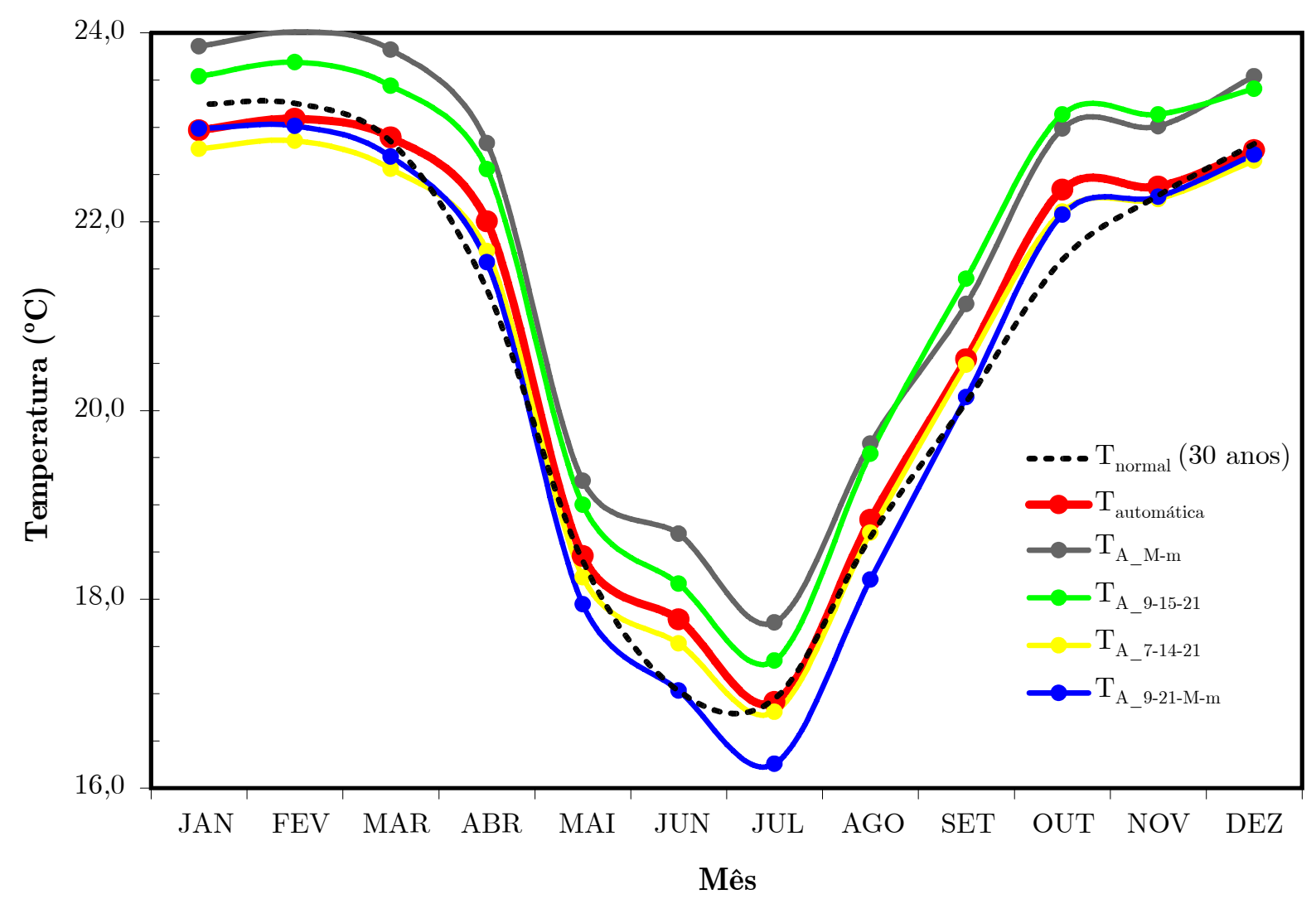

Figura 75 - Comparação, no perfil da representação de uma normal, das séries $T_{A_{-} M-m}$, $T_{A_{-} \text {9-15-21 }}, \quad T_{A_{-} \gamma_{-1}-21}, T_{A_{-} \text {9-21-M-m }}$ e $T_{\text {automática }}$ no período 2001-2005. A curva da normal (tracejada), calculada para o período 1973-2008, é mostrada apenas ilustrativamente.

A Tabela 17 sumariza os valores anuais quando calculados a partir das médias diárias, mensais e anuais. Os valores obtidos nas três escalas são praticamente os mesmos, diferentemente das análises comparativas na elaboração das normais. Este fato é devido à série de dados coletados pela estação automática possuir poucas falhas, enquanto que a série utilizada nas normais possui muitos dias, meses e até anos com lacunas. Na existência de uma série perfeita e sem dados faltantes, os valores finais da série total devem ser idênticos, independente da escala adotada. 
Tabela 17 - Valores médios de temperatura $\left({ }^{\circ} \mathrm{C}\right)$ das séries $\quad T_{A_{-} M-m}, \quad T_{A_{-} 9-15-21}, \quad, \quad T_{A_{-} 7-14-21}, \quad T_{A_{-} 9-21-M-m} \quad \mathrm{e}$ $T_{\text {automática }}$ no período 2001-2005, relativos às diferentes escalas temporais de abordagem.

\begin{tabular}{lccc}
\hline \multirow{2}{*}{ Temperatura } & \multicolumn{3}{c}{ Dados } \\
\cline { 2 - 4 } & Anuais & Mensais & Diários \\
\hline$T_{\text {automática }}$ & 20,91 & 20,95 & 20,90 \\
$T_{A_{-} M-m}$ & 21,71 & 21,75 & 21,70 \\
$T_{A_{-} 9-15-21}$ & 21,53 & 21,57 & 21,53 \\
$T_{A_{-} \text {7-14-21 }}$ & 20,72 & 20,76 & 20,72 \\
$T_{A_{-} 9-21-M-m}$ & 20,57 & 20,62 & 20,57 \\
\hline
\end{tabular}

$\mathrm{Na}$ escala de longo prazo e com base em cinco anos de dados obtidos automaticamente, conclui-se que as fórmulas podem ser classificadas na seguinte ordem de maior para menor aproximação do valor da temperatura verdadeira: $T_{A_{-} \gamma_{-1} \text { - }^{-}}$ ${ }_{21} ; T_{A_{-} 9-21-M-m} ; T_{A_{-} 9-15-21} ;$ e $T_{A_{-} M-m}$. Entretanto, os comportamentos dos desvios são consideravelmente variáveis nas escalas diárias e mensais para cada método. Embora algumas fórmulas tenham provido valores bastante próximos na média de 5 anos, ocorreu alta dispersão de valores na escala diária. Na escala mensal, ocorreram predominantemente valores superestimatidos em $T_{A_{-} 9-15-21}$ e $T_{A_{-} M-m}$, na ordem de 0,6 e $0,8^{\circ} \mathrm{C}$, respectivamente; e $T_{A_{-} \text {-1-14-21 }} ; T_{A_{-} 9-21-M-m}$ subestimaram os valores em 0,2 e $0,3^{\circ} \mathrm{C}$, respectivamente. Esta conclusão contradiz o resultado da comparação das fórmulas quando foram utilizados dados coletados em estação convencional. Inclusive, a fórmula aqui com melhor aproximação do valor real, não é mais utilizada oficialmente, estando em desuso no Brasil desde 1937. Tal fato merece uma discussão mais aprofundada, além de exigir mais estudos em diferentes localidades e com séries automáticas mais extensas, que possam corroborar ou contradizer os resultados obtidos nesta ocasião.

Uma última análise interessante seria comparar os valores de temperatura obtidos pelas máximas e mínimas dos termômetros (estação convencional) com as temperaturas máximas e mínimas obtidas na estação automática. Os procedimentos seriam análogos aos já seguidos anteriormente, porém esta comparação se tornaria demasiadamente exaustiva e se estenderia além do escopo desejado, extrapolando os objetivos do estudo como um todo. Outro enfoque possível seria interpretar os dados de temperatura em diferentes estações do ano, principalmente nos dois extremos dos 
períodos de verão e inverno. Não desmerecendo as suas importâncias, fica a elaboração destas comparações como sugestão para estudos posteriores.

\subsection{Considerações finais}

A OMM (WMO, 2009) alerta que normais calculadas a partir de conjuntos de dados incompletos podem ser tendenciosas. Por exemplo, se um ano em um período foi particularmente frio, a normal calculada sem os dados desse ano seria maior do que a normal que incluísse esse ano. Falhas de observações consecutivas podem ter mais impacto sobre as normais que o mesmo número de observações em falta espalhadas aleatoriamente ao longo do período em questão. Como um guia, as normais devem ser calculadas apenas quando os valores estão disponíveis pelo menos $80 \%$ dos anos do registro, com não mais de três anos consecutivos em falta. Uma opção alternativa, caso exista um período prolongado de falta de dados, mas os dados são razoavelmente completos após esse período, é calcular a média do período usando apenas os dados dos anos posteriores à falha na série registrada. (WMO, 2009).

Vide recomendação da OMM (WMO, 2007), a regra "5/10" foi aplicada para a consideração ou não de meses com falhas de dados, ou seja, não foram calculados os valores mensais em que estavam faltando 5 ou mais valores diários consecutivos ou 10 valores diários não consecutivos ao longo do mês. A aplicação da regra "3/5", preconizada pela norma WCPD N. 10 (WMO, 1989), descartaria muitos meses da série, que já está consideravelmente comprometida com a falta de dados.

As normais aqui calculadas, para o período de 1973-2008, não se enquadram na definição de normais-padrão, pois o período disponível não se enquadra em nenhum dos períodos padronizados estabelecidos (1961-1990 e 1991-2021); também não podem ser definidas como normais, já que também não compreendem pelo menos três períodos consecutivos de dez anos, pois no período 1973-2008 existem falhas completas nos anos de 1977, 1978 e 1979; e no caso da definição de normais provisórias, as normais da estação climatológica do CRHEA seriam, a rigor, enquadradas nesta categoria, uma vez que possuem pelo menos 10 anos de dados. Porém, o período total de anos da série é de 35 anos, possuindo falhas de 3 anos inteiros (1977, 1978 e 1979), um ano pela metade (1973) e alguns anos com falhas em alguns meses (1976, 1981, 1982, 1986 e 1987).

Logo, sugere-se a criação e denominação de uma nova categoria de normais, da qual fariam parte as normais deste presente estudo: normais provisórias estendidas, 
que são médias de um período de pelo menos 25 anos completos e não consecutivos, em um período de total de 35 anos desde o primeiro até o último ano do período analisado. Ou seja, tomando como exemplo o período de 1973-2008, ele possui no total 35 anos, sendo 3 anos completos de falhas, 5 anos com falhas parciais em alguns meses, e 27 anos não consecutivos completos. Sintetizando, as normais provisórias estendidas possuem quase a mesma quantidade de anos do período de 30 anos de uma normal, porém bem mais dos que os 10 anos mínimos necessários para as normais provisórias. Além disso, as normais provisórias estendidas permitem uma maior flexibilização com relação aos anos não consecutivos, que surgem devido à ocorrência habitual de falhas, bastante frequentes nas séries climatológicas.

Realizada a caracterização do clima por meio da elaboração de normais para a região de Itirapina/SP em estudo, a verificação de tendências na região permitiu identificar que, no período de 1973-2008, os dias estão ficando mais quentes e as noites estão ficando mais frias. Ou seja, evidenciou-se um aumento da amplitude de variação da temperatura em que as temperaturas máximas estão ficando mais altas e as mínimas estão ficando mais baixas, resultando, na média, em um aquecimento local. Utilizando as diferentes escalas analisadas, a média dos desvios dos dados diários, mensais e anuais determinou que as tendências de mudança de temperatura nos 35 anos analisados foram de: aumento de $0,15^{\circ} \mathrm{C}$ da temperatura média; aumento de $1,03^{\circ} \mathrm{C}$ da temperatura máxima média; e redução de $0,90^{\circ} \mathrm{C}$ da temperatura mínima média. Portanto, fica reforçado aqui que a média é uma descrição incompleta do clima, justificando a necessidade essencial de sempre interpretar e apresentar as temperaturas médias em conjunto com as temperaturas máximas e mínimas médias, que, juntas, exibem o verdadeiro comportamento das alterações climáticas locais.

$\mathrm{Na}$ segunda etapa deste capítulo, foi realizada a identificação e quantificação das diferenças diárias, mensais e anuais do uso de diferentes métodos de cálculo da temperatura média diária. Quando comparados os valores de 5 anos de dados obtidos em estação convencional com os obtidos em estação automática, notou-se que ocorrem erros da ordem de $10^{\circ} \mathrm{C}$. Entretanto, apesar de estes erros serem de alta magnitude, devidos principalmente a erros aleatórios de digitação, eles são de baixa frequência de ocorrência. Das fórmulas analisadas, é difícil dizer qual foi a mais apropriada e mais próxima dos valores verdadeiros, uma vez que os desvios de temperatura não são constantes, apresentando comportamento não-linear ao longo do tempo. Mas, de um modo geral, pode-se dizer que a fórmula que utiliza apenas a média aritmética dos valores máximos e mínimos $\left(T_{M-m}\right)$ se aproximou mais dos 
valores da média verdadeira $\left(T_{\text {automática }}\right)$ do que a temperatura média obtida com leituras realizadas às 9 e $21 \mathrm{~h}$ e dos valores máximos e mínimos $\left(T_{\text {9-21-M-m }}\right)$.

De um modo geral, as temperaturas obtidas de modo convencional se apresentaram mais baixas que a temperatura verdadeira. Este aspecto merece atenção. Os instrumentos convencionais têm sido recentemente substituídos por instrumentos automáticos. Foi assumido neste estudo que as medições realizadas de meia em meia hora pela estação automática representam a temperatura do ar média diária verdadeira, e por isto os outros métodos foram comparados a ele. Porém, uma análise mais adequada deve ser colocada de outra forma. O ponto de vista deve ser colocado sob o contexto histórico, e não de qual instrumento realiza as medições com maior exatidão. Pelo percebido, a maior série de dados de temperatura foi obtida por medições em instrumentos convencionais, no caso, a partir de termômetros de máximas e mínimas. A utilização das estações modernas automatizadas, mesmo que elas representem um método mais preciso de coleta e registro de dados, não deve ser a referência da série da temperatura no contexto histórico. Ou seja, primeiramente existiam os instrumentos convencionais e só depois veio a implantação das estações automática, tornando viável a coleta automatizada de dados. Logo, invertendo as referências, a conclusão a que se chega não é o fato das medições convencionais serem "mais frias" (menores) do que as realizadas pela estação automática, mas sim a estação automática medir valores de temperatura "mais quentes" (maiores) que os instrumentos convencionais. Sob essa perspectiva, levanta-se a discussão da implantação e substituição das estações convencionais pelas automáticas, que devido a esta mudança podem estar sendo incorporadas heterogeneidades indesejáveis, que no caso produz um aquecimento não-climático na série.

Com a recente utilização de instrumentos automáticos ainda é interessante manter em funcionamento a estação convencional como um parâmetro de comparação, pois assim a coleta simultânea permite identificar heterogeneidades decorrentes de mudanças dos instrumentos. O funcionamento paralelo das duas estações é imprescindível para comparações no local de cada estação, sendo úteis em uma eventual averiguação de heterogeneidades e posterior homogeneização da série. Logo, quanto mais extensas as séries sobrepostas, melhor a compreensão das heterogeneidades envolvidas.

No contexto da discussão de aquecimento global, em que o aumento da temperatura média global foi de cerca de $0,6^{\circ} \mathrm{C}$ no último século, o uso de diferentes fórmulas, nas séries de 5 anos aqui analisadas, implicou em diferenças de 0,2 a $0,5^{\circ} \mathrm{C}$ 
em somente 5 anos. Claro que esta série não é representativa por ser um período bastante reduzido. No entanto, é um indicativo de que mudanças de instrumentação induzem a tendências não-climáticas significativas a médio e longo prazo, cuja identificação e determinação da magnitude são relativamente simples, porém a remoção apropriada das influências é extremamente complicada. Logo, a remoção apropriada destas alterações nos métodos de observação demanda cuidado especial. Estudos mais aprofundados devem ser realizados neste sentido, buscando avaliar diferentes localidades e condições climáticas, além de procurar utilizar dados de origens confiáveis e com séries convencionais e automáticas disponíveis mais extensas.

Por fim, a comparação de quatro fórmulas normalmente utilizadas foi realizada com os dados obtidos na estação automática. Uma vez que os horários das medições na estação convencional não abrangiam todos os horários necessários, somente a coleta de meia em meia hora na estação automática tornou viável esta comparação. Sintetizando as análises, em ordem de melhor para pior aproximação com relação à temperatura verdadeira $\left(T_{\text {automática }}\right)$, as fórmulas ficam classificadas: $T_{A_{-} \gamma_{-14-21}} ; T_{A_{-} 9-21-M-}$ m; $T_{A_{-} 9-15-21} ;$ e $T_{A_{-} M-m}$.

Em relação às estações automáticas, suscita-se uma questão: será que a estação automática realmente mede a temperatura verdadeira? Presumindo que não tenha havido qualquer erro de calibração ou desajuste instrumental, as medições na estação automática estariam sujeitas a algum fator de influência não-climática que poderia induzir alguma heterogeneidade indesejável? Na tentativa de elucidar estas dúvidas, um capítulo foi dedicado exclusivamente ao processo de medição automática da temperatura do ar e os abrigos meteorológicos, disponível a partir da pg. 237.

No próximo capítulo serão analisadas as mudanças de instrumentos, especificamente comparando dados da estação automática com dados obtidos em estação convencional, com o uso de termógrafo. Na prática, no capítulo atual, quando se compararam diferentes fórmulas, também foram comparados instrumentos diferentes (estação automática e termômetros de álcool e mercúrio, e dados de termógrafo). A diferença é que no próximo capítulo a comparação será dada com dados quase contínuos, com relativa alta discretização dos dados. Ou seja, os dados utilizados possuem resolução temporal em intervalos regulares de 30 minutos, totalizando 48 leituras diárias, e, portanto, representativas da temperatura verdadeira. Ao contrário, no capítulo atual, as leituras utilizadas no cálculo das médias diárias neste capítulo estavam reduzidas a no máximo 4 leituras diárias. 



\section{CAPÍTULO 5 - Mudanças dos Instrumentos}

Os modelos climáticos auxiliam na compreensão das mudanças climáticas e na elaboração de tendências e cenários, representando a base para a tomada de decisões. Porém, não existem modelos capazes de representar fielmente todos os importantes processos do complexo sistema atmosférico, sendo que os melhores modelos ainda necessitam de assimilação contínua de dados a fim de corrigir a falta de informações sobre processos dinâmicos e termodinâmicos que regem tanto as grandes quanto as pequenas escalas (ou ambas). Logo, a habilidade de representar os parâmetros ambientais e, consequentemente, fornecer evidências sobre as condições que caracterizam o clima futuro ainda depende da disponibilidade e confiabilidade dos dados primários baseados em observações diretas.

A temperatura do ar na superfície terrestre representa a variável básica no estudo e na análise do clima passado, presente e futuro. A sua importância é devida ao fato do clima ser um tema atualmente com alta visibilidade social, uma vez que as mudanças observadas na temperatura podem estar atribuídas a alterações decorrentes das atividades humanas contribuintes com o aumento do efeito estufa. A tarefa de obter registros regulares e ubíquos da temperatura na superfície terrestre ainda apresenta sérios desafios na Meteorologia Operacional e Climatologia, exigindo contínua atenção e investimento de recursos da comunidade científica para satisfazer a necessidade de manter uma rede suficientemente densa de sítios de medição em todo o globo terrestre.

Uma vez realizada a medição de temperatura, esta requer armazenamento e transmissão a um enorme arquivo de dados. Em todas essas etapas, inúmeros erros, modificações potencialmente incorretas ou não registradas e deteriorações dos dados podem interferir de modo a reduzir a continuidade e legibilidade da série de dados, implicando em consequências indesejáveis sobre a confiança das previsões e dos cenários climáticos desenvolvidos.

Assim, a recente automatização dos métodos de aquisição de dados meteorológicos tem sido amplamente difundida devido à facilidade, eficiência, qualidade e padronização dos dados coletados, inclusive pela consequente redução dos erros de leitura, digitação e interpretação de tais dados. Os avanços tecnológicos nos 
campos da microeletrônica e automação têm registrado um progresso impressionante nos últimos anos, favorecendo o monitoramento massivo das diversas variáveis meteorológicas em tempo real, também em locais remotos, com elevado nível de precisão. Além disso, os sensores eletrônicos têm ganhado progressivamente maior resolução e acurácia, enquanto apresentam menores dimensões e custos relativamente reduzidos.

No entanto, as estações meteorológicas automáticas são de uso relativamente recente no país, embora ainda seja comum a utilização combinada com estações meteorológicas convencionais. A automação na aquisição de dados meteorológicos é uma tecnologia recente e, por conseguinte, tem gerado algumas discussões e críticas sobre a sua confiabilidade, custo e dificuldades de manutenção (PEREIRA et al., 2008). O mau funcionamento do equipamento automático frequentemente causa falhas na aquisição de dados, justificando assim a necessidade de obtenção simultânea das variáveis meteorológicas por meio das estações convencionais. De qualquer forma, verifica-se a tendência de que a tecnologia automatizada está sendo compelida a substituir quase completamente as técnicas observacionais convencionais, uma vez que as modernas técnicas oferecem uma resposta rápida e barata para os problemas de manutenção de pessoal pelas instituições que operam redes de estações.

Alguns problemas ainda persistem na questão da substituição das estações meteorológicas convencionais, que possuem longas séries de dados, muitas vezes compreendendo algumas décadas. A preocupação principal refere-se à homogeneização das novas séries de dados em relação à antiga série: este problema consiste em avaliar a confiabilidade dos valores médios medidos em uma estação automática e na avaliação de possíveis alterações na variância; esses problemas devem ser resolvidos a fim de que a junção da antiga e da nova série possa ser considerada como uma série única e representativa das condições climáticas reais (ALMEIDA, SOUZA, ALCÂNTARA, 2008).

Na apreciação da referida importância das implicações do amplo uso de dados de temperatura do ar, existe uma necessidade real de estudos que visem quantificar as possíveis diferenças sistemáticas entre os valores de temperatura do ar obtidos nas estações automáticas e nas convencionais, identificando as circunstâncias e as causas das diferenças que se encontram acima de um intervalo tolerável. Neste sentido, desde o final da década de 90, diversos estudos têm sido conduzidos no Brasil.

Sentelhas et al. (1997) comparou dados diários de um ano (01/06/1996 30/06/1997) de temperaturas máximas, mínimas e média - obtidos em uma estação 
meteorológica de superfície convencional (EMSC) com termômetros de mercúrio e álcool - com dados obtidos em estação meteorológica de superfície automática (EMSA), ambas localizadas em Piracicaba, SP. Os coeficientes de correlação $\left(\mathrm{R}^{2}\right)$ determinados foram: $T_{\max }=0,9871 ; T_{\min }=0,9691 ;$ e $T_{\text {med }}=0,9527$. Os desvios máximos foram: $T_{\max }$ $=3,549 ; T_{\min }=6,017$; e $T_{m e d}=4,329^{\circ} \mathrm{C}$. No caso dos desvios ocorridos na $T_{\text {min }}$, o autor indica que, apesar da concordância elevada, valores acentuadamente discrepantes, chegando a $6^{\circ} \mathrm{C}$, devem-se ao horário de ocorrência da $T_{m i n}$. Caso ela ocorra um pouco antes da meia-noite, na EMSA ela será registrada como do dia n, porém, na EMSC ela somente será lida no dia $n+1$, sendo isso uma importante fonte de erro. Analisando os valores sob a escala da média mensal, verificou-se a mesma tendência observada para os dados diários, em que a temperatura apresentou tendência de os dados obtidos EMSC serem maiores que os obtidos na EMSA. Os autores concluíram que a substituição das EMSCs pelas EMSAs não deve acarretar em mudanças bruscas na série de dados, em virtude das pequenas discrepâncias observadas no período de 13 meses. No entanto, deve-se considerar essas diferenças principalmente nos casos da temperatura média na escala diária nos estudos do clima, para que tais desvios não sejam atribuídos a uma alteração regional em futuras análises.

Souza et al. (2000) também comparou diários de $T_{\max }, T_{\min }$ e $T_{\text {med }}$ no Distrito de Irrigação Platô de Neópolis, localizado ao norte do Estado de Sergipe. Foram utilizados dados do período de setembro a dezembro de 1999, utilizando termômetros de máximas e mínimas, mas especificação do tipo pelos autores. Não foram utilizadas análises estatísticas dos dados, apenas realizou-se um exame visual com o uso de gráficos. Os desvios máximos $\left(T_{\text {conv }}-T_{\text {aut }}\right)$ foram: $T_{\text {max }}=3,3^{\circ} \mathrm{C} ; T_{\text {min }}=-2,7^{\circ} ;$ e $T_{\text {med }}=3,6^{\circ} \mathrm{C}$. Ou seja, tomando com referência a EMSA, a EMSC superestimou os valores máximos e médios e subestimou os valores mínimos. Apesar da magnitude dos desvios, o autor afirma que houve "uma similaridade muito boa" entre os valores e eles "estiveram muito similares entre si (...) indicando que a calibração original dos sensores da estação automática foi satisfatória, em comparação com os sensores da estação convencional, com alguma limitação para o caso da temperatura mínima".

Dados diários e mensais de $T_{m a x}, T_{m i n}$ e $T_{m e d}$ foram comparados por Souza, Galvani e Assunção (2003) em Maringá, PR. Obtidos por termômetros de mercúrio e álcool, dados de 3 anos (01/03/1999 - 31/12/2001) foram analisados. Neste estudo vale ressaltar que o cálculo da temperatura diária média do ar difere dos dois estudos anteriores, que calculavam como a média aritmética dos valores máximos e mínimos ( $\left.T_{\text {med }}=\left(T_{\text {max }}+T_{\text {min }}\right) / 2\right)$. No estudo de Souza, Galvani e Assunção (2003), a média foi 
calculada como $T_{\text {med }}=\left[T_{12 T M G}+T_{\text {max }}+T_{\text {min }}+\left(2 \cdot T_{24 T M G}\right)\right] / 5$, segundo as Normais Climatológicas (BRASIL, 1992), em que 12 e 24 TMG correspondem as 9 e 21 horas do horário local. O uso de diferentes métodos de obtenção da temperatura média diária pode induzir a diferenças significativas entre os valores, conforme já revelado no capítulo anterior. Os desvios dos valores médios mensais $\left(T_{\text {conv }}-T_{a u t}\right)$ foram de: $\sigma T_{\max }$ $=0,2 ; \sigma T_{\text {min }}=0,35$; e $\sigma T_{\text {med }}=0,04^{\circ} \mathrm{C}$. Os autores não citaram os desvios máximos mensais nem os desvios máximos diários. Em relação aos desvios diários, apenas determinou o coeficiente de correlação: $\sigma T_{\max }=0,9714 ; \sigma T_{\min }=0,966 ;$ e $\sigma T_{\text {med }}=$ 0,9076. Todavia, ao observar o gráfico de correlação das temperaturas, nota-se que os desvios diários máximos chegam a diferenças na ordem de até 5, ${ }^{\circ} \mathrm{C}$. Mesmo assim, os autores concluem que os "elementos meteorológicos $T_{m a x}, T_{m e d}$ e $T_{m i n}$ apresentaram boa concordância entre a EMSC e a EMSA" e que para os elementos meteorológicos comparados no trabalho, a substituição de EMSC por EMSA não implicará diferenças significativas em seus valores. Contudo essa não é uma regra geral, devendo cada localidade efetuar a comparação entre os elementos meteorológicos obtidos por diferentes estações antes da desativação das EMSCs.

Em Botucatu, SP, Cunha e Martins (2004) compararam dados diários de $T_{\text {max }}$, $T_{\text {min }}$, obtidas por termômetros de mercúrio e álcool, e $T_{\text {med }}$ obtida por termógrafo bimetálico, tomados no período de 01/07/1999 a 30/06/2003. A $T_{m e d}$ da EMSC foi calculada pela soma de leituras horárias $\left(T=1 / 24 \cdot \sum_{i=1}^{24} T_{i}\right)$, método, saliente-se, diferente dos utilizados até então. Os desvios diários médios $\left(T_{\text {conv }}-T_{\text {aut }}\right)$ obtidos foram: $\sigma T_{\max }=1,0 ; \sigma T_{\min }=0,3 ;$ e $\sigma T_{m e d}=0,0^{\circ} \mathrm{C}$. E os coeficientes de correlação foram: $T_{\max }=0,9895 ; T_{\min }=0,9703 ;$ e $T_{m e d}=0,9533^{\circ} \mathrm{C}$. Os desvios diários máximos não foram citados no texto, entretanto, observando os gráficos de correlação é possível inferir que seus valores extremos podem chegar até a ordem de: $T_{\max }=2,0 ; T_{\text {min }}=4,0 ;$ e $T_{\text {med }}=$ $6,0^{\circ} \mathrm{C}$. Para o caso da $T_{m e d}$, o gráfico apresentado pelo autor demonstrou desvios bastante expressivos, sendo este fato atribuído pelo autor como oriundo da diferença existente entre o elemento sensor de cada instrumento analisado, ou seja, as lâminas bimetálicas da EMSC demoram mais para responder às variações da temperatura do ar em relação ao resistor elétrico da EMSA. Apesar da EMSA e EMSC apresentarem diferentes sensores e com sensibilidades diferentes, os autores afirmam que foi boa a concordância para cada elemento meteorológico avaliado.

Com dados obtidos em Petrolina, PE, Moura et al. (2005) avaliaram dados diários, do período de 01/05/2003 a 31/12/2004, das temperaturas: $T_{\max }, T_{\min }$ (obtidas 
por termômetros de mercúrio e álcool), $T_{9}, T_{15}, T_{21}$ (obtidas em termohigrógrafo) e $T_{\text {med }}$ (calculada segundo Brasil (1992): $\left.T_{\text {med }}=\left[T_{12 T M G}+T_{\max }+T_{\min }+\left(2 \cdot T_{24 T M G}\right)\right] / 5\right)$. Os desvios diários médios $\left(T_{\text {conv }}-T_{\text {aut }}\right)$ determinados foram: $T_{9}=-0,1 ; T_{15}=-0,3 ; T_{21}=-$ 0,$4 ; T_{\max }=-0,6 ; T_{\min }=-2,5 ;$ e $T_{\text {med }}=-1,1^{\circ} \mathrm{C}$. Os coeficientes de determinação foram: $T_{9}=0,9549 ; T_{15}=0,9694 ; T_{21}=0,9649 ; T_{\text {max }}=0,9742 ; T_{\min }=0,8594 ;$ e $T_{\text {med }}=0,9312$. No caso dos desvios absolutos das temperaturas, a que apresentou valores com maior diferença, tanto negativo quanto positivo foi a $T_{\text {máx }}$, porém com um valor médio igual a $0,27^{\circ} \mathrm{C}$. No entanto, a $T_{m i n}$ do ar foi a que obteve maior valor médio do desvio absoluto $\left(2,55^{\circ} \mathrm{C}\right)$ durante todo o período analisado, seguido da $T_{\text {méd }}$, com o desvio de $0,85^{\circ} \mathrm{C}$; da $T_{15} \operatorname{com} 0,57^{\circ} \mathrm{C} ; T_{21} \operatorname{com} 0,53^{\circ} \mathrm{C} ; T_{\text {máx }} \operatorname{com} 0,11^{\circ} \mathrm{C}$; e o menor desvio absoluto foi obtido pela $T_{9}$, com um valor de $0,06^{\circ} \mathrm{C}$.

Enfim, a breve descrição de alguns estudos brasileiros oferece uma noção do teor e a linha de abordagem adotada nas análises. Além destes trabalhos descritos anteriormente, diversos outros autores também realizaram estudos comparativos entre dados obtidos em estações convencionais e automáticas (BARBOSA et al., 2006; MELLO et al., 2006; SCARPARE et al., 2006; ALMEIDA; SOUZA; ALCÂNTARA, 2008; PEREIRA et al., 2008; TERAMOTO; CARVALHO; DANTAS, 2009) e entre duas estações automáticas (TURCO; BARBOSA, 2008). Destes estudos, merece atenção o trabalho de Almeida, Souza e Alcântara (2008). Nele, comparando os dados de temperaturas (máxima, mínima e média) apresentados na Figura 3 (do estudo deles) de correlação com os valores calculados apresentados na Tabela 4 (do referido estudo), verifica-se uma incompatibilidade nos valores de Erro Máximo (EM). Em comunicação pessoal com o autor principal, por meio de correio eletrônico, ele não respondeu à observação levantada. Porém, em ocasião de contato anterior, cuja mensagem solicitava o referido artigo, o autor havia respondido e atendido ao pedido, enviando o artigo no formato digital. A observação levantada e não respondida foi em relação ao fato de os valores dos desvios máximos apresentados no artigo $\left(T_{\max }=0,55\right.$; $T_{\text {min }}=0,47$; e $T_{m e d}=0,74^{\circ} \mathrm{C}$ ) não condizerem com os valores obtidos pelo exame visual dos gráficos de correlação apresentados (na ordem de 2,0 a $2,5^{\circ} \mathrm{C}$ ).

Em suma, devem ser destacadas algumas características importantes nos trabalhos: a maioria utilizou-se de dados diários e poucos utilizaram dados horários; tipos diferentes de instrumentos foram utilizados, sendo os termômetros de mercúrio e de álcool os principais; fórmulas distintas de determinação da temperatura média diária foram utilizadas, podendo implicar em valores distintos; dados de diversas localidades espalhadas pelo país foram analisados, cada série representando os 
respectivos climas locais; metodologias estatísticas usadas também diferiram, sendo que a maioria utilizou de alguns índices estatísticos principais (coeficiente de correlação, desvios médios) e outros mais elaborados e específicos; gráficos de correlação foram amplamente empregados nas análises visuais, porém nenhum utilizou histogramas como forma de representar a distribuição das frequências dos desvios; e até mesmo erros metodológicos e/ou de cálculos relativamente simples foram identificados.

Portanto, dos trabalhos levantados, existe essencialmente uma certa padronização da abordagem estatística nas análises, com pequenas variações de técnicas aplicadas. No sentido de suprir algumas deficiências e aspectos que ainda carecem de análises mais aprofundadas, como, por exemplo, identificar e discutir quais as heterogeneidades causadoras dos desvios extremos e as condições em que eles ocorreram, tal capítulo tem como objetivo comparar os dados obtidos em duas estações climatológicas, uma automática e outra convencional. Foram aplicados os índices estatísticos convencionalmente utilizados na maioria dos estudos comparativos já realizados, além de análises novas sob um enfoque inédito de comparação de diferentes escalas temporais dos dados.

A maioria dos trabalhos anteriormente citados utilizou dados de temperatura do ar obtidos por termômetros comuns e de máximas e mínimas das estações convencionais, resultando em poucos registros diários para esta variável climática. O diferencial deste trabalho se diz respeito à resolução temporal dos dados, que somente foram possíveis pela conversão automática dos dados em papel dos termogramas no formato digital pelo programa Plot2Data, conforme será descrito em detalhes adiante. Os dados convertidos na resolução de intervalos regulares de 30 minutos, totalizando em 48 valores diários, permitiram comparar os valores nas escalas horárias, diárias, mensais e anual, abordagem até então não explorada pelos pesquisadores.

No contexto das mudanças climáticas e do aquecimento global, a avaliação da confiabilidade das observações meteorológicas motivou o objetivo deste trabalho de apresentar e comparar os registros contínuos de temperatura do ar obtidos em dois anos de operação simultânea de duas estações climatológicas, convencional e automática, instaladas no Centro de Recursos Hídricos e Ecologia Aplicada (CRHEA), Escola de Engenharia de São Carlos (EESC), Universidade de São Paulo (USP), localizada no município de Itirapina, São Paulo, Brasil (Latitude: $22^{\circ} 10^{\prime}$ Sul, Longitude: 4750' Oeste, Altitude: $753 \mathrm{~m}$ ), a $25 \mathrm{~km}$ do município de São Carlos. Além do diagnóstico comparativo, procurou-se caracterizar as ocorrências de valores de diferença consideravelmente acima do desvio médio, identificando possíveis fatores que 
influenciam nos processos de medições e incorporam efeitos adversos nas séries de dados.

\subsection{Materiais e Métodos}

Os dados utilizados de dois anos da temperatura do ar foram coletados em intervalos regulares de 30 minutos, resultando em 48 registros diários, no período de janeiro de 2001 a dezembro de 2002, totalizando 31290 registros, excluindo-se os dias com falhas em alguma das estações. O termógrafo bi-metálico utilizado, da marca R. Fuess, modelo 17, n. G3851 (Figura 76-A), esteve acondicionado em uma Câmara de Stevenson (Figura 76-B); e a estação automática utilizada (Figura 76-C), da Campbell Scientific, possuía o sistema de aquisição e armazenamento de dados modelo $21 \mathrm{X}$, com o sensor de temperatura e umidade relativa modelo HMP35 acoplado ao abrigo não aspirado modelo 41003 da fabricante R.M. Young. As temperaturas médias diárias de ambas as séries foram determinadas pelos valores obtidos a cada meia hora, cujos resultados representam a temperatura verdadeira.
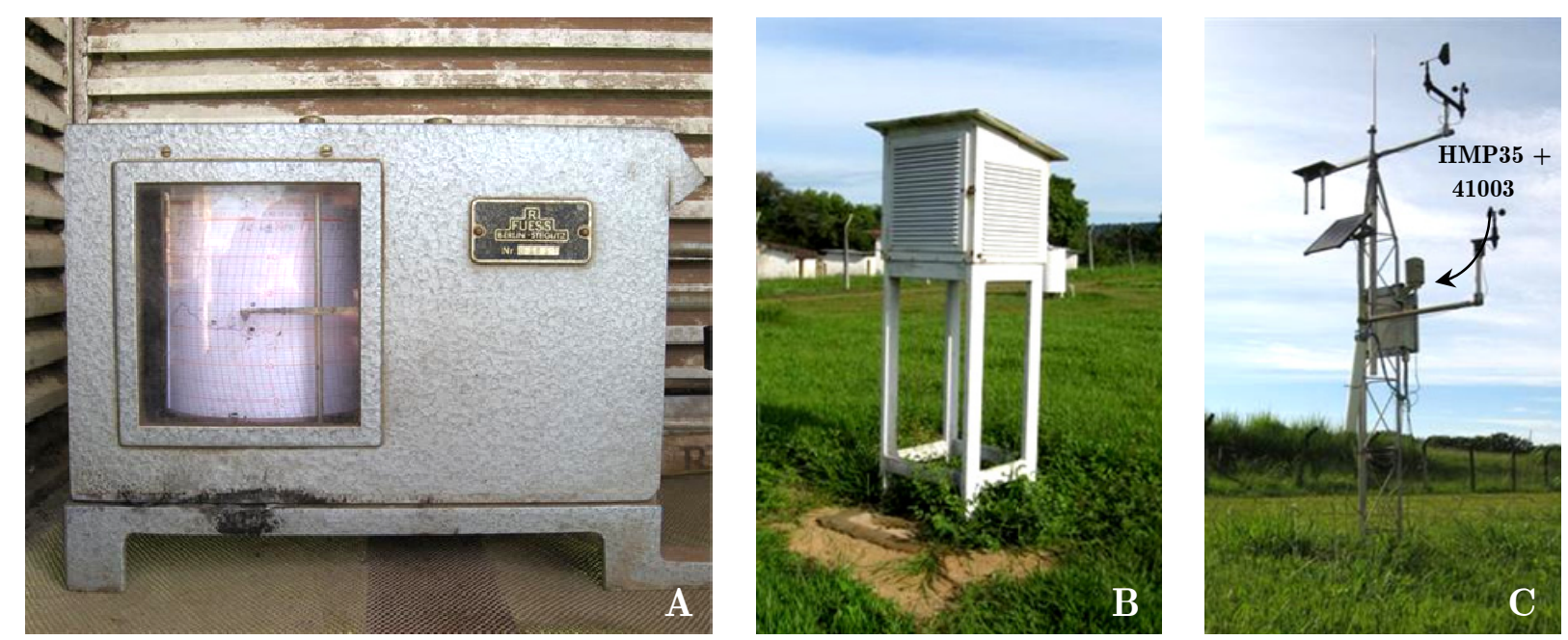

Figura 76 - Estações convencional e automática: (A) Termógrafo R. Fuess; (B) Câmara de Stevenson; (C) Estação climatológica automática, com indicação do sensor de umidade e temperatura do ar modelo HMP45C, acondicionado no abrigo modelo 41008.

Os termogramas - com escala temporal de uma semana, totalizando 95 papéis foram digitalizados pelo scanner da Plustek, modelo OpticPro S16, em resolução de 200 dpi. As imagens digitalizadas foram convertidas pelo programa aplicativo Plot2Data, desenvolvido por um grupo liderado pelo Prof. Roberto Massimo Leonardi do Istituto 
di Scienze dell'Atmosfera e del Clima (CNR), Roma, Itália. Tal software foi responsável pela execução de rotinas automatizadas, descritas detalhadamente em Leonardi et al. (2006), que permitiram a extração dos valores da temperatura dos registros dos termogramas, e na rápida conversão dos dados para um formato digital, facilmente usado em programas aplicativos de planilhas e gráficos.

As análises comparativas utilizaram alguns indicadores estatísticos de precisão e exatidão, com as fórmulas apresentadas da Eq. (10) a Eq. (19), como: coeficiente de correlação de Pearson $(R)$; coeficiente de determinação $\left(R^{2}\right)$, índice de concordância $(d)$, erro máximo $(E M)$, erro absoluto médio $(E A M)$, raiz quadrada do erro médio quadrático normalizado $(R M S E)$, eficiência $(E F)$, coeficiente da massa residual $(C R M)$, erros sistemático $(E s)$ e aleatório $(E a)$, de acordo com Willmott et al. (1985); e critério de interpretação de desempenho ou confiança do modelo $(c)$, estabelecido por Camargo e Sentelhas (1997). Se os valores de temperatura das duas estações coincidirem, os índices estatísticos de exatidão e/ou de precisão serão: $E M=E A M=R M S E=C R M=E_{s}=E_{a}=0$ e $R=R^{2}=d=E F=c=1$.

As variáveis $O$ e $P$ representam as temperaturas obtidas nas estações convencional e automática, respectivamente, tendo seus valores médios calculados por $\bar{P}=(1 / n) \cdot \sum_{i=1}^{n} P_{i}$ e $\bar{O}=(1 / n) \cdot \sum_{i=1}^{n} O_{i}$. O índice $\hat{P}_{i}$ é obtido por $\hat{P}_{i}=a \cdot O_{i}+b$, representando a reta ajustada por regressão linear aos valores de temperatura na correlação. Os nomes das variáveis $O$ e $P$, utilizadas em consonância com os autores supracitados que utilizaram estes índices estatísticos, equivalem respectivamente a $T_{\text {convencional }}$ (ou $T_{\text {conv }}$ ) e $T_{\text {automática }}$ (ou $T_{\text {aut }}$ ), termos que serão utilizados ao longo do texto mais adiante, com a finalidade de facilitar a compreensão mais imediata das correspondências.

Além das análises estatísticas, o estudo teve como propósito a visualização comparativa da distribuição dos dados por meio de confecção de gráficos como: correlações entre os valores de temperaturas; diagrama de densidade das correlações; diferenças de temperatura; histograma das diferenças; e perfis de temperatura. As análises estatísticas, os cálculos, a confecção de gráficos e tabelas foram feitos utilizando-se a planilha eletrônica MS Excel e o programa estatístico R versão 2.9.0. 


$$
\begin{aligned}
& R=\left[\sum_{i=1}^{n}\left(P_{i}-\bar{P}\right) \cdot\left(O_{i}-\bar{O}\right)\right] /\left[\left(\sum_{i=1}^{n}\left(P_{i}-\bar{P}\right)^{2}\right)^{0,5} \cdot\left(\sum_{i=1}^{n}\left(O_{i}-\bar{O}\right)^{2}\right)^{0,5}\right] \\
& d=1-\left[\sum_{i=1}^{n}\left(P_{i}-O_{i}\right)^{2} / \sum_{i=1}^{n}\left(\left|P_{i}-\bar{O}\right|+\left|O_{i}-\bar{O}\right|\right)^{2}\right] \\
& E M=\max \left(\left|O_{i}-P_{i}\right|\right)_{i=1}^{n} \\
& E A M=\left[\frac{1}{n} \sum_{i=1}^{n}\left(O_{i}-P_{i}\right)\right] \\
& R M S E=\left[\frac{1}{n} \sum_{i=1}^{n}\left(O_{i}-P_{i}\right)^{2}\right]^{0,5} \cdot\left(\frac{100}{\bar{O}}\right) \\
& E F=\left[\sum_{i=1}^{n}\left(O_{i}-\bar{O}\right)^{2}-\sum_{i=1}^{n}\left(O_{i}-P_{i}\right)^{2}\right] / \sum_{i=1}^{n}\left(O_{i}-\bar{O}\right)^{2} \\
& C R M=\left[\sum_{i=1}^{n} O_{i}-\sum_{i=1}^{n} P_{i}\right] / \sum_{i=1}^{n} O_{i} \\
& E_{s}=\left[\frac{1}{n} \sum_{i=1}^{n}\left(\hat{P}_{i}-O_{i}\right)^{2}\right]^{0,5} \\
& E_{a}=\left[\frac{1}{n} \sum_{i=1}^{n}\left(\hat{P}_{i}-P_{i}\right)^{2}\right]^{0,5} \\
& c=r \cdot d
\end{aligned}
$$

\subsection{Resultados e Discussão}

A Figura 77 apresenta as falhas de dados diários identificadas nos anos de 2001 e 2002 da série de temperatura obtida pelo termógrafo.

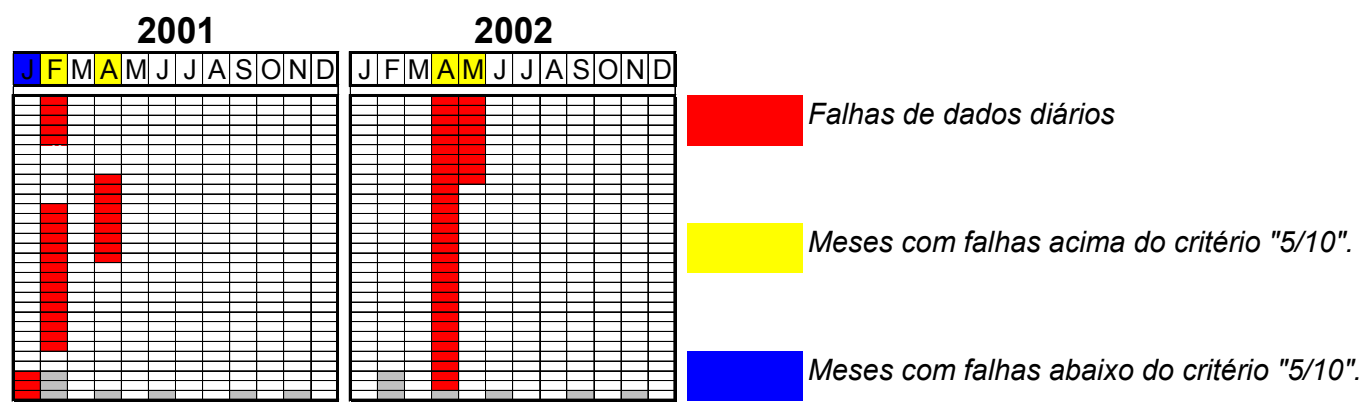

Figura 77 - Distribuição visual das falhas diárias na série de temperaturas obtidas pelo termógrafo, no período de 2001-2002.

A partir dos 95 termogramas disponíveis para o período 2001-2002, o software Plot2Data realizou a conversão automática das figuras digitalizadas para os valores de 
temperatura na resolução de 5 minutos, utilizando-se de algoritmos que detectam e vetorizam a grade curvilínea com base em uma transformação de Fourier. A transformação de coordenadas cilíndricas para cartesianas é aplicada a toda imagem, produzindo a retificação simultânea da grade e da curva da temperatura registrada no papel. Outros algoritmos específicos, baseados em análises morfológicas e colorimétricas, são responsáveis por identificar e remover manchas e riscos de caneta, além de reconstruir a curva de temperatura. A Figura 78 exibe o exemplo de um termograma original (A) e um termograma retificado (B). O procedimento da conversão termina com a geração de um arquivo de dados contendo os valores de temperatura registrados a cada 5 minutos (Figura 79). Médias de 30 minutos foram calculadas para comparar com os dados coletados com o mesmo intervalo na estação automática.

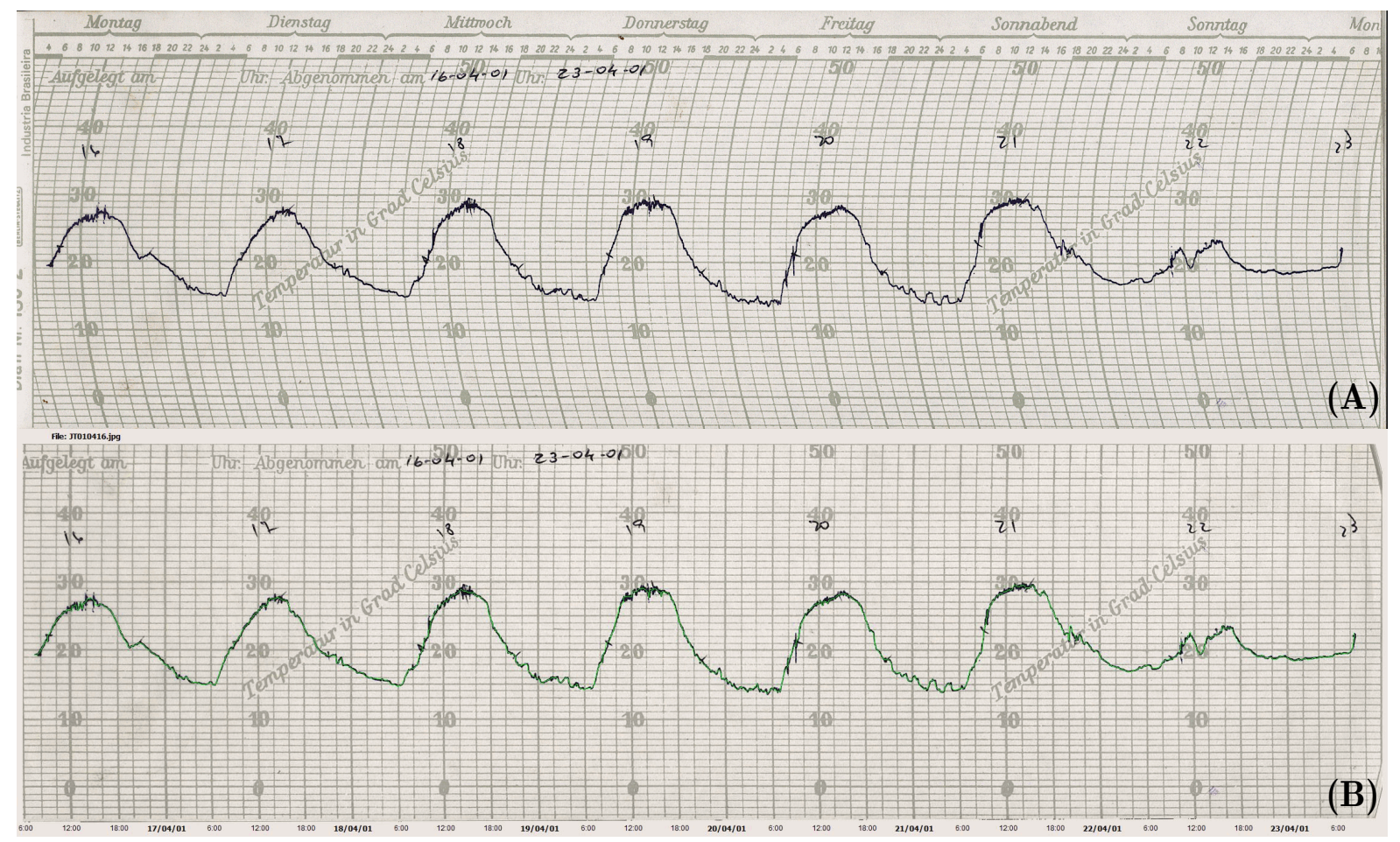

Figura 78 - Termogramas (A) original e (B) convertido para o período de 16 a 23 de abril de 2001. 


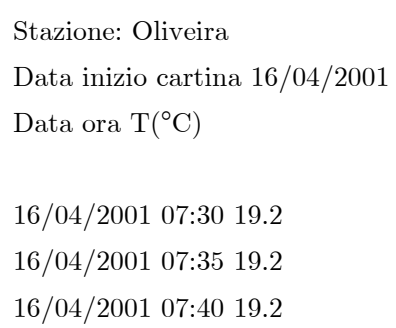

Figura 79 - Trecho do arquivo de dados - gerado pelo software Plot2Data - após a conversão do termograma e extração dos valores de temperatura.

Convertidos e incorporados em planilhas do MS Excel, os valores de temperatura das estações automática e convencional foram submetidos às análises estatísticas. Os resultados dos cálculos das análises de concordância entre os valores na escala temporal com resolução de 30 minutos estão apresentados na Tabela 18. Nota-se que os dados apresentam, a princípio, boa concordância, com valores de $R^{2}, d, E F$, e $c$ próximos de 1. Além disso, verifica que o valor médio da temperatura, para os anos de 2001 e 2002, obtidos pela estação convencional e automática são bastante próximos, nos valores de $21,03{ }^{\circ} \mathrm{C}$ e $21,10{ }^{\circ} \mathrm{C}$, respectivamente, com diferença de apenas $0,07{ }^{\circ} \mathrm{C}$. Entretanto pode-se observar que o valor do erro máximo é da ordem de $10{ }^{\circ} \mathrm{C}$, representando, portanto, que, apesar da média dos valores apresentarem uma boa correlação, existem valores críticos que devem ser analisados em detalhe.

Tabela 18 - Índices estatísticos para análise da concordância de $T_{\text {convencional }}$ e $T_{\text {automática }}$

\begin{tabular}{lcc}
\hline \hline Índice estatístico & Sigla & Valor $\left({ }^{\circ} \mathrm{C}\right)$ \\
\hline Coeficiente de correlação de Pearson & $R$ & 0,9759 \\
Coeficiente de determinação & $R^{2}$ & 0,9523 \\
Índice de concordância & $d$ & 0,9877 \\
Erro máximo & $E M$ & 10,46 \\
Erro absoluto médio & $E A M$ & 0,0673 \\
Raiz quadrada do erro médio quadrático normalizado & $R M S E$ & 5,533 \\
Eficiência & $E F$ & 0,9521 \\
Coeficiente da massa residual & $C R M$ & 0,0032 \\
Erro sistemático & $E_{s}$ & 3,5558 \\
Erro aleatório & $E_{a}$ & 3,6157 \\
Critério de confiança & $c$ & 0,9638 \\
Média da $T_{\text {automática }}$ & $\bar{P}$ & 21,10 \\
Média da $T_{\text {convencional }}$ & $\bar{O}$ & 21,03 \\
\hline
\end{tabular}


A correlação dos valores de temperatura pode ser visualizada na Figura 76. Verifica-se no gráfico (A) que a reta de regressão linear apresenta uma concordância elevada, e gráfico (B) mostra que a maioria dos pontos na correlação está concentrada próxima à reta de regressão. Porém, ainda percebe-se a ocorrência de alguns pontos consideravelmente distantes da reta, implicando em diferenças de temperatura na ordem de $10{ }^{\circ} \mathrm{C}$, tanto positivas quanto negativas.
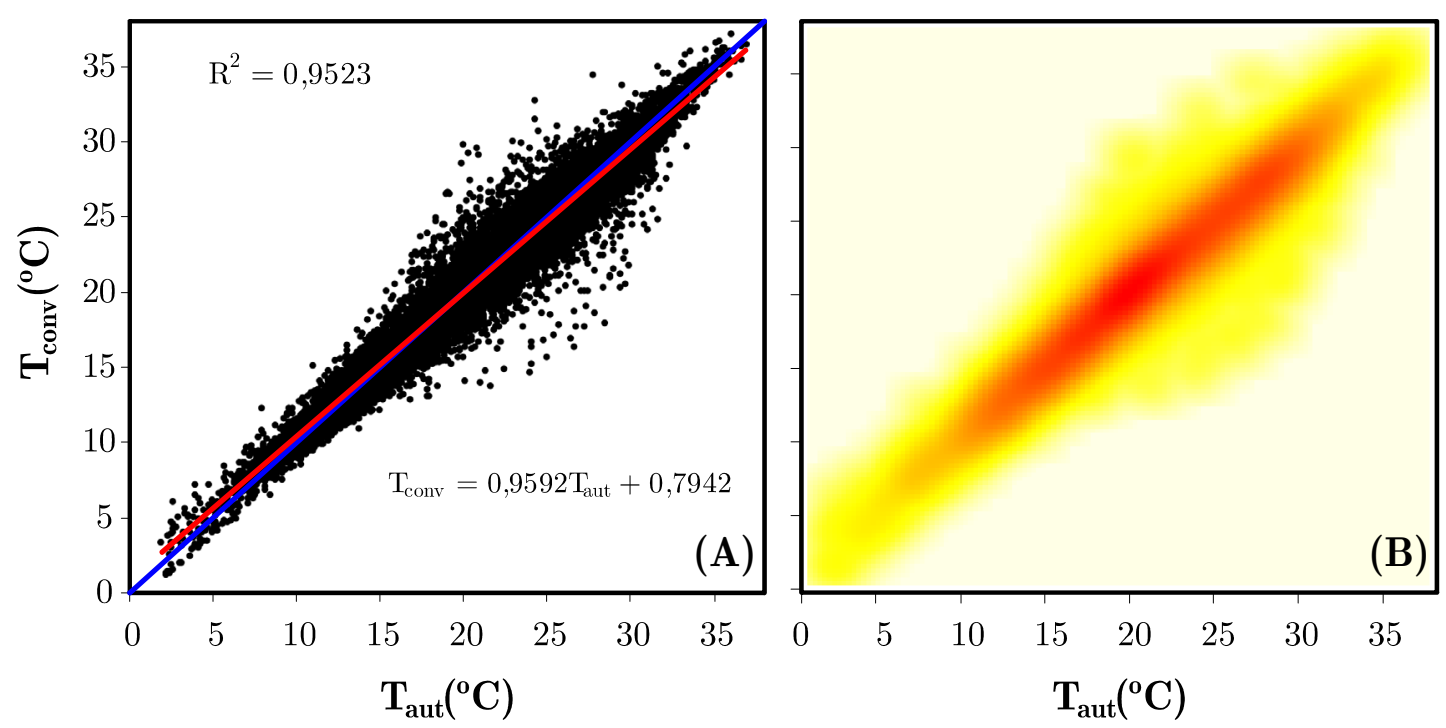

Figura 80 - Correlação das temperaturas provenientes das estações convencional $\left(T_{\text {conv }}\right)$ e automática $\left(T_{\text {aut }}\right)$. (A) Gráfico de dispersão com reta de regressão linear dos pontos. (B) Gráfico de densidade dos pontos na correlação: tons do vermelho representam alta densidade, enquanto tons amarelos representam baixa densidade.

Avaliando a distribuição relativa de ocorrências das diferenças de temperatura, o histograma da Figura 81 exibe que 18,5\% dos valores de temperatura são coincidentes, $52,8 \%$ das diferenças de temperatura estão compreendidas no intervalo de $-0,5{ }^{\circ} \mathrm{C}$ a $0,5{ }^{\circ} \mathrm{C}$, e $95 \%$ das diferenças estão no intervalo de $-2{ }^{\circ} \mathrm{C}$ a $2{ }^{\circ} \mathrm{C}$. 


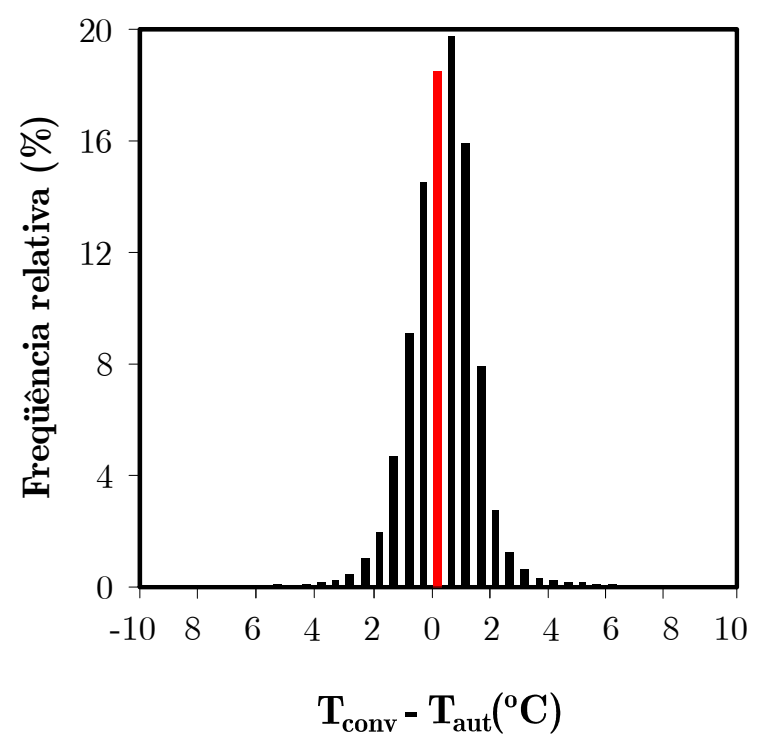

Figura 81 - Histograma de distribuição relativa dos desvios de temperatura da série $T_{\text {convencional }}$ em relação à $T_{\text {automática }}$ no período 2001-2002

Avaliando os casos com alta discrepância nos valores das diferenças dos valores a cada 30 minutos, na Figura 82 é possível constatar os períodos do ano que apresentaram ocorrências que merecem ser estudadas em detalhe. A Figura 83 ilustra o caso do dia 26 de dezembro de 2001, que apresentou o maior valor positivo da diferença entre as medições da temperatura. A explicação para o fenômeno é devido ao fato de uma das duas escalas temporais (notadamente a do termógrafo) estar deslocada em cerca de três registros (uma hora e meia) com relação à outra (escala da estação automática). Com o atraso dos registros do termograma com início no dia 23, verificase a ocorrência de uma queda brusca na temperatura no dia 26 em um intervalo curto de tempo, que produziu, consequentemente, um desvio tão elevado entre as duas medições.

É evidente, neste caso, que ou o operador posicionou indevidamente a nova folha de papel sobre o tambor da gravação do instrumento ou não foi realizado o ajuste do relógio do termógrafo, introduzindo assim um nítido atraso de cerca de 1 hora e 30 $\min$. 

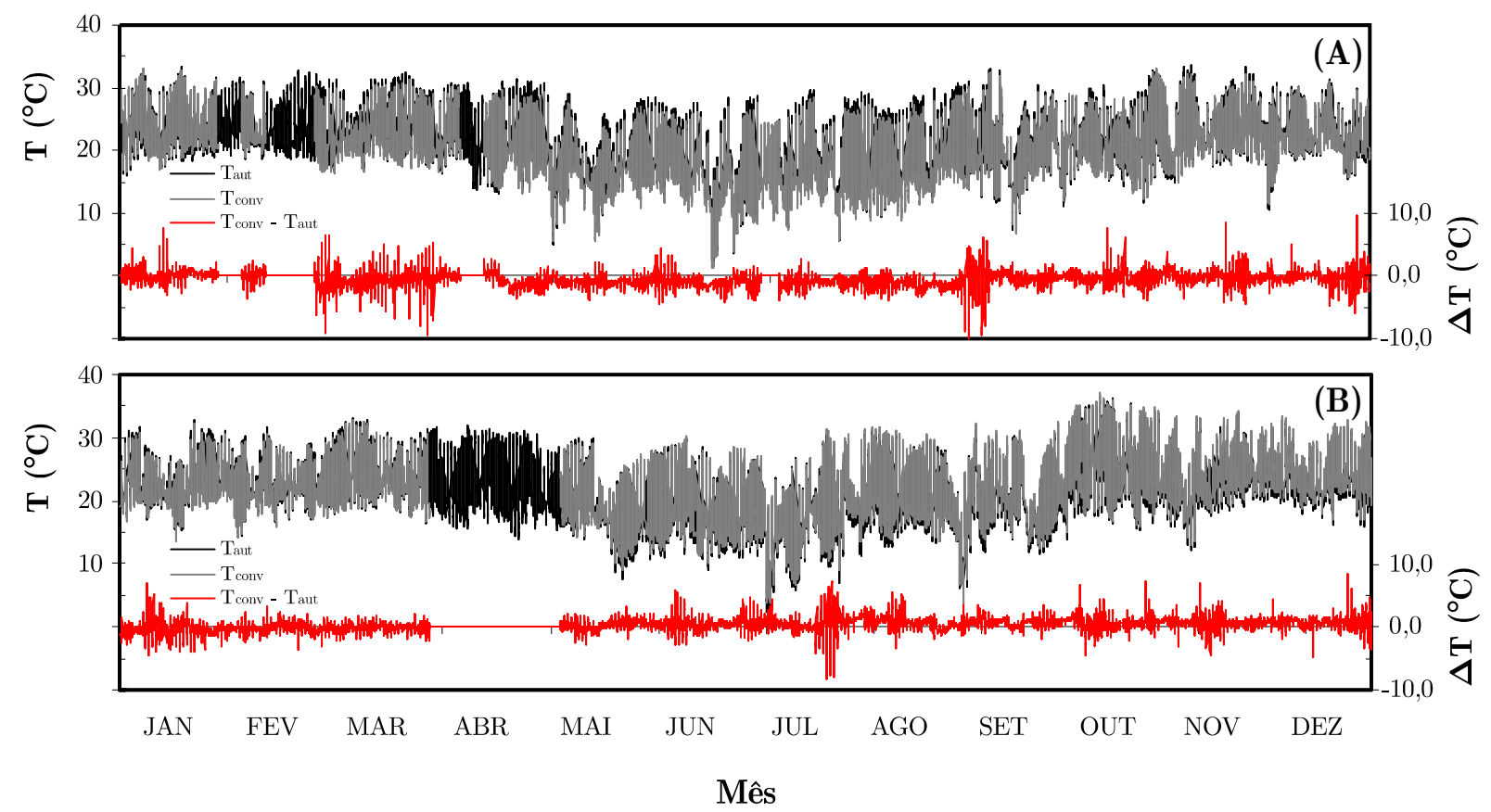

Figura 82 - Perfis de temperatura e respectivos desvios de temperatura das séries $T_{\text {convencional }}$ e $T_{\text {automática }} \operatorname{nos} \operatorname{anos}(\mathbf{A}) 2001$ e (B) 2002.

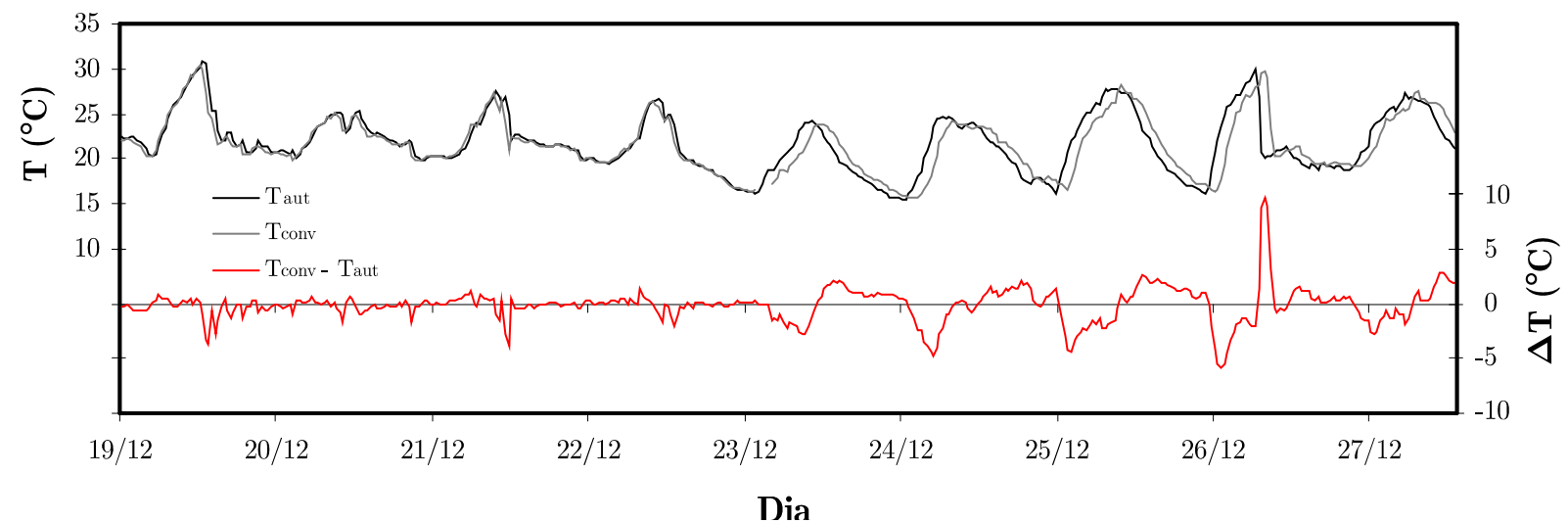

Figura 83 - (A) Perfis de temperatura e (B) desvios de temperatura das séries $T_{\text {convencional }}$ e $T_{\text {automática }}$ no período de 19 a 28 de dezembro de 2001.

Mantendo os procedimentos adotados nas comparações de séries de temperaturas nos demais capítulos, os dados são analisados nas escalas horária, diária e mensal, sintetizados na Figura 84. Sob a perspectiva dos valores médios horários, gráfico (A), nota-se que os desvios variam em uma amplitude de até $10^{\circ} \mathrm{C}$, tanto positivo, quanto negativo. Na escala da temperatura média diária, gráfico (B), a amplitude de variação fica em torno de $2,0^{\circ} \mathrm{C}$. Nesta escala, ficam em evidência três fases distintas do comportamento dos desvios. A primeira fase é caracterizada predominantemente por desvios negativos, estendendo-se de janeiro a agosto de 2001.

A segunda fase, com início em agosto e término em março de 2002, apresenta 
desvios bastante próximos do valor nulo. E na terceira fase, de maio até dezembro de 2002, prevalecem desvios positivos. Tal panorama é reforçada pela apresentação dos desvios mensais no gráfico (C), cuja amplitude varia na ordem de $0,8^{\circ} \mathrm{C}$.

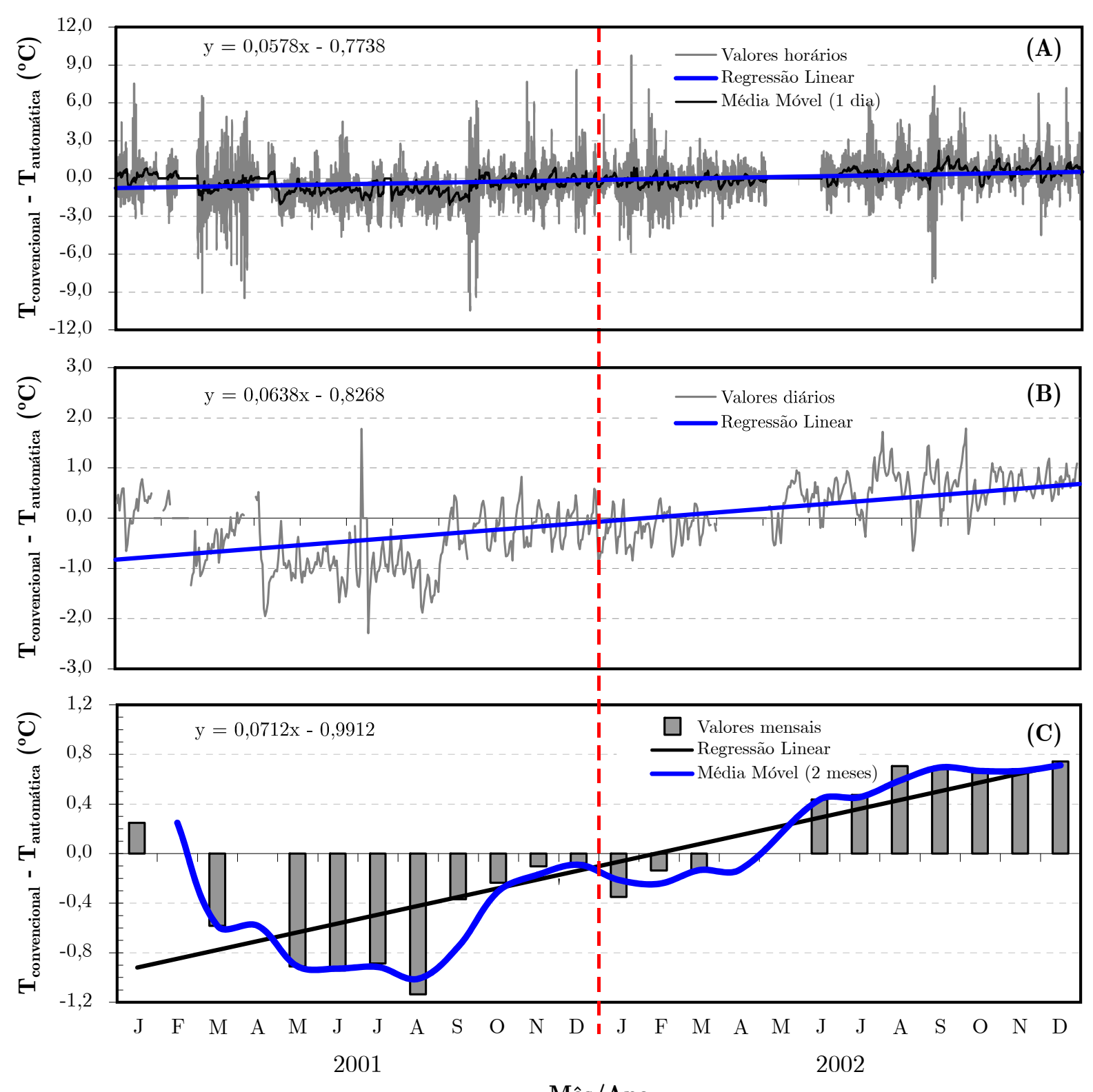

Figura 84 - Desvios em diferentes escalas e tendências das temperaturas da série $T_{\text {convencional }}$ em relação à $T_{\text {automática }}$ no período 2001-2002. Desvios (A) horários, (B) diários e (C) mensais.

Tais fases identificadas denotam a ocorrência de uma heterogeneidade cuja atribuição da(s) causa(s) verdadeira(s) se torna extremamente intrincada. Como possíveis causas, podem ser citadas: mudanças dos instrumentos e sensores devido à calibração ou a falta dela; mudança dos papéis dos termogramas; mudança da pessoa responsável pela troca dos termogramas, causando, consequentemente, alterações das 
técnicas utilizadas; mudança do local físico em que se encontrava o termógrafo durante as medições. Enfim, são vários os possíveis fatores que podem interferir nas medições, acarretando em erros de diferentes ordens de grandeza, de acordo com a escala de análise assumida.

Uma última análise é dada por uma síntese dos valores por meio do cálculo de índices estatísticos. As fórmulas utilizadas anteriormente não são em sua maioria essenciais, sendo desnecessário e redundante utilizar tantas possíveis fórmulas para caracterizar uma análise comparativa. Elas foram utilizadas neste estudo seguindo a metodologia que tem sido empregada em estudos de comparação do gênero. Portanto, com o intuito de evitar um exagero de fórmulas e um excesso de informação com significados repetitivos, a Tabela $\mathbf{1 9}$ apresenta a síntese dos principais índices estatísticos, que foram utilizados em todos os outros os capítulos e se mostraram suficientes para permitir a comparação satisfatória dos desvios em escalas diversas.

Tabela 19 - Análise estatística da série $T_{\text {convencional }}$ em relação à $T_{\text {automática }}$ no período 20012002.

\begin{tabular}{lccc}
\hline \multirow{2}{*}{\multicolumn{1}{c}{ Índice }} & \multicolumn{3}{c}{ Desvio de temperatura $\left({ }^{\circ} \mathbf{C}\right)$} \\
& \multicolumn{3}{c}{$\left(\boldsymbol{T}_{\text {convencional }}-\boldsymbol{T}_{\text {automática }}\right)$} \\
\cline { 2 - 4 } Máximo & Horária & Diária & Mensal \\
\cline { 2 - 4 } Mínimo & 9,72 & 1,79 & 0,74 \\
Desvio padrão & $-10,46$ & $-2,29$ & $-1,13$ \\
Média dos desvios & 1,17 & 0,71 & 0,62 \\
Intervalo de confiança - $95 \%$ & $-2,35-2,11$ & $-1,45-1,11$ & $-0,06$ \\
\hline
\end{tabular}

Ressalta-se a atenção que deve ser dada ao tomar o valor da média dos desvios como representativa da correlação geral entre os valores obtidos na estação convencional e na estação automática. Embora o valor seja praticamente igual a zero no período dos dois anos, em 2001 o desvio médio foi de $-0,50^{\circ} \mathrm{C}$ e em 2002 foi de $0,37^{\circ} \mathrm{C}$ (com base nos valores diários), ou seja, na média dos dois anos os valores se compensaram. Portanto apenas séries maiores possibilitariam conclusões aceitáveis sobre as tendências observadas entre diferentes métodos e instrumentos de obtenção da temperatura do ar. O que se pode inferir nesta comparação é que a magnitude dos desvios é consideravelmente elevada nas três escalas abordadas (horária, diária e mensal), apresentando um padrão não linear e complexo, decorrente de fatores desconhecidos. 


\subsection{Considerações finais}

As análises estatísticas comparativas entre os dados da estação meteorológica convencional e os da automática demonstraram boa concordância entre si. A ocorrência de valores consideravelmente discrepantes, da ordem de $10{ }^{\circ} \mathrm{C}$, não implicou em alterações significativas nos valores médios anuais da temperatura obtida pelos dois métodos, devido ao fato destas diferenças não serem tão frequentes.

A respeito das diferenças críticas infere-se que o ponto crucial consiste apenas na correção escala temporal do instrumento mecânico, uma vez que parece razoável supor que o instrumento automático é dotado de um sistema com base na referência de um relógio de quartzo, ou, de qualquer forma, com um equipamento muito mais confiável para medição do tempo.

Neste sentido, dado que estas mudanças nos registros em papel são frequentes, mas não são facilmente previsíveis, o programa Plot2Data demandaria de implementações para incorporação de um novo algoritmo capaz de detectar automaticamente o deslocamento dos dados, realizando a calibração da escala temporal dos termogramas. Ou melhor, uma rotina poderia ser implementada com referência ao ciclo diurno local, cuja correção dos dados ocorreria independentemente de qualquer comparação com os dados provenientes de uma estação automática em operação simultânea.

Desta forma, com a identificação das circunstâncias e remoção das causas das diferenças que se encontram acima do tolerável, evita-se que registros potencialmente incorretos dos dados possam afetar a continuidade e legibilidade da série de dados e trazer consequências indesejáveis sobre a confiança das previsões e dos cenários climáticos, desenvolvidos com base nos dados observacionais primários da temperatura do ar.

Exalta-se aqui a necessidade e oportunidade para padronização de uma metodologia de análises, uma vez que muitos trabalhos têm sido publicados nestes moldes, mas persistem algumas peculiaridades que dificultam a comparação entre os resultados dos diferentes estudos. Recomenda-se a elaboração de uma revisão bibliográfica extensa e detalhada que permita um confronto entre as dezenas de comparações já realizadas; que sejam identificadas as metodologias em consonância; e que a partir de uma compilação, seja elaborado e recomendado um método padronizado que possa porventura ser futuramente utilizado pelos trabalhos vindouros. 
Além da comparação das temperaturas obtidas pela estação automática com as obtidas em estação convencional com o uso de termógrafo, o aspecto das mudanças de instrumentos também seria possível ao comparar os dados "contínuos" obtidos por termômetros (leituras com resolução de pelo menos 24 leituras diárias, ou idealmente 48 leituras). Este tipo de comparação isolaria a questão do uso de diferentes fórmulas baseadas em leituras reduzidas, e de fato seriam comparados os valores da temperatura verdadeira de cada instrumento. Assim, o desvio de temperatura observado entre instrumentos automáticos e termômetros representaria as diferenças reais entre estas duas modalidades de medição. Para realização desta avaliação, seria necessária, portanto, a coleta contínua de um instrumento analógico, o que a princípio dificultaria a obtenção de dados à noite e por uma quantidade de dias relativamente suficiente para comparar em nas escalas mensais e anuais, devido à necessidade de um observador, que teria uma tarefa bastante exaustiva. Um possível improviso poderia conceber uma forma de registrar indireta e automaticamente os valores indicados nos termômetros. Por exemplo, poderia-se imaginar uma câmera digital que tirasse uma foto legível da marca e da escala da temperatura a cada 30 minutos (ou uma webcam ligada a um computador). Uma vez disponíveis as imagens no computador, com os valores do termômetro fotografados, bastaria apenas fazer a leitura das imagens e transcrever os valores em uma planilha, obtendo, de uma forma relativamente simples e viável, as informações da temperatura. Esta ideia fica apenas como ilustrativa de como viabilizar a leitura contínua dos valores de um termômetro e assim permitir uma comparação com os valores obtidos instrumentos automáticos. 


\section{CAPÍTULO 6 - Mudanças dos Abrigos}

O princípio primário da medição de temperaturas do ar com estações automáticas é o fornecimento de dados de qualidade e fidelidade para que possam ser usados pelas ciências atmosféricas e relacionadas. Vários estudos têm demonstrado que para atingir medições precisas de temperatura são necessários ambos eficientes abrigo de radiação e sistema de ventilação. (LIN; HUBBARD; MEYER, 2004).

Quando se pretende medir a temperatura externa do ar, o abrigo de radiação do sensor não permite bloquear toda a radiação solar e radiação infravermelha sem que se reduza a velocidade do fluxo de ar nas vizinhanças do sensor de temperatura. Um abrigo ideal contra efeitos de radiação seria aquele que bloqueasse toda a radiação solar, mas isto é impossível por causa das aberturas necessárias para o ar fluir através do abrigo (LIN; HUBBARD, 2001).

Portanto, torna-se evidente que, para minimizar a influência de radiações de ondas curtas e longas, o sensor de temperatura necessita condicionamento em abrigo térmico. Quanto ao efeito da ventilação, existem estudos que determinam coeficientes de correção de temperatura em abrigos com ventilação natural em condições de baixa ventilação, a exemplo de Nakamura e Mahrt (2005), porém o sugerido pela OMM (WMO, 2008) e pela maioria dos estudos é a tomada de temperaturas em abrigos com ventilação artificial.

Embora existam termômetros e sensores de diferentes formatos, tipo e qualidade, estes dispositivos tendem, em princípio, a convergirem para uma padronização. Entretanto, o projeto e construção de abrigos demonstram diferenças significativas. O fato é que termômetros e sensores podem ser calibrados em concordância com padrões e normas aprovadas internacionalmente. Já os abrigos não estão, porém, sujeitos a nenhuma padronização. No Manual de Instrumentos e Métodos de Observação (WMO, 2008) sugestões para utilização de abrigos são apresentadas, mas não é recomendado nenhum abrigo padrão típico (VAN DER MEULEN, 1998).

Logo, mesmo existindo diretrizes internacionais que especificam a obtenção de uniformidade das medições, nenhum abrigo padrão foi definido. Consequentemente, 
muitos abrigos estão em uso no mundo, cada um com suas características específicas (VAN DER MEULEN; BRANDSMA, 2008).

Enquanto não são estabelecidas tais normas, e devido à disponibilidade comercial de inúmeros modelos de abrigos, aspirados e não-aspirados, avaliações experimentais $^{27}$ têm sido realizadas na tentativa de comparação e avaliação da eficiência de cada modelo.

A preocupação com a falta de padronização de abrigos resultou na decisão da OMM (WMO, 2003) em criar junto a International Organization for Standardization (ISO) uma norma ${ }^{28}$ de métodos de comparação de desempenho de abrigos, que recentemente foi aprovada e publicada (ISO, 2007).

Assim, conforme Brandsma e Van der Meulen (2008), inter-comparações de abrigos tem sido realizadas por vários autores ${ }^{29}$, comparando abrigos utilizados no passado com termômetros de mercúrio com os abrigos mais novos utilizados em sistemas automáticos de aquisição de dados. Estudos recentes ${ }^{30}$ têm avaliado apenas as diferenças entre os abrigos da nova geração.

Os autores op. cit. acusaram a falta de trabalhos de inter-comparações de abrigos de temperatura ao redor do mundo, alertando sobre a necessidade de estudos que quantifiquem a magnitude da relação de dependência das condições climáticas com as diferenças de temperatura entre os abrigos.

Van der Meulen e Brandsma (2008) relataram que a Commission for Instruments and Methods of Observation (CIMO) recomendou a organização de um estudo internacional de inter-comparação de abrigos de temperatura em diferentes regiões climatológicas, evidenciando a necessidade do entendimento do comportamento destes abrigos em condições variadas.

\footnotetext{
${ }^{27}$ FUCHS; TANNER, 1965; SPARKS, 1972; TANNER 1990; QUAYLE et al., 1991; ANDERSSON; MATTISON, 1992; WARNE, 1995; GUTTMAN; BAKER, 1996; TANNER; SWIATEK; MAUGHAN, 1996; VAN DER MEULEN, 1998; HUBBARD; LIN; WALTER-SHEA, 2001; LIN; HUBBARD; MEYER, 2001; LIN; HUBBARD; WALTER-SHEA, 2001.

28 ISO 17714: Meteorology - Air temperature measurements - Test methods for comparing the performance of thermometer shields/screens and defining important characteristics.

29 MAWLEY, 1897; SPARKS, 1972; PARKER, 1994; BARNETT, HATTON; JONES, 1998; HATTON, 2002.

30 ANDERSON; MATTISSON, 1991; LEFEBVRE, 1998; LARRE; HEGG, 2002.
} 
Tal estudo de inter-comparação ${ }^{31}$ teve início em fevereiro de 2006 com envio de convites aos membros representativos permanentes da OMM espalhados mundialmente. A seleção de participantes potenciais foi realizada em maio, e participantes definitivos em julho. As preparações dos locais de instrumentos e abrigos foram realizadas de julho a novembro. A inter-comparação teve início efetivo das medições em meados de 2007, com previsão de coleta de dados por um período de um ano. O projeto estava previsto para ter terminado em meados de 2009, porém no sítio eletrônico só está disponível um relatório de andamento do projeto, datado de 2007. O relatório final ou ainda não foi elaborado ou não foi disponibilizado. (WMO, 2006).

Além desta inter-comparação, em dezembro de 2006 foi realizada em Genebra, Suíça, a TECO-2006 ${ }^{32}$. Nesta Conferência foram apresentados dois pôsteres ${ }^{33,34}$ na seção "Quality Management, Calibration, Testing And Comparison of Instruments and Observing Systems", que demonstraram a atual preocupação da comunidade acadêmica com este tema.

Neste contexto, este capítulo abrange a comparação do desempenho de diferentes abrigos meteorológicos. Na ausência de abrigos comerciais, a alternativa de análise se baseou na comparação de abrigos caseiros, compatíveis com os utilizados convencionalmente nas estações climatológicas automáticas. No Brasil, alguns estudos foram desenvolvidos com o intuito de avaliar o desempenho de alguns abrigos de baixo custo, dentre os quais podem ser citados os trabalhos de Azevedo e Tarifa (2001), Marin et al. (2001), Cunha, Escobedo e Galvani (2001) e Armani e Galvani (2006), que apresentaram ser eficientes na proteção do sensor contra o aquecimento solar. Todavia, optou-se por tomar como base o trabalho de Tarara e Hoheisel (2007), realizado nos Estados Unidos, uma vez que estes autores compararam

\footnotetext{
31 WMO Combined Intercomparison of Thermometer Screens/Shields in Conjunction with Humidity Measuring Instruments.. Detalhes em <http://www.wmo.ch/pages/prog/www/IMOP/intercomparisons.html>. Acesso em 14 ago. 2010.

32 WMO Technical Conference on Meteorological and Environmental Instruments and Methods of Observation. Disponível em: <http://www.wmo.int/pages/prog/www/CIMO/cimo-teco-meteorex.html>. Acesso em 14 ago. 2010 .

${ }^{33}$ NAGY, Z. Effects of thermometer screens on accuracy of temperature measurements. WMO, Geneva, 2006.

34 XIONG, A. Influence of changes of sensor and shelter on air temperature observation, and analysis to its causes. WMO, Geneva, 2006.
} 
simultaneamente diferentes abrigos de baixo custo, ao contrário dos autores que testaram a eficiência apenas de um abrigo.

Foram avaliados por Tarara e Hoheisel (2007) nove abrigos de baixo custo, no formato de: cone; cone duplo; Gill caseiro; foguete; tubo suspenso; pagode (templo de religião oriental); tubos aspirados com termopar (TP-Aspirado) e sensor comercial de temperatura e umidade relativa (TUR-Aspirado); e tubo super-aspirado com sensor comercial de temperatura e umidade relativa (TUR-Super-Aspirado). Todos os abrigos caseiros foram comparados ao abrigo comercial denominado Gill Comercial, composto pelo abrigo não aspirado modelo 41002, da marca R.M Young, no qual estava acoplado o sensor de temperatura e umidade relativa modelo HMP45C, da marca Campbell Scientific. Foram utilizados termopares do tipo T como os sensores de temperatura dos abrigos de baixo custo. As representações esquemáticas da composição e dimensões destes abrigos estão apresentadas na Figura 85 a seguir.

Sumarizando todas as análises realizadas pelo autor desta comparação, a Figura 86 apresenta os desvios de temperatura dos abrigos em relação à temperatura tomada como referência, medida pelo sensor comercial (HMP45C) acoplado ao abrigo comercial de ventilação natural (Gill Comercial). Pelo gráfico, pode-se notar que o os abrigos de baixo custo com menores desvios, e, portanto, com melhor desempenho, foram o TP-Aspirado e o TUR-Super-Aspirado. Por uma questão de viabilidade financeira e de materiais já disponíveis, para a condução dos estudos subsequentes a selecionou-se a utilização de abrigos no formato semelhante ao TP-Aspirado, que além da sua simplicidade de confecção, apresentou um desempenho satisfatório. 


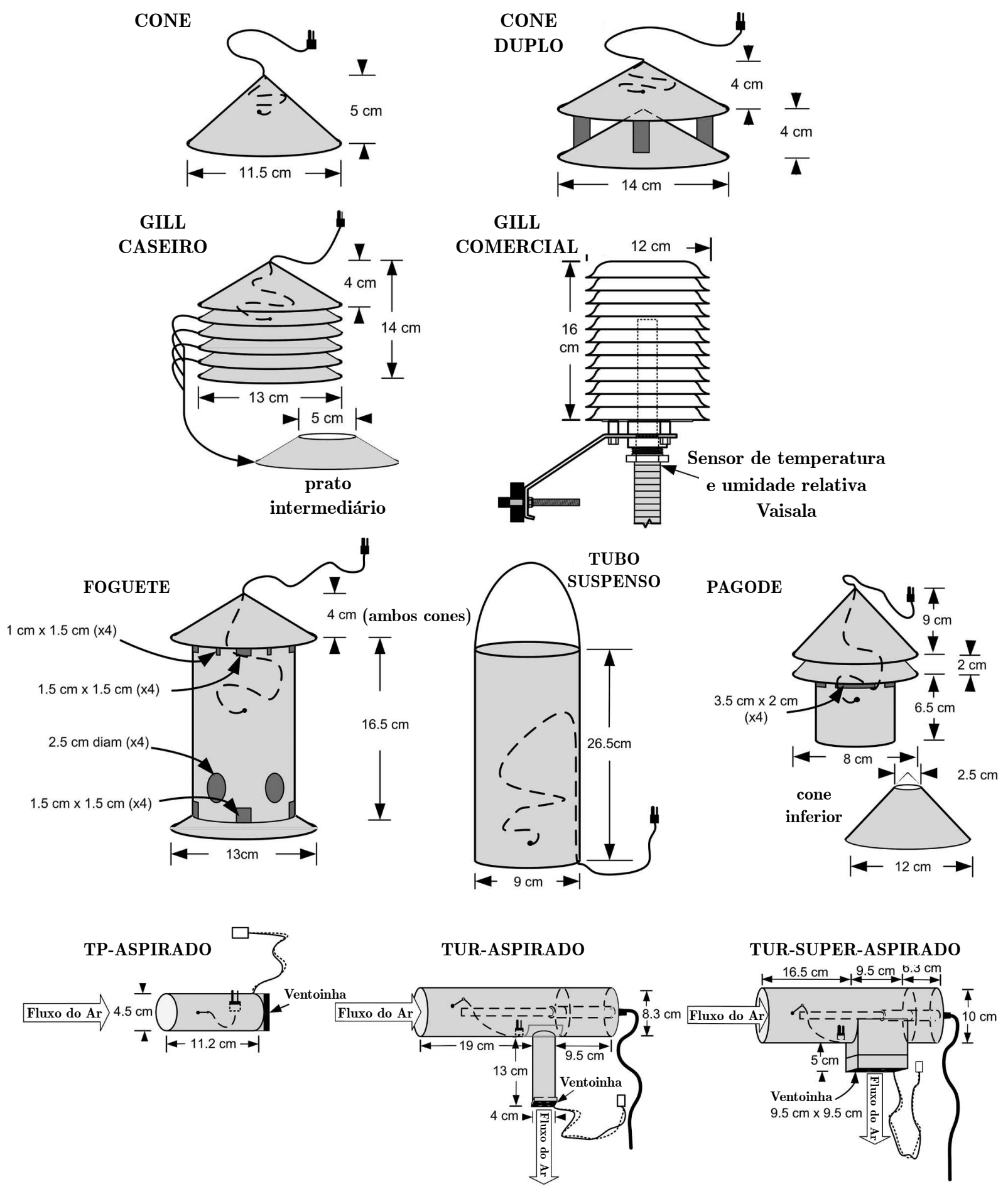

Figura 85 - Diferentes tipos de abrigos de baixo custo cujos desempenhos foram avaliados por Tarara e Hoheisel (2007). Fonte: adaptado de Tarara e Hoheisel (2007) 


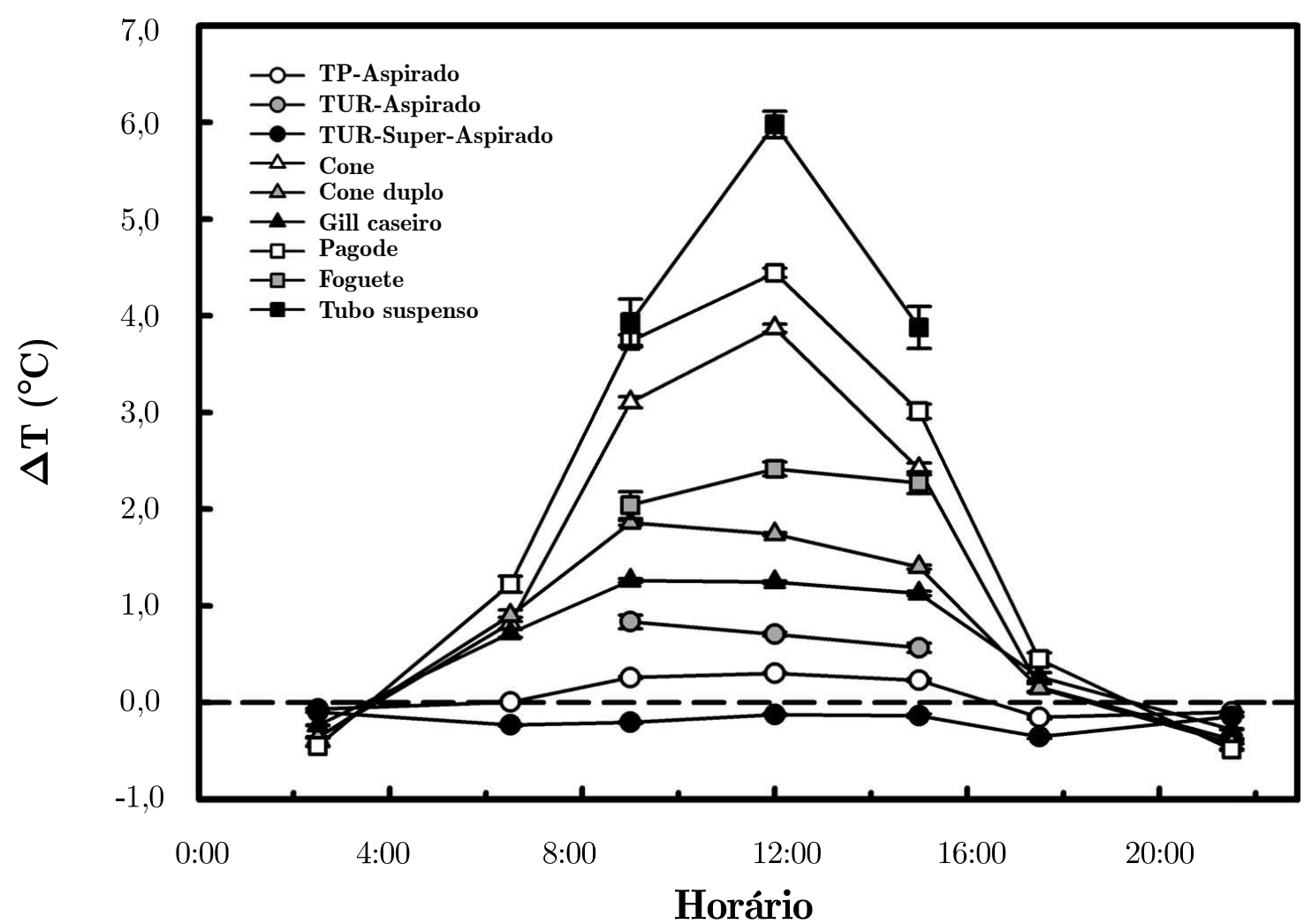

Figura 86 - Avaliação, realizadas por Tarara e Hoheisel (2007), do desempenho dos abrigos experimentais (Figura 85), em termos dos desvios de temperatura dos abrigos em relação à temperatura tomada como referência (sensor comercial HMP45C). Fonte: Tarara e Hoheisel (2007).

Selecionado o tipo de abrigo a ser comparado, dividiu-se o capítulo em duas partes, nas quais serão examinados diferentes aspectos em escalas distintas:

- PARTE A - Causas e efeitos de curto prazo: as influências dos ventos e das trocas de calor por radiação nas medições da temperatura do ar; e

- PARTE B - Efeitos de médio e longo prazo: repercussões das influências nas escalas mensais e anuais

A divisão foi realizada com o intuito de facilitar a compreensão dos aspectos analisados sob escalas distintas. Além disso, uma estação experimental foi utilizada para cada escala temporal de abordagem, ou seja, dois experimentos foram conduzidos em períodos e locais diferentes, cujas estações experimentais possuíam componentes diferentes. O experimento tratado na PARTE A foi realizado de maio a setembro de 2006 no campus 1 da USP - São Carlos, utilizando 4 abrigos 
experimentais; e na PARTE B, experimento conduzido de janeiro a dezembro de 2009 no CRHEA, foram utilizados 9 abrigos experimentais.

Os equipamentos utilizados na realização deste capítulo podem ser divididos em dois grupos:

1. Equipamentos de campo: utilizados na aquisição automática dos dados meteorológicos e do comportamento dos abrigos nos respectivos registros das temperaturas no interior deles;

2. Equipamentos de gabinete: utilizados na tabulação, tratamento e análise dos dados obtidos experimentalmente.

Os equipamentos de gabinete consistem de computador e acessórios periféricos (hardware) e programas aplicativos (softwares). Os dados coletados passaram por uma análise de consistência no programa aplicativo Microsoft Excel, o qual proporcionou, posteriormente, a elaboração de análises estatísticas e confecção de gráficos, base para a discussão dos dados.

\subsection{Referencial Teórico}

As investigações realizadas, de caráter experimental, tiveram em comum o método baseado nos princípios da Climatologia Dinâmica, que, no Brasil, teve seus fundamentos alicerçados por intermédios de Monteiro (1973) como uma abordagem que considera a gênese do clima, os processos atmosféricos e os elementos do espaço geográfico que nele interferem.

A aplicação da abordagem dinâmica representou um aspecto essencial neste estudo, pois, entre outras vantagens, permitiu discernir quais foram os processos que governaram as flutuações do tempo meteorológico (circulação geral e regional da atmosfera), considerando-se a atuação de sistemas atmosféricos (massas de ar) e, identificando episódios representativos do clima e dias típicos experimentais, de acordo com Vecchia (1997) e Vecchia e Nolasco (2005).

Os resultados apresentaram qualitativa e quantitativamente as diferenças observadas ao longo de episódios climáticos representativos do clima, escolhidos dentre os períodos de medição realizados ao longo do ano, descrevendo as modalidades de medição, os tipos de sensores, as variações determinadas na forma de 
medições (à sombra, velocidade do vento, insolação, aspiração do ar por entre os sensores, etc.)

Ressalta-se que a proposta desta pesquisa se restringiu à verificação das diferenças existentes devido à ação desses elementos do clima, radiação e ventilação, não se tratando de analisar a acurácia e a precisão dos sensores existentes. Além disso, também se restringiu ao registro das condições em que essas variações ocorreram, considerando os estados atmosféricos - domínio das massas de ar atuantes no momento das medições, e os valores da radiação e da velocidade do ar tomados a cada 30 minutos.

\subsection{PARTE A - Causas e efeitos de curto prazo: as influências dos ventos e das trocas de calor por radiação nas medições da temperatura do ar}

A PARTE $\mathrm{A}^{35}$ da investigação consistiu na construção de uma estação experimental constituída por 4 abrigos diferentes, que permitissem avaliar as influências isoladas e combinadas dos ventos e da radiação, tanto a radiação solar durante o dia, quanto perdas de radiação noturna. As magnitudes das influências foram analisadas por meio da abordagem dinâmica do clima, sob o enfoque temporal horário e diário (dia típico representativo) e na perspectiva da escala episódica, compreendendo alguns dias.

\subsubsection{Materiais e Métodos}

Os equipamentos de campos eram constituídos pelas estações experimental e de referência (vide APÊNDICE A e APÊNDICE B, pgs. 385 e 387), que foram instaladas no campus 1 da USP de São Carlos (latitude: $22^{\circ} 00^{\prime}$ Sul, Longitude: $47^{\circ} 53^{\prime}$ Oeste, Altitude: $760 \mathrm{~m}$ ), em uma área de cobertura uniforme de grama típica, ao lado do "Laboratório de Ecotecnologias: Novos Materiais e Procedimentos" - equipado com computadores que possibilitaram a análise dos dados coletados de maio a setembro de 2006 .

\footnotetext{
35 Com base em: OLIVEIRA, M. J. Avaliação experimental de interferências causadas pela radiação solar global e pela velocidade dos ventos em medições climatológicas da temperatura do ar. 2007. 127p. Monografia. Escola de Engenharia de São Carlos, Universidade de São Paulo, São Carlos, 2007. Disponível em: $<$ http://www.eesc.usp.br/engamb/index.php?link=trabalhos >. Acesso em: 14 ago 2010.
} 
Para avaliação dos objetivos propostos, na estação experimental utilizou-se de um conjunto constituído por 4 tubos de PVC, dispostos horizontalmente em um suporte metálico à altura de $2 \mathrm{~m}$ do solo com os respectivos sensores termoelétricos no interior de cada tubo, ligados a um sistema automático de aquisição de dados CR10X.

Logo ao lado da estação experimental, uma estação automática de referência contendo o sistema de aquisição e armazenamento de dados CR10X (datalogger), com multiplexador AM416, bateria de $12 \mathrm{~V}$, e painel solar - foi responsável pela coleta e armazenamento dos dados de: radiação solar global; velocidades médias e máximas do ar; umidade relativa, e valores de temperatura, estes obtidos pelo sensor de temperatura e umidade relativa modelo HMP45C-Vaisala, acoplado ao abrigo de proteção modelo 41003 da fabricante R.M. Young, conforme exibido na Figura 8, página 32 .

Além da revisão da literatura, foram executados alguns procedimentos necessários à consecução dos objetivos, de modo a possibilitar a realização dessa investigação. De forma sequencial os procedimentos realizados foram: instalação do equipamento e aquisição dos dados; análise preliminar dos dados e determinação de episódios; aquisição de imagens de satélite; elaboração e confecção de gráficos e tabelas; análise e discussão dos dados.

\section{- Instalação da estação experimental e aquisição dos dados}

Foi construído um conjunto constituído por 4 tubos de PVC de cor branca, de $30 \mathrm{~cm}$ de comprimento e 4 pol. de diâmetro cada, dispostos horizontalmente em um suporte metálico à altura de $2 \mathrm{~m}$ do solo - de acordo com recomendação da OMM (WMO, 2008), com os respectivos sensores termoelétricos na parte central do interior de cada tubo. Os tubos consistem nos abrigos de proteção da incidência direta de radiação solar. Tais abrigos dos sensores foram pendurados paralelos uns aos outros a uma distância de $45 \mathrm{~cm}$ entre eles, sendo o suporte disposto na direção norte-sul, perpendicular à direção do percurso do sol, leste-oeste, conforme mostrado na Figura 87. 


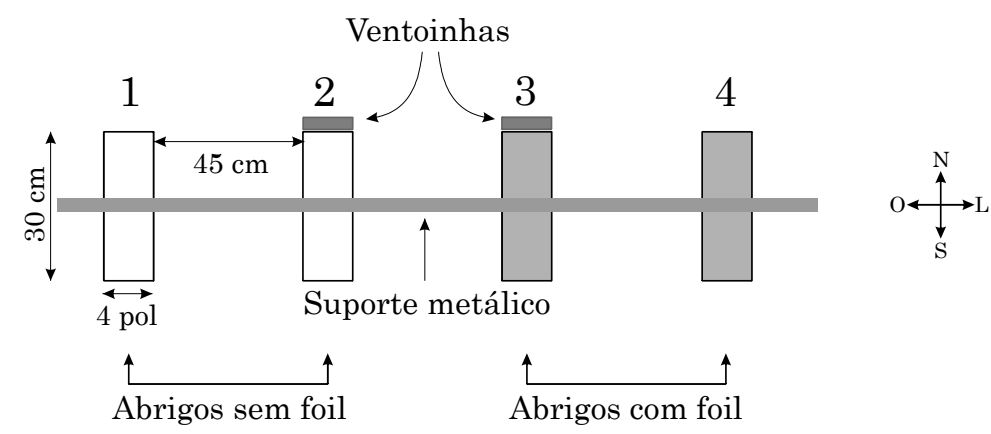

Figura 87 - Representação esquemática, com vista em planta, da disposição dos 4 abrigos experimentais da primeira estação experimental

Esta configuração adotada não permite a incidência direta de radiação solar, e, portanto, evita-se o surgimento de "orelhas de Batman" (Figura 11, pg. 37), ou seja, desvios de temperatura com aspecto de dois picos de nos valores do gráfico senoidal de temperatura ao longo do dia, já descritos em trabalho realizado por Modna e Vecchia (2003). Além disso, com o fato de os abrigos estarem suspensos, evita-se condução térmica proporcionada pelo contato direto com o suporte metálico.

Para a avaliação comparativa dos efeitos das duas variáveis em estudo, radiação global e da velocidade dos ventos, cada abrigo foi construído de modo a se determinar qual a importância da influência isolada e combinada dessas variáveis. A Tabela 20 e a Figura 88 sintetizam a constituição dos 4 diferentes abrigos utilizados no presente estudo (ver também APÊNDICE C, pg. 389).

Para avaliação da influência da radiação, aplicou-se uma camada dupla de material isolante plástico de superfície metalizada (foil), em consonância com uma recomendação feita por Armani e Galvani (2006); e para avaliação da interferência da ventilação, a aspiração forçada do abrigo foi obtida pela instalação de ventiladores, comumente utilizados em microcomputadores (ventoinha), acoplados aos tubos de PVC e fixados a eles por quatro braçadeiras plásticas, vide arranjo do abrigo aspirado de Tarara e Hoheisel (2007). Foram utilizadas ventoinhas modelo Smart Case Fan II - Thermaltake, que possuem alto desempenho e ajuste de velocidade, protegidas da precipitação por uma extensão do foil. 
Tabela 20 - Constituição dos 4 abrigos experimentais da primeira estação

\begin{tabular}{ccc}
\hline \hline \multirow{2}{*}{ Abrigo } & \multicolumn{2}{c}{ Dispositivo } \\
\cline { 2 - 3 } & Ventoinha & Foil \\
\hline 1 & Não possui & Não possui \\
2 & Possui & Não possui \\
3 & Possui & Possui \\
4 & Não possui & Possui \\
\hline
\end{tabular}

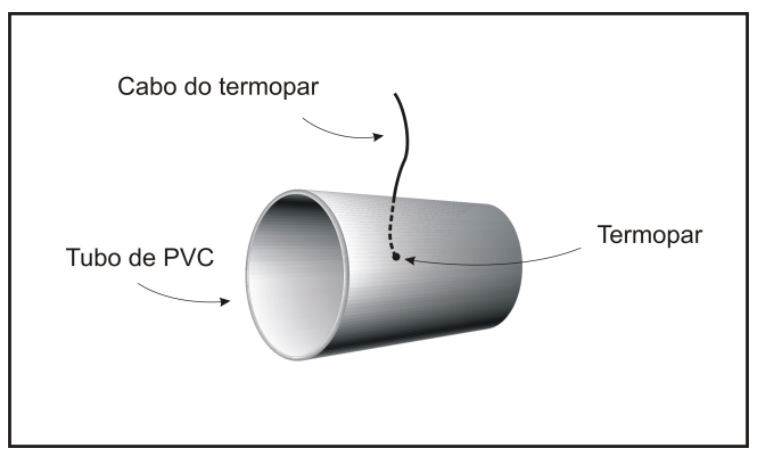

1

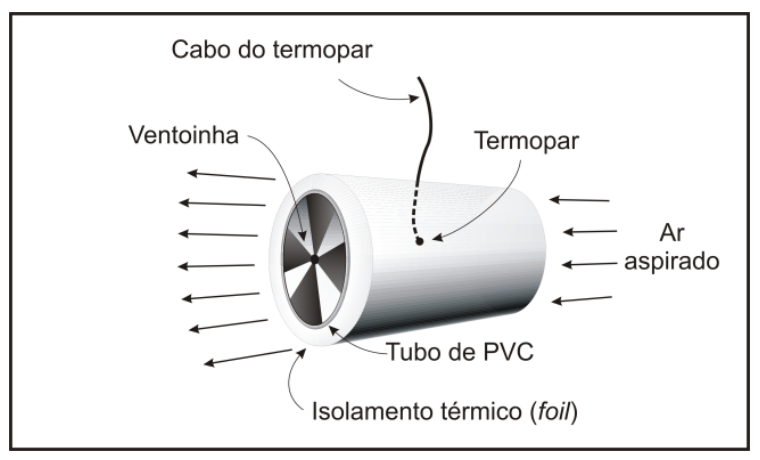

3

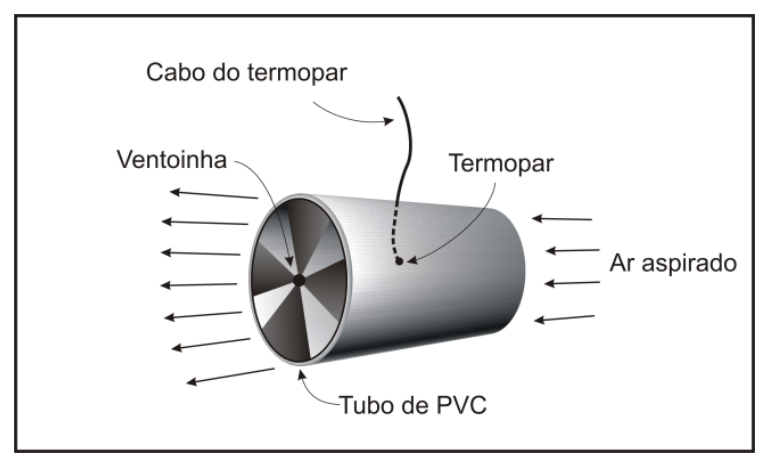

2

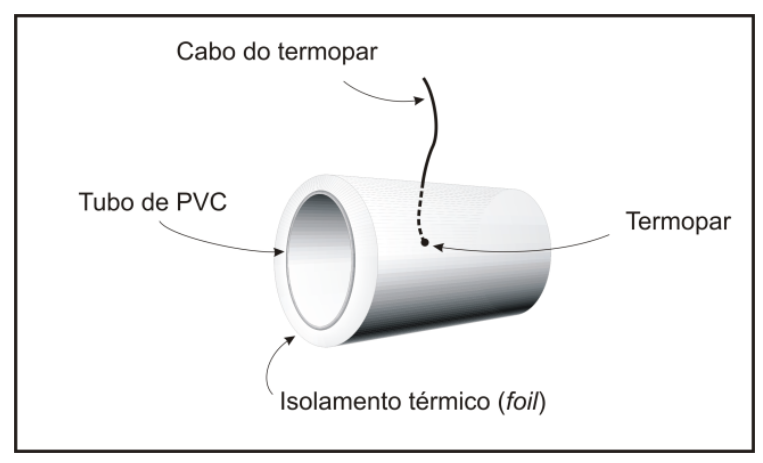

4

Figura 88 - Representação gráfica do conjunto de termopares com o 4 diferentes abrigos de PVC de 4 polegadas. (1) Abrigo de PVC com aspiração interna natural e sem isolamento térmico; (2) Abrigo de PVC com aspiração interna artificial, dada pelo uso de uma ventoinha de $12 \mathrm{~V}$; (3) Abrigo de PVC com aspiração artificial e com isolamento térmico por barreira de radiação (foil); (4) Abrigo de PVC com isolamento térmico e sem aspiração interna artificial.

Como sensores de temperatura foram utilizados termopares do tipo T (Seção 2x24 AWG). A extremidade sensível às alterações térmicas de cada termopar foi disposta no centro dos abrigos. A outra extremidade foi ligada ao multiplexador AM16/32 da Campbell Scientific Inc. de 32 canais, protegida dentro de uma caixa termicamente isolada do meio exterior. Do multiplexador os dados são transferidos e registrados no datalogger CR10X (sistema de aquisição e armazenamento de dados) 
para posteriores coletas e análise dos dados. Ainda fazem parte do sistema de monitoramento uma bateria de $12 \mathrm{~V}$, modelo PS12, da Campbell Scientific Inc., e fonte de alimentação para as ventoinhas utilizadas nos abrigos. O APÊNDICE D (pg. 391) exibe em detalhes uma foto do interior da caixa ambientalmente selada que contém os componentes acima listados.

No início das atividades experimentais, no programa aplicativo do datalogger CR10X o intervalo de tempo entre as aquisições dos valores de temperatura no interior dos abrigos era de 20 segundos. Além disso, os registros dos valores de temperatura - que são as totalizações obtidas por meio das médias dos valores adquiridos, eram realizados a cada 30 minutos. Por uma semana em setembro de 2006, o intervalo das aquisições foi reduzido para 10 segundos, e as totalizações para intervalos de 5 minutos. Com esta alteração do intervalo de tempo, tanto das tomadas dos valores quanto das totalizações registradas, pretendeu-se verificar alguma melhoria na visibilidade do processo por meio do aumento da resolução dos dados.

\section{- Análise preliminar dos dados e determinação de episódios}

Os dados armazenados no datalogger eram coletados periodicamente em intervalos de aproximadamente 15 dias. A extração de dados era realizada por meio da conexão estabelecida - com um cabo tipo $25 / 9$ pinos, filtro e interface de comunicação SC32A - entre o sistema de armazenamento e um microcomputador portátil, que reconhecia o datalogger pelo programa aplicativo PC208W da Campbell Scientific Inc.

Uma vez importados os dados, estes foram convertidos para formato acessível em planilha do Microsoft Excel, no qual era possível identificar episódios representativos do fato climático, para o estudo das interferências causadas pela radiação solar global incidente e pela ação dos ventos nos abrigos dos sensores de temperatura.

A escolha da escala temporal foi determinada de acordo com os propósitos do objetivo do estudo, bem como do tempo de amostragem do monitoramento. Deste modo, utilizou-se a escala instantânea (tempo real), considerando informações meteorológicas horárias. 


\section{- Aquisição de imagens de satélite}

Uma vez selecionados os episódios representativos e dias típicos experimentais, foram adquiridas, por meio da Internet, imagens infravermelho do satélite GOES (Geostationary Operational Enrivonment Satellite), no sítio eletrônico ${ }^{36}$ do Instituto Nacional de Pesquisas Espaciais (INPE). A análise das imagens de satélite e do comportamento dos elementos do clima obtidos nas estações permite uma melhor compreensão dos episódios climáticos de interesse.

\section{- Elaboração de gráficos e análise dos dados}

Os procedimentos anteriormente descritos forneceram as bases necessárias para o diagnóstico da influência exercida pelas duas variáveis em estudo. Gráficos dos perfis da temperatura dos diferentes abrigos foram confeccionados, permitindo em primeira análise verificar os efeitos provocados pela radiação e pelo vento na aquisição de temperatura dos sensores. Em seguida foram elaborados gráficos de inter-comparações e correlações entre as temperaturas dos abrigos, destacando as diferenças observadas. Por fim, elaboraram-se gráficos que correlacionaram as causas das influências e os respectivos efeitos nos abrigos, possibilitando a verificação da magnitude de interferência de cada variável, assim como dos efeitos da utilização dos dispositivos atenuantes dos efeitos interferentes - ventilação forçada e barreira contra radiação (foil).

\subsubsection{Resultados e Discussão}

A abordagem de interpretação dos resultados é dividida ente o estudo dos efeitos e causas das influências dos ventos e das trocas de calor por radiação nas medições da temperatura do ar.

\footnotetext{
${ }^{36}$ Disponível em <http://satelite.cptec.inpe.br/>. Acesso em 14 ago. 2010.
} 


\subsubsection{Análise dos efeitos}

Nesta seção procurou-se demonstrar qualitativa e quantitativamente os efeitos causados pela radiação solar global incidente e pela ação dos ventos nos abrigos da estação experimental.

\section{- Dia típico representativo}

Para obtenção e discussão dos resultados do estudo e de acordo com as necessidades de análise adotou-se conceitos de episódios climáticos representativos, elaborados de acordo com Vecchia (1997), e dia típico representativo, de caráter experimental (VECCHIA e NOLASCO, 2005).

Sob a abordagem em escala temporal diária, por meio de um dia típico representativo, a Figura $\mathbf{8 9}$ apresenta o comportamento da temperatura externa do ar, ao longo do dia 13 de maio de 2006, dia que apresentou a maior diferença de temperatura entre os abrigos: com $2,3^{\circ} \mathrm{C}$ de diferença entre o abrigo sem foil e sem ventilação forçada (abrigo \#1, em vermelho) em comparação com o abrigo com foil e com ventilação forçada (abrigo \#3, azul).

Observando-se os perfis de temperatura em forma aparente aproximada de uma senóide, verifica-se diferença considerável entre os valores de temperatura evidenciada no intervalo das $13 \mathrm{~h}$ às $17 \mathrm{~h}$, ou seja, de maior incidência solar no dia.

Analisando isoladamente cada um dos parâmetros, a radiação e o fluxo do ar, pode-se perceber uma redução maior na diferença de temperatura para o caso da utilização da ventoinha e consequente aumento do fluxo de ar, enquanto que para o caso da minimização do efeito da radiação com a presença de foil, o referido efeito é pouco considerável. 


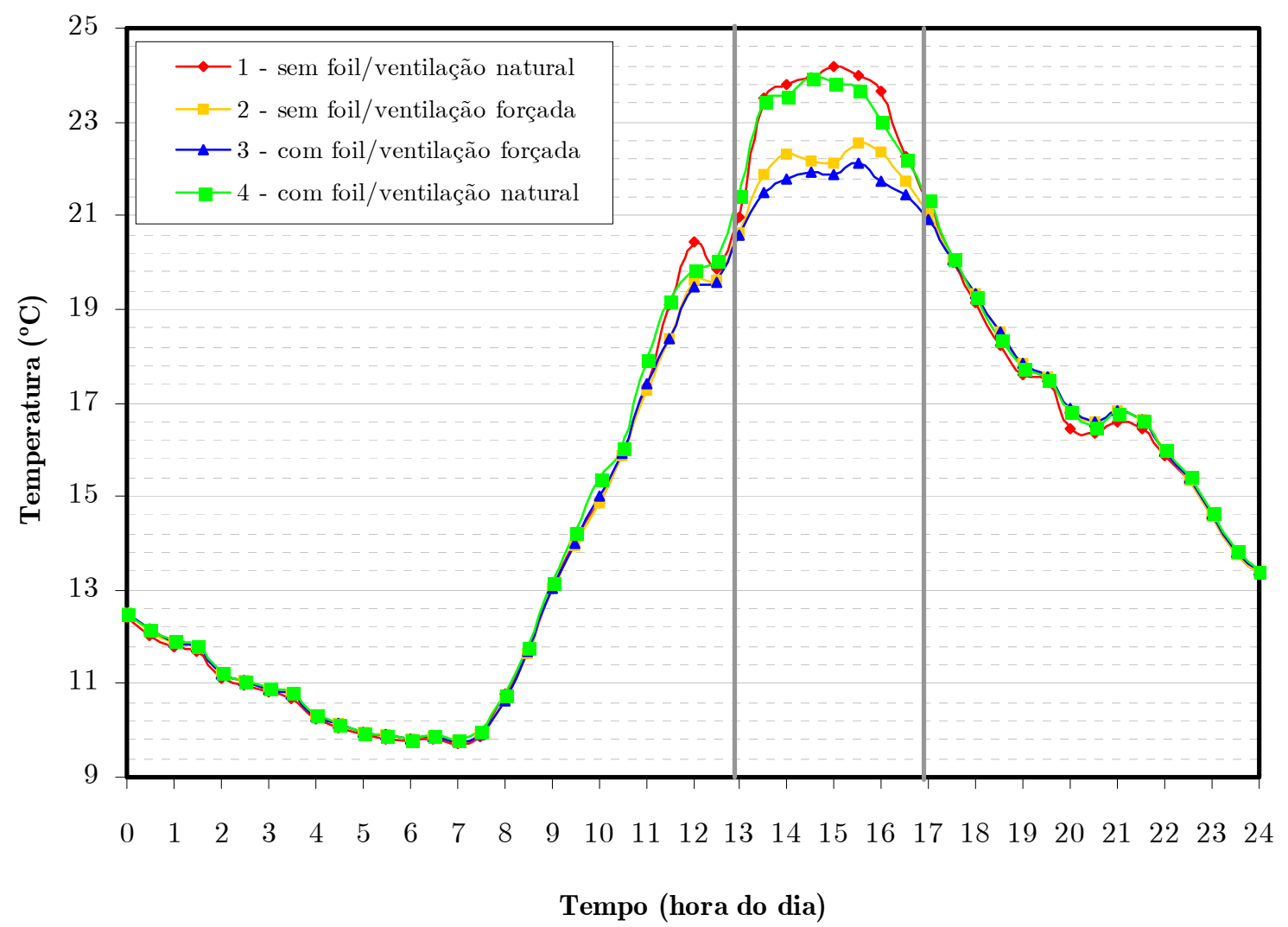

Figura 89 - Comportamento da temperatura ao longo do dia 13 de maio de 2006 para os 4 diferentes abrigos em estudo na primeira estação experimental.

Adotou-se o abrigo \#3 como referência, pois ele apresentou os menores valores de temperatura ao longo do dia. Assim, por meio da Figura 90 é possível observar as diferenças entre as temperaturas dos diferentes abrigos, sobretudo entre 13 e $17 \mathrm{~h}$. Nota-se uma diferença máxima de $2,3^{\circ} \mathrm{C}$ entre os abrigos \#1 e \#3, além de $2,0^{\circ} \mathrm{C}$ entre os abrigos \#2 e \#3, e $0,6^{\circ} \mathrm{C}$ entre os abrigos \#4 e \#3. Portanto, por meio destes gráficos já é possível inferir que a ventilação é o fator com maior influência atenuante das diferenças dos valores de temperatura, sendo que a utilização do foil representa influência pouco significativa. 


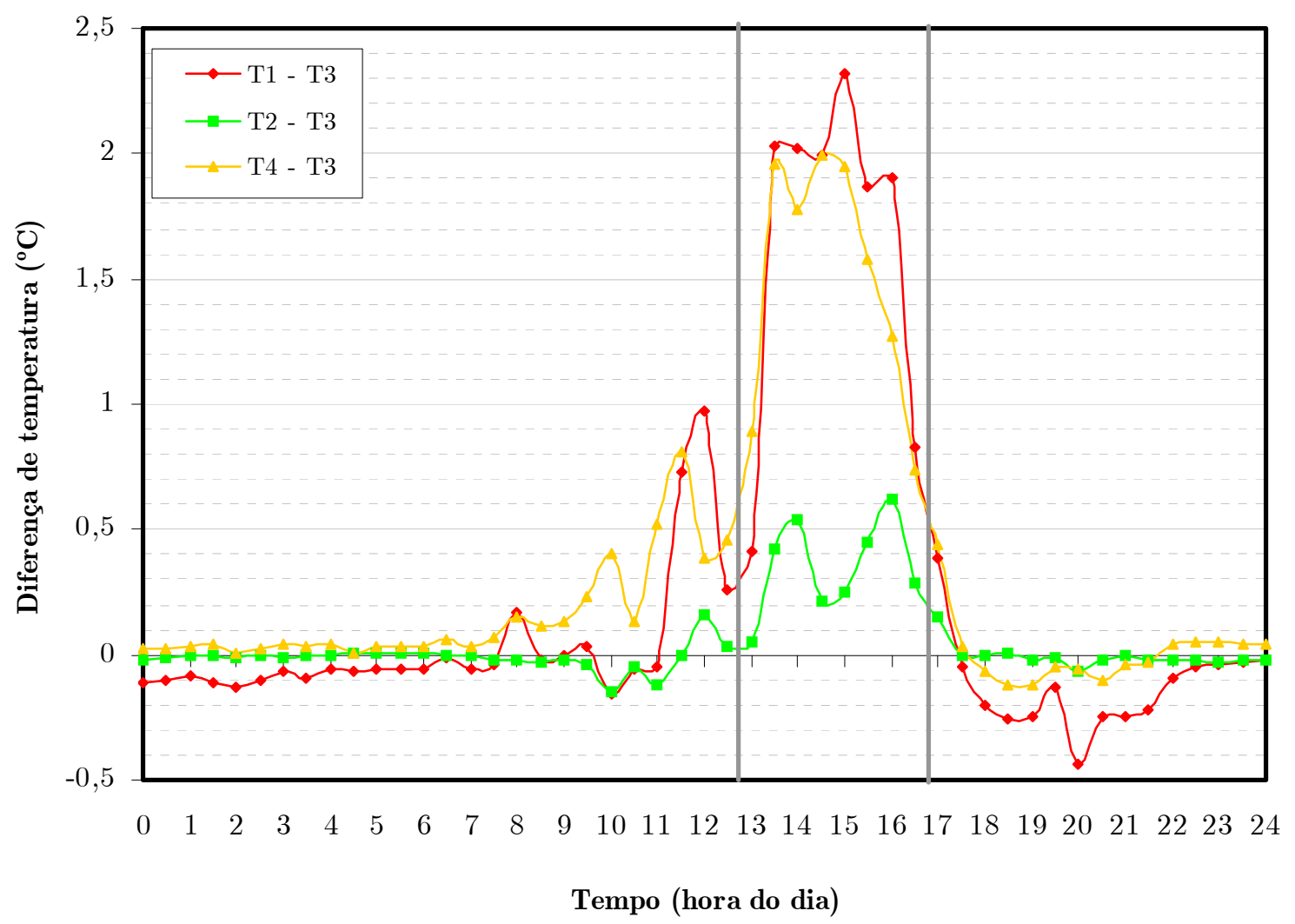

Figura 90 - Diferenças de temperatura ao longo do dia 13 de maio de 2006 para os 4 diferentes abrigos em estudo na primeira estação experimental.

\section{- Correlação entre as temperaturas dos diferentes abrigos}

Tomando como referência a temperatura do abrigo \#3 (com foil e ventoinha), foi possível calcular o erro relativo dos outros abrigos. Analisando o intervalo de dados do mês de maio de 2006, gráficos de distribuição (histogramas) foram gerados, conforme apresentados na Figura 91. Nele foi possível observar-se, no histograma (A), uma maior concentração dos erros positivos para o abrigo \#1 (sem foil e sem aspiração forçada), devido ao fato de este estar sujeito a maiores interferências da radiação solar e do fluxo de vento. 

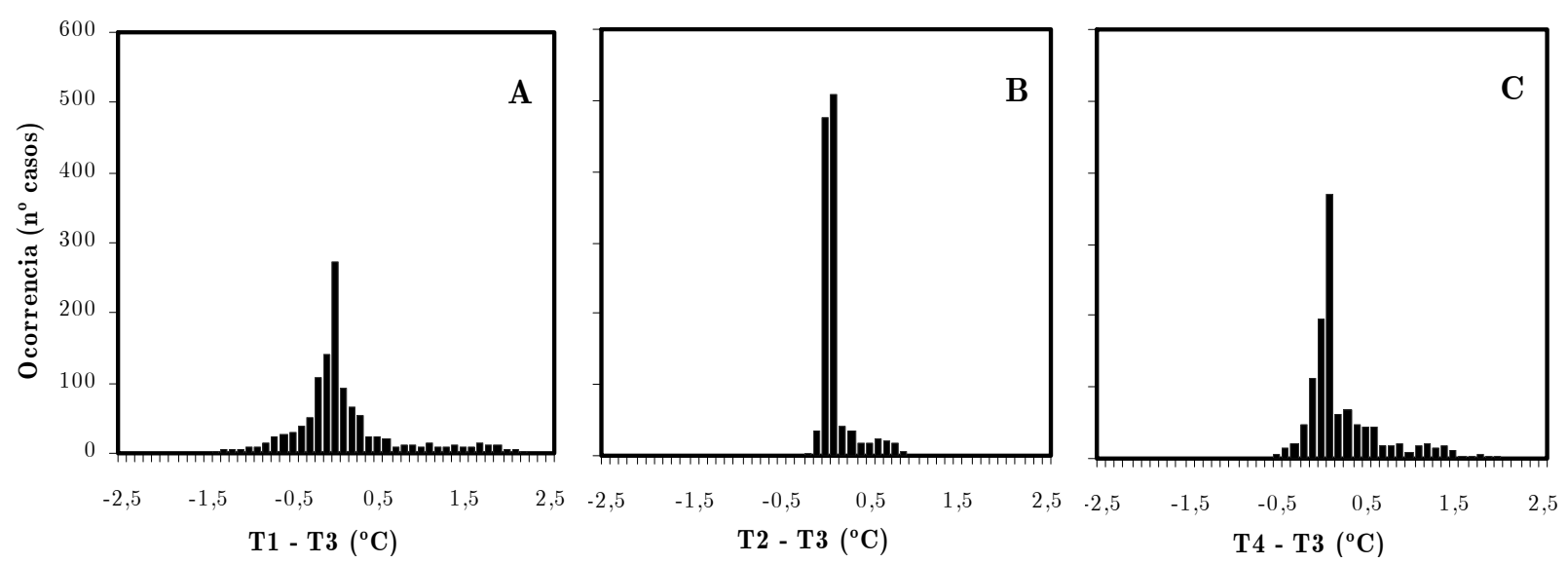

Figura 91 - Histogramas: distribuição das diferenças relativas ao abrigo \#3. (A) Diferença de temperatura entre os abrigos \#1 e \#3; (B) Diferença de temperatura entre os abrigos \#2 e \#3; (C) Diferença de temperatura entre os abrigos \#4 e \#3. Obs.: escala vertical idêntica para os três gráficos; escala horizontal com subdivisões em $0,1^{\circ} \mathrm{C}$.

Comparando os histogramas, evidentemente percebe-se um melhor desempenho do abrigo \#2 (sem foil, com ventoinha) no gráfico (B), pois teve maior concentração dos pontos em intervalos de diferenças pequenas. Para o gráfico (A), $90 \%$ das diferenças relativas se encontram entre os valores $-1,0$ e $1,0^{\circ} \mathrm{C}$; para o gráfico (B), $90 \%$ se encontram no intervalo $-0,2$ a $0,2^{\circ} \mathrm{C}$; e para o gráfico $(\mathbf{C}), 90 \%$ das diferenças se encontram no intervalo $-0,8$ a $0,8^{\circ} \mathrm{C}$.

Esta análise é compatível com a análise anterior do dia típico representativo, ou seja, pode-se perceber que a ventilação forçada é uma característica de maior influência na atenuação das diferenças de temperatura, e o uso de foil atenua muito pouco a influência da radiação solar no aquecimento indesejado do abrigo de PVC.

Ainda, adotando-se como referência os valores do abrigo \#3, é possível correlacionar os valores de temperatura deste abrigo com os dos demais, resultando na obtenção dos gráficos mostrados na Figura 92. 


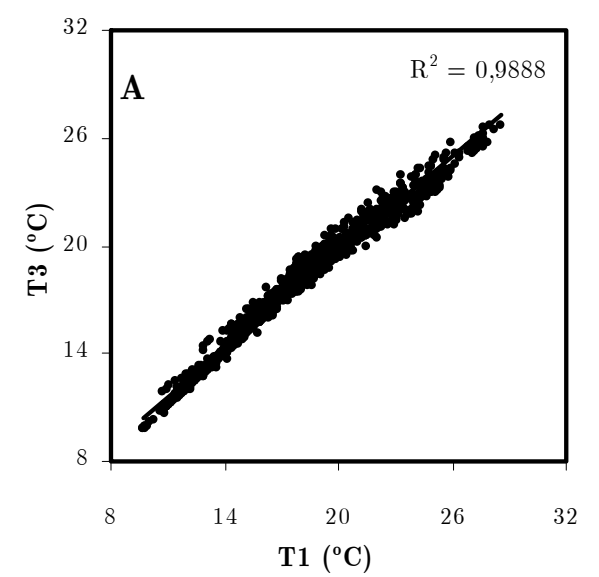

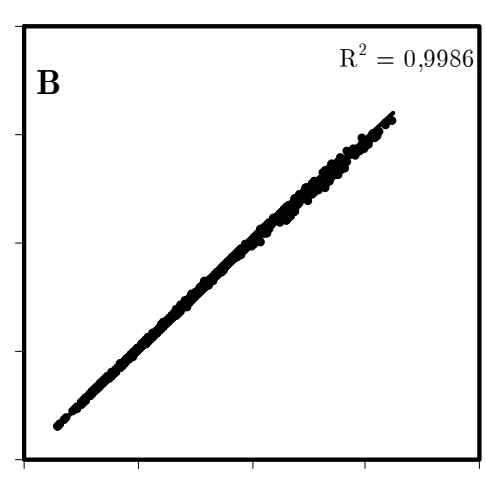

T2 $\left({ }^{\circ} \mathrm{C}\right)$

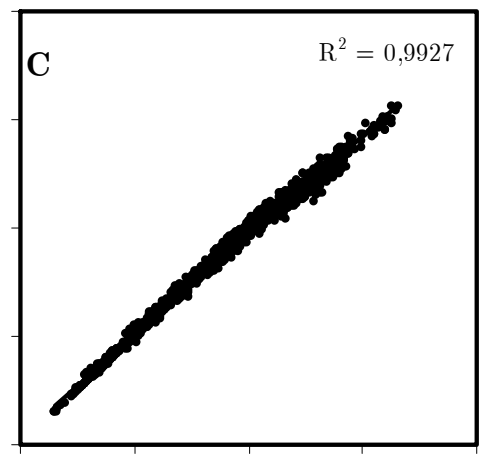

$\mathrm{T} 4\left({ }^{\circ} \mathrm{C}\right)$

Figura 92 - Correlações dos valores das medições de temperatura entre os abrigos da primeira estação experimental. (A) Correlação entre os abrigos \#1 e \#3; (B) Correlação entre os abrigos \#2 e \#3; (C) Correlação entre os abrigos \#4 e \#3. Obs.: escala vertical idêntica para os três gráficos.

Pela figura anterior nota-se que o gráfico (B) apresenta boa concordância entre os valores das temperaturas entre os abrigos de referência e o abrigo \#2, reforçando a hipótese de que a influência do fluxo de ar interno forçado pela ventoinha é mais relevante que a influência do uso de foil na mitigação dos efeitos do aquecimento dos abrigos pela radiação solar incidente.

Uma última análise é dada pela Figura 93, em que as diferenças de temperatura entre os abrigos são distribuídas ao longo dos horários do dia, utilizandose de dados de todos os dias disponíveis. Por meio da constatação do gráfico (B), verifica-se, portanto, mais uma vez a hipótese de que a ventilação forçada é a medida mitigadora que apresenta maior eficiência na diminuição das diferenças de temperatura, tanto durante o dia quanto durante a noite. 

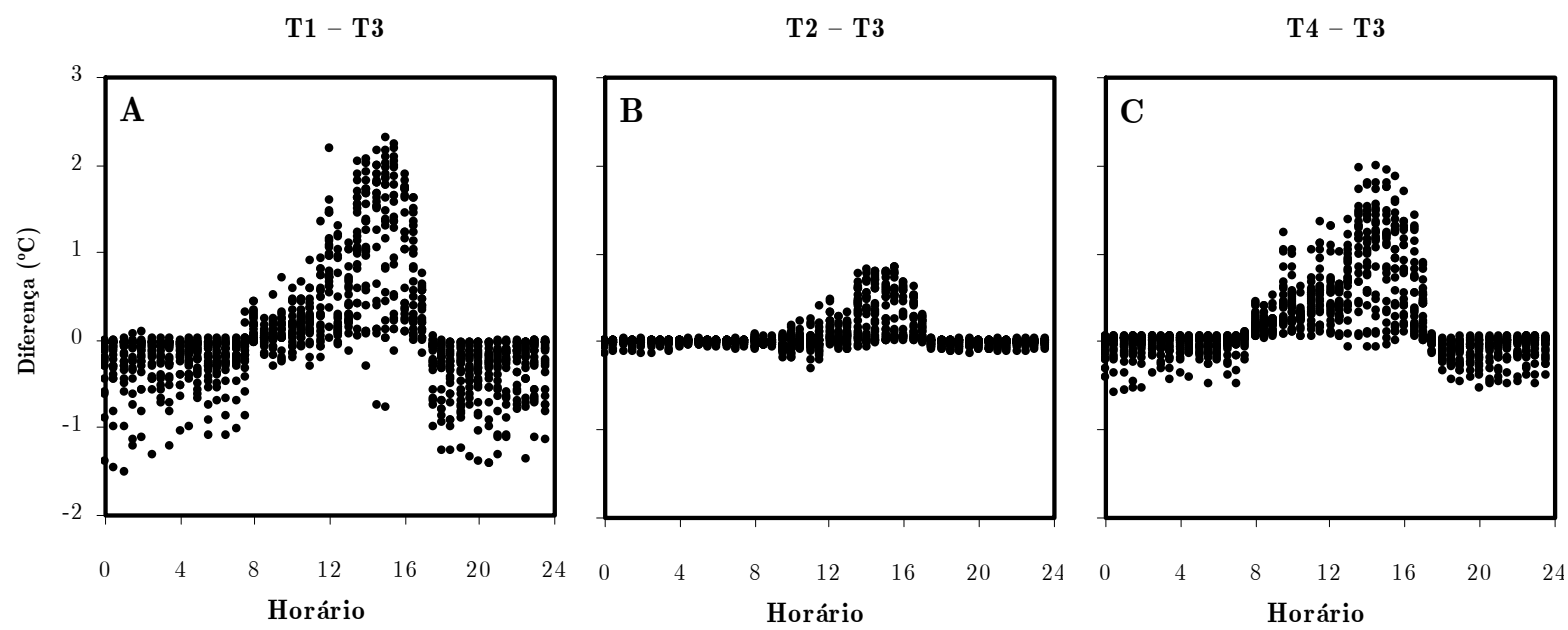

Figura 93 - Distribuição das diferenças dos valores de temperatura ao longo do dia. (A) Diferenças entre os abrigos \#1 e \#3; (B) Diferenças entre os abrigos \#2 e \#3; (C) Diferenças entre os abrigos \#4 e \#3. Obs.: escala vertical idêntica para os três gráficos.

É interessante observar que existem diferenças negativas consideráveis nos casos (A) e (C) no período noturno de aquisição dos dados, com diferença máxima negativa de $-1,5$ e $-0,6^{\circ} \mathrm{C}$, respectivamente, nos abrigos \#1 e \#4. O abrigo \#2, apresentada no gráfico (B), apresentou diferença máxima negativa de apenas $-0,3{ }^{\circ} \mathrm{C}$.

\section{- Análise de episódio climático}

As diferenças negativas noturnas observadas na Figura 93 podem ser mais bem visualizadas por meio da abordagem do clima sob a ótica dos episódios climáticos representativos. Tal análise é ilustrada por um trecho da série total de dados coletados e está apresentada pela Figura 94, referente às variações de temperatura, diferenças de temperatura entre os abrigos, velocidades máxima e média do vento externo e radiação solar para o mês de maio de 2006.

Pela Figura 94 observa-se que as maiores diferenças negativas nos abrigos ocorrem em dois episódios, um durante a noite do dia 9 para o dia 10, e outro durante as noites dos dias 16 a 19. Estes dias representam períodos que antecedem a aproximação de uma frente fria e consequente domínio de uma massa de ar polar, fases do prenúncio e de avanço da massa de ar fria. Tal fato é verificado pela queda de temperatura nos dias seguintes - dia 11 para o $1^{\circ}$ episódio e dias 20 a 23 para o segundo - e pela diminuição da radiação solar incidente, que é o efeito da nebulosidade, nesta fase de domínio da massa de ar polar. 
256

Horário das respectivas fotos de satélite da Figura $\mathbf{9 5} \rightarrow$

Fases da massa de ar frio com entrada no dia $16 \rightarrow$ Domínio mTa

P1 P2 P3 A1A2A3 D1

D2 D3 T1T2 T3

Fases

A

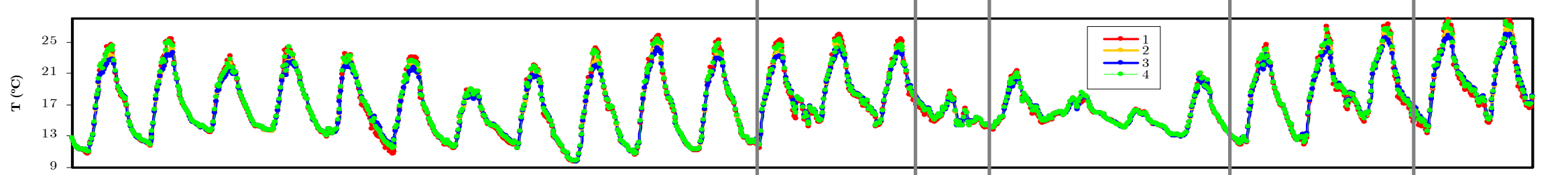

B

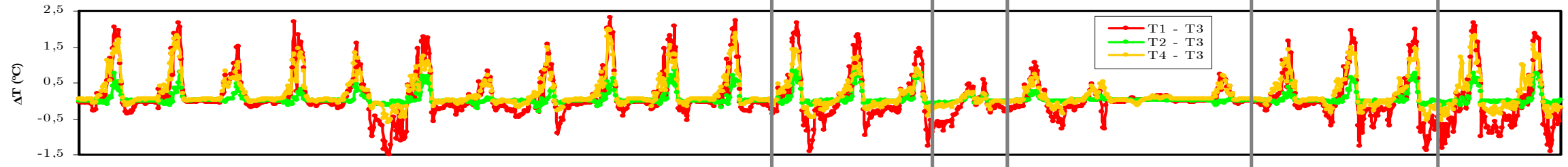

C

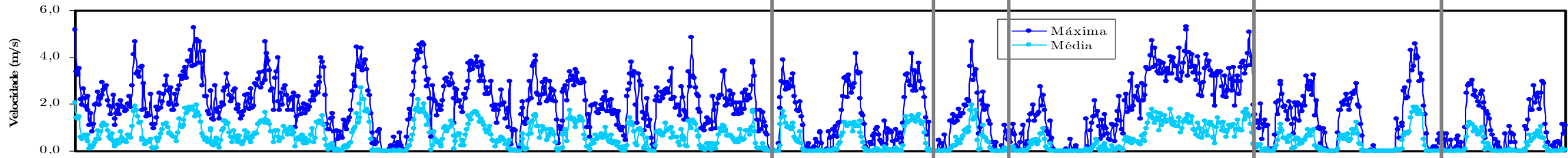

D

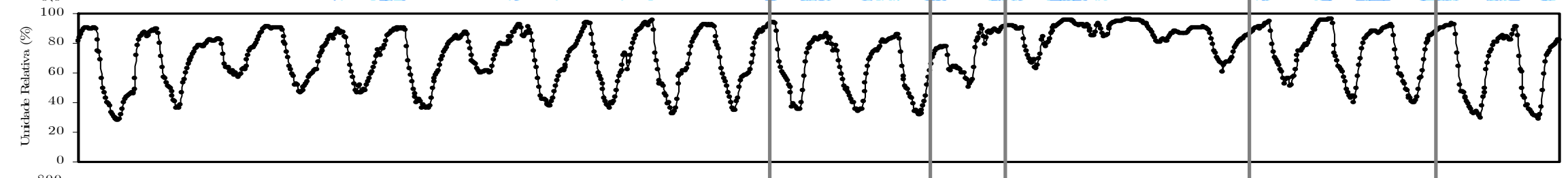

$\mathbf{E}$

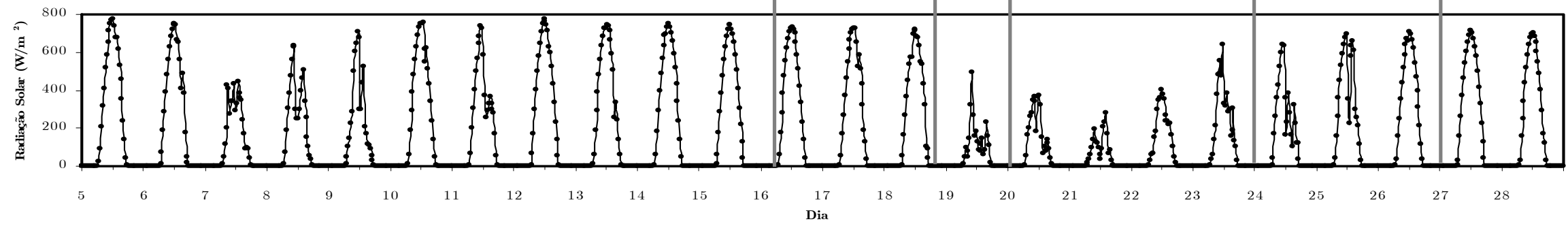

Figura 94 - Mês de maio de 2006, sob escala de abordagem de episódios climáticos. (A) Perfis de temperatura para os diferentes abrigos; (B) Diferenças de temperatura entre os abrigos; (C) Velocidades máxima e média do vento; (D) Umidade relativa do ar; (E) Radiação solar local. Obs. Escala horizontal idêntica para os gráficos. ${ }^{*}$ A: Avanço. 
Verifica-se, também, que o segundo episódio apresenta maior magnitude que o primeiro, estando sob domínio da massa de ar frio por 5 dias, até que a partir do dias 24 e 25, inicia-se a fase de tropicalização da massa de ar frio e consequente recuperação dos comportamentos de temperatura e radiação solar típicos de massa de ar quente.

Tomando-se como base o segundo episódio de entrada de uma frente fria, o fato dos valores negativos da diferença entre as temperaturas dos abrigos terem sido observados nos períodos que antecedem a chegada da massa de ar frio. Tal comportamento das diferenças de temperatura negativas pode ser devido à radiação noturna em períodos que não apresentam nebulosidade, ocorrendo a perda de calor por irradiação para o céu, mecanismo melhor discutido no item "Perdas por radiação noturna", pg. 266.

Nas noites dos dias 17 a 19, o perfil de temperatura é alterado, possuindo amplitude menor que a dos dias anteriores que estão sob domínio de massa de ar quente. Pode-se ainda observar que nas noites dos dias 17 a 19, a velocidade do vento se mantém totalmente nula (período de calmaria), demonstrando um estado de atmosfera estável.

A Figura 95 é composta por imagens do satélite GOES que compreendem as fases de prenúncio, avanço, domínio e tropicalização do episódio representativo que inicia se no dia 16 de maio de 2006. 

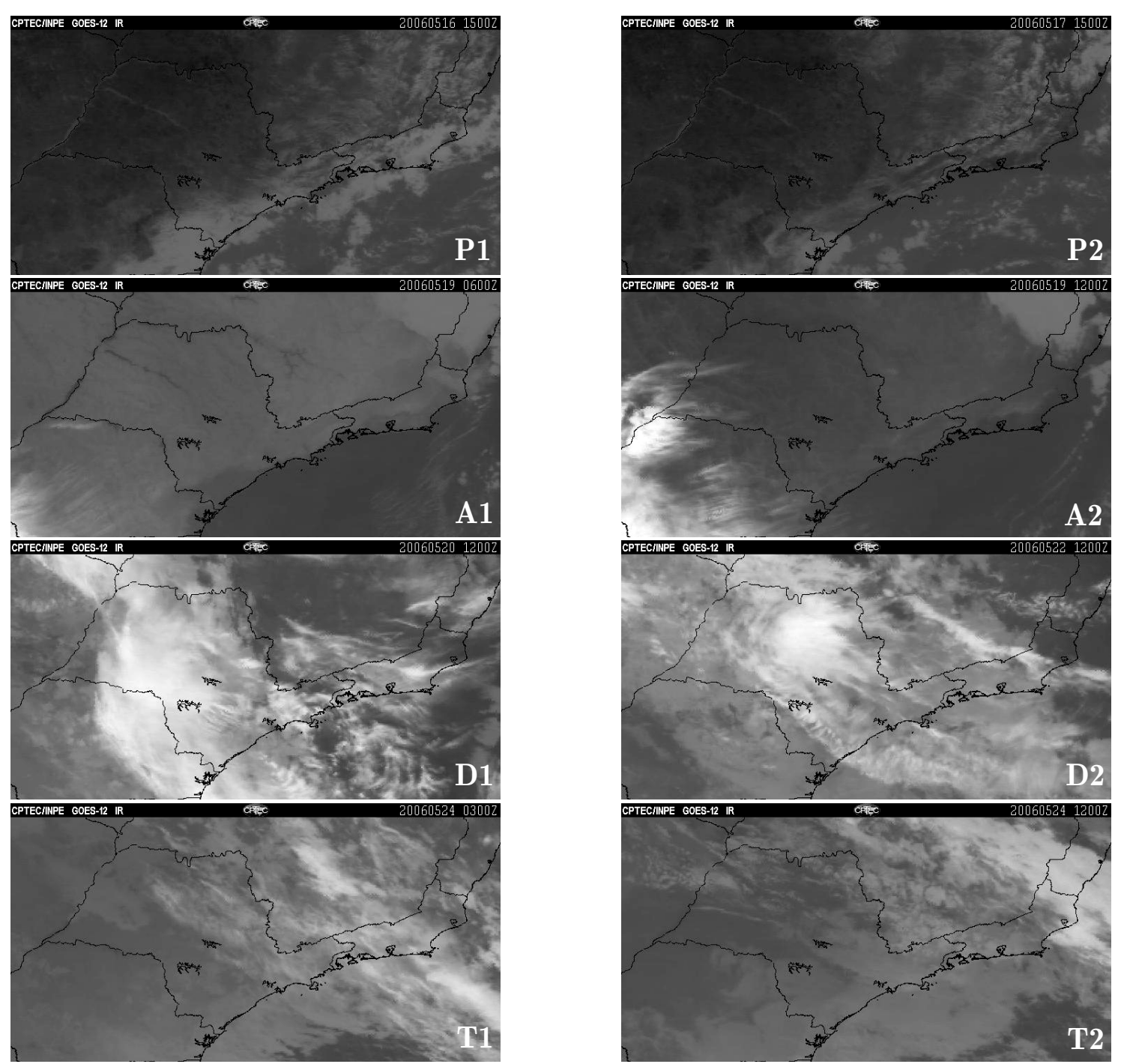
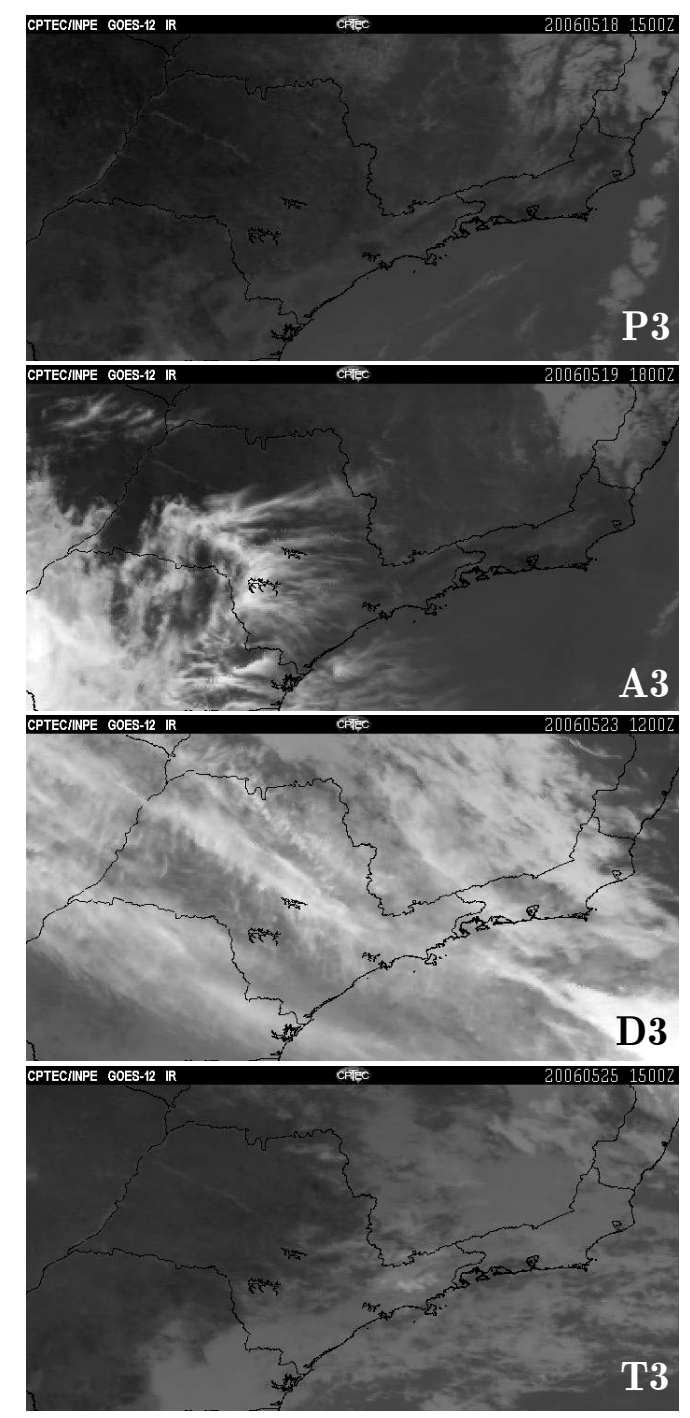

Figura 95 - Imagens em infravermelho captadas pelo satélite GOES para as fases da massa de ar frio com entrada no dia 16 de maio de 2006. P1, P2 e P3: Fase de prenúncio às 15h dos dias 16, 17 e 18, respectivamente; A1, A2 e A3: Fase de avanço às 6, 12 e 16h do dia 19, respectivamente; D1, D2 e D3: Fase de domínio às 12h dos dias 20,22 e 23, respectivamente; T1, T2 e T3: Fase de tropicalização às 3,12 e $15 \mathrm{~h}$ do dia 24 , respectivamente. Fonte: INPE, 2007. 


\subsubsection{Análise das causas}

Uma vez caracterizados, no item anterior, qualitativa e quantitativamente os efeitos causados pela radiação solar global incidente e pela ação do fluxo dos ventos nos abrigos, a seção atual tem o propósito de correlacionar as diferenças de temperatura com os agentes causadores destas interferências.

\section{- Correlação das temperaturas com a radiação solar global}

Os resultados e as respectivas análises anteriormente discutidos tiveram enfoque nos efeitos gerados nos diferentes abrigos em estudo, ou seja, foram caracterizadas detalhadamente as diferenças registradas nas medições de temperatura de cada abrigo, sob abordagem de um único dia, considerado como típico representativo de uma dada situação; e sob a abordagem de episódios meteorológicos, ou seja, de uma sucessão habitual de tipos de tempo. Tal estudo do domínio de sistemas atmosféricos atuantes na região de monitoramento, tomado em escala microclimática e regional, foi realizado com base nos conceitos da abordagem dinâmica do clima.

Uma vez realizadas as análises dos efeitos da influência, caracterizados qualitativamente, da radiação solar e da velocidade dos ventos externos, torna-se necessária a compreensão quantitativa das causas e a magnitude dos parâmetros, sob a ótica dos efeitos combinados e isolados destes fatores de influência em medições de temperatura do ar exterior.

Uma primeira análise quantitativa combinada é dada pela Figura 96, onde estão representados todos os valores das diferenças de temperatura com relação à radiação solar global, para todas as velocidades do vento exterior. O fato já verificado pelas análises anteriores, de que o abrigo que não apresenta ventoinha nem isolante térmico (foil) apresenta maiores diferenças, também é observado no gráfico (A) desta figura. Além disso, pode-se verificar que as maiores diferenças ocorrem para os maiores valores de radiação solar, indicando a tendência de que estas grandezas são diretamente proporcionais.

Analisando isoladamente o efeito da radiação, gerou-se a Figura 97, em que são representadas as distribuições por meio de diagrama do tipo boxplot das diferenças de temperatura em relação à radiação solar, divididas em oito classes de $100 \mathrm{~W} / \mathrm{m}^{2}$ cada. 
Para tal análise utilizou-se de dados de radiação que se encontravam em condições de velocidade média do ar abaixo de $1 \mathrm{~m} / \mathrm{s}$. No gráfico (A), observa-se que até valores de $600 \mathrm{~W} / \mathrm{m}^{2}$ a radiação causa o aumento dos valores da diferença de temperatura.

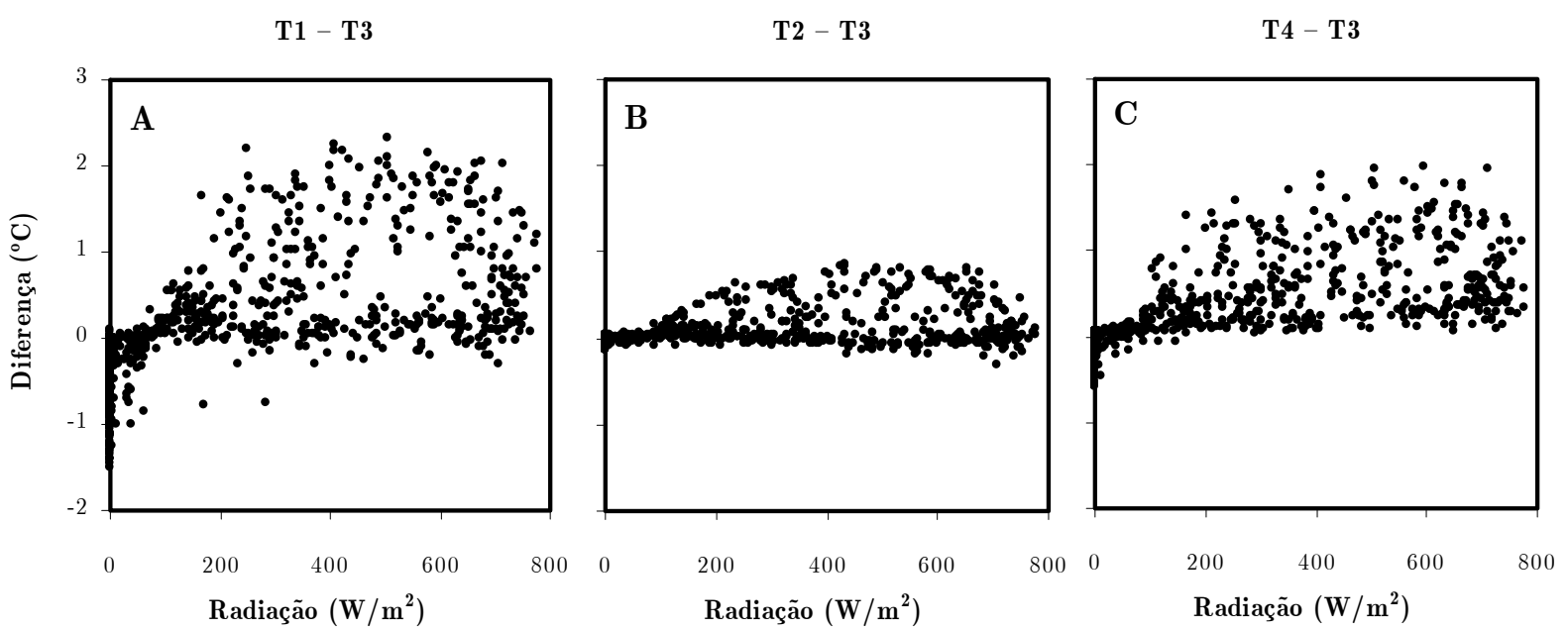

Figura 96 - Correlações da diferenças de temperatura versus radiação solar global. (A) Correlação da diferença de temperatura entre os abrigos \#3 e \#1; (B) Correlação da diferença entre os abrigos \#3 e \#2; (C) Correlação da diferença entre os abrigos \#3 e \#4. Obs.: escala vertical idêntica para os três gráficos.

T1-T3

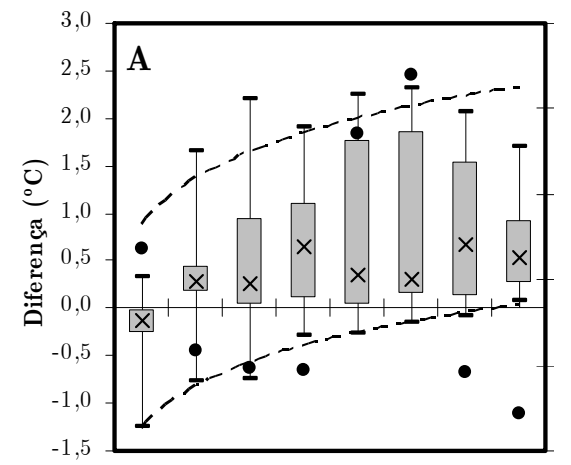

$100 \quad 200 \quad 300 \quad 400 \quad 500 \quad 600 \quad 700 \quad 800$ Radiação $\left(\mathrm{W} / \mathrm{m}^{2}\right)$
T2-T3

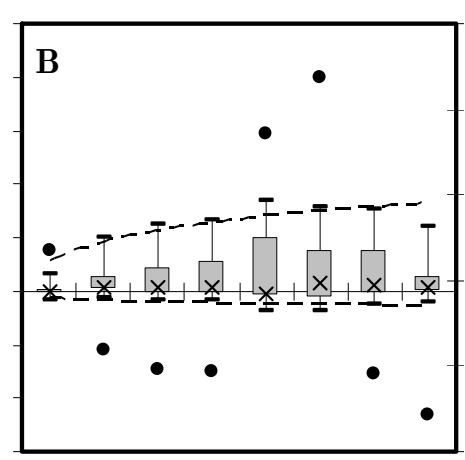

$100200 \quad 300 \quad 400 \quad 500 \quad 600 \quad 700 \quad 800$ Radiação $\left(\mathrm{W} / \mathrm{m}^{2}\right)$
T4-T3

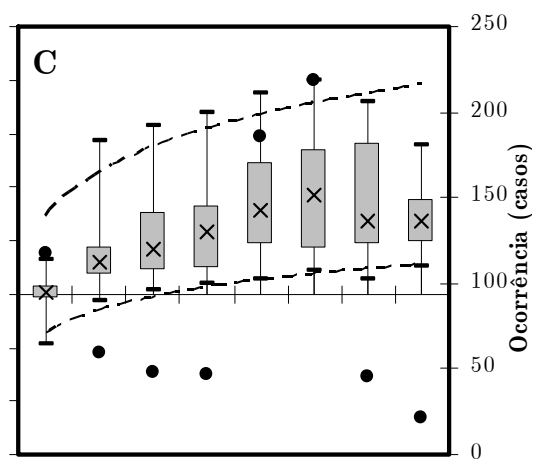

$100200 \quad 300 \quad 400 \quad 500 \quad 600 \quad 700 \quad 800$ Radiação $\left(\mathrm{W} / \mathrm{m}^{2}\right)$

Figura 97 - Distribuição em representação do tipo boxplot das diferenças de temperatura versus radiação solar, em condições de velocidade do vento externo abaixo de $1 \mathrm{~m} / \mathrm{s}$. Cada barra preenchida cinza (box) representa $50 \%$ dos dados; o valor médio é representado pelo símbolo $(\times)$; os valores de máximos e mínimos são representados por meio das barras lineares superior e inferior, respectivamente; e a curvas tracejadas superior e inferior representam os respectivos ajustes dos valores máximos e mínimos. O número de amostras para cada classe de radiação está representado por pontos $(\bullet)$, com escala secundária à direta. (A) Boxplot da diferença entre os abrigos \#3 e \#1; (B) Boxplot da diferença entre os abrigos \#3 e \#2; (C) boxplot da diferença entre os abrigos \#3 e \#4. Obs.: escalas verticais idênticas para os três gráficos. 
A tendência esperada seria de aumento para valores compreendidos no intervalo de 700 a $800 \mathrm{~W} / \mathrm{m}^{2}$, porém a quantidade de ocorrência de valores que se encontravam neste intervalo é muito pequena. Já o gráfico (B) apresenta um comportamento de aumento da diferença de temperatura até o valor de $500 \mathrm{~W} / \mathrm{m}^{2}$, apresentando diminuição da diferença a partir deste valor. Quanto ao gráfico (C), a análise é análoga ao do gráfico (A).

As curvas tracejadas ajustadas proporcionam uma melhor visualização do perfil esperado de variação das diferenças de temperatura conforme variação da radiação. Percebe-se que a diferença de temperatura cresce com o aumento da radiação solar, se tornando menos dependente a partir dos valores maiores de radiação.

É interessante observar nestes gráficos o efeito da radiação nos abrigos que não apresentam dispositivos de atenuação do efeito da radiação. O abrigo \#4, que apresenta apenas foil é ligeiramente mais eficiente que o abrigo \#1, que não apresenta nenhum tipo de proteção. Já o abrigo \#2, que não possui foil, mas possui ventilação interna forçada proporcionada pela ventoinha, apresenta menores valores nas diferenças de temperatura.

Deste modo, este gráfico permite inferir que a ventilação interna é medida mitigadora mais eficiente que o foil no que se refere aos efeitos do aquecimento interno dos abrigos pela radiação solar incidente.

\section{- Correlação das temperaturas com o fluxo dos ventos}

Análise análoga ao do caso da radiação solar está apresentada na Figura 98, em que os valores das diferenças de temperatura são comparados em relação à velocidade média do ar externo, para todas as os valores de radiação. Pode-se verificar que as maiores diferenças ocorrem nos menores valores de velocidade do vento, indicando a tendência de que estas grandezas são inversamente proporcionais.

A faixa da velocidade do vento se apresentou pouco extensa, pois o ideal seria ter a ocorrência de ventos médios acima de $3 \mathrm{~m} / \mathrm{s}$, para que assim fossem avaliadas com melhor precisão as indicações de que as diferenças de temperatura para abrigos não aspirados são significativamente reduzidas em condições de ventos fortes. 
$\mathrm{T} 1-\mathrm{T} 3$

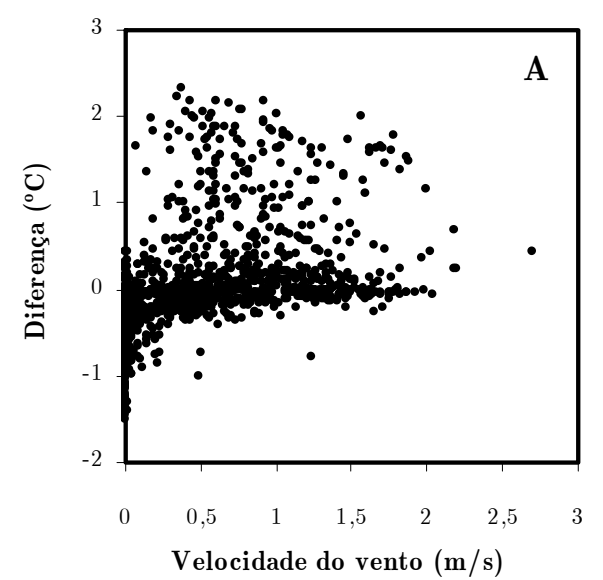

T2 - T3

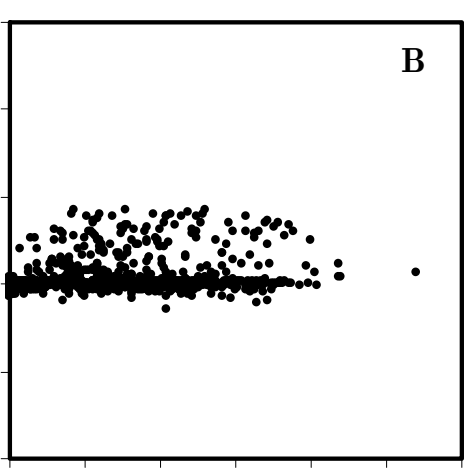

Velocidade do vento $(\mathrm{m} / \mathrm{s})$
$\mathrm{T} 4-\mathrm{T} 3$

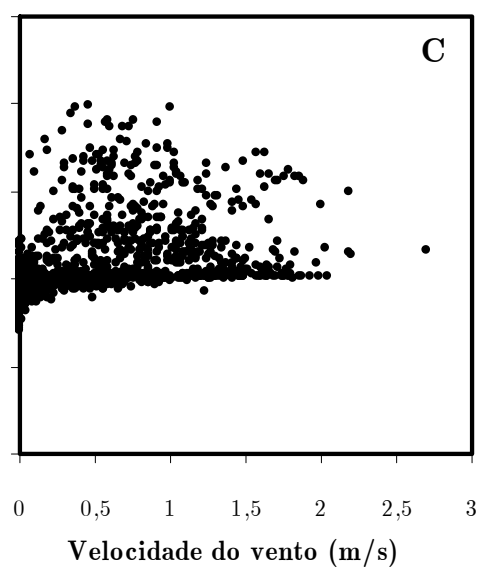

Figura 98 - Correlações das diferenças de temperatura versus velocidade média do ar externo. (A) correlação da diferença entre os abrigos \#3 e \#1; (B) correlação da diferença entre os abrigos \#3 e \#2; (C) correlação da diferença entre os abrigos \#3 e \#4. Obs.: escala vertical idêntica para os três gráficos.

Portanto, pelas caracterizações quantitativas das causas combinadas da radiação e da velocidade do vento, pode-se deduzir que a tendência é que quanto maior for a radiação e quanto menor for a velocidade do vento, maiores serão as diferenças entre os abrigos que não apresentam nenhum tipo de dispositivo que atenue a ação destes fatores.

Fazendo a análise do efeito isolado da velocidade do vento exterior, gerou-se a Figura 99, em que estão representadas as diferenças de temperatura em relação à velocidade do vento, dividido em quatro classes de $0,5 \mathrm{~m} / \mathrm{s}$ cada, com radiação fixada em valores acima de $1 \mathrm{~W} / \mathrm{m}^{2}$, ou seja, restringindo os valores obtidos apenas durante o dia.

Os gráficos apresentados permitem verificar que existe uma sutil tendência na redução das diferenças de temperatura com o aumento da velocidade exterior do ar. Tal comportamento não está claramente visível, pois a série de dados não apresentou valores com velocidade acima de $2,5 \mathrm{~m} / \mathrm{s}$, limitando a série a apenas estes resultados indicativos. 
T1-T3

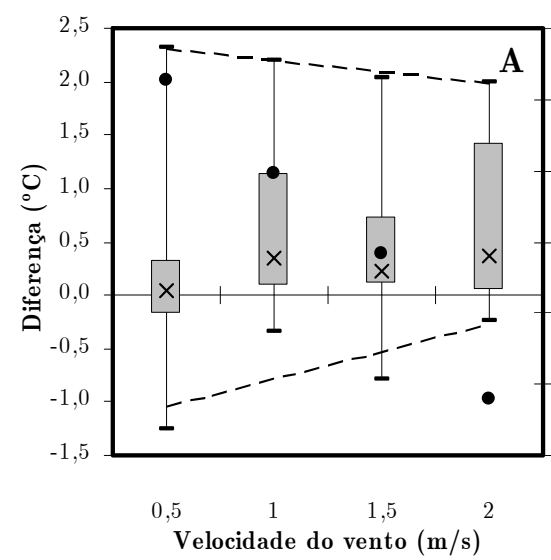

T2-T3

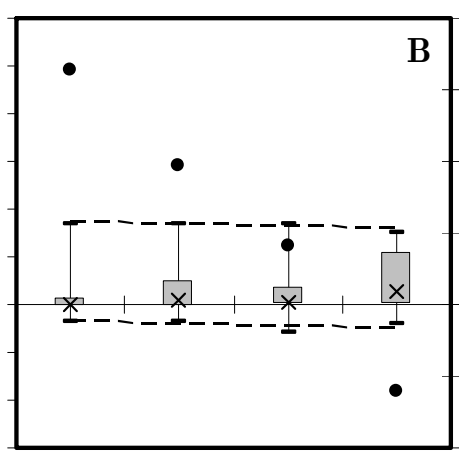

$\begin{array}{lcc}0,5 & 1 & 1,5 \\ \text { Velocidade do vento }(\mathrm{m} / \mathrm{s})\end{array}{ }^{2}$
T4-T3

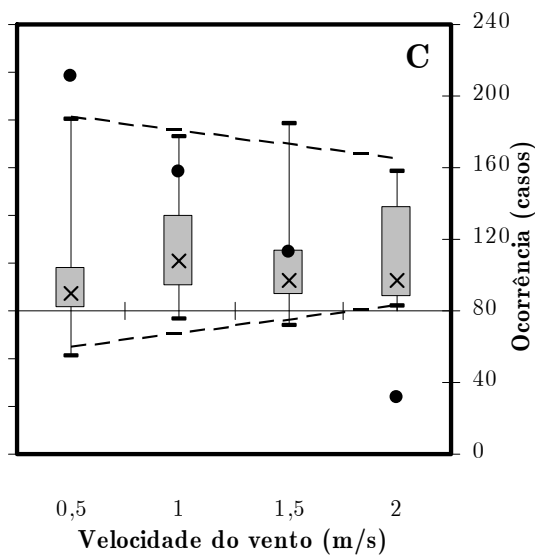

Figura 99 - Distribuição em representação do tipo boxplot das diferenças de temperatura versus velocidade do vento exterior, em condições de radiação solar acima de $150 \mathrm{w} / \mathrm{m}^{2}$. Cada barra preenchida cinza (box) representa 50\% dos dados; o valor médio é representado pelo símbolo $(\times)$; os valores de máximos e mínimos são representados por meio das barras lineares superior e inferior, respectivamente; e a linhas tracejadas superior e inferior representam os respectivos ajustes dos valores máximos e mínimos. O número de amostras para cada classe de radiação está representado por pontos $(\bullet)$, com escala secundária à direta. (A) Boxplot da diferença entre os abrigos \#3 e \#1; (B) Boxplot da diferença entre os abrigos \#3 e \#2; (C) Boxplot da diferença entre os abrigos \#3 e \#4. Obs.: escalas verticais idênticas para os três gráficos.

As linhas tracejadas de ajuste ajudam na visualização desta influência, principalmente nos gráficos (A) e (C). Nota-se também nestas linhas, no gráfico (B), que a velocidade do vento externo não influencia o abrigo \#2, uma vez que este possui ventilação interna forçada.

Destes gráficos deduz-se, portanto, que a ventilação interna forçada implica na redução das diferenças de temperatura, pois o fluxo constante de ar dentro do abrigo é responsável pela minimização do aquecimento decorrente da radiação solar incidente. Deduz-se também que a ventilação externa do ar (vento) não é suficiente para redução destes efeitos da radiação nas condições de velocidades analisadas.

- Síntese da correlação das temperaturas com o efeito combinado do fluxo dos ventos e das trocas por radiação

Caracterizadas as influências isoladas dos ventos e da radiação nos valores da temperatura do ar, convém combinar estes efeitos e apresentá-los de uma forma 
concisa e facilmente compreensível. Considerando a apresentação gráfica de três variáveis, dois formatos são possíveis: uma representação em duas dimensões, com isolinhas de temperatura (isotermas); e uma representação tridimensional.

A primeira representação bidimensional é mostrada na Figura 100. Constata-se que o efeito combinado de aquecimento é preponderante em condições de alta incidência de radiação solar e de baixa velocidade do ar. O efeito, causando um desvio máximo na ordem de $1,5^{\circ} \mathrm{C}$ aproximadamente, é evidente tanto no abrigo \#1, sem proteção alguma, no gráfico (A); quanto do abrigo \#4, apenas com foil, no gráfico (C). No gráfico (B) o efeito é reduzido, com desvio de cerca de $0,5^{\circ} \mathrm{C}$. Destes gráficos é possível extrair uma inferência relevante: conforme a intensidade dos ventos aumenta, o efeito do aquecimento dos abrigos é atenuado e os desvios são diminuídos, mesmo quando expostos a valores altos de radiação solar.

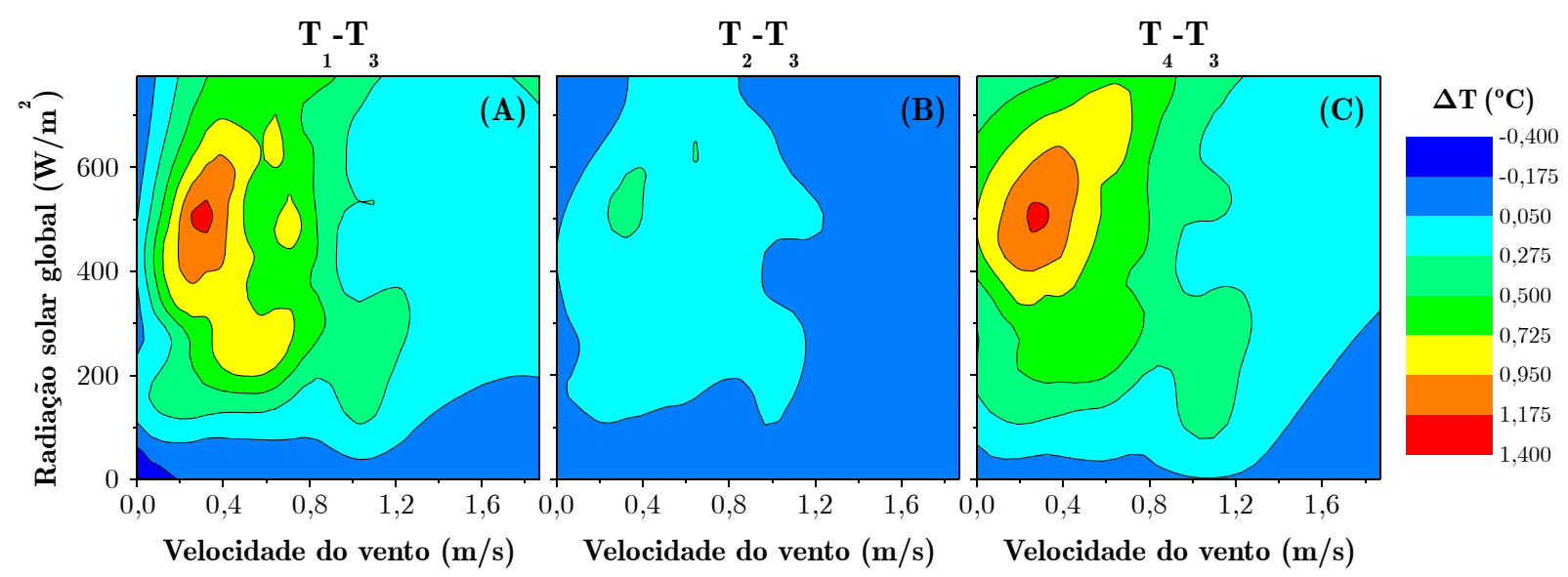

Figura 100 - Representação bidimensional da correlação das diferenças de temperatura, em termos de isotermas, em relação aos efeitos combinados da velocidade média do ar e da radiação solar global. Distribuição das isotermas das diferenças de temperatura entre os abrigos $(\mathbf{A}) \# 3$ e \#1, (B) \#2 e \#3 e (C) \#4 e \#3.

Um segundo tipo de representação, tridimensional, está apresentado na Figura 101, cujo formato permite um panorama das dimensões "volumétricas" e proporções relativas entre os desvios de temperatura. Esta forma de representação se trata de uma superfície aproximada, cujos valores são oriundos de cálculos de uma matriz de médias baseadas em todos os pontos da série. 

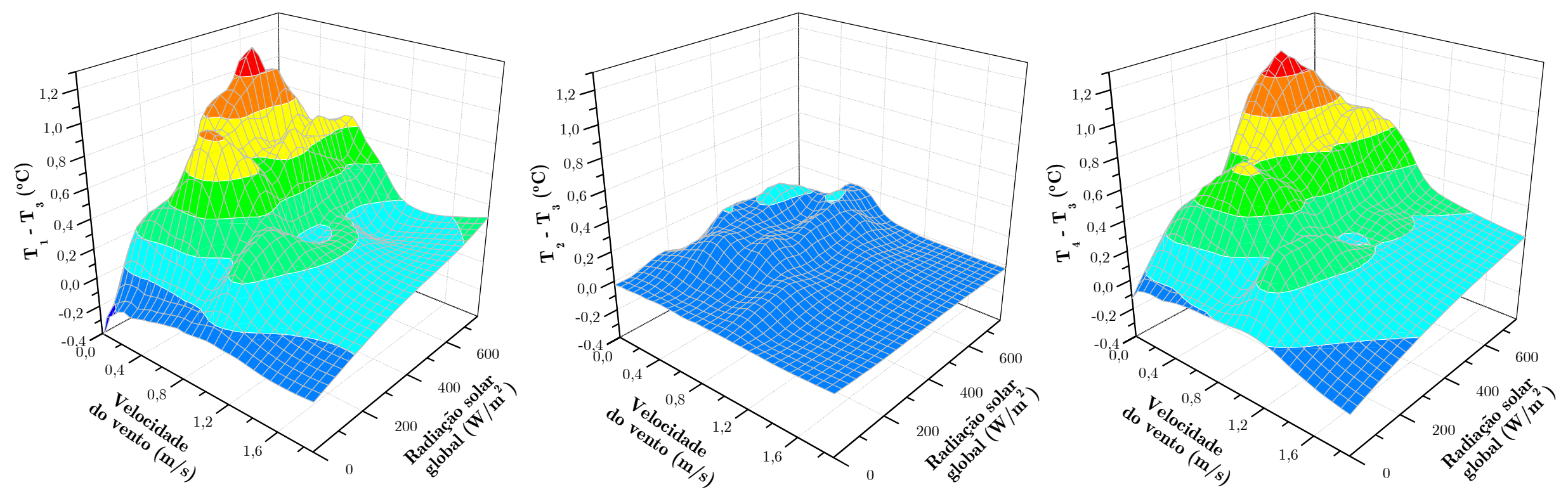

Figura 101 - Representação tridimensional das diferenças de temperatura em relação aos efeitos combinados da velocidade média do ar e da radiação solar global. Distribuição das diferenças de temperatura entre os abrigos: (A) \#1 e \#3; (B) \#2 e \#3; e (C) \#4 e \#3. 


\section{- Perdas por radiação noturna}

Conforme pôde ser percebido, a ocorrência de desvios de temperatura não só sucedeu-se positivamente durante o período do dia, caracterizado pela incidência da radiação solar, mas também desvios negativos de temperatura ocorreram durante a noite. Este fato é devido a perdas por radiação noturna para o céu (corpo negro) a partir do solo, que recebeu e acumulou toda energia solar durante o dia e a vai perdendo aos poucos durante a noite.

O mês de setembro de 2007 foi o que apresentou ausência de nebulosidade mais evidente no período, favorecendo a ocorrência de efeitos mais significativos de perda de calor dos abrigos por radiação noturna. A noite típica representativa selecionada para análise deste comportamento ocorreu na passagem do dia 13 para o dia 14 de setembro, cujo perfil de temperaturas é ilustrado na Figura 102.

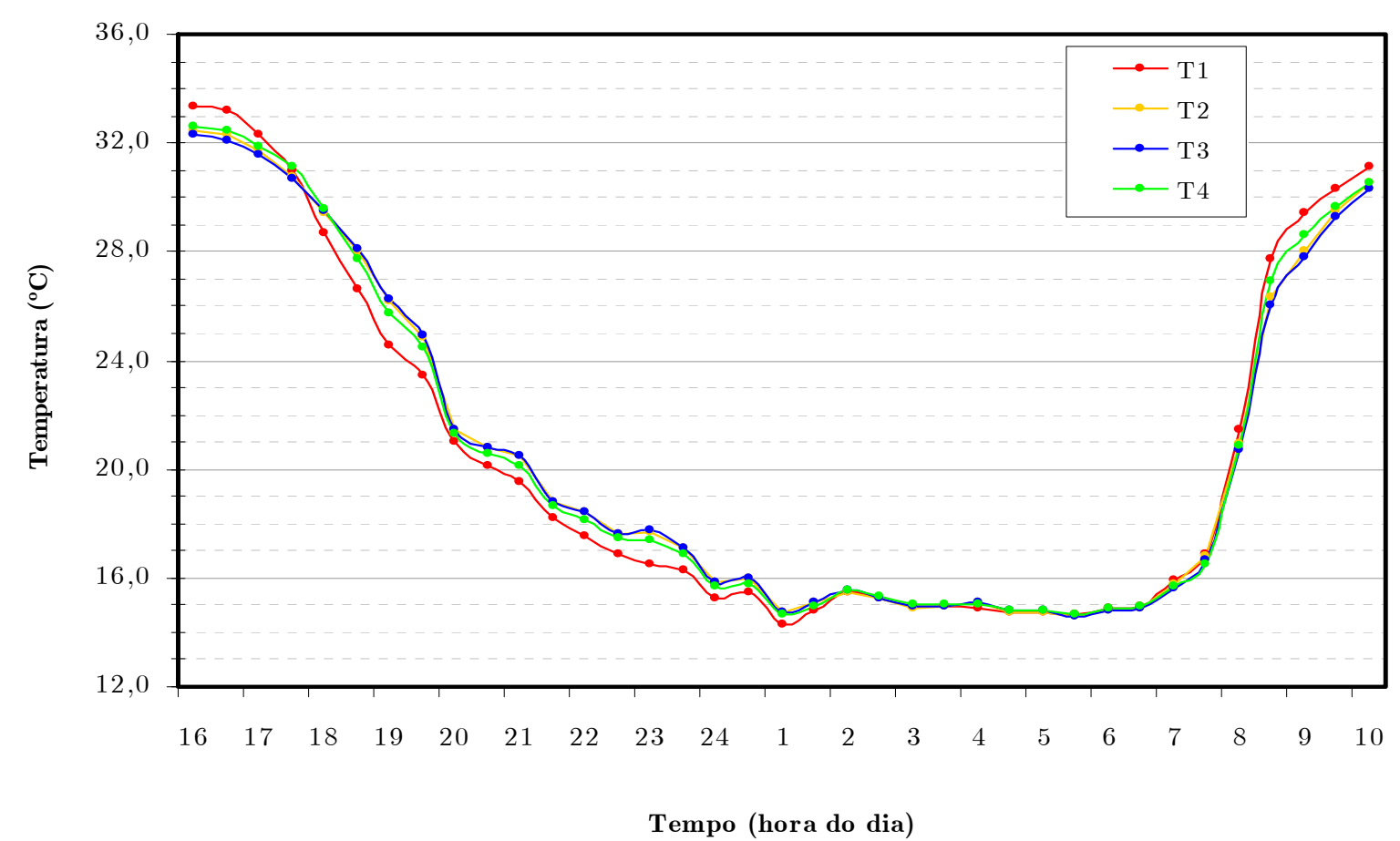

Figura 102 - Temperatura dos abrigos ao longo da noite da passagem do dia 13 para o dia 14 de setembro de 2006.

Melhor visualização é fornecida pela Figura 103, que apresenta as diferenças de temperatura entre os abrigos para a noite em questão. Verifica-se que o início da alteração do comportamento dos abrigos ocorre por volta das 18h, horário em que a radiação solar global não exerce mais efeito significativo no aquecimento dos abrigos. 
Tomando o abrigo \#1 como o exemplo do caso mais extremo, por não apresentar nem dispositivo de barreira de radiação (foil) nem aspiração forçada (ventoinha), e tendo como referência a temperatura do abrigo \#3, observa-se que por volta das $19 \mathrm{~h}$ é atingida uma diferença de temperatura de $1,6^{\circ} \mathrm{C}$. Esta diferença vai diminuindo até as $2 \mathrm{~h}$ da manhã do dia 14, permanecendo a partir de então praticamente nula até o aparecimento do sol, que ocorre entre 6 e 7h da manhã do dia 14.

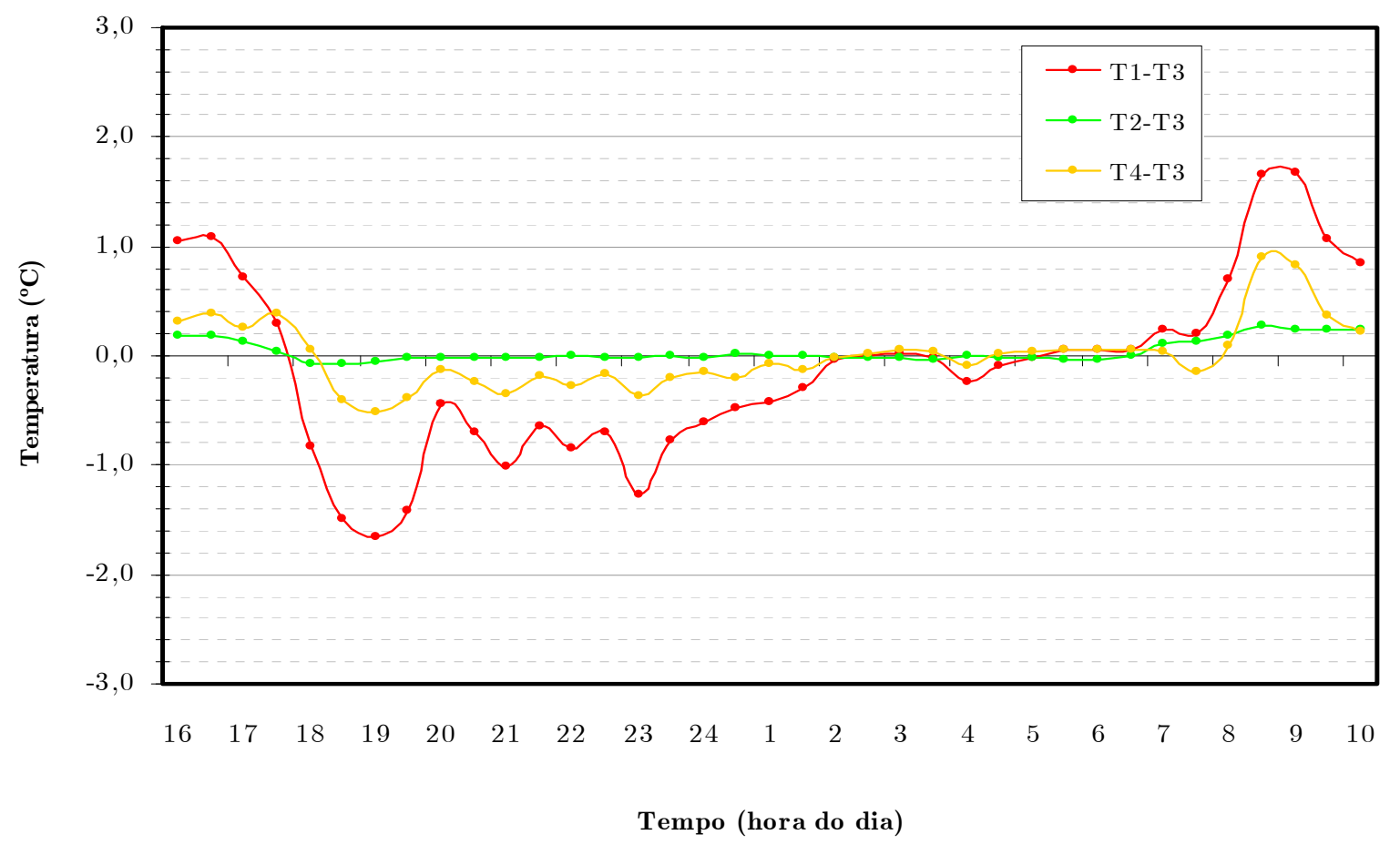

Figura 103 - Diferenças de temperatura dos abrigos ao longo da noite da passagem do dia 13 para o dia 14 de setembro de 2006.

Podem ser supostas três fases distintas no comportamento do abrigo \#1 em relação ao abrigo \#3 de referência, caso extremo que apresenta as maiores diferenças de temperatura:

- $1^{\text {a }}$ Fase: é iniciada com o entardecer seguido pelo crepúsculo, fase em que as diferenças de temperatura deixam de ser positivas e se tornam negativas, indicando que o ar no interior do abrigo \#1 está deixando de ser mais quente e passando a ser mais frio que o ar que se encontra no abrigo \#3. Nesta fase ocorre a perda mais significativa de calor por radiação noturna, fato devido ao alto calor específico do abrigo \#1, uma vez que, por este ser o mais fácil de aquecer e ganhar calor durante o dia por meio da radiação solar global, 
também é o mais fácil de se resfriar e perder durante a noite o calor acumulado de dia, por meio de radiação noturna - perda de energia para o céu, corpo negro que absorve toda a radiação que nele incide.

- $2^{\text {a }}$ Fase: com inicio às $19 \mathrm{~h}$ do dia 13, instante em que as diferenças de temperatura deixam de aumentar e iniciam uma diminuição gradual até às $2 \mathrm{~h}$ da manhã do dia 14, esta fase se caracteriza pelo aumento gradual da temperatura do abrigo \#1 em um intervalo de cerca de 7 horas. Este aumento no abrigo \#1 é devido ao ganho de calor que está sendo irradiado pelo solo, que recebe enorme quantidade de energia durante o dia, mas que, durante a noite, a re-emite por irradiação, porém, com uma taxa menor que a perda ocorrida no abrigo, pois o solo possui calor específico menor.

- $3^{\mathrm{a}}$ Fase: inicia-se às $2 \mathrm{~h}$ da manhã do dia 14 e termina com o alvorecer, sendo caracterizada pelo equilíbrio térmico entre todos os abrigos e o ar exterior, implicando em diferenças praticamente nulas entre as temperaturas medidas pelos termopares no interior dos abrigos.

Sintetizando, o fenômeno observado pelas perdas noturnas de calor ocorre provavelmente devido às diferenças de calor específico dos abrigos. Enquanto que durante o dia o abrigo \#1, que não possui barreira de radiação (foil), é aquecido mais rapidamente, durante a noite ele é resfriado também mais rapidamente.

\section{- Alteração da escala temporal de aquisição de dados}

O intervalo entre as aquisições dos valores de temperatura no interior dos abrigos foi reduzido de 20 para 10 segundos, e os registros dos valores de temperatura, que são totalizações obtidas pela média dos valores adquiridos, tiveram o seu intervalo reduzido de 30 para 5 minutos. Tal medida aumentou de 48 para 288 registros diários de temperatura para cada abrigo, permitindo assim o aumento da resolução dos dados, conforme pode ser observado na Figura 105, relativa ao dia 12 de setembro.

Sob a abordagem em escala temporal diário e por meio de um dia típico representativo, o dia 12 de setembro se encontrava sob domínio de massa tropical, verificado pela alta amplitude térmica - em torno de $10^{\circ} \mathrm{C}$ a diferença entre a máxima e mínima temperatura do dia; pela alta incidência solar; e pela ausência de 
nebulosidade, conforme pode ser verificado na imagem de satélite (A) da Figura 104. Nesta figura também estão apresentadas outras duas imagens de satélite, de caráter comparativo: a imagem (B) do dia 15 ilustrando o prenúncio de entrada de uma frente fria no estado de SP, verificado pelas nuvens (em branco) nos estados da Região Sul; e a imagem (C) do dia 16 ilustrando o domínio da massa polar no estado de São Paulo, totalmente coberto pelas nuvens.

As características do dia 12 descritas anteriormente contribuíram para a ocorrência de maiores diferenças de temperatura entre os abrigos, com $3,7^{\circ} \mathrm{C}$ de diferença máxima entre o abrigo sem foil e sem ventilação forçada (abrigo \#1, em vermelho) em comparação com o abrigo com foil e com ventilação forçada (abrigo \#3 de referência, azul).
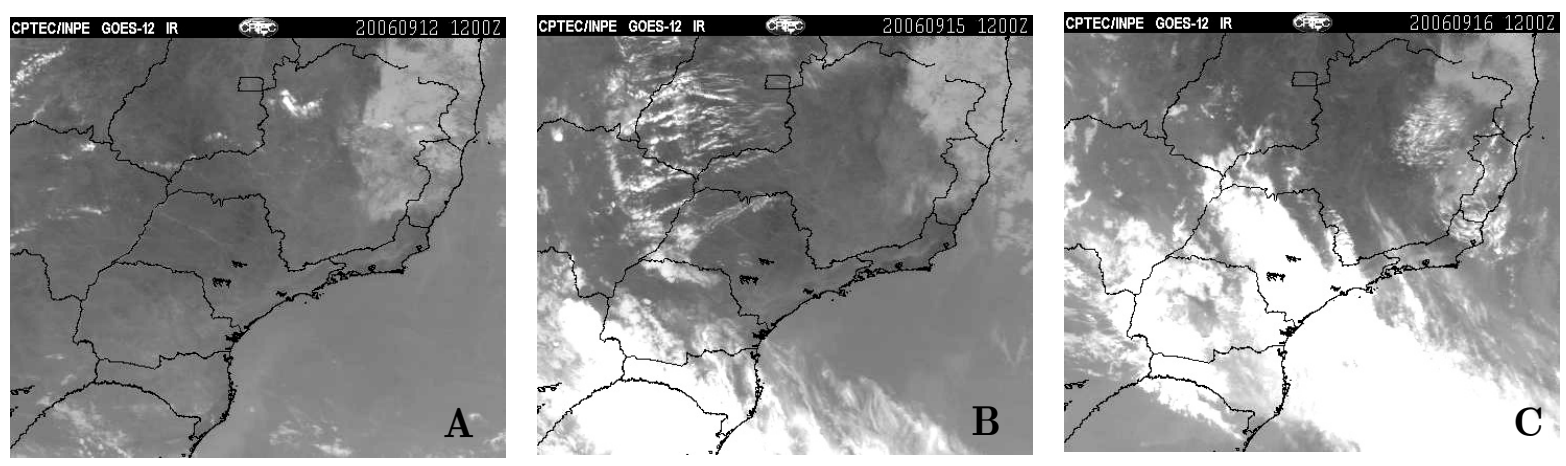

Figura 104 - Imagens em infravermelho captadas às 12h pelo satélite GOES nos dias 12, 15 e 16 de setembro. (A): imagem do dia 12, sob o domínio de massa tropical; (B): imagem do dia 15, apresentando a fase de prenúncio da entrada da frente fria; (C): imagem do dia 16, com o estado de SP sob o domínio da massa polar. Fonte: INPE, 2006.

Para fins de comparação e verificação visual de diferenças, elaborou-se um gráfico do mesmo dia com valores médios da temperatura em intervalos de 30 minutos, sendo estes valores obtidos pela média aritmética dos dados experimentalmente obtidos a cada 5 minutos, com o resultado mostrado na Figura 106. Comparando com a Figura 105, verifica-se um aumento da resolução dos dados, sendo que o aumento da discretização tende a um comportamento menos suave dos perfis de temperatura, que apresentam suas flutuações instantâneas e induções eletrônicas.

Os sensores termoelétricos, acondicionados nos abrigos, estão muito sujeitos à ação dos ventos e do microclima gerado em cada abrigo, sendo que, tendo os ventos grandes variações a cada instante, estes causam efeitos mais significativos nos abrigos 
com ventilação natural. A aparência, portanto, dos perfis de temperatura para o caso de registros em intervalos de 5 minutos é de uma curva com ruídos de alta frequência.

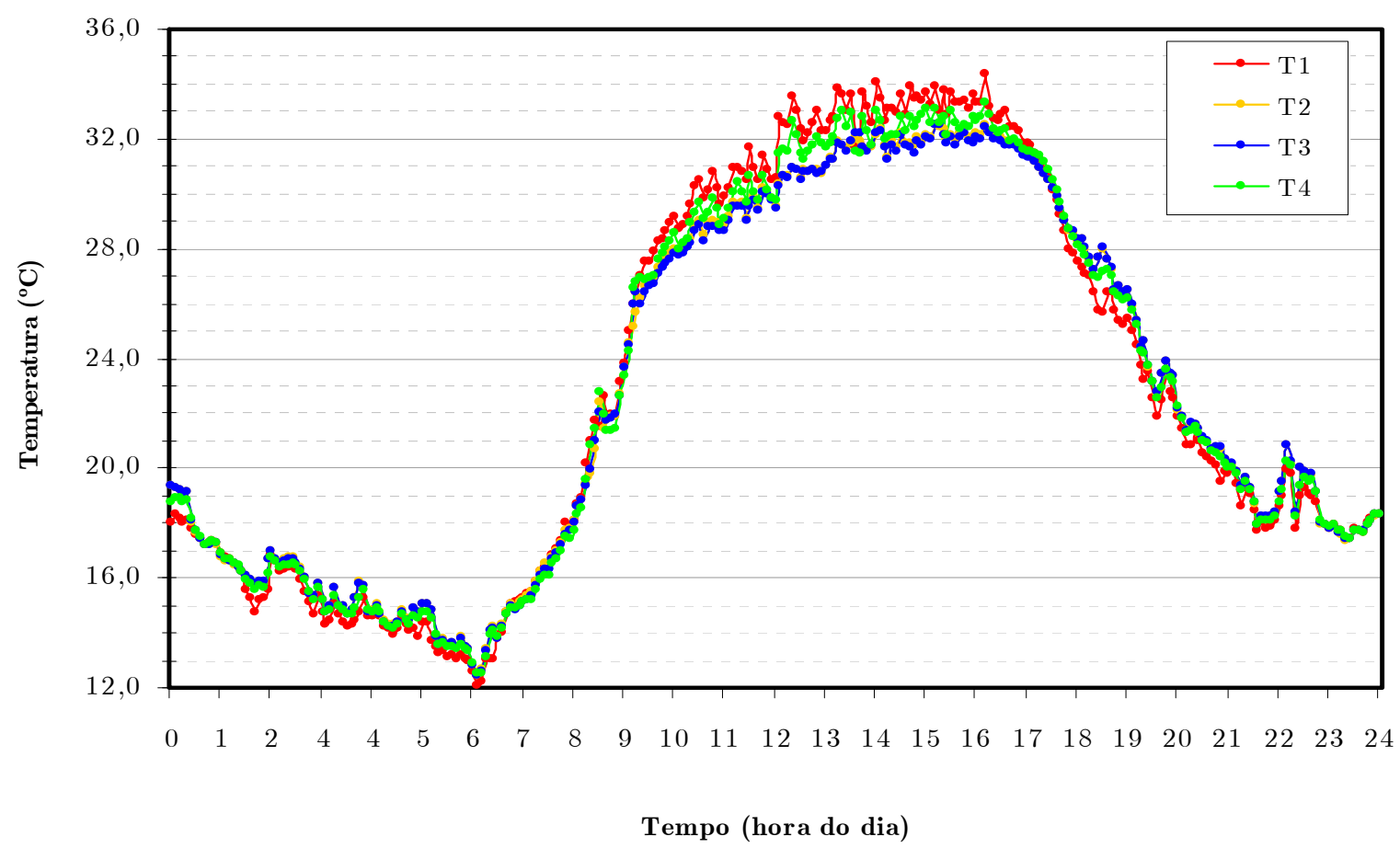

Figura 105 - Temperatura dos abrigos ao longo do dia 12 de setembro de 2006, com registros realizados a cada 5 minutos.

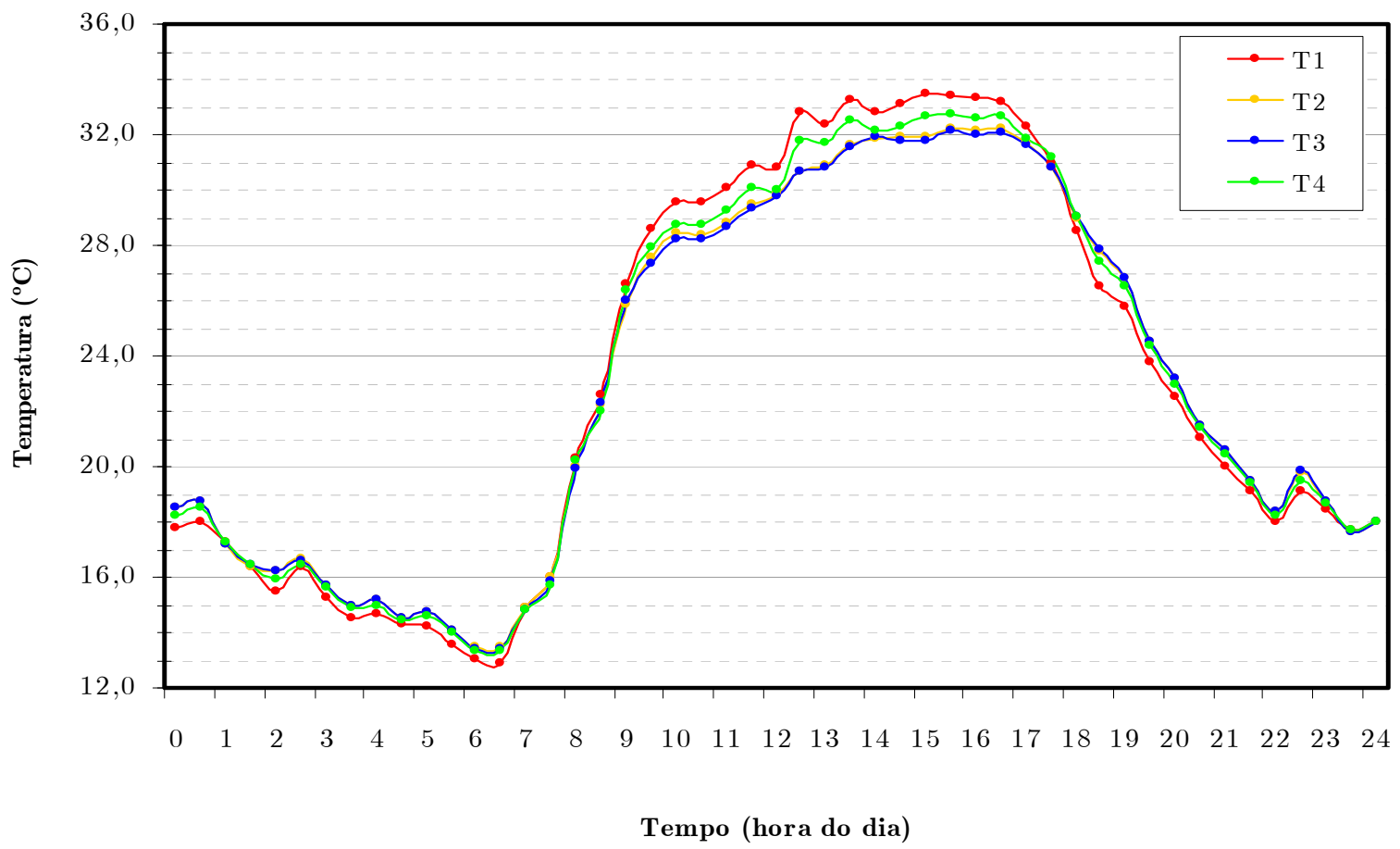

Figura 106 - Temperatura dos abrigos ao longo do dia 12 de setembro de 2006, com registros realizados a cada 30 minutos. 
A verificação dessa mudança de resolução, de que o aumento da resolução não permitiu melhor visualização do processo, fica melhor evidenciada por meio da comparação dos valores de máxima diferença entre os abrigos \#1 e \#3, diferença esta que de $3,7^{\circ} \mathrm{C}$ no caso de registros a cada 5 minutos, adquire valor de $2,2^{\circ} \mathrm{C}$ no caso dos valores médios obtidos em intervalos de 30 minutos. Esta redução dos valores máximos da diferença entre os valores de temperatura é também observada nos outros dois abrigos, conforme apresentado na Tabela 21. Nesta tabela verifica-se ainda que os valores de temperatura máxima para cada abrigo também é reduzido, e, ao contrário, os valores de temperatura mínima são aumentados.

Tabela 21 - Valores de temperatura $\left({ }^{\circ} \mathrm{C}\right)$ nos 4 diferentes abrigos da primeira estação experimental, sob diferentes intervalos de registros

\begin{tabular}{ccccccc}
\hline \hline \multirow{2}{*}{ Abrigo } & \multicolumn{3}{c}{ Máxima } & \multicolumn{3}{c}{ Mínima } \\
\cline { 2 - 7 } & $\mathrm{R}_{5}$ & $\mathrm{R}_{30}$ & $\mathrm{R}_{5}-\mathrm{R}_{30}$ & $\mathrm{R}_{5}$ & $\mathrm{R}_{30}$ & $\mathrm{R}_{5}-\mathrm{R}_{30}$ \\
\hline $\mathrm{T} 1$ & 34,4 & 33,5 & 0,9 & 12,1 & 12,9 & $-0,8$ \\
$\mathrm{~T} 2$ & 32,5 & 32,3 & 0,3 & 12,5 & 13,4 & $-1,0$ \\
$\mathrm{~T} 3$ & 32,5 & 32,2 & 0,4 & 12,5 & 13,4 & $-1,0$ \\
$\mathrm{~T} 4$ & 33,3 & 32,7 & 0,6 & 12,5 & 13,3 & $-0,8$ \\
\hline $\mathrm{T} 1-\mathrm{T} 3$ & 3,7 & 2,2 & 1,6 & $-2,3$ & $-1,3$ & $-1,0$ \\
$\mathrm{~T} 2-\mathrm{T} 3$ & 0,4 & 0,2 & 0,1 & $-0,3$ & $-0,1$ & $-0,2$ \\
$\mathrm{~T} 4-\mathrm{T} 3$ & 1,8 & 1,2 & 0,6 & $-0,8$ & $-0,4$ & $-0,4$ \\
\hline
\end{tabular}

$\mathrm{R}_{5}$ e $\mathrm{R}_{30}$ : Registros realizados a cada 5 e 30 min., respectivamente.

T1, T2, T3 e T4: Temperaturas dos abrigos \#1, \#2, \#3 e \#4, respectivamente.

Infere-se, portanto, que os registros realizados a cada 5 minutos apresentam desvios positivos para valores de temperatura máxima e desvios negativos para os valores de temperatura mínima em comparação aos valores de temperatura obtidos com os registros médios de 30 minutos. Assim, fica demonstrado que o registro em intervalos de 30 minutos proporciona perfis de temperatura mais suaves e menos sujeitos às variações bruscas nos abrigos naturalmente ventilados devido à ação instantânea dos ventos, e, assim, atenuando as oscilações e ruídos indesejáveis dos valores de temperatura. Tais oscilações são facilmente observadas comparando-se os gráficos da Figura 107 - pág. 272, e, Figura 108 - pág. 272, que exibem as diferenças de temperatura dos abrigos - tendo como referência o abrigo \#3, com os registros em intervalos de 5 e 30 minutos, respectivamente.

É interessante destacar que segundo recomendações da WMO (2008), as aquisições de valores devem ser realizadas em intervalos de 1 a 10 minutos, e as 
totalizações registradas em intervalos de 30 minutos a 24 horas. Comumente realizam-se aquisições a cada 1 minuto e totalizações a cada 1 hora para a maioria das aplicações meteorológicas e climatológicas.

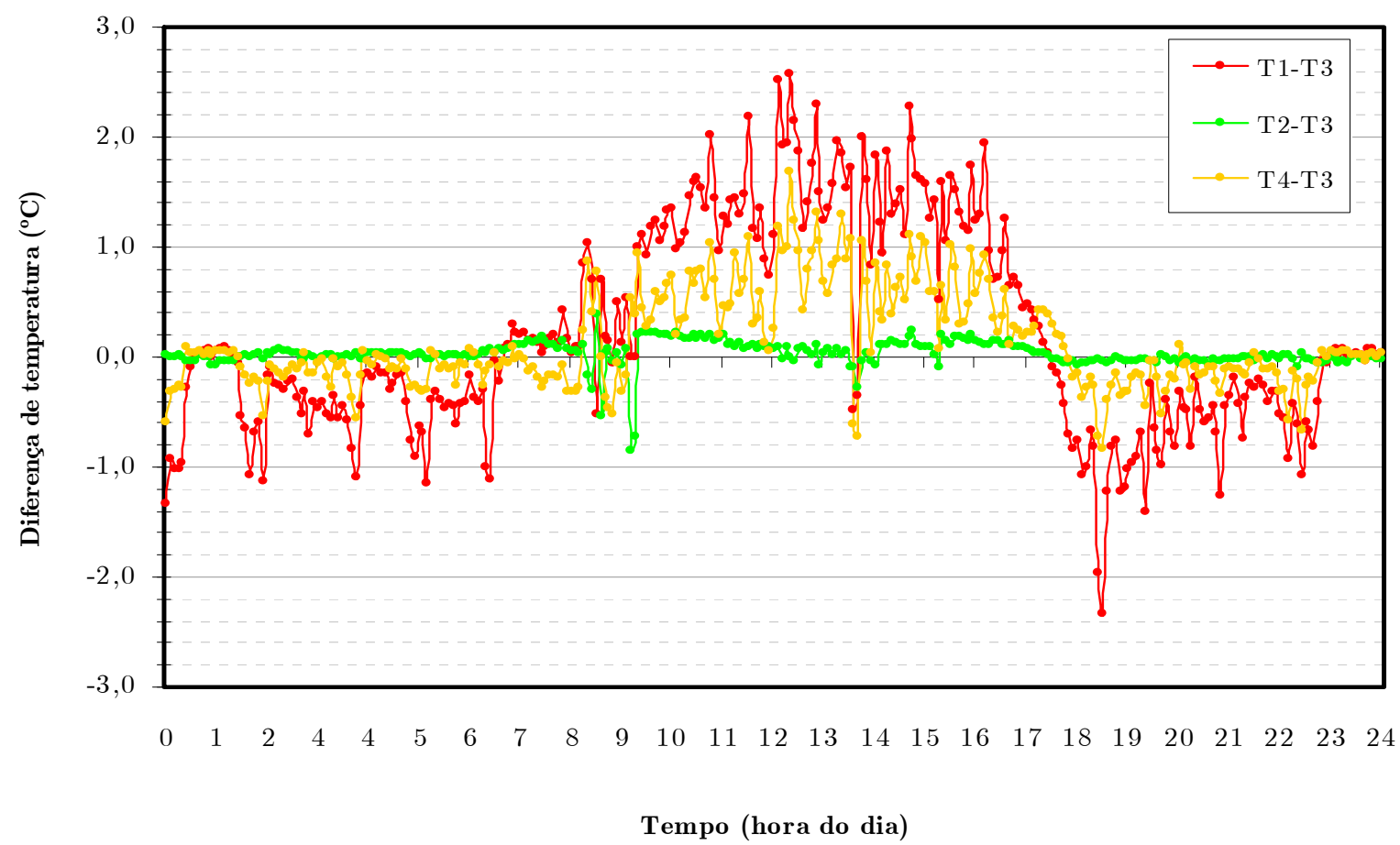

Figura 107 - Diferenças de temperatura dos abrigos ao longo do dia 12 de setembro de 2006, abrigo \#3 como referência, com registros a cada 5 minutos.

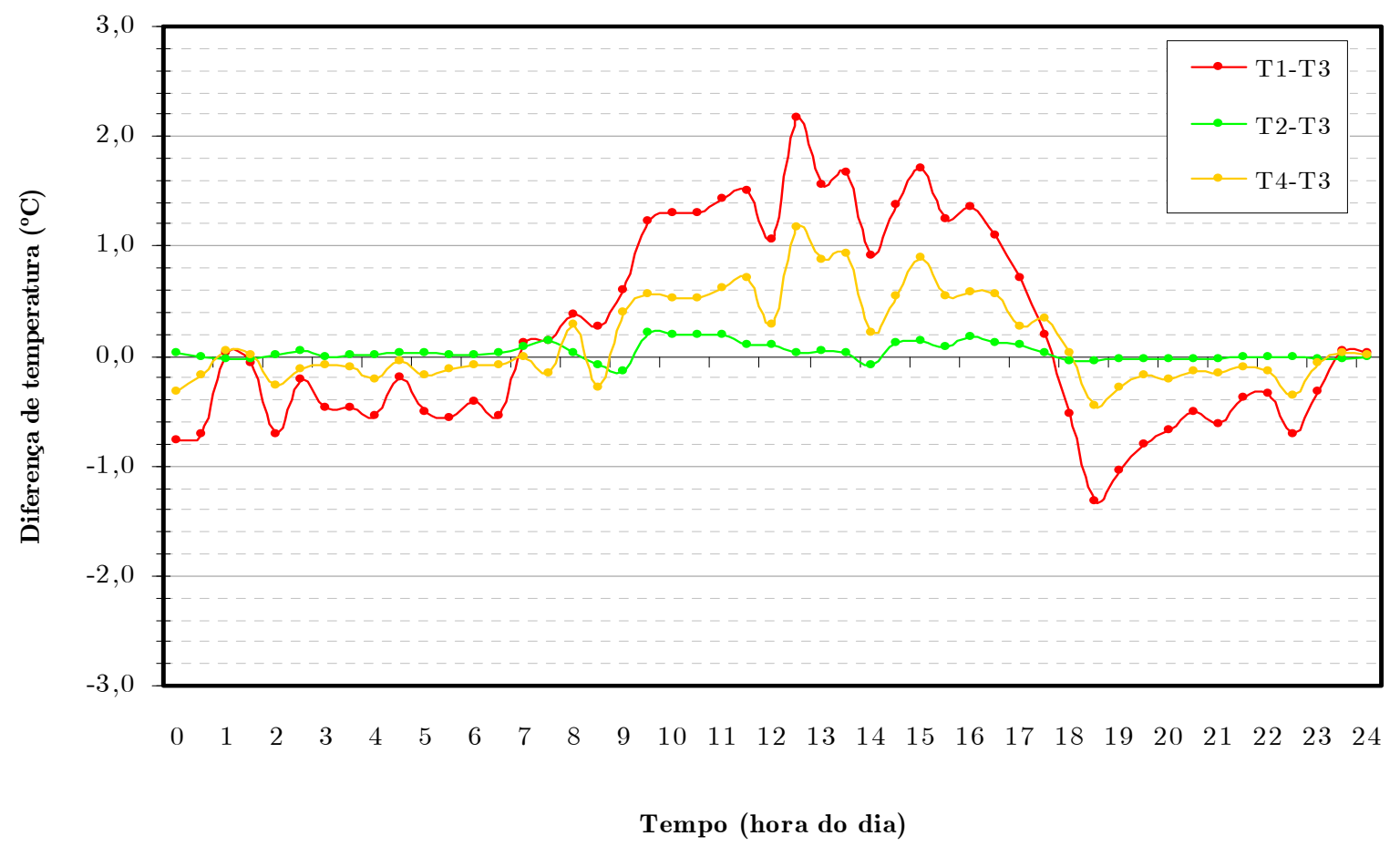

Figura 108 - Diferenças de temperatura dos abrigos ao longo do dia 12 de setembro de 2006, abrigo \#3 como referência, com registros a cada 30 minutos. 


\section{- Comportamento do sensor HMP45C-Vaisala acoplado ao abrigo 41003}

Conforme mencionado, foi realizada na estação de referência a coleta simultânea dos dados de temperatura com o sensor de temperatura e umidade relativa modelo HMP45C-Vaisala acoplado ao abrigo de proteção modelo 41003-R.M. Young, vide Figura 8 - pág. 32. Entretanto, durante o período de coleta de dados, verificou-se que o sensor não estava registrando corretamente os valores, apresentando falhas e valores fisicamente inválidos. Desta maneira, uma alternativa pensada foi utilizar os dados de temperatura do "Laboratório de Conforto Ambiental", localizado no mesmo campus, porém, localizado a cerca de $800 \mathrm{~m}$ da estação experimental. Tal procedimento não é recomendável, e os dados comparados não são representativos, uma vez que cada local possui microclima específico, provavelmente diferentes.

Como intervalo de análise adotaram-se como dias típicos representativos os dias 26, 27 e 28 de maio de 2006, que apresentam características semelhantes, conforme ilustra a Figura 109. Nesta figura estão apresentadas respectivamente: (A) os perfis de temperatura; (B) perfis de diferenças de temperatura; (C) velocidades média e máxima dos ventos; e (D) radiação solar global.

Verifica-se que a temperatura medida pelo sensor HMP45C apresenta, durante o dia, valores menores que os valores de temperatura dos abrigos \#1 e \#4 (ambos sem aspiração forçada); e valores maiores que os abrigos \#2 e \#3 (ambos com aspiração forçada).

Tal fato permite dizer que o comportamento do abrigo 41003 é equivalente, mas, com desempenho ligeiramente superior aos abrigos experimentais não aspirados utilizados. Isto pode ser devido a dois fatores: o material plástico do abrigo 41003 não ser o mesmo dos tubos de PVC utilizados como abrigo dos termopares, e, portanto, apresentando características físicas diferentes, tal como no comportamento térmico; e também pelo design característico do abrigo, formado por dez pratos plásticos sobrepostos que criam um microclima distinto daquele observado nos abrigos experimentais. Mas esta inferência dos comportamentos diários não deve ser considerada representativa, já que durante a noite as diferenças foram consideravelmente discrepantes. 


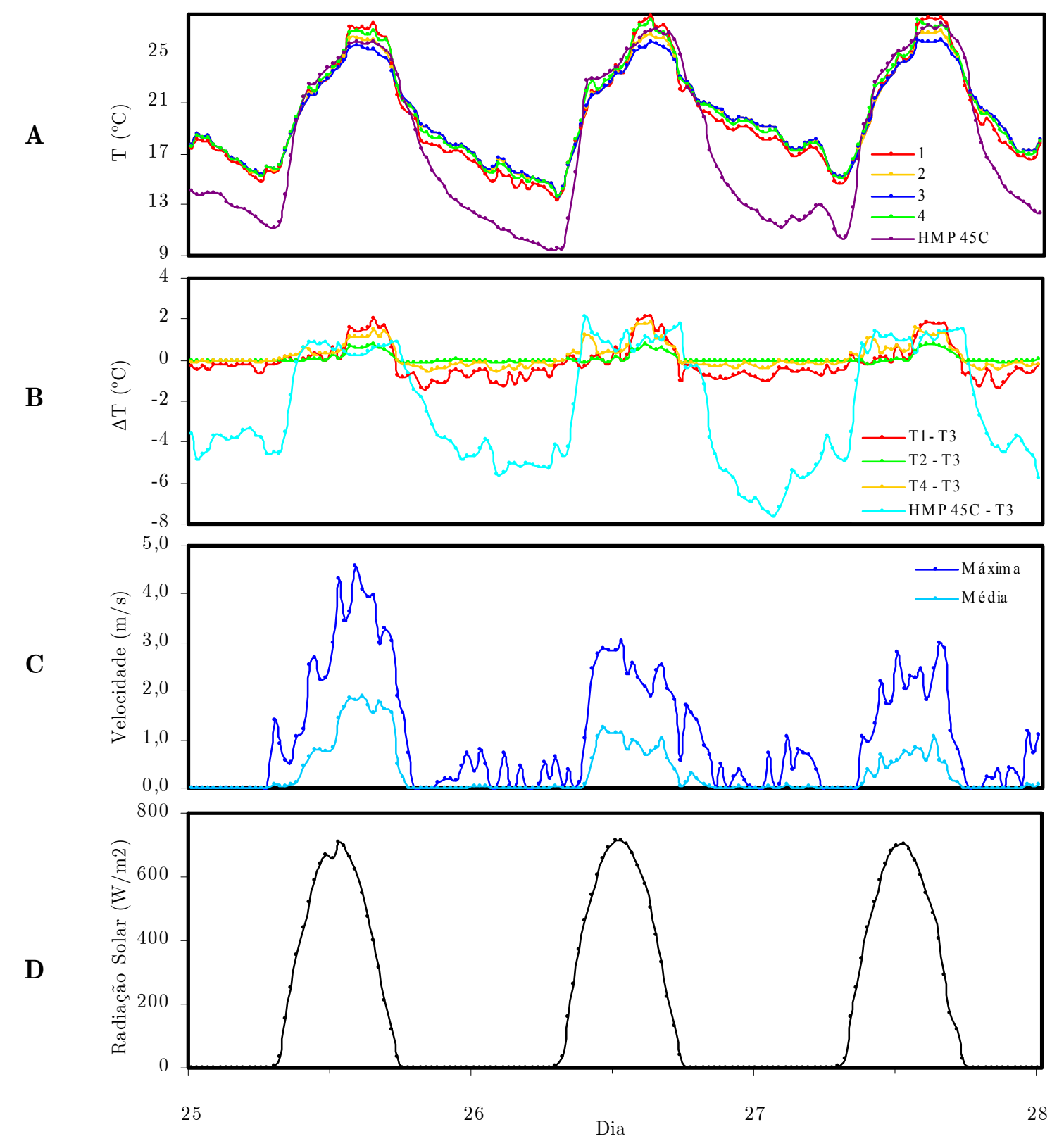

Figura 109 - Análise dos dias 26, 27 e 28 de maio de 2006 com o uso do sensor HMP45C acoplado ao abrigo 41003. (A) Perfis de temperatura para os diferentes abrigos; (B) Diferenças de temperatura entre os abrigos; (C) Velocidades máxima e média do vento exterior; (D) Radiação solar local. Obs. Escala horizontal idêntica para os gráficos.

No período noturno fica destacada a nítida diferença que o abrigo 41003 apresenta em relação aos abrigos experimentais. Esta característica pode ser devido à localização da estação em que se encontrava o sensor comercial HMP45C: ela está a cerca de 100 metros do córrego do Tijuco Preto, cujos entornos são caracterizados por baixas temperaturas, fato reconhecidamente notado por quem anda a pé por ali à noite. Ou seja, o microclima local interfere nas medições, não permitindo uma 
comparação adequada desta estação com as temperaturas obtidas nos abrigos experimentais. A alternativa improvisada foi, portanto, apenas ilustrativa, ressalvando que as temperaturas não são compatíveis e passíveis de uma comparação apropriada. Já que não foi possível comparar os abrigos com uma estação de referência, na segunda parte procedeu-se em realizar um estudo mais criterioso e com novos abrigos. Com uma estação de referência funcionando adequadamente, foi possível coletar uma série de dados de temperatura durante um ano, permitindo analisar efeitos de longo prazo.

\subsection{PARTE B - Efeitos de médio e longo prazo: repercussões das influências nas escalas mensais e anuais}

Esta segunda etapa do estudo, PARTE B, consistiu na construção de uma nova estação experimental, esta composta de 9 abrigos diferentes. Visando estudar outros aspectos além dos determinados na PARTE A, os abrigos foram construídos e confeccionados com diferentes materiais e cores. Os dados foram coletados durante o ano de 2009, e devido a escala maior que da parte anterior, foi concebida uma representação concomitante dos valores mensais, diários e horários em um diagrama circular anual. Tal formato permitiu uma perspectiva inédita sob o caráter dinâmico do clima.

\subsubsection{Materiais e Métodos}

As estações experimental e de referência da PARTE B foram instaladas no Centro de Recursos Hídricos e Ecologia Aplicada (CRHEA), Escola de Engenharia de São Carlos (EESC), Universidade de São Paulo (USP), localizada no município de

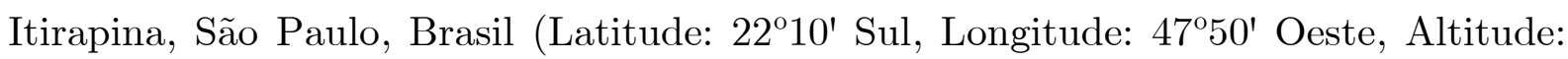
$753 \mathrm{~m})$, a $25 \mathrm{~km}$ do município de São Carlos, ao lado da Estação Climatológica, em uma área de cobertura uniforme de grama típica.

Ao contrário da estação da PARTE A, no local desta segunda estação montada não havia nenhum obstáculo (árvore, edificação) ou superfície de concreto ou asfalto próxima. Na primeira estação experimental, as condições do local das medições poderiam estar sendo influenciadas pela presença das construções a cerca de 10 metros de distância do local das medições (vide fotos do APÊNDICE A, pg. 385). 
Havia também a presença de árvores e de um estacionamento asfaltado. Como na ocasião das primeiras medições não se estava determinando o clima de uma forma mais ampla, os resultados obtidos são representativos somente àquele ambiente local, de microclima com características particulares, não podendo os resultados serem extrapolados para representação do clima em outras regiões, mesmo que próximas ao local.

Nesta segunda parte do estudo, foram utilizados nove diferentes abrigos na estação experimental (APÊNDICE E, pg. 393), sendo oito abrigos constituídos por tubos de PVC e um abrigo metálico. Foi avaliada a diferença do comportamento proporcionada pela cor do abrigo, pela presença de anteparo vertical e pelo tipo de material do abrigo, além do uso de foil e ventoinha. A descrição de cada abrigo está detalhada na Tabela 22. Todos os demais periféricos e componentes da estação experimental (datalogger CR10X, multiplexador AM416, bateria e painel solar) foram os mesmos utilizados na estação experimental da PARTE A. No local, a cerca de 30 metros da estação experimental, foi montada uma estação automática de referência com características idênticas à utilizada na PARTE A, porém, com sensores novos. Ambas as estações faziam aquisições das variáveis a cada 20 segundos, e totalizavam a média a cada 30 minutos, valor que era registrado. Assim, totalizavam-se 48 registros por dia, 1.440 registros por mês e 17.280 em um ano.

Tabela 22 - Constituição dos nove abrigos experimentais

\begin{tabular}{cll}
\hline \hline Abrigo & \multicolumn{1}{c}{ Descrição } & \multicolumn{1}{c}{ Temperatura correspondente } \\
\hline 1 & PVC azul com ventoinha & $T_{\text {azul }}$ \\
2 & PVC vermelho com ventoinha & $T_{\text {vermelho }}$ \\
3 & PVC verde com ventoinha & $T_{\text {verde }}$ \\
4 & PVC branco com ventoinha & $T_{\text {branco }}$ \\
5 & PVC preto com ventoinha & $T_{\text {preto }}$ \\
6 & PVC branco com foil e com ventoinha & $T_{\text {foil }}$ \\
7 & PVC com anteparo e com ventoinha & $T_{\text {anteparo }}$ \\
8 & PVC branco sem foil e sem ventoinha & $T_{\text {sem_protesão }}$ \\
9 & Metálico com ventoinha e sem foil & $T_{\text {metálico }}$ \\
\hline
\end{tabular}

As dimensões destes abrigos são as mesmas dos utilizados na PARTE A: $30 \mathrm{~cm}$ de comprimento e 4 pol. de diâmetro cada. Com exceção do abrigo 9 (sem proteção alguma), todos os demais possuíam ventilação artificial fornecida por ventoinha. As 
cores designadas representam a cor da tinta acrílica brilhante utilizada na pintura dos abrigos coloridos - inclusive o abrigo branco foi pintado de tinta branca. Em termos de formato, o abrigo metálico se difere dos demais ao apresentar uma forma paralelepipedal, ou seja, um corpo em forma de bloco retangular. E por fim, o abrigo com anteparo possuía duas placas verticais de PVC ao lado de cada orifício do tubo. As placas cortavam transversalmente a seção do tubo, uma partindo de cima e a outra de baixo (semelhante à disposição de chicanas utilizadas em sistemas de separação de poeira e partículas sólidas presentes em gases), mas não encostando totalmente do lado oposto, deixando uma abertura que permita a passagem livre do ar no interior do tubo. Este dispositivo foi utilizado para testar a influência da radiação refletida que pudesse incidir diretamente no sensor e interferir nas medições da temperatura do ar. Tal anteparo foi uma tentativa de estar em concordância com o abrigo elaborado por Azevedo e Tarifa (2001), que tiveram a preocupação prudente de construir um abrigo que impedisse o acesso direto da radiação termal emitida do solo aos sensores.

Esta segunda estação experimental foi montada em 2008, com funcionamento e coleta de dados a partir do mês de março. Durante o ano todo de 2008, a estação climatológica automática do CRHEA (APÊNDICE F, pg. 395) sofreu consecutivos e prolongados períodos de mau funcionamento, comprometendo as análises e comparações para o ano de 2008. Esta estação climatológica estava funcionando desde 1999 (Figura 62, pg. 195), e seus sensores se apresentavam envelhecidos e deteriorados devido à exposição às intempéries climáticas.

Após certo atraso e dificuldades em se obter recursos financeiros para compra de equipamentos novos, decidiu-se montar uma a estação no CRHEA com instrumentos e sensores já disponíveis no "Laboratório de Ecotecnologias: Novos Materiais e Procedimentos". Logo, no final de 2008, foi montada uma nova estação automática climatológica de referência, cuja coleta dos dados - após os ajustes e configurações necessárias - iniciou-se satisfatoriamente a partir de dezembro.

Portanto, foi considerado o ano de 2009 o período de análise desta segunda parte do estudo. Após a Qualificação de Mestrado no início de 2009, uma das recomendações feita pela banca foi a calibração dos termopares, ou seja, determinar se estes estavam realizando a leitura correta dos valores de temperatura - etapa fundamental que não havia sido efetuada no experimento conduzido e descrito na PARTE A. Os dados realmente confiáveis podem ser considerados, portanto, a partir de abril de 2009, logo após a realização da calibração dos sensores. 
Na ocasião da calibração, a estação experimental passou por uma manutenção e limpeza geral (APÊNDICE G, pg. 397): todas as ventoinhas foram trocadas, uma vez que algumas já se apresentavam fracas e falhando; o material isolante plástico de superfície metalizada (foil) foi trocado, pois estavam degradados e sujos; e os abrigos e as pontas dos termopares foram limpos, pois haviam acumulado muita poeira. O evento de calibração, manutenção e limpeza implicou em mudanças nos valores registrados, conforme poderá ser observado nas análises e gráficos adiante.

Quando aplicáveis, as análises se procederam analogamente às realizadas na PARTE A, sendo que análises adicionais foram efetuadas à medida que as escalas de tempo foram aumentando. Ou seja, na interpretação com abordagem diária, mensal e anual, foram empregados procedimentos semelhantes aos executados no "CAPÍTULO 4 - Mudanças dos Horários de Observações e dos Cálculos de Médias" (pg. 159), com o uso de análises estatísticas, tendências, distribuições e correlações.

\subsubsection{Resultados e Discussão}

A calibração foi realizada com gelo fundente de água destilada a $0^{\circ} \mathrm{C}$ (valor confirmado por termômetro de álcool de alta precisão), no qual os termopares foram imersos simultaneamente (APÊNDICE G, pg. 397). As leituras das temperaturas, realizadas pelo datalogger a cada 20 segundos, foram anotadas e a partir delas confeccinou-se o gráfico apresentado na Figura 110. Os sensores entraram em equilíbrio térmico 220 segundos após a imersão. O desvio padrão médio das temperaturas obtidas pelos termopares foi calculado em $0,12^{\circ} \mathrm{C}$ no intervalo de 220 a 280 segundos. Deste modo, os sensores apresentaram precisão e exatidão bastante satisfatórias.
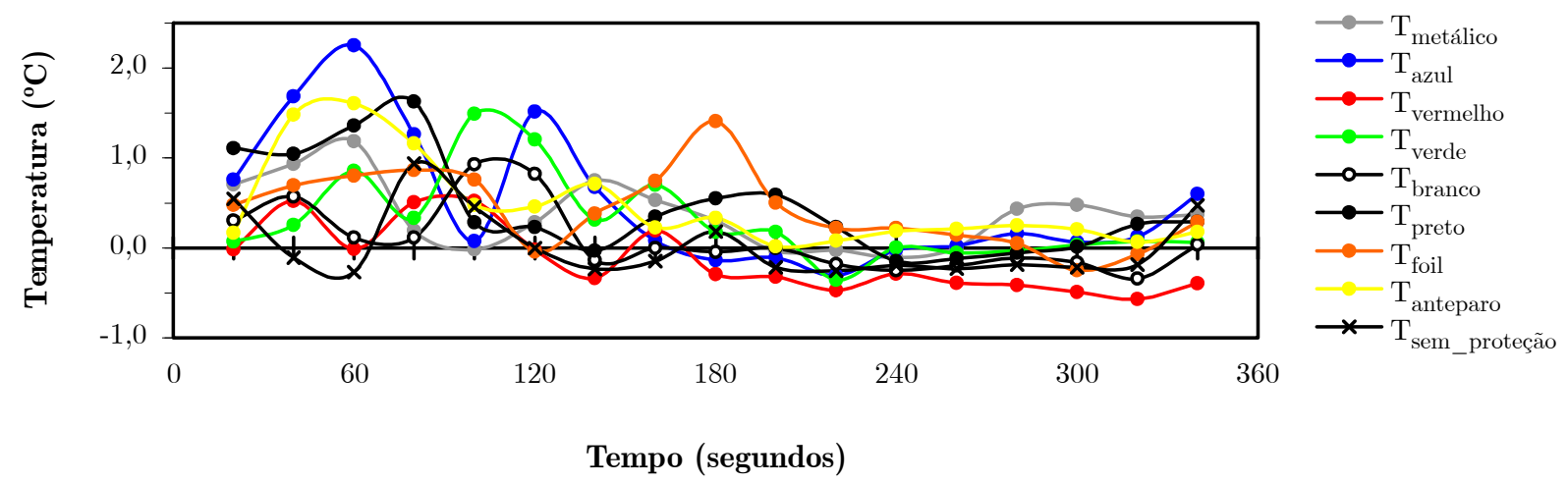

Figura 110 - Variações das temperaturas após a imersão em gelo fundente durante a calibração dos termopares da segunda estação experimental, com 9 abrigos. 
Satisfeita a verificação da precisão e exatidão das medições, as análises podem ser conduzidas normalmente. Primeiro, a Figura 111 apresenta as falhas verificadas na série de temperatura de 2009, coletada na segunda estação experimental. As falhas verificadas foram decorrentes de dois eventos imprevistos e indesejáveis: 1. O primeiro foi o corte acidental do fio de eletricidade, que alimentava as ventoinhas da estação, por um trator que realizava o corte da grama no local. Os dados comprometidos deste período foram descartados; e 2. A bateria, que alimentava o datalogger durante as noites, apresentou falhas e não estava mais carregando suficientemente, também causando insuficiência nos dados.

\section{9}
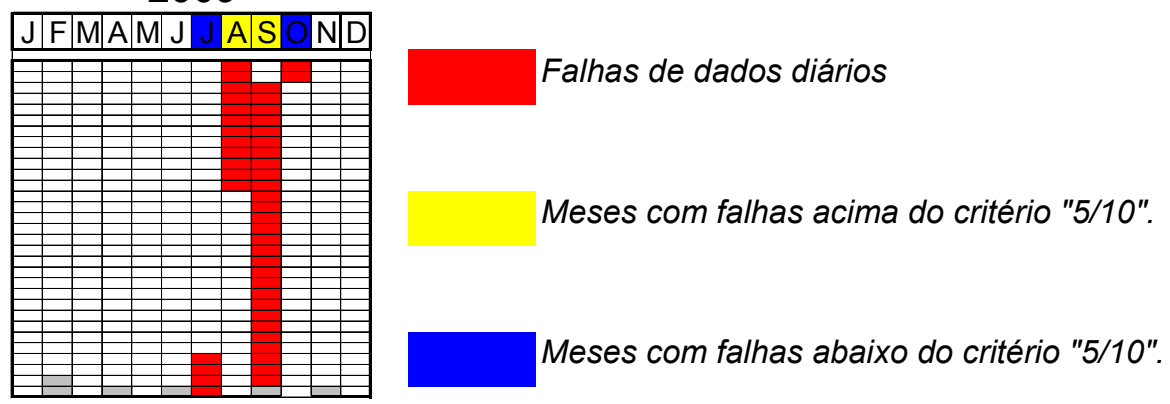

Figura 111 - Diagrama tabular, anual e mensal, apresentando as falhas de dados diários na série de temperatura do ar registrada na segunda estação experimental, com 9 abrigos.

Apesar de dois meses apresentarem falhas acima do permitido pelo critério "5/10" (conforme explicado em "5.2. Cálculo da temperatura média mensal e anual: Normais climatológicas", pg. 123), a não inclusão deles nas análises não prejudica tanto os resultados, já que pelo menos os períodos mais contrastantes de verão e inverno estão disponíveis.

Repetindo a metodologia adotada nos capítulos anteriores, inicia-se analisando os desvios das temperaturas obtidas em relação à temperatura da estação automática $\left(T_{\text {automática }}\right)$ na escala temporal mais curta, que no caso são os valores registrados a cada meia hora em ambas as estações. Nesta primeira abordagem, na Tabela 23 são mostrados alguns índices estatísticos, os quais são indicativos do comportamento e desempenho dos abrigos experimentais. Nota-se valores extremos, tanto positivos, quanto negativos, na ordem média de $5^{\circ} \mathrm{C}$, mas chegando até $13^{\circ} \mathrm{C}$, que foi o caso do desvio máximo do abrigo metálico. 
Com base nos valores e em ordem do melhor para o pior, uma primeira classificação pode ser tentada: os abrigos foil e branco apresentam os menores desvios; os abrigos vermelho, azul e verde apresentam desempenho um pouco pior, porém semelhantes; o abrigo sem proteção alguma vem na sequência; o abrigo preto se apresenta um pouco pior; seguido pelo abrigo com anteparo; e finalmente, o abrigo metálico como o com pior desempenho, ou seja, mais sujeito a efeitos das trocas de calor, principalmente em relação ao aquecimento devido à radiação solar.

Tabela 23 - Análise estatística das séries $T_{\text {azul }}, T_{\text {vermelho, }}, T_{\text {verde }}, T_{\text {branco }}, T_{\text {pretoto }}, T_{\text {foil }}, T_{\text {anteparoo }}, T_{\text {sem_protecão }} \mathrm{e}$ $T_{\text {metalico }}$ em relação à $T_{\text {automatica }}$ no ano de 2009.

\begin{tabular}{lccccc}
\hline \multicolumn{1}{c}{ Abrigo } & Máximo & Mínimo & Desvio padrão & $\begin{array}{c}\text { Média dos } \\
\text { desvios }\end{array}$ & $\begin{array}{c}\text { Intervalo de } \\
\text { confiança - 95\% }\end{array}$ \\
\hline$T_{\text {azul }}-T_{\text {aut. }}$ & 6,28 & $-5,75$ & 0,80 & 0,20 & $-1,01$ a 2,20 \\
$T_{\text {vermelho }}-T_{\text {aut. }}$ & 5,82 & $-4,76$ & 0,89 & 0,21 & $-1,13$ a 2,52 \\
$T_{\text {verde }}-T_{\text {aut. }}$ & 5,75 & $-4,59$ & 0,82 & 0,18 & $-1,07$ a 2,27 \\
$T_{\text {branco }}-T_{\text {aut. }}$ & 4,69 & $-5,80$ & 0,74 & 0,11 & $-1,11$ a 1,95 \\
$T_{\text {preto }}-T_{\text {aut. }}$ & 7,49 & $-5,68$ & 0,97 & 0,29 & $-1,07$ a 2,71 \\
$T_{\text {foil }}-T_{\text {aut. }}$ & 3,76 & $-5,75$ & 0,64 & 0,03 & $-1,13$ a 1,50 \\
$T_{\text {anteparo }}-T_{\text {aut. }}$ & 7,76 & $-5,46$ & 1,35 & 0,36 & $-1,48$ a 3,66 \\
$T_{\text {sem__protesão }}-T_{\text {aut. }}$ & 8,58 & $-4,79$ & 0,96 & 0,17 & $-1,39$ a 2,30 \\
$T_{\text {metálico }}-T_{\text {aut. }}$ & 13,27 & $-5,65$ & 1,25 & 0,29 & $-1,15$ a 3,25 \\
\hline
\end{tabular}

Os valores apresentam apenas uma noção inicial e bastante preliminar, que não deve, necessariamente, ser levada à risca. A análise de correlação e de distribuição dos dados pode fornecer informações mais interessantes. Na Figura 112 as correlações são exibidas das temperaturas obtidas pelos abrigos experimentais em relação à temperatura da estação automática de referência. Pelos coeficientes de correlação $\left(\mathrm{R}^{2}\right)$, a classificação a partir do melhor abrigo, ou seja, maior correlação com a referência, seria: $T_{\text {foill }}, T_{\text {branco }}, T_{\text {azul }}, T_{\text {verde }}, T_{\text {vermelho }}, T_{\text {sem_protesão }}, T_{\text {preto }}, T_{\text {anteparo }}$, e $T_{\text {metálico }}$. Percebe-se uma pequena tendência dos maiores valores serem mais quentes que os de referência no caso de $T_{\text {preto }}$, [gráfico $(\mathbf{E})$ ] uma tendência um pouco maior no caso de $T_{\text {anteparo }}[$ gráfico $(\mathbf{G})$ ] e uma tendência realmente grande, bastante acentuada e saliente para o caso de $T_{\text {metálico }}[$ gráfico $(\mathbf{I})]$. 

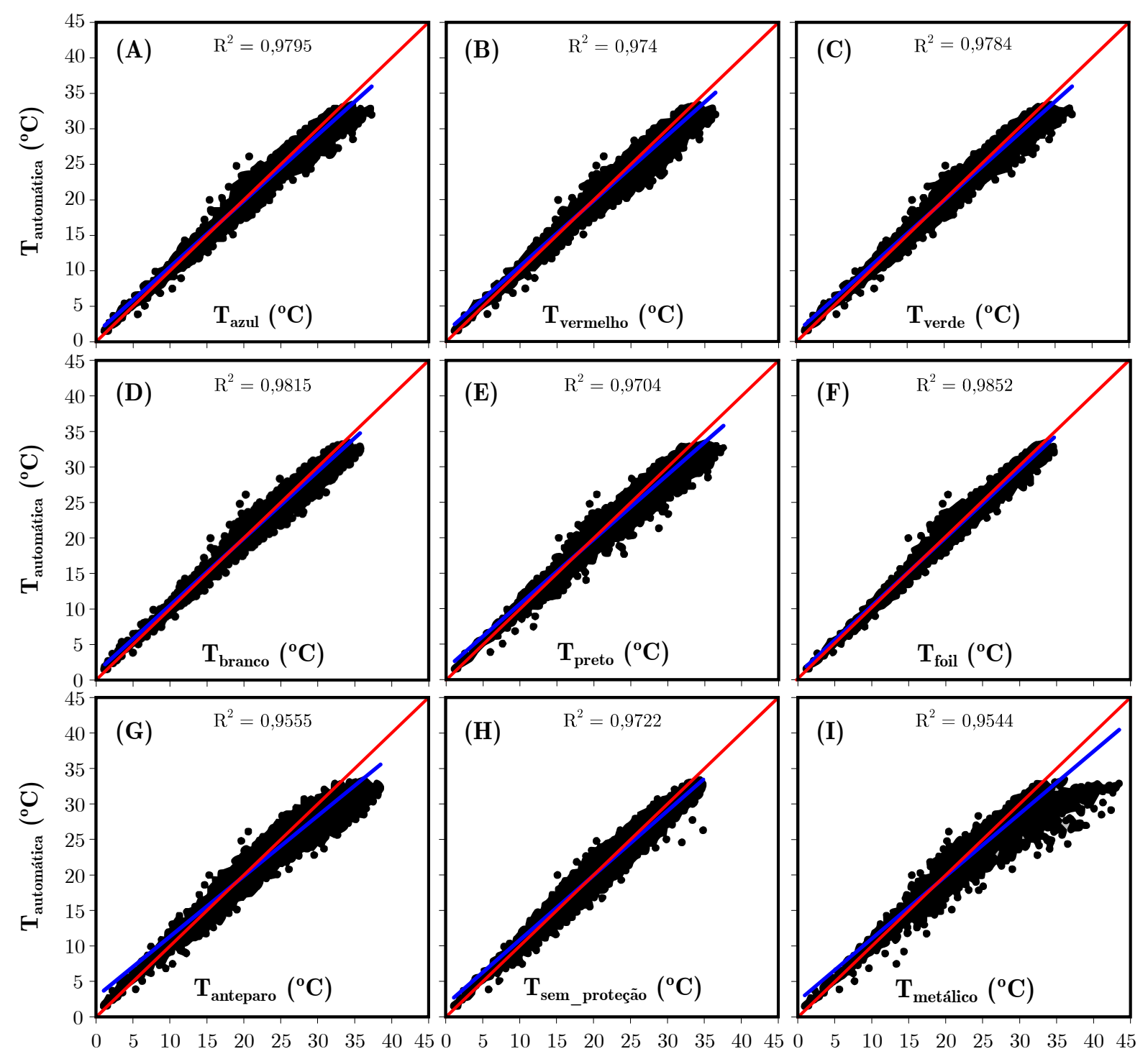

Figura 112 - Gráficos de correlação entre as séries $T_{\text {azul }}, T_{\text {vermelho, }}, T_{\text {verde, }}, T_{\text {branco }}, T_{\text {preto }}, T_{\text {foil }}$, $T_{\text {anteparo }}, T_{\text {sem_protecão }}$ e $T_{\text {metálico }}$ em relação à $T_{\text {automática }}$ no ano de 2009.

Representados no formato de distribuição relativa, a Figura 113 apresenta os histogramas dos desvios de temperatura. Observam-se comportamentos semelhantes nos histogramas dos abrigos azul [gráfico (A)], vermelho [gráfico (B)], verde [gráfico (C)] e branco [gráfico (D)]; o abrigo com foil [gráfico (F)] denota uma distribuição mais uniforme e quase simétrica em relação ao desvio zero; os abrigos preto [gráfico $(\mathbf{E})$ ], com anteparo [gráfico $(\mathbf{G})$ ] e o sem proteção [gráfico $(\mathbf{H})$ ], descrevem uma frequência maior de desvios positivos; já o abrigo metálico [gráfico (I)] não exibe neste histograma os valores discrepantes, pois a escala não compreendeu desvios acima de $5,0^{\circ} \mathrm{C}$. 

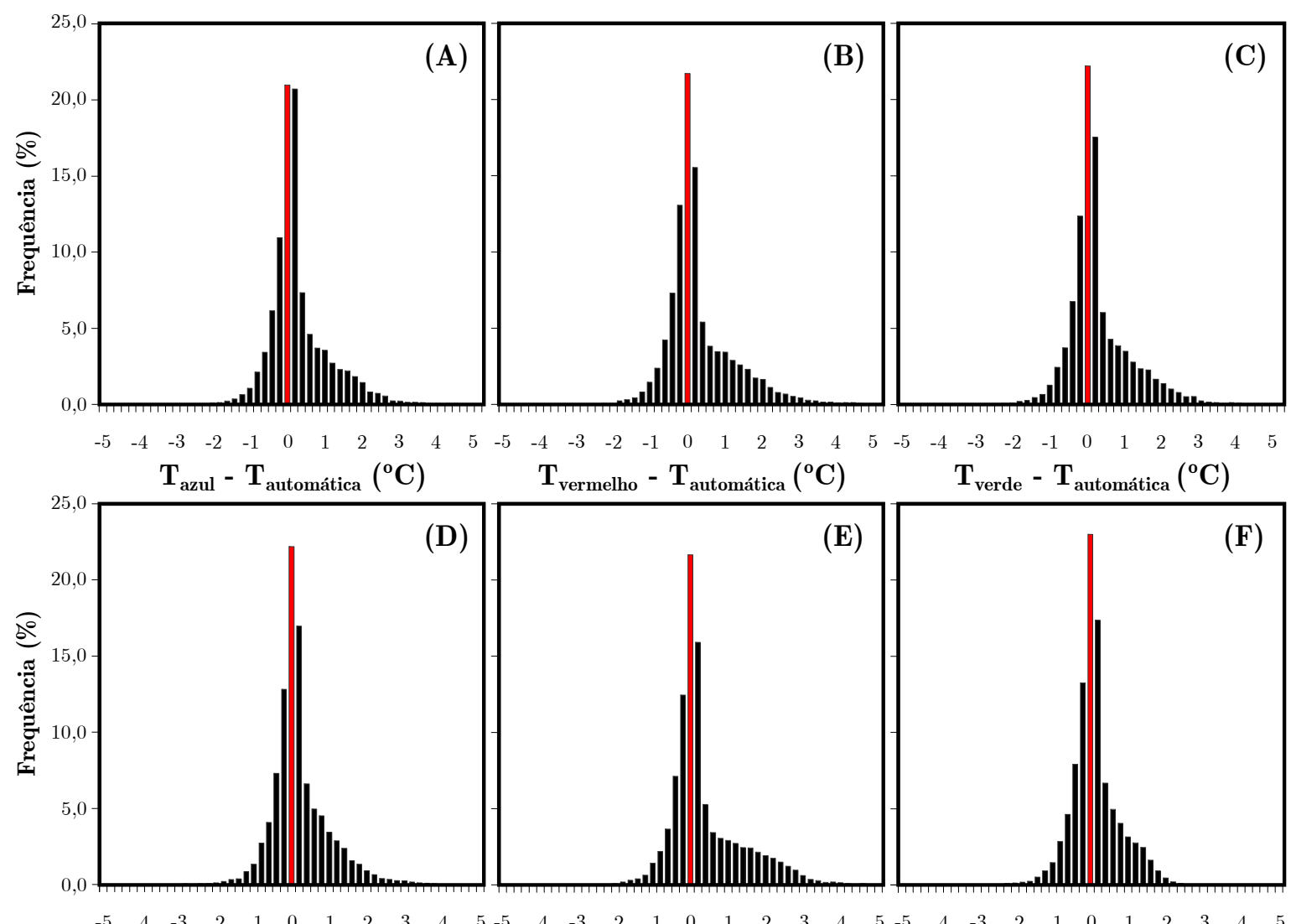

$\mathbf{T}_{\text {vermelho }}-\mathbf{T}_{\text {automática }}\left({ }^{\circ} \mathbf{C}\right)$

$\mathbf{T}_{\text {verde }}-\mathbf{T}_{\text {automática }}\left({ }^{\circ} \mathbf{C}\right)$
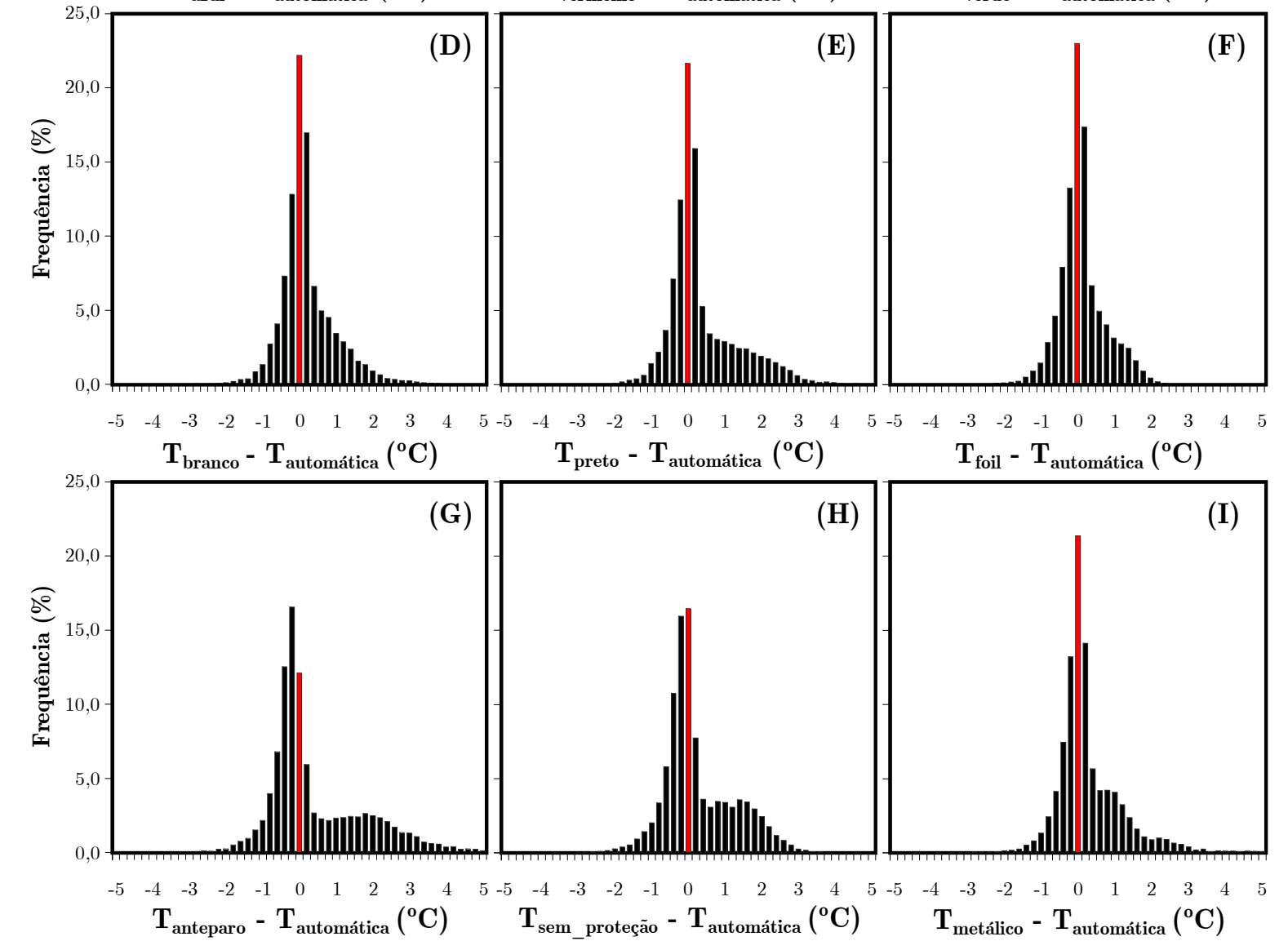

$\mathbf{T}_{\text {foil }}-\mathbf{T}_{\text {automática }}\left({ }^{\circ} \mathrm{C}\right)$

Figura 113 - Histogramas dos desvios de temperatura das séries $T_{\text {azul }}, T_{\text {vermelho }}, T_{\text {verde }}, T_{\text {branco }}$, $T_{\text {preto }}, T_{\text {foil }}, T_{\text {anteparo }}, T_{\text {sem_proteção }}$ e $T_{\text {metálico }}$ em relação à $T_{\text {automática }}$ no ano de 2009.

Dadas as distribuições e correlações dos desvios independentemente dos horários em que eles ocorreram, é conveniente associá-los à sua distribuição vinculada à escala temporal, para determinar em quais instantes eles se sucederam. A Figura 114 exibe os desvios de temperatura com base nos dados coletados a cada meia hora. Nesta figura fica nítida uma ruptura no comportamento dos desvios que foi causada pela calibração dos sensores, limpeza e manutenção geral da estação experimental. Ou 
seja, os valores extremos apresentados na tabela se referem a um período de dados pouco confiáveis e não são representativos de toda a série anual.

Todavia, mesmo após analisar visualmente o período pós-calibração na Figura 114, ainda parecem ser válidas as classificações preliminares elaboradas anteriormente Percebe-se que realmente alguns abrigos desempenham seu papel de proteção melhor que outros. Basta observar com atenção o extremo direito da figura, período do verão. A maioria dos abrigos apresenta desvios positivos maiores daqueles apresentados no período do inverno, ou seja, estão sofrendo mais aquecimento durante os dias com maior intensidade de radiação solar. Apenas o abrigo com foil sofre menos esta influência da radiação, devido à presença deste material isolante com superfície metalizada. 


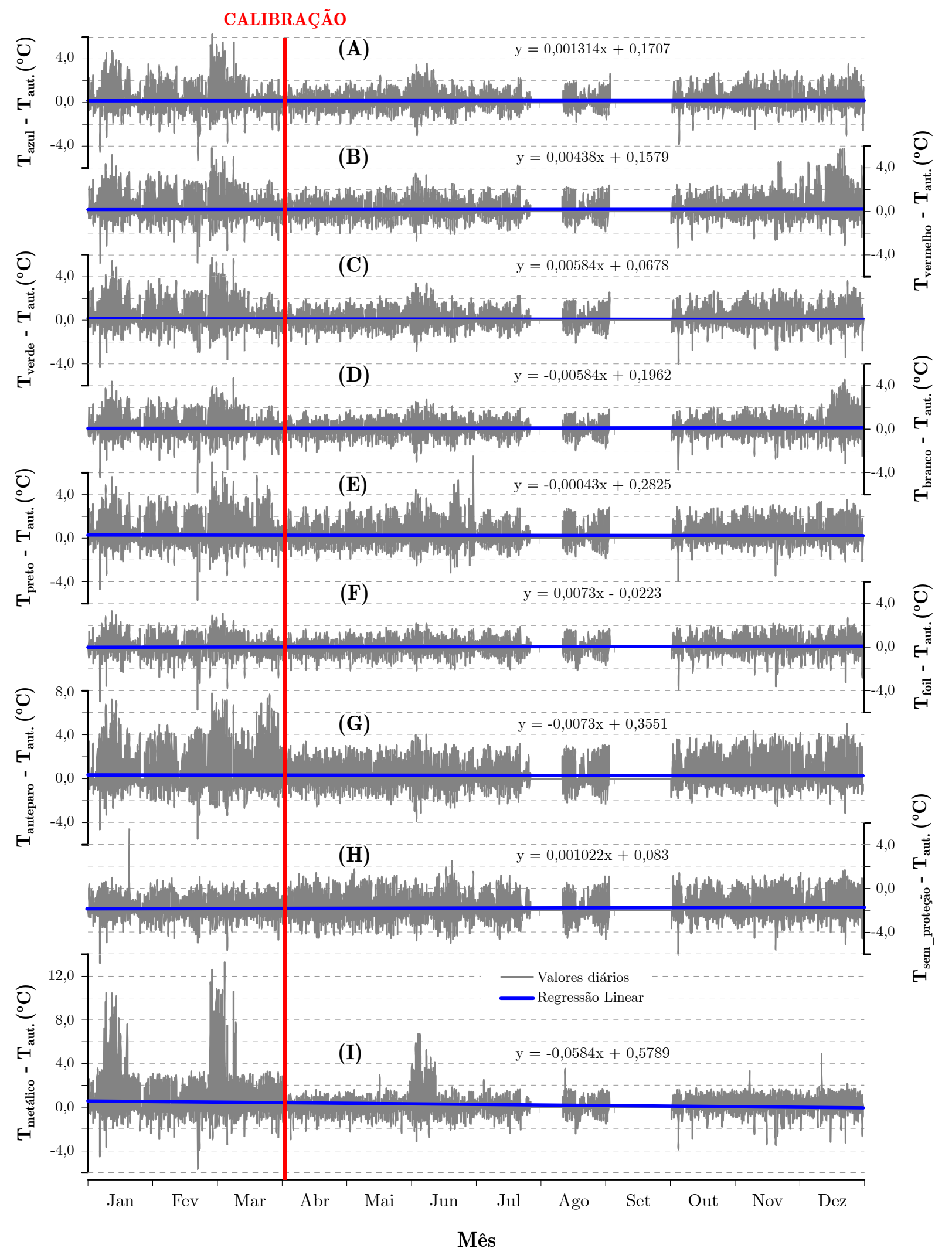

Figura 114 - Desvios horários e tendências das temperaturas das séries $T_{\text {azul }}, T_{\text {vermelho }}, T_{\text {verde }}$, $T_{\text {branco }}, T_{\text {preto }}, T_{\text {foil }}, T_{\text {anteparo }}, T_{\text {sem_proteção }}$ e $T_{\text {metalico }}$ em relação à $T_{\text {automática }}$ no ano de 2009. 
Prosseguindo a análise, a Figura 115 apresenta a variação dos desvios sob a escala dos valores médios diários, calculados pela média aritmética dos 48 registros em cada dia. Esta figura permite distinguir melhor as retas de tendência dos valores diários, demonstrando que a maioria dos abrigos sofrem, na média do período de um ano, sobreaquecimento de cerca de 0,2 a $0,3^{\circ} \mathrm{C}$, com exceção do abrigo com foil, que apresenta desvio quase nulo. Notar que nesta figura a escala possui amplitude de $2,0^{\circ} \mathrm{C}$, enquanto que na da figura anterior, a amplitude era de $8,0^{\circ} \mathrm{C}$. Este fato decorre dos cálculos das médias diárias que suavizam as variações de alta frequência da temperatura.

Merece atenção um fato ressaltante do abrigo metálico. A princípio ele aparentava ser o pior abrigo de todos, porém olhando o gráfico (I) da Figura 115, fica demonstrado que ele apresenta um comportamento razoável após a calibração, exceto por um pico de aquecimento que ele sofreu no começo do mês de junho, causado pela falha de sua ventoinha. A propósito, os dois grandes picos que ocorreram anteriormente - na metade janeiro e do final de fevereiro, atingindo valores de aproximadamente $8^{\circ} \mathrm{C}$ nesta escala - são oriundos de ventilação forçada insuficiente ou falhas das ventoinhas antigas, que já estavam bastante utilizadas e desgastadas. A diferença entre os dois primeiros picos com o terceiro, do começo de junho, foi a intensidade a que estava sujeito o abrigo durante o período de funcionamento inadequado da ventoinha: nos dois primeiros casos o referido período era de verão; e no segundo, o período era de inverno. Respectivamente, levando-se em consideração e desprezando os dois picos, duas retas de regressão linear foram traçadas. A reta com linha contínua denota-se acentuadamente decrescente, enquanto que a com linha tracejada exibe um tendência levemente crescente, porém nitidamente mais próxima do eixo zero, mais condizente com os dados pós-manutenção e com maior correspondência em relação aos valores de referência. 


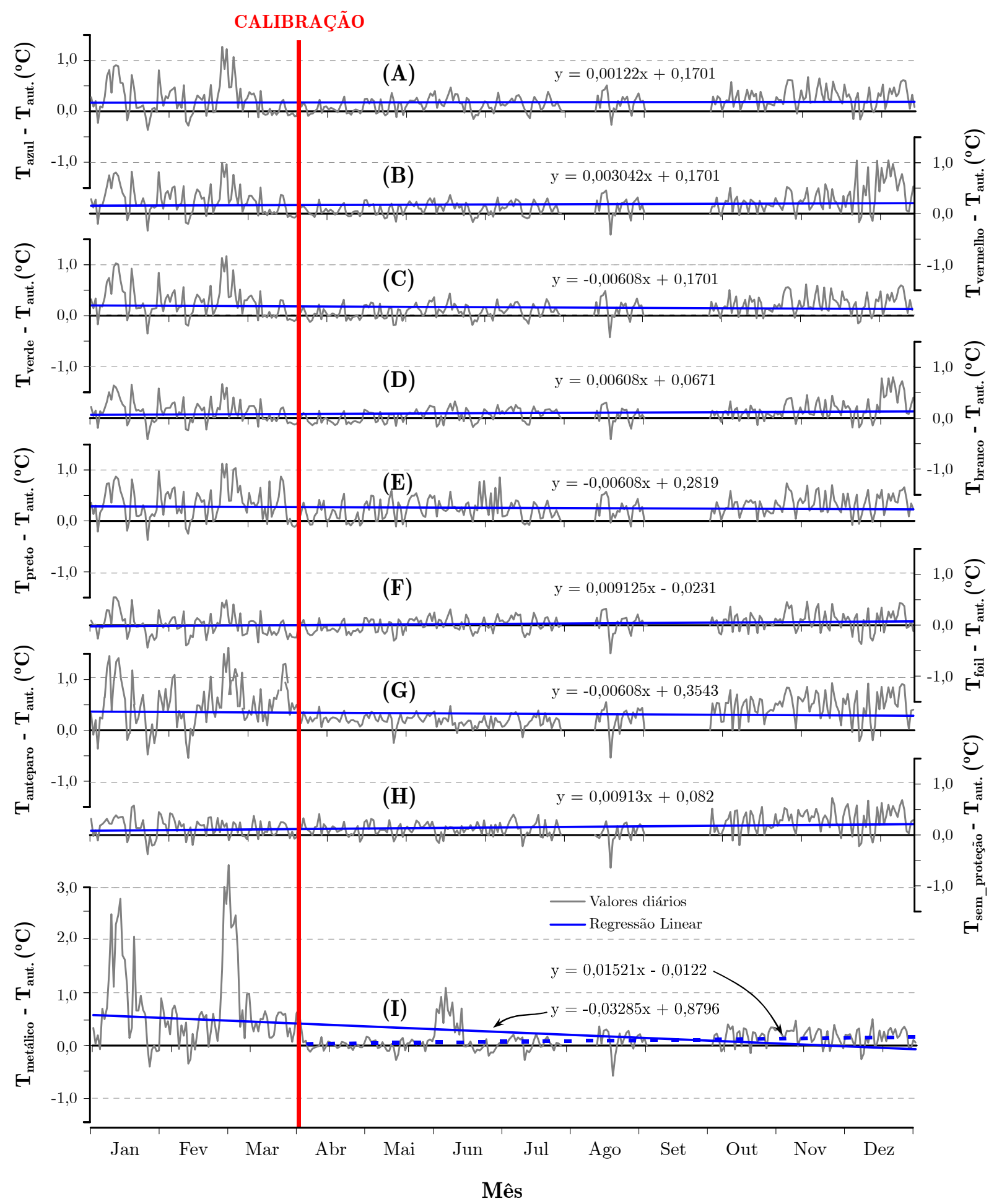

Figura 115 - Desvios diários e tendências das temperaturas das séries $T_{\text {azul }}, T_{\text {vermelho }}, T_{\text {verde }}$, $T_{\text {branco }}, T_{\text {preto }}, T_{\text {foil }}, T_{\text {anteparo }}, T_{\text {sem_protesão }}$ e $T_{\text {metalico }}$ em relação à $T_{\text {automática }}$ no ano de 2009 .

Por fim, uma última análise é procedida em termos dos desvios mensais, vide os gráficos apresentados na Figura 116. Na escala mensal fica saliente, de um modo geral, o aumento dos desvios durante o verão (extremo direito dos gráficos) em relação ao período de inverno. Os desempenhos se mantêm os mesmos. Em relação à 
temperatura de referência: o abrigo com foil aquece menos [gráfico $(\mathbf{F})$ ]; seguido pelos abrigos branco, azul, verde e vermelho $[$ gráficos (D), (A), (C) e (B)]; depois pelos abrigos sem proteção, preto e anteparo [gráficos $(\mathbf{H}),(\mathbf{E})$ e $(\mathbf{G})]$; e o abrigo metálico [gráfico (I)] com desempenho pior, quando considerada a série completa, ou com desempenho comparável e equivalente ao do abrigo branco, após a calibração e manutenção da estação. Novamente, atenção especial deve ser dada à escala nesta figura, que possui amplitude média de $0,4^{\circ} \mathrm{C}$, enquanto das figuras nas escalas diárias e horárias eram de 2,0 e $8,0^{\circ} \mathrm{C}$ de amplitude, respectivamente. 

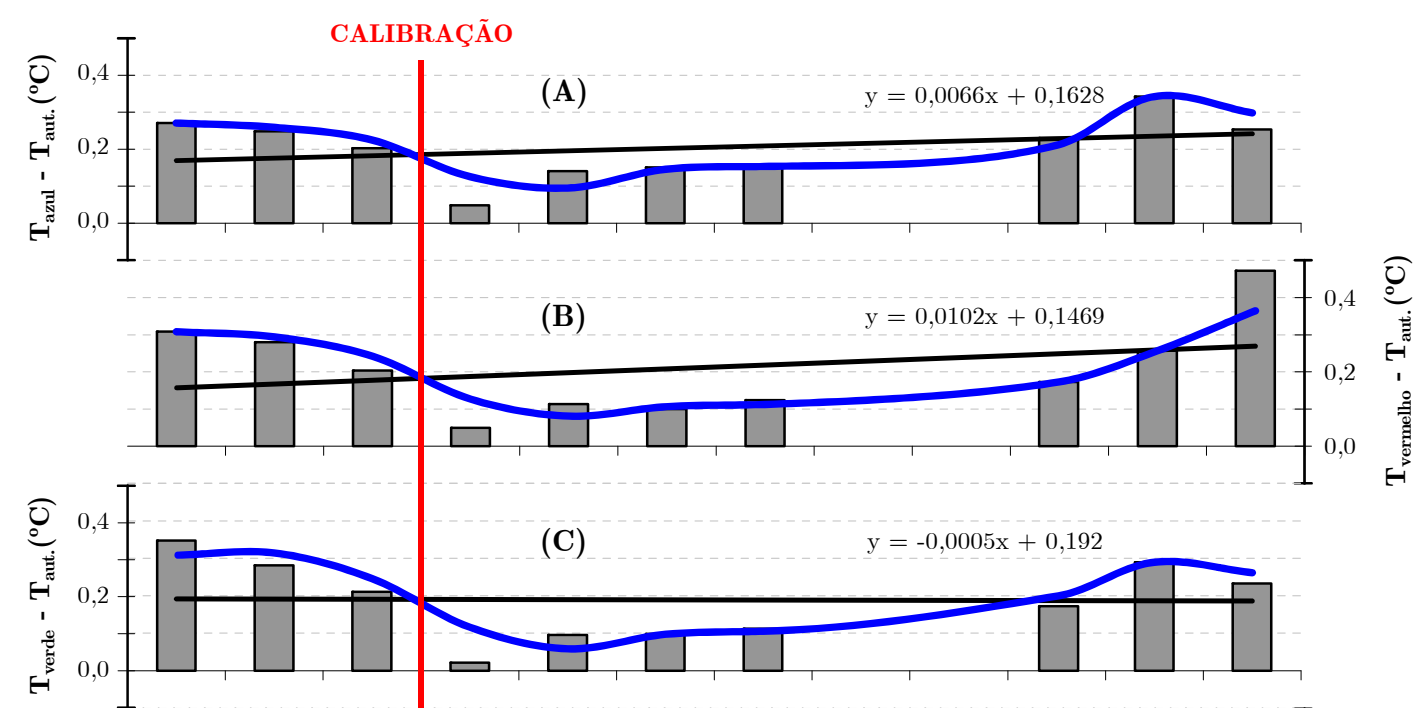

(D)
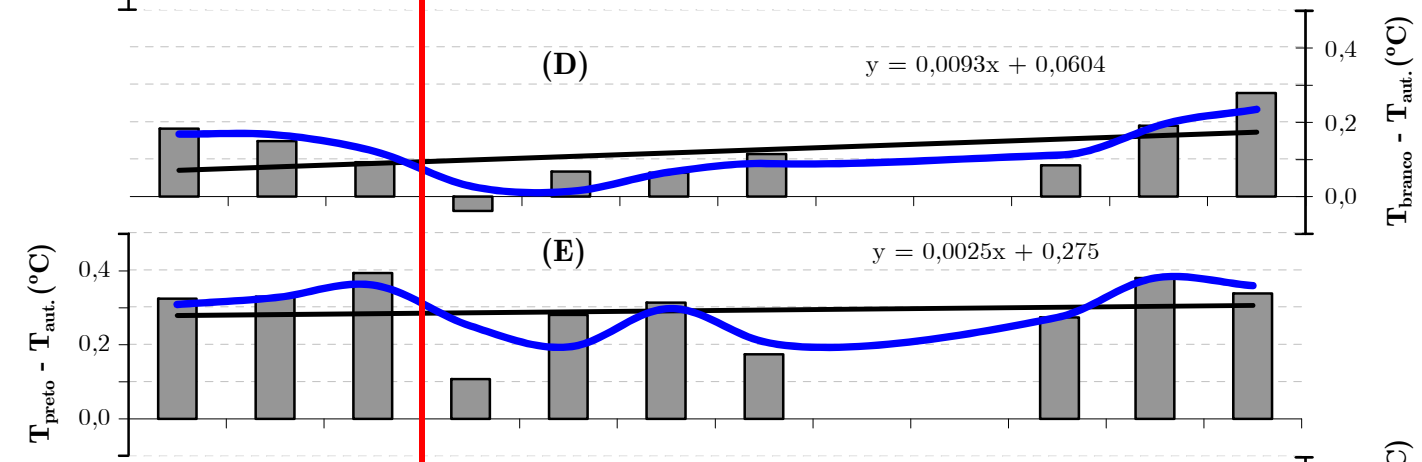

(F)

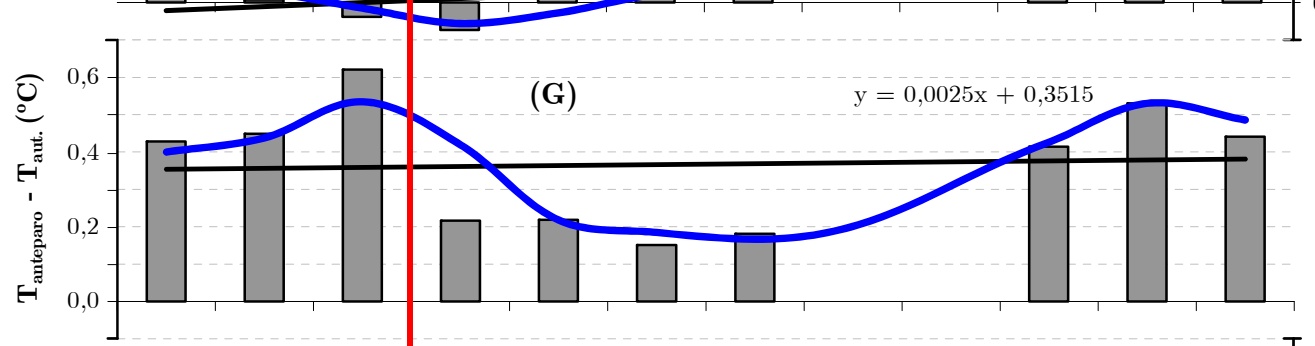

(H)
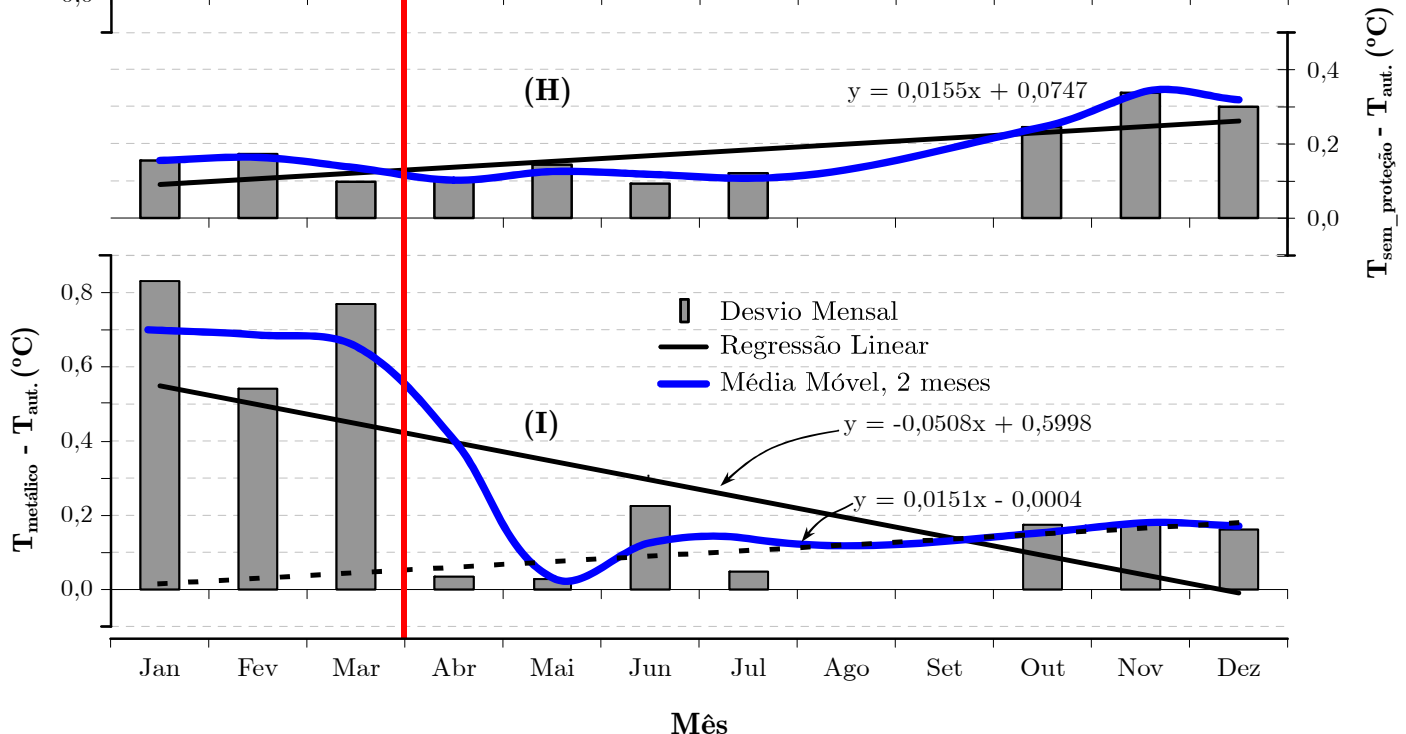

Figura 116 - Desvios mensais e tendências das temperaturas das séries $T_{\text {azul }}, T_{\text {vermelho }}, T_{\text {verde }}$, $T_{\text {branco }}, T_{\text {preto }}, T_{\text {foil }}, T_{\text {anteparo }}, T_{\text {sem_protesão }}$ e $T_{\text {metálico }}$ em relação à $T_{\text {automática }}$ no ano de 2009. 
Sintetizando, os valores médios dos desvios são apresentados na Tabela 24, no período total do ano de 2009, com base nas retas de regressão linear dos gráficos nas escalas horárias, diárias e mensais. Lembrando que existem pequenas diferenças entre os valores, pois há falhas de dados na série. Se não houvesse dados faltantes, os valores seriam idênticos. Enquanto que as escalas horárias e diárias utilizaram todos os dados disponíveis, a escala mensal ou excluiu alguns dados de meses com lacunas de dados acima do permitido pelas normas, ou naqueles meses com poucas falhas, adotou-se a média dos meses como sendo representativa.

Tabela 24 - Valores médios dos desvios de temperatura $\left({ }^{\circ} \mathrm{C}\right)$ nos diferentes abrigos, sob diferentes escalas

\begin{tabular}{|c|c|c|c|c|}
\hline \multirow{2}{*}{\multicolumn{2}{|c|}{ Abrigo }} & \multicolumn{3}{|c|}{ Escala } \\
\hline & & Horária & Diária & Mensal \\
\hline \multicolumn{2}{|l|}{$T_{\text {azul }}-T_{\text {automática }}$} & 0,20 & 0,20 & 0,21 \\
\hline \multicolumn{2}{|l|}{$T_{\text {vermelho }}-T_{\text {automática }}$} & 0,21 & 0,21 & 0,21 \\
\hline \multicolumn{2}{|l|}{$T_{\text {verde }}-T_{\text {automática }}$} & 0,18 & 0,18 & 0,19 \\
\hline \multicolumn{2}{|l|}{$T_{\text {branco }}-T_{\text {automática }}$} & 0,12 & 0,12 & 0,12 \\
\hline \multicolumn{2}{|l|}{$T_{\text {preto }}-T_{\text {automática }}$} & 0,29 & 0,29 & 0,29 \\
\hline \multicolumn{2}{|l|}{$T_{\text {foil }}-T_{\text {automática }}$} & 0,03 & 0,03 & 0,03 \\
\hline \multicolumn{2}{|l|}{$T_{\text {anteparo }}-T_{\text {automática }}$} & 0,36 & 0,36 & 0,37 \\
\hline \multicolumn{2}{|c|}{$T_{\text {sem_proteseão }}-T_{\text {automática }}$} & 0,17 & 0,17 & 0,18 \\
\hline \multirow{2}{*}{$T_{\text {metálico }}-T_{\text {automática }}$} & Série completa & 0,28 & 0,28 & 0,28 \\
\hline & Período pós-calibração & 0,10 & 0,09 & 0,10 \\
\hline
\end{tabular}

A partir dos valores da Tabela 24, pode-se elaborar uma classificação definitiva do desempenho dos abrigos. Na ordem do melhor (menor desvio médio) para o pior desempenho (maior desvio), tem-se: $T_{\text {foil }}, T_{\text {metálico }}$ (período pós-calibração), $T_{\text {branco }}$, $T_{\text {sem_protesão }}, T_{\text {verde }}, T_{\text {azul }}, T_{\text {vermelho }}, T_{\text {metálico }}$ (série completa), $T_{\text {preto }}$ e $T_{\text {anteparo }}$.

Uma ressalva deve ficar enfatizada: o abrigo metálico até pode ter um bom desempenho quando em perfeitas condições de funcionamento de sua ventilação forçada, comportamento presente no período pós-calibração dos sensores e manutenção da estação. No entanto, um período de algum mau funcionamento, falha ou ventilação fraca e insuficiente, o abrigo metálico aquece significativamente, alterando o microclima interno e causando a elevação das temperaturas nas medições realizadas pelo termopar. As ventoinhas também ocasionalmente sofreram falhas nos 
demais abrigos de composição de plástico PVC, porém os efeitos não foram propagados às medições.

Já os abrigos com superfície de alta reflexão (abrigo com foil) ou de cores claras (abrigo pintado de branco e o abrigo de PVC, sem tinta), foram os que apresentaram melhor desempenho, ou seja, menor desvio em relação à temperatura de referência. Na sequência seguem os abrigos pintados com cores (verde, azul, vermelho e preto) que absorvem determinadas comprimentos de ondas da região visível do espectro de radiação, porém refletem outros gamas de comprimentos. Por isso a cor preta, que absorve quase toda radiação incidente, aquece mais o abrigo internamente e, assim, os valores de temperatura foram superiores aos de referência. E o abrigo com anteparo provocou um efeito oposto do esperado: foi o abrigo que mais aqueceu. Isto pode ser devido à condução do calor pelas placas verticais, que, devido à proximidade com o sensor termoelétrico, tornaram-se em mais superfícies quentes e radiantes, contribuintes com as trocas por radiação de onda longa. Ou seja, uma massa adicional das placas absorveu a energia solar, de ondas curtas, e a reemitiu em forma de ondas longas (calor), colaborando com o aquecimento interno do abrigo e com a elevação dos valores de temperatura medidos pelos termopares. Ele pode até ter bloqueado as radiações refletidas e difusas que pudessem adentrar pelos orifícios laterais, porém se tornou uma fonte expressiva de re-emissão de radiação, cujo efeito foi o maior aquecimento de todos os abrigos testados.

E a última consideração é em relação à escala temporal a ser adotada nos estudos que possam utilizar os abrigos experimentais e de baixo custo examinados aqui. Brevemente sumarizando, tome-se como exemplo o abrigo com foil, que apresentou o melhor desempenho de todos. Na escala dos valores com resolução horária, os erros chegam até a cerca de $4,0^{\circ} \mathrm{C}$, tanto positivo (acima) quanto negativo (abaixo) em relação à temperatura de referência; na escala de resolução de valores diários, os desvios estão na ordem de $0,5^{\circ} \mathrm{C}$; na escala mensal os desvios oscilam em torno de $0,1^{\circ} \mathrm{C}$; e na escala anual, o desvio foi menor ainda, valor desprezível de $0,03^{\circ} \mathrm{C}$ em relação à média da estação de referência.

Deste modo, o abrigo com foil e ventoinha juntamente com o termopar podem ser satisfatoriamente utilizados para estudos de médio a longo prazo nas escalas mensais e anuais, substituição equivalente aos valores das temperaturas obtidas em abrigos e sensores comerciais usualmente empregados. Mas é claro, existem restrições no sentido de que os resultados obtidos neste estudo estão vinculados aos instrumentos utilizados, e, além disso, são representativos para a região e período de 
tempo em questão. Neste contexto, cabe estudar em detalhes o comportamento da distribuição dos desvios sob abordagem dinâmica do clima, que pode evidenciar uma perspectiva mais inovadora e abrangente, em contraste ao caráter generalista e de ampla abstração que é a utilização de médias e cálculos estatísticos diversos.

\subsubsection{Análise rítmica anual dos desvios de temperatura do ar}

Na PARTE A foi feita uma análise episódica (item "Análise de episódio climático", página 255) dos desvios de temperatura nos abrigos experimentais. Na escala utilizada na ocasião, existe certa limitação em se extrapolar as análises para uma maior quantidade de episódios climáticos, que permitam examinar simultaneamente a ocorrência de vários episódios (análise rítmica), de uma forma simples, sintetizada e, ao mesmo tempo, rica em informações.

Para isto, este trabalho apresenta um formato de representação visual que auxilia na análise rítmica integrada, onde a exibição em forma de um diagrama circular anual demonstra a síntese das variações diárias e horárias dos elementos climáticos. Este método e técnica de representação - designada aqui como Climatiris, em alusão ao seu aspecto visual semelhante à íris de um olho - está detalhadamente descrito no APÊNDICE H, pg. 399.

De acordo com as necessidades imediatas, apenas dois diagramas circulares, ou melhor, duas Climatiris serão utilizadas para demonstrar a capacidade de condensação e síntese dos elementos e das escalas horárias, diárias e mensais deste modelo de gráfico circular anual. Será suficiente apresentar as Climatiris da temperatura média do ar $\left(T_{\text {automática }}\right)$ e dos desvios de temperatura do abrigo com foil em relação à temperatura de referência $\left(T_{\text {foil }}-T_{\text {automática }}\right)$. A escolha deste abrigo em específico foi devido ao seu desempenho apresentado, que foi o melhor de todos os abrigos avaliados. Além disso, os desvios do abrigo com foil não sofreram mudanças bruscas após a calibração, possuindo uma série anual homogênea, apesar das falhas de dados em dois meses.

A Figura 117 exibe a Climatiris da temperatura do ar ao longo do ano de 2009. Uma breve explicação da composição das Climatiris: nelas são exibidas as variações diárias no percorrer de um ano, iniciando pelo dia indicado pelo zero e terminando, após uma volta completa no sentido horário, no mesmo ponto. Linhas que cortam o diagrama circular indicam períodos de 15 dias, sendo que duas destas 
frações equivalem aos meses correspondentes, também indicados. À esquerda é exibida a escala horária, indicando os horários que correspondem aos anéis circulares presentes no interior do diagrama. E à direita está a escala gráfica colorida dos valores da variável selecionada, que no caso, é a temperatura ao longo do ano de 2009 .

Desta Climatiris da temperatura ${ }^{37}$, podem ser constatados vários aspectos interessantes: o contraste de verão (hemisfério superior) e inverno (hemisfério inferior), exibindo períodos mais quentes e mais frios, respectivamente; as variações diárias, mostrando os horários sujeitos à luz solar mais quentes que os períodos noturnos; e o mais interessante, as sucessivas "ilhas quentes" intercaladas por períodos mais frios, demonstrando nitidamente a atuação das massas de ar quente (predominantemente e mais vigorosas no verão) e as respectivas entradas e domínios de massas de ar frio (mais intensas durante o período do inverno).

Esta representação concretiza um ponto fundamental na análise rítmica mencionado por Monteiro (1971, p. 9) quando ele diz que:

O ritmo climático só poderá ser compreendido através da representação concomitante dos elementos fundamentais do clima em unidades de tempo cronológico pelo menos diárias, compatíveis com a representação da circulação atmosférica regional, geradora dos estados atmosféricos que se sucedem e constituem o fundamento do ritmo.

Apresentado sucintamente o seu conceito, o potencial de compreensão e a abrangência que as Climatiris podem proporcionar, cabe fazer um paralelo ao tema deste capítulo e demonstrar uma aplicação viável e eficiente. No mesmo formato da Climatiris da temperatura, elaborou-se a Climatiris dos desvios de temperatura do abrigo com foil, cujo resultado está apresentado na Figura 118.

Comparando as duas Climatiris, infere-se que, durante o dia, existe uma alta correlação entre os desvios positivos de temperatura em relação à temperatura externa do ar medida na estação climatológica de referência. Ainda, esta relação é diretamente proporcional, ou seja, quanto maior a temperatura do ar, maior é o aquecimento do abrigo experimental, e maior também é o seu desvio. Nota-se que os

\footnotetext{
37 Além da Climatiris da temperatura média do ar, no APÊNDICE H (pg. 387) também estão disponíveis as Climatiris da radiação solar, umidade relativa do ar, pressão atmosférica, velocidades média e máxima dos ventos, direção dos ventos e precipitação.
} 
desvios máximos ocorrem ao meio-dia, enquanto que as maiores temperaturas do ar ocorrem às 15h. Tal fato demonstra que os abrigos experimentais aquecem mais rapidamente que o abrigo convencional, e também que os termopares são sensores mais sensíveis às variações da temperatura. Isto não quer dizer que o conjunto do abrigo experimental com o termopar mede a temperatura errada. Na verdade, a simplicidade de sua construção implicou em diferenças das condições daquelas que são em que são realizadas as medições nos abrigos e sensores comerciais. Ou seja, enquanto o termopar fica exposto e em contato direto com o ar, nos instrumentos comerciais, o sensor HMP45C possui uma estrutura plástica que envolve o sensor, visando à proteção dos componentes eletrônicos e evitando acúmulo de poeira e contato com a água.

Outro fato notável é a ocorrência de "ilhas" com temperaturas correspondendo a desvios negativos da temperatura, ou seja, decorrentes de supostas perdas por radiação noturna. Porém, neste tipo de representação é possível notar que tais perdas ocorrem com maior intensidade às $18 \mathrm{~h}$, período que ainda apresenta certa quantidade de luz solar. Neste caso, levanta-se uma nova hipótese a respeito das perdas por radiação noturna: considerando o aspecto da variação da temperatura ao longo de um dia,, semelhante ao de uma senóide, toma-se como exemplo as curvas da temperatura medida no abrigo com foil e da temperatura medida na estação automática de referência. Sabendo que o primeiro perfil aquece mais rápido que o segundo, e igualmente esfria mais rapidamente, existe, portanto uma defasagem ou deslocamento de fases dos perfis de temperatura. Ou seja, primeiro ocorre um pico de $T_{\text {foil }}$, (cujo valor é maior que $T_{\text {automática }}$ no mesmo instante), causando um desvio positivo alto; em um segundo instante ocorre a queda da temperatura de $T_{\text {foil }}$, seguida pelo aumento atrasado de $T_{\text {automática }}$ Em um terceiro momento, ocorre o pico de $T_{\text {automática, }}$ porém a $T_{\text {foil }}$ já apresenta queda nos seus valores, e, consequentemente, o desvio neste instante é negativo. 


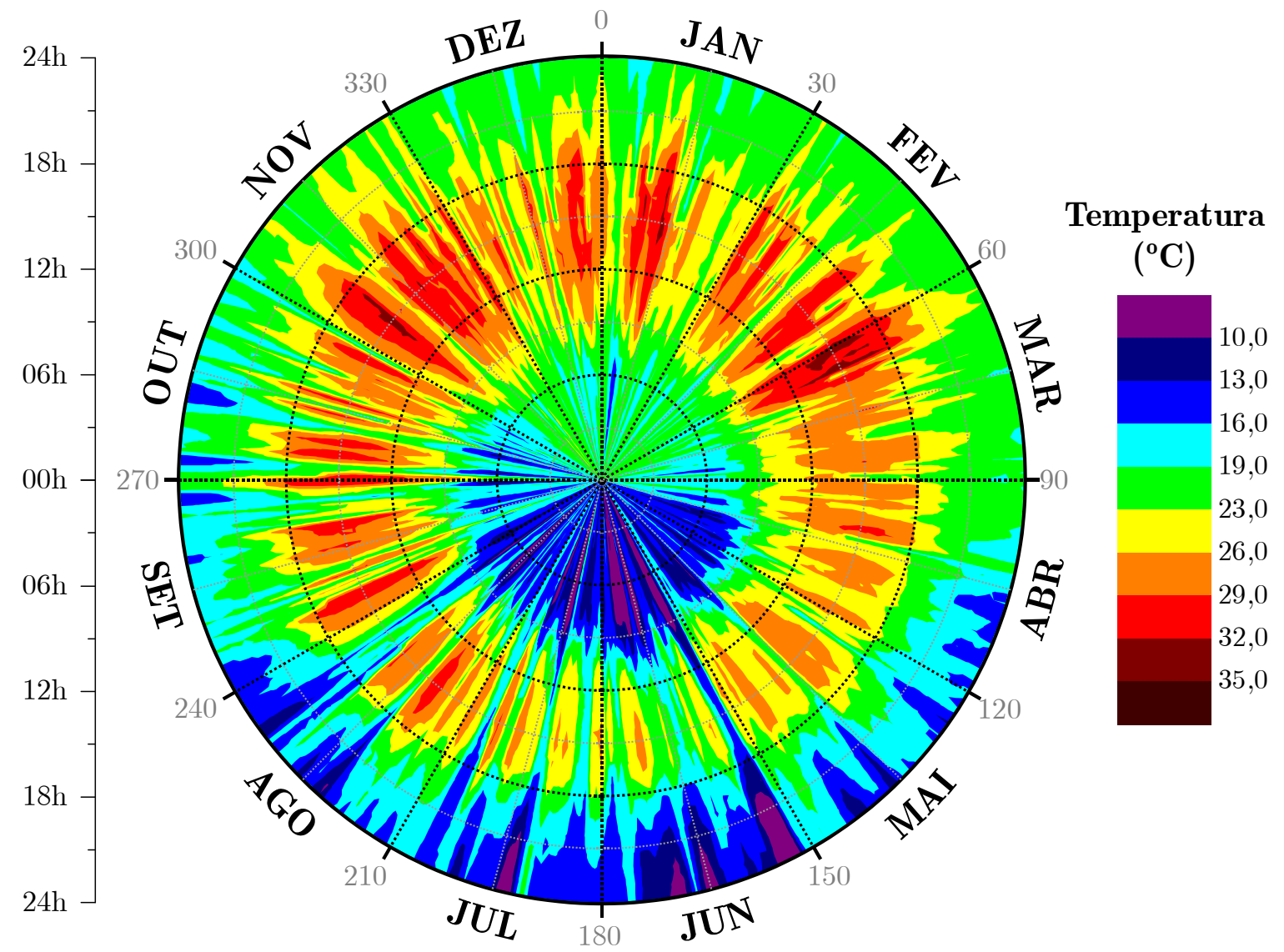

Figura 117 - Climatiris da temperatura do ar ao longo do ano de 2009.

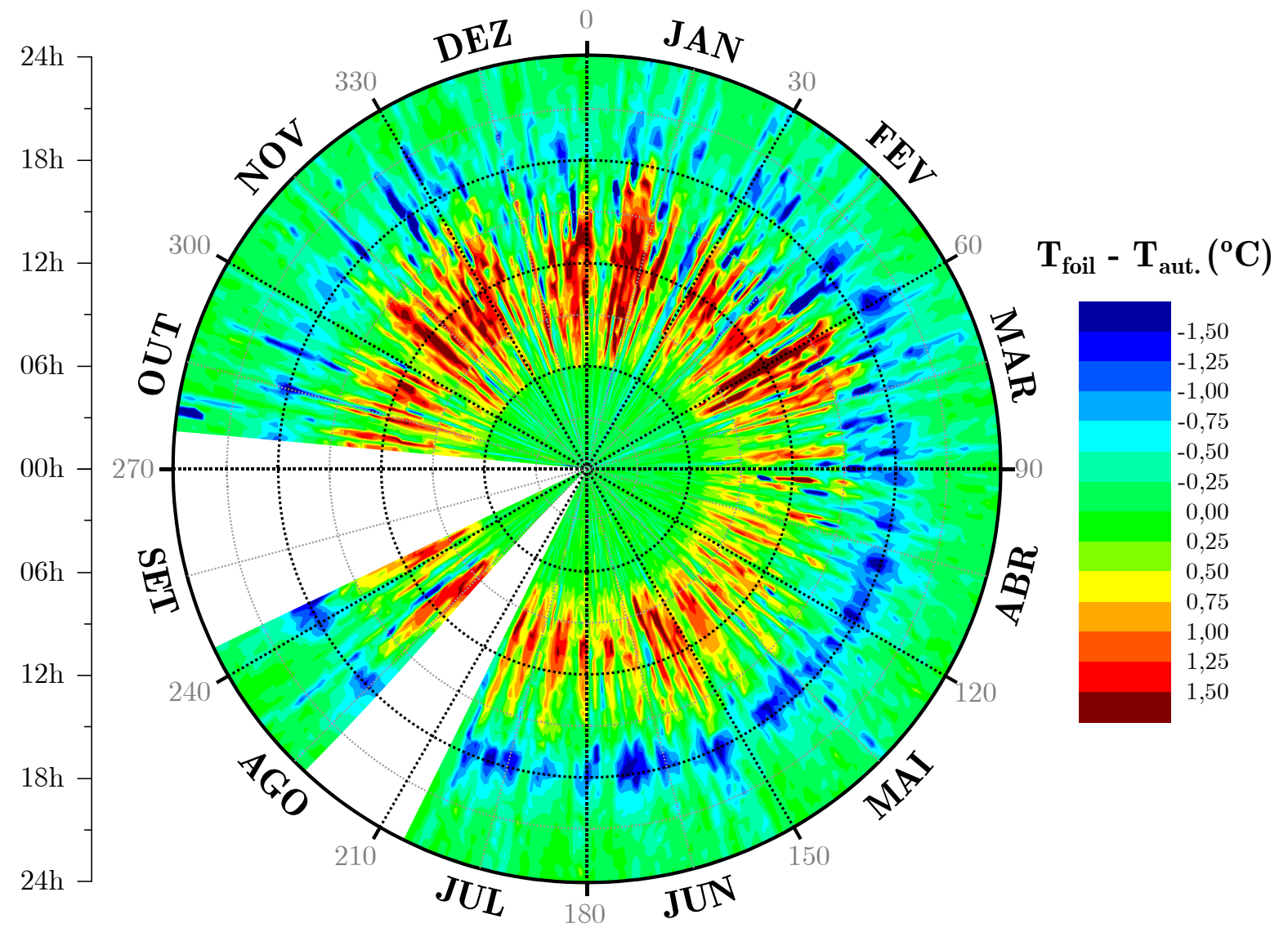

Figura 118 - Climatiris dos desvios de temperatura $\left(T_{\text {foil }}-T_{\text {aut. }}\right)$ ao longo do ano de 2009 
A hipótese levantada pode ser mais bem visualizada fazendo-se um recorte de um episódio climático, tomado como ilustrativo. Escolhe-se o período de 30 dias com início em $14 / 2$ e término em $14 / 3$, correspondendo na Climatiris desde o raio que corta a segunda metade do mês de fevereiro até a primeira metade do mês de março. No centro deste período (dia 60), ocorre a atuação de uma massa de ar bastante persistente, senão a mais quente de todo ano de 2009, provocando, consequentemente, desvios expressivos das temperaturas nos abrigos. Dois formatos de visualização são utilizados para auxiliar na confirmação da hipótese: comparação episódica, envolvendo mais de um dia simultaneamente; e a comparação dos perfis de temperatura em um dia somente.

A Figura 119 ilustra a abordagem de dois episódios da atuação de duas massas de ar quente, a segunda mais intensa que a primeira, intercaladas pela entrada e atuação de uma massa de ar frio na região das medições. Comparando os gráficos (A) e (B), contata-se que as temperaturas registradas no abrigo com foil foram maiores que as da estação de referência. Pelo gráfico (C) nota-se a ocorrência de "áreas quentes", com os máximos em torno do meio-dia, seguidas por "áreas frias", com o mínimo próximo às 18h. Estas áreas, "quentes" e "frias", são na verdade, respectivamente, desvios positivos e negativos, que denotam o aquecimento e o resfriamento mais rápidos do abrigo com foil em relação ao abrigo comercial da estação de referência. A Figura $\mathbf{1 2 0}$ exibe a representação tridimensional dos episódios, ressaltando as áreas "quentes" e "frias" como picos e vales. 


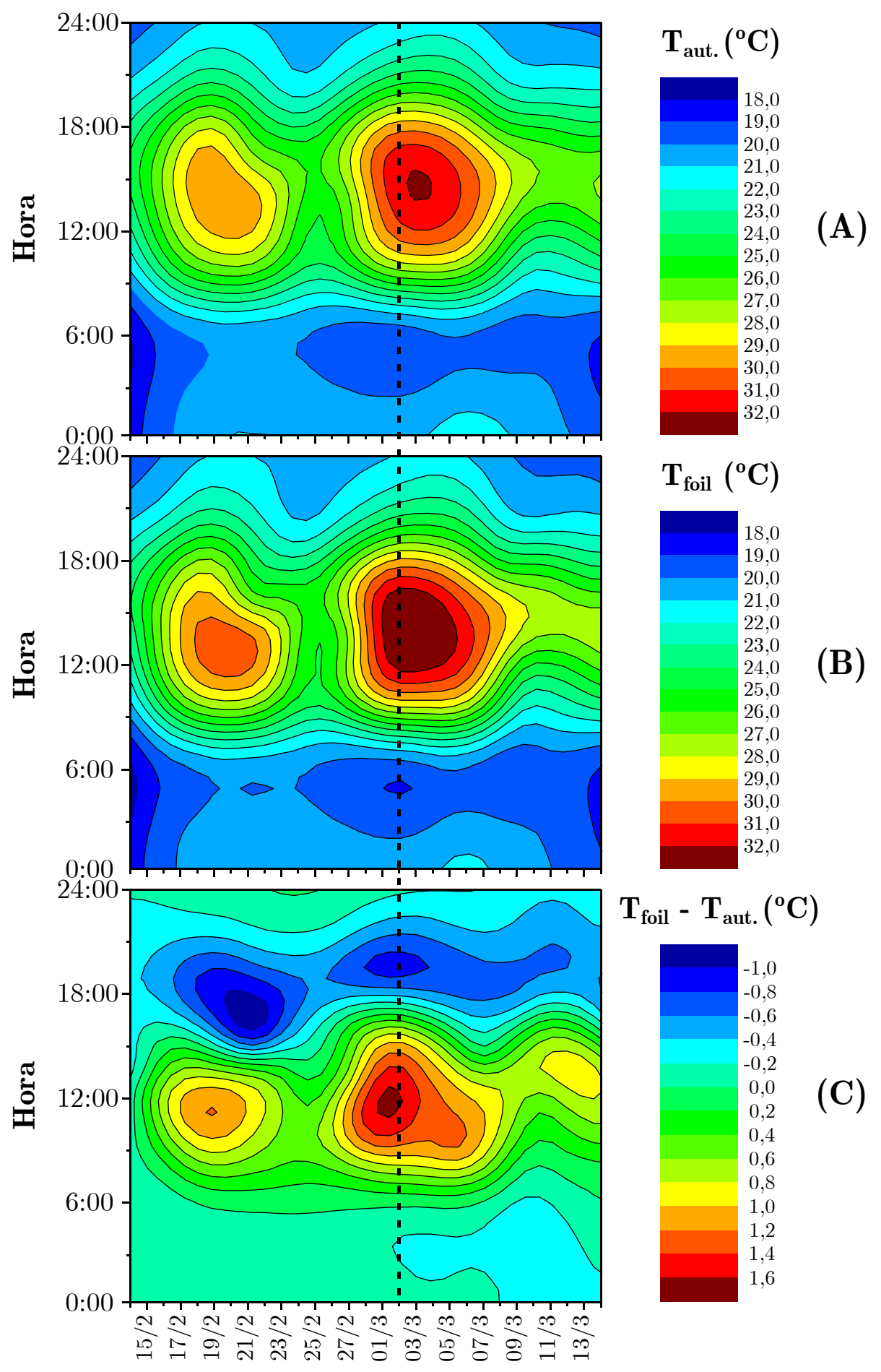

\section{Dia}

Figura 119 - Isolinhas com recorte de dois episódios climáticos representando as temperaturas (A) $T_{\text {automática, }}$ (B) $T_{\text {foil }}$ e (C) desvios de temperatura $\left(T_{\text {foil }}-T_{\text {automática }}\right)$ no período de 15 de fevereiro a 13 de março de 2009. A linha vertical tracejada indica o instante considerado na elaboração das curvas apresentadas na Figura 121. 


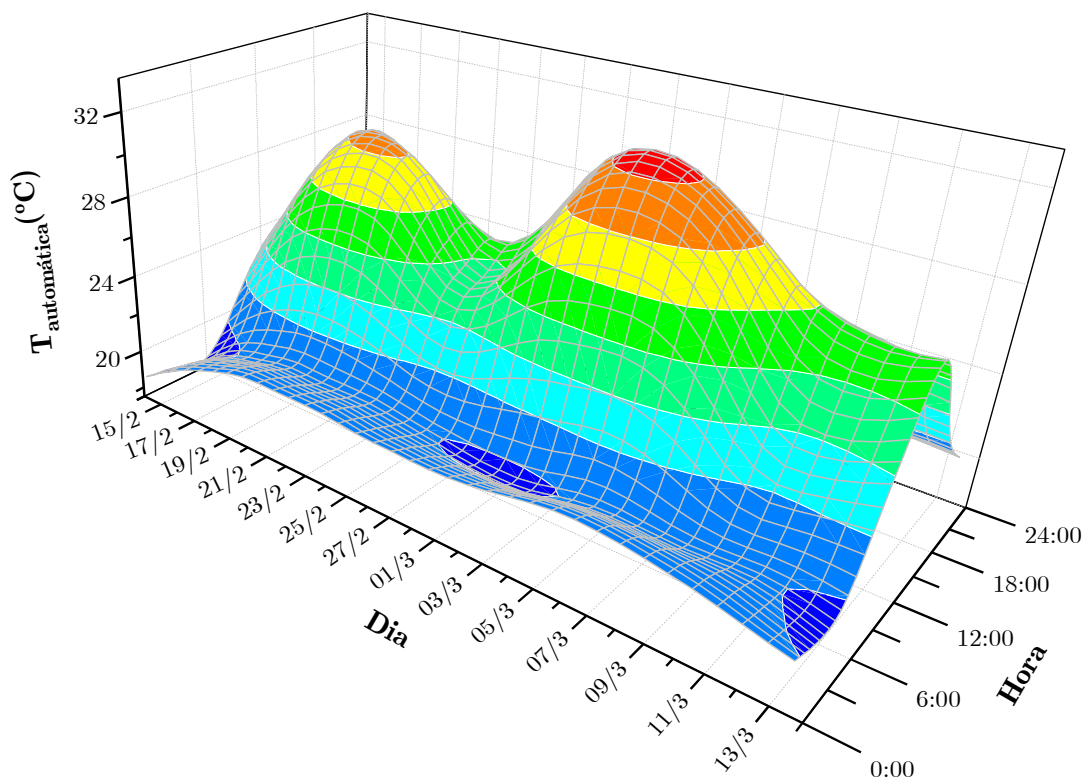

(A)

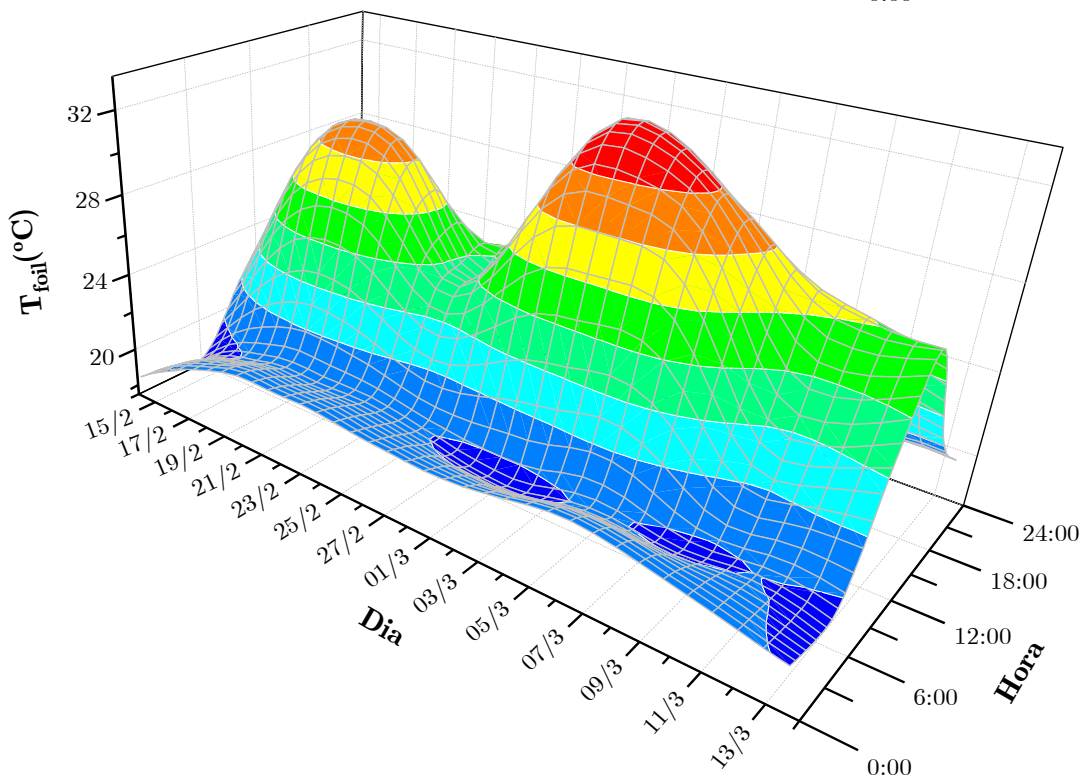

(B)

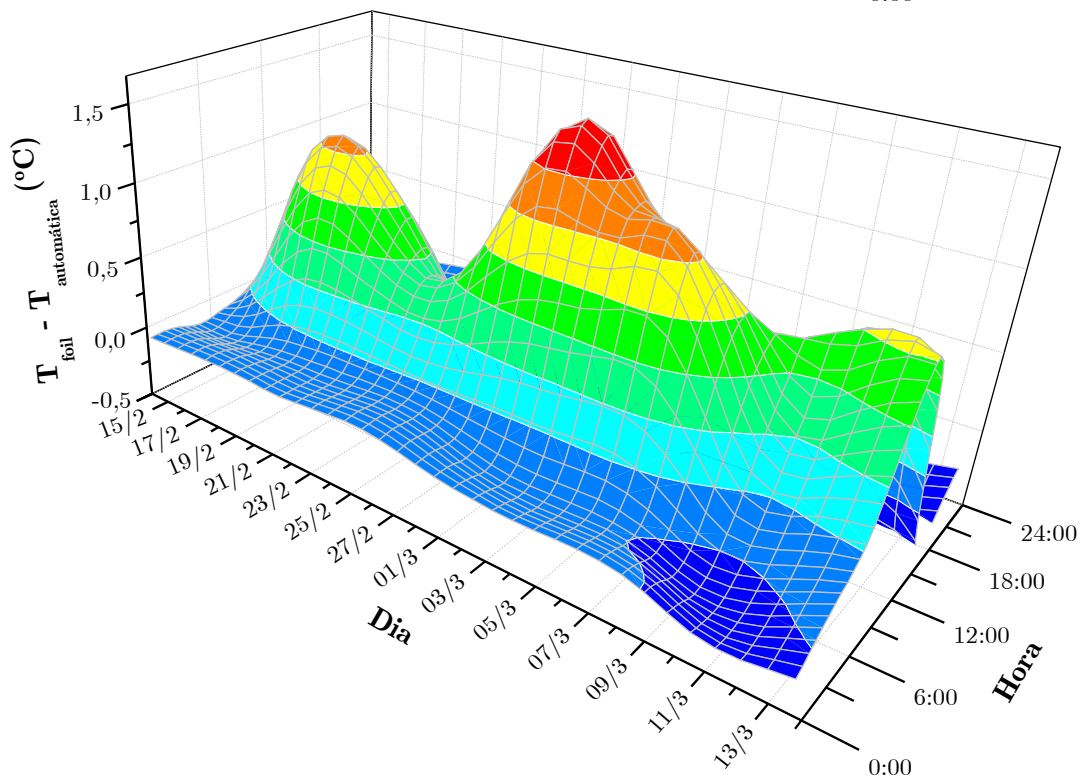

(C)

Figura 120 - Representação tridimensional das isolinhas apresentadas na Figura 119. 
Para elucidar com mais clareza a ocorrência de desvios positivos e negativos no decorrer de todo o ano, a Figura 121 representa a seção transversal do corte correspondente à linha pontilhada da Figura 119, representando as curvas de temperatura aproximadas e idealizadas, obtidas com base nas superfícies tridimensionais calculadas a partir dos dados registrados a cada 30 minutos. De fato, fica demonstrado pela Figura 121 que ocorre em um primeiro momento um aquecimento maior e mais rápido do abrigo experimental (curva azul) em relação ao abrigo comercial (curva preta), causando os desvios positivos (curva pontilhada vermelha); e, em seguida, o resfriamento, com queda mais acelerada dos valores, causando os desvios negativos.

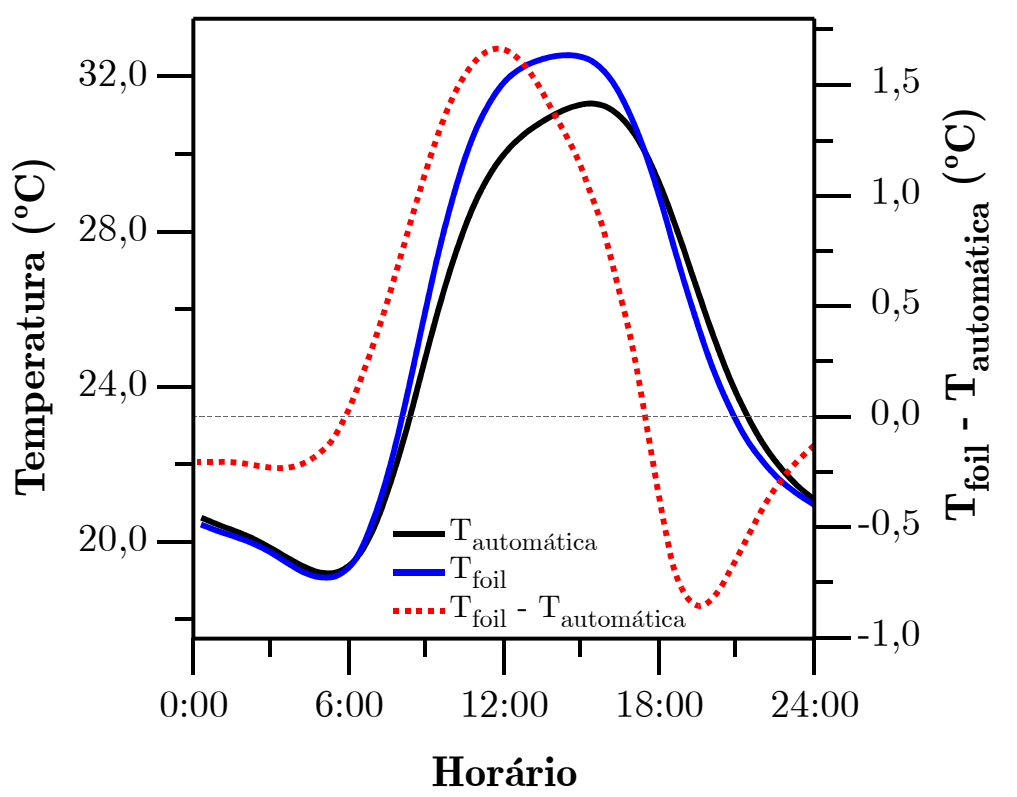

Figura 121 - Curvas idealizadas representando o comportamento das temperaturas $T_{\text {foil }} \mathrm{e}$ $T_{\text {automática }}$ e os respectivos desvios $\left(T_{\text {foil }}-T_{\text {aut. }}\right)$, referente ao corte indicado pela linha vertical tracejada indicada na Figura 119.

Portanto, os mecanismos físicos de transporte de calor que atuam nestes desvios positivos e negativos, inicialmente supostos como perdas por radiação noturna no caso dos desvios negativos, não envolvem necessariamente troca de calor entre o solo, o abrigo e o céu, conforme descrito no item "Perdas por radiação noturna" (pg. 266), mas sim uma diferença de resposta e sensibilidade dos sensores utilizados, termopar e HMP45C, diferentes em sua composição e estrutura física, especialmente com relação à proteção inexistente no sensor termoelétrico, mas presente no sensor comercial. Logo, a inércia térmica do ambiente microclimático criado internamente 
em cada abrigo é um fator preponderante nas medições da temperatura, sendo este aspecto determinado pela constituição do conjunto do abrigo e dos sensores, dos materiais utilizados e do formato e dimensões estruturais da proteção externa (abrigo) e interna do sensor (ponta de plástico que protege o sensor elétrico).

\subsubsection{Considerações finais}

Neste capítulo foi utilizada a menor série de temperaturas de todo o estudo, compreendendo um ano de dados somente. O ideal seria a utilização de séries mais extensas, permitindo assim a visualização dos desvios inter-anuais. Além disso, os abrigos utilizados foram confeccionados artesanalmente, e, portanto, os resultados são válidos apenas para este tipo de abrigo nas condições climáticas locais a que eles estavam sujeitos durante as medições. De qualquer forma, a metodologia aplicada é válida e aplicável aos estudos de intercomparações do gênero. Devido às limitações do estudo, recomenda-se como oportunidade futura a comparação dos principais abrigos comerciais, aspirados e naturalmente ventilados, em condições climáticas quentes e sob forte incidência de radiação, que é o caso de grande parte do Brasil. Esta demanda se insere na quantificação das influências da radiação nos abrigos em regiões de climas tropicais, uma vez que o estudo internacional, da OMM, de intercomparação de abrigos de temperatura em diferentes regiões climatológicas deu ênfase em países de clima mais frio e, logo, com regiões que recebem menor quantidade de radiação ao longo do ano.

Quanto à metodologia, a utilização dos episódios representativos e dos dias típicos experimentais foi de fundamental importância nessa investigação, sendo utilizados como ferramenta metodológica aplicada ao estudo dos elementos do clima e a relação de causa e efeito no comportamento dos abrigos térmicos que estão sujeitos às intempéries climáticas, e, portanto, vulneráveis a inevitável ocorrência de um microclima interno que interfere nas aquisições da temperatura do ar pelos sensores. A concepção do diagrama Climatiris também inovou no sentido de permitir uma compreensão holística anual do ritmo climático, evidenciando os dias e horários de ocorrência dos efeitos mais significativos de trocas de calor no abrigo, que afetam as medições da temperatura do ar.

De acordo com a ISO (2007), os abrigos podem ser aquecidos pela radiação solar direta e indireta, aquecendo também o ar interior e inferindo valores de temperatura de um ar que não corresponde ao ar exterior. Além disso, o vento ou a 
ventilação artificial podem proporcionar uma influência benéfica no desempenho, reduzindo drasticamente os efeitos da radiação.

Esta pesquisa de caráter experimental permitiu notar a forte correlação existente entre a temperatura, a radiação solar e a ventilação (natural ou forçada), que é facilmente observada pelos resultados e gráficos obtidos. A hipótese levantada no decorrer dos resultados permite concluir que os abrigos sofrem aquecimento ao longo do dia, propagando parte deste calor aos sensores de temperatura, que, consequentemente, registram um valor de temperatura acima da temperatura real do ar externo.

Além disso, o efeito de ganho de calor ao longo do dia é análogo ao fenômeno de perda deste calor no período noturno, em que foram verificadas perdas de calor na ausência de radiação. A partir destas verificações, conclui-se que os abrigos que não oferecem nenhum tipo de proteção contra radiação, diurna ou noturna, são os que apresentam maior susceptibilidade às interferências nas leituras de temperatura do ar, proporcionando diferenças positivas ao longo do dia e negativas no período noturno.

Como medidas de minimização destas influências ocasionadas pela radiação, foram avaliadas os usos de dois dispositivos, que atuam de dois modos: primeiro preventivamente, por meio do bloqueio e isolamento térmico da radiação, por meio da utilização de isolante metálico refletor (foil); e segundo de modo corretivo, por meio da aspiração forçada do ar interno com o uso de ventoinhas, que renovam o ar que foi aquecido pelo microclima gerado pelo abrigo. Destas medidas, foi verificado que o uso das ventoinhas foi a medida mais eficiente na atenuação dos efeitos de aquecimento da radiação sobre as medidas de temperatura, resultado coerente com afirmação da ISO (2007). Ou seja, mesmo sem bloqueio adicional por meio do foil, o ar quente e estagnado dentro dos abrigos representa o principal indutor de efeitos indesejáveis nas medições, cuja aquisição fornece valores que não correspondem ao ar ambiente que se deseja mensurar. Verificou-se que as diferenças entre os valores de temperaturas possuem relação diretamente proporcional à intensidade de radiação solar global e relação inversamente proporcional à velocidade externa do vento.

Portanto, o abrigo experimental mais se aproximou do conceito de "abrigo ideal" da OMM (WMO, 2008), que é aquele "que proporciona um ambiente interno uniforme e com as mesmas condições do ar externo" foi abrigo que apresentava simultaneamente proteção contra radiação e ventilação forçada. 


\section{CAPÍTULO 7 - Implicações e repercussões no contexto da interação entre Ciência, Mídia, Política e Economia}

O aquecimento global é um tópico que cada vez mais tem ocupado a atenção mundial. Inúmeros estudos científicos têm sido realizados, e um volume imenso de conhecimento tem sido produzido e divulgado, seja pelo meio acadêmico em suas publicações especializadas, seja pelos meios de comunicação em massa que transmitem à população as informações científicas e respectivas decisões políticas decorrentes.

A Ciência pode fornecer a base para a tomada de decisão e ação política, com a cautela de levar em consideração as incertezas inerentes às evidências científicas, garantindo, assim, a apresentação de informações adequadas para proposição de ações governamentais seguras ao bem-estar da sociedade e à manutenção do equilíbrio ecológico.

Com o aumento da complexidade dos problemas ambientais, notadamente no que concerne a atual temática das mudanças climáticas e do aquecimento global, torna-se questionável se os dados, métodos, modelos, técnicas e hipóteses científicas são suficientemente confiáveis, incorporando incertezas no conhecimento científico gerado, sobre o qual os tomadores de decisões (policymakers), ou políticos, se informam e se baseiam.

Segundo Gupta (1999), as provas científicas só podem gerar uma autoridade social para ações políticas acerca de questões ambientais complexas apenas quando há consenso dentro da sociedade sobre a natureza do problema - mas mesmo esse consenso da sociedade, ela achando que o clamor pelas mudanças surgiu pela própria vontade, pode legitimar as ações do Estado. As informações científicas não são automaticamente traduzidas em decisões políticas, mas sim percorre um processo longo e complicado, no qual as partes interessadas (stakeholders) e os políticos interpretam as informações e negociam uns com os outros um acordo que represente os interesses da coletividade.

Conforme as informações são trocadas - e a estas os interesses vão sendo incorporados - podem surgir falhas, distorções e opiniões tendenciosas durante o processo de comunicação entre a Ciência e a Política, atingindo, consequentemente, a 
divulgação dessas informações pelos meios de comunicação em massa e influenciando na formação da opinião pública.

Na tentativa de elucidar o estado atual das divergentes opiniões científicas e discussões sobre as mudanças climáticas globais e do aquecimento global causado pelas atividades humanas, o objetivo deste capítulo foi realizar uma revisão das informações que levam à geração do caráter polêmico e controverso desta temática, procurando compreender quais os agentes envolvidos e seus respectivos interesses. Considerando a discussão do papel da mídia neste contexto, serão citadas algumas notícias veiculadas na Internet, que foram acompanhadas quase que diariamente desde meados de 2009.

\subsection{Breve histórico das Mudanças Climáticas ${ }^{38}$}

O clima não é estático, mas sim dinâmico; ao longo de milhões de anos de existência da Terra, ele tem mudado inúmeras vezes em resposta a causas naturais. Atualmente, quando se fala em mudanças climáticas, remete-se o conceito de aquecimento global, que representa o aumento da temperatura média do ar próxima à superfície terrestre desde a metade do século passado.

A suposta causa desta recente mudança climática global é atribuída às atividades antrópicas emissoras de gases do efeito estufa (GEEs), notadamente o dióxido de carbono $\left(\mathrm{CO}_{2}\right)$, cuja concentração na composição da atmosfera tem sofrido progressivo incremento, decorrente principalmente da crescente queima de combustíveis fósseis, da prática do desmatamento e das queimadas.

$\mathrm{O}$ pioneirismo do estudo do $\mathrm{CO}_{2}$ iniciou-se em 1753, quando o gás foi descoberto pelo físico e químico escocês Joseph Black. A primeira constatação da relação dos gases na atmosfera e o aumento da temperatura da Terra, o que mais tarde seria designado como "efeito estufa", é creditada ao matemático e físico francês Joseph Fourier ${ }^{39}$ em 1824.

\footnotetext{
${ }^{38}$ Com base em Harper (2007).

${ }^{39}$ FOURIER, J. Remarques générales dur les températures du globe terrestre et des espaces planétaires. Annales de Chimie et de Physique. v. 27, p. 136-67, 1824.
} 
Consolidando este conceito, em 1896 o químico sueco Svante Arrhenius ${ }^{40}$ foi o primeiro cientista a quantificar experimentalmente os impactos do dióxido de carbono no efeito estufa terrestre, sugerindo que variações na concentração deste gás poderiam exercer grande influência nas mudanças do clima passado. Logo após, ele se tornou o primeiro a predizer sobre a possibilidade do aquecimento global antropogênico no clima contemporâneo.

Dando continuidade aos trabalhos de Arrhenius, o engenheiro inglês Stewart Callendar ${ }^{41}$ contribuiu com o estabelecimento do conceito do efeito estufa, que em 1938, sugeriu o efeito do gás carbônico proveniente de queima de combustíveis fósseis nas alterações do clima e o consequente aumento da temperatura média global.

A concentração do gás carbônico atmosférico teve suas primeiras medições somente em 1958, realizadas pelo cientista norte-americano Charles David Keeling, no vulcão de Mauna Loa, na grande ilha do Hawaii. O gráfico que mostra a variação da concentração do $\mathrm{CO}_{2}$ na atmosfera desde o início das medições ficou conhecido como a "Curva Keeling", tornando-se crucial nos estudos do monitoramento deste gás.

A era da modelagem global do clima (Global Climate Model - GCM) com simulação em computadores foi inaugurada em 1967 pelo meteorologista japonês Syukuro Manabe ${ }^{42}$ e pelo norte-americano Richard Wetherald, demonstrando que o incremento da concentração do $\mathrm{CO}_{2}$ atmosférico poderia elevar a altitude em que a Terra irradia o calor para o espaço.

Resultante da crescente preocupação da comunidade científica com as questões climáticas, em 1979 culminou-se a "Primeira Conferência Mundial do Clima", predominantemente de caráter científico, onde se alertou que a expansão contínua das atividades humanas na Terra poderia causar mudanças regionais e até mesmo globais no clima.

Em 1988, o "Painel Intergovernamental sobre Mudanças Climáticas", reconhecido pela sua sigla em inglês IPCC (Intergovernmental Panel on Climate Change) foi estabelecido pelas Nações Unidas, por meio de duas de suas organizações:

\footnotetext{
40 ARRHENIUS, S. On the influence of carbonic acid in the air upon the temperature of the ground. Philos. Mag. v. 41, p. $237-76,1896$.

${ }^{41}$ FLEMING, J. R. The Callendar Effect: the life and work of Guy Stewart Callendar (1898-1964). Boston: Amer Meteor Soc. 2007.

42 MANABE, S.; WETHERALD, R. T. Thermal equilibrium of the atmosphere with a given distribution of relative humidity. Journal of the Atmospheric Sciences, v. 24, n. 3, p. 241-259. 1967.
} 
o "Programa das Nações Unidas para o Meio Ambiente" (PNUMA), juntamente com a "Organização Meteorológica Mundial" (OMM).

Dois anos depois, em 1990, foi realizada a "Segunda Conferência Mundial do Clima", apresentando uma abordagem de caráter mais político do que na primeira edição. No mesmo ano ainda, pouco antes da Conferência, o Primeiro Relatório de Avaliação do IPCC (IPCC First Assessment Report) foi concluído, servindo de base para a "Convenção-Quadro das Nações Unidas sobre a Mudança do Clima" (CQNUMC), tratado internacional resultante da "Conferência das Nações Unidas para o Meio Ambiente e o Desenvolvimento" (CNUMAD) - evento realizado em 1992 no Rio de Janeiro e conhecido popularmente como "ECO-92", "Rio-92" ou ainda "Cúpula da Terra". O Segundo, Terceiro e Quarto Relatórios do IPCC foram publicados em 1995, 2001 e 2007, respectivamente.

Os países membros da Convenção (CQNUMC) passaram a realizar a "Conferência das Partes" (COP) anualmente a partir de 1995, sendo a mais notória a terceira edição destas reuniões (COP-3), realizada em 1997 na cidade japonesa de Quioto, a qual deu nome ao bastante conhecido "Protocolo de Quioto", constituindose a primeira iniciativa global com metas quantitativas de redução das emissões ou captura ("sequestro de carbono") dos gases do efeito estufa.

Desde então, nestas Conferências das Partes tem sido debatidas os meios pelos quais serão atingidas as metas adotadas, discutindo-se os Mecanismos de Flexibilização como:

1. CIE - "Comércio Internacional de Emissões", que permite aos países que possuem metas (chamados "Anexo 1") a transferência do excesso de suas reduções para países Anexo 1 que não atingiram;

2. MDL - "Mecanismo de Desenvolvimento Limpo", e o respectivo "Créditos de carbono" ou "Redução Certificada de Emissões" (RCE), que incentiva países que não possuem metas ("Não Anexo 1") a desenvolver projetos de redução e/ou captura dos GEEs em troca do recebimento de créditos dos países do Anexo 1, para que estes cumpram suas metas. Os créditos podem ser negociados e vendidos no mercado financeiro, constituindo assim o "Mercado de Carbono";

3. IC - "Implementação Conjunta", mecanismo análogo ao MDL, mas com a distinção de incentivar projetos de redução ou captura de GEEs em países Anexo 1; e 
4. REDD - "Redução de Emissões por Desmatamento e Degradação", mecanismo que visa reduzir os GGE por meio da valoração e conservação dos recursos florestais a conservação da biodiversidade.

Ao longo dos anos, muito se discutiu a respeito das metas necessárias, inclusive da participação efetiva e concreta dos países signatários do Protocolo, em especial os Estados Unidos - o maior emissor de GEEs do mundo - cuja postura é insistente em recusar fortemente a adoção de práticas redutoras de emissões, alegando que os custos de implantação afetariam negativamente sua economia.

Em 2009, foi realizada de 31 de agosto a 4 de setembro a "Terceira Conferência Mundial do Clima", na cidade de Genebra, Suíça, com o foco em cenários futuros do clima e informações para os tomadores de decisões em escalas sazonais e multi-decadais. Ainda, de 7 a 18 de dezembro do mesmo ano, foi realizada a $15^{\text {a }}$ edição da "Conferência das Partes" (COP-15), sediada em Copenhague, Dinamarca. Neste encontro, com o tema "Mudanças Climáticas: Riscos Globais, Desafios e Decisões", pretendeu-se estabelecer um novo e ambicioso acordo global ${ }^{43}$ para o pós2012, ano em que o Protocolo de Quioto expirará. Porém, houve um fracasso neste sentido, pois o acordo não estabeleceu metas de emissões, apenas chegou ao consenso de que os países concordam que a temperatura do planeta não pode subir mais de $2^{\circ} \mathrm{C}^{44}$. Na COP-16, a ser realizada de 29 de novembro a 10 de dezembro de $2010 \mathrm{em}$ Cancun, México, será novamente negociado um acordo global legalmente vinculante, mas as esperanças de ser obter sucesso são baixas ou praticamente nulas ${ }^{45,46,47}$. E

43 Com a criação de taxas sobre emissões de $\mathrm{CO}$ de países ricos, criação de metas de redução para países em desenvolvimento e inclusão de preservação de florestas no acordo.

44 Ambientebrasil. Governos confirmam planos de cortes de emissões. 01/02/2010. Disponível em: $<$ http://noticias.ambientebrasil.com.br/clipping/2010/02/01/51562-governos-confirmam-planos-de-cortes-deemissoes.html>. Acesso em 14 ago. 2010.

45 Ambientebrasil. Máxima autoridade da ONU em mudança climática está pessimista quanto a acordo. 22/02/2010. Disponível em: <http://noticias.ambientebrasil.com.br/clipping/2010/02/22/

52019-maxima-autoridade-da-onu-em-mudanca-climatica-esta-pessimista-quanto-a-acordo.html $>$. Acesso em 14 ago. 2010 .

46 Ambientebrasil. Acordo climático global é impossível em 2010, diz ONU. 12/04/2010. Disponível em: $<$ http://noticias.ambientebrasil.com.br/clipping/2010/04/12/53363-acordo-climatico-global-e-impossivel-em-2010diz-onu.html>. Acesso em 14 ago. 2010. 
este processo de negociação parece que não será resolvido tão cedo, podendo levar 2 $\operatorname{anos}^{48}$ ou até décadas a solução dessa decisão política ${ }^{49}$.

\subsection{Representantes envolvidos}

Inicialmente de caráter científico, com as bases fortemente estabelecidas na década de 70, o tema das mudanças climáticas e do aquecimento global antropogênico foi despertando, no decorrer dos últimos 40 anos, bastante interesse da esfera política mundial. Consequentemente, fica evidenciada a crescente participação dos governantes no que se refere às ações políticas de incentivo ${ }^{50} \mathrm{e} / \mathrm{ou}$ imposição ${ }^{51}$ de atitudes de mitigação dos efeitos dos GEEs.

Dando o respaldo científico necessário para tomada de decisões, verifica-se igualmente a massiva presença e atuação da Ciência, que desde o começo da discussão vem contribuindo com o melhor entendimento da dinâmica climática e da relação das atividades humanas e de seus respectivos efeitos no clima.

Portanto, percebe-se a estrita relação existente entre Ciência e Política, com o primeiro grupo representado pelos cientistas, responsáveis pelo fornecimento de conclusões e evidências científicas frutos de suas pesquisas; e a segunda parte, utilizando e baseando-se nesses resultados para tomada de decisões, o que implic no estabelecimento de tratados e acordos internacionais, que por sua vez refletem em diretrizes de leis nacionais, e, finalmente, afetam o modo de viver da sociedade em geral.

\footnotetext{
${ }^{47}$ Ambientebrasil. Chefe da ONU já admite fracasso na reunião climática de Cancún. 10/08/2010. Disponível em: $<$ http://noticias.ambientebrasil.com.br/clipping/2010/08/10/58751-chefe-da-onu-ja-admite-fracasso-na-reuniaoclimatica-de-cancun.html>. Acesso em 14 ago. 2010.

48 Ambientebrasil. Acordo climático vai levar dois anos para ser selado, diz Yvo de Boer. 25/02/2010. Disponível em: <http://noticias.ambientebrasil.com.br/clipping/2010/02/25/52075-acordo-climatico-vai-levar-dois-anos-paraser-selado-diz-yvo-de-boer.html>. Acesso em 14 ago. 2010.

${ }^{49}$ Ambientebrasil. ONU: faltam décadas para solucionar problema do aquecimento global. 10/06/2010. Disponível em: $\quad<$ http://noticias.ambientebrasil.com.br/clipping/2010/06/10/55864-onu-faltam-decadas-para-solucionarproblema-do-aquecimento-global.html>. Acesso em 14 ago. 2010.

${ }^{50}$ Via Mecanismos de Flexibilização.

51 Via Impostos, vide exemplo: Estadão Online. Suécia vai propor imposto europeu sobre emissão de CO2. 09/06/2009. Disponível em <http://www.estadao.com.br/noticias/vidae,suecia-vai-propor-imposto-europeu-sobreemissao-de-co2,384827,0.htm>. Acesso em 14 ago. 2010.
} 
Torna-se, portanto, necessário definir quais os principais atores envolvidos neste processo, para compreender quais interesses estão sendo negociados. Protagonizam neste debate: de um lado, o IPCC, representando a atuação política, juntamente com o respaldo de cientistas favoráveis ao aquecimento global antropogênico; e, do outro lado, o NIPCC (sigla em inglês para "Nongovernmental International Panel on Climate Change", ou Painel Não-Governamental sobre Mudanças Climáticas) representando e centralizando a opinião dos cientistas contrários (reconhecidos como "céticos") ao "consenso científico" do aquecimento global antropogênico.

\subsubsection{IPCC}

O IPCC ${ }^{52}$, segundo sua auto-descrição, organismo científico intergovernamental, foi criado em 1988 para fornecer, aos políticos e outros interessados em clima, uma fonte de informação objetiva sobre mudanças climáticas. O Painel não conduz nenhuma pesquisa nem monitora dados ou parâmetros relacionados. Seu papel é avaliar de forma compreensiva, objetiva, aberta e transparente uma base com as literaturas científica, técnica e sócio-econômicas produzidas mundialmente, e pertinentes para o entendimento do risco das mudanças climáticas induzidas pelo homem. Produzidos por meio de um rigoroso processo científico de revisão por pares (peer review) elaborado por especialistas e aprovados pelos membros governamentais, os relatórios gerados são neutros em relação à política, embora eles lidem com aspectos que possam servir para a aplicação de políticas específicas. (IPCC, 2004; IPCC, 2009a).

Constituído por representantes da comunidade científica e do governo, o IPCC é aberto a todos os membros da ONU e da OMM. O Painel reúne-se anualmente em Plenárias, onde representantes do governo decidem sobre a eleição do presidente do IPCC, a estrutura e o escopo de atuação dos Grupos de Trabalho, entre outras atividades. Responsáveis pela elaboração dos Relatórios de Avaliação, os Grupos de Trabalho (Working Group - WG) são divididos em três: I. As Bases Científicas; II. Impactos, Adaptação e Vulnerabilidade; e III. Mitigação. Resultantes do trabalho destes grupos, os Relatórios de Avaliação (Assesment Report - AR) possuem três

\footnotetext{
52 Disponível em: <http://www.ipcc.ch/>. Acesso em: 20 jun. 2010.
} 
volumes correspondentes a cada WG. O "relatório do IPCC" é usualmente atribuído ao relatório do WG I. (IPCC, 2009b).

Quatro Relatórios de Avaliação ${ }^{53}$ foram publicados respectivamente em 1990, 1995, 2001 e 2007, cada um contendo um volume para cada WG mais um volume que sintetiza os relatórios de cada grupo: o "Relatório Síntese" - sujeito a aprovação pelo Painel - cuja linguagem não-técnica é adequada para os políticos. Todos Relatórios de Avaliação também possuem uma "Síntese para Políticos" (Summary for Policymakers), que, da mesma forma, tem seu conteúdo aprovado nas Plenárias. O IPCC está atualmente delineando o seu Quinto Relatório, que será finalizado em 2014. (IPCC, 2009c).

Na Síntese para Políticos do Primeiro Relatório de Avaliação (FAR - First Assesment Report) foi alegado que as emissões resultantes das atividades humanas estavam substancialmente incrementando a concentração dos GEEs, resultando no aumento da temperatura média global. Foi determinado que nos últimos 100 anos, a temperatura média do ar na superfície terrestre teria aumentado de 0,3 a $0,6^{\circ} \mathrm{C}$, podendo este aquecimento ser devido à causa natural ou resultante das atividades humanas. Apesar de, por meio de cenários futuros, calcularem o aumento de cerca de $0,3{ }^{\circ} \mathrm{C}$ por década, durante o século 21 , o Relatório admitia que ainda existiam muitas outras incertezas nas previsões (IPCC, 1990).

As principais conclusões do Segundo Relatório de Avaliação (SAR - Second Assesment Report) foram: a concentração dos GEEs continuou crescendo; o clima tem mudado nos últimos 100 anos e acredita-se que continuará mudando no futuro; o balanço das evidências sugere uma influência humana discernível nas mudanças climáticas, e que o aquecimento verificado é pouco provável de ocorrer devido a causas naturais; e ainda há muitas incertezas (IPCC, 1995).

Além de reforçar os resultados dos relatórios anteriores, os principais tópicos abordados no Terceiro Relatório de Avaliação (TAR - Third Assesment Report) do WG1 acrescentam que: a confiança dos modelos em projetar cenários futuros aumentou devido ao aprimoramento do seu desempenho em geral; as evidências demonstram que grande parte do aquecimento observado nos últimos 50 anos é atribuível às atividades humanas; e que a temperatura média do ar na superfície terrestre pode, de acordo com os cenários projetados, subir de 1,4 a $5,8^{\circ} \mathrm{C}$ no período de 1900 a 2100, além do aumento do nível dos oceanos de 0,1 a 0,9 m no mesmo

\footnotetext{
${ }^{53}$ Disponíveis em: <http://www.ipcc.ch/ipccreports/assessments-reports.htm>. Acesso em: 20 jun. 2010.
} 
período. Os cenários utilizados consideraram diferentes concentrações de gás carbônico, mas a estas previsões não foram atribuídas a nenhuma probabilidade de ocorrência (IPCC, 2001b).

Por fim, o Quarto Relatório de Avaliação (AR4) do WG2, concluiu que: o aquecimento do sistema climático é inequívoco; o aumento verificado na temperatura média do ar na superfície terrestre desde a metade do século 20 é bastante provável que, com 90\% de confiança, seja devido ao aumento das emissões dos GEEs antropogênicos, sendo menor que $5 \%$ a probabilidade do aquecimento ser causado por processos climáticos naturais; a temperatura do ar pode aumentar de 1,1 a $6,4^{\circ} \mathrm{C}$ durante o século 21; e o nível dos oceanos pode subir de 18 a $59 \mathrm{~cm}$ (IPCC, 2007c).

\subsubsection{NIPCC}

O NIPCC é um painel internacional criado em 2007 por cientistas e estudiosos não-governamentais unidos no entendimento das causas a consequências das mudanças climáticas. Uma vez que este painel não está associado a nenhuma agência ou órgão governamental, e igualmente pelo fato dos membros não estarem convencidos a acreditar que as mudanças climáticas são causadas pelos GEEs antropogênicos, o NIPCC se dispõe a oferecer uma "segunda opinião" das evidências revisadas e utilizadas pelo IPCC. A ideia inicial de criação do painel surgiu no encontro destes cientistas em uma reunião em Milão, em 2003, organizada pelo Projeto de Ciência e Políticas Ambientais (do inglês Science E Environmental Policy Project - SEPP $\left.{ }^{54}\right)$, organização educacional sem fins lucrativos fundada, em 1990, pelo físico atmosférico Fred Singer (SEPP, 2009; SINGER, 2009).

Examinando as mesmas evidências originais utilizadas pelo IPCC, o NIPCC chega a diferentes conclusões em duas de suas recentes obras ${ }^{55}$ : "A Natureza, Não as Atividades Humanas, dita o Clima" (SINGER, 2008) e "Mudanças Climáticas Reconsideradas" (SINGER; IDSO, 2009).

Ambos os documentos foram publicados pelo The Heartland Institute ${ }^{56}$, organização norte-americana de pesquisa e educação, criada em 1984, sem fins lucrativos e não filiada a nenhum partido político, negócio, nem fundação, possuindo

\footnotetext{
${ }^{54}$ Disponível em <http://www.sepp.org >. Acesso em: 20 jun. 2010.

${ }^{55}$ Disponíveis em <http://www.nipccreport.org >. Acesso em: 20 jun. 2010.

56 Disponível em <http://www.heartland.org >. Acesso em: 20 jun. 2010.
} 
a missão de descobrir, desenvolver e promover soluções de mercados livres a problemas sociais, econômicos, e de proteção ambiental (THE HEARTLAND INSTITUTE, 2009).

Publicada em fevereiro de 2008, a primeira obra (40 páginas) representa uma Síntese para Políticos, em que Singer e vários outros cientistas oferecem uma refutação das principais alegações feitas pelo IPCC.

Já com 880 páginas, o segundo relatório do NIPCC, lançado no início do mês de junho de 2009, editado por Singer em co-autoria com Craig Idso, é fruto do trabalho de três anos de pesquisa, representando uma crítica cientificamente embasada ao conteúdo apresentado no AR4 do WG1 do IPCC. A referida obra do NIPCC é resultado de uma coligação internacional de cientistas que examinaram uma série de artigos de pesquisa ignorados pelo IPCC, além de atualizarem com artigos publicados após maio de 2006, prazo da conclusão do AR4 - que só foi publicado em 2007. O conteúdo do livro tenta demonstrar que o aquecimento global, ocorrido ao longo do século 20, foi moderado e não sem precedentes, e que seu impacto sobre a saúde humana e para a biodiversidade pode ser positivo, além do fato de que o dióxido de carbono não é, provavelmente, o principal fator determinante das mudanças climáticas.

Singer (2008) relata que o FAR ignorou completamente dados de satélite, já que estes não apresentaram nenhum aquecimento; alerta ainda que o SAR sofreu alterações significativas no seu texto após a aprovação dos cientistas, sugerindo uma manipulação pelos representantes governamentais com a fim de transmitir a impressão de uma influência humana no aquecimento global. O TAR alegou que o século 20 apresentou um aquecimento incomum, o qual Singer critica o uso de um gráfico ("Taco de Hóquei", vide Figura 13, pg. 47) desacreditado para justificar esta alegação. Por fim, o AR4 é julgado por desvalorizar completamente as contribuições das mudanças na atividade solar, que segundo Singer são predominantes sobre qualquer influência humana.

Do Prefácio quase idênticos nas duas obras, alguns trechos interessantes, merecem destaque e reprodução. A respeito das conclusões do NIPCC sobre o aquecimento global, o autor esclarece:

Sobre a questão mais importante, a alegação do IPCC de que "a maior parte do aumento observado na temperatura média mundial desde meados do século 20 é muito provável devido ao incremento da concentração dos gases 
do efeito estufa antropogênicos", o NIPCC obtém conclusão oposta - a saber que as causas naturais que são muito provavelmente a causa dominante. Nota: Nós não estamos dizendo que os GEEs antropogênicos não podem produzir algum aquecimento. Nossa conclusão é que a evidência mostra que os eles não estão desempenhando um papel significante. (SINGER, 2008, p. iv, grifo do autor).

Do vínculo financeiro dos cientistas com o IPCC, relata ainda que:

O pessoal-chave do IPCC e os autores líderes são indicados por governos, e a Síntese para Políticos é submetida à aprovação pelos representantes dos governos membros da ONU. Os cientistas envolvidos com o IPCC são quase todos financiados por contratos governamentais, que pagam não só pelas suas pesquisas, mas também pelas atividades relacionadas ao IPCC. A maioria das viagens e hospedagens em lugares exóticos, realizadas pelos autores [que elaboram os estudos], é paga com fundos governamentais. (SINGER, 2008, p. iv).

No trecho a seguir o autor alerta sobre a interferência da esfera governamental sobre o trabalho realizado pelos cientistas do IPCC, com alterações no conteúdo científico para sustentação dos interesses políticos:

Desde o início, o IPCC foi uma entidade política e não científica, com os seus cientistas líderes que refletem as posições dos seus governos ou tentam induzir os seus governos a adotar a posição do IPCC. Em particular, um pequeno grupo de ativistas escreveu a toda-importante Síntese para Políticos para cada um dos quatro relatórios. Embora muitas vezes sejamos informados sobre os milhares de cientistas cujos trabalhos sobre os quais os Relatórios de Avaliação se baseiam, a grande maioria destes cientistas não têm qualquer influência direta sobre as conclusões expressas pelo IPCC. Estas são produzidas por um núcleo interno de cientistas, e as Sínteses para Políticos são revistas e aceitas, linha-por-linha, pelos representantes dos governos. Isto obviamente não é a maneira como a investigação científica real é revisada e publicada. (SINGER, 2008, p. v).

O exemplo típico deste tipo de interferência é nitidamente ilustrado pelos trechos:

O SAR foi fortemente criticado novamente, desta vez por ter sofrido alterações significativas no corpo do relatório para torná-lo "em conformidade" com a Síntese para Políticos - depois que foi finalmente 
aprovado pelos cientistas envolvidos em redação do relatório. Não só foi alterado o relatório, mas também um gráfico importante foi manipulado para sugerir uma influência humana. As provas apresentadas para apoiar a conclusão da Síntese acabaram se tornando completamente ilegítimas. (SINGER, 2008, p. v).

[...] a Síntese para Políticos do Grupo de Trabalho I foi lançada em Fevereiro [2007]; o relatório completo a partir deste Grupo de Trabalho foi lançado em maio - após ter sido alterado, mais uma vez, para "ficar em conformidade" com a Síntese. (SINGER, 2008, p. v).

Indagando sobre os motivos que poderiam ter levado o IPCC a adotar tais atitudes em "Porque é que os relatórios do IPCC têm sido manchados por controvérsia e tão frequentemente são contrariados por pesquisas subsequentes?" Singer (2008, p. vi), levanta três hipóteses logo em seguida:

Certamente a sua agenda [do IPCC] para encontrar evidência de um papel humano nas alterações climáticas é uma principal razão; sua organização como uma entidade governamental atrelada a agendas políticas é outra grande razão; e as grandes recompensas profissionais e financeiras que vão para os cientistas e burocratas que estão dispostos a distorcer fatos científicos, a fim de acompanhar as agendas é ainda um terceiro grande motivo. (SINGER, 2008, p. vi).

Por fim, o autor conclui o Prefácio, esclarecendo que as discussões sobre o aquecimento global não cessaram.

\subsubsection{Meios de comunicação}

Os meios de comunicação desempenham um papel essencial na divulgação da informação e formação de opinião. No âmbito das mudanças no clima, as notícias veiculadas pelos meios de comunicação usuais (televisão, rádio, jornais, revistas e Internet) normalmente transmitem informações em basicamente em duas vertentes: uma na esfera política, relatando especialmente as negociações, acordos climáticos e apoios financeiros; e a outra apresentando os avanços, pesquisas e descobertas da Ciência.

Em termos da esfera política, a cobertura da imprensa sobre o aquecimento global ocorre de forma cíclica, acompanhando a divulgação dos relatórios do IPCC - 
o último publicado em 2007 e o próximo a ser publicado em 2014 - e as Conferências das Partes (COP), reuniões de lideranças mundiais que ocorrem nos finais de todos os anos. Com menor destaque, ao longo do ano também ocorre a cobertura dos encontros que antecedem a COP.

No sentido de divulgação das notícias de conteúdo científico, é comum a simplificação exagerada que induz a conclusões indevidas e precipitadas, mesmo com base em estudos científicos. É comum a exposição de resultados de modelos aparentemente absurdos, com cenários possíveis, porém muito improváveis de ocorrer. Outra característica recorrente é observar manchetes que não correspondem fielmente ao teor do conteúdo, pois certo grau de sensacionalismo ocasiona a uma superficialidade demasiada do conteúdo, não transmitindo com a devida pertinência os erros e incertezas associados aos resultados, considerações essenciais na pesquisa científica.

Já as notícias na linha científica, elas podem ser categorizadas entre as que abordam os "efeitos" e as que levantam as "soluções" para as mudanças climáticas.

Em termos de efeitos futuros indesejáveis, e utilizando cenários que levam em conta os piores cenários de modelos climáticos, notícias absurdamente alarmistas citam: a possibilidade de metade do mundo se tornar inabitável até 2300, com o aquecimento médio de $12^{\circ} \mathrm{C}^{57}$; a possibilidade de a raça humana de tornar extinta em $100 \operatorname{anos}^{58}$; ou mesmo a humanidade entrar em extinção em até 50 anos, se a Terra aquecer $6^{\circ} \mathrm{C}^{59}$.

No campo das soluções, notícias veiculam as medidas "convencionais" de redução de emissões pela substituição por tecnologias "mais limpas", ou seja, menos dependentes de combustíveis fósseis e baseadas em energias renováveis. Também

\footnotetext{
57 Estadão Online. Metade do mundo pode ficar inabitável com mudança climática, afirma estudo. 12/05/2010. Disponível em <http://www.estadao.com.br/noticias/vidae,metade-do-mundo-pode-ficar-inabitavel-com-mudancaclimatica-afirma-estudo,550721,0.htm>. Acesso em: 14 ago. 2010.

58 redOrbit. Scientist Predicts Human Extinction In $\mathbf{1 0 0}$ Years. 17/06/2010. Disponível em $<$ http://www.redorbit.com/news/science/1881226/scientist_predicts_human_extinction_in_100_years/>. Acesso em: 14 ago. 2010.

59 Congress.org. Global Warming could make Humans EXTINCT within 50 years. Jun/2010. Disponível em: $<$ http://www.congress.org/soapbox/alert/15194771>. Acesso em: 14 ago. 2010.
} 
veiculam soluções tecnologicamente mais ousadas e arriscadas, como o emprego de técnicas de geoengenharia ${ }^{60}$ :

- Controle da radiação solar pela reflexão da luz solar. Redução da radiação por meio de: 1. Instalação de espelhos no espaço; 2. Uso de aerossóis estratosféricos, com aplicação de sulfatos; 3. Reforço do albedo das nuvens; e 4. Incremento do albedo da superfície terrestre, instalando telhados brancos nas edificações;

- Captura e armazenamento de carbono (CCS, do inglês Carbon Capture and Storage): 1. Remoção de dióxido de carbono por meio da captura do carbono da atmosfera, ou "árvores artificiais"; 2. Sequestro de carbono por meio de bioenergia; 3. Fertilização do oceano com o lançamento de ferro para estimular algas que capturam o $\mathrm{CO}_{2}$ do ar; e 4. Armazenamento de carbono no solo ou nos oceanos.

Apesar de as técnicas emergenciais de geoengenharia parecerem promissoras, elas apresentam vários riscos, com efeitos colaterais potencialmente desastrosos: o lançamento de aerossóis na estratosfera poderia trazer acúmulo nos trópicos e reduzir as monções asiáticas, causando seca na região e prejudicando a agricultura ${ }^{61}$; a fertilização dos oceanos pode trazer a proliferação de algas que produzem toxinas fatais para seres marinhos ${ }^{62}$; os gases armazenados no solo e oceanos poderiam vazar e causar danos perigosos ${ }^{63}$.

Por fim, existem soluções curiosas, inusitadas, inviáveis e absurdas, como: o pagamento de uma "taxa bebê", sugestão dada pelo médico Barry Walters na

\footnotetext{
60 Agência FAPESP. Caminhos para o clima. 31/3/2010. Disponível em: <http://www.agencia.fapesp.br/materia/11978/caminhos-para-o-clima.htm>. Acesso em: 14 ago. 2010.

61 Folha Online. Cientistas tentam prevenir abuso da engenharia do clima. 12/04/2010. Disponível em $<$ http://www1.folha.uol.com.br/folha/ambiente/ult10007u719448.shtml>. Acesso em: 14 ago. 2010.

62 Folha Online. Há 17 riscos e 6 benefícios em técnica de engenharia do clima, conclui grupo. 12/04/2010. Disponível em <http://www1.folha.uol.com.br/folha/ambiente/ult10007u719461.shtml>. Acesso em: 14 ago. 2010. ${ }^{63}$ Folha Online. Captura e armazenamento de carbono encara dilema, diz estudo. 28/06/2010. Disponível em $<$ http://www1.folha.uol.com.br/ambiente/758305-captura-e-armazenamento-de-carbono-encara-dilema-dizestudo.shtml $>$. Acesso em: 14 ago. 2010.
} 
Austrália ${ }^{64}$. Famílias com mais de dois filhos deveriam pagar, a cada nascimento adicional, um imposto de US\$ 5.000, e uma taxa anual de US\$ 800 por criança. Segundo o médico, "todo bebê recém-nascido na Austrália representa uma fonte potente de emissões de gás estufa por uma média de 80 anos, não simplesmente por respirar, mas por consumir de modo extravagante os recursos típicos da nossa sociedade". Outra solução sugerida foi pintar de branco a montanha dos Andes peruanos para esfriá-la, atividade já em prática por uma ONG local ${ }^{65}$. Na mesma linha, uma geleira na Itália tem sido coberta com uma tela térmica para diminuir o ritmo de seu derretimento durante o verão europeu ${ }^{66}$.

Embora grande parte das notícias com viés alarmista e sensacionalista sejam mais frequentes no espaço midiático, até mesmo estudos publicados em revistas científicas - que, teoricamente, possuem um sistema de revisão por pares (peer review), e, portanto, possui critérios fundamentados no rigor do método científico apresentam conteúdos e temas bastante ousados e pretensiosos em suas correlações e aformações. Essex, Mckitrick e Andersen (2007) apontam algumas atribuições de causas e efeitos colaterais peculiares publicadas em periódicos científicos de grande prestígio: pequenos aumentos nas medidas estatísticas globais foram citados na explicação da formação de furacões; na ocorrência de infecções virais em rãs, de encefalite em equinos; e até mesmo causa de doença pulmonar, delírio e suicídios em seres humanos. Outro caso de correlação direta entre suicídio foi pesquisado por Preti, Lentini e Maugeri (2007), que com base em análise estatística chegou à inferência de que o aquecimento global causou o aumento do número de suicídios na Itália nas últimas três décadas. Outro exemplo é o estudo de Kearney et al. (2010) que constatou que a borboleta marrom (Heteronympha merope) estaria nascendo 10 dias mais cedo do que há 60 anos atrás, devido ao aquecimento global atribuído

\footnotetext{
64 News Digital Media. Baby tax needed to save planet, claims expert. 10/12/2007. Disponível em $<$ http://www.news.com.au/baby-tax-needed-to-save-planet-claims-expert/story-e6frfkp9-1111115071784>. Acesso em: 14 ago. 2010.

65 Ambientebrasil. ONG vai caiar montanha dos Andes peruanos para esfriá-la. 21/06/2010. Disponível em $<$ http://noticias.ambientebrasil.com.br/clipping/2010/06/21/56387-ong-vai-caiar-montanha-dos-andes-peruanospara-esfria-la.html>. Acesso em: 14 ago. 2010.

66 Ambientebrasil. Italianos cobrem geleira para evitar derretimento. 09/07/2010. Disponível em $<$ http://noticias.ambientebrasil.com.br/clipping/2010/07/09/57287-italianos-cobrem-geleira-para-evitarderretimento.html>. Acesso em: 14 ago. 2010.
} 
exclusivamente às emissões de $\mathrm{CO}_{2}$. Este caso de "efeito borboleta" repercutiu na Internet como "defeito borboleta".

Diversos efeitos, soluções, e tantas outras possíveis co-variações são constantemente divulgadas na Internet, muitas delas de sítios eletrônicos renomados. De uma lista ${ }^{67}$ de mais de 800 notícias absurdas e relações estranhas com o aquecimento global e mudanças climáticas em geral, podem ser citadas os seguintes efeitos como os mais discrepantes e chamativos: aumento de alergia; relação com o terrorismo; queda de aviões; aumento do risco de colisões de asteróide; aumento de casos de morte por câncer; canibalismo em massa; insônia em crianças; declínio de circuncisões; ataques de puma; aumento da criminalidade; depressão; danos à saúde de cães; mudanças no eixo da Terra; redução ou aumento da velocidade de rotação da Terra; terremotos; extinções de inúmeras espécies, da civilização humana ou até mesmo metade de todas as espécies animais e vegetais; fome; desastre no mundo da moda; envenenamento de comida; mudanças genéticas; infartos; redução da fertilidade humana; indigestão; fim das Olimpíadas; aumento da prostituição; aumento do avistamento de OVNIs (Objetos Voadores Não Identificados); onda de estupros; guerras; guerra nuclear; aumento da quantidade de lixo espacial; disfunções sexuais; movimentos tectônicos; erupções vulcânicas; desemprego; casamentos precoces; epidemia de AIDS; tsunami etc.

As variações simultâneas nestas relações coincidentes, ou co-variações, não devem ser confundidas com correlações, que são relações intrinsecamente conectadas, com variações dependentes. Ou seja, os exemplos de co-variações ilustram que o aquecimento global tem sido utilizado como bode-expiatório de todos os problemas ambientais, inclusive tem sido apontado como a causa de tantos outros problemas de ordens aparentemente não relacionadas. A simples constatação da co-variação entre aumento das emissões de gases do efeito estufa ou da temperatura média na superfície terrestre em relação a qualquer outra variável de interesse, já está sendo suficiente para alegar que o aquecimento global é o motivo de tantos males e adversidades da humanidade. Seguindo esta lógica, poderia-se afirmar que o aumento da população, do PIB, ou de qualquer outro parâmetro está sendo causado pelo aquecimento. Todavia, é evidente que as mudanças climáticas estão sendo associadas somente aos aspectos negativos e problemáticos presentes na sociedade.

67 Brignell, J. Global Warming List. Disponível em: <http://www.numberwatch.co.uk/warmlist.htm>. Acesso em: 14 ago. 2010 . 
É notável o tom predominantemente pessimista, apimentado com um sensacionalismo alarmista e catastrofista, algumas vezes até mesmo apocalíptico, com o propósito de chocar, amedrontar e apavorar a pessoas. De fato, eles conseguiram exatamente isso:

\section{Pais atiram em bebê por desespero ante o aquecimento global}

02 de março de 2010 - Estadão Online ${ }^{68}$

Uma bebê de sete meses baleada no peito pelos próprios pais sobreviveu depois de permanecer sozinha por três dias até ser encontrada pela polícia, na última quinta-feira, na cidade de Goya, norte da Argentina. Francisco Lotero, de 56 anos, e Miriam Coletti, de 23 anos, teriam firmado um pacto de suicídio por temerem os efeitos do aquecimento global. Assim, eles mataram a tiros o filho de dois anos, balearam a filha de sete meses e se suicidaram.

Sobre uma mesa na casa foi encontrada uma carta em que os pais expressavam seu nervosismo diante da falta de ações dos países contra a crise ambiental. A bebê só foi encontrada depois de os vizinhos desconfiarem do cheiro que exalava da casa e notificarem a polícia.

Segundo o hospital local que cuida da menina, ela recebeu um tiro de calibre 32 que atravessou seu peito, mas sem atingir nenhum órgão vital. Quando foi encontrada, ela estava banhada em sangue e apresentava um quadro grave de desidratação.

Os médicos informaram que a paciente se recupera bem e está fora de perigo. Depois de receber alta, ela deve ficar aos cuidados de seus avós maternos.

Este fato, lamentável, ficou conhecido como "aquecimenticídio" (warmcide). Este sim foi um efeito concreto e chocante do aquecimento global, ou melhor, do medo provocado pelo "terrorismo climático" pregado pela mídia.

Enfim, a partir das inúmeras notícias e filmes, mesmo aquelas embasadas cientificamente, é fundamental analisá-las critica e cuidadosamente, para que seja possível averiguar se uma afirmação está baseada em observações e dados, em

${ }^{68}$ Estadão Online. Pais atiram em bebê por desespero ante o aquecimento global. 02/03/2010. Disponível em: $<$ http://www.estadao.com.br/noticias/geral,pais-atiram-em-bebe-por-desespero-ante-o-aquecimentoglobal,518277,0.htm>. Acesso em 14 ago. 2010. 
interpretações objetivas de dados, em interpretação baseadas na experiência de algum especialista da área ou em opiniões subjetivas e especulativas. Mesmo os pesquisadores não estão isentos de sua responsabilidade das conclusões de suas pesquisas, pois eles possuem valores, interesses e contextos culturais que podem influenciar as suas interpretações dos dados e induzir distorções nas suas afirmações ou enunciados.

Infelizmente, o papel da mídia em massa tem falhado em cobrir imparcial e objetivamente o debate da polêmica do aquecimento global e mudanças climáticas em geral. O reconhecimento de possíveis influências por parte de pesquisadores ou por parte da imprensa é primordial. Compreender as interações entre os atores envolvidos, além dos respectivos interesses em questão, é um primeiro passo para uma interpretação sensata das informações relacionadas ao clima dentro deste contexto instaurado.

\subsection{Interação entre a Ciência e a Mídia ${ }^{69}$}

Em meio a tanta informação sobre o aquecimento global, quando se pergunta às pessoas quanto o planeta aqueceu ao longo do século passado, a maioria responde que foi entre dois e três graus Celsius. ${ }^{70}$ Mas as pessoas nem chegam perto do valor real, que segundo o IPCC, é de $0,6^{\circ} \mathrm{C}$. Não é surpreendente que a maioria das pessoas tenha um palpite errado. Todos são bombardeados constantemente por notícias alertando que o aquecimento global está fora de controle, ou seja, os efeitos das alterações climáticas estão a sendo exagerados.

Em 2005, a revista científica Nature publicou os primeiros resultados de um estudo realizado por um grupo de cientistas do Reino Unido. Eles tinham testado o efeito que a duplicação da quantidade de dióxido de carbono na atmosfera teria de temperatura. A grande maioria dos resultados mostrou que o dobro de $\mathrm{CO}_{2}$ levaria a um aumento de temperatura de cerca de $3,0^{\circ} \mathrm{C}$. Esse aumento, estimado por modelos, foi semelhante aos resultados produzidos por outros cientistas. No entanto uma pequena porcentagem dos modelos apresentou níveis muito altos de aquecimento - o

\footnotetext{
69 Com base em: Spiegel Online. How Global Warming Research is Creating a Climate of Fear. 24/01/2005. Disponível em: <http://www.spiegel.de/international/spiegel/0,1518,342376,00.html> Acesso em 14 ago. 2010.

${ }^{70}$ BBC News. A load of hot air?. 20/04/2006. Disponível em:

<http://news.bbc.co.uk/2/hi/uk_news/magazine/4923504.stm>. Acesso em 14 ago. 2010.
} 
maior resultado foi de $11,0^{\circ} \mathrm{C}$. Quando se procedeu à "venda" da história aos jornalistas, a imprensa só mencionou um ponto: $11,0^{\circ} \mathrm{C}$.

Por um lado, cientistas podem tentar culpar a mídia pela dramatização excessiva dada à notícia, mas por outro lado, em um mundo com cada vez mais informação, a disputa por espaço e reconhecimento se torna uma questão difícil para os cientistas. Para receberem atenção e destaque da veiculação dos resultados suas pesquisas na mídia, os cientistas precisam de algo inusitado, emocionante e chocante para ter uma chance de publicação, e, assim, justificar os financiamentos recebidos para as pesquisas.

A comunidade científica tem de fato enfrentado um problema sério quando se trata de entendimento e percepção pública das alterações climáticas. A investigação científica enfrenta uma crise porque suas figuras públicas estão exagerando os problemas para ganhar a atenção em um mercado disputado para a informação noticiosa.

A dificuldade para os cientistas do clima é que seus trabalhos possuem uma dimensão política. E este é o âmago da relação entre a ciência e a política. O uso dos dados científicos possui uma implicação prática política, que, após a elaboração e publicação de leis, regras valem para toda uma população. Havendo o problema do aquecimento global, suportado por várias "evidências" - muitas vezes as mais extremas e irrealistas -, os políticos agem no sentido de tentar criar uma solução.

A crença geral é que, a fim de manter a atenção do público, centrou-se na questão da catástrofe climática, que deve ser apresentada cada vez mais atraente e comovente. A mídia tem veiculado notícias com um teor predominantemente pessimista: os meios de comunicação estão repletos de histórias de ondas de calor, enchentes, inundações, tempestades, tempestades de areia, secas prolongadas, queimadas, e outros eventos climáticos extremos. E com a globalização das informações, o noticiamento instantâneo passa a impressão de que sempre está ocorrendo, em algum lugar do mundo, um desastre de origem climática.

Os meios de comunicação têm alegado cada vez mais que todos os tipos de eventos extremos estão aumentando em intensidade e frequência, atribuídos como resultados das mudanças climáticas. Tem sido frequente interpretar qualquer evento 
meteorológico fora do comum ${ }^{71}$, até mesmo eventos que não são exclusivamente relacionados, como evidência do aquecimento global causado pelos seres humanos.

A saturação de matérias sobre o aquecimento global na imprensa nos últimos meses pode provocar a banalização do tema. A atenção pública não continuará a se preocupar sobre estas questões por muito tempo. Logo as pessoas se habituarão às advertências do clima e voltarão a se preocupar com questões mais cotidianas: o desemprego, a falta de educação de qualidade, de condições adequadas do sistema de saúde, de transporte público, etc. E por causa da falta de atenção que vai se instaurando, serão noticiados os perigos das alterações climáticas em detalhes cada vez mais escabrosos e apavorantes. Logo, esses cenários vão se tornando insuficientemente dramáticos e chocantes. Por esta razão, haverá cada vez mais conexões entre os eventos climáticos extremos atuais e a mudança climática causada pela atividade humana. O exagero de sensacionalismo, recurso geralmente utilizado para ganhar audiência e chocar a mente dos espectadores, reforçado pelo catastrofismo, pode resultar em um efeito ainda pior: tirar a esperança das pessoas.

Quando as perspectivas para o futuro são discutidas, o cenário que prevê as maiores taxas de crescimento das emissões de gases de efeito estufa - que, é claro, vem com as consequências mais dramáticas climáticas - é sempre o escolhido de entre todos os cenários possíveis. Os cenários que estimam aumentos significativamente menores nos níveis de gases de efeito estufa não são mencionados. Com toda este

71 O conhecimento de cada vez mais eventos do gênero não implica que estes estejam sofrendo um aumento. A noção é puramente aparente. Até antes da difusão da energia elétrica, do rádio, da televisão e da Internet, dificilmente se sabia o que estava ocorrendo em outras cidades, estados, países e continentes, se não fossem pelas informações trazidas pelos jornais. Além disso, a população na época era menor e também eram as construções e bens materiais produzidos pelo homem. Logo, o aumento da população afetada e os prejuízos de patrimônio físico e financeiro causados por eventos climáticos não denotam que os eventos estão se tornando mais intensos ou extremos, mas sim que tem muito mais pessoas e construções vulneráveis a eventos que sempre ocorreram naturalmente. Os efeitos podem estar se tornando maiores, mas não as causas. Alguns eventos nas cidades, especialmente enchentes, alagamentos, desmoronamento de casas em morros também passam a sensação de que as chuvas têm ficado mais fortes. Entretanto, estes dois exemplos citados são, respectivamente, consequências da falta de planejamento urbano que permitem a ocupação irregular de áreas de risco e da impermeabilização excessiva dos solos, que realmente altera o ciclo hidrológico, porém a alteração não é necessariamente na quantidade de precipitação, mas sim na redução da infiltração e consequente aumento do escoamento superficial. 
estado de medo imposto e mantido, quem se beneficia com isso? A suposição é de que o medo obriga as pessoas a agir, mas também pode produzir uma reação um pouco curta.

As alterações climáticas, por outro lado, exige uma resposta de longo prazo. O impacto sobre o público pode ser "melhor" no curto prazo, portanto, também influenciando positivamente a reputação e o financiamento de pesquisas. Mas, para garantir que todo o sistema continue a funcionar a longo prazo, cada nova alegação sobre o futuro do clima e do planeta deve ser um pouco mais dramático do que a anterior. E tudo isso conduz a um ciclo vicioso, em que o conhecimento transmitido ao público sobre o clima e os efeitos associados fica dramaticamente distorcido da realidade.

Infelizmente, os mecanismos de correção na ciência estão falhando. Exposições públicas de opinião no que diz respeito aos elementos de evidência de catástrofes climáticas são muitas vezes vistas como infelizes no meio científico, uma vez que prejudicam a "causa digna", especialmente porque poderiam ser utilizadas pelos céticos. A dramatização em pequena escala é considerada aceitável, enquanto que corrigir o exagero é visto como perigoso, porque é politicamente inoportuno. Isto significa que as dúvidas e incertezas não são expressas publicamente. Em vez disso, a comunidade científica dá a impressão de que os fundamentos científicos da investigação sobre alterações climáticas são sólidos e necessita apenas de pequenos acréscimos e ajustes.

Assim, a ciência está se deteriorando em uma loja de reparos das afirmações científicas convencionais e politicamente oportunas. Não só a ciência se torna impotente, mas também perde a sua capacidade objetiva de informar o público. Silenciar a dissidência e incerteza para o benefício de uma causa digna de política reduz a credibilidade, porque o público é mais bem informado do que geralmente se supõe. No longo prazo, a dramatizações e sensasionalismos supostamente úteis conseguirão exatamente o contrário daquilo que se destinam a atingir: colocar as pessoas contra a ciência, ao invés de tê-las ao seu lado.

A ciência não é perfeita e nem pode ser apresentada como tal. É arriscado assumir previsões e cenários como verdades absolutas, pois se previsões não ocorrerem, o público pode deixar de acreditar na Ciência. A função da mídia, portanto, é muito influente neste processo de propagação das informações. Os profissionais da comunicação, ao traduzirem os resultados científicos complexos em uma linguagem mais acessível e compreensível ao público em geral, podem acabar 
simplificando demais as incertezas presentes nas pesquisas, reduzindo sua importância no contexto ou até mesmo omitindo tais informações. As generalizações decorrentes podem induzir a conclusões imprecisas e incompletas, porém muitas vezes assumidas como a verdade plena. A forma convencionalmente parcial com que as mensagens são divulgadas não permite que o público incorpore uma visão da complexidade das relações que envolvem a temática climática. Portanto, é ideal que os jornalistas divulguem as incertezas científicas inerentes na produção de reportagens sobre o tema climático.

Mais que um agregador de opiniões, fatos e dados em um texto, o jornalista deveria ser um mediador social. Como tal, o profissional de comunicação precisa dominar conceitos básicos em mudanças climáticas e relacioná-la com o contexto político, econômico, social e ambiental mais amplo. Só assim é possível ajudar o público a entender como tal ou qual fato, dado, descoberta e opinião influenciam mudanças econômicas, políticas, sociais, ambientais e na vida cotidiana.

Entretanto, a função social dos jornalistas se torna subjugada a um fator determinante no conteúdo da notícia veiculada: os interesses aos quais a mídia está atrelada. A linha editorial de revistas, jornais, telejornais, entre outros, determina o teor e tendência de opinião que será adotada nos respectivos meios de comunicação. Desta maneira, o princípio ético da imparcialidade do jornalismo se torna seriamente comprometido. Consequentemente, a falta de uma postura de neutralidade conduz à distribuição da informação de maneira enviesada e tendenciosa, favorecendo a difusão de determinado ponto de vista específico, e reforçando tentativas de manipulação ideológica do assunto. É lamentável que a mídia esteja contaminada com tal pressão editorial, evitando o relato dos verdadeiros fatos que têm ocorrido pelo mundo. $\mathrm{O}$ mais sensato e ético seria, pelo menos, dar o mesmo "tempo de defesa" de cada opinião oposta. Se não houvesse interesses escusos nos efeitos da veiculação de determinados assuntos, seria oferecida a mesma oportunidade de exibição das opiniões divergentes, e assim o público que seria o responsável pela formação de sua própria opinião.

Caso porventura seja revelado algo inesperado que provoque alguma reviravolta, pode-se imaginar a mídia se isentando de qualquer responsabilidade no processo. Os responsáveis pela comunicação podem ser capazes até de culparem exclusivamente os cientistas, na tentativa de se eximirem da grande parcela de culpa que tiverem ao serem cúmplices, mesmo alegando que a função deles foi apenas "repassar" a informação, teoricamente, de forma imparcial. Mas esta neutralidade, 
como já registrado, não ocorre. Marilena Chaui expressa com clareza a conduta desempenhada pela mídia atualmente:

\begin{abstract}
Os meios de comunicação de massa não informam, desinformam. Ou melhor, transmitem as informações de acordo com os interesses de seus proprietários e das alianças econômicas e políticas destes com grupos detentores de poder econômico e político. (CHAUI, 2000, p. 435).
\end{abstract}

\title{
9.4. Interação entre a Ciência e a Política
}

Nas questões relacionadas ao clima, a interação entre a Ciência e a Política tem sido dada por meio do conceito "política baseada em evidência" (Evidence-based Policy). Não é nova a ideia de usar evidências para informar a Política. O conceito se desenvolveu de forma considerável a partir de 1997, muito embora tenha surgido, primeiramente, na Grécia antiga com Aristóteles. Os debates iniciaram no início da década de 1990 na Inglaterra, no setor médico, quando a medicina baseada em evidência começou a ser utilizada. No âmbito da política, foi a partir do Governo Britânico de Blair (1997-2001) que esse conceito ganhou espaço e relevância, quando foi incluído no documento do Governo Inglês White Paper, em 1999, onde se destaca a recomendação de que as políticas produzidas devem realmente lidar com os problemas, o que significa olhar adiante e calcar-se em evidências mais do que nas respostas às pressões de curto prazo, que atacam apenas as causas e não os sintomas (SUTCLIFFE; COURT, 2005).

A política baseada em evidências se constitui em um discurso ou em um conjunto de métodos os quais direcionam o processo político, que consiste numa abordagem mais racional, rigorosa e sistemática. Dessa forma, os tomadores de decisão, uma vez melhor informados e embasados nas evidências, podem proceder a análises mais racionais, e, consequentemente, produzirem melhores resultados. Portanto, a implementação de políticas é baseada nas melhores evidências disponíveis, desenvolvidas ou coletadas a partir da pesquisa.

Entretanto, quando a evidência está sujeita a incertezas, o processo decisório pode ser gravemente comprometido em sua efetividade. Sutcliffe e Court (2005) discutem que há três problemas principais que afetam o uso da política baseada em evidências: 
- Quais evidências devem ser utilizadas - na literatura está claro que se deve utilizar um conjunto mais abrangente de evidências, devem-se considerar também problemas chaves como qualidade, credibilidade, relevância e custo;

- Como a evidência é incorporada ao processo - destacam que as evidências podem ser incorporadas em qualquer fase do ciclo da política, desde a definição da agenda e identificação do problema até a formulação, implementação e avaliação da política;

- A evidência não deve ser considerada como um único fator que influencia a política pública - é importante conhecer cada estágio do ciclo da política e o número de fatores que podem afetá-la. Esses fatores podem variar desde o nível individual relativo às limitações do próprio indivíduo, tais como experiência, conhecimento e capacidade de julgamento, bem como as limitações institucionais, tais como a capacidade institucional. Há também outras restrições que impactam a identificação das evidências, tais como a pressão para que a decisão seja tomada rapidamente. Por outro lado, é importante destacar que o processo não é neutro, nem totalmente objetivo, pois se constitui em um processo político.

Considerando a amplitude do termo "evidência", cabe detalhá-lo. Evidência consiste uma variedade de tipos de pesquisas de evidências: conhecimento especializado; pesquisa publicada; pesquisa existente; consultas aos stakeholders; avaliações prévias de políticas; pesquisas na Internet; resultados de consultorias; preços de custo de diversas opções de políticas; resultados da modelagem econômica e estatística (SUTCLIFFE; COURT, 2005).

Outro ponto destacado por Shaxson (2005 ${ }^{72}$, apud SUTCLIFFE; COURT, 2005, p. 9) se refere ao estabelecimento de quais evidências serão úteis, pois nem todas têm a mesma validade ou peso. O autor identificou algumas característicaschave:

- Qualidade, precisão, objetividade - se refere à exatidão da evidência, ou seja, a evidência descreve corretamente o que pretende fazer? Elas são aritméticas (os números são somados corretamente), estatísticas (os parâmetros de causa e

\footnotetext{
72 SHAXSON, L (2005) 'Is your evidence robust enough? Questions for policy makers and practitioners' Evidence and Policy: A Journal of Research, Debate and Practice, v. 1, n. 1, p .101-111, 2005.
} 
efeito estão corretamente especificados) e representativas (as amostras representam o grupo que se quer) de problemas que podem ser considerados para direcionar a relevância da evidência? Há também problemas que envolvem a objetividade da evidência e de suas fontes. É importante questionar tendências ou preconceitos em relação às evidências com vistas a aprofundar o entendimento de como isso condiciona a interpretação das evidências para a política;

- Credibilidade - a credibilidade da evidência conta com uma forte e clara linha de argumento; métodos analíticos experienciados e testados, rigor analítico ao longo de todo o processo de coleta e análise de dados; e uma clara apresentação das conclusões. Isto está relacionado à confiabilidade da evidência e, portanto, pode-se ou não depender da evidência para controlar, avaliar ou avaliar os impactos - planejando para a abordagem das lições aprendidas. Na realidade, é muito difícil para estrategistas políticos verificar as evidências,, portanto eles contam, frequentemente, com a reputação da fonte como uma entidade autorizada. Por exemplo, pesquisas e resultados de pesquisas de instituições acadêmicas tendem a serem vistos como mais crível que, por exemplo, grupos da sociedade civil ou opiniões de líderes de comunidade. A reputação, no entanto, é subjetiva e depende da personalidade decisora;

- Relevância - o problema está centrado em se a evidência é oportuna, atual e se tem implicações políticas. O tipo de evidência se refere a questões relacionadas com o público para o qual está sendo apresentada e o possível impacto que pode criar. Por exemplo, estrategistas políticos do setor público estariam mais interessados em evidência de ação (o que já aconteceu) do que em opinião. Implícita à ideia de relevância está a necessidade de a evidência ser generalizável, ou seja, há informação ampla ou somente estudos de casos selecionados. Também se relaciona à maneira como se faz inferências. Para alguns tipos de informações, a generalização se referirá principalmente a procedimentos de amostragem; para outros, será mais sobre o entendimento do contexto.

- Praticidade - Está relacionada a quanto a evidência está acessível aos estrategistas políticos; se estas encontram-se em uma forma utilizável, acessível e útil de forma que possa facilmente ser traduzida em política. Refere-se também ao custo das implicações políticas da pesquisa, e, portanto, se é viável e se está disponível. 
Cable (2003) cita que há cinco fatores que limitam o uso de evidências para apoiar a tomada de decisão: velocidade das decisões, superficialidade das análises, rotatividade dos políticos, sigilo das informações e ignorância científica. Evidências e pesquisas representam um papel dominante na forma com que a maioria das decisões serão tomadas. Para impulsionar o uso de evidências se faz necessário construir pontes para interação entre os grupos sociais que desenvolvem pesquisa e conhecimento e o grupo social responsável pelo ciclo da política. Deve-se promover e incrementar a comunicação e interação entre esses grupos por meio de grupos de discussão, fóruns, treinamentos etc.

Com relação ao processo de comunicação Davies (2004) ressalta que é necessária a tradução das evidências coletadas por pesquisadores para uma linguagem adequada e compreensível para os usuários dessas evidências, evitando distorções ou uma falsa representação da evidência pesquisada.

\subsection{Incertezas e Consenso Científico}

Sem aprofundar-se nos argumentos científicos favoráveis ao aquecimento global antropogênico, liderados pela opinião do IPCC; nem nos argumentos céticos liderados pelo NIPCC a este aquecimento, é fato demonstrado que a ciência das mudanças climáticas está envolvida em inúmeras incertezas, além de estar sujeita a interesses políticos aparentemente escusos.

Até pouco antes do Protocolo de Quioto, os governos não tomaram nenhuma atitude concreta e efetiva em relação ao aquecimento global. Esta postura reflete que, até certo ponto, existia uma cautela de não fazer nada a respeito de um problema que poderia até mesmo não ocorrer. Porém, se determinados problemas incertos, como no caso das mudanças climáticas, viessem a ocorrer, poderia trazer grandes e irreversíveis problemas ambientais, sociais e econômicos.

Foi assim que, na Segunda Conferência Mundial do Clima em 1990, os cientistas e políticos resolveram adotar o Princípio da Precaução, que foi adotado também dois anos depois na "Convenção sobre Diversidade Biológica" e na "Convenção-Quadro das Nações Unidas sobre a Mudança do Clima", durante a Cúpula da Terra em 1992. Este Princípio da Precaução definiu o marco inicial do "consenso científico" de que o problema de mudanças climáticas poderia ser sério, mas ainda era incerto. 
Com a evolução do tema e aumento da visibilidade pública, políticos foram naturalmente se envolvendo e infiltrando-se na esfera científica, culminando na formação do IPCC, que, desde a publicação de seus Relatórios de Avaliação, tem despertado críticas de cientistas céticos e descrentes com relação às premissas do IPCC. Estes questionam a incerteza dos resultados, argumentando que o "consenso científico" é na realidade um "consenso político" e controverso.

De acordo com Gupta (1999), a incerteza do problema torna o processo de tomada de decisão complexo; mas a controvérsia circundante da incerteza torna o processo ainda mais complexo, podendo levar a interpretar o Princípio da Precaução apenas simbolicamente.

A compreensão e a resolução de problemas ambientais requerem a aplicação do melhor conhecimento científico disponível, uma vez que lidar com os meios físicos, químicos, biológicos e sociais e suas inter-relações implica na manutenção do equilíbrio ecológico, essencial à sobrevivência dos seres vivos, inclusive à espécie humana - com a satisfação de suas necessidades.

Entretanto, conforme os problemas ambientais têm se tornado cada vez mais complexos, a confiança dos dados e evidências científicas é fator crucial a ser considerado na informação adequada para tomada de decisões ambientais. Embora a incerteza científica e outras relacionadas às questões ambientais sejam bastante conhecidas pelos cientistas e gestores, são poucas as análises críticas da incerteza e suas implicações para o meio ambiente e a sociedade, nos quais consequências podem representar impactos ambientais e impactos na saúde da população em diferentes magnitudes (LEMONS, 1996). Os fundamentos da relação entre a Ciência e a Política são levantados por Lemons (1996) em:

Os tomadores de decisões normalmente baseiam suas decisões, em parte, sobre cálculos e conclusões tiradas de análises de riscos e de custo-benefício. As informações científicas são usadas como a base para tais cálculos e conclusões. Logo, sob condições de incerteza científica, especialmente quando cientistas não providenciam um tratamento explícito e rigoroso da incerteza científica na análise dos problemas específicos, os políticos e gestores aceitam as análises científicas como sendo a verdade absoluta. Tal suposição pode implicar em erros nos resultados dos procedimentos utilizados pelos políticos, assim como nas análises de riscos e de custo-benefício. Além disso, este viés não é aparentemente percebido por muitos tomadores de decisão, gestores, ou pelo público em geral a não ser que eles sejam avisados sobre as incertezas e suas implicações. (Lemons, 1996, p. 1) 
A banalização do tema e simplificação do conhecimento científico, com resultados indesejáveis com a omissão das incertezas, tem ocorrido não só devido aos interesses e posicionamento dos pesquisadores, políticos e jornalistas, mas também tem sido refletido em uma abrangência social que transcende para além do escopo da Ciência, da Política e dos meios de comunicação em massa. A crença e defesa de determinada ideologia extrapola as diversas áreas e atividades humanas, influenciando, inclusive, a indústria do entretenimento cinematográfico, o qual tem contribuído com o processo de difusão simplificada da realidade, muitas vezes não condizente com o grau necessário de informações requeridas nesta temática notadamente complexa.

Coincidente à publicação do último relatório do IPCC em 2007, o qual alegou que a contribuição humana no aquecimento global é predominante, foi lançado o filme "Uma Verdade Inconveniente" de Al Gore, político e vice-presidente dos EUA no mandato de Bill Clinton. Este filme teve grande repercussão e popularidade na época, tendo sido agraciado pelo Prêmio Nobel da Paz, juntamente com o IPCC. Neste filme foram utilizadas evidências científicas favoráveis ao aquecimento global antropogênico, mas que posteriormente foram alvo de muitas controvérsias, conforme levantam Onça e Felício (2008). Com tanta evidência popular, nesta época consagrouse o "consenso científico", que na verdade foi insistentemente pregado por Al Gore, um político.

As evidências utilizadas nas interpretações e atribuições de mudanças climáticas estão sujeitas a erros, incertezas, diferentes interpretações e até mesmo manipulações tendenciosas. Estes fatores representam o cerne da discussão científica em torno da polêmica do aquecimento global. Enquanto apoiadores da hipótese do aquecimento global antropogênico alegam um consenso científico, existe um movimento cético intenso tentando combater esta condição infiel da realidade.

\subsection{Ceticismo, Controvérsias e o Climategate}

Por que os céticos, ou aqueles que não concordam com algum aspecto da hipótese antropogênica das mudanças climáticas, não possuem tanta visibilidade? Primeiro que eles não fazem parte dos órgãos governamentais oficiais (ONU, IPCC), e não possuem o apoio da mídia, pois ambos os setores já adotaram o posicionamento favorável à influência humana no clima. Segundo que no campo da Ciência, os 
cientistas aquecimentistas recebem grande apoio financeiro dos órgãos financiadores, costumam ter equipes grandes e, logo, uma alta produtividade acadêmica. Com currículos extensos, os pesquisadores conseguem mais verbas, aumentam suas equipes e produção, conseguem mais recursos, e, assim, fica estabelecido um círculo vicioso.

Existe, enfim uma imensa organização, centralização e controle das informações ditando os rumos das pesquisas, valorizando aquelas que apóiam o aquecimento global, em detrimento daquelas que levantam as incertezas e pontos ainda controversos.

Em análise anterior, procedeu-se à escolha do NIPCC como um representante dos céticos, pois o documento publicado por eles conseguiu algo que não é comum aos céticos: agregar e centralizar, de forma organizada, as informações em um local único. Os céticos, não tendo o devido espaço na mídia de massa, buscaram refúgio no único local democrático, aberto a todos sem censura, e cada vez mais utilizado: a Internet.

Com a rede mundial de computadores - ferramenta facilitadora do acesso instantâneo a uma quantidade infindável de informações - tornou-se viável a divulgação de informações contrárias à hipótese antropogênica. A atuação e repercussão dos céticos tem sido cada vez mais intensa por meio de blogs e sites pessoais. Entretanto, apesar dos benefícios da Internet, nem toda população possui acesso a ela. Além disso, a informação se encontra descentralizada e difusa, dificultando a busca e o acesso a materiais de qualidade. Mesmo com a liberdade de expressão proporcionada por ela, ainda é deficiente a abrangência de público e o poder de formação de opinião devido à dispersão das informações.

Ainda assim, com a tendência de aumento da popularização da Internet, será maior a visibilidade e influência do ceticismo, pois neste meio as pessoas têm o contato e oportunidade do confronto de ideias diferentes. Assim, a partir da leitura e conjuntura de cada argumento, elas experimentam um processo ativo de formação de sua própria opinião, abandonando a passividade habitual proporcionada pelos meios de comunicação de massa, que noticiam parcial e tendenciosamente por já possuírem uma posição pré-estabelecida e comprometida com outros interesses. 
De uma forma geral, boa parte do material produzido pelo ceticismo climático é divulgada em blogs em Inglês ${ }^{73}$. Sites brasileiros ou em língua portuguesa ${ }^{74}$, as iniciativas são relativamente incipientes, mas crescentes. De um modo geral, com o aumento da popularidade na Internet, além de também terem tido a oportunidade de divulgarem seus estudos científicos, observações, opiniões e críticas, os céticos têm conquistado espaço em sites prestigiados de notícias.

Em relação às personalidades céticas no Brasil, destaca-se a atuação do Prof. Luiz Carlos B. Molion, do Prof. Ricardo Augusto Felicio, e da Prof. ${ }^{a}$ Daniela de Souza Onça, todos vinculados a universidades de renome. Uma produção expressiva de artigos em periódicos, jornais, fóruns, participações em eventos, entrevistas fazem parte do currículo destes pesquisadores, contrariando o argumento de que os céticos não publicam seus trabalhos. Dentre as publicações no meio acadêmico, evidenciam-se as contribuições de Onça (2007) e Rodrigues (2009), além de vários artigos de Molion, dentre eles os já citados ao longo do trabalho (MOLION, 2006, 2008). No âmbito de divulgação de pontos polêmicos do aquecimento global, merecem ser citados os livros em Português: Blüchel (2008), Veiga (2008) - o qual contém um Capítulo de Molion -, Maruyama (2009), Lino (2009) e Baptista (2009).

Todos os pesquisadores e pesquisas possuem em comum pontos controversos da hipótese do aquecimento antropogênico. Dentre os principais, podem ser destacados os pontos: se existe ou não aquecimento (dependendo das escalas temporais e espaciais adotadas); se ele é real ou culpa de efeitos não-climáticos (mudanças de técnicas de observação, dos tipos e locais dos instrumentos, ou nos microclima locais, como o efeito de ilhas de calor urbana); se o aquecimento recente é de causa humana ou natural; os modelos não são confiáveis; o nível do mar não tem subido além do esperado e não irá causar um grande dilúvio; o efeito estufa não é determinante no aquecimento; o papel da água no efeito estufa; os efeitos do aumento de $\mathrm{CO}_{2}$ pode ser

\footnotetext{
${ }^{73}$ Dentre os inúmeros, destacam-se:

http://wattsupwiththat.com/

http://joannenova.com.au/

http://climateaudit.org/

http://scienceandpublicpolicy.org/

${ }^{74}$ Destacam-se:

http://www.fakeclimate.com/

http://mitos-climaticos.blogspot.com/

http://ecotretas.blogspot.com/

http://www.midiaamais.com.br/
} 
benéfico para plantas; as temperaturas recentes não são sem precedentes; algumas reconstruções da temperatura no passado não foram elaboradas com critérios válidos, vide o conhecido caso Taco de Hóquei; etc.

Alguns destes assuntos foram abordados ao longo deste trabalho e muitos deles culminaram e se tornaram mais notórios com o caso que ficou conhecido Climategate $^{75}$, escândalo que surgiu pouco antes da conferência mundial de Copenhague. Neste episódio, milhares de arquivos e mensagens eletrônicas pessoais de cientistas prestigiados que colaboraram com o IPCC foram roubadas de um servidor da Universidade de East Anglia na Inglaterra e publicadas na Internet. O conteúdo vazado desses e-mails revelou que os autores manipularam e ocultaram dados que contradiziam o aquecimento climático. Na sequência deste evento, houve a divulgação de uma série de outros pontos controversos: Glaciergate $^{\gamma 6}$, onde foi afirmado, erroneamente nos relatórios do IPCC, que as geleiras no Himalaia iriam desaparecer até 2035; Amazongate ${ }^{77}$, afirmação baseada em um estudo sem bases científicas de que até $40 \%$ da Floresta Amazônica poderia reagir de forma drástica e ser substituída por savanas até mesmo por uma ligeira diminuição nas chuvas; Stationgate ${ }^{78}$, em relação ao desaparecimento de $70 \%$ dos dados de estação de temperatura que geraria a tendência de aquecimento.

Em meio a todo esse contexto polêmico nos meios científico, político e midiático, fica demonstrado que além de enfatizarem exageradamente notícias e até mesmo estudos científicos, buscando visibilidade e reconhecimento, também são capazes de manipular intencional e tendenciosamente dados e estudos, para demonstrar uma atribuição humana nas mudanças climáticas. Seria ideal que todos os envolvidos fossem mais éticos sobre as incertezas que cercam a temática, inclusive na

\footnotetext{
75 Nome dado em alusão ao escândalo político denominado de Watergate, que ocorreu nos EUA na década de 1970, resultando na renúncia do presidente norte-americano Richard Nixon.

${ }^{76}$ Inovação Tecnológica. IPCC divulgou alerta não-científico sobre geleiras do Himalaia. 20/01/2010. Disponível em: <http://www.inovacaotecnologica.com.br/noticias/noticia.php?artigo=climagate-2-ipcc-divulgou-alerta-naocientifico-sobre-geleiras-himalaia\&id=010125100120>. Acesso em 14 ago. 2010.

77 Inovação Tecnológica. NASA divulga estudo negando previsões do IPCC sobre a Amazônia. 12/03/2010. Disponível em: <http://www.inovacaotecnologica.com.br/noticias/noticia.php?artigo=nasa-divulga-estudonegando-previsoes-ipcc-sobre-amazonia\&id=0201751003120>. Acesso em 14 ago. 2010.

78 Inovação Tecnológica. Falhas de medição invalidam tese do aquecimento global, diz cientista. 17/02/2010. Disponível em: <http://www.inovacaotecnologica.com.br/noticias/noticia.php?artigo=falhas-medicao-invalidamtese-aquecimento-global-diz-cientista\&id=030175100217>. Acesso em 14 ago. 2010.
} 
esfera científica que tem demonstrado falta de honestidade e transparência nos métodos, dados utilizados e resultados gerados. Uma vez ignoradas as incertezas intrínsecas das evidências, tem sido assumido que as evidências já são suficientes para a tomada de decisão política. E o resultado das decisões políticas, em forma de leis, determina mudanças que trazem repercussões práticas a toda sociedade.

\subsection{Repercussões Práticas}

Disponíveis os interesses políticos, embasados no conhecimento científico e aliados à ampla atuação e apoio dos meios de comunicação, criou-se um clima propício no sentido de induzir ou forçar a mudança de atitudes e comportamentos da sociedade. A reformulação do sistema energético mundial para uma economia de baixo carbono inicialmente poderia ser alcançada por meio de iniciativas e compromissos voluntários - tais como os mecanismos de flexibilização (MDL, Créditos de Carbono, REDD) - ou por meio de obrigações legais dispostas em legislação. Em relação a este segundo aspecto, cabe acompanhar a evolução e avaliar como os decisões políticas têm surtido efeito prático na elaboração de leis no Brasil.

\subsubsection{Legislação}

Mesmo em um ambiente cercado de incertezas, controvérsias e interesses, os resultados políticos têm implicado em regulamentações que visam à mitigação e adaptação às mudanças climáticas.

No mundo, houve tentativas de se estabelecer um acordo vinculante, ou seja, com peso de lei, já que o Protocolo de Quioto parece não ter surtido efeito de redução de emissões e cumprido as metas voluntárias estabelecidas para os países desenvolvidos. Não foi em Copenhague que se atingiu um consenso político e pode ser que em 2010 também não seja obtido um acordo, conforme já citado anteriormente. Em termos mundiais, até então não há notícias de qualquer país que tenha assumido metas de redução de emissões prevendo a cobrança de taxações por meio da elaboração de leis. No Brasil, o cenário é um pouco diferente. Existem iniciativas de criação de leis no âmbito municipal, estadual e até mesmo nacional (Política Nacional sobre Mudança do Clima). Segue um resumo das leis que foram encontradas. 
Em 2007, no Estado do Amazonas, a Lei Estadual n. 3.135, de 05 de junho de 2007, instituiu a "Política Estadual sobre Mudanças Climáticas, Conservação Ambiental e Desenvolvimento Sustentável do Amazonas". Em seu artigo segundo, alínea "b", está determinada a adoção do princípio da precaução, "representado pela prática de procedimentos que, mesmo diante da ausência da certeza científica formal acerca da existência de um risco de dano sério ou irreversível, permitam prever esse dano, como garantia contra os riscos potenciais que não possam ser ainda identificados, de acordo com o estado atual do conhecimento". Ponto que merece destaque nesta Lei é em relação aos instrumentos financeiros e fiscais, em que é prevista a participação do Poder Público Estadual em uma Fundação Privada, à qual o governo está a efetuar doação no valor de até $\mathrm{R} \$ 20.000 .000,00$ (vinte milhões de reais).

Em 2008, entrou em vigor em Tocantins a Lei Estadual n. 1.917, de 17 de abril de 2008, instituindo a "Política Estadual sobre Mudanças Climáticas, Conservação Ambiental e Desenvolvimento Sustentável do Tocantins". O princípio de precaução está identicamente reproduzido a partir do texto da Lei Estadual do Amazonas. Não há nenhum outro trecho relevante.

O ano de 2009 apresentou a publicação de uma quantidade expressiva de leis. Foram sancionadas leis no Município de São Paulo, no Estado de São Paulo e a Política Nacional sobre a Mudança do Clima.

A cidade de São Paulo publicou a Lei 14.933, de 5 de junho de 2009, que instituiu a "Política de Mudança do Clima no Município de São Paulo". No inciso segundo do artigo primeiro, também é adotado o princípio da precaução, "segundo o qual a falta de plena certeza científica não deve ser usada como razão para postergar medidas de combate ao agravamento do efeito estufa". Possui como diretriz (art. $3^{\circ}$, inciso XII) a "utilização de instrumentos econômicos, tais como isenções, subsídios e incentivos tributários e financiamentos, visando à mitigação de emissões de gases de efeito estufa" e como o objetivo (art. $4^{\circ}$ ) "permitir que o desenvolvimento econômico prossiga de maneira sustentável". A Lei Municipal foi a primeira a estabelecer metas de redução de gases do efeito estufa: "Art 5. fica estabelecida para o ano de 2012 uma meta de redução de 30\% das emissões antrópicas agregadas oriundas do Município (...) em relação ao patamar expresso no inventário realizado pela Prefeitura Municipal de São Paulo e concluído em 2005".

No Estado de São Paulo, em 9 de novembro de 2009, foi aprovada e sancionada a "Política Estadual de Mudanças Climáticas - PEMC" (Lei Estadual n. 
13.798). É pressuposto o princípio da precaução (art. $2^{\circ}$ ), "pelo qual a ausência de certeza científica não pode ser utilizada como razão para postergar medidas eficazes para prevenir a degradação ambiental quando houver ameaça de danos sérios ou irreversíveis à civilização humana". Estão previstos incentivos econômicos aos setores mais limpos, bem como desincentivos aos mais poluentes. Incentivos poderão ser dados de diversas formas: subsídios, desonerações, financiamentos; e desincentivos poderão ser feitos por meio de regulamentações e até eventuais taxações, conforme é apresentado no artigo 22: "Para os objetivos desta lei, o Poder Executivo deverá: II estabelecer preços e tarifas públicas, tributos e outras formas de cobrança por atividades emissoras de gases de efeito estufa". É assumida pelo governo estadual, no art. 32, a meta de redução global de $20 \%$ (vinte por cento) das emissões de dióxido de carbono, relativas a 2005, em 2020.

No final do ano de 2009, no dia 29 de dezembro, foi sancionada, pelo Presidente da República, a "Política Nacional sobre Mudança do Clima - PNMC" (Lei Federal n. 12.187). A PNMC observará o princípio da precaução, porém não declara o argumento da ausência de certeza científica. Um dos instrumentos da PNMC é (art. $6^{\circ}$, inciso VI) "medidas fiscais e tributárias destinadas a estimular a redução das emissões e remoção de gases de efeito estufa, incluindo alíquotas diferenciadas, isenções, compensações e incentivos". E "para alcançar os objetivos da PNMC, o País adotará, como compromisso nacional voluntário, ações de mitigação das emissões de gases de efeito estufa, com vistas em reduzir entre $36,1 \%$ e 38,9\% suas emissões projetadas até 2020." (art. 12).

Em 2010, foram publicadas leis no Estado do Rio de Janeiro (Lei $\mathrm{n}^{0} 5.690$, de 14 de abril de 2010) - que adota o princípio da precaução, mas não faz menção à falta de certeza científica - e em Pernambuco (Lei $\mathrm{n}^{\circ}$ 14.090, de 17 de junho de 2010), que não cita o princípio da precaução, mas prevê a criação de instrumentos econômicos, financeiros e fiscais. E por fim, existe um Projeto de Lei no Rio Grande do Sul da "Política Gaúcha de Mudanças Climáticas - PGMC", que possui o princípio da precaução como um dos princípios e também possui como objetivo instrumentos econômicos, financeiros e fiscais.

Em todas as leis existe um ponto em comum na citação da "Convenção Quadro das Nações Unidas sobre Mudança do Clima", a qual estabelece em seu artigo 3.3 que: 
As Partes devem tomar medidas cautelares para antecipar, prevenir ou minimizar as causas da mudança do clima e mitigar seus efeitos negativos. Quando houver ameaça de danos sérios ou irreversíveis, a ausência de certeza científica absoluta não deverá ser utilizada como razão para postergar essas medidas (...) (UNITED NATIONS, 1992a).

A ideia do princípio da precaução também está presente na Convenção da Biodiversidade de 1992, na Agenda 21 e no princípio 15 da Declaração do Rio de 1992:

De modo a proteger o meio ambiente, o princípio de precaução deve ser amplamente observado pelos Estados, de acordo com suas capacidades. Quando houver ameaça de danos sérios ou irreversíveis, a ausência de absoluta certeza científica não deve ser utilizada como razão para postergar medidas eficazes e economicamente viáveis para prevenir a degradação ambiental. (UNITED NATIONS, 1992b).

Sintetizando, toda legislação até então elaborada é baseada em um princípio que ignora totalmente discussão acerca das incertezas cientificas inerentes. Tal procedimento demonstra que não importa se existe ou não consenso científico, pois o que é válido é o consenso político na criação dessas leis. Boa parte das leis cria diversos planos, mecanismos, instrumentos e procedimentos que visam o combate às mudanças do clima. Dentre as opções de solução, algumas leis já preveem o uso de instrumentos financeiros, inclusive por meio da cobrança de taxas e impostos.

No contexto mundial, a situação do encaminhamento de legislação pertinente ao controle de carbono está no caminho contrário ao adotado no Brasil, ocorrendo casos, inclusive, de países recuando na adoção de cobrança de taxas ou impostos. Em setembro de 2009, a França foi primeiro país do mundo a criar um imposto sobre a emissão de dióxido de carbono ${ }^{79}$. O curioso é que imposto seria aplicado a residências e a empresas, mas não a indústrias pesadas e do setor energético que estão incluídas no esquema de comércio de emissões da União Europeia. O imposto iria cobrir $70 \%$ das emissões no país e trazer 4,3 bilhões de euros anualmente para os cofres públicos. O imposto tinha como objetivo inicial persuadir os franceses a mudar os hábitos e reduzir o consumo de energia. Porém, na prática, o imposto aumentaria os custos dos

79 BBC Brasil. França anuncia novo imposto para combater aquecimento global. 10/9/2010. Disponível em: <http://www.bbc.co.uk/portuguese/noticias/2009/09/090910_francacarbonog.shtml>. Acesso em: 14 ago. 2010. 
lares franceses com aquecimento, além de aumentar o preço dos combustíveis. Provavelmente por este motivo, cerca de $75 \%$ dos franceses se opuseram ao imposto ${ }^{80}$, o que pode ter pressionado e conduzido o governo a abondonar, no final de março de 2010, a proposta da taxa de carbono ${ }^{81}$. Entre outros motivos, a aplicação dessa taxa seria muito complicada e possuía muitas isenções em favor dos maiores poluidores, além de ser alegado que a mesma deveria ser aplicada em nível europeu e não pesar na competitividade das empresas francesas. Na Austrália, em março de 2010, foi engavetado por dois anos o projeto de lei de cobrança de taxas de emissões de carbono $^{82}$, sendo alegado que a eventual aprovação da lei no ano eleitoral poderia surtir efeitos eleitorais colaterais: o preço da energia subiria, enfurecendo os eleitores e tirando votos do partido governista.

\subsection{Considerações finais}

Longe de esgotar o tema ou de fazer um levantamento e avaliação dos argumentos com dados científicos favoráveis ou não à questão do aquecimento global antrópico, este capítulo teve a intenção de levantar os principais atores e argumentos envolvidos no processo da discussão das mudanças climáticas globais, assim como procurou identificar de que forma os interesses estão sendo apresentados, debatidos, arbitrados e decididos.

De tantas possíveis reflexões, apenas uma conclusão pode ser aqui inferida: a controversa questão das mudanças climáticas do aquecimento global ainda não acabou, pois ainda não há consenso científico estabelecido. E neste processo todo, em que o poder da Política parece prevalecer perante a Ciência, fica o questionamento: quais seriam os verdadeiros interesses dos governos no alarmismo do aquecimento global? Estariam os representantes dos governos defendendo algum interesse econômico por trás de todo este contexto?

\footnotetext{
80 Folha Online. Imposto sobre CO2 é rejeitado por $\mathbf{7 5 \%}$ dos franceses. 11/09/2009. Disponível em: $<$ http://www1.folha.uol.com.br/folha/ambiente/ult10007u622483.shtml>. Acesso em: 14 ago. 2010.

81 Ambientebrasil. Governo francês abandona projeto da taxa carbono. 24/03/2010. Disponível em: $<$ http://noticias.ambientebrasil.com.br/clipping/2010/03/24/52619-governo-frances-abandona-projeto-da-taxacarbono.html >. >. Acesso em: 14 ago. 2010.

82 Ambientebrasil. Austrália engaveta lei contra emissões de carbono. 28/04/2010. Disponível em: $<$ http://noticias.ambientebrasil.com.br/clipping/2010/04/28/54226-australia-engaveta-lei-contra-emissoes-decarbono.html>. Acesso em: 14 ago. 2010.
} 
Um exemplo típico e bastante conhecido, assumido abertamente, foi o caso em que, durante vigência do presidente W. Bush no poder, os EUA se recusaram ratificar $^{83}$ o Protocolo de Quioto sob a justificativa de causaria sérios prejuízos à economia norte-americana, cuja matriz energética é fortemente baseada no consumo de combustíveis fósseis, notadamente o petróleo. Mas, e nos demais países, favoráveis ao aquecimento global, o que justificaria tal postura? Várias teorias conspiratórias são difundidas, desde a perspectiva de promissoras fontes de recursos financeiros com o mercado de carbono $^{84}$, e o favorecimento outras fontes de energia, como nuclear e biodiesel etc.

Já quanto aos céticos do aquecimento global antropogênico, estes cientistas que questionam o "consenso científico", são acusados de serem financiados pela indústria de energia (carvão, petróleo) e de acreditarem que a noção das mudanças climáticas antropogênicas é uma conspiração.

Certo ou errado, não importa o lado, todos têm algum interesse em apoiar ou recusar a associação do papel humano no aquecimento global. O fato é que o aquecimento global pode representar a fórmula mágica para desatrelar o carbono da produção e do consumo, sendo capaz de realizar o sonho dos ambientalistas de uma sociedade igualitária, baseada na rejeição do crescimento econômico em favor de populações reduzidas, muito menos consumistas, mas capazes de compartilhar um nível muito maior de recursos e com muito mais igualdade. (WILDAVSKY, [199?] apud LINDZEN, 1992).

Mas esta utopia parece não ser viável. Fica nítido que as prioridades do mundo são outras: na "Tabela 1.12 - As prioridades do mundo?" do Relatório de Desenvolvimento Humano de 1998 da ONU (PNUD, 1998, Cap. 1, pg. 37), são apresentadas estimativas dos custos anuais para garantir acesso universal a serviços sociais básicos nos países em desenvolvimento.

Em 1998, para garantir a todas as pessoas no mundo que ainda não tem acesso aos serviços, seriam necessários (PNUD, 1998):

- US\$ 6 bilhões para garantir a educação básica;

83 FOLHA ONLINE. Washington reitera rejeição ao Protocolo de Kyoto. 30/09/2004. Disponível em $<$ http://www1.folha.uol.com.br/folha/mundo/ult94u77051.shtml>. Acesso em 20 jun. 2009.

84 ESTADÃO ONLINE. Mercado de CO2 fica mais rentável e eficiente. 28/01/2009. Disponível em <http://www.estadao.com.br/vidae/not_vid183994,0.htm>. Acesso em 23 jun. 2009. 
- US\$ 9 bilhões para oferecer água potável e saneamento básico;

- US\$ 13 bilhões para proporcionar saúde básica e condições mínimas de nutrição.

Enquanto isso, eram gastos anualmente:

- US\$ 9 bilhões com cosméticos nos EUA;

- US\$ 11 bilhões com sorvetes na Europa;

- US\$ 17 bilhões com comida para animais de estimação nos EUA;

- US\$ 35 bilhões com a indústria de entretenimento no Japão;

- US\$ 50 bilhões com cigarros na Europa;

- US\$ 100 bilhões com bebidas alcoólicas na Europa;

- US\$ 400 bilhões com drogas narcóticas no mundo; e

- US\$ 780 bilhões com o militarismo mundial.

Isso tudo, há 10 anos atrás. Considerando que o PIB era de aproximadamente 30 trilhões de dólares em 1998 e que atualmente (2008) ele é de cerca de US\$ 60 trilhões ${ }^{85}$, os valores citados anteriormente seriam atualizados para o dobro, supondo que as proporções se mantiveram praticamente as mesmas.

Atualmente, para implementação de medidas de redução de emissões e/ou captura do gás carbônico e controlar o aquecimento global, seria necessário gastar cerca de $1 \%$ do PIB mundial, de acordo com o Relatório Stern ${ }^{86}$, para assim poder evitar a perda de $20 \%$ do mesmo PIB nos próximo 30 anos, devido aos impactos das alterações climáticas. De acordo com McKinsey \& Company (2009) esse 1\% representa algo entre US\$ 256 bilhões a US\$ 448 bilhões anualmente até 2030. Considerando o PIB de US\$ 60 trilhões, poderia alcançar a quantia de até 600 bilhões de dólares.

De forma a ilustrar tais montantes de dinheiro, são apresentados na Figura 122 os valores necessários para solucionar alguns problemas urgentes e concretos da humanidade, os gastos desnecessários de algumas atividades supérfluas, e os gastos previstos para combater o aquecimento global. No gráfico da esquerda (A), são

\footnotetext{
${ }^{85}$ Segundo o Banco Mundial. The World Bank Data. 2010. Disponível em <http://data.worldbank.org/>. Acesso em 14 ago. 2010.

${ }^{86}$ Disponível em <http://www.hm-treasury.gov.uk/sternreview_index.htm>. Acesso em: 20 jun. 2009.
} 
exibidos os valores em escala normal e à direita [gráfico (B)] são exibidos os valores em escala logarítmica, com acréscimo de alguns exemplos mais palpáveis e cotidianos de referência.

A relação das mudanças climáticas com outros problemas humanitários têm sido frequente em várias reuniões entre entidades internacionais. Por exemplo, a "Terceira Conferência Mundial do Clima", realizada em setembro de 2009, teve a intenção contribuir com o alcance das "Metas de Desenvolvimento do Milênio", acordo internacional promovido pela ONU em 2000 que pretende, até 2015, acabar com a extrema pobreza e a fome; combater a AIDS e a mortalidade infantil, entre outras metas de um total de oito metas (WMO, 2010).

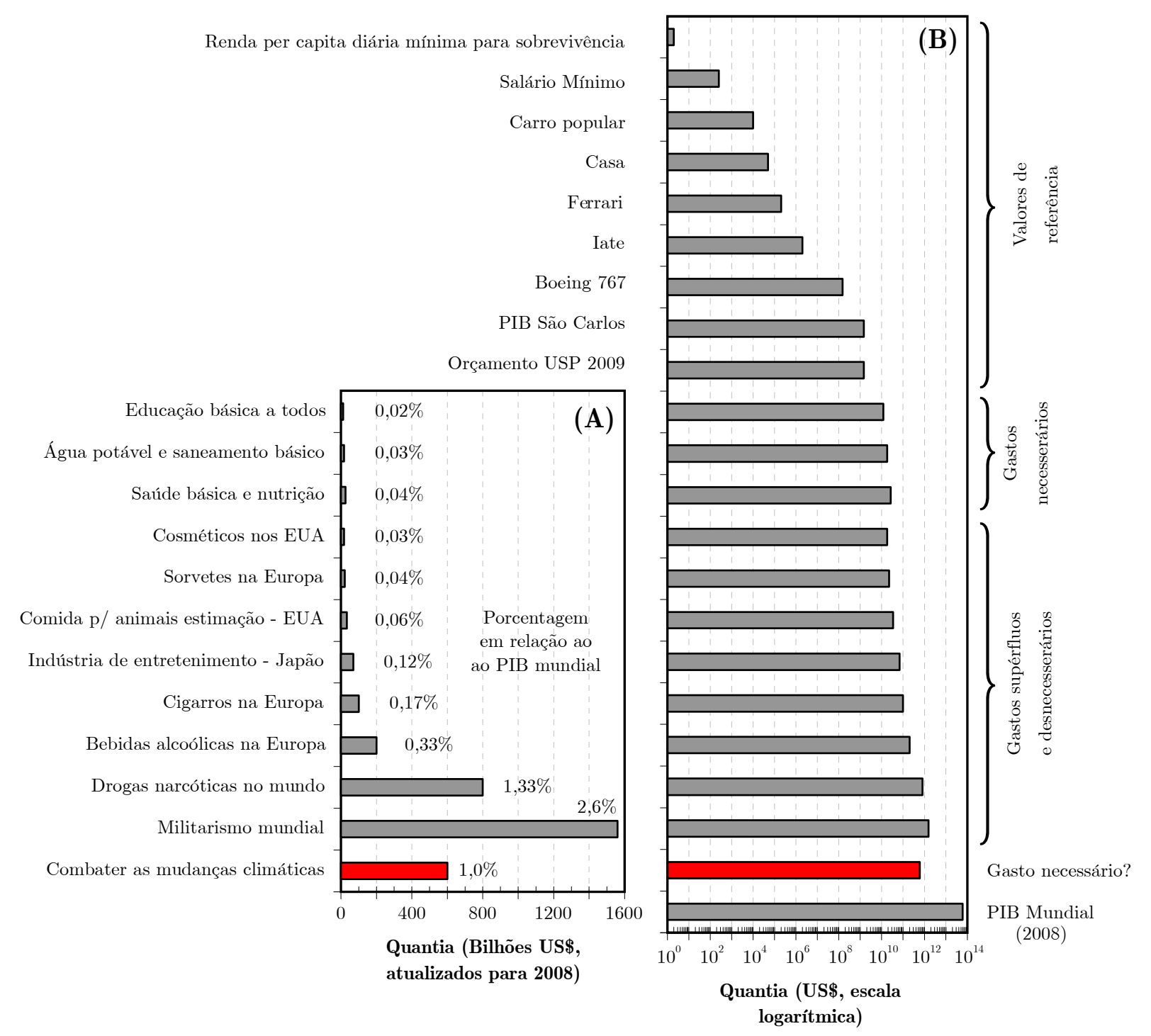

Figura 122 - Gastos com mudanças climáticas (vermelho) em relação aos (A) gastos mundiais (escala normal) e (B) valores cotidianos (escala logarítmica). 
Depois de levantados todos estes números e valores, indaga-se: de que servem todos esses acordos, convenções e metas se nenhum deles é colocado efetivamente em prática? Houve a criação da Agenda 21 em 1992, mas onde está o tão sonhado Desenvolvimento Sustentável? Houve a Convenção-Quadro das Nações Unidas sobre a Mudança do Clima, depois o Protocolo de Quioto em 1997, e na sequência vários documentos do IPCC; onde está o consenso se existe ou não aquecimento global antropogênico? E se realmente existe, onde as metas de emissões estão sendo cumpridas? Se elas serão cumpridas pelas indústrias e empresas, eles terão prejuízo ou externalizarão os custos para manter seus lucros ${ }^{87}$ ? Em 2000 foram estabelecidas as Metas do Milênio, mas porque ainda persistem a fome, o analfabetismo, a ocorrência de doenças e de desigualdade entre os sexos? E será que até 2015, ou seja, em menos de 5 anos, todos ou pelos menos parte destes problemas serão sanados ou reduzidos?

Parece que tais acordos são apenas formosos no papel, tornando-se pura demagogia devido ao seu efeito prático insatisfatório, quase nulo, demonstrando ampla falta de interesse real na intenção de contribuir com o respeito à vida, das pessoas e da natureza. "Acima dos discursos, é preciso considerar o que tem sido feito na prática em nome da precaução ante a ameaça do 'aquecimento global' [...] assim como o que se planeja fazer. Quem ganha com isso? [...]" (FELÍCIO, ONÇA E VILELA, 2009).

Acordos podem demonstrar a intenção, mas não representam um interesse real demonstrado por meio de atitudes concretas. Parece que, para que certos fatos ocorram não são necessários acordos, mas, sim, determinados interesses, como foi o recente caso da crise econômica de 2009 e os pacotes econômicos dos EUA: um pacote lançado em 2008, no valor de 700 bilhões de dólares ${ }^{88}$, e outro em 2009 com mais US\$ 819 bilhões $^{89}$.

Nesta crise econômica de 2009, a indústria financeira internacional recebeu quase dez vezes mais dinheiro público em ajuda do que todos os países pobres em

87 ESTADÃO ONLINE. Grandes empresas querem dinheiro para cortar C02. 25/05/2009. Disponível em $<$ http://www.estadao.com.br/vidae/not_vid376707,0.htm>. Acesso em 23 jun. 2009.

${ }^{88}$ FOLHA ONLINE. Câmara aprova pacote bilionário para setor financeiro nos EUA. 03/10/2008. Disponível em $<$ http://www1.folha.uol.com.br/folha/dinheiro/ult91u451790.shtml>. Acesso em 20 jun. 2009.

${ }^{89}$ FOLHA ONLINE. Deputados dos EUA aprovam pacote de US\$ 819 bi para estimular economia. 28/01/2009. Disponível em <http://www1.folha.uol.com.br/folha/dinheiro/ult91u495577.shtml>. Acesso em 20 jun. 2009. 
meio século, segundo apontou um relatório divulgado pela Campanha da ONU pelas Metas do Milênio ${ }^{90}$. Os países em desenvolvimento receberam, em 49 anos, o equivalente a US\$ 2 trilhões em doações de países ricos, enquanto que, em um ano, os bancos e outras instituições financeiras ameaçadas pela crise global receberam US $\$ 18$ trilhões em ajuda pública. O relatório da Campanha pelas Metas do Milênio argumenta que a destinação de dinheiro ao desenvolvimento dos países mais pobres não é uma questão de falta de recursos, mas sim de vontade política. "O que é ainda mais paradoxal é que esses compromissos (firmados pelos países ricos para ajudar os pobres) são voluntários. Ninguém os obriga a firmá-los, mas logo eles são renegados", lamentou o diretor da Campanha pelas Metas do Milênio, Salil Shetty.

Nesta miscelânea de valores, o quê parece que realmente interessa? Quais as prioridades do mundo e dos governantes? Estaria a Economia, de interesse privado, acima do Meio Ambiente, de interesse coletivo? Desnecessário responder. Em suma, "A Ciência Climática já não representa mais uma verdade imparcial, mas sim um subterfúgio para o entrelaçamento entre a política e o oportunismo.", sintetiza McLean (2009). Mesmo com um discurso de caráter coletivo, humanista e sustentável, o oportunismo fica sujeito à possibilidade do discurso das mudanças climáticas de tornarem um meio para satisfação de uma finalidade econômica.

90 BBC Brasil. Ajuda a bancos em 1 ano supera a para países pobres em 50, diz relatório. 24/06/2010. Disponível em: <http://www.bbc.co.uk/portuguese/noticias/2009/06/090624_relatoriobancos_rw.shtml>. Acesso em 20 jun. 2009 . 



\section{CONCLUSÃO}

No contexto da possível atribuição dos impactos da responsabilidade da ação antrópica nas mudanças climáticas globais, esta pesquisa permitiu verificar que existem fatores inerentes ao processo de medição e obtenção da temperatura do ar, grandeza física que representa o parâmetro-chave nas discussões do clima passado, atual e principalmente no clima futuro. Sobretudo, foi possível constatar quantitativamente as causas e efeitos de heterogeneidades mais comuns interferentes nos valores resultantes das medições e das metodologias de cálculos da temperatura do ar obtida em estações terrestres.

Embora não tenha sido o objetivo principal ter discutido a magnitude nem testado a validade dessas mudanças atuais, alguns aspectos abordados na extensa revisão do tema no "CAPÍTULO 2 - Variabilidade e Mudanças Climáticas Globais" (pg. 41) forneceram evidências de que a temperatura do ar tem variado consideravelmente na história da Terra, em diferentes escalas temporais e espaciais. Além disso, o conhecido "aquecimento global" não denota que está ocorrendo um aquecimento em todas as regiões terrestres, mas sim que a temperatura média na superfície terrestre tem supostamente aumentado. Ou seja, ficou demonstrado que o hemisfério norte tem sofrido um aquecimento maior em relação ao hemisfério sul, este que apresenta, inclusive, regiões de resfriamento próximas à Antártida.

De todas as séries de temperatura apresentadas - desde as reconstruções paleoclimáticas, registros históricos em estações de superfície (tanto terrestre quanto nos oceanos) e registros mais recentes da temperatura obtida por sensoriamento remoto (satélites) -, aquelas obtidas por estações em superfície tem sido amplamente utilizadas como evidências de que a Terra está esquentando.

Após a revisão de dados secundários de pesquisas, artigos e publicações internacionais no segundo capítulo, uma abordagem inicial de séries - obtidas em estações terrestres - de casos brasileiros foi conduzida no "CAPÍTULO 3 Caracterização e Tendências Climáticas Locais", pg. 117. Utilizando-se igualmente de dados secundários, as interpretações decorrentes de séries locais, com base no estudo de normais climatológicas, permitem concluir que o aumento da temperatura média não quer dizer que o clima está esquentando de um modo geral e que os períodos 
diurnos estão ficando mais quentes. O fato é que, no cálculo das normais, a temperatura média é embasada nos valores máximos e mínimos, que, combinados, podem apresentar variações diferentes e implicar em resultados igualmente diferentes na temperatura média. Por exemplo, o aumento da temperatura média pode acontecer sem mesmo que as temperaturas máximas aumentem, desde que as temperaturas mínimas sofram um incremento em seus valores. Logo, neste caso foi possível acontecer um aquecimento que não provocou dias mais quentes, mas na verdade, fez com que as noites estivessem "menos frias" (mais quentes).

As análises dos dados secundários no Capítulo 3 não permitiram identificar as diferentes causas de mudanças significativas nos valores observados entre dois períodos normais utilizados, devido à limitação da escala disponível, representada pelas médias de 30 anos de dados. Apenas suposições de possíveis fatores foram levantadas (como, por exemplo, as possíveis mudanças da localização da estação e/ou alterações nos entornos do local das medições), porém tais alegações só poderiam ser confirmadas com acesso aos dados originais diários. Com isso, justificou-se a necessidade de estudar, com um olhar mais detalhado e aprofundado, algumas séries que tivessem disponíveis dados na escala de dados diários e mensais. Na ocasião, estavam à disposição séries de temperatura obtidas no Centro de Recursos Hídricos e Ecologia Aplicada (CRHEA-EESC-USP). Todavia, cada série possuía períodos distintos de medição, e, além disso, haviam sido registradas em equipamentos diferentes.

Perante a oportunidade - e na possibilidade de se comparar as séries que possuíam algum período em sobreposição, ou seja, períodos em que as temperaturas haviam sido coletadas concomitantemente - foram confrontadas as séries em diferentes situações de: mudanças no cálculo de médias ("CAPÍTULO 4 - Mudanças dos Horários de Observações e dos Cálculos de Médias", pg. 159), mudanças dos tipos de instrumentos utilizados nas medições ("CAPÍTULO 5 - Mudanças dos Instrumentos", pg. 219), e mudanças dos abrigos protetores dos sensores de temperatura ("CAPÍTULO 6 - Mudanças dos Abrigos", pg. 237).

Nos Capítulos 4 e 5, os dados utilizados foram semi-primários, ou algo intermediário entre dados secundários (baseados em resultados de publicações) e dados primários (baseados em medições realizadas pelo próprio autor/pesquisador). Ou seja, os dados não foram coletados pelo responsável pelo presente estudo, mas eles estavam na forma "bruta", não trabalhados, e exigiram um certo controle de qualidade e realização de cálculos e índices estatísticos. Portanto, mesmo em relação 
às séries tomadas como referências nas comparações, não se pode afirmar com certeza se tais equipamentos estavam, de fato, calibrados e com manutenção em dia.

Já em relação ao Capítulo 6, os dados foram essencialmente primários, uma vez que foi realizada desde a montagem da estação, sua operação e manutenção, calibração dos sensores, coleta de dados além de das etapas posteriores, que são comuns a todos os casos. Este capítulo se destaca também com o diferencial da abordagem dinâmica do clima, aspecto que não foi considerado nos demais capítulos. A inovação em ter utilizado a abordagem dos processos sob o ponto de vista da Climatologia Dinâmica, permitiu identificar episódios representativos do clima e dias típicos experimentais na medida necessária para o entendimento dos diferentes comportamentos das influências nos abrigos em diferentes condições do tempo, especialmente em relação à radiação e à velocidade dos ventos.

Nestes capítulos foi verificada, frequentemente, a ocorrência de falhas de dados (as quais todas foram identificadas e exibidas) e erros nas séries de dados analisados. Antes mesmo da aquisição do valor da temperatura, a ocorrência de falhas é algo recorrente, mas geralmente pouca importância é reservada a este tipo de erro. No caso de dados faltantes, os critérios da OMM estabelecem se determinado mês será considerado ou excluído do cálculo das médias. Existem métodos de preenchimento de falhas, que não foram utilizados aqui, mas estes estão sujeitos a subjetividades de quem tenta preencher as lacunas. Este é uma área que demanda um estudo aprofundado, uma vez que a maioria dos gráficos comumente exibidos nos estudos climáticos apresenta linhas contínuas da variação da temperatura, ainda que mostrem, na maioria dos casos, uma área correspondendo ao intervalo de erro ou confiança. De qualquer forma, a curva ajustada é uma aproximação dos valores disponíveis com extrapolações não necessariamente coincidentes aos valores reais não mensurados.

Quanto aos erros nas séries de dados, estes ocorreram durante ou após a medição do valor da temperatura do ar. Os erros aleatórios estavam associados a deslizes na leitura nos instrumentos analógicos, na digitação do valor anotado em computador e no arredondamento de valores. Erros sistemáticos e tendenciais foram aqueles responsáveis pela ocorrência de heterogeneidades, ou seja, uma descontinuidade sistemática artificial que pode ser evidenciada por variações bruscas, fáceis de serem identificadas, ou variações graduais e menos perceptíveis.

Uma breve análise de alguns erros aleatórios diários permitiu inferir que, por um lado, a magnitude deles pode ser alta, na ordem acima de $10^{\circ} \mathrm{C}$. Por outro lado, a 
frequência de ocorrência destes valores discrepantes é relativamente baixa em uma série grande de dados. Logo, dependendo da exorbitância do valor, estes erros não são propagados de forma expressiva nas médias mensais e anuais, mas cada caso deve ser analisado individualmente.

Quanto aos erros sistemáticos, estes demandaram maior atenção ao longo de todo trabalho, sendo que foi dedicado exclusivamente um capítulo para determinação das diferentes situações de ocorrência de heterogeneidades. Em suma, os valores aproximados da influencia de cada heterogeneidade, em termos de desvios horários, diários, mensais, anuais, interanuais e normais (quando possível em cada caso), estão sintetizados na Tabela 25. Nesta tabela, de um modo geral, pode ser estabelecido que quanto mais próximos os valores observados nos índices estatísticos estiverem do zero, mais compatíveis as séries analisadas estão em concordância com a respectiva referência adotada em cada caso.

Não convém aqui estabelecer especificamente quais foram os métodos e/ou instrumentos mais condizentes com as séries adotadas como referência, já que esta etapa já foi elaborada no decorrer de cada capítulo. Cabe analisar os desvios obtidos em cada escala e comparar o comportamento de uma forma mais ampla.

Assim, para facilitar a compreensão de uma forma mais imediata, elaborou-se uma nova tabela (Tabela 26) em que: os valores foram ordenados primeiro em ordem crescente pela escala, e em seguida em ordem decrescente em relação ao valor dos desvios positivos máximos; e a cada valor foi atribuída uma coloração específica de fundo, o qual representa sua importância relativa aos demais valores dentro da mesma coluna. Ou seja, ao maior valor absoluto de uma coluna é atribuída a cor vermelha, e ao menor valor absoluto (mais próximo de zero) é atribuída a cor verde clara. Por exemplo, na coluna de desvio positivo máximo, o valor $13,3{ }^{\circ} \mathrm{C}$ recebeu a cor vermelha mais intensa, enquanto que os valores nulos foram coloridos de verde intenso. Os valores intermediários receberam cores em dégradé, cujas tonalidades variam proporcionalmente às posições relativas dos valores na escala adotada. Assim por diante foi feita, individualmente, a coloração nas demais colunas, cada uma com uma extremos diferentes. Portanto, as colorações entre as colunas não são compatíveis, ou seja, mesmo valores idênticos em colunas diferentes podem possuir cores desiguais.

Interpretando visualmente, pode-se perceber que os maiores desvios (de colorações vermelha e próximas dela) estão concentrados na parte superior da Tabela 
26, cujas linhas são referentes à escala horária das medições da temperatura do ar. Conforme vai descendo pela tabela e, assim, aumentando em direção às escalas superiores (diária, mensal, anual e normal), os valores dos desvios vão adquirindo tonalidades mais próximas do verde (menores ou mais próximos de zero). Conclui-se, portanto, que o aumento da escala de abordagem diminui proporcionalmente os desvios observados entre as séries analisadas em relação às séries assumidas como referência. Esta inferência fica nítida ao se observar os gráficos da Figura 123.

Nota-se que conforme a escala vai aumentando, os desvios vão diminuindo. $\mathrm{Na}$ Figura 123, onde foram plotados os valores positivos máximos e negativos mínimos dos desvios de todas as séries e escalas, a ordem de grandeza envolvida em cada escala é de aproximadamente (com base nas curvas de tendência aproximadas): $10,0^{\circ} \mathrm{C}$ na escala das medições horárias; $5,0^{\circ} \mathrm{C}$ na escala das médias diárias; $2,0^{\circ} \mathrm{C}$, na escala mensal; $1,0^{\circ} \mathrm{C}$ na escala anual; e $1,5^{\circ} \mathrm{C}$ na escala normal de exibição dos valores médios da temperatura do ar. Pelo detalhe do gráfico (B), percebe-se que a ordem dos valores dos desvios na escala normal é um pouco superior que da escala anterior, anual. Isso se deve ao fato de a comparação não ter sido realizada de forma ideal. Ou seja, foram comparadas séries de 5 anos de dados com a série normal de 30 anos. Logo, a comparação na escala de normal climatológica (média de 30 anos de dados) foi prejudicada e não completamente válida, tendo um significado apenas ilustrativo. Com comparações de séries completas de 30 anos, os desvios deveriam provavelmente apresentar valores na ordem de $0,5^{\circ} \mathrm{C}$. Ressalva-se que neste tipo de análise foram utilizados os valores extremos, tanto positivos quanto negativos, e que uma percepção mais representativa seria utilizar todos os desvios disponíveis nas séries. 
Tabela 25 - Síntese estatística dos desvios, por tipo de heterogeneidade, em diferentes escalas, de todas as séries estudadas.

\begin{tabular}{|c|c|c|c|c|c|c|c|c|c|}
\hline \multicolumn{4}{|c|}{ Informações das séries } & \multicolumn{6}{|c|}{ Índices estatísticos $\left({ }^{\circ} \mathrm{C}\right)$} \\
\hline$C^{1}$ & $\mathrm{~T}^{2}$ & $\begin{array}{c}\text { Desvio } \\
\text { (Série - Referência) }\end{array}$ & Escala & Máx. & Mín. & $\begin{array}{l}\text { Desvio } \\
\text { padrão }\end{array}$ & $\begin{array}{c}\text { Média dos } \\
\text { desvios }\end{array}$ & $\begin{array}{c}\text { Intervalo } \\
\text { confiança } \\
(95 \%)\end{array}$ & $\begin{array}{l}\text { Tendência } \\
\text { no período }\end{array}$ \\
\hline \multirow{26}{*}{4} & \multirow{6}{*}{$5 / 5$} & \multirow{4}{*}{$T_{M-m}-T_{\text {automática }}$} & Diária & 11,7 & $-8,4$ & 1,0 & $-0,5$ & $-2,5-1,3$ & $-0,55$ \\
\hline & & & Mensal & 1,1 & $-1,0$ & 0,6 & $-0,2$ & $-0,9-1,0$ & $-0,56$ \\
\hline & & & Anual & 0,3 & $-0,6$ & 0,3 & $-0,2$ & $-0,6-0,2$ & $-0,48$ \\
\hline & & & Diária & 6,5 & $-5,0$ & 1,3 & $-0,1$ & $-2,6-2,4$ & 0,37 \\
\hline & & \multirow{2}{*}{$T_{9-21-M-m}-T_{\text {automática }}$} & Mensal & 0,4 & $-1,9$ & 0,5 & $-0,5$ & $-1,5-0,4$ & 0,47 \\
\hline & & & Anual & $-0,3$ & $-0,8$ & 0,2 & $-0,5$ & $-0,7--0,3$ & 0,40 \\
\hline & \multirow{3}{*}{$5 / 30$} & $T_{M-m}-T_{\text {normal }}$ & Normal & 0,8 & $-0,6$ & 0,4 & 0,0 & $-0,5-0,8$ & 0,20 \\
\hline & & $T_{9-21-M-m}-T_{\text {normal }}$ & Normal & 0,2 & $-1,0$ & 0,4 & $-0,3$ & $-0,9-0,2$ & 0,18 \\
\hline & & $T_{\text {automática }}-T_{\text {normal }}$ & Normal & 0,8 & $-0,3$ & 0,4 & 0,2 & $-0,2-0,8$ & 0,32 \\
\hline & \multirow{12}{*}{$5 / 5$} & \multirow{3}{*}{$T_{A_{-} M-m}-T_{\text {automática }}$} & Diária & 3,3 & $-2,2$ & 0,6 & 0,8 & $-0,3-2,0$ & $-0,16$ \\
\hline & & & Mensal & 1,3 & 0,4 & 0,2 & 0,8 & $0,5-1,1$ & $-0,17$ \\
\hline & & & Anual & 0,9 & 0,7 & 0,8 & 0,1 & $0,7-0,9$ & $-0,12$ \\
\hline & & \multirow{4}{*}{$T_{A \_9-15-21}-T_{\text {automática }}$} & Diária & 3,7 & $-2,4$ & 0,7 & 0,6 & $-0,7-1,9$ & $-0,09$ \\
\hline & & & Mensal & 1,0 & 0,2 & 0,2 & 0,6 & $0,3-0,9$ & $-0,11$ \\
\hline & & & Anual & 0,7 & 0,6 & 0,6 & 0,1 & $0,6-0,7$ & $-0,17$ \\
\hline & & & Diária & 2,3 & $-4,1$ & 0,6 & $-0,2$ & $-1,6-1,1$ & 0,37 \\
\hline & & \multirow[t]{3}{*}{$T_{\text {A_7-14-21 }}-T_{\text {automática }}$} & Mensal & 0,2 & $-0,5$ & 0,2 & $-0,2$ & $-0,5-0,2$ & 0,43 \\
\hline & & & Anual & 0,0 & $-0,3$ & $-0,2$ & 0,1 & $-0,3-0,0$ & 0,41 \\
\hline & & & Diária & 1,4 & $-3,7$ & 0,5 & $-0,3$ & $-1,3-0,6$ & $-0,09$ \\
\hline & & \multirow[t]{2}{*}{$T_{A \_9-21-M-m}-T_{\text {automática }}$} & Mensal & 0,1 & $-0,9$ & 0,3 & $-0,3$ & $-0,8-0,1$ & $-0,07$ \\
\hline & & & Anual & $-0,3$ & $-0,4$ & $-0,3$ & 0,0 & $-0,4--0,3$ & $-0,06$ \\
\hline & & $T_{A \_M-m}-T_{\text {normal }}$ & Normal & 0,8 & $-0,3$ & 0,4 & 0,2 & $-0,2-0,8$ & 0,32 \\
\hline & & $T_{A_{-}-9-15-21}^{-}-T_{\text {normal }}$ & Normal & 1,7 & 0,6 & 0,3 & 1,0 & $0,6-1,6$ & 0,03 \\
\hline & $5 / 30$ & $T_{A_{-7-14-21}}-T_{\text {normal }}$ & Normal & 1,5 & 0,3 & 0,4 & 0,8 & $0,3-1,5$ & 0,58 \\
\hline & & $T_{A-9-21-M-m}-T_{\text {normal }}$ & Normal & 0,5 & $-0,5$ & 0,4 & 0,0 & $-0,5-0,5$ & 0,50 \\
\hline & & $T_{\text {automática }}-T_{\text {normal }}$ & Normal & 0,5 & $-0,7$ & 0,3 & $-0,1$ & $-0,6-0,4$ & 0,26 \\
\hline \multirow{3}{*}{5} & \multirow{3}{*}{$2 / 2$} & \multirow{3}{*}{$T_{\text {convencional }}-T_{\text {automática }}$} & Horária & 9,7 & $-10,5$ & 1,2 & $-0,1$ & $-2,5-2,1$ & 1,39 \\
\hline & & & Diária & 1,8 & $-2,3$ & 0,7 & $-0,1$ & $-1,5-1,1$ & 1,53 \\
\hline & & & Mensal & 0,7 & $-1,1$ & 0,6 & $-0,1$ & $-1,1-0,7$ & 1,7 \\
\hline & & & Horária & 6,3 & $-5,8$ & 0,8 & 0,2 & $-1,0-2,2$ & 0,02 \\
\hline & & $T_{\text {azul }}-T_{\text {automática }}$ & Diária & 1,3 & $-0,4$ & 0,2 & 0,2 & $-0,2-0,8$ & 0,01 \\
\hline & & & Mensal & 0,3 & 0,0 & 0,1 & 0,2 & $0,1-0,3$ & 0,08 \\
\hline & & & Horária & 5,8 & $-4,8$ & 0,9 & 0,2 & $-1,1-2,5$ & 0,05 \\
\hline & & $T_{\text {vermelho }}-T_{\text {automática }}$ & Diária & 1,0 & $-0,4$ & 0,2 & 0,2 & $-0,1-0,8$ & 0,04 \\
\hline & & & Mensal & 0,5 & 0,0 & 0,1 & 0,2 & $0,1-0,4$ & 0,12 \\
\hline & & & Horária & 5,8 & $-4,6$ & 0,8 & 0,2 & $-1,1-2,3$ & $-0,07$ \\
\hline & & $T_{\text {verde }}-T_{\text {automática }}$ & Diária & 1,2 & $-0,4$ & 0,2 & 0,2 & $-0,2-0,8$ & $-0,07$ \\
\hline & & & Mensal & 0,3 & 0,0 & 0,1 & 0,2 & $0,0-0,3$ & $-0,06$ \\
\hline & & & Horária & 4,8 & $-5,8$ & 0,7 & 0,1 & $-1,1-2,0$ & 0,07 \\
\hline & & $T_{\text {branco }}-T_{\text {automática }}$ & Diária & 0,8 & $-0,4$ & 0,2 & 0,1 & $-0,2-0,6$ & 0,07 \\
\hline & & & Mensal & 0,3 & 0,0 & 0,1 & 0,1 & $0,0-0,3$ & 0,11 \\
\hline & & & Horária & 7,5 & $-5,7$ & 1,0 & 0,3 & $-1,1-2,7$ & $-0,01$ \\
\hline 6 & $1 / 1$ & $T_{\text {preto }}-T_{\text {automática }}$ & Diária & 1,1 & $-0,4$ & 0,2 & 0,3 & $-0,1-0,8$ & $-0,07$ \\
\hline & & & Mensal & 0,4 & 0,1 & 0,1 & 0,3 & $0,1-0,4$ & 0,03 \\
\hline & & & Horária & 3,8 & $-5,8$ & 0,6 & 0,0 & $-1,1-1,5$ & 0,09 \\
\hline & & $T_{\text {foil }}-T_{\text {automática }}$ & Diária & 0,5 & $-0,5$ & 0,2 & 0,0 & $-0,3-0,4$ & 0,11 \\
\hline & & & Mensal & 0,1 & $-0,1$ & 0,1 & 0,0 & $-0,1-0,1$ & 0,13 \\
\hline & & & Horária & 7,8 & $-5,5$ & 1,4 & 0,4 & $-1,5-3,7$ & $-0,09$ \\
\hline & & $T_{\text {anteparo }}-T_{\text {automática }}$ & Diária & 1,6 & $-0,5$ & 0,3 & 0,4 & $-0,2-1,2$ & $-0,07$ \\
\hline & & & Mensal & 0,6 & 0,2 & 0,2 & 0,4 & $0,2-0,6$ & 0,03 \\
\hline & & & Horária & 8,6 & $-4,8$ & 1,0 & 0,2 & $-1,4-2,3$ & 0,01 \\
\hline & & $T_{\text {sem_proteção }}-T_{\text {automática }}$ & Diária & 0,7 & $-0,6$ & 0,2 & 0,2 & $-0,2-0,6$ & 0,11 \\
\hline & & & Mensal & 0,3 & 0,1 & 0,1 & 0,2 & $0,1-0,3$ & 0,19 \\
\hline & & & Horária & 13,3 & $-5,7$ & 1,3 & 0,3 & $-1,2-3,3$ & $-0,70$ \\
\hline & & $T_{\text {metálico }}-T_{\text {automática }}$ & Diária & 3,4 & $-0,6$ & 0,5 & 0,3 & $-0,2-2,3$ & $-0,39$ \\
\hline & & & Mensal & 0,8 & 0,0 & 0,3 & 0,3 & $0,0-0,8$ & $-0,61$ \\
\hline
\end{tabular}

1Capítulos: 4 - "CAPÍTULO 4 - Mudanças dos Horários de Observações e dos Cálculos de Médias"; 5 - "CAPÍTULO 5 Mudanças dos Instrumentos" ; 6 - "CAPÍTULO 6 - Mudanças dos Abrigos". 2 Tamanho da série (anos): o primeiro valor denota o tamanho da série comparada em relação à série de referência, representada pelo segundo valor. Obs.: Esta é uma tabela completa, ou seja, boa parte dos valores aqui apresentados não foram citados ao longo dos capítulos. 
Tabela 26 - Síntese de todas as séries estudadas no trabalho, com colorações proporcionais à relatividade dos valores em cada coluna.

\begin{tabular}{|c|c|c|c|c|c|c|c|}
\hline \multicolumn{2}{|c|}{ Informações das séries } & \multicolumn{6}{|c|}{ Índices estatísticos $\left({ }^{\circ} \mathrm{C}\right)$} \\
\hline $\begin{array}{c}\text { Desvio } \\
\text { (Série - Referência) }\end{array}$ & Escala & Máximo & Mínimo & $\begin{array}{l}\text { Desvio } \\
\text { padrão }\end{array}$ & $\begin{array}{l}\text { Média dos } \\
\text { desvios }\end{array}$ & $\begin{array}{c}\text { Amplitude do } \\
\text { intervalo de } \\
\text { confiança - 95\% }\end{array}$ & $\begin{array}{l}\text { Tendência } \\
\text { no período }\end{array}$ \\
\hline$T_{\text {metálico }}-T_{\text {automática }}$ & Horária & 13,3 & $-5,7$ & 1,3 & 0,3 & 4,5 & $-0,70$ \\
\hline$T_{\text {convencional }}-T_{\text {automática }}$ & Horária & 9,7 & $-10,5$ & 1,2 & $-0,1$ & 4,6 & 1,39 \\
\hline$T_{\text {sem_proteção }}-T_{\text {automática }}$ & Horária & 8,6 & $-4,8$ & 1,0 & 0,2 & 3,7 & 0,01 \\
\hline$T_{\text {anteparo }}-T_{\text {automática }}$ & Horária & 7,8 & $-5,5$ & 1,4 & 0,4 & 5,2 & $-0,09$ \\
\hline$T_{\text {preto }}-T_{\text {automática }}$ & Horária & 7,5 & $-5,7$ & 1,0 & 0,3 & 3,8 & $-0,01$ \\
\hline$T_{\text {azul }}-T_{\text {automática }}$ & Horária & 6,3 & $-5,8$ & 0,8 & 0,2 & 3,2 & 0,02 \\
\hline$T_{\text {vermelho }}-T_{\text {automática }}$ & Horária & 5,8 & $-4,8$ & 0,9 & 0,2 & 3,6 & 0,05 \\
\hline$T_{\text {verde }}-T_{\text {automática }}$ & Horária & 5,8 & $-4,6$ & 0,8 & 0,2 & 3,4 & $-0,07$ \\
\hline$T_{\text {branco }}-T_{\text {automática }}$ & Horária & 4,8 & $-5,8$ & 0,7 & 0,1 & 3,1 & 0,07 \\
\hline$T_{\text {foil }}-T_{\text {automática }}$ & Horária & 3,8 & $-5,8$ & 0,6 & 0,0 & 2,6 & 0,09 \\
\hline$T_{M-m}-T_{\text {automática }}$ & Diária & 11,7 & $-8,4$ & 1,0 & $-0,5$ & 3,8 & $-0,55$ \\
\hline$T_{9-21-M-m}-T_{\text {automática }}$ & Diária & 6,5 & $-5,0$ & 1,3 & $-0,1$ & 5,0 & 0,37 \\
\hline$T_{\text {A_9-15-21 }}-T_{\text {automática }}$ & Diária & 3,7 & $-2,4$ & 0,7 & 0,6 & 2,6 & $-0,09$ \\
\hline$T_{\text {metálico }}-T_{\text {automática }}$ & Diária & 3,4 & $-0,6$ & 0,5 & 0,3 & 2,5 & $-0,39$ \\
\hline$T_{A \_M-m}-T_{\text {automática }}$ & Diária & 3,3 & $-2,2$ & 0,6 & 0,8 & 2,3 & $-0,16$ \\
\hline$T_{A \_7-14-21}-T_{\text {automática }}$ & Diária & 2,3 & $-4,1$ & 0,6 & $-0,2$ & 2,7 & 0,37 \\
\hline$T_{\text {convencional }}-T_{\text {automática }}$ & Diária & 1,8 & $-2,3$ & 0,7 & $-0,1$ & 2,6 & 1,53 \\
\hline$T_{\text {anteparo }}-T_{\text {automática }}$ & Diária & 1,6 & $-0,5$ & 0,3 & 0,4 & 1,4 & $-0,07$ \\
\hline$T_{A \_9-21-M-m}-T_{\text {automática }}$ & Diária & 1,4 & $-3,7$ & 0,5 & $-0,3$ & 1,9 & $-0,09$ \\
\hline$T_{\text {azul }}^{-}-T_{\text {automática }}$ & Diária & 1,3 & $-0,4$ & 0,2 & 0,2 & 1,0 & 0,01 \\
\hline$T_{\text {verde }}-T_{\text {automática }}$ & Diária & 1,2 & $-0,4$ & 0,2 & 0,2 & 1,0 & $-0,07$ \\
\hline$T_{\text {preto }}-T_{\text {automática }}$ & Diária & 1,1 & $-0,4$ & 0,2 & 0,3 & 0,9 & $-0,07$ \\
\hline$T_{\text {vermelho }}-T_{\text {automática }}$ & Diária & 1,0 & $-0,4$ & 0,2 & 0,2 & 0,9 & 0,04 \\
\hline$T_{\text {branco }}-T_{\text {automática }}$ & Diária & 0,8 & $-0,4$ & 0,2 & 0,1 & 0,8 & 0,07 \\
\hline$T_{\text {sem_proteção }}-T_{\text {automática }}$ & Diária & 0,7 & $-0,6$ & 0,2 & 0,2 & 0,8 & 0,11 \\
\hline$T_{\text {foil }}-T_{\text {automática }}$ & Diária & 0,5 & $-0,5$ & 0,2 & 0,0 & 0,7 & 0,11 \\
\hline$T_{A \_M-m}-T_{\text {automática }}$ & Mensal & 1,3 & 0,4 & 0,2 & 0,8 & 0,6 & $-0,17$ \\
\hline$T_{M-m}-T_{\text {automática }}$ & Mensal & 1,1 & $-1,0$ & 0,6 & $-0,2$ & 1,9 & $-0,56$ \\
\hline$T_{\text {A_9-15-21 }}-T_{\text {automática }}$ & Mensal & 1,0 & 0,2 & 0,2 & 0,6 & 0,6 & $-0,11$ \\
\hline$T_{\text {metálico }}-T_{\text {automática }}$ & Mensal & 0,8 & 0,0 & 0,3 & 0,3 & 0,8 & $-0,61$ \\
\hline$T_{\text {convencional }}-T_{\text {automática }}$ & Mensal & 0,7 & $-1,1$ & 0,6 & $-0,1$ & 1,8 & 1,70 \\
\hline$T_{\text {anteparo }}-T_{\text {automática }}$ & Mensal & 0,6 & 0,2 & 0,2 & 0,4 & 0,4 & 0,03 \\
\hline$T_{\text {vermelho }}-T_{\text {automática }}$ & Mensal & 0,5 & 0,0 & 0,1 & 0,2 & 0,3 & 0,12 \\
\hline$T_{\text {preto }}-T_{\text {automática }}$ & Mensal & 0,4 & 0,1 & 0,1 & 0,3 & 0,3 & 0,03 \\
\hline$T_{9-21-M-m}-T_{\text {automática }}$ & Mensal & 0,4 & $-1,9$ & 0,5 & $-0,5$ & 1,9 & 0,47 \\
\hline$T_{\text {azul }}-T_{\text {automática }}$ & Mensal & 0,3 & 0,0 & 0,1 & 0,2 & 0,2 & 0,08 \\
\hline$T_{\text {verde }}-T_{\text {automática }}$ & Mensal & 0,3 & 0,0 & 0,1 & 0,2 & 0,3 & $-0,06$ \\
\hline$T_{\text {branco }}-T_{\text {automática }}$ & Mensal & 0,3 & 0,0 & 0,1 & 0,1 & 0,3 & 0,11 \\
\hline$T_{\text {sem_proteção }}-T_{\text {automática }}$ & Mensal & 0,3 & 0,1 & 0,1 & 0,2 & 0,2 & 0,19 \\
\hline$T_{A \_7-14-21}-T_{\text {automática }}$ & Mensal & 0,2 & $-0,5$ & 0,2 & $-0,2$ & 0,7 & 0,43 \\
\hline$T_{\text {foil }}-T_{\text {automática }}$ & Mensal & 0,1 & $-0,1$ & 0,1 & 0,0 & 0,2 & 0,13 \\
\hline$T_{A}$ 9-21-M-m $-T_{\text {automática }}$ & Mensal & 0,1 & $-0,9$ & 0,3 & $-0,3$ & 0,9 & $-0,07$ \\
\hline$T_{A \_M-m}-T_{\text {automática }}$ & Anual & 0,9 & 0,7 & 0,8 & 0,1 & 0,2 & $-0,12$ \\
\hline$T_{A \_9-15-21}-T_{\text {automática }}$ & Anual & 0,7 & 0,6 & 0,6 & 0,1 & 0,1 & $-0,17$ \\
\hline$T_{M-m}-T_{\text {automática }}$ & Anual & 0,3 & $-0,6$ & 0,3 & $-0,2$ & 0,8 & $-0,48$ \\
\hline$T_{\text {A_7-14-21 }}-T_{\text {automática }}$ & Anual & 0,0 & $-0,3$ & $-0,2$ & 0,1 & 0,3 & 0,41 \\
\hline$T_{9-21-M-m}-T_{\text {automática }}$ & Anual & $-0,3$ & $-0,8$ & 0,2 & $-0,5$ & 0,4 & 0,40 \\
\hline$T_{A \_9-21-M-m}-T_{\text {automática }}$ & Anual & $-0,3$ & $-0,4$ & $-0,3$ & 0,0 & 0,1 & $-0,06$ \\
\hline$T_{A \_9-15-21}-T_{\text {normal }}$ & Normal & 1,7 & 0,6 & 0,3 & 1,0 & 1,0 & 0,03 \\
\hline$T_{A \_7-14-21}-T_{\text {normal }}$ & Normal & 1,5 & 0,3 & 0,4 & 0,8 & 1,2 & 0,58 \\
\hline$T_{M-m}^{-}-T_{\text {normal }}$ & Normal & 0,8 & $-0,6$ & 0,4 & 0,0 & 1,3 & 0,20 \\
\hline$T_{\text {automática }}-T_{\text {normal }}$ & Normal & 0,8 & $-0,3$ & 0,4 & 0,2 & 1,0 & 0,32 \\
\hline$T_{A \_M-m}-T_{\text {normal }}$ & Normal & 0,8 & $-0,3$ & 0,4 & 0,2 & 1,0 & 0,32 \\
\hline$T_{A \_9-21-M-m}-T_{\text {normal }}$ & Normal & 0,5 & 0,5 & $-0,4$ & 0,0 & 1,0 & 0,50 \\
\hline$T_{\text {automática }}-T_{\text {normal }}$ & Normal & 0,5 & 0,7 & $-0,3$ & $-0,1$ & 1,0 & 0,26 \\
\hline$T_{9-21-M-m}-T_{\text {normal }}$ & Normal & 0,2 & 1,0 & $-0,4$ & $-0,3$ & 1,1 & 0,18 \\
\hline
\end{tabular}

Obs: As colorações em dégradé são proporcionais à distância relativa ao valor zero em cada coluna. Ou seja, valores absolutos altos são coloridos de vermelho; quanto mais próximas de zero, as cores vão se tornando mais verdes. Logo, cada coluna possui limites extremos diferentes e, igualmente, correspondências diferentes entre as cores e os valores. Portanto, a comparação pela cor, entre as colunas, não é necessariamente válida. 


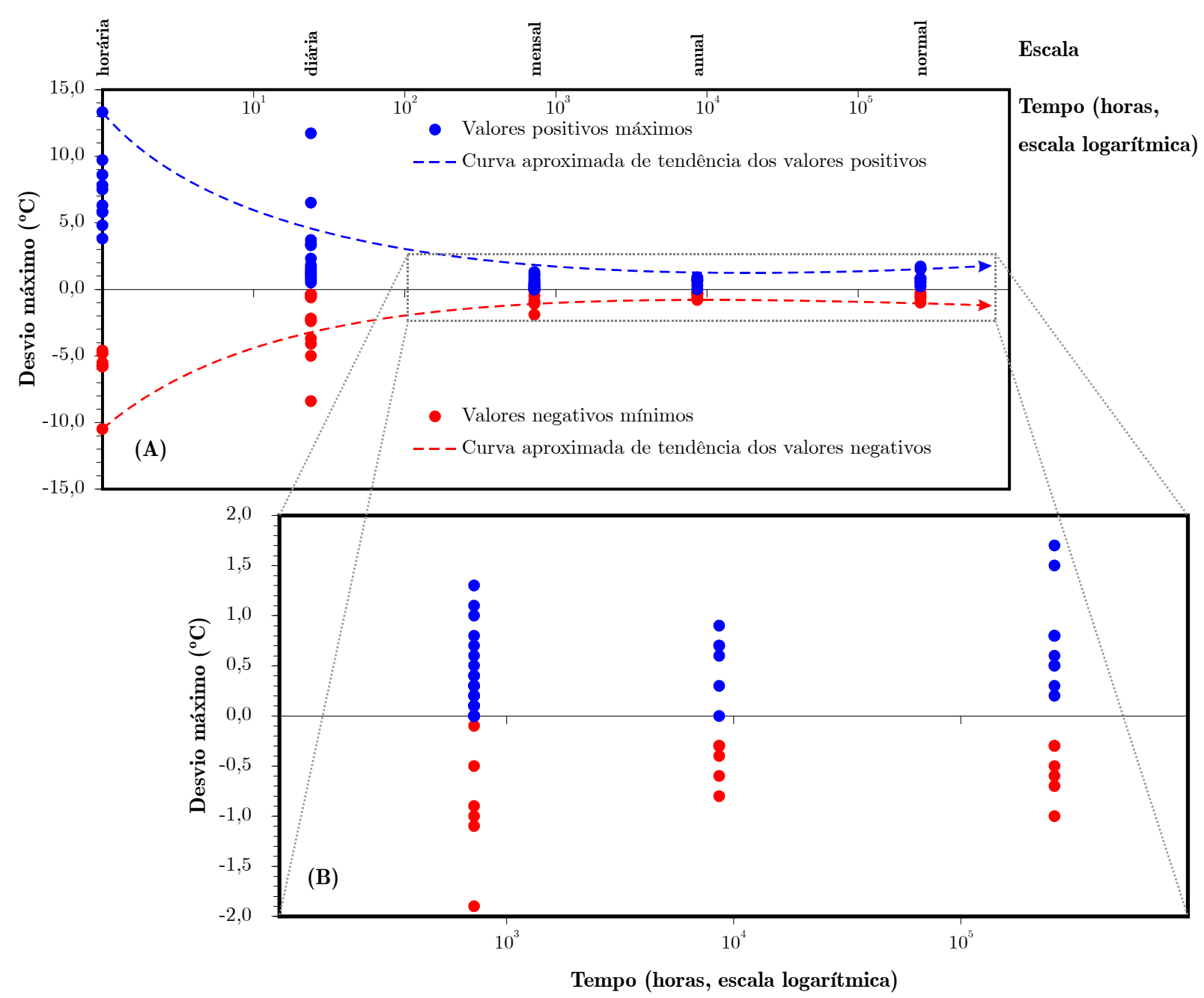

Figura 123 - Desvios máximos e mínimos de todas as séries sob diferentes escalas de abordagem.

É consequência natural querer saber qual das causas de heterogeneidades possui efeitos mais preponderantes e introduzem maiores incertezas nas séries de temperatura do ar. Pelos resultados anteriores é possível arriscar uma ponderação da importância relativa das causas de heterogeneidades de acordo com os efeitos (desvios) provocados nas séries. Para isto, escolhe-se uma escala que seja comum a todas as séries, que no caso é a escala mensal. O ideal seria tomar a escala anual como a base de comparação nos estudos de longo prazo do clima, porém a limitação das séries menores não permite a comparação nesta escala. Simplificando a análise, serão considerados os valores médios dos desvios máximos, mínimos e médios das séries em cada categoria (relativa a cada capítulo). Assim, pelos valores médios calculados e exibidos na Tabela 27, pode-se classificar as heterogeneidades na ordem do menor ao maior potencial de indução de erros oferecido por cada tipo: mudanças dos abrigos, mudanças dos cálculos de médias; e mudanças dos instrumentos. 
Tabela 27 - Ponderação dos efeitos por tipo de heterogeneidade, com base nas médias dos valores máximos, mínimos e médios.

\begin{tabular}{lccc}
\hline \hline Tipo de heterogeneidade e respectivo & \multicolumn{3}{c}{ Média dos desvios $\left({ }^{\circ} \mathbf{C}\right)$} \\
\cline { 2 - 4 } capítulo que a abordou & Máximos & Mínimos & Médios \\
\hline Cap. 4 - Mudanças das médias & 0,7 & $-0,6$ & 0,0 \\
Cap. 5 - Mudanças dos instrumentos & 0,7 & $-1,1$ & $-0,1$ \\
Cap. 6 - Mudanças dos abrigos & 0,4 & 0,0 & 0,2 \\
\hline
\end{tabular}

Esta classificação é apenas uma das várias combinações possíveis de critérios que podem considerados. Deste modo, se torna apenas um indicativo, por ser um método muito generalista, que ignora tantos outros aspectos que caracterizam com maior precisão os desvios de temperatura. Por um lado, a análise estatística é uma ferramenta bastante útil, poderosa e com uma capacidade de sintetizar uma quantidade imensa de dados. Por outro lado, ela abstrai significativamente os resultados, ocultando os comportamentos e distribuições dos desvios ao longo do tempo. Apenas gráficos de dispersão (correlação), histogramas (frequência de distribuição) e gráficos de desvios indicam explicita e imediatamente o comportamento ao longo do tempo. E pelo exposto em cada capítulo, os gráficos demonstraram que as variações dos desvios não são lineares, o que dificultaria, em uma etapa posterior, a remoção destas heterogeneidades.

Em suma, em escalas reduzidas (horárias e diárias) existem erros de alta magnitude de variação, porém de baixa frequência de ocorrência. Com o aumento da escala, a magnitude dos desvios diminui. Ficam classificadas as causas de heterogeneidades, de acordo com os efeitos provocados, na ordem de menor para a maior intensidade: as mudanças dos abrigos dos sensores de temperatura; mudanças dos cálculos das médias diárias da temperatura; e mudanças dos instrumentos, principalmente quando são substituídos os equipamentos convencionais (analógicos) pelos automáticos (digitais).

De toda esta análise final das heterogeneidades, põe-se em discussão a extrapolação de médias regionais e globais a partir de séries locais. O aumento da temperatura média terrestre no último século foi de cerca de $0,6^{\circ} \mathrm{C}$. Mas os desvios encontrados aqui, em termos das médias dos desvios do período total das séries (Tabela 25), variam praticamente nesta mesma magnitude de valor. Estes erros anuais de ordem baixa podem ser propagados a escalas superiores, pois normalmente são feitas extrapolações ao nível regional e global a partir de séries locais. 
Consequentemente, esta extrapolação pode não representar fielmente mudanças reais do clima, uma vez que podem estar sendo incorporados fatores não-climáticos nos dados locais.

Neste sentido, em relação às extrapolações, deve-se salientar um aspecto de extrema relevância que não foi levantado neste trabalho: a propagação dos erros envolvidos nos cálculos. A toda medição está associada uma incerteza inerente, fato inevitável. Tais incertezas são propagadas e, muitas vezes, amplificadas quando são realizados cálculos matemáticos de desvio padrão e outros índices estatísticos por meio de operações de soma, subtração, divisão e multiplicação dos valores dos erros associados às medições ${ }^{91}$.

Portanto, as heterogeneidades, fatores indesejados de difícil remoção, e as respectivas propagações dos erros envolvidos nos cálculos podem comprometer a utilização das temperaturas obtidas em estações na superfície terrestre como um indicador confiável de mudanças reais do clima.

Além disso, os dados da temperatura global terrestre estão gravemente comprometidos, uma vez que mais de três quartos dos 6.000 postos da principal rede de estações meteorológicas em terra $(G H C N)$ não estão mais reportando os valores de temperatura. Parece existir um sucateamento das estações, e a continuidade de medições futuras é algo preocupante e incerto. Talvez, um motivo deste declínio seja realmente a ascensão das tecnologias de sensoriamento remoto, que, por meio de satélites, foi possível a obtenção relativamente fácil das variações da temperatura de

91 A etapa importante de propagação de erros não foi realizada no presente estudo, mas é algo que se deve dar maior atenção. Artigo recente de Frank (2010) levou em conta este aspecto em um estudo da incerteza na temperatura média do ar na superfície global. O estudo calculou a propagação dos erros sistemáticos das medições de estações de temperaturas máximas e mínimas - que são da na ordem de $\pm 0,2^{\circ} \mathrm{C}$ - e chegou ao valor de $\pm 0,46^{\circ} \mathrm{C}$ de variação como sendo o limite de incerteza das anomalias da temperatura média anual global. Segundo o autor, a incerteza relativamente grande do registro instrumental da superfície global significa que a tendência centenária da temperatura não pode ser usada como uma referência de precisão para os testes de validação dos modelos climáticos. Da mesma forma, o registro atual instrumental da superfície não poderia ser usado para calibrar ou normalizar qualquer reconstrução com base em testemunhos, fisicamente válidos de paleotemperatura, com precisão suficiente para distinguir qualquer diferença de temperatura inferior a, pelo menos, $1^{\circ} \mathrm{C}$. Assim, segundo Frank (2010), é impossível saber se a taxa de aquecimento durante o século 20 foi climatologicamente sem precedentes, ou para saber a magnitude da diferença de temperatura do ar mais quente ou mais frio do que o presente, dentro de $\pm 1^{\circ} \mathrm{C}$, em qualquer ano anterior à era dos satélites. Concluiu o autor que a tendência das anomalias da temperatura do ar na superfície global, de 1880 a 2000, é estatisticamente indistinguível de $0^{\circ} \mathrm{C}$. Deste modo, a velocidade e a magnitude do aquecimento do século 20 são, portanto, irreconhecíveis, e sugestões de uma tendência sem precedentes no século 20 a temperatura do ar global de superfície são insustentáveis. 
um modo global, que representou uma alta distribuição de medições, algo que as estações na superfície nunca conseguiram atingir, mesmo no seu auge. A esperança da manutenção de uma rede densa e bem distribuída de estações está no Projeto "Berkeley Earth Surface Temperature”, conforme apresentado na pág. 101.

Apesar de todas as incertezas e erros inerentes dos registros passadas e do futuro incerto das medições da temperatura do ar por estações, o uso de series baseadas em medições terrestres ainda é a única fonte de evidencia razoavelmente confiável no período entre 1850 e 1980. Antes de 1800, reconstruções são possíveis, mas também estão sujeitas a seus erros e incertezas específicos, tanto nas medições quanto nas calibrações. Depois de 1980 iniciaram as medições confiáveis por satélite. $\mathrm{Ou}$ seja, os registros históricos de medições representam a única fonte capaz de informar as variações que ocorreram no passado recente (últimos 150 anos), já que nesta escala, dificilmente não são possíveis determinar por meio de métodos de reconstrução indireta da temperatura, além de que as medições de satélite são muito recentes - lembrando que estes também possuem limitações e incertezas associadas às medições. Talvez no futuro, pode ser que o uso destes satélites seja a causa do abandono definitivo de boa parte das medições terrestres.

Mesmo com as dificuldades existentes, o uso dos registros de temperatura do ar é essencial e, até o momento, insubstituível. É melhor ter algo disponível do que não ter nenhuma outra informação. Quanto à utilização do que está disponível, é necessária a identificação e remoção dos erros encontrados. No presente estudo, a partir de algumas séries locais, foram feitas as analises e identificação dos principais fontes de erros e heterogeneidades. De todas as causas de heterogeneidades, somente duas não puderam ser verificadas e quantificadas (apesar de terem sido discutidas hipoteticamente na análise das normais no Capítulo 3): 1. Mudanças localização da estação; e 2. Mudanças no entorno do local de medição, principalmente devido à urbanização e efeitos decorrentes do surgimento de ilhas de calor. Para que este segundo fator fosse analisado, seria necessária a presença de duas estações em uma mesma cidade, sendo que uma deveria estar na área rural e outra dentro da cidade. A princípio, seria difícil encontrar duas estações relativamente próximas e que somente uma tivesse sofrido o efeito de alterações do uso e ocupação dos solos ao longo do tempo. Acima de tudo, seria primordial que as duas estações tivessem séries extensas o suficiente para evidenciar uma diferença discernível.

Pelo exposto, identificar a existência da falta de homogeneidade e determinar a magnitude é relativamente fácil. Determinar o momento em que ocorreu alguma 
heterogeneidade e definir os ajustes adequados para homogeneização dos consistem na principal dificuldade e desafio. Mesmo os ajustes estão sujeitos a incertezas e subjetividades da pessoa que determinou qual o método utilizado. Mesmo com a identificação e remoção das heterogeneidades, nunca se terá uma certeza confiável o suficiente para assumir esta evidência como a principal indicadora de mudanças. Na ausência de outros métodos, estas séries históricas seriam a única fonte disponível nos últimos 150 anos. Mas, desde o início da década de 80, medições em satélite parecem ser a solução que irá sanar: 1. O problema da distribuição espacial insuficiente das estações em terra; 2. As heterogeneidades a que estão sujeitas as medições na superfície terrestre.

Enfim, em um contexto mais aplicado, a utilização dos dados de temperatura é necessária e tem sido frequentemente utilizada como a base das decisões políticas de controle de mudanças no clima, assumidas como de causas antropogênicas. Em termos nacional, o setor político tem avançado com a criação de legislação no combate ao aquecimento global, mas no meio científico, não existe um diagnóstico nacional das variações da temperatura do ar em todo o território. O Brasil parece possuir uma base de dados considerável no INMET, mas salvo ignorância, não se tem notícia de como as temperaturas têm variado ao longo do tempo nas terras nacionais: não existe uma série consistente de "temperatura média nacional brasileira". Quanto ao uso de uma evidência no processo de tomada de decisão política, cujo atual momento já tem sido refletido na elaboração de leis que controle de gases do efeito estufa, justifica-se a necessidade de diagnóstico das variações da temperatura no país. Antes de utilizar uma evidência, convém analisá-la quanto à sua confiabilidade. Portanto, fica a recomendação da elaboração de uma série nacional, da variação da temperatura média no Brasil, que utilize todas ou a maior quantidade possível de séries locais, e que sejam identificadas e removidas as heterogeneidades encontradas. Nesta eventual empreitada, seria ideal a visitação das estações para verificação das condições em que as leituras estão sendo realizadas. Esta pesquisa consistiria em um desafio grande, devido aos deslocamentos de grandes distâncias e os custos envolvidos na operação.

Quanto ao uso da evidência científica fora do contexto da Ciência, bastante foi discutido no "CAPÍTULO 7 - Implicações e repercussões no contexto da interação entre Ciência, Mídia, Política e Economia", pg. 301. Em uma área cercada de incertezas inevitáveis, que requerem constante cuidado quando a sua identificação, remoção, ou minimização, ficou demonstrado que os diferentes setores tratam este 
aspecto fundamental nas Ciências de forma superficial e tendenciosa. Aliados a interesses econômicos oportunistas em relação ao surgimento de um promissor mercado de carbono ou então de eventuais taxações exigidas por políticas públicas, existe uma aliança intersetorial cuja postura tem ignorado as incertezas e manipulado as informações difundidas na sociedade de modo parcial, todas com a posição assumida que as mudanças no clima são decorrentes das atividades humanas.

Anterior à atribuição das mudanças, é necessário primeiro conferir se as evidências das mudanças são realmente confiáveis. Com diversas incertezas associadas, um grande desafio consiste em julgar se os erros encontrados nos registros terrestres da temperatura invalidam a tese do aquecimento global antropogênico. John Christy, professor de ciência atmosférica da Universidade do Alabama, em Huntsville, um dos principais autores do IPCC, diz que "Os registros de temperatura não podem ser invocados como indicadores da mudança global”. As dúvidas de Christy consistem no fato de que as estações têm sido seriamente comprometidas por fatores como a urbanização, mudanças no uso da terra e, em muitos casos, por ser transferidas de localidade (LEAKE, 2010).

$\mathrm{Na}$ mídia e na política, as incertezas são tratadas com menor rigor científico. Ficou demonstrada a forma simplificada com que a mídia e a política tratam as evidências e suas incertezas de mudanças climáticas: ignoram, desprezam, diminuem a importância das incertezas; e aumentam, exageram e manipulam as evidências de causas e efeitos de vários problemas que a sociedade enfrenta, não somente relacionados aos aspectos climáticos, mas também outros que não parecem apresentar uma co-variação tão imediata.

A discussão da atribuição do aquecimento global e da contribuição antrópica no sentido da contestação desta influência humana, especialmente por aqueles que são reconhecidos como "céticos", não deve ser vista como uma afronta ao ambientalismo de uma forma geral. Ser contrário à concepção de que o homem determina o clima e as suas alterações não implica em ser contrário à conservação e os cuidados que a natureza merece ter. O meio ambiente deve ser cuidado, em primeiro lugar, pela justificativa moral de se dar o direito e condições para a existência da vida, que possui seu valor próprio, intrínseco, independente do ser humano. Em segundo lugar, justifica-se a preocupação com o meio ambiente devido ao entendimento de que a existência da vida e a manutenção do equilíbrio ecológico possuem efeitos secundários que interessam aos seres humanos. Alguns aspectos ambientais possuem valor em 
função de que eles fornecem alguns indivíduos ou recursos que são direta ou indiretamente necessários à sobrevivência humana.

O problema em contrariar a hipótese do aquecimento global antropogênico é visto como um ataque ao ambientalismo porque as mudanças climáticas se tornaram o grande mote da área ambiental. Ou seja, confunde-se que o clima - por estar em alta evidência e, assim, ofuscando outras áreas relacionadas ao meio ambiente - é a única grande preocupação de ordem ambiental para a qual se deve dedicar e concentrar esforços na mitigação dos impactos que ele tem sofrido. Mas não devem ser ignorados tantos outros temas ambientais relevantes que deveriam, também, ser motivo de preocupação. De uma forma geral, existem impactos não somente na atmosfera, mas também na hidrosfera, litosfera e biosfera. Ou seja, existem inúmeras formas de poluição da água, dos solos, e inclusive de poluição do ar, além de outras atividades que provocam impactos negativos na biodiversidade de um modo geral.

A discussão, portanto, não se insere na recusa de assumir a importância do meio ambiente, mas sim de alertar os interesses econômicos envolvidos e os beneficiários das quantias elevadas de investimentos dedicados à solução de um problema que, supostamente, pode não ser tão sério assim. Tudo se resume em uma questão de dedicação excessiva de esforços, focados prioritariamente em um tema que não demandaria tanta atenção.

O homem pode exercer influências no clima nas escalas locais. Em termos globais, é pouco provável que ele consiga induzir alguma quantidade de mudanças. Não há evidências tão claras, e isentas de dúvidas, de que as mudanças são decorrentes principalmente da influência humana, uma vez que causas naturais representam influências de ordem muito mais elevadas. Discernir qual a predominância das causas, naturais ou induzidas pelos humanos, é um tema que persistirá por muito tempo ainda e que este trabalho passa longe de responder esta questão controversa. Neste contexto, o presente estudo buscou ponderar alguns aspectos polêmicos e apresentar a importância da consideração das incertezas das evidências, especialmente a temperatura do ar. É fundamental avaliar os esforços necessários no combate de um tema sujeito a inúmeras incertezas e interesses antes de se tomar decisões que afetam toda uma sociedade. Pode-se estar criando um problema a ser resolvido pela humanidade, que pode não sofrer uma influência humana significativa, cujos custos demandados superam em até 20 vezes os custos necessários para resolver os problemas humanitários que ainda persistem na vida de milhões de 
pessoas que enfrentam a fome, a falta de educação, saúde, água potável e saneamento básico.

É uma questão importante a mudança climática provavelmente causada pela atividade humana. Mas seria realmente o problema mais importante do planeta? Seria a maior ameaça e emergência que a humanidade enfrenta? Não seriam os conflitos globais e os desafios atuais da pobreza de uma magnitude semelhante, senão superior? E quanto ao crescimento populacional, as mudanças demográficas e as catástrofes naturais mais comuns?

Pretende-se colocar o ser humano como o ponto sensibilizante de uma ameaça catastrófica que poderia conduzir à extinção humana, na tentativa de forçar um altruísmo utópico e inexistente. Mas as ameaças futuras não fazem sentido se atualmente ainda persiste na humanidade a existência de tantos problemas associados à miséria e à pobreza - como a fome, mortalidade infantil e mortes decorrentes de doenças veiculadas pela água e provocadas pela falta de saneamento básico - que afetam diariamente a vida de milhões de pessoas.

Diante de toda ameaça do aquecimento global e das mudanças climáticas, é bastante comum ouvir que este é o principal problema e desafio que a humanidade possui atualmente; e que se nada for feito, estar-se-ia pondo em risco não só a própria existência humana, mas também ameaçando o equilíbrio ecológico e, logo, até mesmo a própria vida no planeta Terra. Mas, como salvar o planeta se as pessoas ainda não sabem como tomar conta delas mesmas; se ainda não sabem nem mesmo cuidar uns dos outros? 



\section{REFERÊNCIAS}

ABREU, C. P. (1961). Contribuição ao estudo da determinação da temperatura média diária. 1961. 62p. Tese (Doutorado em Agronomia)-Escola Superior de Agricultura "Luiz de Queiroz", Universidade de São Paulo, Piracicaba, 1961.

AGÊNCIA FAPESP. (2010). Impacto acabou com dinossauros. Divulgação Científica. 5 mar. 2010. Disponível em: <http://www.agencia.fapesp.br/materia/11852/impacto-acabou-comdinossauros.htm>. Acesso em: 14 ago. 2010.

ALCOFORADO, M. J. (1988). O clima na região de Lisboa. Vento, insolação e temperatura. Faculdade de Letras de Lisboa, 1988.

ALLEY, R.B. (2004). GISP2 Ice Core Temperature and Accumulation Data. IGBP PAGES/World Data Center for Paleoclimatology Data Contribution Series \#2004-013. NOAA/NGDC Paleoclimatology Program, Boulder CO, USA. 2004. Disponível em: < http://www.ncdc.noaa.gov/paleo/metadata/noaa-icecore-2475.html>. Acesso em: 14 ago. 2010.

ALMEIDA, H. A.; SOUZA, J. A.; ALCÂNTARA, H. M. (2008). Análise comparativa de dados meteorológicos obtidos por estação convencional e automática no semi-árido paraibano. Revista Brasileira de Agrometeorologia, v. 16, n. 1, p. 58-66, abril, 2008.

ANDERSSON, T.; MATTISION, I. (1992). A Field Test of Thermometer Screens. Instr. and Obs. Meth. Rep. 49. WMO No. 462, p. 436, 1992.

ANTUNES, A.A.N. (1966). Propriedades da Matéria. L. P. M., 1966.

ANUNCIAÇÃO, P. E. M. (1984). Meteorologia para Agricultura. Maringá: Gráfica Clichetec. 1984.

ARMANI, G.; GALVANI, E. (2006). Avaliação do desempenho de um abrigo meteorológico de baixo custo. Revista Brasileira de Agrometeorologia, v. 14. n.1, p.116-122, 2006.

ASTM (AMERICAN SOCIETY FOR TESTING AND MATERIALS). (1987). Manual on the use of Thermocouples in Temperature Measurement. Philadelphia: ASTM Special Publication 470B, 1987.

AYLLÓN, T. (1996). Elementos de meteorología y climatología. México: Trillas, 1996. 
AZEVEDO, T. R. ; TARIFA, J. R. (2001). Miniabrigo Meteorológico Aspirado do Laboratório de Climatologia e Biogeografia e seu uso no estudo geográfico do clima. Geousp, São Paulo, v. 10, p. 165-174, 2001.

BAKER, D. G. (1975). Effect of Observation Time on Mean Temperature Estimation. Journal of Applied Meteorology, v. 14, p. 471-476, june 1975.

BAKER, H. D.; RYDER, E. A.; BAKER, N. H. (1961). Temperature Measurement In Engineering, Vol. 2. New York: John Wiley \& Sons, Inc, 1961.

BAPTISTA, G. M. M. (2009). Aquecimento Global: Ciência ou Religião? 1 ed. Brasília: Hinterlândia Editorial, 2009. 186 p.

BARBOSA, C. M. S; MOURA, E. M.; MATtOS, A. RIGUETTO, A. M. (2006). Análise comparativa entre os dados das estações convencional e automática localizadas em Serra Negra do Norte/RN. In: CONGRESSO BRASILEIRO DE METEOROLOGIA, 14., 2006, Florianópolis. Anais... Florianópolis/SC: Editora da Assoc. Brasileira de Meteorologia, 2006. v. 1. p. 1-10.

BARBOSA, R. V. R.; BARBIRATO, G.; VECCHIA, F. (2004). Vegetação urbana: análise experimental em cidade de clima quente e úmido. In: Anais do VII ENCONTRO NACIONAL SOBRE CONFORTO NO AMBIENTE CONSTRUÍDO. PUC - PR, Curitiba, 2004.

BARNETT A, HATTON D. B.; JONES D. W. (1998). Recent changes in thermometer screen design and their impact. Geneva: WWW/OSY (Instruments and observing methods, Report No.: 66). WMO/TD871. 1998, 12pp.

BARRY, R. G.; CHORLEY, R. J. (1980). Atmósfera, tiempo y clima. 3 ed. Barcelona, Omega, 1980. 395 p.

BARTLEIN, P. J. (2006). Time Scales of Climate Change. In: ELIAS, S.A. (ed.). (2006). Encyclopedia of Quaternary Science, 1 ed. 2006. p. 1873-1883.

BEER, J.; MENDER, W.; STELLMACHER, R. (2000). The role of the sun in climate forcing. Quaternary Science Reviews, v. 19, p. 403-415, 2000.

BENEDICT, R. P. (1984). Fundamentals of temperature, pressure, and flow measurements. 3 ed. New York: Wiley, 1984. 
BERKELEy EARTH SURFACE TEMPERATURE. (2010). Data Set. 2010. Disponível em: $<$ http://www.berkeleyearth.org/dataset>. Acesso em: 10 set. 2010.

BERTRAND, C.; VAN YPERSELE, J.-P.; BERGER, A. (1999). Volcanic and solar impacts on climate since 1700. Climate Dynamics, v. 15, p. 355-367, 1999.

BLÜCHEL, K. G. (2008). A fraude do efeito-estufa: aquecimento global, mudança climática os fatos. Tradução LOBMAIER, H. São Paulo: PHL, 2008. 316 p. Tradução de: Der klimaschwindel: erderwarmung, treibhauseffekt, klimawandel - die fakten.

BRANDSMA, T.; VAN DER MEULEN, J. P. (2008). Thermometer Screen Intercomparison in De Bilt (the Netherlands) - Part II: Description and modeling of mean temperature differences and extremes. International Journal of Climatology, v. 28, p. 389-400, 2008.

BRASIL. Ministério da Agricultura e Reforma Agrária. Secretaria Nacional de Irrigação. Departamento Nacional de Meteorologia. (1992). Normais climatológicas (1961-1990). Brasília: Departamento Nacional de Meteorologia, 1992. 84 p.

BRASIL. Ministério da Agricultura. Escritório de Meteorologia. (1969). Normais climatológicas (São Paulo, Paraná, Santa Catarina, Rio Grande do Sul), vol. IV. Rio de Janeiro: Escritório de Meteorologia, 1969.

BROOKS, C. E. P. (1921). True mean temperature. Monthly Weather Review, v. 49, p. 226$229,1921$.

BRYDEN, H. L.; LONGWORTH, H. R.; CUNNINGHAM, S. A. (2005) Slowing of the Atlantic meridional overturning circulation at $25^{\circ}$ N. Nature, v. 438, p. 655-657, 2005.

CABLE, Vincent (2003). The political context. In: ODI Meeting Series: Does evidence matter?, 7, May. 2003. Disponível em:

$<$ http://www.odi.org.uk/Rapid/Meetings/Evidence/Presentation_3/Cable.html>.Acesso em: 14 ago. 2010.

CAMARGO, A.P.; SENTELHAS, P.C. (1997). Avaliação do desempenho de diferentes métodos de estimativa da evapotranspiração potencial no estado de São Paulo, Brasil.

Revista Brasileira de Agrometeorologia, Santa Maria, v. 5, n. 1, p. 89-97, 1997.

CAMPBELL SCIENTIFIC INC. (2003). Naturally Aspirated Radiation Shields. Logan, Campbell Scientific, 2003. Disponível em:

$<$ ftp://ftp.campbellsci.com/pub/outgoing/lit/b_radshields.pdf> Acesso em: 14 abr. 2005. 


\section{CAMPBELL SCIENTIFIC INC. (2004). Model HMP45C Temperature and Relative}

Humidity Probe Instruction Manual. 2004. Disponível em: <ftp://ftp.campbellsci.com/pub/ outgoing/manuals/hmp45c.pdf $>$ Acesso em: 6 abr. 2005.

CARLETTO, C. (2005). Subcoberturas: aplicação de isolantes térmicos em sistemas de coberturas. 2005. 193 f. Dissertação (Mestrado em Ciências da Engenharia Ambiental)-Escola de Engenharia de São Carlos, Universidade de São Paulo, São Carlos. 2005.

CHAUI, M. (2001). Convite à filosofia. 12 ed. São Paulo: Editora Ática, 2001.

CHIQUiTO, E. A. (2006). Expansão Urbana e Meio Ambiente nas Cidades nãometropolitanas: o caso de Franca-SP. Dissertação (Mestrado)-Escola de Engenharia de São Carlos, Universidade de São Paulo, São Carlos, 2006.

COMMITTEE ON SURFACE TEMPERATURE RECONSTRUCTIONS FOR THE LAST 2,000 YEARS. (2006). Surface Temperature Reconstructions for the Last 2,000 Years (Prepublication Copy). National Research Council, The National Academies Press. Washington, 2006.

CONDIE, C. K. (1998). Episodic continental growth and supercontinents: a mantle avalanche connection?. Earth and Planetary Science Letters, v. 163, p. 97-108, 1998.

CONTI, J. B. Epistemologia: Métodos e Técnicas em Geografia Física - Climatologia. In: SIMPÓSIO BRASILEIRO DE GEOGRAFIA FÍSICA APLICADA. 6. Anais... Curitiba: UFPR, 1997.

CONTI, J. B. (2000). Considerações sobre Mudanças Climáticas Globais. In: SANT'ANNA NETO, J.L.; ZAVATINI, J. H.. (Org.). Variedade e Mudanças Climáticas - Implicações Ambientais e Sócio-econômicas. Maringá - PR: Universidade Estadual de Maringá, 2000, p. $17-28$.

COURTILlOT, V.; GALLET, Y.; MOUËL, J.L.; FLUTEAU, F.; GENEVEY, A. (2007). Are there connections between the Earth's magnetic field and climate? Earth and Planetary Science Letters, v. 253, p. 328-339, 2007.

CRITCHFIELD, H. J. General climatology. 2. ed. Englewood Cliffs, N.J.: Prentice-Hall, 1966.

CUADRAT, J. M.; PITA, M. F. (1997). Climatologia. Madrid: Editora Catedra. 1997. 
CUNHA, A. R.; ESCOBEDO, J. F.; GALVANI, E. (2001). Avaliação de um psicrômetro de termopar de baixo custo. Revista Brasileira de Agrometeorologia, Santa Maria, v. 9, n. 1, p. $17-22,2001$.

CUNHA, A. R.; MARTINS, D. (2004). Estudo comparativo entre elementos meteorológicos obtidos em estações meteorológicas convencional e automática em Botucatu, SP, Brasil.

Revista Brasileira de Agrometeorologia, Santa Maria, v. 12, n. 1, p. 103-111, 2004.

CUNHA, D. G. F.; VECCHIA, F. (2007). As abordagens clássica e dinâmica de clima.

Ciência e Natura, v. 29, p. 137-149, 2007.

D'ALEO, J. WATTS, A. Surface Temperature Records: Policy Driven Deception? Science \& Public Policy Institute. 2010. Disponível em:

$<$ http://scienceandpublicpolicy.org/originals/policy_driven_deception.html $>$. Acesso em 14 ago. 2010 .

DALL'AMICO, M.; HORNSTEINER, M. (2006). A simple method for estimating daily and monthly mean temperatures from daily minima and maxima. International Journal of Climatology, v. 26, p. 1929-193, 2006.

DAVIES, P. (2004). Is evidence-based government possible? In: Annual Campbell Collaboration Colloquium, 4. Washington, Feb. 2004. 28p. Disponível em $<$ http://www.odi.org.uk/rapid/Bibliographies/EBP/bibliography.html>. Acesso em: 14 ago. 2010.

DEFFUNE, G. (1993). O estudo do clima e do tempo atmosférico e o planejamento Ambiental. Maringá: UEM, n. 16, p.47 (Série Apontamentos). 1993.

DESONIE, D. (2008). Climate: causes and effects of climate change. New York: Chelsea House, 2008.

DIMOUDI, A.; NIKOLOPOULOU, M. (2003). Vegetation in the urban environment: microclimatic analysis and benefits. Energy and Buildings, n. 35: 69-76, 2003.

EDWARDS, H. B. (1982). Measurement of True Mean Temperature for Determination of Climatic Trends. Journal of Applied Meteorology, v. 21, p. 1763-1766, 1982.

EMILIANI, C. (1987). Dictionary of the Physical Sciences. New York: Oxford University Press, 1987. 
EMPLASA (EMPRESA PAULISTA DE PLANEJAMENTO METROPOLITANO). (2003). Mapeamento de uso e ocupação do solo da RMSP - 2002. São Paulo, 2003.

ESSEX, C. MCKITRICK, R.; ANDERSEN, B. (2007). Does a Global Temperature Exist? Journal of Non-Equilibrium Thermodynamics, v. 32, pp. 1-27, 2007.

FELÍCIO, R. A.; ONÇA, D. S.; VILELA, M. A. L. Esquentando notícias. Folha de São Paulo, São Paulo, 8 abr. 2009. Tendências/Debates, p.A3. Disponível em: $<$ https://conteudoclippingmp.planejamento.gov.br/cadastros/noticias/2009/4/8/esquentando -noticias/>. Acesso em: 20 jun. 2009.

FIEDLER, B. (2009). [Professor of Meteorology, National Weather Center, University of Oklahoma] Milankovitch Cycles, Orbit, and Cores. [mensagem pessoal]. Mensagem recebida por < marcos.jose@gmail.com> em 12 dez. 2009. [Com citação das fontes originais de dados, imagem também disponível em:

$<$ http://en.wikipedia.org/wiki/File:MilankovitchCyclesOrbitandCores.png > . Acesso em 14 ago. 2010].

FLORIDES, G. A.; CHRISTODOULIDES, P. (2009). Global warming and carbon dioxide through sciences. Environment International, v. 35, p. 390-401, 2009.

FRAKES, L. A.; FRANCIS, J. E.; SYKTUS, J. I. (1992). Climate Modes of the Phanerozoic. Cambridge: Cambridge Univ. Press, 1992. 274 p.

FRANK, P. (2010). Uncertainty in the global average surface air temperature index: a representative lower limit. Energy \& Environment. v. 21, n. 8, p. 969-989, 2010.

FUCHS, M.; TANNER, C. B. (1965). Radiation shields for air temperature thermometers. J. Appl. Meteor., 4, 544-547, 1965.

GHILL; M. (2002). Natural Climate Variability. In: MUNN, T. (ed.). The Earth system: physical and chemical dimensions of global environmental change. Volume 1, The Earth system: physical and chemical dimensions of global environmental change [MACCRACKEN, M. C.; PERRY, J. S. (ed.)], 2002. pp 544-549.

GONÇALVEZ, H.; et al. (2004). Ambiente construído, clima urbano e utilização racional de energia nos edifícios da cidade de Lisboa. Lisboa, Instituto Nacional de Engenharia e Tecnologia Industrial, Departamento de Energias renováveis, 2004.

GOOGLE. (2010). GoogleMaps. Disponível em <http://maps.google.com.br/>. Acesso em 14 ago. 2010. 
GORNITZ, V. (ed.) (2009). Encyclopedia of Paleoclimatology and Ancient Environments. Encyclopedia of Earth Sciences Series. Dordrecht: Springer. 2009.

GRAY, H. J.; ISAACS, A. (1975) A New Dictionary of Physics. Second Edition. London: Longman Group Limited, 1975.

GUPTA, J. (1999). Global Decision Making: Climate Change Politics. In: Climate Change: An Integrated Perspective. Martens, P; Rotmans, J. (Org.). Dordrecht: Kluwer Academic Publishers, 1999. 414 p. Cap. 9, p. 320-356.

GUTTMAN, N. B.; BAKER, C. B. (1996). Exploratory analysis of the difference between temperature observations recorded by ASOS and conventional methods. Bull. Amer. Meteor. Soc., 77, 2865-2873, 1996.

HALLAM. A. (1984). Pre-quaternary sea-level changes. Annual Review of Earth and Planetary Sciences. v. 12, p. 205-243. 1984.

HARPER, C. K. (2007). Weather and Climate: Decade by Decade. New York: Facts On File, Inc. 2007.

HATTON, D. B. (2002). Results of an intercomparion of wooden and plastic thermometer screens. In: papers presented at the WMO Technical Conference on Meteorological Instruments and Methods of Observation (TECO-2002), Bratislava, Slovak Republic, 23-25 September 2002, P1.1 (19). Instruments and Observing Methods report No.75 (WMO/TD No 1123), WMO, Geneva, 2002.

HOLLAND, H. D. (2005). Sea level, sediments and the composition of seawater. American Journal of Science, v. 305, p. 220-239, march, 2005.

HUBBARD, K. G.; LIN, X.; WALTER-SHEA, E. A. (2001). The effectiveness of the ASOS, MMTS, Gill and CRS air temperature radiation shields. J. Atmos. Oceanic Technol., 18, 851$864,2001$.

ICL CALIBRATION LABORATORIES INC (2010). PRT Calibration. 2010. Disponível em: $<$ http://www.icllabs.com/prt_calibration.htm> Acesso em: 14 ago. 2010.

INMET. (2010). Monitoramento das Estações Convencionais. Instituto Nacional de Meteorologia. Disponível em <http://www.inmet.gov.br/sim/sonabra/convencionais.php $>$. Acesso em 14 ago. 2010. 
INPE. (2007). Imagens de Satélite. São José dos Campos: Instituto Nacional de Pesquisas Espaciais. 12 imagens de satélite. $65 \mathrm{~KB}$ por imagem. Dias 16, 17, 18, 19 e 24 de maio e 12, 15, 16 de setembro de 2006. Disponível em:

$<$ http://satelite.cptec.inpe.br/acervo/goes_anteriores.jsp> Acesso em 14 ago. 2010.

IPCC. (1990). Scientific Assessment of Climate Change. Contribution of Working Group I to the First Assessment Report of the Intergovernmental Panel on Climate Change. Cambridge University Press. 1990.

IPCC. (1995). Climate Change 1995: The Science of Climate Change. Contribution of Working Group I to the Second Assessment Report of the Intergovernmental Panel on Climate Change. Cambridge University Press, 1995.

IPCC. (2001a). Summary for Policymakers. In: Climate Change 2001: The Physical Science Basis. Contribution of Working Group I to the Third Assessment Report of the Intergovernmental Panel on Climate Change. Cambridge: Cambridge University Press, 2001a. Disponível em:

$<$ http://www.grida.no/publications/other/ipcc_tar/?src=/climate/ipcc_tar/wg1/index.ht $>$. Acesso em: 14 ago. 2010.

IPCC. (2001b). Climate Change 2001: The Scientific Basis. Contribution of Working Group I to the Third Assessment Report of the Intergovernmental Panel on Climate Change.

Cambridge : Cambridge University Press, 2001b. Disponível em:

$<$ http://www.grida.no/publications/other/ipcc_tar/?src=/climate/ipcc_tar/wg1/index.htm >. Acesso em: 14 ago. 2010.

IPCC. (2004). 16 Years of Scientific Assessment in Support of the Climate Convention. 2004. Disponível em <http://www.ipcc.ch/pdf/10th-anniversary/anniversary-brochure.pdf>, Acesso em: 20 jun. 2009.

IPCC. (2007a). Fourth Assessment Report: Climate Change 2007: The AR4 Synthesis Report. Geneva: IPCC, 2007a. Disponível em:

$<$ http://www.ipcc.ch/publications_and_data/ar4/syr/en/contents.html >. Acesso em: 14 ago. 2010 . 
IPCC. (2007b). Summary for Policymakers. In: Climate Change 2007: The Physical Science

Basis. Contribution of Working Group I to the Fourth Assessment Report of the Intergovernmental Panel on Climate Change. Cambridge: Cambridge University Press, 2007b. Disponível em:

$<$ http://www.ipcc.ch/publications_and_data/ar4/wg1/en/contents.html>. Acesso em: 14 ago. 2010 .

IPCC. (2007c). Climate Change 2007: The Physical Science Basis. Contribution of Working Group I to the Fourth Assessment Report of the Intergovernmental Panel on Climate Change. Cambridge: Cambridge University Press, 2007c. 996 pp. Disponível em:

$<$ http://www.ipcc.ch/publications_and_data/ar4/wg1/en/contents.html>. Acesso em: 14 ago. 2010 .

IPCC. (2009a). About IPCC. 2009a. Disponível em < http://www.ipcc.ch/about/index.htm>, Acesso em: 20 jun. 2009.

IPCC. (2009b) How the IPCC is organized. 2009b. Disponível em

$<$ http://www.ipcc.ch/about/how-the-ipcc-is-organized.htm>, Acesso em: 20 jun. 2009.

IPCC. (2009c). IPCC Reports. [2009c]. Disponível em

$<$ http://www.ipcc.ch/ipccreports/index.htm>, Acesso em: 20 jun. 2009.

ISAACS, A. (1985). Concise Dictionary of Physics. Oxford: Oxford University Press, 1985.

ISO (INTERNATIONAL ORGANIZATION FOR STANDARDIZATION). (2007). Norma N. 17714. Meteorology - Air temperature measurements: Test methods for comparing the performance of thermometer shields/screens and defining important characteristics, Geneva, 2007.

KEARNEY, M. R.; BRISCOE, N. J.; KAROLY, D. J.; PORTER, W. P.; NORGATE, M.; SUNNUCKS, P. (2010). Early emergence in a butterfly causally linked to anthropogenic warming. Biology Letters, published online 17 March 2010. doi:10.1098/rsbl.2010.0053

KERTON, A. K. (2009). Climate Change And The Earth's Magnetic Poles, A Possible Connection. Energy \& Environment, v. 20, n. 1-2, pp. 75-83, january, 2009.

KINZIE, P. A. (1973). Thermocouple Temperature Measurement. New York: John Wiley \& Sons, Inc., 1973.

KIRKBY, J. (2007). Cosmic Rays and Climate. Surveys in Geophysics, v. 28, p. 333-375, 2007. 
KREITH, F. (1973). Princípios da Transmissão de Calor. São Paulo: Editora Edgard Blucher Ltada. 1973.

KRUSCHE, M.; SARAIVA, J. M. B.; REBOITA, M. S. (2002). Normais Climatológicas

Provisórias de 1991 a 2000 para Rio Grande, RS. Rio Grande: FURG, 2002.

LAMBECK, K.; CHAPPELL, J. (2001). Sea Level Change Through the Last Glacial Cycle. Science, v. 292, p. 679-686, 2001.

LARRE, M.H.; HEGG, K. (2002). Norwegian national thermometer screen intercomparison. In: papers presented at the WMO Technical Conference on Meteorological Instruments and Methods of Observation (TECO-2002), Bratislava, Slovak Republic, 23-25 September 2002, P1.1 (1). Instruments and Observing Methods report No.75 (WMO/TD - No 1123), WMO, Geneva, 2002.

LAURIAN, A.; DRIJFHOUT, S.S.; HAZELEGER, W.; VAN DEN HURK, B. (2010) Response of the Western European climate to a collapse of the thermohaline circulation. Climate Dynamics, v. 34, n. 5, p. 689-697, 2010.

LEAKE. J. World may not be warming, say scientists. Times Online. 14 feb. 2010.

Disponível em: <http://www.timesonline.co.uk/tol/news/environment/article7026317.ece>. Acesso em: 14 ago. 2010.

LEFEBVRE, G. (1998). Comparison of Meteorological Screens for Temperature Measurement, Paper presented at TECO-98 (Casablanca), Instruments and Observing Methods Report No. 70 (WMO/TD-No. 877), pp. 315, Geneva, 1998.

LEMONS, J (Ed.). (1996). Scientific uncertainty and environmental problem solving. Cambridge: Blackwell Science. 1996.

LEONARDI, R.M.; MONTEFINALE, T.; MALVESTUTO, V.; TESTA, O.; BELTRANO, M.C. (2006). The automatic digitization of time series recorded on graph paper supports. In: Posters presented at the WMO Technical Conference on Meteorological Instruments and Methods of Observation (TECO-2006), Geneva, Switzerland, 4-6 December 2006.

Instruments and Observing Methods report No. 94 (WMO/TD - No 1354). WMO, Geneva, 2006.

LIN, X. (1999). Microclimate inside air temperature radiation shields. University of Nebraska. Lincoln, 1999. 
LIN, X; HUBBARD, K. G. (2001). Relating temperature errors to underlying surface characteristics. In Automated Weather Stations for Applications in Agriculture and Water Resources Management: Current Use and Future Perspectives. World Meteorological Organization, Geneva, Switzerland. 93-110, 2001.

LIN, X; HUBBARD, K. G.; MEYER, G. E. (2001). Airflow characteristics of commonly used temperature radiation shields. J. Atmos. Oceanic Technol., 18, 329-339, 2001.

LIN, X; HUBBARD, K. G.; MEYER, G. E. (2004). Sensor and electronic biases/errors in air temperature measurements in common weather networks. Journal of Atmospheric and Oceanic Technology. 21(7): 1025-1032, 2004.

LIN, X; HUBBARD, K. G.; WALTER-SHEA, E. A. (2001). Radiation loading model for evaluating air temperature errors with a non-aspirated radiation shield. Trans. ASAE, 44, 1299-1306. 2001.

LINACRE, E.; GEERTS, B. (2002). City trees and the urban climate. 1997. Disponível em: $<$ http://www.das.uwyo.edu/ geerts/cwx/notes/chap01/city_trees.htm > Acesso em: jun. 2002.

LINDZEN, R. (1992). Global warming: the origin and nature of the alleged scientific consensus. Regulation, Spring 1992. p. 87-98. Disponível em $<$ http://eaps.mit.edu/faculty/lindzen/153_Regulation.pdf>. Acesso em: 20 jun. 2009.

LINO, L. G. (2009). A fraude do aquecimento global: como um fenômeno natural foi convertido numa falsa emergência mundial. 2 ed. Rio de Janeiro: Capax Dei, 2009.

LOEHLE, C. (2007). A 2000-year global temperature reconstruction based on non-treering proxies. Energy \& Environment, v. 18, p. 1049-1058, 2007.

LOEHLE, C. (2009). Trend analysis of satellite global temperature data. Energy \& Environment. v. 20, n. 7, p. 1087-1098, 2009.

LOEHLE, C.; MCCULLOCH, J.H. (2008). Correction to: A 2000-year global temperature reconstruction based on non-treering proxies. Energy \& Environment, v. 19, p. 93-100, 2008.

LOMBARDO, M. A. Ilha de calor nas metrópoles: o exemplo de São Paulo. São Paulo: Hucitec, 1985. 244 p. 
MAIRINC, I.; OCHOA, J. M. (2003). Metodologia de análisis de iluminación natural para edifícios educativos em clima cálido seco. In: ENCAC - ENCONTRO NACIONAL, 6., e ENCONTRO LATINO-AMERICANO SOBRE CONFORTO NO AMBIENTE CONSTRUÍDO, 3., São Pedro, SP, 11 a 14 de novembro de 2001. Segunda Coletânea de Anais dos Encontros Nacionais sobre Conforto no Ambiente Construído. Anais... Curitiba, 2003.

MANN, M. E.; BRADLEY; R. S. (1999). Northern Hemisphere Temperatures During the Past Millennium: Inferences, Uncertainties, and Limitations. Geophysical Research Letters, v. 26, n. 6, p. 759-762, march, 1999.

MANN, M. E.; BRADLEY; R. S.; HUGHES, M. K. (1998). Global-scale temperature patterns and climate forcing over the past six centuries. Nature, v. 392, n. 23, p. 779-787, 1998.

MARIN, F. R.; ANGELOCCI, L. R.; COELHO FILHO, M. A.; NOVA, N. A. V. (2001). Construção e avaliação de psicrômetro aspirado de termopar. Scientia Agricola, v. 58, n.4, p. 839-844, out./dez., 2001.

MARUYAMA, S. (2009) Aquecimento global? Tradução SUGUIO, K. São Paulo: Oficina de Textos, 2009. 125 p. Tradução de: Do not be taken in by the global warming theory.

MASON, B. G.; PYLE, D. M.; OPPENHEIMER, C. (2004). The size and frequency of the largest explosive eruptions on Earth. Bulletin of Volcanology, v. 66, p. 735-748, 2004.

MASUDA, K.; NAGAYA, K.; MIYAHARA, H.; MURAKI, Y.; NAKAMURA. T. (2009). Cosmogenic Radiocarbon and the Solar Activity. Journal of the Physical Society of Japan, v. 78 , p. 1-6, 2009 .

MAWLEY, E. (1897). Shade temperature. Quarterly Journal of the Royal Meteorological Society, XXIII (102):69-87, 1897.

MCGREGOR, G. R.; NIEUWOLT, S. (1998). Tropical climatology: an introduction to the climates of the low latitudes. 2 ed. New York: Wiley, 1998. 339p.

MCGUFFIE, K.; HENDERSON-SELLERS, A. (2005). A climate modelling primer. 3. ed. Chichester, West Sussex: John Wiley \& Sons, 2005. 280 p.

MCKINSEY \& COMPANY. (2009). Pathways to a Low Carbon Economy. 2009. Disponível em: <http://www.mckinsey.com/globalGHGcostcurve>. Acesso em: 20 jun. 2009. 
MCLEAN, J. (2009). Science a slave to expediency. In: The Australian: Online newspaper of the year. 06 May 2009. Disponível em:

$<$ http://www.theaustralian.news.com.au/story/0,25197,25434631-7583,00.html>. Acesso em: 20 jun. 2009.

MCLEAN, J. D.; FREITAS, C. R.; CARTER, R. M. (2009). Influence of the Southern Oscillation on tropospheric temperature. Journal of Geophysical Research, v. 114, D14104, 2009.

Mello, L. T. A.; FORTES, L. T. G.; LUCIO, P. S.; MANHAES, F. P.; LUCAS, E. W. M. (2006) Uma análise comparativa de dados meteorológicos observados em estações automáticas e convencionais do INMET. In: XIV Congresso Brasileiro de Meteorologia, 2006, Florianópolis. Anais... Florianópolis/SC: Editora da Assoc. Brasileira de Meteorologia, 2006.

MENNE, M. J.; WILLIAMS JR., C. N. (2008). Homogenization of Temperature Series via Pairwise Comparisons. Journal of Climate, v. 22, p. 1700-1717, 2008.

MENNE, M. J.; WILLIAMS JR., C. N.; VOSE, R. S. (2009). The U.S. historical climatology network monthly temperature data, version 2. American Meteorological Society, v. 90, p. 993-1007, july, 2009.

MILLER, K. G.; et al. (2005). The Phanerozoic Record of Global Sea-Level Change. Science, v. 310, p. 1293-1298, 2005.

MITCHELL, J. M. (1976). An Overview of Climatic Variability and Its Causal Mechanisms. Quaternary Research, v. 6, p. 481-493, 1976.

MODNA, D. (2004). Influência das áreas verdes urbanas na temperatura e umidade do ar da cidade de São Carlos, SP. 2004. 98 f. Dissertação. Escola de Engenharia de São Carlos, Universidade de São Paulo, 2004.

MODNA, D.; VECCHIA, F. Calor e áreas verdes: um estudo preliminar do clima urbano de São Carlos, SP. In: ENCONTRO NACIONAL SOBRE CONFORTO NO AMBIENTE COnSTRUÍDO, 7., 2003, Curitiba. Anais... Curitiba: ANTAC. 2003. 1 CD-ROM.

MOLION, L. C. B. (2006). Aquecimento Global, El Niños, Manchas Solares, Vulcões e Oscilação Decadal do Pacífico. Revista Climanálise, ano 3, n. 1, 5 p., 2006.

MOLION, L. C. B. (2008). Mitos do aquecimneto global. Revista Plenarium, v. 5, n. 5, p. 4865 , out. 2008. 
MONTEIRO, C. A. F. (1967). Ritmo hibernal da frente polar e as chuvas na fachada subtropical atlântica do Brasil: contribuição metodológica à análise geográfica dos tipos de tempo no Brasil. 1967. Tese (Doutorado). São Paulo: FFLCH. 1967.

MONTEIRO, C. A. F. (1969). A frente polar atlântica e as chuvas na fachada sul-oriental do Brasil. Série Teses e Monografias. N. 1. São Paulo: IGEOG-USP. 1969.

MONTEIRO, C. A. F. (1971). Análise rítmica em climatologia: problemas da atualidade climática em São Paulo e achegas para um programa de trabalho. São Paulo: IGEOG-USP. 1971.

MONTEIRO, C. A. F. (1973). A dinâmica climática e as chuvas do Estado de São Paulo: estudo geográfico sob forma de Atlas. São Paulo. Universidade de São Paulo, Instituto de Geografia. 1973. 68p.

MOURA, M. S. B.; SILVA, T. G. F.; TURCO, S. H., NETO, A. J. S. (2005). Comparação dos dados de temperatura do ar obtidos em estação meteorológica convencional e automática na Região do Submédio São Francisco. In: CONGRESSO BRASILEIRO DE AGROMETEOROLOGIA, 14., 2005, Campinas, SP. Resumos... Campinas: SBA; UNICAMP, 2005. 1 CD-ROM. Disponível em $<$ http://www.infoteca.cnptia.embrapa.br/handle/CPATSA/31946>. Acesso em 14 ago. 2010.

NAGY, Z. (2006). Effects of thermometer screens on accuracy of temperature measurements. In: Posters presented at the WMO Technical Conference on Meteorological Instruments and Methods of Observation (TECO-2006), Geneva, Switzerland, 4-6 December 2006.

Instruments and Observing Methods report No. 94. WMO, Geneva, 2006. Disponível em: $<$ http://www.wmo.int/web/www/IMOP/publications/IOM-94TECO2006/P3(14)_Nagy_Hungary.pdf>, Acesso em: 10 jan. 2007

NAKAMURA, R.; MAHRT, L. (2005). Air temperature measurement errors in a naturally ventilated radiation shield. Journal of Atmospheric and Oceanic Technology. 22: 1046-1058, 2005.

NASA. (2010). NASA Study Finds Atlantic 'Conveyor Belt' Not Slowing. NASA News \& Features. 25 mar. 2010. Disponível em:

$<$ http://www.jpl.nasa.gov/news/news.cfm?release=2010-101>. Acesso em 14 ago. 2010.

NCDC (National Climatic Data Center) (2010). GHCN-Monthly Version 2. NOAA Satellite and Information Service, Disponível em: <http://www.ncdc.noaa.gov/oa/climate/ghcnmonthly/index.php>. Acesso em: 14 ago. 2010. 
NICHOLAS, J. V.; WHITE, D. R. (1994). Traceable temperatures: an introduction to temperature measurement and calibration - Wiley series in measurement science and technology. Chichester: John Wiley \& Sons, 1994.

OLIVEIRA, A. S. (1969). Umidade relativa e temperatura do ar: fórmulas usuais e fórmulas novas com horários para leituras simultâneas. 1969. 103p. Tese (Doutorado em Agronomia)Escola Superior de Agricultura "Luiz de Queiroz", Universidade de São Paulo, Piracicaba, 1969.

ONÇA, D. S. (2007). Curvar-se diante do existente: o apelo às mudanças climáticas pela preservação ambiental. 2007. 242 p. Dissertação (Mestrado Geografia Física)-Faculdade de Filosofia, Letras e Ciências Humanas, Universidade de São Paulo, São Paulo, 2007.

ONÇA, D. S. (2008) A Controvérsia do Taco de Hóquei. In: SIMPÓSIO BRASILEIRO DE Climatologia GEOGRÁFICA, 8., 2008, Alto Caparaó, Anais..., Uberlância: EDUFU, v. 1, 2008. [CD-ROM].

ONÇA, D. S.; FELÍCIO, R. A. (2008). As mudanças climáticas segundo Al Gore. In: FÓRUM AMBIENTAL DA AlTA PAUliSTA, 6., 2008, Tupã. Anais..., Tupã: 2008. PANEL ON RECONCILING TEMPERATURE OBSERVATIONS. (2000). Reconciling Observations of Global Temperature Change. National Research Council The National Academies Press. Washington, 2000.

PARKER, D. E. (1994). Effects of changing exposure of thermometers at land stations. International Journal of Climatology, 14: 1-31, 1994.

PARKER, D. E.; BASNETT, T.A.; BROWN, S. J.; GORDON, M.; HORTON, E.B.; RAYNER, N.A. (2000). Climate Observations - The Instrumental Record. Space Science Reviews, v. 94, p. 309-320, 2000.

PARKER, D.; HORTON, B. (2005). Uncertainties in Central England temperature 18782003 and some improvements to the maximum and minimum series. International Journal of Climatology, v. 25, p. 1173-1188, 2005.

PEREIRA, L. M. P; CARAMORI, W. S. R.; RICCE, W. S.; CAVIGLIONE, J. H. (2008). Análise comparativa de dados meteorológicos obtidos por estação convencional e automática em Londrina - PR. Semina: Ciências Agrárias, Londrina, v. 29, n. 2, p. 299-306, abr./jun. 2008. 
PETERSON, T. C.; VOSE, R. S. (1997). An Overview of the Global Historical Climatology Network Temperature Database. Bulletin of the American Meteorological Society, v. 78, n. 12, dec. 1997.

PETIT, J. R.; et al. (1999). Climate and atmospheric history of the past 420,000 years from the Vostok ice core, Antarctica. Nature, v. 399, p. 429-436, 1999.

PETIT, J.R.; et al. (2001).Vostok Ice Core Data for $\mathbf{4 2 0 , 0 0 0}$ Years, IGBP PAGES/World Data Center for Paleoclimatology Data Contribution Series \#2001-076. NOAA/NGDC Paleoclimatology Program, Boulder CO, USA. 2001. Disponível em: $<$ http://www.ncdc.noaa.gov/paleo/metadata/noaa-icecore-2453.html>. Acesso em: 14 ago. 2010.

PHILANDER; S. G. (2008). Encyclopedia of global warming and climate change. London: SAGE Publications Inc., 2008.

PITTON, S. E. C. (1985). Análise de Sistemas de Organização Climática do Espaço. 1985. Dissertação (Mestrado). Rio Claro: IGE/UNESP. 1985.

PNUD. (1998). Human Development Report 1998: Consumption for Human Development. Chapter 1: The state of human development. 1998. Disponível em: <http://hdr.undp.org/en/reports/global/hdr1998/>. Acesso em: 20 jun. 2009.

PRETI, A., LENTINI, G.; MAUGERI, M. (2007). Global warming possibly linked to an enhanced risk of suicide: Data from Italy, 1974-2003. Journal of Affective Disorders, v. 102, p. 19-25, 2007.

QUAYLE, R. G.; EASTERLING, D. R.; KARL, T. R.; HUGHES, P. Y. (1991). Effects of recent thermometer changes in the Cooperative Station Network. Bull. Amer. Meteor. Soc., 72, 1718-1723, 1991.

QUINN, T. J. (1983). Monographs in Physical Measurement: Temperature. London: Academic Press Inc., 1983.

RAMPINO, M. R.; SELF, S. (1993). Climate-Volcanism Feedback and the Toba Eruption of 74,000 Yeras Ago. Quaternary Research, v. 40, p. 269-280, 1993.

REIMER; P. J.; et al. (2004). IntCal04 Terrestrial Radiocarbon Age Calibration, 0-26 cal kyr BP. Radiocarbon, v. 46, n. 3, p. 1029-1058, 2004. Dados disponíveis em: $<$ http://www.radiocarbon.org/IntCal04.htm>. Acesso em: 14 ago. 2010. 
ROBOCK, A.; OMAN, L.; STENCHIKOV, G. L.; TOON, O. B.; BARDEEN, C.; TURCO, R. P. (2007). Climatic consequences of regional nuclear conflicts. Atmospheric Chemistry and Physics, v. 7, p. 2003-2012, 2007.

RODRIGUES; G. P. (2009). A farsa do aquecimento global. 2009. 79 p. Trabalho de Graduação Individual (Bacharelado em Geografia)-Faculdade de Filosofia, Letras e Ciências Humanas, Universidade de São Paulo, São Paulo, 2009.

ROGERS; J. J. W.; SANTOSH, M. (2004). Continents and Supercontinents. Oxford: Oxford University Press, 2004.

RYAN, P. D.; DEWEY, J. F. (1997). Continental eclogites and the Wilson Cycle. Journal of the Geological Society, v. 154, p. 437-442, 1997.

SALMONI, R. (1966). Transmissão de Calor. São Paulo: Editora Gustavo Gilli. 1966.

SALTZMAN, B. (2002). Dynamical paleoclimatology: generalized theory of global climate change. San Diego: Academic Press, 2002. 354 p.

SCAFETTA, N. (2010). Empirical evidence for a celestial origin of the climate oscillations and its implications. Journal of Atmospheric and Solar-Terrestrial Physics, v. 72, p. 951-970, 2010.

SCARPARE; F. V.; OLIVEIRA, G.X.; SIMON; J.; PIEDADE, S. M. S.; ANGELOCCI, L. R. (2006). Comparação da uniformidade de dados meteorológicos de estação meteorológica convencional e automática - Piracicaba/SP. In: XIV Congresso Brasileiro de Meteorologia, 2006, Florianópolis. Anais... Florianópolis/SC : Editora da Assoc. Brasileira de Meteorologia, 2006.

SCHAAL, L. A.; DALE, R. F. (1977). Time of Observation Temperature Bias and "Climatic Change". Journal of Applied Meteorology, v. 16, n. 3, p. 215-222, 1977.

SCHIERMEIER, Q. (2005). Atlantic currents show signs of weakening. Nature News. 30 Nov. 2005. Disponível em <http://www.nature.com/news/2005/051128/full/news0511289.html>. Acesso em 14 ago. 2010.

SCHIERMEIER, Q. (2006). A Sea Change. Nature, v. 439, p. 256-260, 2006.

SCHNEIDER, D. A.; KENT, D. V.; MELLO, G. A. (1992). A detailed chronology of the Australasian impact event, the Brunhes-Matuyama geomagnetic polarity reversal, and global climate change. Earth and Planetary Science Letters, v. 111, p. 395-405, 1992. 
SCHÖLL, M.; STEINHILBER, F.; BEER, J.; HABERREITER, M.; SCHMUTZ, M. (2007). Long-term reconstruction of the total solar irradiance based on neutron monitor and sunspot data. Advances in Space Research, v.40, p. 996-999, 2007.

SCHULTE, P.; et al. (2010). The Chicxulub Asteroid Impact and Mass Extinction at the Cretaceous-Paleogene Boundary. Science, v. 327, p. 1214-1218.

SENTElHAS, P. C.; MORAES, S. O.; PIEDADE, S. M. S.; PEREIRA, A. R. Análise comparativa de dados meteorológicos obtidos por estações convencional e automática.

Revista Brasileira de Agrometeorologia, Santa Maria, v. 5, n. 2, p. 215-221, 1997.

SEPP (2009). About the Project. [2009]. Disponível em

$<$ http://www.sepp.org/about\%20sepp/abtsepp.html>, Acesso em: 20 jun. 2009.

SHASHUA-BAR, L.; HOFFMANN, M. E. (2000). Vegetation as a climactic component in the design of an urban street: an empirical model of predicting the cooling effect of urban green areas with trees. Energy and Buildings, v. 31, n.3: 221-235, 2000.

SHAVIV, N. J. (2003). The spiral structure of the Milky Way, cosmic rays, and ice age epochs on Earth. New Astronomy, v. 8, p. 39-77, 2003.

SILVA, A. C. (2001). Estudos Climáticos e Ambiente Construído no Município de

Descalvado - SP. 92p. Dissertação (Mestrado) - Escola de Engenharia de São Carlos, Universidade de São Paulo, São Carlos. 2001.

SINGER, S.F. (2009). Nature, Not Human Activity, Rules the Climate. Chicago: The Heartland Institute, 2008. Disponível em <http://www.heartland.org/books/NIPCC.html>. Acesso em: 20 jun. 2009.

SINGER, S.F; IDSO, C. (2009). Climate Change Reconsidered. Chicago: The Heartland Institute, 2009. Disponível em <http://www.nipccreport.org>. Acesso em: 20 jun. 2009.

SOLANKI, S. K.; USOSKIN, I. G.; KROMER, B.; SCHÜSSLER, M.; BEER, J. (2004). Unusual activity of the Sun during recent decades compared to the previous 11,000 years. Nature, v. 431, p. 1084-1087, 2004.

SORRE, M. (1951). Le Climat. In: Le fondaments de La Geographie Humain. 3 ed. Paris: Armand Colin. 
SORRE, M. (2006). Objeto e método da climatologia. Revista do Departamento de Geografia, n. 18, p. 89-94, 2006. Tradução CONTI, J. B. Disponível em $<$ http://www.geografia.fflch.usp.br/publicacoes/RDG/RDG_18/RDG18_089_094.pdf >. Acesso em 26 nov. 2007. Tradução de "Traité de climatologie biologique et medicale".

SOUZA, I. A.; GALVANI, E.; ASSUNÇÃO, H. F. (2003). Estudo comparativo entre elementos meteorológicos monitorados por estações convencional e automática na região de Maringá, Estado do Paraná. Acta Scientiarum. Technology, Maringá, v. 25, n. 2, p. 203-207, 2003.

SOUZA, I. F., NOGUEIRA, L. C., BAStOS, D. B., MELO, D. L. F. M, BARRETO, A. N., COSTA, L. C., MANTOVANI, E. C. (2000). Comparação de dados meteorológicos obtidos em estações convencional e automática do Distrito de Irrigação do Platô de Neopólis. IN: CONGRESSO BRASILEIRO DE METEOROLOGIA, 11., 2000, Rio de Janeiro. Anais... Rio de Janeiro: Sociedade Brasileira de Meteorologia, 2000.

SPARKS, W. R. (1972). The Effect of Thermometer Screen Design on the Observed Temperature, WMO-No. 315, 1972.

SPECIAN, V. (2003). Clima e Ambiente Construído. Análise da Predicting Indoor Air Temperature Formula. 2003. 189 f. Dissertação (Mestrado em Ciência Ambiental) - Escola de Engenharia de São Carlos, Universidade de São Paulo, São Carlos. 2003.

SUN, B.; BAKER, C. B. (2004). A comparative study of ASOS and CRN temperature measurements. In: XII Symposium on Integrated Observing and Assimilation Systems for Atmosphere, Oceans, and Land Surface - 84th AMS Annual Meeting. Seattle, 2004.

SUTCLIFFE, S.; COURT, J (2005). Evidence-based policymaking: what is it? How does it works? What relevance for developing countries? [s.l.]: Overseas Development Institute, 2005. 45p. Disponível em: <http://www.odi.org.uk/rapid/projects/PPA0117/Index.html>. Acesso em: 14 ago, 2010.

SVENSMARK, H. (2007) Cosmoclimatology: a new theory emerges. Astronomy \& Geophysics, v. 48, n. 1, p. 1.18-1.24, feb. 2007.

TAHA, H. (1997). Urban climates and heat islands: albedo, evapotranspiration, and anthropogenic heat. Energy and Buildings, v. 25, p. 99-103, 1997.

TANNER, B. D. (1990). Automated weather stations. Remote Sensing Reviews, v. 5, p. 7398, 1990. 
TANNER, B. D.; SWIATEK, E.; MAUGHAN, C. (1996). Field comparisons of naturally ventilated and aspirated radiation shields for weather station air temperature measurements. Preprints, 22d Conf. on Agricultural and Forest Meteorology, Atlanta, GA, Amer. Meteor. Soc., 227-230, 1996.

TARARA, J. M.; HOHEISEL, G. (2007). Low-cost Shielding to Minimize Radiation Errors of Temperature Sensors in the Field. Hortscience, v. 42, n. 6, p. 1372-1379, 2007.

TARIFA, J. R.; ARMANI, G. (2001). As unidades climáticas urbanas da cidade de São Paulo: os clima e a (re)produção do espaço nas metrópoles. In: VII ENCUENTRO DE GEÓGRAFOS DE AMÉRICA LATINA. Santiago do Chile: Universidad de Chile. 2001.

Teramoto, E. T.; CARVAlHO, L. GO.; DANTAS, A. A. A. (2009). Comparação entre valores de temperatura média do ar de estação convencional com valores obtidos em estação automática e análise de equações para estimativas de médias da temperatura do ar em Lavras, MG. Ciência e Agrotecnologia, Lavras, v. 33, Edição Especial, p. 1798 -1803, 2009.

THE HEARTLAND INSTITUTE. (2009). Welcome to the Heartland Institute. [2009]. Disponível em <http://www.heartland.org/about/>. Acesso em: 20 jun. 2009.

TOLETINO, M. (1967). Estudo crítico sobre o clima da região de São Carlos. São Carlos: S.N., 1967. 78 p.

TOON, O. B.; ROBOCK, A.; TURCO, R. P. (2008) Environmental consequences of nuclear war. Physics Today. v. 61, n. 12, p. 37-42, 2008.

TOON, O. B.; TURCO, R. P.; COVEY, C. (1997). Environmental perturbations caused by the impacts of asteroids and comets. Reviews of Geophysics, v. 35, p 41-78, feb. 1997.

TRENBERTH, K. E.; FASULLO, J. T.; KIEHL, J. (2009). Earth's global energy budget. Bulletin of the American Meteorological Association, v. 90, p. 311-323, 2009.

TREWIN, B. (2004). Effects of changes in algorithms used for the calculation of Australian mean temperature. Australian Meteorological Magazine, v. 53, n. 1, p. 1-11, march 2004.

TURCO, J. E. P.; BARBOSA, J. C. (2008). Avaliação de duas estações meteorológicas automatizadas, para estimativa diária da evapotranspiração de referência obtida pelo método de Penman-Monteith. Irriga, Botucatu, v. 13, n. 3, p. 339-354, julho-setembro, 2008. 
TURCO, R. P.; TOON, O. B.; ACKERMAN, T. P.; POLLACK, J. B.; SAGAN. C. (1983). Nuclear Winter: Global Consequences of Multiple Nuclear Explosion. Science, v. 222, p. 1283-1292, 1983.

UNITED NATIONS. (1992). United Nations Framework Convention On Climate Change, FCCC/INFORMAL/84 GE.05-62220 (E) 200705. 1992. Disponível em:

$<$ http://unfccc.int/resource/docs/convkp/conveng.pdf>. Acesso em: 18 ago. 2010.

UNITED NATIONS. (1992b). Annex I. Rio Declaration on Environment and Development. In: Report of the United Nations Conference on Environment and Development. A/CONF.151/26 (Vol. I). Rio de Janeiro, 3-14 June 1992. Disponível em: $<$ http://www.un.org/documents/ga/conf151/aconf15126-1annex1.htm>. Acesso em: 14 ago. 2010.

UNUR. S. (2010). Dude, where is my thermometer. 2010. Disponível em $<$ http://blog.qtau.com/2010/05/dude-where-is-my-thermometer.html>. Acesso em: 14 ago. 2010.

VAIL, P. R.; MITCHUM, R. W.; THOMPSON, S. (1977). Seismic stratigraphy and global changes in sea level 4, Global cycles of relative changes in sea level. American Association of Petroleum Geologists Memoir, v. 26, p. 82-97, 1977.

VAN DER MEULEN, J. P. (1998). A Thermometer Screen Intercomparison. Instruments and Observing Methods Reports. World Meteorological Organization, Geneva, Switzerland. n. 70 , pg. $319,1998$.

VAN DER MEULEN, J. P.; BRANDSMA, T. (2008). Thermometer Screen Intercomparison in De Bilt (the Netherlands) - Part I: Understanding temperature differences for particular days. International Journal of Climatology, v. 28, p. 371-387, 2008.

VECCHIA, F. (1990). Condicionantes termo-energeticas das edificacoes. Sao carlos como estudo de caso. São Paulo, 1990. Dissertação (Mestrado) - Programa de Pós-Graduação em Arquitetura e Urbanismo, Escola de Engenharia de São Carlos, Universidade de São Paulo, São Carlos. 1990.

VECCHIA, F. (1997). Clima e ambiente construído: a abordagem dinâmica aplicada ao Conforto Humano. São Paulo, 1997. Tese (Doutorado) - Programa de Pós-Graduação em Geografia, Faculdade de Filosofia, Letras e Ciências Humanas (FFLCH USP), Universidade de São Paulo, São Paulo. 1997. 
VECCHIA, F. (2001). Projeto Conforto Térmico: Estudo comparativo do comportamento térmico de sistemas de cobertura. Projeto Conforto, Convênio Eternit S.A. São Carlos: EESC/FIPAI. 2001.

VECCHIA, F.; NOLASCO, G. C. (2005). Comportamiento térmico de casa experimental construida con bajareque mejorado. Ciencia y Tecnología en la Frontera, México, v. 1, n. 1, p. 25-33, 2005 .

VEIGA, J. E. (2008). Aquecimento global: frias contendas científicas. São Paulo: Editora Senac São Paulo, 2008.

WARNE, J. (1995). Temperature Screen Comparison. Australian Bureau of Meteorology Test Facility, Melbourne, Australia. 1995.

WATTS. A. (2009). Is the U.S. Surface Temperature Record Reliable? Chicago: The Heartland Institute. 2009. Disponível em < SurfaceStations.org>. Acesso em 14 ago. 2010.

WEBER, R. O. (1993). Influence of Different Daily Mean Formulas on Monthly and Annual Averages of Temperature. Theoretical and Applied Climatology, v. 47, p. 205-213, 1993.

WILLIAMS, M. A.J.; et al. (2009) Environmental impact of the 73 ka Toba super-eruption in South Asia. Palaeogeography, Palaeoclimatology, Palaeoecology, v. 284, p. 295-314, 2009.

WILLIS, J. K. (2010). Can in situ floats and satellite altimeters detect long-term changes in Atlantic Ocean overturning?. Geophysical Research Letters, v. 37, L06602, 2010.

WILLMOTT, C.J.; ACKLESON, S.G.; DAVIS, R.E.; et al. (1985). Statistics for the evaluation and comparison of models. Journal of Geophysical Research, Ottawa, v. 90, n. C5, p. 8995-9005, 1985.

WMO. (1983). Guide to Climatological Practices. 2 ed. WMO N. 100. Geneva: World Meteorological Organization, 1983. Disponível em:

$<$ http://www.wmo.int/pages/prog/wcp/ccl/guide/guide_climat_practices.html $>$. Acesso em 14 ago. 2010 .

WMO. (1989). Calculation of monthly and annual 30-years standard normals. WCDP-No. 10. WMO-TD/No. 341. Geneva: World Meteorological Organization. 1989.

WMO. (2000). Representativeness, data gaps and uncertainties in climate observations. WCDMP-No. 44, WMO-TD 977. Geneva: World Meteorological Organization. 2000. 
WMO. (2003). Commission for Instruments and Methods of Observation: Bridged Final Report with Resolutions and Recommendations, thirteenth session. WMO-No. 947, Geneva, Switzerland. 2003.

WMO. (2006). Commission for Instruments and Methods of Observation: WMO Combined Intercomparison of Thermometer Screens/Shields in Conjunction with Humidity Measuring Instruments, Operational Aspects of the Intercomparison. Geneva, Switzerland. 2006.

Disponível em <http://www.wmo.int/web/www/IMOP/intercomparisons/Temp-Hum2007/Algeria_Operational-Aspects.doc>, acesso em 10 jan. 2007.

WMO. (2007). The role of climatological normals in a changing climate. WCDP-No. 61. WMO-TD/No. 1377. Geneva: World Meteorological Organization. 2007.

WMO. (2008). Guide to Meteorological Instruments and Methods of Observation, 7 ed., WMO-No. 8. Geneva: World Meteorological Organization, 2008.

WMO. (2009). Guide to Climatological Practices (draft). 3 ed. WMO N. 100. Geneva: World Meteorological Organization, 2009. Disponível em:

$<$ http://www.wmo.int/pages/prog/wcp/ccl/guide/guide_climat_practices.html $>$. Acesso em 14 ago. 2010.

WMO. (2010). Not just another climate conference. 2010. Disponível em:

$<$ http://www.wmo.int/wcc3/conf_en.php>. Acesso em: 14 jun. 2010.

WOOD, R. A.; VELLINGA, M.; THORPE, R. (2003). Global Warming and thermohaline circulation stability. Philosophical Transactions of the Royal Society A: Mathematical, Physical and Engineering Sciences, v. 361, p. 1961-1975, 2003.

WORM, H.U. (1997). A link between geomagnetic reversals and events and glaciations. Earth and Planetary Science Letters, v. 147, p. 55-67, 1997.

XIONG, A. (2006). Influence of changes of sensor and shelter on air temperature observation, and analysis to its causes. In: Posters presented at the WMO Technical Conference on Meteorological Instruments and Methods of Observation (TECO-2006), Geneva, Switzerland, 4-6 December 2006. Instruments and Observing Methods report No. 94. WMO, Geneva, 2006. Disponível em: <http://www.wmo.int/web/www/IMOP/publications/IOM-94TECO2006/P3(07)_Xiong_China.pdf>, Acesso em: 10 jan. 2007. 
ZAIKI, M.; KIMURA, K.; MIKAMI, T. (2002). A statistical estimate of daily mean temperature derived from a limited number of daily observations. Geophysical Research Letters, v. 29, N. 18, p. 39-1 - 39-4, 2002.

ZAVATTINI, J. A. (2000). Desenvolvimento e perspectivas da climatologia geográfica no Brasil: o enfoque dinâmico, a noção de ritmo climático e as mudanças climáticas. In: SANT'ANNA NETO; J. L.; ZAVATTINI, J. A. (orgs). Variabilidade e Mudanças Climáticas. Maringá: EDUEM, 2000. p. 225-252. 
APÊNDICES-383

APÊNDICES 

APÊENDICE A - Vistas panorâmicas opostas da primeira estação experimental, juntamente com a estação de referência.

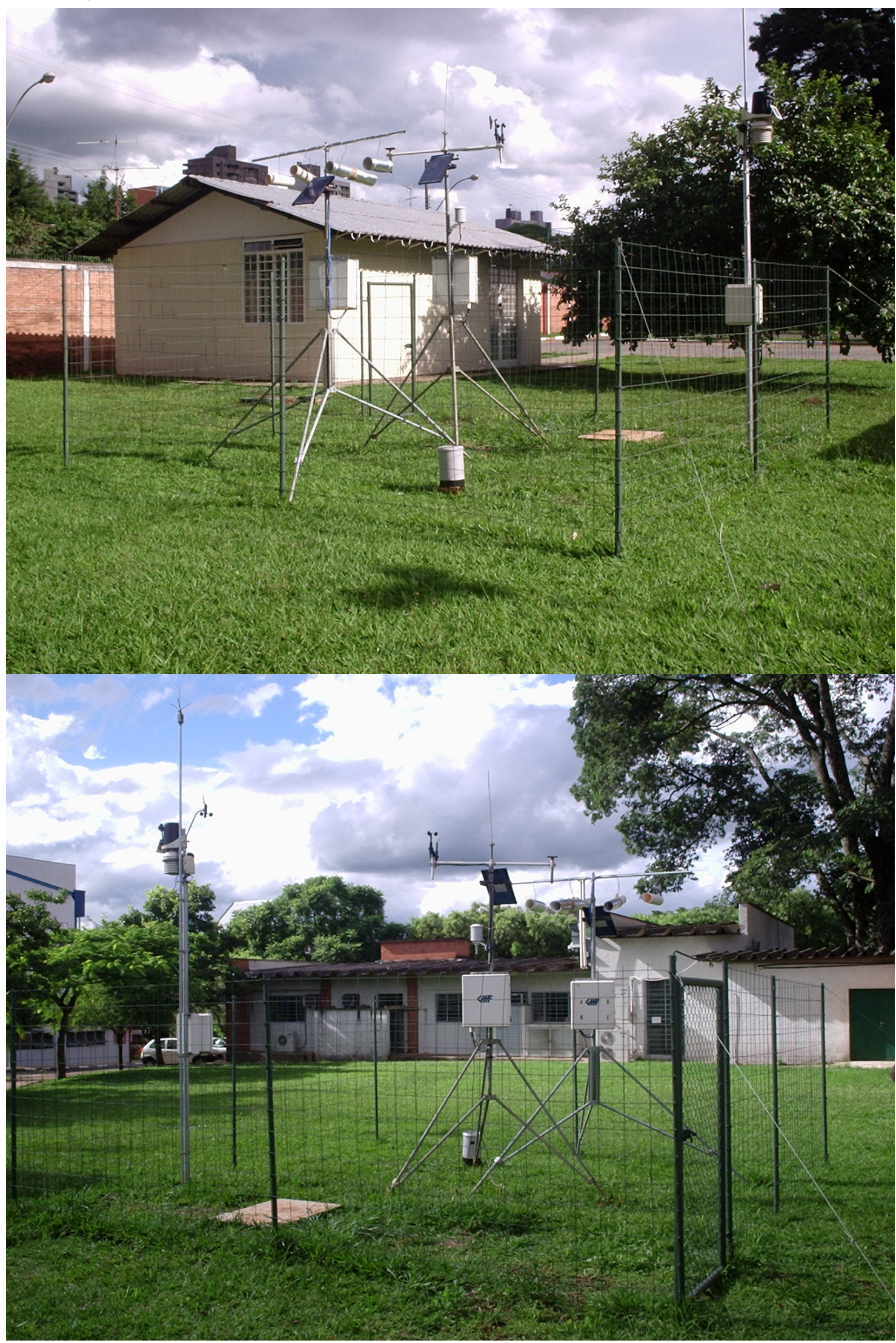



APÊNDICE B - Primeira estação experimental (esquerda) e a de referência (direita). Ao fundo, Laboratório de Ecotecnologias: Novos Materiais e Procedimentos.

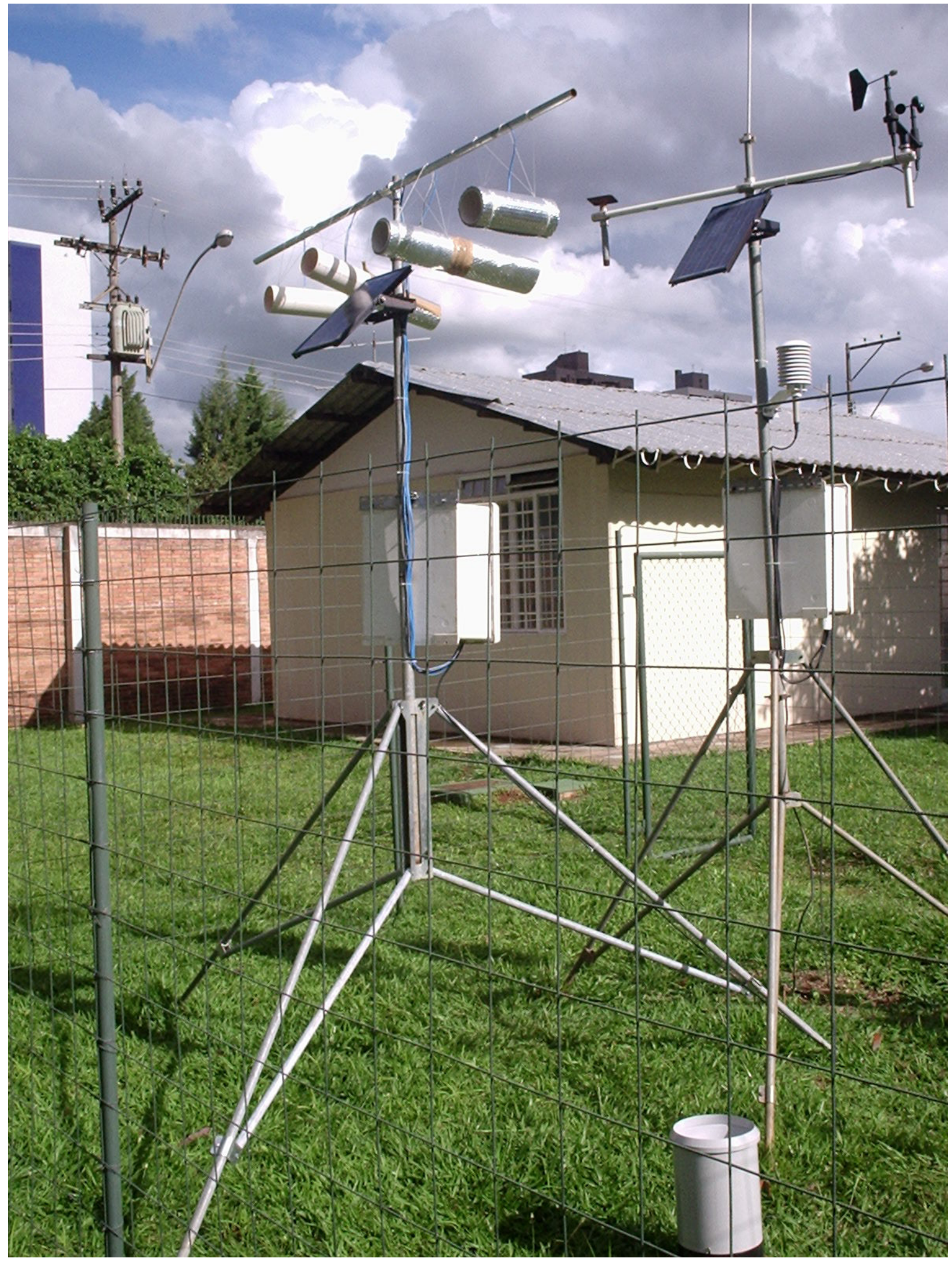



APÊNDICE C - Primeira estação experimental com 4 abrigos. Disposição dos abrigos: (1) Abrigo sem foil e ventilação natural; (2) Abrigo sem foil e ventilação forçada; (3) Abrigo com foil e ventilação forçada; (4) Abrigo com foil e ventilação natural. (A) Painel solar, fonte de energia da bateria; (B) Caixa ambientalmente vedada.

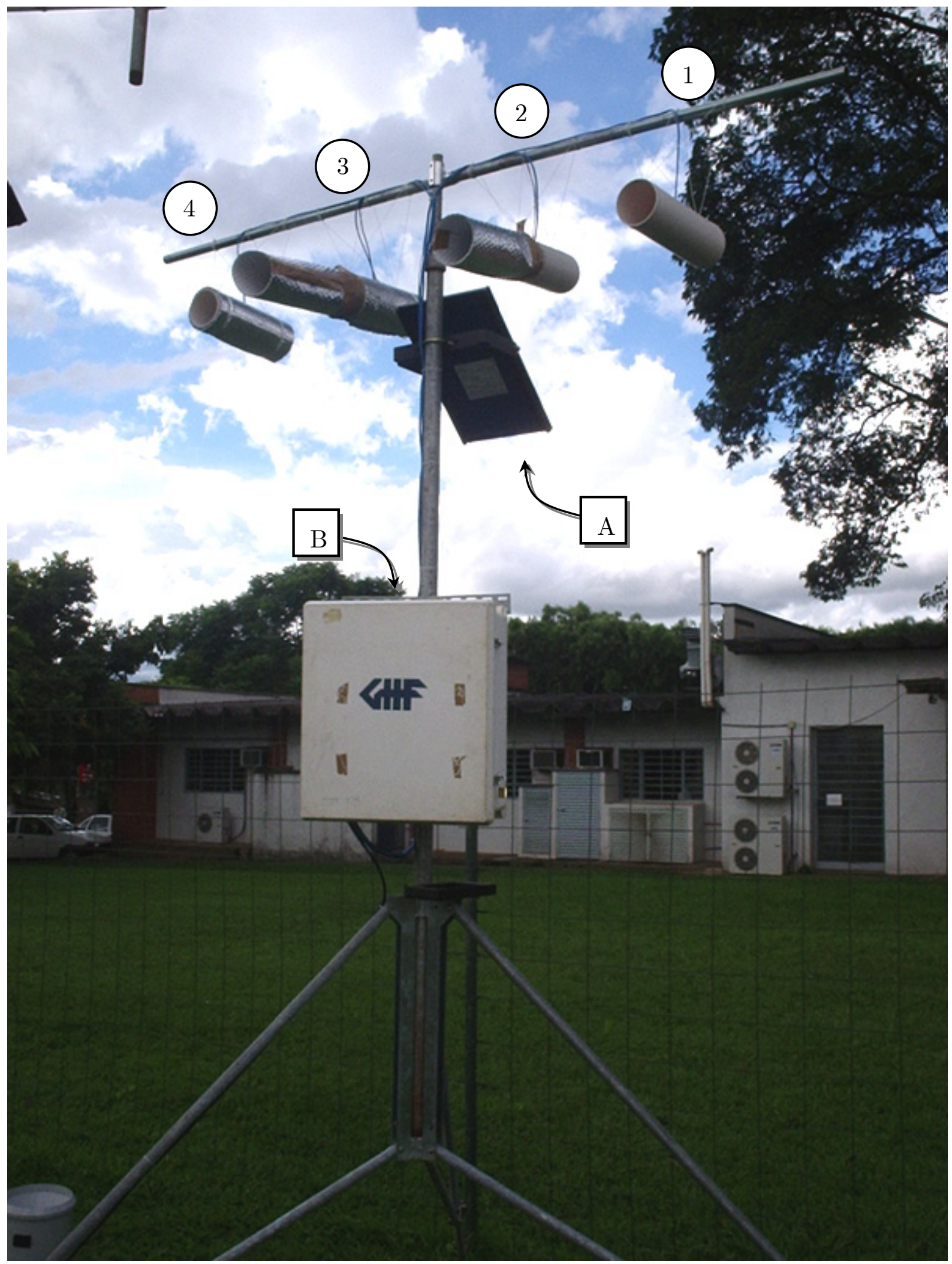



APÊNDICE D - Detalhe do interior da caixa ambientalmente selada. (A) Bateria de $12 \mathrm{~V}$ modelo PS12 da Campbell Scientific Inc.; (B) Multiplexador AM 16/32 da Campbell Scientific Inc. de 32 canais; (C) Sistema de aquisição e armazenamento de dados (datalogger) CR10X Campbell Scientific Inc.; (D) Fonte de alimentação para as ventoinhas.

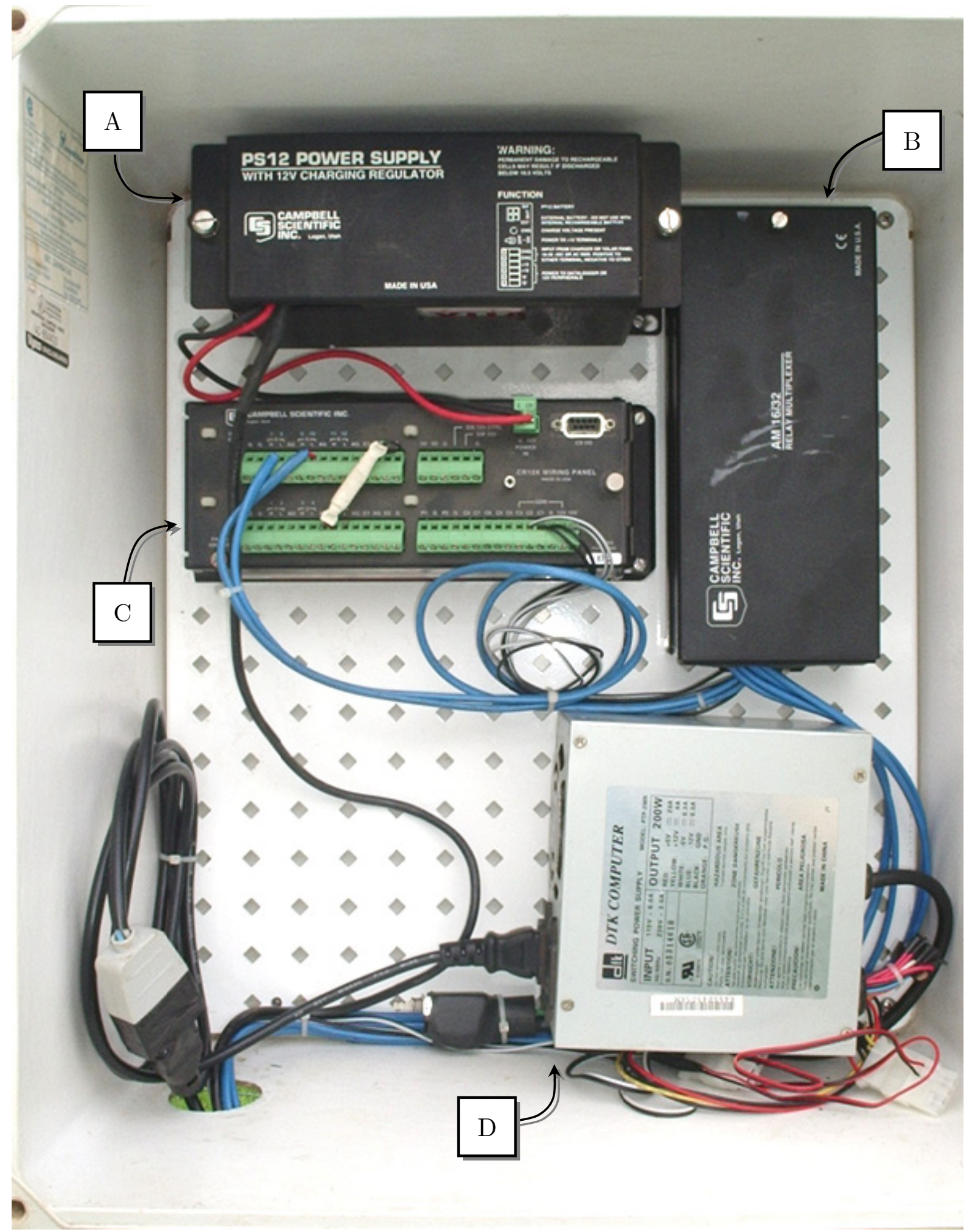



APÊNDICE E - Segunda estação experimental, com 9 abrigos. Disposição dos abrigos: (1) PVC azul com ventoinha; (2) PVC vermelho com ventoinha; (3) PVC verde com ventoinha; (4) PVC branco com ventoinha; (5) PVC preto com ventoinha; (6) PVC branco com foil e com ventoinha; (7) PVC com anteparo e com ventoinha; (8) PVC branco sem foil e sem ventoinha; (9) Metálico com ventoinha e sem foil;

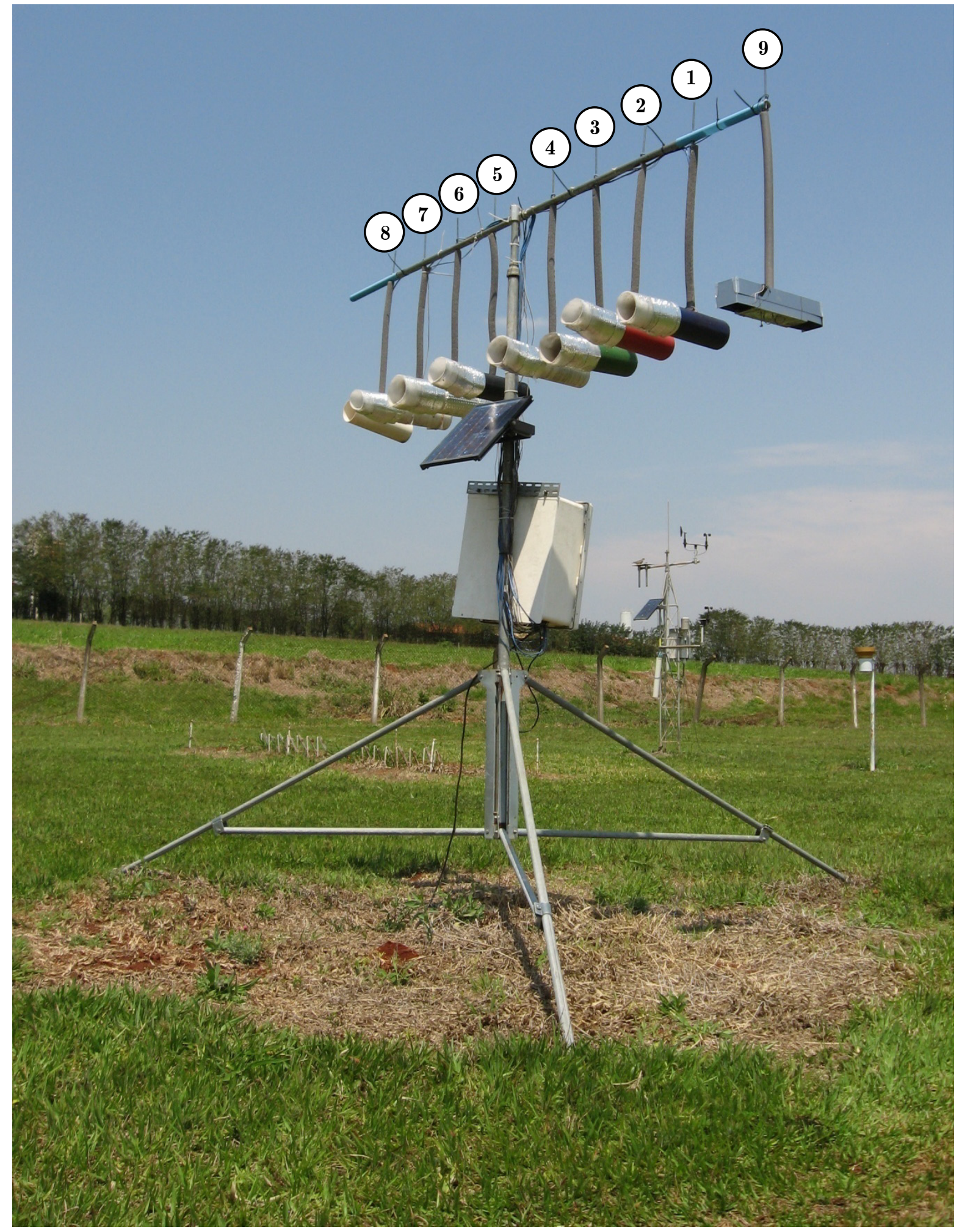



APÊNDICE F - Estação de referência Campbell Scientific. Ao fundo, segunda estação experimental. (A e B) Sensores de velocidade e direção dos ventos a $2 \mathrm{~m}$ e $1,5 \mathrm{~m}$ de altura, respect.; (C) Sensor de radição solar global; (D) Sensor de temperatura HMP45C acoplado ao abrigo 41003; (E) Painel solar; (F) Caixa ambientalmente vedada com sistema automático de aquisição de dados. Esta estação, devido aos desgastes de uso, não estava coletando corretamente os dados. Assim, foi montada uma nova estação de referência ao seu lado esquerdo, atrás da estação experimental, conforme mostrada no próximo apêndice.

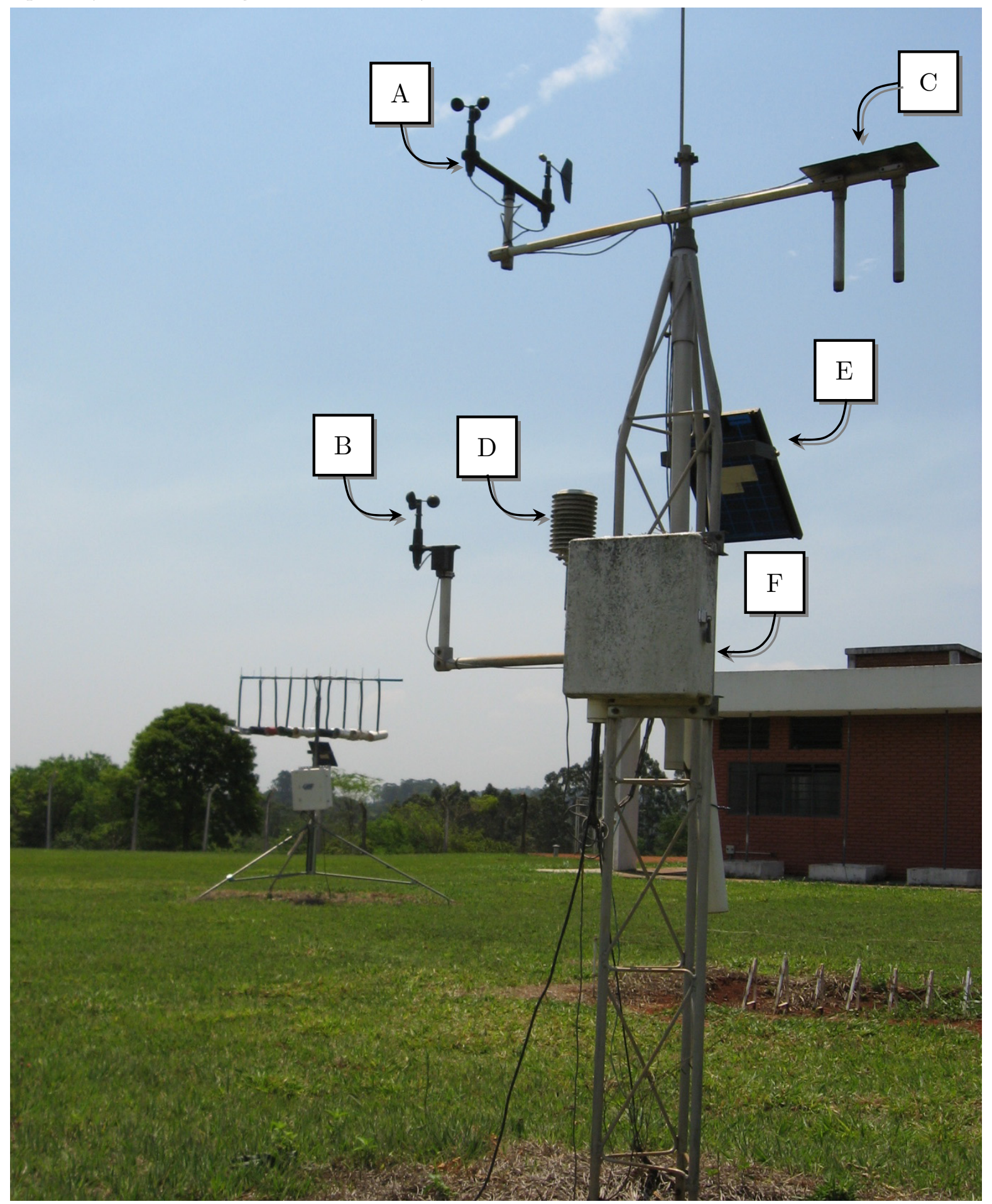



APÊNDICE G - Manutenção da $2^{\text {a }}$ estação experimental, tratada na PARTE B, Capítulo 5, pg. 275. (A) Montagem e (B) limpeza da estação; (C, D, E) calibração dos termopares. No lado esquerdo da foto (A), nova estação de referência ao fundo.
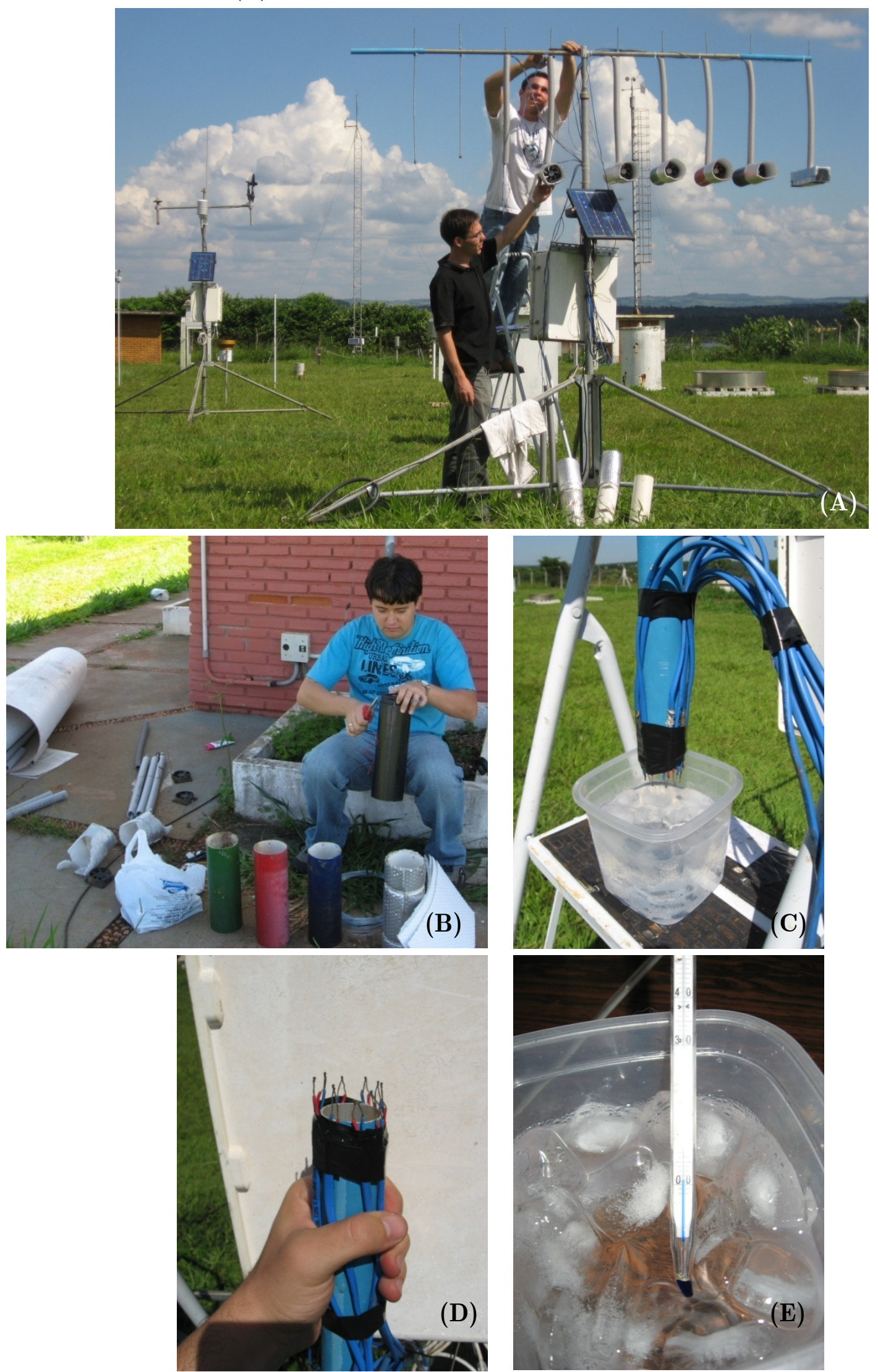



\section{APÊNDICE H - Representação e síntese anual dos elementos do clima: Climatiris, diagrama circular de isolinhas}

\section{Introdução}

Antigamente, quando ainda não estavam disponíveis os recursos e benefícios tecnológicos proporcionados pela microinformática, o principal desafio no tratamento e manipulação da enorme quantidade de dados climáticos consistia na realização de cálculos que, no princípio, eram realizados manualmente. Tal procedimento demandava muito tempo e estavam sujeitos a inúmeros erros humanos. Os resultados dos esforços descomunais dos pesquisadores eram divulgados principalmente por meio de tabelas.

Com o surgimento dos primeiros computadores modernos na década de 70, uma nova era foi iniciada. A popularização dos computadores pessoais nas décadas seguintes e difusão do seu uso em todos os setores e atividades humanas, inclusive nas Ciências Atmosféricas, Meteorologia e Climatologia, permitiram ultrapassar e superar o obstáculo de realização de numerosos cálculos repetitivos. Embora a capacidade de processamento de dados tenha aumentado consideravelmente, é cada vez maior a quantidade de dados que são coletados e registrados nas diversas áreas do conhecimento. Ou seja, o problema de manipulação de dados foi resolvido, porém, foi criado um novo desafio com a crescente geração de dados.

Para sanar esta nova dificuldade, estão disponíveis atualmente técnicas computacionais modernas de extração de informação de grandes bases de dados. Por exemplo, uma dessas técnicas é a mineração de dados (data mining), processo eficiente que utiliza inteligência artificial para buscar relações de similaridade ou discordância entre dados. A mineração de dados é capaz de encontrar, automaticamente, padrões, anomalias e regras com o propósito de transformar dados, aparentemente ocultos, em informações úteis para a tomada de decisão e/ou avaliação de resultados.

Resolvidas as dificuldades de obtenção, armazenamento, manipulação, seleção e extração de dados importantes, resta apenas mais uma etapa importante na transformação de dados em informação, e de informação em conhecimento: a exibição e divulgação da informação. No estudo do clima, dados numéricos de algum fenômeno observado que variam com o decorrer do tempo são classificadas como séries 
temporais, que consistem em sequências únicas de dados obtidos (ou estimados) representativos para um determinado período de tempo, representando a base de toda análise climática.

De forma a facilitar a compreensão das alterações das variáveis de interesse, as séries são representadas por meio de gráficos, que expressam visualmente dados ou valores numéricos, de distintas maneiras. Diferentemente das tabelas, os gráficos oferecem uma capacidade de compreensão instantânea da importância relativa dos diversos números assumidos pelas variáveis. A forma ou tipo de gráfico utilizado depende da natureza das variáveis analisadas e das escalas de suas variações. As variáveis podem apresentar valores predominantemente contínuos - como a temperatura do ar, radiação solar, velocidade do vento, direção do vento, pressão, umidade relativa - ou valores pontuais - como a precipitação.

Cada elemento do clima possui um intervalo de variação: a temperatura do ar pode assumir valores negativos $\left(-89^{\circ} \mathrm{C}\right.$ foi a menor temperatura registrada na Terra), valores nulos $\left(0^{\circ} \mathrm{C}\right)$, e valores positivos ( $58^{\circ}$ foi a maior temperatura registrada); a radiação solar só pode assumir valores iguais a zero ou valores positivos (menores que a constante solar de $1.366 \mathrm{~W} / \mathrm{m}^{2}$ ); a velocidade do vento só assume valores nulos ou positivos (372 km/h foi a maior velocidade registrada); a direção do vento assume valores de 0 a $360^{\circ}$, com sub-intervalos específicos correspondentes aos pontos cardeais e pontos colaterais; a pressão assume apenas valores positivos (sendo 1084 mbar o maior valor registrado e 870 mbar o menor); a umidade relativa assume valores nulos e positivos (pode variar de 0 a 100\%); e a precipitação assume valores nulos (maior parte do tempo) e valores positivos (os valores máximos registrados no mundo foram de $3.12 \mathrm{~mm}$ em 1 minuto, $187 \mathrm{~mm}$ em 24 horas, $923 \mathrm{~mm}$ em 1 mês e $2647 \mathrm{~mm}$ em 1 ano) (valores extremos do clima segundo Oliver, 2005 ${ }^{92}$, pg. 279).

Basicamente, boa parte dos gráficos utilizados na climatologia para representação de séries é bi-dimensional e utilizam as coordenadas cartesianas, com o eixo horizontal ( $X$, abscissas) representando a variável temporal, e o eixo vertical ( $Y$, ordenadas) representando a variável de interesse. Antigamente os gráficos não possuíam cores, eram somente em branco e preto. Hoje em dia, é difundido o emprego de cores nas representações, visando à diferenciação dos elementos gráficos e melhoria do aspecto visual em geral. Diversos tipos de gráficos estão disponíveis, alguns tri-

${ }^{92}$ OLIVER, J.E. (ed.). Encyclopedia of World Climatology. Dordrecht: Springer, 2005. 854 p. 
dimensionais e outros com características adaptadas e adequadas de acordo com o interesse e intenção da exposição das informações.

Um aspecto limitante que prejudica as análises das séries é a dificuldade de representar simultaneamente os dados sob a perspectiva de diferentes escalas temporais. Por exemplo, normais climatológicas são representativas de dados médios de uma série de 30 anos, mas não são uma representação apropriada para comparar com as variações horárias que os valores sofrem ao longo de um dia.

Neste contexto, apresenta-se uma forma inédita de representação de dados climáticos, capaz de integrar e apresentar simultaneamente as escalas horárias, diárias, anuais e provavelmente até as escalas decadais das normais. Esta forma de representação aqui sugerida é uma síntese anual dos elementos climáticos. Ela possui formato de um diagrama circular, exibe informações coloridas e bi-dimensionais, com a apresentação da variável climática e de variáveis temporais (horária, diária e mensal). O objetivo consiste, portanto, em apresentar uma solução do desafio de representar uma quantidade imensa de dados de uma maneira que facilite a compreensão dos fenômenos envolvidos nas diferentes escalas temporais.

\section{Material e Métodos}

Foram utilizados dados, do ano de 2009, de radiação solar, temperatura do ar, umidade relativa do ar, pressão atmosférica, velocidades média e máxima dos ventos, direção dos ventos e precipitação. Os dados foram coletados e registrados na Estação Climatológica do Centro de Recursos Hídricos e Ecologia Aplicada (CRHEA), Escola de Engenharia de São Carlos (EESC), Universidade de São Paulo (USP), localizada no município de Itirapina, São Paulo, Brasil (Latitude: $22^{\circ} 10^{\prime}$ Sul, Longitude: $47^{\circ} 50^{\prime}$ Oeste, Altitude: $753 \mathrm{~m}$ ), a $25 \mathrm{~km}$ do município de São Carlos, interior do Estado de São Paulo.

A coleta de dados foi realizada por uma estação automática da Campbell Scientific, com sistema de aquisição e armazenamento de dados modelo CR10X. Todos os dados obtidos pela estação automática foram registrados em intervalos regulares de 30 minutos, totalizando 48 registros diários.

Os dados foram importados no programa aplicativo OriginPro 8.0, onde então foram confeccionados os gráficos. A rotina utilizada foi selecionar os dados da variável de interesse, e plotar o gráfico executando os seguintes passos: Plot $>$ Contour $>$ theta $(X) r(Y) Z$ Polar Contour. À variável $X$ (ângulo de variação polar) foram 
atribuídos os dias; à variável $Y$ (raio do diagrama) foram atribuídos os horários do dia; e à variável $Z$ (dimensão do elemento do clima) foram atribuídas as variáveis de cada elemento do clima. Ajustes de escalas foram realizados para evidenciar as diferenças e melhorar o contraste visual das cores.

\section{Resultados e Discussão}

Após o final do texto, são apresentados nas Figuras de $\mathbf{H}-\mathbf{1}$ a $\mathbf{H}-\mathbf{8}$ os diagramas elaborados para: a radiação solar (Fig. H-1); temperatura do ar (Fig. H-2); umidade relativa do ar (Fig. H-3); pressão atmosférica (Fig. H-4); velocidade média do vento (Fig. H-5); velocidade máxima do vento (Fig. H-6); direção do vento (Fig. H-7); e precipitação (Fig. H-8).

Devido ao aspecto visual semelhante à íris de um olho, este tipo de diagrama circular de isolinhas dos diferentes elementos do clima foi designado como "Climatiris". Nas Climatiris são exibidas as variações diárias ao longo do ano, iniciando pelo dia indicado pelo zero e terminando, após uma volta completa no sentido horário, no mesmo ponto. Linhas que cortam o diagrama circular indicam períodos de 15 dias, sendo que duas destas frações equivalem aos meses correspondentes, também indicados. À esquerda é exibida a escala horária, indicando os horários que correspondem aos anéis circulares presentes no interior do diagrama. E à direita está a escala gráfica colorida dos valores da variável selecionada.

A partir das imagens apresentadas, é possível notar a interdependência dos elementos do clima. Primeiro, a principal característica evidenciada é o contraste dos hemisférios superiores e inferiores, que denotam, respectivamente, os períodos quentes e frios do verão e inverno.

A Figura H-1, da radiação solar, fator primário e determinante das condições gerias do clima, apresenta valores mais intensos e com maior intervalo de horas de duração no hemisfério superior (verão). A temperatura, fator secundário do clima, acompanha proporcionalmente a intensidade da radiação.

Outro aspecto interessante que fica em evidência é a visualização dos ciclos de deslocamento de massas de ar e atuação de ciclones e anticiclones na região da medição das variáveis climáticas. Analisando a temperatura na Figura H-2 é facilmente percebido os períodos que se encontram sob efeitos e domínio de uma massa de ar quente, que apresentam altas temperaturas; e períodos que se encontram 
sob domínio de uma massa de ar fria (baixos valores de temperatura). Além disso, são ilustradas as fases transitórias de avanço e tropicalização das massas de ar fria. Por exemplo, no período próximo ao dia indicado por 150, ocorreu a entrada da frente fria mais vigorosa do ano.

A Figura H-3 da umidade relativa permite identificar os períodos mais secos do ano, que, em 2009, ocorreram nos meses de agosto e setembro. A Figura H-4 da pressão atmosférica exibe com nitidez a atuação dos sistemas atmosféricos de baixa pressão (ciclones no verão) e de alta pressão (anti-ciclones no inverno).

As velocidades média e máxima do vento nas Figuras H-5 e H-6, respectivamente, mostram que os ventos são mais intensos ao longo do período diurno. Verifica-se também, a ocorrência de alguns episódios de rajadas e ventos mais intensos (em Janeiro, Outubro e Novembro). Quanto à direção dos ventos, Figura H7, existe um padrão mais heterogêneo, devido à alta variabilidade habitual.

E por fim, a FiguraH-8 das precipitações, apresenta a distribuição e intensidade das chuvas ao longo do ano, com uma falha de dados do começo de abril até final de julho, devido a um defeito no pluviômetro.

Os gráficos apresentados na sequência auxiliam nas análises dos episódios climáticos que são fundamentais na Climatologia Geográfica ou Dinâmica, visão introduzida no Brasil por Monteiro $(1967)^{93}$. Este tipo de diagrama circular com isolinhas, ou Climatiris, apresenta a vantagem de permitir uma visualização anual que sintetiza simultaneamente todos os principais elementos do clima, evidenciando a dinâmica dada pela sucessão habitual de movimentos de frentes frias e deslocamentos de massas de ar.

Apesar das vantagens de integração das escalas horárias, diárias e mensais, tentativas de novas aplicações, aprimoramentos e estudos complementares ainda são necessários para este tipo de representação. Existe a perspectiva da possibilidade de aplicar esta técnica com séries de dados maiores, utilizando-se de escalas decadais. Por exemplo, seria possível plotar os valores médios de uma série de 10 anos. Entretanto, para que isto seja viável, seria necessária uma extensa série de dados coletados por uma estação climatológica automática, que apresenta alta resolução temporal de dados.

93 MONTEIRO, C. A. F. Ritmo hibernal da frente polar e as chuvas na fachada subtropical atlântica do Brasil: contribuição metodológica à análise geográfica dos tipos de tempo no Brasil. Tese (Doutorado) - FFLCH, USP. São Paulo, 1967. 
Salvo estar sob a mais completa desinformação e ignorância, este tipo de diagrama, confeccionado ao acaso, pode ser considerado inédito, mas não totalmente. Após a confecção da Climatiris, foram realizadas buscas na Internet, as quais constataram que, em 1943, o geógrafo alemão Carl Troll desenvolveu um diagrama análogo, não-circular, para o caso da temperatura, que ficou conhecido como Thermoisoplethendiagramm (diagrama de isopletas ou isolinhas de temperatura, ou simplesmente isotermas $^{94}$ ). Na ocasião da época, os valores apresentados eram valores médios, na escala das normais climatológicas. Permitia uma visualização mais geral da temperatura, ilustrando diferenças maiores entre os meses, mas não diferenças diárias e horárias. A Figura H-9 apresenta uma amostra deste tipo de representação.
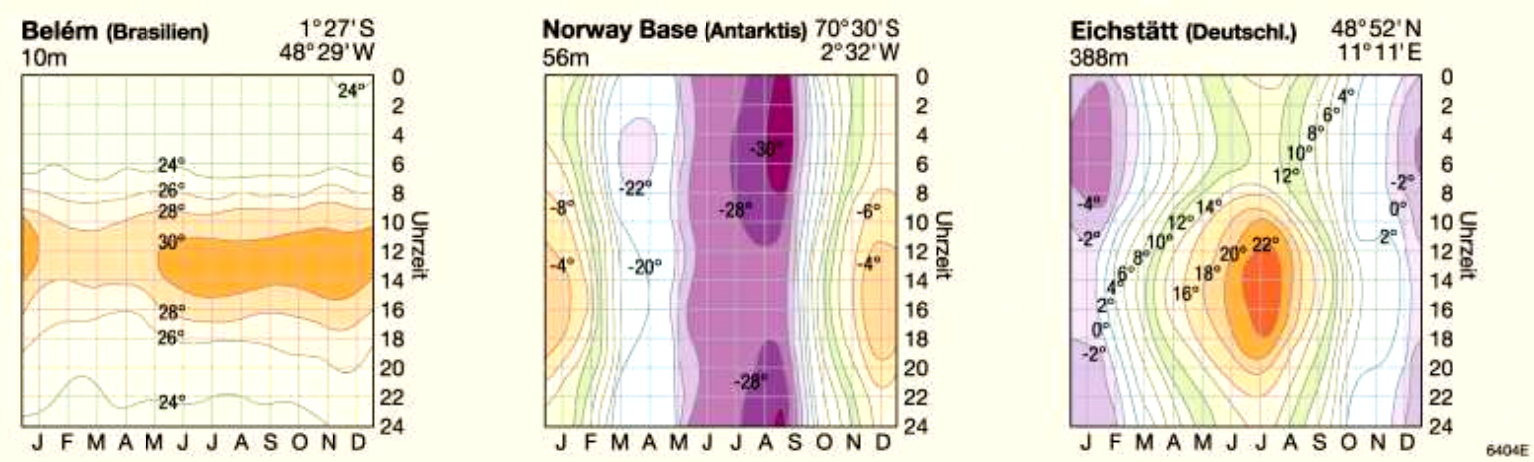

Figura H-9 - Diagrama de isolinhas de temperatura na concepção original (Thermoisoplethendiagramm). Devido à escala temporal adotada (valores médios mensais interpolados, provavelmente) verifica-se uma variação mais suave. Fonte: Atlas Mundial Diercke - Climas da Terra segundo Siegmund/Frankenberg. Disponível (em Alemão) em $<$ http://www.diercke.de/kartenansicht.xtp?artId=978-3-14-100700-

8\&stichwort=Frankenberg $>$. Acesso em 31/05/2010.

94 O termo "isotermas" foi inventado pelo geógrafo, naturalista e explorador alemão Alexander von Humboldt (1769 - 1859), considerado o Pai da Geografia. Humboldt estabeleceu esse conceito ao comparar as diferentes condições climáticas, em termos de temperatura, de vários países. 


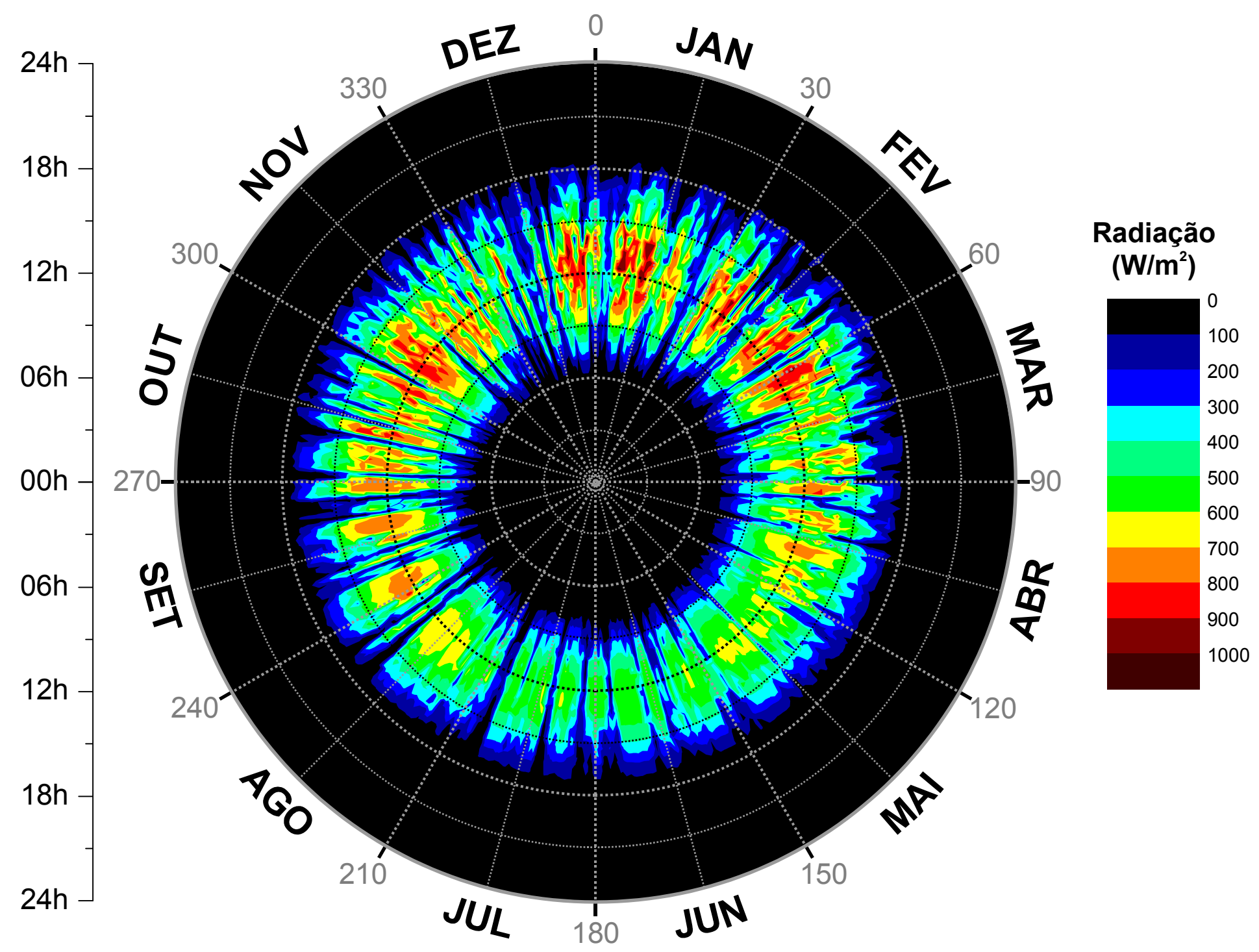

Figura H-1 - Climatiris da radiação solar global no ano de 2009. 



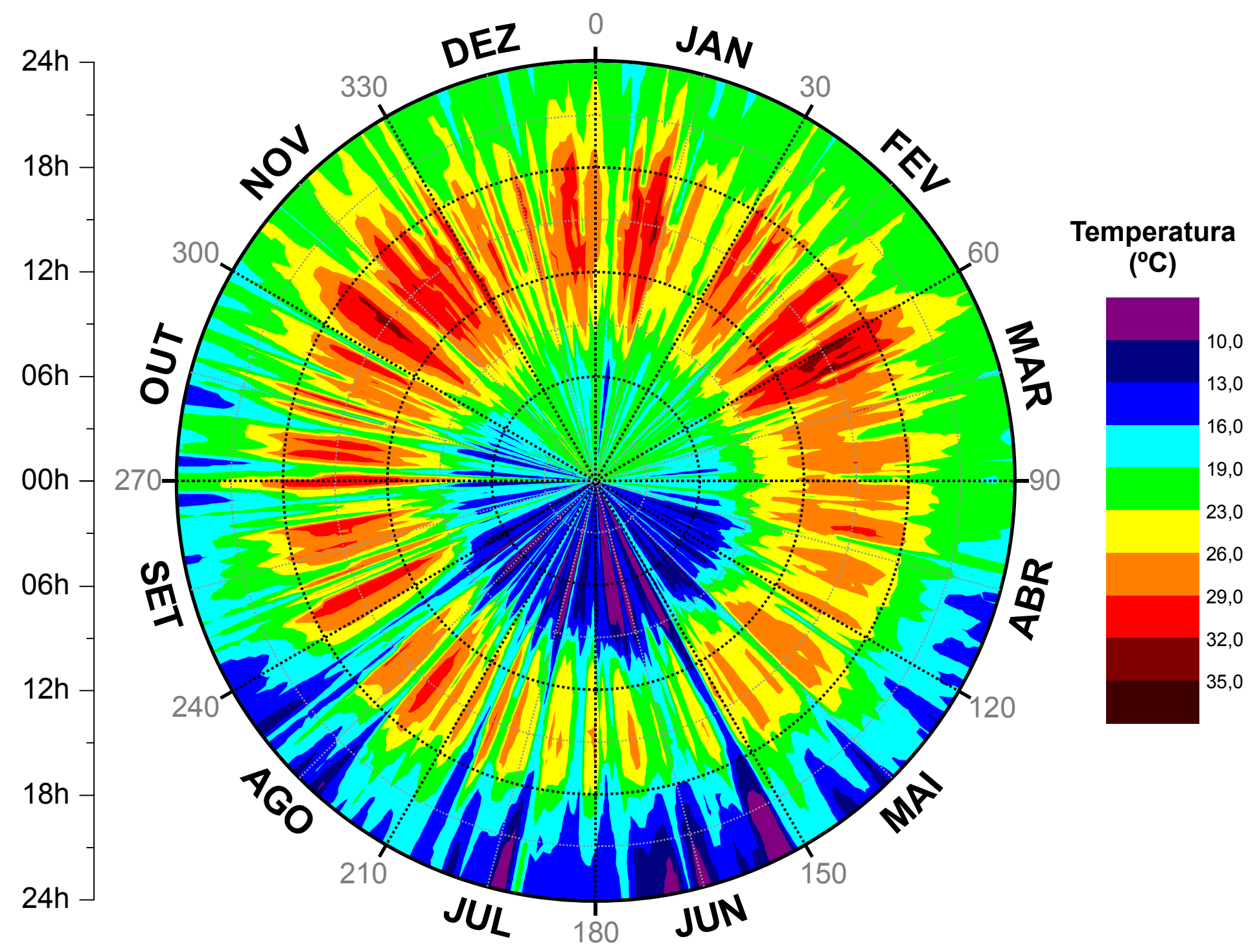

Figura H-2 - Climatiris da temperatura média do ar no ano de 2009. 



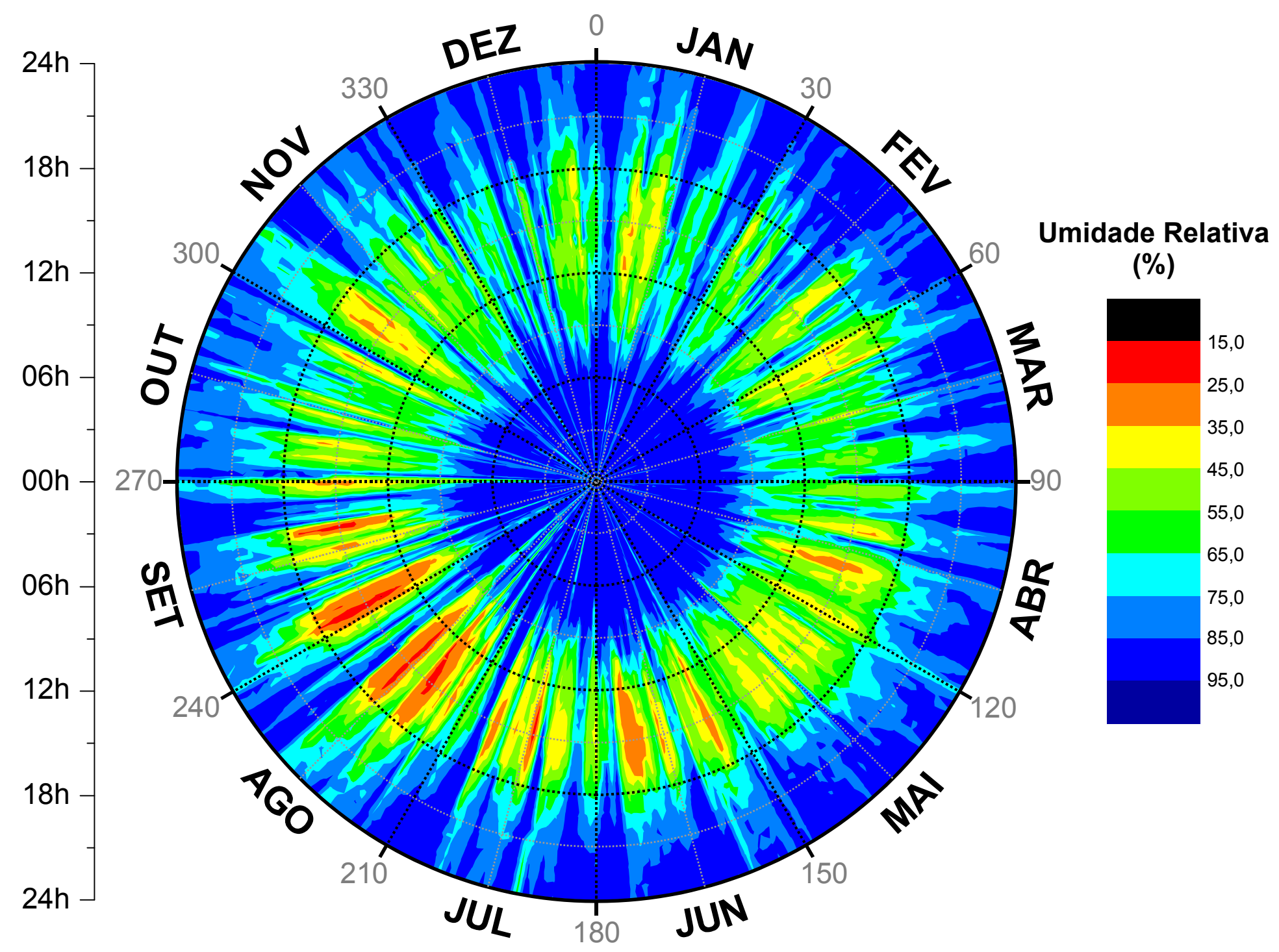

Figura H-3 - Climatiris da umidade relativa no ano de 2009. 



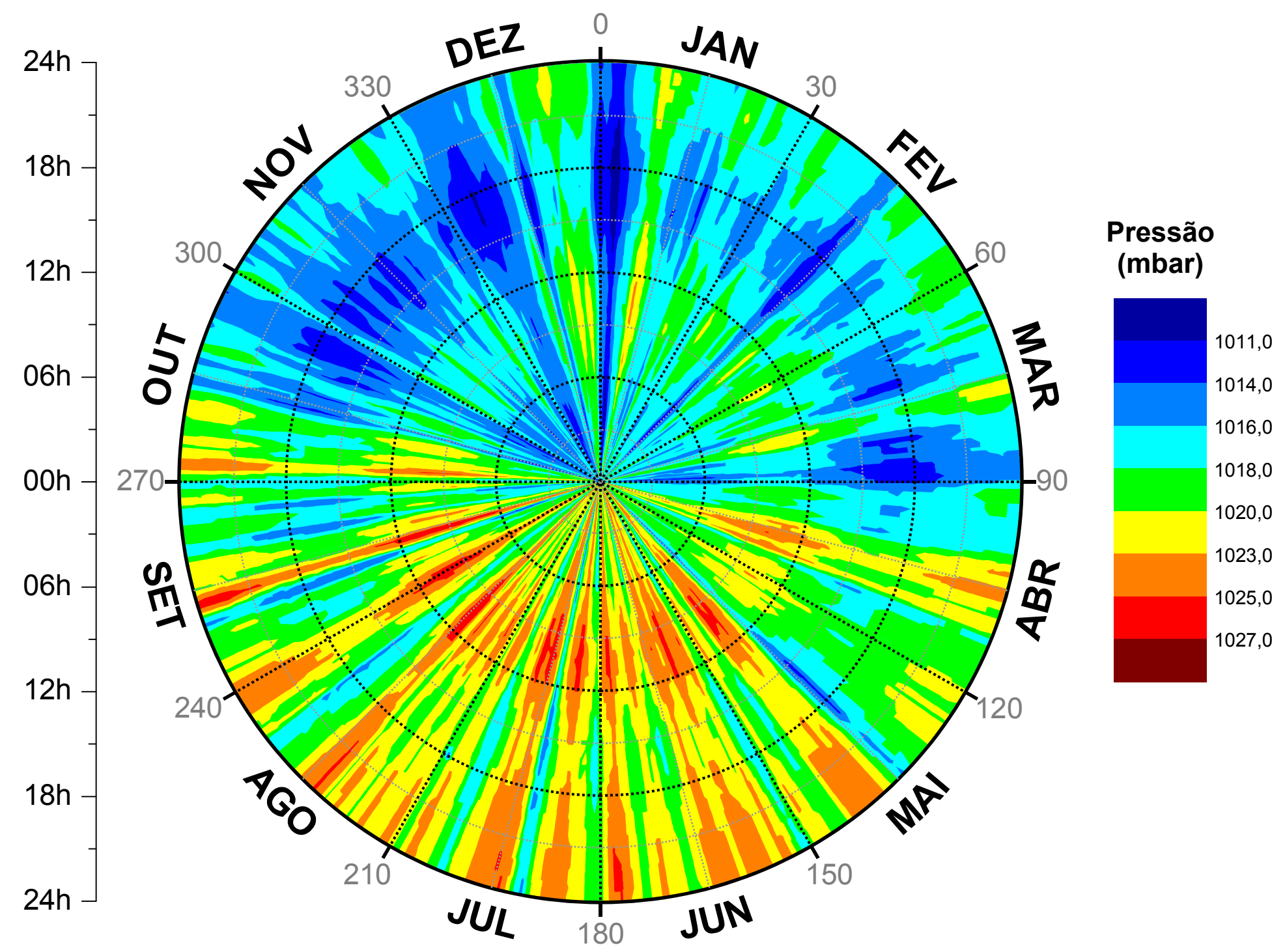

Figura H-4 - Climatiris da pressão atmosférica no ano de 2009. 



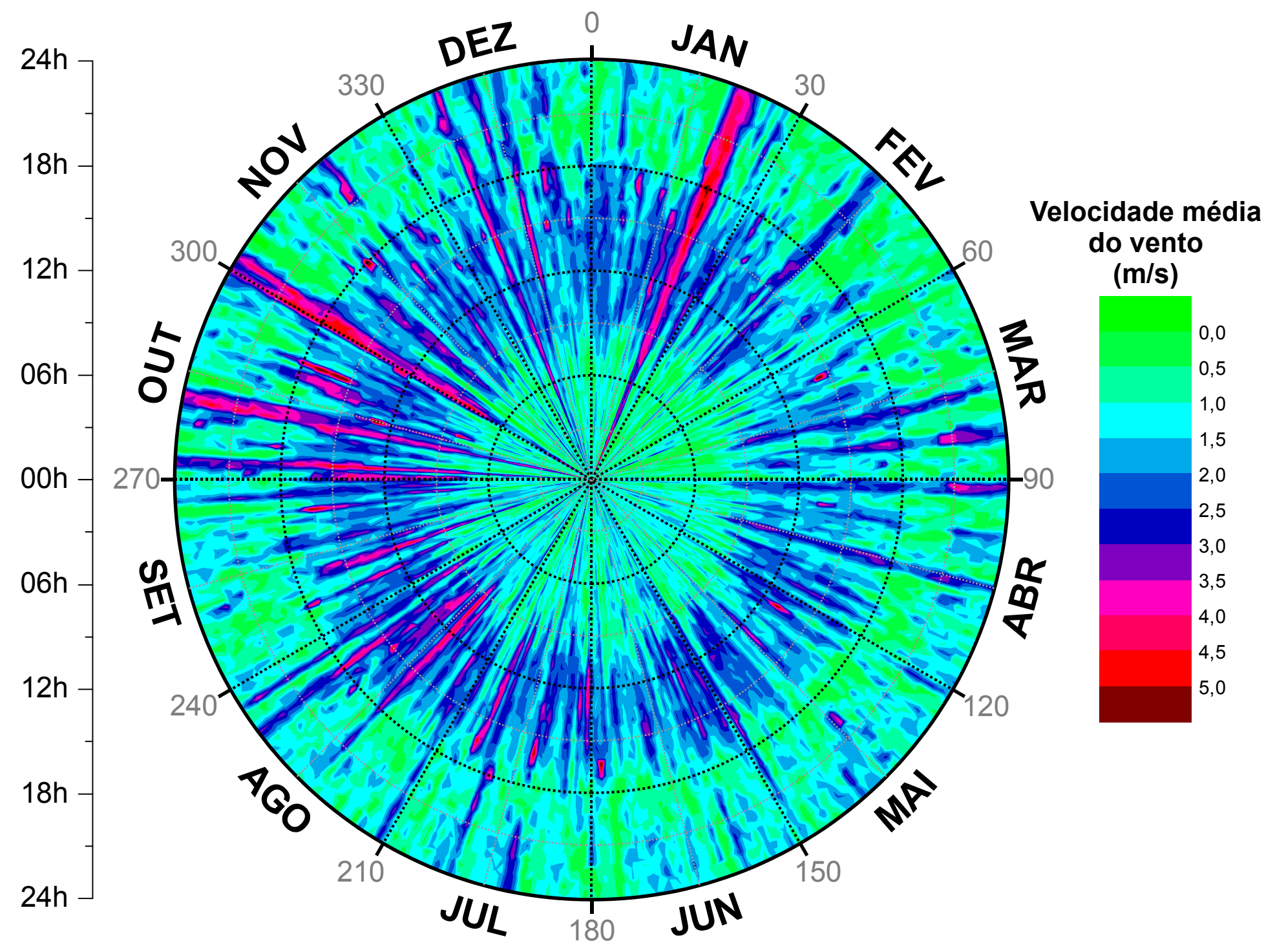

Figura H-5 - Climatiris da velocidade média do vento no ano de 2009. 



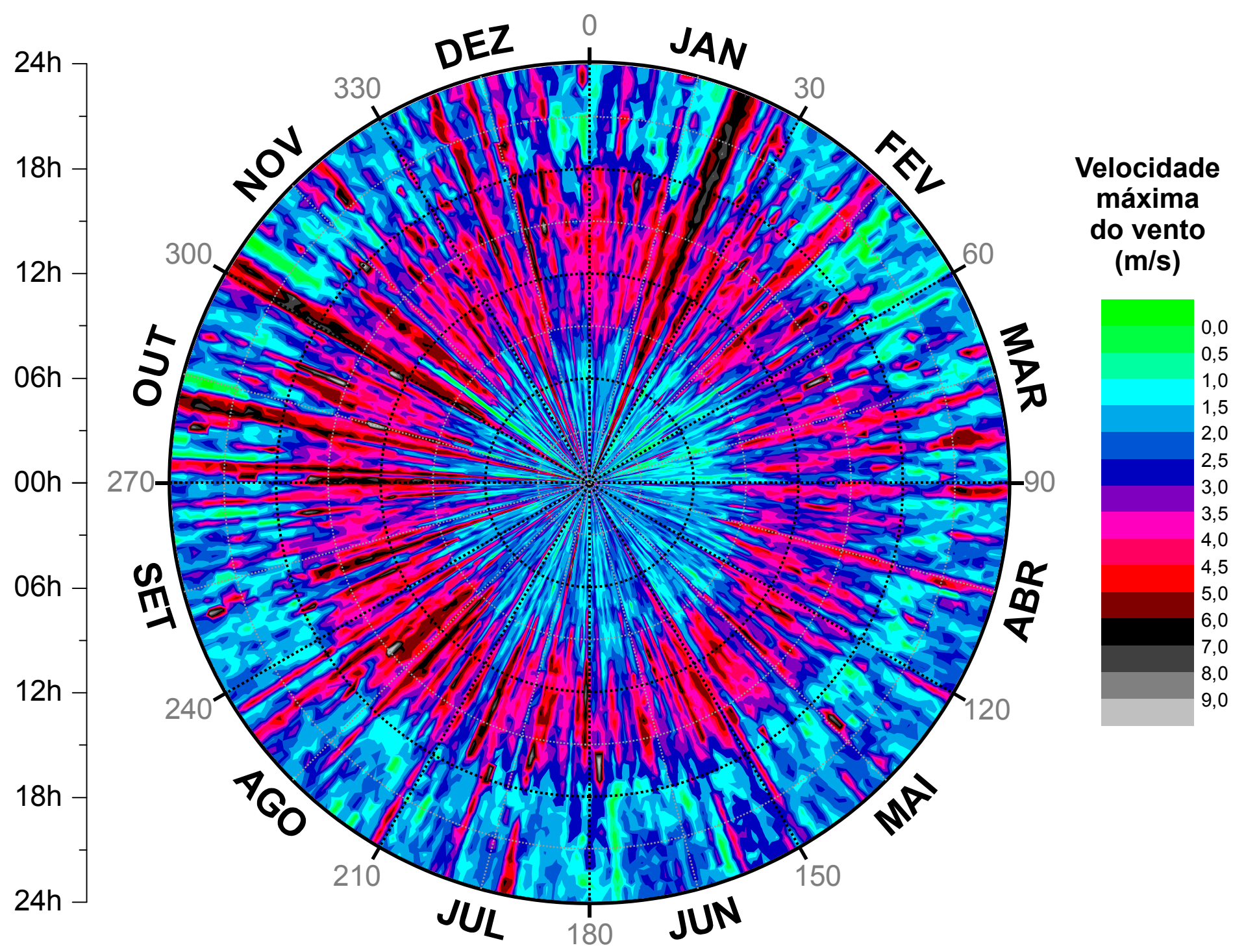

Figura H-6 - Climatiris da velocidade máxima do vento no ano de 2009. 



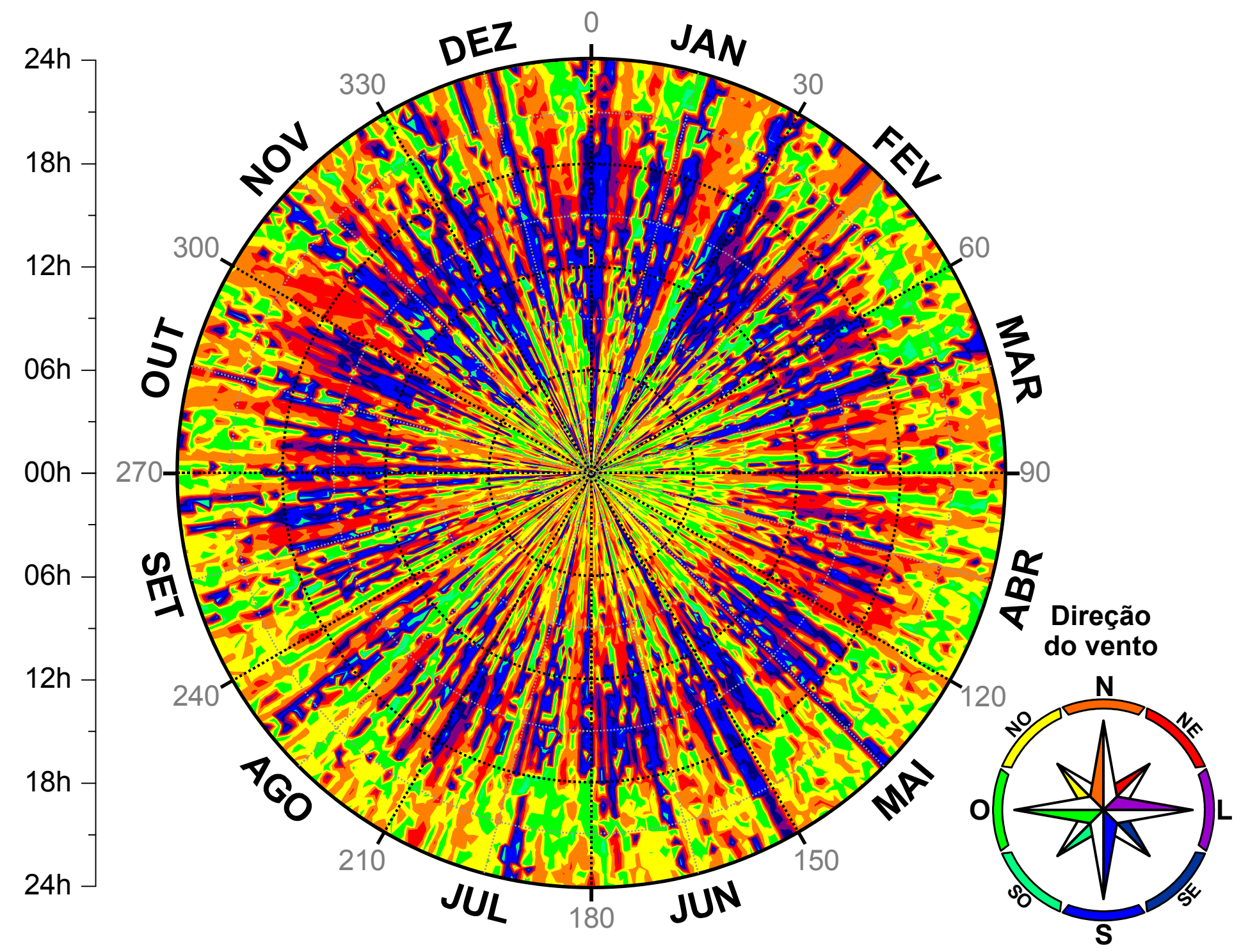

Figura H-7 - Climatiris da direção do vento no ano de 2009. 



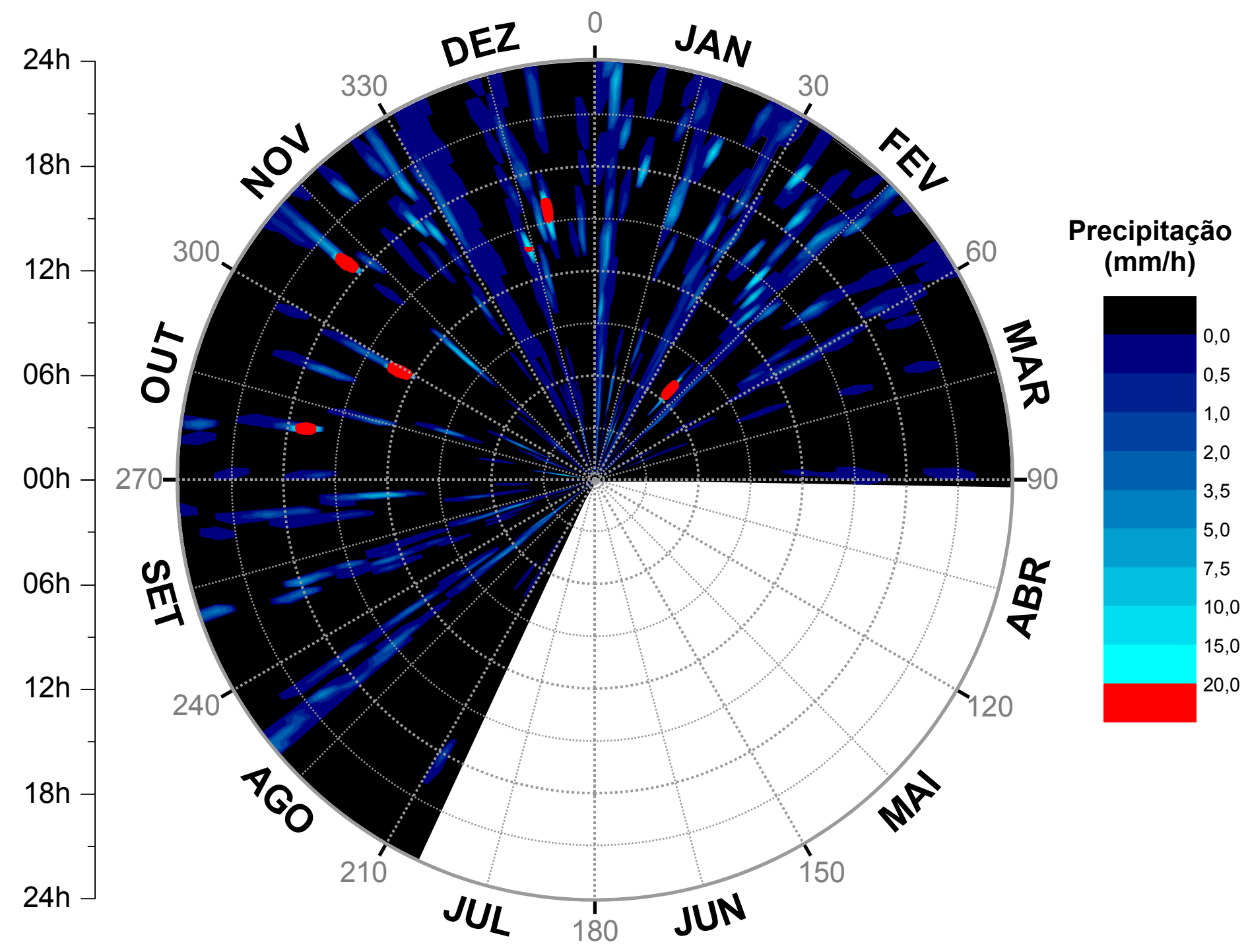

Figura H-8 - Climatiris da precipitação no ano de 2009 (com falha de dados, em branco, de abril a julho). 


